\title{
RECONSTITUIÇĀO PALEOAMBIENTAL DE FÁCIES LAGUNARES COM BASE EM FORAMINÍFEROS: O NÍVEL DO MAR NO QUATERNÁRIO SUPERIOR NA ÁREA DE CABO FRIO, RJ.
}

Cátia Fernandes Barbosa

Orientador: Prof. Dr. Kenitiro Suguio

TESE DE DOUTORAMENTO

Programa de Pós-Graduação em Geologia Sedimentar 


\section{RECONSTITUIÇÃO PALEOAMBIENTAL DE FÁCIES LAGUNARES COM BASE EM FORAMINIFFEROS: O NIVEL DO MAR NO QUATERNÁRIO SUPERIOR NA ÁREA DE CABO FRIO, RJ}

\section{CÁTIA FERNANDES BARBOSA}

Orientador: Prof. Dr. Kenitiro Suguio

TESE DE DOUTORAMENTO COMISSÃO JULGADORA

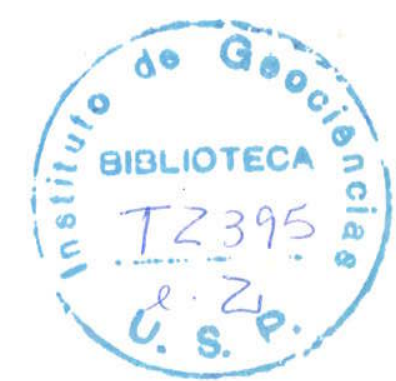

Nome

Assinatura

Presidente: Prof. Dr. Kenitiro Suguio

Examinadores: Prof ${ }^{\mathrm{a}} \mathrm{Dr}^{\mathrm{a}}{ }^{-}$Beatriz Beck Eichler Prof. Dr. Dimas Dias Brito Prof. Dr. Setembrino Petri Prof ${ }^{\mathrm{a}}-\mathrm{Dr}^{\mathrm{a}} \cdot$ Silvia Helena de M. e Souza

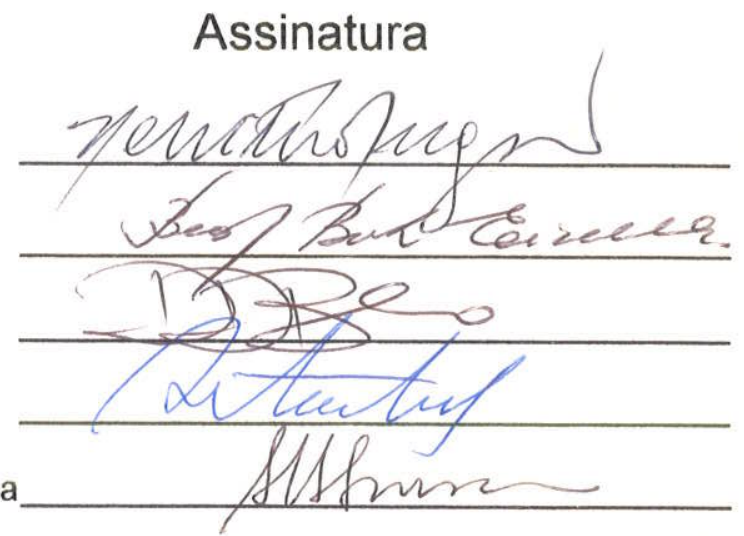




\section{UNIVERSIDADE DE SĀO PAULO INSTITUTO DE GEOCIENCIAS}

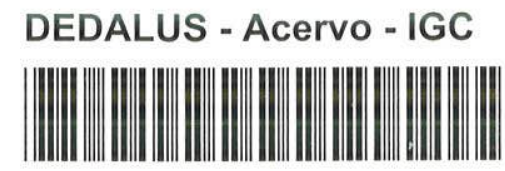

30900004549

RECONSTITUIÇĀO PALEOAMBIENTAL DE FÁCIES LAGUNARES COM BASE EM FORAMINÍFEROS: $O$ NÍVEL DO MAR NO QUATERNÁRIO SUPERIOR NA - ÁREA DE CABO FRIO, RJ.

Cátia Fernandes Barbosa

Orientador: Prof. Dr. Kenitiro Suguio

TESE DE DOUTORAMENTO

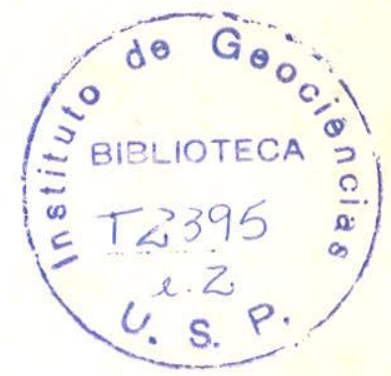

Programa de Pós-Graduação em Geologia Sedimentar 
Ao meus filhos

Yasmin e Yuri,

\section{$\grave{A}$}

Cainho,

meus amores e maior motivação na vida. 


\section{RESUMO}

Dezesseis biofácies de foraminíferos e tecamebas em cinco bordas lagunares (Araruama, Saquarema e lagoas Vermelha, Brejo do Espinho e Jacarepiá), sob regime de salinidade diferenciados, caracterizam zonas sazonalmente distintas, ao longo de 11 seções de verão (65 estações) e 10 seções de inverno (64 estações), na superfície atual das praias lagunares. Estas biofácies permitem o reconhecimento em subsuperfície de paleoambientes deposicionais e paleoníveis marinhos, com resolução variando em função de cada amplitude vertical e melhor potencial de preservação das espécies que as deteminam. Para a laguna de Araruama são definidas cinco biofácies, com pequena variação sazonal e baixa resolução, devido a grande amplitude de batimetria em que ocorrem. Para as lagoas Vermelha e Brejo do Espinho são determinadas quatro biofácies de verão e três de inverno, com menores amplitudes e melhores potenciais de preservação. Para a laguna de Saquarema e lagoa de Jacarepiá são definidas três biofácies de foraminíferos e uma de tecamebas, sem variação sazonal aparente. Seis biofácies marcam as zonas batimétricas supramaré, intermaré e submaré, sendo reconhecidas ao longo de três testemunhos. Uma das biofácies definidas para a zona pós-praia lagunar, ou supramaré, e que apresenta a menor amplitude vertical de ocorrência $(10 \mathrm{~cm})$ dentre as biofácies registradas nos testemunhos, é caracterizada por Discorinopsis aquayoi e Agglutinella martiniiana, apesar do baixo potencial de preservação.

As biofácies, analisadas em conjunto com a associação de litofácies, datações pelo método do radiocarbono e dados geoquímicos e isotópicos dos testemunhos indicam para o Quaternário Superior da área de Cabo Frio no Rio de Janeiro, um paleoambiente perimaré, progressivamente mais raso, marcado por deposição carbonática e siliciclástica variável, e datum de referência litofacilógico (paleossolo, níveis de conchas e crostas carbonáticas) com idades variando de $7.170 \pm 110$ anos A.P. a $760 \pm 80$ anos A.P. Permitem o reconhecimento de cinco fases evolutivas, às quais estão íntimamente relacionadas as flutuações do nível relativo do mar.

Fase I - Idades de $6530 \pm 100$ anos A.P a $7.170 \pm 110$ anos A.P, deposição siliciclástica arenosa, espécimens de Ammonia spp. Cribroelphidium excavatum $\mathrm{f}$. selseyensis e conchas de Anomalocardia brasiliensis, $\delta^{18} \mathrm{O}$ e $\delta^{13} \mathrm{C}$ muito negativos, indicando uma laguna ampla, com comunicação oceânica, mas com presença de itha ou ilhas barreiras à frente.

Fase II - Idades de 5.790 \pm 90 anos A.P, $5.180 \pm 70$ anos A.P e $4320 \pm 100$ anos A.P. A laguna se instala definitivamente, com diminuição na energia do meio físico, anóxico, marcada por Ammonia spp., Cribroelphidium spp e Bolivina spp. Deposição siliciclástica variável com lama orgânica e menor índice de sedimentação. Discontinuidade erosiva marca a transgressão do Holoceno (com ápice a 5.180 anos A.P.) indicada por Globocassidulina subglobosa, Brizalina sp. A, Abditodentrix rhomboidalis e Bolivina sliteri subsp. asperoides.

Fase 111 - individualização das lagunas intercordão, deposição siliciclástica variável na base passando a carbonato variável no topo. A associação de fácies perimaré com nódulos carbonáticos e paleossolo (2.340 90 anos A.P.). Tendência regressiva marcada pela passagem de fácies submaré para intermaré e pelas espécies $P$. lecalvezae, Affinetrina sommeri, $D$. aquayoi e Massilina protea; o $\delta^{13} \mathrm{C}$ indica maior continentalidade e queda do nivel do mar. A bacia lagunar, antes de seu fechamento definitivo, foi invadida por águas muito frias a $2.400 \pm 50$ anos A.P provenientes da 
corrente de ressurgência adjacente, registrada pela presença de Buccela frigida e Miliolinella antarctica.

Fase IV - Litofácies carbonáticas de ambiente perimaré raso, com tapetes algálicos, grada de biofácies intermaré e supramaré na base para submaré no topo; precipitados de anidrita e $\delta^{18} \mathrm{O}$ ilustram paleotemperatura média superior a $20^{\circ} \mathrm{C}$. Os foraminíferos correspondem a Agglutinella martiniiana, D. aquayoi, Varidentella $\mathrm{sp}$. A, Quinqueloculina dilatata, P. lecalvezae e Q. patagonica. T. lutea marca a base desta fase mais quente e tubos (pipes) de dissolução seguidos por laminaçã̃o escurecida sugerem momento de cheia na laguna em direção ao topo.

Fase V- lama orgânica carbonática, bioturbada, marcada por $P$. lecalvezae e $A$. beccarii f. tepida, $Q$. patagonica, A. sommeri e B. variabilis, salinidades acima da marinha normal, eventuais entrada de águas marinhas e baixos teores de oxigênio dissolvido.

A análise dos testemunhos, em associação com as biofácies, permite a construção de três curvas de variação do nível relativo do mar, comparáveis entre si e com a curva de Martin et al.1979, facilitando o cálculo do índice de sedimentação e índice de variação do nível relativo do mar para o Holoceno. Estas curvas evidenciam dois períodos de estabilidade ou subida do nivel do mar (stillstand ou highstand) e mostram para os últimos centímetros do registro, uma inversão na tendência regressiva observada no Holoceno Superior. 
Sixteen biofacies characterized by foranminifera and thecamoebians from the borders of five lagoons of various salinities (Araruama, Saquarema, Vermelha, Brejo do Espinho e Jacarepiá) indicate zonations influenced by sazonality along the surface of present lagoonal shores, with 11 transections sampled in the summer (65 stations) and 10 transections sampled in the winter (64 stations).

The aplication of these biofacies to drill cores allows the recognition of depositional paleoenvironments e paleosealevels in subsurface, with resolutions varying as a function of vertical ranges and preservation potential of the species that determine the biofacies. Five biofacies are recognized in the Araruama lagoon, with little seasonal variation and low resolution, due to the large bathimetric range in which they occur. Four biofacies are represented in the summer samples of Vermelha and Brejo do Espinho lagoons, and three are recognized in the winter samples, with low ranges and good preservation potential. Three foraminiferal and one arcellacea biofacies, with no aparent seasonal variation, are present in the samples of Saquarema and Jacarepiá lagoons. Six biofacies are characteristic of supratidal, intertidal and subtidal zones in the core samples. Of these, a biofacies defined for the lagoonal backshore/supratidal zone has the lowest vertical range $(10 \mathrm{~cm})$, being recognized in the Vermelha lagoon core, despite its low preservation potential composed of Discorinopsis aquayoi and Agglutinella martiniiana.

The lithofacies, radiocarbon dating, geochemical and isotopic data, when analised with the biofacies from the core samples indicate a peritidal shallowing upward association of facies for the late Holocene of the Cabo Frio area of the State of Rio de Janeiro. This paleoenvironment is characterized by variable carbonate and siliciclastic deposition and mean datum lines (paleosols, shell-rich layers and carbonatic crusts) ranging in ages from $7,170 \pm 110$ yrs B.P. to $760 \pm 80$ yrs B.P.

The paleoenvironmental evolution is therefore divided in 5 main stages, intrinsically related to mean sea level fluctuations.

Stage I : Ages ranging from $6.530 \pm 100$ yrs B.P. to $7.170 \pm 110$ yrs B.P.,siliciclastic sand deposition, Ammonia spp. Cribroelphidium excavatum f. selseyensis and Anomalocardia brasiliensis shells, $\delta^{18} \mathrm{O}$ e $\delta^{13} \mathrm{C}$ extremely negative, characterizing a huge lagoon with inlets, protected by one or more barriers islands.

Stage II - Ages ranging from $5.790 \pm 90$ yrs B.P. to $4.230 \pm 100$ yrs B.P. Main event of lagoonal setting, with low energy,anoxic environment characterized by Ammonia spp. Cribroelhidium sp. e Bolibina spp. Variable siliciclastic deposition with organic muds and low sedimentation rates. Bounding discontinuity flagginng the Holocene transgression (highest at 5.180 yrs B.P.), characterized by Globocassidulina subglobosa, Brizalina sp. A, Abditodentrix rhomboidalis and Bolivina sliteri subsp. asperoides

Stage III - individuation of internal lagoons. Variable siliciclastic deposition, grading towrds variable carbonate deposition on the top of the stage. Peritidal facies association with carbonatic nodules and paleosol $(2,434 \pm 90$ yrs B.P). Regressive trend indicated by the gradation from subtidal to intertidal facies and by $P$. lecavezae, Affinetrina sommeri, $D$. aquayoi e Massilina protea; $\delta^{13} \mathrm{C}$ indicates greater continentality and lowering sea level. Before its final closing, the lagoonal basin was invaded by very cold waters at $2,400 \pm 50$ yrs B.P., probably due to the adjacent upwelling current as registered by the presence of Buccella frigida and $M$. antarctica. 
Stage IV - Shallow peritidal carbonatic lithofacies, with algal mats, grading from inter and supratidal biofacies at the bottom towards subtidal biofacies at the top of the stage. Anidrite precipitates and $\delta^{18} \mathrm{O}$ indicate average temperatures above $20^{\circ} \mathrm{C}$. Characteristic foraminifera are Agglutinella martiniana, D. aquayoi, Varidentella $\mathrm{sp}$. A, Quinqueloculina dilatata, $P$. lecalvezae and $Q$. patagonica. $T$. lutea signs the base of the warmer stage, and dissolution pipes followed by darker laminae suggest a flooding of the lagoon towards the top of the stage.

Stage V - Bioturbated carbonatic organic rich mud, with $P$. lecalvezae, $A$. beccarii f. tepida, Q. patagonica, A. sommeri and B. variabilis, above normal marine salinities, eventual entering of marine waters and low grades of dissolved oxigen.:

From each core and its biofacies, three relative sea level curves are constructed and comapred to each other and to the existing curve of Martin et al (1979), resulting in estimations of sedimentation rates and Holocene sea levels. Two stillstand or highstand are evidenced and the last 3 centimeters of the cores show the inversion of the Late Holocene regressive trend. 
RESUMO

ABSTRACT

CAPÍTULO 1 - INTRODUÇÃO 1

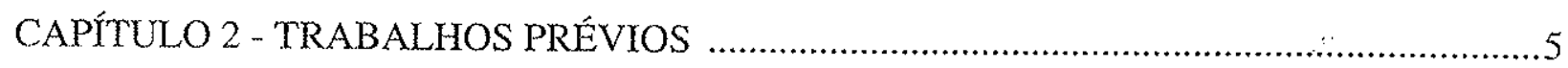

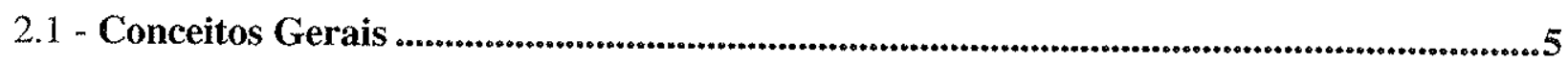

2.2 - Definição e Classificação de Lagunas Costeiras .............................................................5

2.3 - Mudanças do Nível Relativo do Mar ............................

2.4 - Reconstituição de Antigos Níveis Marinhos $\ldots$......

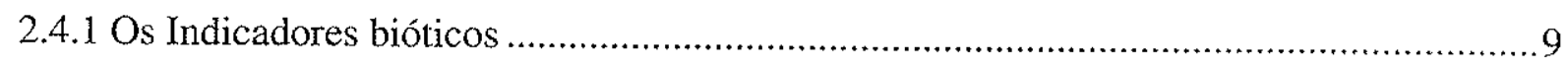

2.4.2 - Zoneamentos de Assembléias de Foraminíferos..................................................... 10

CAPÍTULO 3 - ÁREA DE ESTUDO

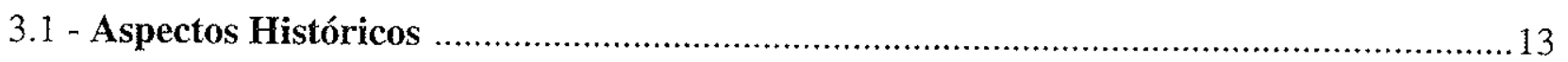

3.2 - Características Climáticas e Oceanográficas ............................................................. 14

3.2.1 - Precipitação e Evaporação ……............................................................................. 15

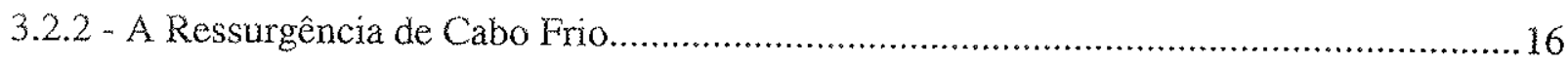

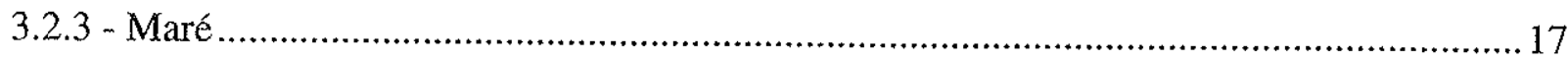

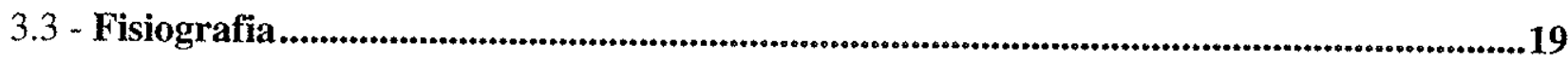

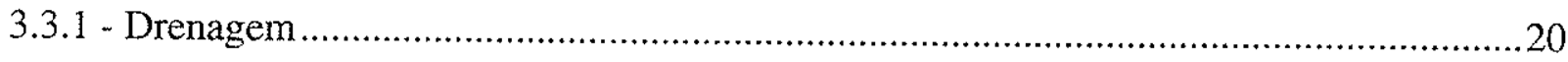

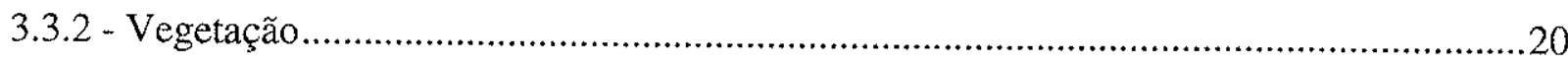

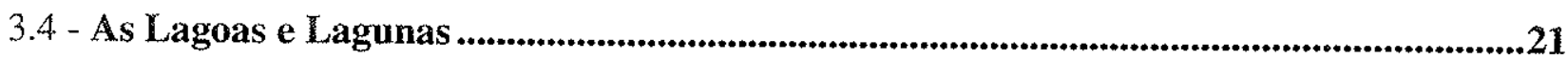

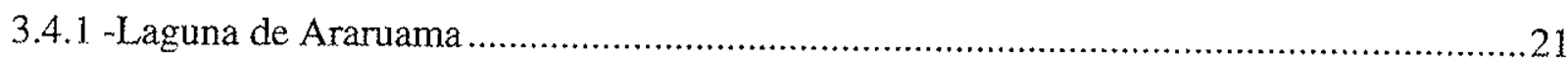

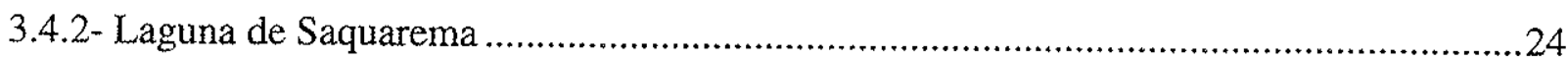

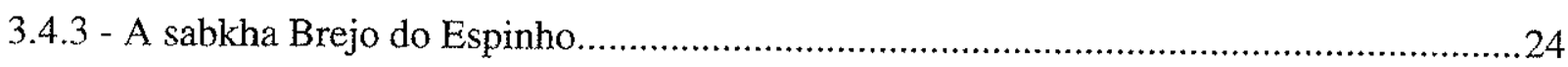

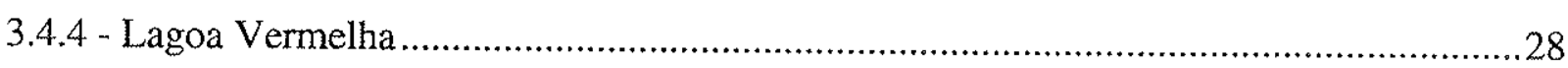

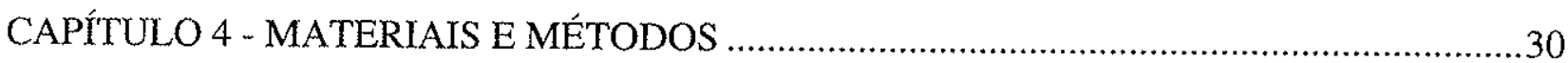

4.1 - Perfis Topográficos Transversais das Bordas Lagunares ...............................................30

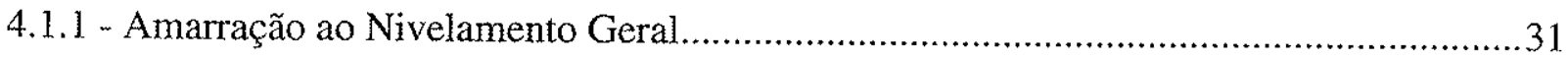

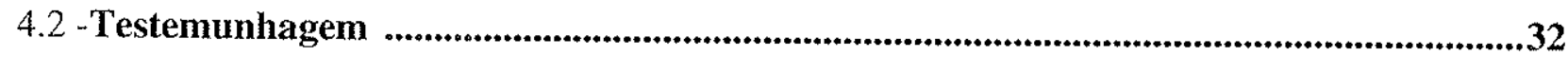

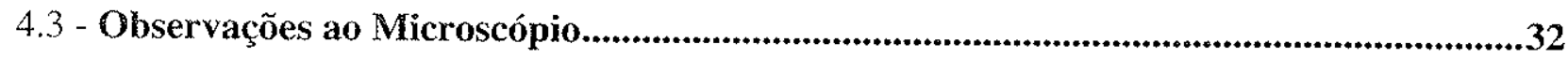

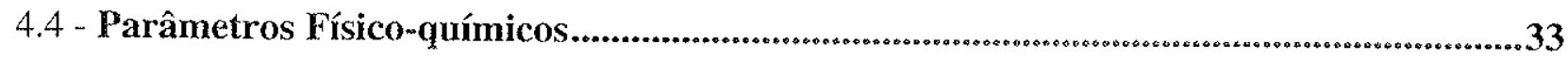

4.4.1 - Carbonato, Nitrogênio, Carbono Orgânico ...............................................................33

4.4.2 - Datações pelo Radiocarbono e Análises Isotópicas ...................................................33 
4.5.1 - Processamento das Amostras de Microorganismos ...................................................... 34

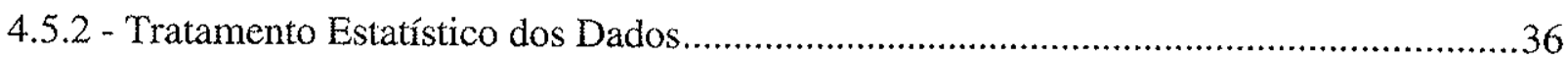

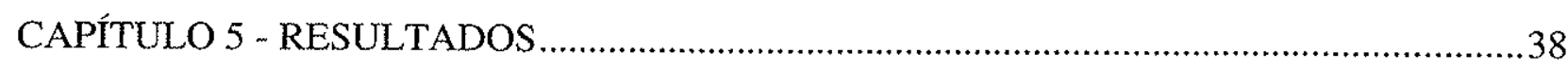

5.1 - Seções Topográficas Transversais das Bordas Lagunares ............................................38

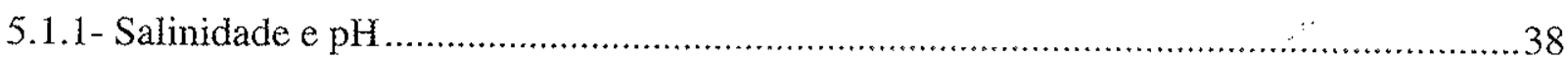

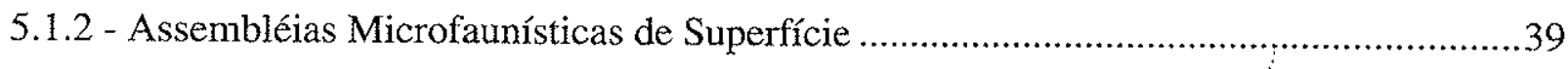

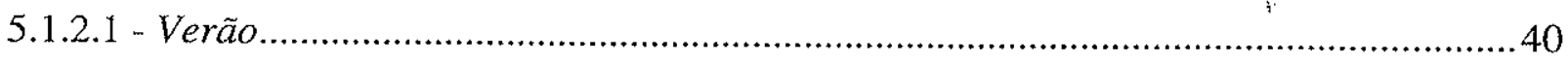

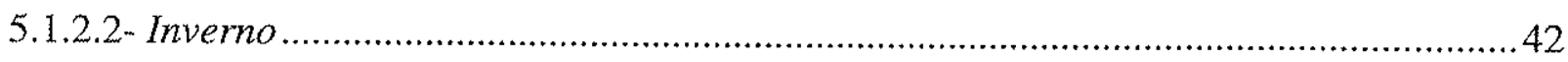

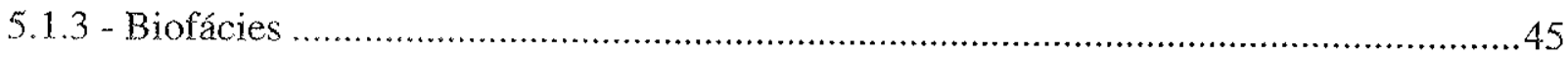

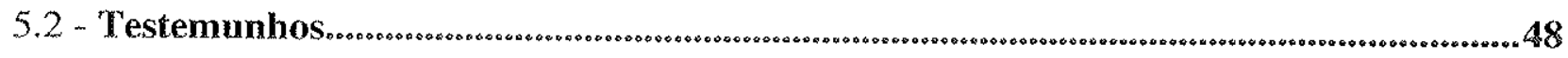

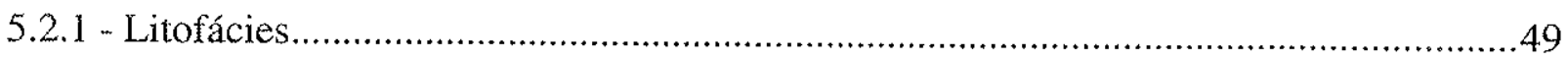

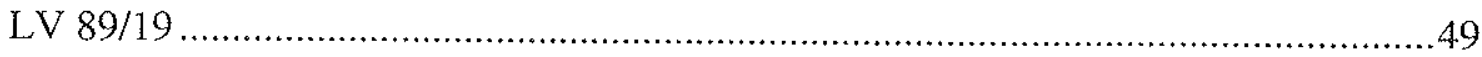

Resultados Geoquímicos e Isotópicos em LV 89/19 ........................................50

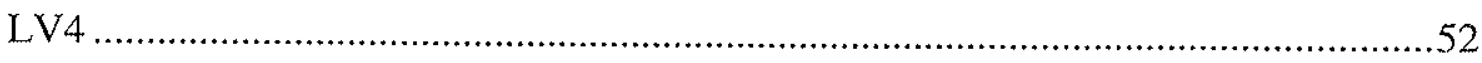

Resultados Geoquímicos e Isotópicos em LV 4 ................................................53

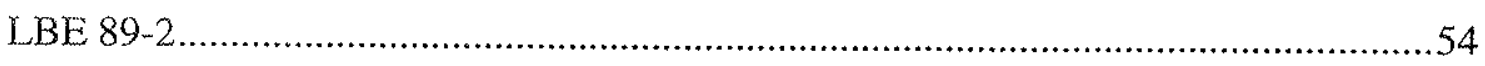

Resultados Geoquímicos e Isotópicos em LBE 89-2 ….......................................56

5.2.2- Assembléias Microfaunísticas nos Testemunhos........................................................56

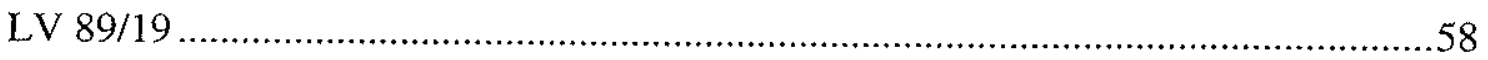

Flutuações do Nivel Relativo do Mar e Índice de Sedimentação em LV89/19 ........59

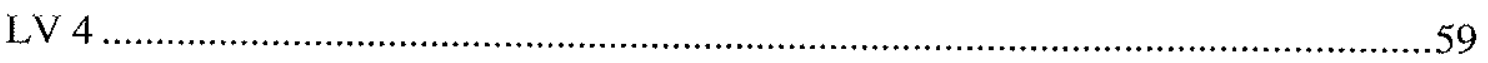

Flutuações do Nivel Relativo do Mar e Índice de Sedimentação em LV4 ..............60

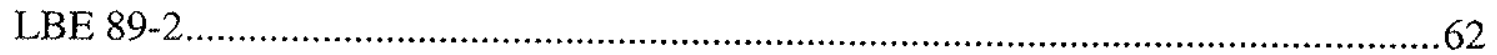

Flutuações do Nível Relativo do Mar e Índice de Sedimentação em LBE 89-2 ....62

CAPÍTULO 6 - INTERPRETAÇÕES E DISCUSSÃO ….....................................................65

6.1 - Interpretação Paleoambiental e das Flutuações do Nível do Mar.....................................67

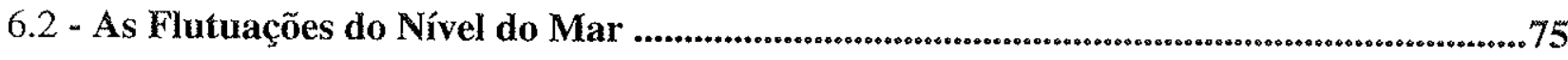

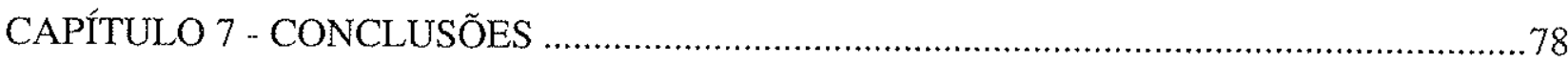

REFERÊNCIAS BIBLIOGRÁFICAS

ANEXOS

TAXONOMIA

GLOSSÁRIO

ESTAMPAS

REFERENCIAS BIBLIOGRÁFICAS DA TAXONOMIA E SINONÍMIA 


\section{ÍNDICE DE FIGURAS}

Fig. 1 - Mapa geológico esquemático e de localização.

Fig. 2 - Curva das variações do nível do mar holocênico para a costa central brasileira, mostrando a alternância entre momentos de submersão e de emersão para os últimos 7:000 anos A. P.

Fig. 3 - Vista da seção 2 - Araruama - mostrando aspecto da praia lagunar.

a - zona supralitorânea

b - zona de arrebentação da laguna

c - perfil esquemático das bordas lagunares

Fig. 4 - Aspecto da borda do Sabkha Brejo do Espinho no verão

Fig. 5 - Detalhe das crostas de tapetes algálicos na fácies supramaré do Brejo do Espinho

Fig. 6 - Detalhe das crostas de tapetes algálicos na fácies intermaré do Brejo do Espinho

Fig. 7A-C - Seção topográfica transversal, abundância absoluta e porcentagem de ocorrência de foraminíferos no verão na seção 1- Araruama (Praia da Pontinha).

Fig. 8 A-C - Seção topográfica transversal, abundância absoluta e porcentagem de ocorrência de foraminíferos no verão na seção 2 - Araruama (Faculdade de Veterinária-UFF).

Fig. 9 A-C-Seção topográfica transversal, abundância absoluta e porcentagem de ocorrência de foraminíferos no verão na seção 3 - Araruama (Porto da Aldeia)

Fig.10 A-B-Seção topográfica transversal, e porcentagem de ocorrência de foraminíferos no verão na seção 4- Araruama (Praia da Figueira)

Fig. 11 A-C- Seção topográfica transversal, abundância absoluta e porcentagem de ocorrência de foraminíferos no verão na seção 5- Araruama (Próximo ao rio das Moças)

Fig. 12 A-C- Seção topográfica transversal, abundância absoluta e porcentagem de ocorrência de foraminíferos no verão na seção 6 - Brejo do Espinho

Fig. 13 A-C- Seção topográfica transversal, abundância absoluta e porcentagem de ocorrência de foraminíferos no verão na seção 7- Lagoa Vermelha

Fig. 14 - Seção topográfica transversal no verão na seção 8- Laguna de Saquarema (Fora)

Fig. 15 A-B-Seção topográfica transversal, e porcentagem de ocorrência de foraminíferos no verão na seção 9 - Laguna de Saquarema (Boqueirão)

Fig. 16 A-B- Seção topográfica transversal, e porcentagem de ocorrência de foraminíferos no verão na seção 10 - Laguna de Saquarema (Urussanga)

Fig. 17 A-B- Seção topográfica transversal, e porcentagem de ocorrência de foraminíferos no verão na seção 11 - Lagoa de Jacarepiá

Fig. 18 A-C- Seção topográfica transversal, abundância absoluta e porcentagem de ocorrência de foraminíferos no inverno na seção 1- Araruama (Praia da Pontinha).

Fig.19 A-C- Seção topográfica transversal, abundância absoluta e porcentagem de ocorrência de foraminíferos no inverno na seção 2- Araruama (Faculdade de Veterinária-UFF)

Fig. 20 A-C-Seção topográfica transversal, abundância absoluta e porcentagem de ocorrência de foraminíferos no inverno na seção 3- Araruama (Porto da Aldeia). 
Fig. 21 A-B-Seção topográfica transversal, e porcentagem de ocorrência de foraminíferos no inverno na seção 4 - Araruama (Praia da Figueira)

Fig. 22 A-C-Seção topográfica transversal, abundância absoluta e porcentagem de ocorrência de foraminíferos no inverno na seção 5- Araruama (Próximo ao rio das Moças)

Fig. 23 A-B-Seção topográfica transversal, e porcentagem de ocorrência de foraminíferos no inverno na seção 6- Brejo doEspinho

Fig. 24 A-B- Seção topográfica transversal, e porcentagem de ocorrência de foraminíferos no inverno na seção 7 Lagoa Vermelha

Fig. 25 - Seção topográfica transversal no inverno da seção 8 - Laguna de Saquarema (Fora)

Fig. 26 A-B-Seção topográfica transversal, e porcentagem de ocorrência de foraminíferos no inverno na seção 9- Laguna de Saquarema (Boqueirão)

Fig. 27 A-B-Seção topográfica transversal, e porcentagem de ocorrência de foraminúferos noinverno na seção 10- Laguna de Saquarema (Urussanga).

Fig. 28 A - Dendrogramas hierárquicos mostrando a classificação das amostras das seções 1 a 5 da Laguna de Araruama no verão e inverno.(B)- Agrupamentos de biofácies para o verão e inverno nas seções 1 a 5 na laguna de Araruama reconhecidos pela análise de agrupamento. A tabela de resultado refere-se a análise sintetizada.

Fig. 29 - Dendrogramas hierárquicos mostrando a classificação das amostras das seções 6-7 das Lagoas Vermelha e Brejo do Espinho no verão e inverno.

Fig. 30-Dendrogramas hierárquicos com a classificação das amostras das seções 9-11 das Lagoas de Saquarema no verão e inverno e Jacarepiá no verão. A análise de agrupamento separou quatro grupos para o verão e três grupos para o inverno, no entanto,outro agrupamento conjugado demonstrou a possibilidade de agrupamento sazonal.

Fig. 31 - Fotomontagem da associação de litofácies paleolagunares do testemunho LV 89/19 mostrando estruturas sedimentares, descrições litofaciológicas, datações e identificação das lâminas delgadas (A,B). A descrição está detalhada no texto.

Fig. 32 - Fotomontagem da associação de litofácies paleolagunares do testemunho LV4 mostrando estruturas sedimentares, descrições litofaciológicas, datações e identificação das lâminas delgadas $(C, \ldots I)$. As lâminas delgadas $E$ e $G$ estão ilustradas e a escala equivale a 750 $\mu \mathrm{m}$ e o aumento é de 2,5x, nicóis cruzados. Adescrição está detalhada no texto.

Fig. 33 - Fotomontagem da associação de litofácies paleolagunares do testemunho LBE 89-2 mostrando estruturas sedimentares, descrições litofaciológicas, datações e identificação das lâminas delgadas $(\mathrm{J}, \ldots \mathrm{T})$. A lâmina delgada $\mathrm{J}$ está ilustradas e a escala equivale a $750 \mu \mathrm{m}$ e o aumento é de $2,5 x$, nicóis cruzados. Adescrição está detalhada no texto.

Fig. 34 - Fotografias das lâminas delgadas dos intervalos M,N,P,Q,S,T da base para o topo da fácies 6 do testemunho LBE 89-2. A localização no testemunho deve ser vista na figura 33 .

Fig. 35-A-F- (A) Abundância absoluta de espécimens em $10 \mathrm{~cm}^{3}$ ao longo do testemunho LV 89/19. (B-F) Abundância relativa de espécies que ocorrem com frequiência acima de $4 \%$.

Fig. 36 - A.E- (A) Abundância absoluta de espécimens em $10 \mathrm{~cm}^{3}$ ao longo do testemunho LV4. (B-E) Abundância relativa de espécies que ocorrem com freqüência acima de $4 \%$.

Fig. 37 - A.E- (A) Abundância absoluta de espécimens em $10 \mathrm{~cm}^{3}$ ao longo do testemunho LBE 89-2. (B-E) Abundância relativa de espécies que ocorrem com frequiência acima de $4 \%$. 
Fig. 38- Curva de variação do nível relativo do mar para a área de Cabo Frio com base em biofácies de foraminíferos definidas no testemunho LV 89/19 da Lagoa Vermelha.

Fig. 39- Curva de variação do nível relativo do mar para a área de Cabo Frio com base em biofácies de foraminíferos definidas no testemunho LV 4 da Lagoa Vermelha.

Fig. 40- Curva de variação do nível relativo do mar para a área de Cabo Frio com base em biofácies de foraminíferos definidas no testemunho LBE 89-2 da sabkha Brejo do Espinho.

\section{ÍNDICE DE TABELAS}

Tab. 1 - Dados climáticos de Cabo Frio e Iguaba Grande

Tab. 2 - Dados climáticos e oceanográficos da laguna de Saquarema

Tab. 3 - Dados de maré do Porto do Forno

Tab. 4 - Localização, profundidade da água e comprimento dos testemunhos

Tab. 5 - Dataçöes de ${ }^{14} \mathrm{C}$ das amostras dos testemunhos lagunares

Tab. 6 - Dados físico-químicos das amostras superficiais de verão e inverno nas bordas lagunares.

Tab. 7 - Porcentagem de ocorrência de foraminíferos ao longo da seção 1 no verão.

Tab. 8 - Porcentagem de ocorrência de foraminiferos ao longo da seção 2 no verão.

Tab. 9 - Porcentagem de ocorrência de foraminíferos ao longo da seção 3 no verão.

Tab. 10 - Porcentagem de ocorrência de foraminíferos ao longo da seção 4 no verão.

Tab. 11 - Porcentagem de ocorrência de foraminíferos ao longo da seção 5 no verão.

Tab. 12 - Porcentagem de ocorrência de foraminíferos ao longo da seção 6 no verão.

Tab. 13 - Porcentagem de ocorrência de foraminíferos ao longo da seção 7 no verão.

Tab. 14 - Porcentagem de ocorrência de foraminíferos ao longo da seção 8 no verão.

Tab. 15 - Porcentagem de ocorrência de foraminíferos ao longo da seção 9 no verão.

Tab. 16 - Porcentagem de ocorrência de foraminíferos ao longo da seção 10 no verão.

Tab. 17 - Porcentagem de ocorrência de foraminíferos ao longo da seção 11 no verão.

Tab. 18 - Porcentagem de ocorrência de foraminíferos ao longo da seção 1 no inverno.

Tab. 19 - Porcentagem de ocorrência de foraminíferos ao longo da seção 2 no inverno.

Tab. 20 - Porcentagem de ocorrência de foraminíferos ao longo da seção 3 no inverno.

Tab. 21 - Porcentagem de ocorrência de foraminíferos ao longo da seção 4 no inverno.

Tab. 22 - Porcentagem de ocorrência de foraminíferos ao longo da seção 5 no inverno.

Tab. 23 - Porcentagem de ocorrência de foraminíferos ao longo da seção 6 no inverno.

Tab. 24 - Porcentagem de ocorrência de foraminíferos ao longo da seção 7 no inverno.

Tab. 25 - Porcentagem de ocorrência de foraminf́feros ao longo da seção 8 no inverno.

Tab. 26 - Porcentagem de ocorrência de foraminíferos ao longo da seçấo 9 no inverno.

Tab. 27 - Porcentagem de ocorrência de foraminíferos ao longo da seção 10 no inverno. 
Tab. 28 - Porcentagem de ocorrência de foraminíferos no testemunho LV4.

Tab. 29 - Porcentagem de ocorrência de foraminíferos no testemunho LV89/19.

Tab. 30 - Porcentagem de ocorrência de foraminíferos no testemunho LBE 89/2. 


\section{AGRADECIMENTOS}

Agradeço ao Prof. Dr. Kenitiro Suguio pela confiança sempre demonstrada e liberdade de criação.

A ORSTOM pelo apoio financeiro e logístico e nas etapas de cãñpo, bem como pelo fornecimento dos testemunhos e alguns dados através dos Professores Louis Martin e Bruno Turcq.

Ao Centro de Pesquisas Manoel Teixeira da Costa (CPMTC/UFMG) e aos professores Lydia Lobato, Allaoua Saadi, Carlos Alberto Rosière e Antônio Gilberto Costa.pelo apoio desde o início deste trabalho, facilitando a utilização de seus laboratórios e equipamentos

A PETROBRÁS pela oportunidade do estágio nas dependências do CENPES /DIVEX/ SEBIPE e DIGER e ao seu corpo técnico Adali Ricardo Spadini, Eduardo Koutsoukos, José Henrique, Paulo Milhomem, Ricardo Latgé, Rosely de Araújo Marçal, Uyara Mundim Praça. Aos técnicos Ligia, Fabiano Loureiro e Rocir Gonçalves pela realização das fotomicrografias. Um agradecimento especial a Ms. Alita C. F. Mesquita pelo constante apoio, conselhos e sugestões.

Ao colega Prof. Aristóteles Rios Netto que contribuiu com a leitura crítica do texto da taxonomia bem como com as ricas discussões e receptividade a utilização do laboratório e lupa do IG/UFRJ e a colega Claudia Gutterres Vilela pelas dicas sempre bem vindas.

Ao Prof. Dr. Ricardo Absalão [B/UFRJ pelas discussões na classificação dos gastrópodes. E ao Prof. Dr João Carlos Coimbra IG/ UFRGS pela confirmação da classificação dos ostracodes e discussões. A Pamela Hallock, University of South Florida e John Lee pela tentativa de esclarecimento quanto as micro-crostas carbonáticas. A Benjamin Sloan, University of Texas, Austin pelo banco de dados sobre Ammonia.

Ao Prof. Dr. Harry F.L. Williams (University of North Texas) por auxiliar na interpretação da curva de variação do nível relativo do mar a partir das biofácies.

A amiga Jessica B. Carvalho/ UNB pelo constante apoio e colaboração.

$\mathrm{E}$ a todos aqueles que mesmo indiretamente contribuíram com pensamentos positivos para a efetivação deste trabalho. 


\section{CAPÍTULO 1}

\section{1 - INTRODUÇÃO}

O ambiente transicional de áreas lagunares apresenta alto potencial de preservação devido à fraca influência exercida por ondas, marés e correntes, que acarretam fenômenos de erosão e deposição.

Desta forma a dinâmica das bordas lagunares, com comunicação restrita com o mar aberto, é diferente das lagoas totalmente fechadas. De uma maneira geral, materiais autóctones e alóctones contribuem para a sedimentação, sendo o primeiro dependente da variação na direção do vento e circulação da água, promovendo diferentes processos autigênicos bióticos/ abióticos e o segundo determinado por transporte de sedimentos clásticos e orgânicos derivados das áreas adjacentes. As lagunas que apresentam comunicação com o mar, mesmo restrita, recebem sedimentos marinhos transportados por correntes de maré residuais (Meade 1969), além dos normalmente transportados pelo vento e pelos cursos de água, comuns também à lagoas fechadas.

As características desta interface terrestre lagunar são refletidas não só no tipo de sedimento, como também nas composições faunística e botânica desses ambientes. Como resultado, esta interface exibe biozonas que se deslocam de acordo com a posição do nível lagunar, com variação nas assembléias representativas de cada biofácies, expressas em pequena amplitude vertical.

Deste modo, a interpretação paleoambiental dos depósitos de interface terrestre lagunar, baseada em biozoneamentos topográficos atuais, fornece dados relativamente precisos, das antigas posições do nível de água lagunar e, consequientemente, do nível do mar adjacente.

Lagunas fechadas tornam-se locais ideais ao desenvolvimento de ciclos transgressivosregressivos, respondendo de maneira sensível as variações nas intensidades de evaporação, pluviosidade e influxo fluvial. Por outro lado, lagunas com comunicações permanentes com o oceano aberto, tendem a apresentar linhas de costa mais estáveis, com sedimentação química e bioquímica e de clásticos marinhos, uma vez que o influxo fluvial (inflow) e a precipitação são balanceados pelo fluxo costa afora (outflow) e evaporação (Alen e Collinson 1986; Glenn e Kelts 1991).

Áreas com intensa deposição carbonática, como a estudada neste trabalho, favorecem a preservação dos componentes bióticos carbonáticos, contrariamente às áreas de baixo pH. As 
biofácies definidas por foraminíferos bentônicos com assembléias mundialmente reconhecidas, marcando zonas em função de sutis variações topográficas, evidenciam pequenas flutuações de nível do mar nas áreas intermarés de pântanos salinos. Constituem assim, ferramenta muito útil na interpretação paleoambiental dessa interface, com alta precisão na definição das flutuações relativas do nível do mar, permitindo a distinção de bioecozonas* altas (marés de sizígia e/ou tempestades em áreas lagunares) médias e baixas em subsuperfície.

A reconstituição da história evolutiva do nível relativo do mar na área estudada, será baseada em idades absolutas, fornecidas por datações pelo método do radiocarbono, por informações fornecidas pelos foraminíferos como biomindicadores, originadas à partir dos zoneamentos atuais nas superfícies das bordas lagunares, além das evidências estratigráficas, isotópicas e sedimentológicas obtidas dos testemunhos. Outros bio-indicadores, como tecamebas, ostracodes, gastrópodes e carófitas, ocorrentes nas bordas lagunares e ao longo dos testemunhos, serão considerados nas interpretações.

Os termos supramaré, intermaré e submaré serão usados e o termo perimaré será aplicado para designar fácies sob influência de maré, independente de posicionamento na planície de maré.

O objetivo desse estudo é a definição de assembléias de foraminíferos que caracterizem zonas da interface terrestre-lagunar de cinco áreas lagunares com diferentes regimes de salinidade. São elas lagunas de Araruama e de Saquarema e as lagoas Vermelha, Brejo do Espinho e Jacarepiá (Fig. 1). As biofácies reconhecidas são utilizadas na interpretação dos paleoambientes deposicionais representados por três testemunhos, (dois da lagoa Vermelha - LV4 e LV-89/19 - e um do Brejo do Espinho - LBE-89/2) relacionadas à história evolutiva do nível relativo do mar e conseqüentes mudanças na sedimentação dessas lagunas. As lagunas recebem forte influência do clima local, com características semi-áridas, causando intensa deposição carbonática.

Em detalhe, este estudo terá como objetivos:

1 - Reconhecimento de mudanças sazonais nas assembléias de microorganismos das bordas lagunares. A amostragem superficial dessas áreas em diferentes estações mostra que mudanças climáticas podem mascarar assembléias definidas para o nível mais alto atingido pela água em condições de maré de sizígia e/ou tempestade, podendo faĩsear os resultados. Isto ocorre uma vez que as fácies sedimentares em ambientes lagunares de micromarés são de difícil reconhecimento, o que torna sua correlação complicada e relaçōes faciológicas complexas.

\footnotetext{
*Bioecozonas correspondem a ecozonas com paleoambientes inferidos de seu conteúdo fóssil (Poag 1978)
} 
2 - Caracterizar a sucessão de depósitos antigos visando a reconstrução paleoambiental e das flutuações do nível do mar, e o registro das mudanças na sedimentação local com base nas biofácies definidas.

3 - Elaboração da curva local de variação do nível relativo do mar com base nas biofácies locais. 


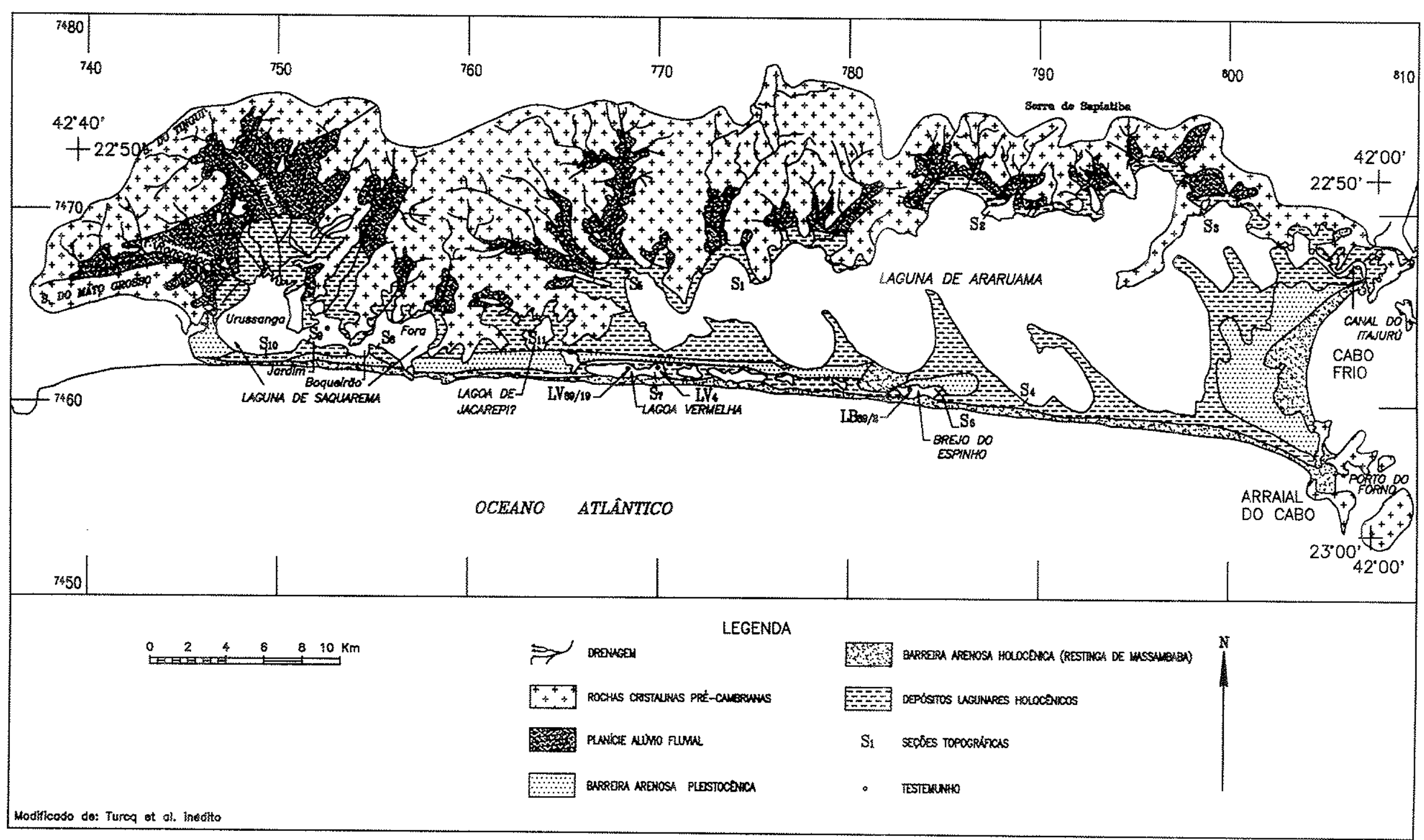

FIG.1 MAPA GEOMORFOLOGICO E DE LOCALIZACAO DAS AREAS DE ESTUdO E AMOSTRAGENS. 


\section{CAPÍTULO 2}

\section{2- TRABALHOS PRÉVIOS}

\section{1-Conceitos Gerais}

A origem dos chamados depósitos de restinga (aqui chamados como cordôes litorâneos) tem sido amplamente discutida. No entanto, trabalhos recentes tendem a considerar sua evolução como uma combinação de causas, isto é, progradação lateral e frontal de pontais arenosos (Ponçano et al. 1979) e a migração de ilhas-barreiras rumo ao continente, associada a oscilações transgressivas do nível relativo do mar (Coe Neto 1984; Dias e Silva 1984; Turcq et al. 1986; Muehe e Corrêa 1989). Suguio e Tessler (1984) discutem a gênese e nomenclatura para as planícies de cordões litorâneos, em substituição a denominação de planícies de restinga, uma vez que, para esses autores, as planícies litorâneas arenosas brasileiras são relacionadas a cordões regressivos.

As alcioudes dos cordôes inorâneos intemo e externo parecem refletir diferenças de alturas dos eventos transgressivos pleistocênicos e holocênicos, respectivamente, que deixaram registros em várias localidades da região sudeste do Brasil. Turcq et al. (inédito) postulam idade pleistocênica para o primeiro cordão uma vez que o topo dos mais altos está posicionado 6 a 10 ma acima do nível atual de maré alta.

\section{2 - Definição e Classificação de Lagunas Costeiras}

Para a classificação de lagos e lagunas, a origem era tomada como importante parâmetro até o trabalho de Reineck e Singh (1986). A partir dele o determinante climático, como controlador das características desses ambientes, é considerado. Allen e Collinson (1986) estabeleceram uma classificação objetiva, que é a adotada neste trabalho, distinguindo bacias lagunares hidrologicamente abertas das fechadas.

As bacias lagunares podem variar segundo as propriedades das suas águas e são denominados lagoas costeiras (quando hidrologicamente fechadas) e lagunas costeiras (quando hidrologicamente abertas). As lagunas situadas internamente ao primeiro cordão, são maiores e hidrologicamente abertas (com exceção de Jacarepiá); e as menores localizadas entre o primeiro 
e o segundo cordão litorâneo são hidrologicamente fechadas e recebem águas oceânicas por influência da percolação e por aerossol marinho.

Os lagos continentais ou lagoas e lagunas costeiras podem apresentar diferentes comportamentos em função de estratificação por temperatura do seu corpo aquoso. Lagos com estratificação térmica apresentam a porção superior mais aquecida e oxigenada, denominada epilímnio. Esta se apresenta sobreposta ao hipolímnio, mais frio e algumas vezes anóxico e sem turvação. O plano de separação térmica entre essas duas camadas é denominado de termoclínio (Allen e Collinson 1986). Entretanto em lagoas tropicais, nas quais a variação sazonal na temperatura da água não é tão marcante como nos lagos temperados, os gradientes temais podem ser baixos e não exibem contrastes suficientes para o aparecimento da estratificação térmica.

Lagoas e lagunas costeiras são efêmeros e pequenos, apresentando gradiente vertical de temperatura, diretamente relacionado à radiação solar, variação na densidade da água, morfologia e tamanho da bacia, influxo fluvial e de maré. A diferença na densidade da água, por sua vez, é função não só da temperatura, mas também da concentração de sedimentos e salinidade. A densidade govena as características físico-químicas dos lagos e sua interaçăo. O decréscimo da densidade é proporcional ao aumento da temperatura (Allen e Collinson 1986).

As lagunas costeiras podem ser definidas, de acordo com Kjerfve e Magill (1989), como corpos de água litorâneos, paralelos a costa e separados do oceano aberto por uma barreira, conectadas à este por um canal de entrada (ou inlet) restrito, apresentando-se rasas, podendo ou não estar sujeitas a misturas de águas de características físico-químicas diferenciadas.

Kjerfve (1986) propõe classificação geomórfica de lagunas baseado na dinâmica, comportamento e processos formadores, em: lagunas confinadas (choked lagoons), restritas (restricted lagoons) e com vários canais (leaky lagoons). O primeiro tipo corresponde, em parte, aos aqui estudados, sendo comumente encontradas ao longo de regiões costeiras dominadas por micromarés, com alta energia de ondas e significativa deriva litorânea. São caracterizadas por um canal de entrada longo e estreito, tempo de residência longo (limitada troca entre a água do sistema e as águas oceânicas) força do vento dominante, baixas profundidades e grandes flutuações de salinidade, principalmente em resposta a eventos climáticos locais e hidrológicos. Portanto, são mais suscetíveis à eutrofização, assoreamento e poluição (Kjerfve e Knoppers 1991).

Entre as aqui estudadas, as lagunas de Araruama e Saquarema enquadram-se dentro da definição de lagunas confinadas, de Kjerfve e Knoppers (1991), e apresentam um canal de entrada muito estreito. A lagoa de Jacarepiá encontra-se totalmente isolada bem como a lagoa 
Vermelha e Brejo do Espinho. Essas duas últimas, que foram as estudadas em maior detalhe neste trabalho, também apresentam as características gerais, acima descritas, que definem esses sistemas e poderiam ser classificadas como lagunas confinadas se apresentassem comunicação com o mar aberto; como isso não ocorre, serão consideradas nesse trabalho, como lagoa hipersalina e sabkha costeira (Suguio 1992), respectivamente.

\section{3 - Mudanças do Nível Relativo do Mar}

A evolução geológica mais recente da área de estudo está vinculada às flutuações do nível relativo do mar durante o Quaternário, reconhecidas ao longo do litoral brasileiro, que moldam as feições deixando registros sedimentológicos, biológicos e pré-históricos.

A transgressão ocorrida no Pleistoceno Superior em escala mundial (Bloom et al. 1974, Chapell 1983) pôde ser datada na costa brasileira com base em cinco amostras de corais, encontrados na base de um terraço marinho no sul do Estado da Bahia, pelo método do Io/U, que forneceu idade média de $123.000 \pm 5.700$ anos A.P., (Martin et al. 1982), atribuível ao estádio interglacial Sangamoniano (Riss-Wüm). Essa transgressão deixou poucos registros datáveis ao longo da costa brasileira.

Os arenitos essencialmente marinhos, de cor marrom escura, freqüentemente impregnados por ácidos húmicos, presentes na costa S-SE, em alguns locais apresentando estratifícações preservadas, e ocorrência de tubos fósseis de Callichirus, correspondem aos depósitos da Formação Cananéia, deixados pela transgressão do Pleistoceno Superior. São análogos aos depósitos aflorantes próximos ao Delta do Paraíba do Sul, e estão presentes na ilha-barreira interna de Massambaba. Este arenito apresenta se também na base dos testemunhos aqui analisados, abaixo da discordância que separa estes depósitos dos depósitos lagunares interbarreiras, datados em $7170 \pm 110$ anos A. P., (datação da base do depósito lagunar), e anteriores portanto, à última transgressão Holocênica. A idade pleistocênica atribuída por Martin e Suguio (1989) para os depósitos da primeira ilha-barreira (mais interna), era objeto de controvérsia. No entanto, a sua ocorrência na base desses testemunhos parece dissipar qualquer dúvida.

As reconstituições temporais e espaciais são melhor estabelecidas para os eventos holocênicos, embora ainda não tenham sido sistematicamente estudadas nesta porção da costa. Para essa trecho do litoral, a curva de flutuaçăo do nível do mar holocênico adotada corresponde à elaborada para o Estado da Bahia, (Fig.2), a qual apresenta tendência diagnosticada de nível do 
mar mais alto a 5.100 anos A.P., quando atingiu altitude máxima de + 3.5 a $4.7 \mathrm{~m}$ (Martin et al. 1984) acima do nível atual.

Turcq et al.(inédito) discutem a evolução geológica quaternária do Estado do Rio de Janeiro, com mapeamento geológico em nível de reconhecimento, dos depósitos costeiros presentes na área de estudo e consideram que duas oscilações com aproximadamente 2 e 3 metros acima do atual ocorreram após a última transgressão e podem ser consideradas de origem principalmente glácio-eustática. Em resumo, são reconhecidos três episódios de submersão (7.000-5.100; 3900-3.600; 2.700-2.500 anos A.P.) intercalados a outros três de emersão (5.100$3.900 ; 3.600-2.700 ;$ e após 2.500 anos A.P.) (Fig. 2). Acredita-se que alguma variação na amplitude vertical dos picos entre a curva de flutuação do nível do mar elaborada para a Bahia e da área de estudo possa ocorrer. Os mecanismos de sedimentação litorânea atuantes sob baixa influência fluvial, clima semi-árido local e tendência a subsidência conhecida ( Martin et al. 1984), poderiam eventualmente explicar as variações nas amplitudes dos picos da curva estabelecida.

Kowsmann e Costa (1979) interpretaram a escarpa da plataforma continental superior de Cabo Frio, posicionada na isóbata de $110 \mathrm{~m}$, como remanescente de antiga face praial, juntamente com as isóbatas de $-130,-110,-90,-75,-60$, e -40 metros, admitindo idades holocênicas para todas elas (considerando-se o início do Holoceno em 14.000 anos A. P.). Esses dados sugerem que existe um gap de informações de integração entre os dados obtidos em área emersa e os obtidos em área submersa, bem como os subsuperficiais, principalmente em termos de duração, freqüencia e intensidade dos eventos. Para a planície deltaica do rio Paraíba do Sul, que difere em sua gênese das áreas aqui analisadas, Dias et al. (1984) fizeram a correlação entre as espessuras de camadas subsuperficiais e o desnível batimétrico, observando uma coincidência da faixa de ocorrência de sedimentos correlacionáveis no fundo submarino adjacente.

Para o posicionamento preciso do nível médio do mar atual (nível médio da maré neste estudo), o regime de marés, bem como a amplitude da maré de sizígia local, são considerados de modo a se estabelecer a margem de erro $(\mathrm{em} \mathrm{cm}$ ) para as antigas zonas marginais superiores, ficando estabelecido, de acordo com Jardine (1986), o indicador do nível do mar com a distância vertical do ponto acima de um datum de referência. Em outras palavras, a altitude precisa dos indicadores bióticos atuais deve ser determinada para que se possa correlacioná-los corretamente a uma altitude original nos testemunhos. 


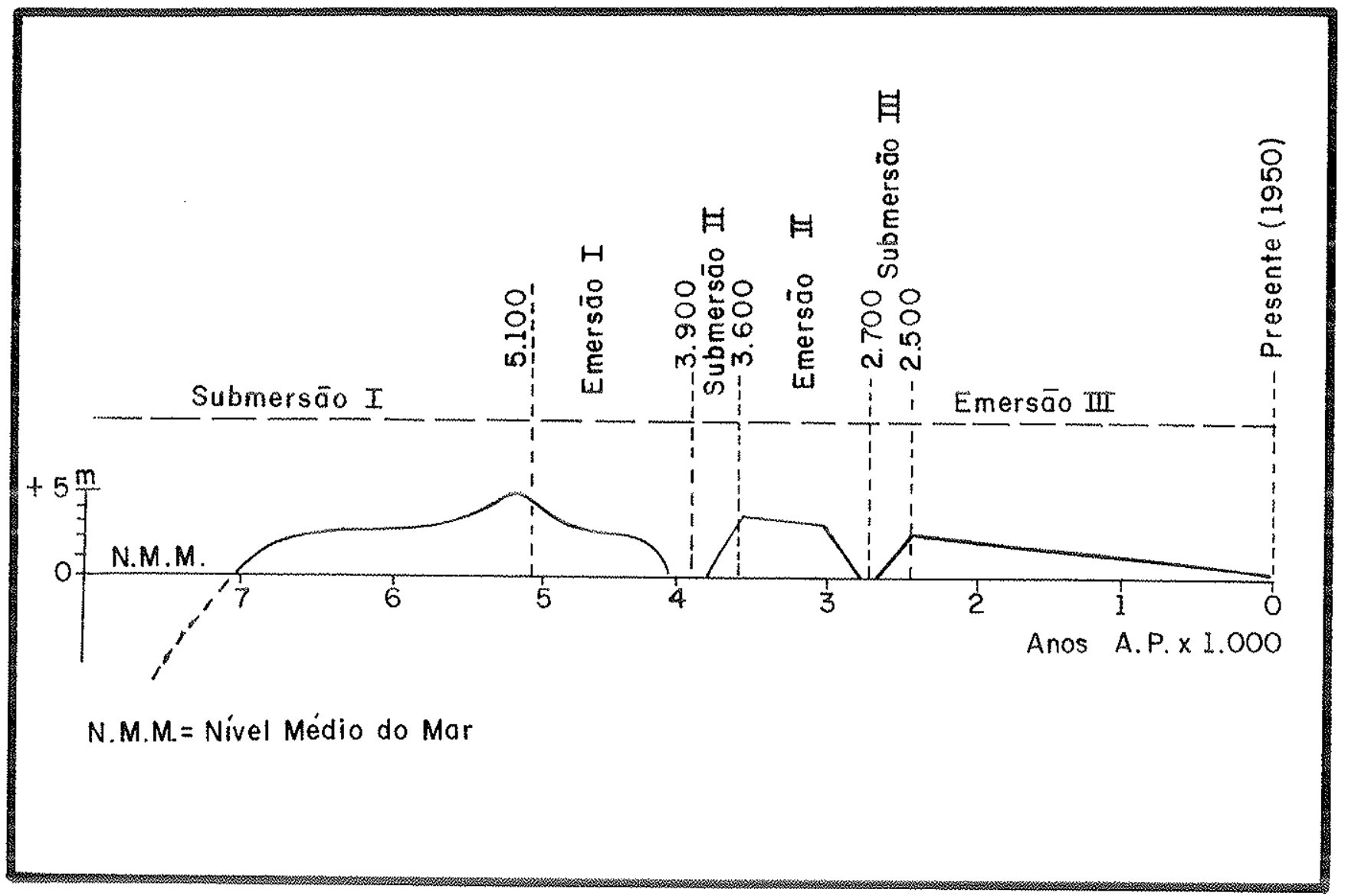

Fig. 2 -Curva das variações do nível do mar holocênico para a costa central brasileira, mostrando a alternância entre momentos de submersão e emersão para os últimos 7.000 anos A.P. (Martin et al. 1979).

\section{4- Reconstituição de Antigos Níveis Marinhos -}

\subsection{1 - Os Indicadores bióticos}

Os métodos atuais de reconstituição de antigos níveis marinhos (pelo uso de depósitos praiais, de turfa, terraços marinhos, níveis de conchas, ostras, depósitos de manguezais, e plantas dentre outros) não são muitas vezes, suficientemente precisos para detectar possíveis mudanças mínimas nos níveis marinhos. A alta resolução da análise biofaciológica de foraminíferos no comportamento das curvas de variação do nível do mar, principalmente para o Quaternário Superior, supera a de outros indicadores comumente utilizados, devido ao pequeno volume de amostras necessário para obtenção dos dados, facilidade de comparação entre áreas bem como pequena amplitude vertical ocupada pelas assembléias atuais nas superfícies dos pântanos salinos quando preservados em subsuperfície.

Depósitos de manguezais, por exemplo, ocupam a porçăo superior completa de uma amplitude de maré, com variaçăo topográfica de 1 a $2,5 \mathrm{~m}$. As assembléias botânicas indicariam precisamente os níveis de maré (Chapman 1960), mas os remanescentes das plantas são 
pobremente preservados em depósitos de subsuperfície, dificultando a diferenciação florística. Talvez estudos palinológicos possam ser utilizados.

Para as zonas supralitorâneas tropicais do Brasil, Laborel (1979) aponta como bioindicador o gastrópode Littorina zigzag brasiliensis e um crustáceo do gênero Ligia, mas segundo este autor esses não constituem bons biomarcadores, uma vez que não deixam remanescentes fósseis interpretáveis. Para esse autor, o resto de um organismo marinho indica um paleonível do mar se, ele permanecer in situ e em sua posição de crescimenton. A altura do paleonível do mar será melhor medida pela diferença de altitude entre o resto fóssil e seu vivente homólogo, porém essas medidas não devem ser tomadas em zonas batidas por ondas, devido a problemas de deslocamento das zonas faunísticas e, por esta mesma razão, nunca deve ser medida uma zona fóssil em relação ao mesmo fóssil vivente em outro local, mesmo que próximo.

Considera-se zoneamento como o estabelecimento da distribuição vertical de organismos em faixas paralelas à linha de costa em resposta a uma ou mais variações verticais dos fatores ecológicos. A zona supramaré, por ser relativamente estreita em ambientes de águas calmas, será a zona de maior interesse nesse estudo, onde um bioindicador uma vez definido e comparado com seu remanescente fóssil, quando presente, poderá diminuir a incerteza de definição do nível relativo do mar.

Os foraminíferos, são geralmente bem preservados em sedimentos de subsuperfície. As tecas aglutinadas, comuns em ambientes estagnantes, são capazes de se preservar sob condições de baixo pH sem desintegração de suas carapaças, embora nesses ambientes as bactérias possam destruí-las. As tecas carbonáticas apresentam baixo potencial de preservação nesses ambientes, mas o seu potencial de preservação é bom em ambientes mais alcalinos e ricos em carbonatos.

Como os foraminíferos exibem zoneamento vertical análogo às plantas (Scott e Medioli 1980, Barbosa 1991), constituem também valiosa ferramenta para o estudo mais preciso de mudanças do nível do mar durante o Quaternário.

\subsection{2- Zoneamento de Assembléias de Foraminíferos}

A microfauna de foraminíferos viventes em ambientes muito próximos ou nas lagunas do Rio de Janeiro aqui estudadas, já foi objeto dos estudos de Tinoco (1955, 1958), Ribas (1969, 1973), Rodrigues et al. (1981), Dias et al.. (1983), Dias e Silva (1984), Madeira e Carvalho (1992). No Brasil, embora já se tenha caracterizado as assembléias ocorrentes em ambientes marinhos marginais, há uma carência de dados quantitativos e zoneamentos passíveis de 
aplicação paleoambiental. Zoneamentos quantitativos das assembléias de foraminúferos e tecamebas atuais foram, pela primeira vez, elaborados por Barbosa (1991) no sistema estuáriomanguezal de Guaratuba (PR).

A observação de variações nas assembléias de foraminíferos na superfície das áreas litorâneas, iniciou-se com os trabalhos de Phleger (1965). A partir desse estudo, os padrões de distribuição observados têm sido relacionados a diversas variáveis ambientais, tais como salinidade, pH e topografia (Phleger, 1966, 1967, 1970; Phleger e Bradshaw, 1966, Bradshaw, 1968 e Murray, 1971, 1973), já mostrando assim uma tendência de interação entre diversas variáveis na explicação desses padrões.

A identificação dos limites das biofácies ocupadas pelos foraminíferos, segundo variações topográficas, iniciou-se com Scott (1976) na Califórnia, e posteriormente aplicou-se à diversas regiões, objetivando reconstituir antigos níveis marinhos (Scott, 1977; Scott e Medioli, 1978, 1980, 1982, 1986; Scott et al.. 1979, 1990; Scott e Martini, 1982). Apesar de considerar outras variáveis na análise de seus trabalhos, a elevação acima do nível médio do mar toma lugar de destaque nas interpretações dos ambientes de clima temperado analisados. A partir dos estudos de Scott et al.., 1990; Barbosa, 1991, as comparações em termos globais e entre salt marshes e manguezais começam a ser elaboradas.

Os zoneamentos superficiais das assembléias de foraminíferos e tecamebas atuais, aplicados em subsuperfície, tem fornecido as bases para diversas interpretações paleoambientais (Steineck e Bergstein, 1979; Petrucci et al..,1983; Smith et al.., 1984; De Vernal et al..,1984; Williams, 1989, 1994).

Apesar de muitos estudos em áreas de pântanos salinos de diversos locais, somente nos trabalhos mais recentes outros autores têm elaborado o zoneamento proposto por Scott e Medioli $(1978,1986)$. Williams (1989) aplicou o zoneamento de foraminíferos atuais do delta do rio Fraser (Canadá) na interpretação dos paleoambientes deposicionais em testemunhos e reconheceu uma regressão marinha da ordem de 4 a $5 \mathrm{~m}$ durante o Holoceno Médio. Culver (1990) realizou o primeiro zoneamento e quantificação de foraminíferos atuais de ambiente marinho marginal de manguezal-laguna na plataforma carbonática de Porto Rico. Scott e Leckie (1990) definiram o zoneamento vertical atual nos pântanos salinos do Sul da Nova Inglaterra para a interpretação dos depósitos de turfa em subsuperfície. Jennings e Nelson (1992) mostram que as assembléias de foraminíferos, em seções feitas na costa central do Oregon refletem o zoneamento botânico, relacionando-as aos níveis de maré e como a submergência durante eventos de terremotos podem ser estimadas a partir de foraminíferos fósseis. Gehrels (1994) encontrou assembléias de salt marsh em Maine, similares àquelas encontradas por Scott no 
maritime Canada com $T$. macrescens f. macrescens como a espécie usualmente indicadora do nível do mar para a região. Williams (1994) documenta a distribuição de foraminíferos em três pântanos de maré com regimes de salinidade contrastantes na costa central do Golfo do México, no Texas, definindo seis biofácies aplicáveis a reconstrução do nível do mar local. Jennings et al.. (1995) distinguem para o pântano de maré superior do estuário de Valdívia no Chile a zona composta por Trochamminita salsa com base nas assembléias botânicas locais, entretanto a identificação de somente duas zonas faunísticas e nenhuma delas com pequena amplitude, limitou a utilização da assembléia de foraminíferos reconhecida para interpretação de antigos níveis marinhos nessa região, periodicamente afetada por terremotos. De Rijk (1995) através da amostragem em 12 seções nos pântanos de maré de Massachusetts, pelo período de 35 dias analisando em detalhe a salinidade, não confirma o conceito de zoneamento vertical das espécies, observando que a salinidade seria o principal controlador na distribuição faunística. No entanto, este autor admite fraca correlação entre salinidade e a distribuição encontrada em seu estudo e admite um coeficiente de correlação mais forte para a espécie $H$. manilaensis sugerindo a preferência dessa espécie a áreas mais elevadas. Para as outras espécies encontradas, a correlação é muito baixa, indicando nenhuma relação com a topografia local. 


\section{CAPÍTULO 3}

\section{3- ÁREA DE ESTUDO}

As lagunas costeiras estudadas são cinco e estão situadas ao longo da linha de costa subtropical norte do Estado do Rio de Janeiro. De leste para oeste tem-se:

- Laguna de Saquarema $\left(22^{\circ} 55^{\prime} \mathrm{S}, 42^{\circ} 33^{\prime} \mathrm{W}\right)$ com área de $18,3 \mathrm{~km}^{2}$, é composta de quatro setores (Urussanga, Jardim, Boqueirão e Fora ), todos apresentando-se mixohalinos e o Urussanga liga-se a partir de um estreito canal com a Laguna de Jaconé ( não analisada neste estudo) e o setor denominado Fora apresenta estreita ligação com o mar aberto (Fig. 1).

- Lagoa de Jacarepiá (22 $55^{\prime} \mathrm{S}, 42^{\circ} 23^{\prime} \mathrm{W}$ ) com uma área de $0,7 \mathrm{~km}^{2}$, é a única a apresentar salinidade nula, caracterizando-se como uma lagoa fechada, posicionada mais internamente entre a Laguna de Saquarema e Lagoa Vermelha.

- Laguna de Araruama $\left(22^{\circ} 53^{\prime} \mathrm{S}, 42^{\circ} 10^{\prime} \mathrm{W}\right)$ com uma área de $220 \mathrm{~km}^{2}$, posicionada atrás do primeiro cordão litorâneo, apresenta-se hipersalina e através do canal de Itajuru, com $8,3 \mathrm{~km}$, comunica-se com as águas oceânicas.

- Lagoa Vermelha $\left(22^{\circ} 56^{\prime} \mathrm{S}, 42^{\circ} 23^{\prime} \mathrm{W}\right)$ possui área de $1,6 \mathrm{~km}^{2}$ e está localizada entre dois cordões litorâneos apresentando hipersalinidade.

- Lagoa Brejo do Espinho $\left(22^{\circ} 56^{\prime} \mathrm{S}, 42^{\circ} 14^{\prime} \mathrm{W}\right)$ com área de $1 \mathrm{~km}^{2}$, igualmente localizada entre dois cordões litorâneos sendo também hipersalina.

As linhas de costa dominadas por ondas e sedimentação essencialmente arenosa, tendem ao desenvolvimento de cristas praiais (cordões litorâneos). Dentro deste complexo sistema deposicional existem praticamente três elementos geomórficos distintos na região analisada:

1 - duplo sistema de cordões litorâneos com $48 \mathrm{~km}$ de extensão, o mais interno com altitudes em torno de 6 a $7 \mathrm{~m}$ e o externo com altitudes em torno de 3 a $4 \mathrm{~m}$ e $350 \mathrm{~m}$ de largura;

2 - as lagunas e

3 - os leques de lavagem, principalmente com registro nos testemunhos analisados.

\section{1 - Aspectos Históricos}

O grande interesse turístico e econômico da região fez com que as primeiras perturbações ambientais fossem sentidas já com a construção da rodovia que liga Rio de Janeiro a Cabo Frio em 1940. Na década de 70, com a construção da ponte que liga a cidade do Rio de Janeiro a 
Niterói, intensificou-se a urbanização local. Esse processo de ocupação causou o desmatamento da planície, dragagens manuais e mecânicas dos pântanos e lagunas; a aceleração do processo de eutrofização processou-se através dos efluentes de esgotos (Carmouze e Barroso 1989). Hoje, na laguna de Araruama, por exemplo, tem-se aproximadamente 350 lançamentos de esgoto diretamente em sua porção setentrional (próxima a rodovia Amaral Peixoto) e apenas 1 em sua porção meridional.

Das 54 salinas que existiam ao redor da laguna de Araruama, antes da década de 70, hoje mais de 20 já foram desativadas devido à intensa especulação imobiliária. Em Saquarema, onde a principal atividade econômica local era a pesca, dos 200 pescadores que viviam dessa atividade, hoje restaram menos que 10 devido à queda da produtividade de peixes levada pela destruição dos nichos, pântanos de maré e vegetação macrobêntonica.

\section{2 - Características climáticas e oceanográficas}

As características climáticas locais têm sido estudadas por Barbière $(1975,1981,1984$, 1985 e no prelo). Em 1984, este autor comparou os dados climáticos de Cabo Frio e Iguaba Grande, observando dois microclimas distintos em locais distantes de apenas $20 \mathrm{~km}$. Na Tab. 1 estão sintetizadas as variações climáticas mensais e anuais no período 1971-1980.

Seu clima tropical quente favorece a ocorrência de ecossistemas costeiros secos que ocupam c. $79 \%$ de toda a costa brasileira conforme De Lacerda et al.(1993). O clima de Iguaba Grande reflete as condições tropicais regionais prevalecentes em $67 \%$ das áreas costeiras onde esses ecossistemas estão inseridos.

\begin{tabular}{|c|c|c|c|c|}
\hline DADOS CLIMÁTTCOS & \multicolumn{2}{|c|}{ CABO FRIO } & \multicolumn{2}{|c|}{ IGUABA GRANDE } \\
\hline TEMPERATURA $\left({ }^{\circ} \mathrm{C}\right)$ & Verão & Inverno & Verão & Inverno \\
\hline Médias compensadas & 25 & 21.5 & $26.1-26.7$ & 21.3 a 21.7 \\
\hline Média das máximas & 29 & 24.5 & $30.8+31.6$ & 25.5 \\
\hline Máximas absolutas & 36.5 & 30.5 & 41 & 32.8 \\
\hline Mínimas absolutas & 19 & 12 & 18.1 & 10 \\
\hline Média das mínimas & 22.5 & 19 & $23.2-22.6$ & 17.9 e 18.9 \\
\hline UMIDADE RELATIVA & \multicolumn{2}{|c|}{$>80 \%$} & \multicolumn{2}{|c|}{$<79 \%$} \\
\hline EVAPORAC̆ÃO & \multicolumn{2}{|c|}{$894 \mathrm{~mm} / a \mathrm{no}$} & \multicolumn{2}{|c|}{$1.372 \mathrm{~mm} / \mathrm{ano}$} \\
\hline VENTOS (frequéncia e velocidade) & \multicolumn{2}{|c|}{$\begin{array}{l}58 \% \mathrm{Ne} \mathrm{NE} \\
4.6 \mathrm{~m} / \mathrm{seg}\end{array}$} & \multicolumn{2}{|c|}{$32,5 \% \mathrm{NE}, 0,4-0,7 \mathrm{~m} / \mathrm{seg}$} \\
\hline CLASSIFICAÇAODE KOPPEN & \multicolumn{2}{|c|}{$\begin{array}{l}\text { Clima semi-arido quente } \\
\text { (Bsh) }\end{array}$} & \multicolumn{2}{|c|}{$\begin{array}{l}\text { Transicional entre topical com chuvas de } \\
\text { verão e seca de inverno (Aw") e o Bsh }\end{array}$} \\
\hline
\end{tabular}

Fonte: Barbiére (1984)

Tabela. 1- Dados climáticos de Cabo Frio e Iguaba Grande. 


\subsection{1 - Precipitação e Evaporação}

A predominância de ventos do quadrante nordeste, na região, influem de forma especial nas taxas de precipitação e evaporação. Os ventos quentes e secos, originados no Anticlone Subtropical Marítimo do Atlântico Sul, ocorrem mais comumente no verão e no inverno. A freqüência e velocidade dos ventos (Tab. 2) ilustram a intensidade de atuação deste agente climático na região, onde a força de seu atrito sobre a superfície da água é capaz de gerar correntes que se movimentam em direção as bordas lagunares, produzindo acumulações de água e consequentemente aumento do nível de água lagunar principalmente onde o volume de água é maior.

Barbière (no prelo) analisou dados, obtidos continuamente ao longo de sessenta anos, concluindo que $77 \%$ da precipitação pluviométrica foi inferior a $100 \mathrm{~mm}$ mensais e apenas 2,7 \% ultrapassaram $200 \mathrm{~mm}$ mensais. Esses dados ilustram as características climáticas da região, sendo a freqüência das alturas pluviométricas mensais, menores ou iguais a $50,0 \mathrm{~mm}$ predominantes no outono (48,9\% e inverno (65\%); são freqüentes no verão, com $37,2 \%$ e na primavera o intervalo passa para 50,1 a $100,0 \mathrm{~mm} \operatorname{com} 44,4 \%$.

As precipitações pluviométricas para o município de Saquarema foram obtidas entre 1982 - 1991 a partir de dados mensais da SERLA (De Sá 1993), nas estações de Saquarema

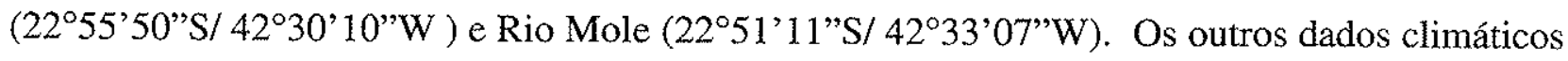
e oceanográficos, da laguna de Saquarema para 1987, foram sintetizados de Moreira (1989), conforme Tab. 2.

\begin{tabular}{|c|c|}
\hline \multicolumn{2}{|l|}{ SAQUAREMA } \\
\hline Clima & sub-úmido seco \\
\hline Temperatura média anual & $23-25^{\circ}$ \\
\hline $\begin{array}{l}\text { Temperatura da água (mín. e máx } \\
\text { anuais) }\end{array}$ & $18-30^{\circ}$ \\
\hline $\begin{array}{l}\text { Ventos }+ \text { freqüentes } \\
\quad+\text { intensos (Maio - Junho) }\end{array}$ & $\begin{array}{l}N-N E \\
S\end{array}$ \\
\hline Maré (mín. e máx.) & $0,60-1,20 \mathrm{~m}$ \\
\hline
\end{tabular}

Fonte: Moreira (1989)

Tabela 2 - Dados climáticos e oceanográficos da laguna de Saquarema para 1987. 


\subsection{2 - A Ressurgência de Cabo Frio}

A circulação atmosférica na região de Cabo Frio, sob domínio do Anticiclone Subtropical Marítimo do Atlântico Sul, caracterizada por ventos predominantemente do quadrante E-NE, somada a orientação costeira NE/SW entre Cabo Frio e o Cabo de São Tomé, o posicionamento das isóbatas de 50-100 m muito próximas da tha de Cabo Frio, bem como pela interação entre as correntes marinhas locais, favorecem a ocorrência de ressurgências costeiras.

O fenômeno de ressurgência de águas frias e de baixa salinidade nấ região tem sido objeto de vários cruzeiros oceanográficos e estudos de diversas naturezas e uma síntese atualizada dos trabalhos realizados pode ser encontrada em Torres (1995).

O clássico mecanismo de Ekman, associado a ressurgência, inicia-se com os ventos de NE forçando a água de superfície (Água Tropical - AT), que corresponde à água carreada para Sul pela Corrente do Brasil, a se afastar da costa para SE, transformando-se na força geradora da ressurgência da ACAS (Água Central do Atlântico Sul, segundo classificação de massas d'água de Sverdrup et al., 1942) na costa. A disponibilidade do mecanismo de Ekman à ACAS é devida ao seu posicionamento abaixo da AT em subsuperfície, sobre a plataforma continental, e à localização das isóbatas de 50-100 m próximas à llha de Cabo Frio. Ferreira da Silva et al. (1984) e Tanaka (1985) observaram a ACAS em profundidades mais rasas no verão e aflorando junto a costa. Gamma de Almeida e Tanaka (1981) ilustram o fenômeno com imagens do satélite da série NOAA (5) que a partir de Cabo Frio é desviada para SW e, baseados também em modelagem numérica, afirmam que os ventos de NE provocam ressurgências na região da plataforma entre Cabo Frio e Cabo de São Tomé, e que os ventos de E-NE provocam a ressurgência ao longo do litoral com alinhamento E-W.

O predomínio dos ventos do quadrante E-NE ocorre no verão e no outono, quando o fenômeno é mais freqüente. No inverno e primavera, quando passam a predominar ventos de SW-W é menos freqüente. Nestas estações, os sistemas anticiclônicos polares dividem com o Anticiclone Subtropical Marítimo do Atlântico Sul o controle na circulação dos ventos na região, uma vez que geram as frentes frias, invertendo os ventos para SW, S, SE, (Moreira da Silva 1977). Passa então a ocorrer aporte de águas quentes da Corrente do Brasil para a costa e subsidencia da ACAS. Os movimentos sazonais do eixo da Corrente do Brasil, que escoa ao longo do talude continental, se intensificam no verão e enfraquecem sob o domínio dos ventos de SW.

O efeito da ressurgência e do mecanismo de Ekman associado aos movimentos sazonais da Corrente do Brasil e das outras correntes oceânicas produz variaçôes do nível do mar na 
região de Cabo Frio. Palácios (1993) postula que o rebaixamento do nível do mar estaria associado aos ventos zonais de $W$ para $E$ (contrários ao mecanismo de Ekman) ou seja, os eventos de ressurgência levariam a um abaixamento do nível do mar, enquanto a aproximação da Corrente do Brasil levaria a subida do nível do mar, filtrados os efeitos da maré e pressão atmosférica em suas análises.

Outro fator que tem sido apontado mais recentemente, como um modificador climático e oceanográfico de amplo alcance no hemisfério Sul, já com registros sugeridos ẹm alguns estudos, é o evento quase periódico denominado El Niño (Southern Oscillation-ENSO). A influência deste mecanismo ao longo da costa brasileira é sugerida por Martin et al (1988), que propõem mudanças nos processos costeiros sob domínio do Anticiclone Subtropical Marítimo do Atlântico Sul, quando da ocorrência dos eventos de El Niño.

Parece razoável admitir-se que este evento possa deixar seu registro nos ambientes lagunares pela influência metereológica global exercida como, por exemplo, a postulada para o lago Turkana no Quênia (Halfman e Johnson 1988). No entanto, calibrações atuais são necessárias uma vez que os eventos ENSO não ocorrem segundo padrão ordenado e sim parecem recorrer irregulamente variando em força e intensidade de atuação com amplitudes de tempo de 2-10 anos (Glenn e Kelts 1991).

Em regiões lagunares de clima semi-árido, como as aqui tratadas, talvez ocorram anomalias de precipitação evidenciadas no registro geológico dessas áreas, plausíveis de serem associadas a tais eventos.

As mudanças climáticas e eustáticas que afetam as condições oceanográficas das margens continentais, modificam o fornecimento de nutrientes e organismos com reflexo no registro geológico das plataformas atuais e ambientes marinhos marginais afetados.

\subsection{3 - Maré}

As medidas realizadas na área de Cabo Frio pela DHN (Diretoria de Hidrografia e Navegação) indicam um regime de micromarés semidiurna, com altura média de 1,05 $\mathrm{m}$, sendo a amplitude da maré de sizígia de $1,30 \mathrm{~m}$ e da maré de quadratura de $0,80 \mathrm{~m}$ ( Tab. 3).

Medidas da variaçẫo do nível da maré para as lagunas estudadas praticamente inexistem. Na laguna de Araruama, segundo medidas executadas por Lessa (1990) no Canal do Itajuru (maior

profundidade $>$ de $5 \mathrm{~m}$, na desembocadura, e menores profundidades nas partes média e a montante com aproximadamente $1,6 \mathrm{~m}$ ), a maré perde sua força e após $14 \mathrm{~km}$ do canal não é percebida nos registros. Embora a variação de maré seja pequena na laguna de Araruama, 
Kjerfve et al. (1995), com base em medições realizadas em estação localizada no Boqueirão e através de simulação por modelo númerico, calcularam amplitude média de maré de $0,01 \mathrm{~m}$ para a laguna e para o canal em toda a sua extensão.

\begin{tabular}{|c|c|c|c|c|c|}
\hline \multicolumn{6}{|c|}{ MARE } \\
\hline \multicolumn{5}{|c|}{ Porto do Forno Lat. 22 } \\
\hline VER & 58'3 S Long. $42^{\circ} 00^{\prime} 9 \mathrm{~W}$ \\
\hline $17 / 02 / 93$ & 0123 & 1.0 & $27 / 08 / 93$ & 0526 & 0.2 \\
& 0654 & 0.4 & & 1300 & 1.0 \\
& 1234 & 0.9 & & 1832 & 0.5 \\
& 1851 & 0.1 & & & \\
& & & & & \\
& 0147 & 1.0 & $28 / 08 / 93$ & 0009 & 0.9 \\
& 0726 & 0.4 & & 0623 & 0.1 \\
& 1309 & 1.0 & & 1326 & 1.0 \\
& 1934 & 0.1 & & 1906 & 0.4 \\
\hline
\end{tabular}

Fonte: Diretoria de Hidrografia e Navegação, 1993.

Tab. 3 - Dados de maré do Porto do Forno nas datas de amostragem de campo deste trabalho.

Marégrafos instalados pela SERLA, no interior da laguna, registraram oscilações do nível lagunar em resposta a variações metereológicas locais, como passagem de frentes frias e momentos de maior pluviosidade (Lessa 1990). Este mesmo autor verificou elevação do nível de água no canal em cerca de $0,15 \mathrm{~m}$ devido a chuva de $33,7 \mathrm{~mm}$ em 7 dias ocorrida entre suas campanhas caracterizadas por marés de sizígia e quadratura. Kjerfve et al. (1990) observaram elevação do nível de água de 0,45 m entre 1985 e 1988 na laguna de Guarapina em conseqüência de maior pluviosidade, indicando comportamento hidráulico similar em outras lagunas da região. Provavelmente, maiores elevações do nível de água ocorrerem quando os pulsos de maré e precipitação coincidem também com seiches internos.

Na laguna de Saquarema, Moreira (1989) descreveu aumento no nível de água com a entrada de frentes frias e ventos de S-SW, apresentando dados de maré com mínima de 0,60 m e máxima de 1,20 m quando então ocorre o transbordamento da laguna. Knoppers et al. (1991) apresentaram para a laguna de Saquarema, particularmente para os compartimentos de Urussanga e Fora, amplitudes médias de maré da ordem de $0,01 \mathrm{~m}$ e 0,04 m, respectivamente.

As lagoas Vermelha e Brejo do Espinho exibem provável influência marinha por percolaçäo, uma vez que Vasconcelos (1988) encontrou para a lagoa Vermelha razões iônicas em relação ao íon $\mathrm{Cl}$ comparáveis às águas oceânicas adjacentes. Variações no nível de água desses sistemas fechados são fortemente influenciadas pela evaporação, uma vez que a distribuição sazonal da precipitação é relativamente constante, apresentando picos máximos entre Novembro - Dezembro e mínimos de Junho - Agosto. O índice médio de evaporação anual, segundo 
Kjerfve et al. (1995), é de $1.390 \mathrm{~mm}$ com picos nos meses de verão, quando a temperatura está maior e os ventos mais fortes, ocorrendo em todos os meses um déficit líquido substancial de água o qual é mais pronuciado nos meses de Fevereiro e Agosto. A Fig. 4 ilustra nível baixo de água no verão de Fevereiro de 1993, com evaporação intensa no sabkha Brejo do Espinho e exposição das fácies supramaré e intermaré.

\section{3 - Fisiografia}

O trecho costeiro em estudo pode ser considerado como um excelente laboratório natural, com variação ambiental intensa em pequena escala temporal e espacial. Todas as lagunas apresentam a norte e nordeste o cinturão de serras costeiras (Maciço Costeiro, Serra do Mar e Serra da Mantiqueira) com altitudes próximas a $1000 \mathrm{~m}$. A leste divisores posicionados perpendicularmente à linha de costa alcançam a área oceânica e dividem a região costeira do Estado do Rio de Janeiro em vários compartimentos, sendo um deles o compartimento Saquarema-Araruama. A sul a segunda ilha-barreira, que possui altitudes entre 4 e 7 metros, separa a região oceânica. Sondagens elétricas verticais realizadas por Drews (1995) para estudos de fundações e aqüíferos na cidade de Arraial do Cabo caracterizam o relevo do embasamento como bastante irregular, principalmente sob as ilhas-barreiras, estando a profundidades em torno de $80 \mathrm{~m}$ (variando de 7,5 a $133 \mathrm{~m}$ ).

Os sistemas lagunares analisados localizam-se na porção continental adjacente à Bacia de Santos, próximos ao limite com a Bacia de Campos, estando estas bacias separadas entre elas pelo Alto de Cabo Frio. As várias lagunas existentes neste trecho da costa do Rio de Janeiro apresentam alinhamento SW-NE acompanhando a forma geral da região costeira e, em geral a mesma morfologia de bolsões, principalmente aquelas posicionadas atrás da primeira ilha barreira. A laguna de Araruama, na extremidade E do sistema, possui a maior extensão e Azevedo (1984) observou para o sistema de Araruama e Guarapina ligeira inclinação para leste. Estas bacias lagunares podem ter sido formadas a partir de depressões irregulares que apresentaram subsidência lenta e de longa duração, fazendo parte do sistema rifte da Serra do Mar.

A sismicidade relativamente acentuada evidenciada na regiāo continental adjacente à Bacia de Santos e Campos (Assunção et al. 1980; Mioto 1984) demonstra que esta área, alinhada com a Zona de Transferência do Rio de Janeiro, ainda está sujeita a reajustes tectônicos.

Geomorfologicamente, a região apresenta três tipos de relevo: as montanhas mais próximas, com altitude média entre $400-500 \mathrm{~m}$, sendo a mais alta a montanha do Mato Grosso 
com $890 \mathrm{~m}$; as colinas, com altitudes de $80 \mathrm{~m}$ aproximadamente e a baixada com dunas eólicas, ilhas barreiras e alguns pântanos salobros e de água doce

\subsection{1 - Drenagem}

As áreas estudadas não apresentam rios de grande porte em suas bacias de drenagem, os rios de médio porte apresentam-se condicionados pelo arcabouço estrutural local com direção preferencial NE-SW e os menores irregularmente ramificados. A drenagem é dendrítica, sendo a área da laguna de Saquarema a que recebe o maior influxo fluvial com o aporte de pelo menos oito rios, apresentando grande área de captação em sua bacia de drenagem. De acordo com Moreira (1989), este maior aporte fluvial pode gerar aumento do nível da lagoa de 10 à $20 \mathrm{~cm}$ acima do nível do mar, podendo chegar a $40 \mathrm{~cm}$.

A laguna de Araruama é alimentada por apenas dois rios perenes: Maratana (ou Limão) e das Moças que desaguam em sua porção noroeste. Com o aumento da população local, a Companhia Estadual de Águas e Esgotos (CEDAE) desde 1977 faz a captação de água da bacia de drenagem do rio São João à Norte, Kjerfve et al. 1995 estimam que 60 65 \% da água bombeada (índice de bombeamento de $1,1 \mathrm{~m}^{3} \mathrm{~s}^{-1}$ ) entram na laguna de Araruama em menos de um mês gerando um fiuxo de água de $+0,7 \mathrm{~m}^{3} \mathrm{~s}^{-1}$ sendo a água restante descarregada na laguna de Saquarema ou no oceano.

A lagoa de Jacarepiá recebe poucos afluentes fluviais todos de pequeno porte, sendo a única de água doce e as lagoas hipersalinas intercordões não recebem nenhum aporte fluvial.

\subsection{2 - Vegetação}

Existem poucos inventários da vegetação ocorrente no litoral do Estado do Rio de Janeiro, dentre estes está o de Araújo e Henriques (1984), que cobre a área aqui estudada.

A vegetação litorânea é composta por alguns arbustos e flora variada e diversa, e mesmo separadas fisicamente podem possuir afinidades florísticas. Basicamente as bordas lagunares hipersalinas apresentam-se desprovidas de vegetação. Somente acima da porção supramaré, fora do alcançe do nível mais alto atingido pela água em marés de sizígia e/ou tempestades, ocorrem, em abundância, gramíneas. A laguna de Saquarema apresenta nas bordas Typha dominguensis e pteridófitas, principalmente nos compartimentos Urussanga e Boqueirão; Laguncularia racemosa ocorre na onla SW no compartimento de Fora. A lagoa de Jacarepiá talvez seja o local com maior freqüência de estudos botânicos ( Ana Angélica (?) 1996; De Sá 1993), devido à ocorrência de vegetação de restinga parcialmente preservada. 
Nas bordas de ambientes lagunares hipersalinos, a ausência de vegetação parece mostrar que sua influência na distribuição faunística é inexpressiva, diferente do que ocorre em áreas de pântanos salobros e manguezais, o que nos leva a levantar a hipótese que o zoneamento é definido pelas condições físico-químicas, hidrológicas e topográficas locais.

\section{4 - As Lagoas e Lagunas}

A presença de lagunas distingue linhas de costa caracterizadas por um sistema de ilhasbarreira de uma planície costeira caracterizada por uma sucessão de cordōes litorâneos ou cristas praiais. Além disso, as fácies sedimentares resultantes de flutuações de processos físicos (migrações da linha de costa, padräo de circulação da água) e bioquímicos (conteúdo de oxigênio dissolvido, variações nas condições de pH ) são expressas vertical e horizontalmente.

Nas lagunas, as desembocaduras atuam também como controladoras da altitude da coluna de água e por esse motivo, a sedimentação desses ambientes difere das lagoas. Nas lagunas o influxo oceânico é um importante controlador, enquanto em lagos, a concentração iônica é alterada pela evaporação associada a precipitação de sais. São observados nos lagos, principalmente no verão, concentraçóes iônicas muito altas, ao contrário do inverno quando ocorre diluição.

As flutuações no nível de água e nas características bioquímicas das lagoas, associadas à sensibilidade ao clima, favorecem o arranjo cíclico das fácies. Lâminas de menor espessura podem representar momentos de cheia ou esvaziamento da bacia, com consequiente flutuação de suas margens, enquanto lâminas de maior espessura representam variações mais acentuadas e temporalmente mais longas nas características do ambiente de sedimentação e hidrologia local. Segundo Allen e Collinson (1986), as lagoas apresentam biohermas, fácies de grãos cobertos com película de material carbonático secundário e areias carbonáticas conchíferas, com deposição siliciclástica restrita às áreas próximas a desembocaduras de tributários fluviais.

\subsection{1- Laguna de Araruama}

É a maior do Estado do Rio de Janeiro e está situada na extremidade leste do sistema lagunar analisado, entre as coordenadas $22^{\circ} 29^{\prime} \mathrm{S}, 42^{\circ} 00^{\prime} \mathrm{W}$ e $22^{\circ} 57^{\prime} \mathrm{S}, 42^{\circ} 44^{\prime} \mathrm{W}$. Possui 47 $\mathrm{km}$ de comprimento, $14 \mathrm{~km}$ de largura máxima, profundidade média de $3 \mathrm{~m}$ e máxima de $17 \mathrm{~m}$ na enseada de Massambaba e, em algumas fossas de dragagens para fins econômicos. Apresenta canal profundo na direção E-W (Branco e Ramalho 1984) e está ligada ao oceano através do canal do Itajuru, longitudinalmente posicionado à frente da Bacia de Campos. 
A intensa evaporação observada durante o dia e a baixa temperatura do ar causada pela passagem dos ventos sobre as áreas de ressurgência à noite, aumentam a densidade da coluna de água superficialmente provocando mistura vertical (André et al. 1979). Estes autores analisaram outros dados que, embora obtidos em apenas três dias de observações, indicam que o oxigênio já subsaturado nas camadas superficiais, sofre acentuada redução em profundidade, com baixas concentrações de nutrientes; por outro lado, constatou-se uma relação inversa pára o silicatos e a salinidade após o período chuvoso. Para estes autores, as diatomáceas bentônicas seriam as responsáveis pela diminuição nas concentrações de silicatos.

Nas partes mais profundas são depositadas vasas orgânicas constituídas de matéria orgânica coloidal, argilas cauliníticas e esmectítitas, com ocorrência de minerais pesados (principalmente ilmenita, Barroso 1987).

Estão ilustradas, nas estampas 21/1-6 deste trabalho, através de microscopia eletrônica de varredura, crostas endurecidas formadas por colônias de diatomáceas que compõem parte significativa dos sedimentos e servem de fixação para estas. Observar também na mesma estampa os dados composicionais obtidos por meio da análise de espectometria da energia dispersiva de raios $x$ (EDS) de dois pontos dessas crostas.

Os sedimentos da superfície de fundo são ricos em indivíduos da família Bacillariophyceae Patrick e Reimer (diatomáceas) e Cyanophyceae Sachs (cianobactérias), além de moluscos, entre eles abundantes conchas de bivalves mortos. Os únicos encontrados como forma vivente referem -se a Anomalocardia brasiliana Gmelim. Protozoários vivos da ordem Foraminiferida também ocorrem com abundância de Pseudotriloculina lecalvezae (Kaaschieter).

Os sedimentos fluviais que entram no sistema devem ser transportados principalmente em suspensão (Azevedo 1984), sendo depositados principalmente em suas margens à oeste, onde as areias flúvio-lagunares, quando mais lamosas, apresentam os mais altos teores de C orgânico, $\mathrm{N}$ orgânico e fósforo total (Campos et al 1979, in Barroso 1987). 

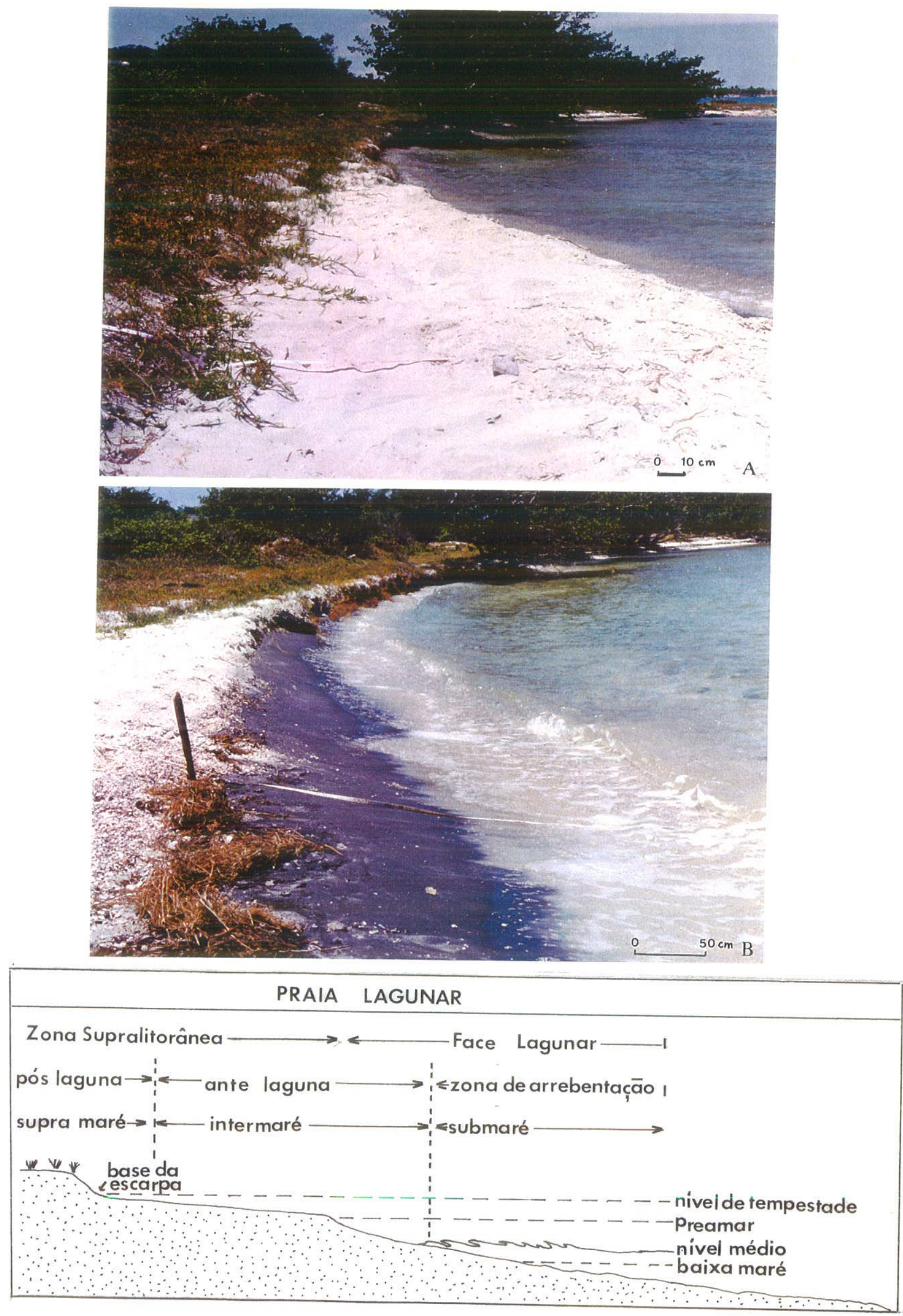

Fig. 3 - Vista do perfil da seção 2 - Laguna de Araruama (Faculdade de Veterinária-UFF). A - zona supralitorânea; B - zona de arrebentação da laguna; C- perfil esquemático da borda lagunar de Araruama 


\subsection{2 - Laguna de Saquarema}

Com características predominantemente mixohalinas, os quatro compartimentos que compõem a laguna de Saquarema apresentam profundidade média de $1,15 \mathrm{~m}$ e exibem sedimentos flúvio-lagunares nas bordas. O compartimento denominado Fora, juntamente com o Urussanga são os que apresentam as maiores diferenças de salinidade entre os momentos de amostragem desse trabalho.(Tab. 6).

Através da análise de disponibilidade dos componentes biogênicos ( $\mathrm{C}, \mathrm{N}, \mathrm{P}$ orgânicos), dados físico-químicos básicos (temperatura, salinidade e $\mathrm{O}_{2}$ dissolvido) e morfologia da bacia lagunar, Moreira (1989) avaliou as condiçöes do ecossistema aquático. Comportou-se como hipertróficos no verão (maior enriquecimento em $\mathrm{P}$ e na relação COP/COD, ou seja carbono orgânico particulado/ carbono orgânico dissolvido) e eutróficos nas demais estaçôes do ano de 1987, estando entre as mais eutrofizadas da chamada "Região dos Lagos". Knoppers et al. (1991) mostraram que os estados tróficos de Saquarema e outras lagunas da região estão relacionados ao tempo de residência da água no sistema (maior no compartimento Urussanga que no compartimento Fora, por ser o setor menos afetado por trocas de maré além de ser um dos mais alimentados por efluentes). As cargas de nutrientes antropogênicos afetam a relação tempo de residência-estados tróficos. Estes autores apontam o domínio de fitoplâncton na produção primária desse ecossistema. Domingos et al. (1989) observaram que a passagem de frentes frias ocasionam entrada de água marinha, chuvas e baixas temperaturas no sistema lagunar, determinando diminuição na atividade biológica e na biomassa fitoplanctônica. Diniz et al. (1989), através de estudo sedimentológico, concluem que a matéria orgânica apresenta maiores concentrações nas desembocaduras fluviais com os teores de carbonato, na fração $2 \mathrm{~mm}$ ou inferior, variando de 0 a $5 \%$.

\subsection{3 - A Sabkha Brejo do Espinho}

A sabkha Brejo do Espinho ocupa uma depressão topográfica suave em frente ao terceiro compartimento de Araruama e o Oceano Atlântico, localizada entre o primeiro e o segundo cordão arenoso costeiro da chamada Restinga de Massambaba. Apresenta ambientes deposicionais evaporíticos subaéreos e subaquosos, tanto no atual como no registro geológico holocênico.

No verão, as salinidades apresentavam-se com $95 \%$ devido à alta evaporação e à baixa pluviosidade Iocal, em decorréncia da maior incidência de ressurgências na região oceânica nesta 
época do ano. No inverno, a salinidade apresentamse com $39 \%$ devido à baixa evaporação. (Tab.3).

No verão, o rebaixamento da coluna de água a menos de $1 \mathrm{~m}$ de profundidade e abaixo do nível do mar, bem como do lençol freático, devido a evaporação, pode levar à percolação das águas marinhas através do cordão arenoso e o influxo por concentração iônica acelerada dos fluidos nos poros para as águas do sabkha, através do processo de ascenção da água intersticial conhecido como bombeamento evaporítico (evaporitic pumping) (Hsü e Siegenthaler 1969). Este processo favorece a precipitação intersticial da halita e dois tipos de depósitos são formados nas bordas do sabkha:

a) o primeiro, de natureza evaporítica, ocupa a porção supramaré, exposta subaereamente em momentos de descida da coluna de água; é caracteristicamente formado por crostas colunares de halita estratiformes, com a superfície em polígonos compressionais e com grãos acessórios de quartzo, sobre lama carbonática e tapete algálico. O primeiro depósito de crostas pode ser formado pela evaporação das águas supersaturadas que sobem por capilaridade. A característica efêmera destes depósitos é evidenciada nos momentos de cheia, quando já não são observados e quando a água alcança rapidamente a saturação através da dissolução da halita dos ciclos prévios de evaporação (Fig. 5).

b) o segundo, ocupando a porção intermaré ainda seca mas mais úmida que a anterior, composto por lama carbonática e cristais de halita com aspecto mais fino, mais poroso, sugerindo retrabalhamento e perda da definição das formas com redistribuição aparente da halita. Esta porção é inundada com maior freqüência, devido a batimetria favorável. Com a exposição subaérea desses sedimentos mais finos, a superfície das crostas colunares apresentam-se arredondadas, mais aplainadas e suavizadas pelo efeito das chuvas e dos ventos (deflação). Os micro-canais formados entre as crostas possuem maior largura, retilinidade e regularidade (Fig.6).

A velocidade de precipitação dos minerais evaporíticos é controlada principalmente pela umidade relativa, embora variáveis como a concentração iônica, temperatura e compostos orgânicos dissolvidos possam apresentar-se como fatores adicionais determinantes do tipo de mineral precipitado e hábito cristalino. Já os grãos de quartzo, associados aos depósitos supramaré e intermaré, são finos a muito finos sugerindo transporte por suspensão a partir das dunas e como areia em lençol, sedimentada por águas de tempestade e de maré alta carreando sedimentos provenientes dos cordões arenosos adjacentes. 
A proliferação das algas ocorre no inverno, quando os índices de evaporação e a salinidade são menores, desenvolvendo-se desde a porção inferior da zona supramaré, intermaré até inframaré superior.

O tipo de tapete algálico que se desenvolve é determinado pela forma como as partículas sedimentares são aprisionadas e/ou ligadas ao tapete, sendo a distribuição do tapete em área determinada pelo nível de dessecação através da planície de maré e área dé supramaré. A dessecação provoca uma diminuição no número de espécies e mudança no arranjo da comunidade algálica e, portanto, no tipo de tapete (Schreiber 1986). Quatro tipos de tapetes algálicos estratiformes são considerados por este autor: gelatinoso (gelatinous mai), ramoso (tufted mat), bolhante (blister mat), e pelicular (film mat). Este último parece corresponder aos observados nas bordas do sabkha Brejo do Espinho na zona intermaré.

$\mathrm{O}$ aparecimento de carófitas (Charophytae spp., macroalga bentônica com estrutura calcificada do orgão reprodutivo feminino ovóide ou oogônia ) é freqüente na borda deste sabkha. Sua ocorrência é comumente associada a águas doces, oligotróficas e rasas, cuja salinidade máxima observada foi de $70 \%$ (cf. Burne et al. 1980). 


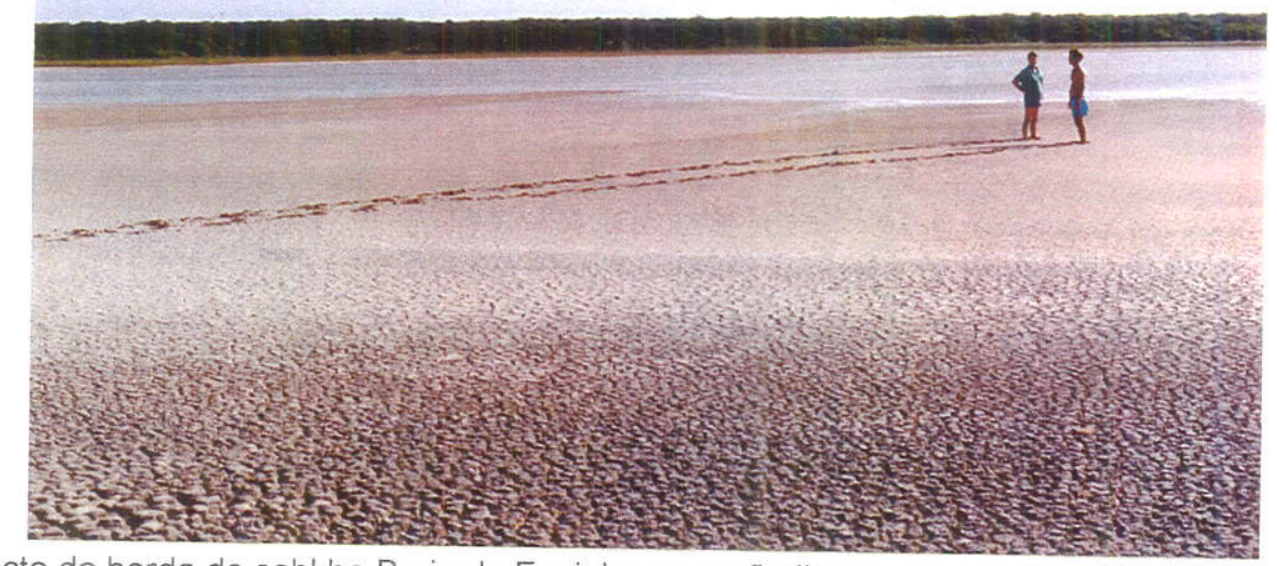

Fig. 4 - Aspecto da borda do sabkha Brejo do Espinho no verão ilustrando redução acentuada na coluna de água.

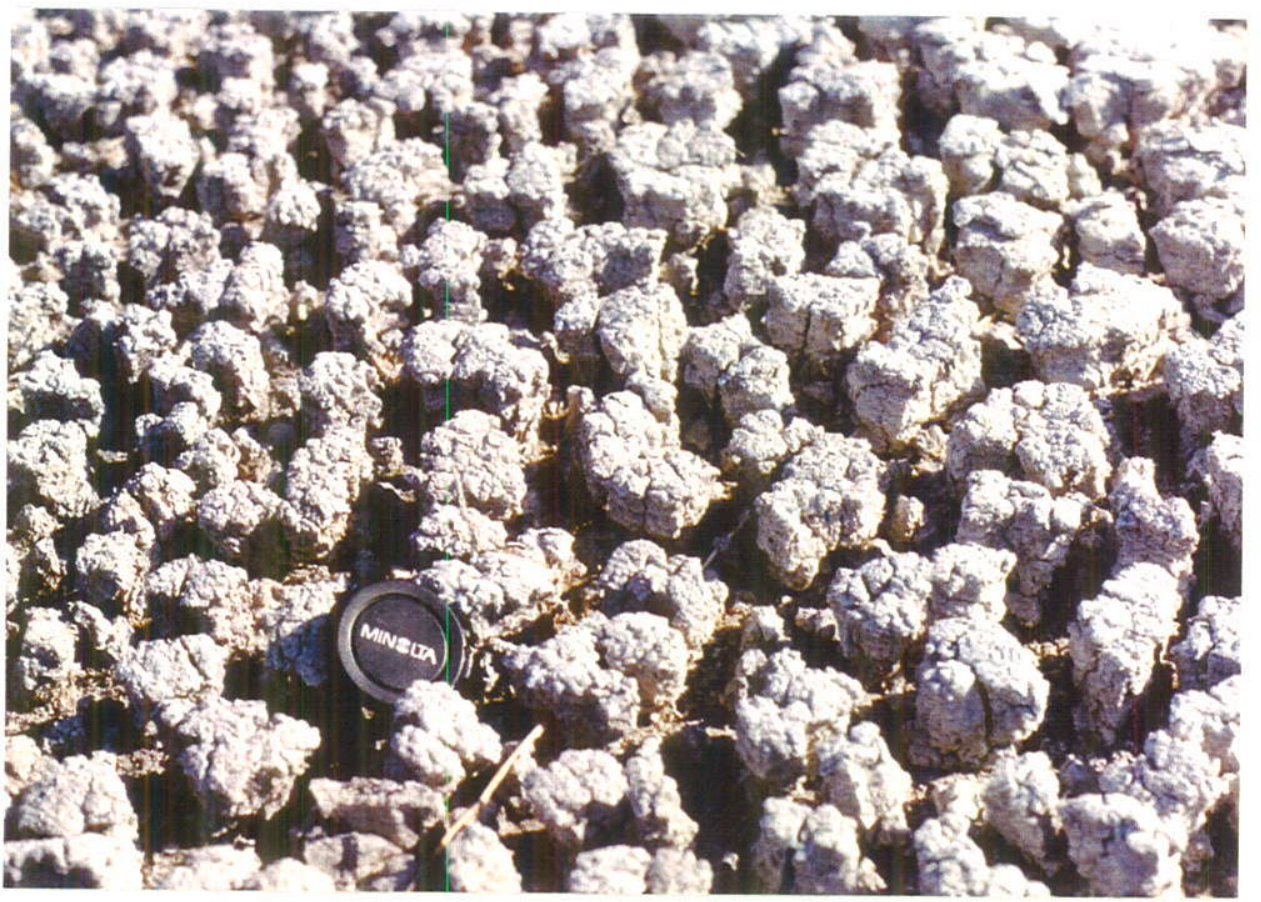

Fig. 5 - Detalhe das crostas de tapetes algálicos na fácies supramaré do Brejo do Espinho no verão.

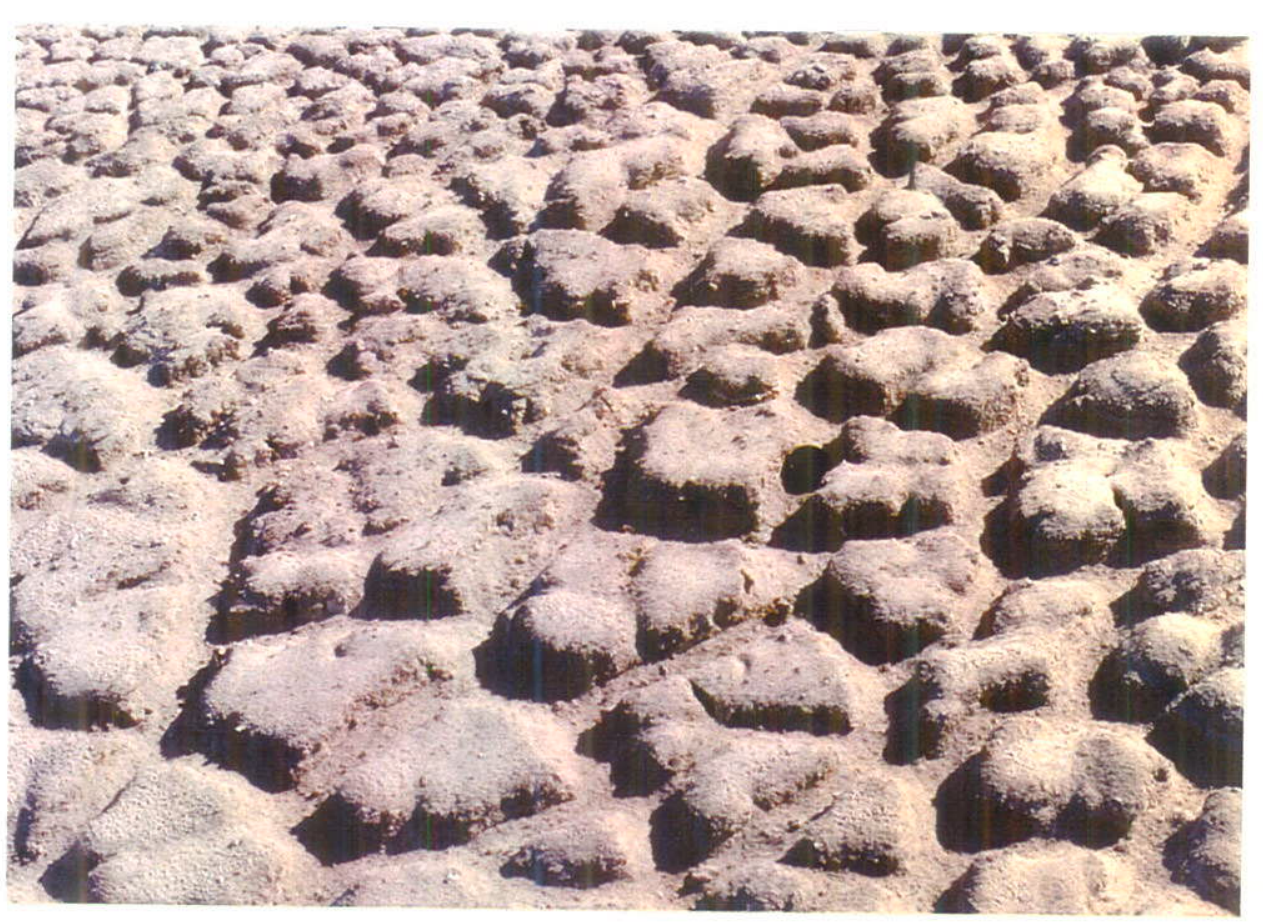

Fig. 6 - Detalhe das crostas de tapetes algálicos da fácies intermaré do Brejo do Espinho no verão 


\subsection{4 - Lagoa Vermelha}

Localizada entre as lagunas de Saquarema e Araruama, possui 4,4 km de comprimento e largura que varia de $250 \mathrm{~m}$ a $850 \mathrm{~m}$, estando posicionada entre a primeira e a segunda ilhabarreira. O nível mais baixo de seu espelho de água situa-se a $1,5 \mathrm{~m}$ abaixo do nível do mar, com a profundidade máxima variando de $1,0 \mathrm{~m}$ no verão e $1,70 \mathrm{~m}$ no inverno. Os fortes ventos e a pequena profundidade não favorecem a estratificação da coluna de água (Höhn et al.1986). A temperatura média local do ar varia entre $19^{\circ}$ e $32^{\circ} \mathrm{C}$, o índice pluviométrico é de $700 \mathrm{~mm} /$ ano e a evaporação de $1400 \mathrm{~mm} /$ ano (Patchineelam et al.1984).

Seus sedimentos são constituídos de areias médias a finas, em que 46 a $96 \%$ são carbonáticos. Tapetes algálicos ocorrem, apresentando espessura de $2-5 \mathrm{~cm}$ no fundo lagunar e nas partes úmidas de suas bordas. De acordo com Vasconcelos (1988) sua porção central é formada por estruturas de oncólitos (algal biscuit) e tapetes de cianobactérias, tendo-se ainda sedimentos classificados como calcilutitos, formados por aragonita, calcita, calcita-Mg, protodolomita e dolomita. Suas análises mostram que calcita-Mg, aragonita e dolomita possuem evidência de formação primária, visto que podem ser encontradas na superfície dos sedimentos lacustres, enquanto que a dolomita diagenética é encontrada já nos primeiros centímetros dos sedimentos.

A origem por precipitação química dos carbonatos pode estar relacionada à retirada de $\mathrm{CO}_{2}$ pelo processo de fotossíntese das cianobactérias do fundo lacustre, que apresenta alta relação $\mathrm{Mg} / \mathrm{Ca}$ favorecendo o crecimento de agulhas de aragonita, ou pode ocorrer a partir da evaporação da água, causando supersaturação em $\mathrm{CaCO}_{3}$, onde a elevação da alcalinidade nas sêcas ocasiona a concentração dos íons $\mathrm{HCO}_{3}, \mathrm{CO}^{-2}$ e $\mathrm{B}(\mathrm{OH})^{-}$. De qualquer forma, seguramente a origem dos carbonatos no sistema está parcialmente relacionada à formação por bioacumulação, que corresponde a $10 \%$ dos sedimentos, com dominância de bivalves (50\%), seguidas de gastrópodes (30\%), ostracodes e foraminíferos $(20 \%)$ (Vasconcelos 1988).

A percolação das águas marinhas através da ilha-barreira pôde ser comprovada pelo autor supra-citado com base na relação $\mathrm{Mg} / \mathrm{Cl}$ das águas intersticiais dos testemunhos analisados. Esta percolação ocorre pelo fundo lagunar onde não existe o tapete algálico e não através de suas bordas. As águas provenientes da parte continental, mais ácidas, devido a presença de $\mathrm{CO}_{2} \mathrm{e}$ estados de saturação carbonática menores, também favorecem a dolomitização, fazendo com que ocorra diagenese precoce.

Comparando-se as duas áreas lacustres intercordōes, ou seja, lagoas Brejo do Espinho e Vermelha, observamos que nesta última não ocorre no verão a diminuição da coluna de água de 
forma tão acentuada como a observada no Brejo do Espinho. Desta forma, parece haver constante fornecimento de água doce para a lagoa Vermelha causando a dissolução dos sedimentos carbonáticos, onde a alta razão $\mathrm{Mg} / \mathrm{Ca}$ na solução leva à dolomitização observada por Vasconcelos. A precipitação de sal nas bordas lacustres não é observada, embora o balanço hidráulico do lago pareça ser controlado pela relação precipitação/evaporação exatamente como no Brejo do Espinho.

Vasconcelos et al. (1995) explicam a formação de precipitados de dolomita devida à presença de bactérias redutoras de sulfato do grupo Desulfovibrio, que promoveriam a precipitação contínua de dolomita com reordenamento da estrutura dos cristais e formação das concreções. A produção bacteriológica da dolomita pode ser alcançada em condições anóxicas de baixa temperatura em tempo relativamente curto, de acordo com seus experimentos. As nanobactérias utilizam a superfície do quartzo como substrato de crescimento, onde a precipitação da dolomita em conjunto com a atividade microbiológica, aparentemente cimenta os grãos de quartzo formando agregados. Estes autores propõem que microorganismos podem ser importantes como centros de nucleação da dolomita na lagoa Vermelha e outros ambientes igualmente hipersalinos e platatormas carbonáuicas. 


\section{CAPÍTULO 4}

\section{4- MATERIAIS E MÉTODOS}

\section{1 - Perfis Topográficos Transversais das Bordas Lagunares}

A amostragem de verão foi realizada entre 17 e 18 de Fevereiro de 1993 e a localização dos perfis pode ser vista na Fig. 1. Nesta etapa foram realizadas amostragens em 65 estações, distribuídas ao longo de 11 perfis topográficos transversais para o zoneamento dos microorganismos e suas relações com a dinâmica das praias lagunares. Na lağuna de Araruama foram levantadas 5 seções, em Saquarema 3 seções e nas lagoas Vermelha, Brejo do Espinho e Jacarepiá foi levantada uma seção em cada (Fig. 8 - Seções 1 a 11).

$\mathrm{Na}$ etapa de campo de inverno, executada entre 27 e 28 de Agosto de 1993, as amostragens foram repetidas nas mesmas seções de verão, com exceção da seção 3 de Araruama (Porto da Aldeia), que foi deslocada lateralmente $1 \mathrm{~m}$ devido a presença de toras de madeira, exatamente acima do local amostrado no verão. A mesma metodologia da etapa de verão foi empregada, para o monitoramento da variabilidade topográfica entre o verão e o inverno, com amostragem em 64 estações distribuídas ao longo de 10 perfis (Fig. 9- Seções 1 a 10). A seção 11 (Jacarepiá).não foi amostrada no inverno pois somente com análise minunciosa das amostras percebeu-se a presença de foraminíferos e tecamebas, devido ao reduzido tamanho dos espécimens. Os perfis não foram estendidos à zona submersa mais profunda pois para se atingir os objetivos propostos, o detalhamento deve-se restringir ao segmento subaéreo da borda lagunar, até o recuo máximo da onda na zona de arrebentação das lagunas.

Na planície de maré dessas áreas foram realizadas amostragens de sedimentos para estudo de foraminíferos e tecamebas, embora outros microorganismos, tais como, ostracodes, gastrópodes, bivalves e carófitas tenham sido também considerados na análise na medida em que apareciam nas amostras, assim sendo, nenhum tratamento específico para recuperação desses organismos foi efetuado. Dessa forma o tratamento qualitativo dos outros organismos, apresenta-se listado abaixo das tabelas de freqüência de foraminíferos e tecamebas. Os dados de salinidade e pH foram obtidos no momento da amostragem, estimados a partir da análise da água nas bordas lagunares, utilizando-se um refratômetro ótico e peagâmetro.

Os perfis topográficos transversais foram feitos através de caminhamentos perpendiculares às bordas, seguindo-se direção escolhida com a bússola, desde o pós-praia lagunar até a face praial da laguna, onde a base da vegetação foi tomada como o nível superior do pós-praia ou nível da maré mais alta, devido a baixíssima amplitude de maré dessas áreas (Fig. 3). A face praial da laguna corresponde a zona de arrebentação na borda lagunar. 
O nivelamento topográfico das estaçôes amostradas, foi obtido da leitura, em mira topográfica (régua), utilizando-se como balizador uma mangueira de borracha transparente preenchida com líquido colorido à partir do princípio dos vasos comunicantes. A cota de cada ponto foi obtida a partir da diferença de altura entre dois pontos ao longo do perfil, determinada pela medida na mira, expressa pelo líquido colorido, através da leitura do observador da mira de ré e da mira de vante. As medidas das distâncias horizontais entre os pontos ao longo do perfil foram obtidas com trena e a distância total do perfil foi somada acumuladamentét.

As amostras foram coletadas em diferentes estações, estabelecidas em função das variações na superfície dos perfis topogxáficos, tais como linha de espraiamento, marcas onduladas, sulcos de escoamento de maré, concentrações de minerais pesados e de conchas, utilizando-se o amostrador "Phleger", empregado nas amostragens feitas anteriormente por Barbosa (1991) em Guaratuba (PR).

Neste amostrador, o tubo interno é segurado com a mão e girado para penetrar no sedimento sendo, depois, retirado tapando-se com os dedos a abertura inferior para que o sedimento não caia. A seguir, coloca-se o tubo externo e são cortados exatamente os $10 \mathrm{~cm}^{3}$ $\left(10 \mathrm{~cm}^{2} \times 1 \mathrm{~cm}\right)$ superficiais, onde devem ser encontrados os microorganismos. Deste modo, podem ser obtidas amostras de volumes padronizados em todas as estações. O tubo interno tem o objetivo de cortar o sedimento sem comprimi-lo em forma de um pequeno cilindro. Essas amostras foram colocadas em frascos plásticos com adição, em campo, de formol a $40 \%$ para a preservação do protoplasma dos microorganismos contra o ataque das bactérias.

As amostras de microorganismos foram processadas e analisadas no Centro de Pesquisa Manoel Teixeira da Costa (CPMTC-UFMG).

\subsection{1- Amarração ao Nivelamento Geral}

Para o sistema Saquarema-Guarapina, Kjerfve e Knoppers (1991) mostram que a amplitude de maré dentro da Lagoa é em média $1,4 \%$ da variação de maré externa. Como esta variou em no máximo 1,00m (Tab.3) na ocasião de amostragem, a correção seria no máximo $1,4 \mathrm{~cm}$, considerada negligenciável. Para a laguna de Araruama as seções encontram-se fora da área de influência de maré determinada por Lessa (1989), onde a amplitude é de 0,12m a 8,3km de distância da desembocadura do Canal do trajurú ou $2,2 \mathrm{~cm}$ de amplitude na junção do Canal com a laguna (Kjerfve et al. 1995), similarmente considerada negligenciável, visto que os perfis estão posicionados mais internamente e por conseqüência tais amplitudes devem ser ainda menores. 


\section{2- Testemunhagem}

As amostragens subsuperficiais foram executadas utilizando-se um vibrotestemunhador ("vibracorer") nas áreas identificadas na Fig. 1 e foram coletados pela equipe da ORSTOM em 1989 (Tab.4).

Como na época de coleta dos testemunhos não foi prevista análise microfaunística, as amostras não foram colocadas em "freezer" para melhor conservação. Amostrạ̀ de $10 \mathrm{~cm}^{3}$ foram retiradas dos testemunhos ao intervalo de $10 \mathrm{~cm}$, utilizando-se o amostrador "Phleger".

Uma vez que nas lagoas testemunhadas a lâmina d'água está aproximadamente ao nível médio do mar e não sofre influência significativa da maré de acordo com Kjerfve et al (1995) e Lessa (1989), a amarração ao nivelamento geral foi feita da seguinte forma: $O$ topo dos testemunhos apresentava-se na superfície de fundo lagunar à profundidades expressas na tabela 5, utilizadas para converter a profundidade média de cada amostra do testemunho a uma elevação relativa ao nível médio lagunar, correspondente ao nível médio do mar. Por exemplo: uma amostra do testemunho LV4 à $55-58 \mathrm{~cm}$ de profundidade, tem uma profundidade média de $56 \mathrm{e}$ uma elevação de $156 \mathrm{~cm}$ abaixo do nível médio do mar.

\begin{tabular}{|c|c|c|c|c|c|}
\hline Testemunhos & $\begin{array}{c}\text { Latitude } \\
(\mathbf{S})\end{array}$ & Longitude (W) & $\begin{array}{c}\text { Data da } \\
\text { coleta }\end{array}$ & $\begin{array}{c}\text { Profundidade } \\
\text { da água (m) }\end{array}$ & $\begin{array}{c}\text { Comprimentos } \\
\text { dos testemunhos } \\
(\mathbf{m})\end{array}$ \\
\hline LV4 & $22^{\circ} 55.8^{\prime}$ & $42^{\circ} 21.5^{\prime}$ & Nov. 1988 & 1,00 & 3,24 \\
LV89/19 & $22^{\circ} 55.8^{\prime}$ & $42^{\circ} 22.5^{\prime}$ & Jun. 1989 & 1,50 & 1,16 \\
LBE 89/2 & $22^{\circ} 56.0^{\prime}$ & $42^{\circ} 14.5^{\prime}$ & Jun. 1989 & 1,00 & 3,60 \\
\hline
\end{tabular}

Tabela 4 - Localização, profundidade da água e comprimentos dos testemunhos.

\section{3 - Observações ao Microscópio}

A confecção das lâminas delgadas e as observações ao microscópio sob luz polarizada foram efetuadas no Laboratório da PETROBRÁS/CENPES/DIGER. As lâminas analisadas correspondem a níveis carbonáticos de laminitos e de crostas, que foram estudadas com o objetivo de se conhecer os principais constituintes minerais dos sedimentos.

As amostras para estudo de microorganismos foram analisadas sob lupa binocular Zeiss. Todos os exemplares ilustrados nas estampas foram fotografados, após metalização com ouropaládio a fim de torná-los condutores em microscópio eletrônico de varredura (MEV), utilizandose câmaras PENTAX-MX acopladas aos equipamentos ZEISS DSM 940-A e JEOL 840 - A, 
pertencentes à PETROBRÁS/CENPES/DIVEX. O segundo equipamento possibilitou também a identificação da composicição das fases minerais de alguns indivíduos, através da análise de espectometria da energia dispersiva de raios-X-EDS TRACOR-NORTERN, pertencente à PETROBRÁS/CENPES/DIGER.

\section{4 - Parâmetros Físico-químicos}

\subsection{1 - Carbonato, Nitrogênio e Carbono Orgânico}

Os dados abióticos foram obtidos das amostras dos testemunhos, sendo as dosagens dos carbonatos efetuadas no "Laboratoire de Géologie du MNHN" (Paris) utilizando-se um manocalcímetro Mélières (MCM), que mede o volume do $\mathrm{CO}_{2}$ produzido durante o ataque de $100 \mathrm{mg}$ de amostra por ácido clorídrico $8 \mathrm{~N}$. O princípio teórico é o seguinte: a $25^{\circ} \mathrm{C}$ sob pressão atmosférica, o ataque ácido de $100 \mathrm{mg}$ de calcita pura $\left(\mathrm{CaCO}_{3}\right)$ produz a liberação de um milimol de $\mathrm{CO}_{2}$, ou seja, $22,4 \mathrm{~cm}^{3}$. Este volume corresponde ao volume interno do recinto fechado do $\mathrm{MCM}$, de tal forma que a pressão ao fim da reação é de 1 bar. A leitura se faz diretamente no calibrador entre 0 e 1 bar, ou seja de 0 a $100 \%$ de $\mathrm{CaCO}_{3}$.

As medidas de controle sobre o carbonato puro, são efetuadas ao início e ao fim de cada série de amostras, de modo a se corrigir eventuais variações de temperatura e pressão. A leitura do conteúdo de carbonato é direta somente em amostras que contém $\mathrm{CaCO}_{3}$. Por outro lado, amostras que contenham outras fases carbonáticas, notadamente a dolomita, exigem correções em função da massa molecular dos minerais envolvidos. O erro absoluto é de mais ou menos 1 $\%$.

Para a análise de nitrogênio e carbono orgânico foi utilizado um analisador CHN da marca Fisons Instruments, modelo NA 2000, com metodologia padronizada onde em geral são colocados $5 \mathrm{mg}$ de sedimento num cadinho de alumínio e introduzido no analisador automático. $\mathrm{O}$ princípio do método é a dosagem dos gazes liberados pela combustão a $900^{\circ} \mathrm{C}$ por cromatografia gazoza. Para não se levar em conta os carbonatos o sedimento foi previamente atacado por $\mathrm{HCl}$ 1N. Estas análises foram realizadas no Laboratoires des Formations Superficielles - ORSTOM, em Bondy na França.

\subsection{2 - Datações pelo Radiocarbono e Análises Isotópicas}

As datações pelo método do radiocarbono, foram feitas no laboratório Beta Analytic em Miami e foram obtidos pela equipe da ORSTOM, que integra o projeto e posteriormente cedidos 
para este trabalho (Tab. 5). Martin et al. (1986) descrevem detalhadamente o método do radiocarbono e a correção devida ao fracionamento isotópico, que foi utilizada nas análises desse estudo. As análises isotópicas $\left({ }^{18} \mathrm{O}\right.$ e $\left.\partial^{13} \mathrm{C}\right)$ foram efetuadas no Laboratoire d'Océanographie Dynamic et Climatologie (LODYC) utilizando-se um espectômetro de massa do tipo VG Isogas

\begin{tabular}{|c|c|c|c|c|}
\hline $\begin{array}{c}\text { Amostra } \\
(\mathrm{cm})\end{array}$ & Ref. do Lab. & $\begin{array}{l}\text { Natureza } \\
\text { da Amostra }\end{array}$ & $\begin{array}{c}\partial^{13} \mathrm{C} / \mathrm{PDB} \\
\% 0\end{array}$ & $\begin{array}{l}\text { Idade }{ }^{14} \mathrm{C} \\
\text { anos A.P. }\end{array}$ \\
\hline LV 89-19 & \multirow{3}{*}{$\begin{array}{l}\text { Beta - } 45734 \\
\text { Beta - } 45735\end{array}$} & \multirow{3}{*}{$\begin{array}{l}\text { Conchas } \\
\text { Mat. org. }\end{array}$} & \multirow{3}{*}{$\begin{array}{l}-110 \\
-19,00\end{array}$} & \multirow{3}{*}{$\begin{array}{c}760 \pm 80 \\
3700 \pm 80\end{array}$} \\
\hline $30-35$ & & & & \\
\hline $110-115$ & & & & \\
\hline LV4 & \multirow{4}{*}{$\begin{array}{l}\text { Beta- } 45729 \\
\text { Beta- } 45731 \\
\text { Beta- } 45732\end{array}$} & \multirow{4}{*}{$\begin{array}{l}\text { Madeira } \\
\text { Conchas } \\
\text { Mat. org. }\end{array}$} & \multirow{4}{*}{$\begin{array}{c}-25,30 \\
0,20 \\
-17,70\end{array}$} & \multirow{4}{*}{$\begin{array}{c}2330 \pm 90 \\
5180 \pm 70 \\
6530 \pm 100\end{array}$} \\
\hline 114 & & & & \\
\hline $216-218$ & & & & \\
\hline $317-322$ & & & & \\
\hline LBE 89-2 & \multirow{7}{*}{$\begin{array}{l}\text { Beta- } 45722 \\
\text { Beta- } 45723 \\
\text { Beta- } 45724 \\
\text { Beta- } 45725 \\
\text { Beta- } 45726 \\
\text { Beta- } 45727\end{array}$} & \multirow{7}{*}{$\begin{array}{l}\text { Conchas } \\
\text { Mat. org. } \\
\text { Conchas } \\
\text { Mat. org. } \\
\text { Conchas } \\
\text { Conchas }\end{array}$} & \multirow[b]{2}{*}{$-2,80$} & \multirow[b]{2}{*}{$2400 \pm 50$} \\
\hline $85-95$ & & & & \\
\hline $150-155$ & & & $-15,80$ & $3620 \pm 70$ \\
\hline $205-210$ & & & 0,50 & $4430 \pm 90$ \\
\hline $265-275$ & & & $-16,10$ & $5790 \pm 90$ \\
\hline $320-324$ & & & 0,40 & $6660 \pm 70$ \\
\hline $335-340$ & & & 1,20 & $7170 \pm 110$ \\
\hline
\end{tabular}

SIRA 9 medidos sobre o carbonato total, calcita, dolomita e ostracodes.

Tab. 5 - Datações ${ }^{14} \mathrm{C}$ das amostras dos testemunhos lagunares.

\section{5 - Dados Bióticos}

\subsection{1 - Processamento das Amostras de Microorganismos}

As amostras coletadas de superfície foram colocadas em solução corante (Rosa de Bengala) e formol para colorir o protoplasma dos organismos vivos no momento da coleta.

Todas as amostras foram passadas, a úmido, pelas peneiras de $0,500 \mathrm{~mm}$ e $0,062 \mathrm{~mm}$, descartando-se as granulações acima e abaixo deste intervalo. O material orgânico grosso bem como os organismos maiores ficaram retidos na peneira de $0,500 \mathrm{~mm}$ e os foraminíferos passaram para a peneira de $0,062 \mathrm{~mm}$. No intervalo entre a lavagem das amostras, as peneiras eram mergulhadas em azul de metileno para coloração de organismos que, por ventura, após ficarem retidos na malha das peneiras, pudessem vir a contaminar a amostra subseqüente.

As amostras que continham muita areia foram secadas e os foraminíferos separados da areia por flotação em tetracloreto de carbono. 
Todas as amostras foram examinadas sob lupa binocular e contadas em placas de plástico com o fundo quadriculado, que permitiu uma contagem sistemática de todos os indivíduos. Quando a amostra apresentavamse com muitos filamentos de algas, vegetação e particulados orgânicos, era examinada sob imersão em álcool etílico.

Amostras com número de indivíduos superior a $500 / 10 \mathrm{~cm}^{3}$ de sedimento foram quarteadas em microquarteador. Procurou-se contar sempre pelo menos 300 indivíduos ou metade da amostra quarteada, conforme metodologia adotada por diversos autores e descrita em Boltovskoy e Wright (1976). A metodologia utilizada em campo e laboratório, tem sido aplicada e discutida desde Barbosa (1991), e sua aplicação en depósitos de subsuperficie foi extensamente discutida por Scott e Medioli $(1978,1986)$.

Serão aplicados em subsuperfície os zoneamentos atuais de foraminíferos encontrados em superfície, de acordo com método desenvolvido por Scott e Medioli (1986). As associações serão caracterizadas com base na fauna total, ou seja, fauna viva mais morta. A fauna viva será considerada em algumas interpretações ecológicas.

A lavagem e separação dos foraminíferos de amostras obtidas dos testemunhos apresentou alguns problemas metodológicos. Devido ao estado extremamente ressecado do material, bem como pela presença de carbonatos juntamente com siltes e argilas, a lavagem em peneiras de 0,500 e $0,062 \mathrm{~mm}$, foi repetida várias vezes para separação dos foraminíferos e outros microorganismos do material detrítico.

Foram empregados o método da gasolina proposto por Boltovskoy (1965) para fragmentação das pelotas de argila, bem como o método sugerido por Lethiers e Crasquin-Soleau (1988) que utiliza ácido acético, para separação do carbonato dos organismos. Esses métodos não apresentaram resultados satisfatórios. Com o método da gasolina o carbonato ficou impregnado e, mesmo após lavagem exaustiva, permaneceu contaminando a amostra e dificultando a separação dos foraminíferos durante a flotação em tetracloreto de carbono. $O$ método da gasolina, deve ser utilizado após a eliminação do carbonato, mas mesmo assim, no material analisado, não houve desintegração total das pelotas de argila.

O método do ácido acético, da mesma forma, mostrou -se ineficiente devido à presença de argila. Deste modo, o material argiloso que também continha foraminíferos em quantidades significativas também não se fragmentava, resultando em pelotas de argila retidas na peneira de $0,062 \mathrm{~mm}$.

Tentou-se a utilização de detergente, método este empregado na PETROBRÁS, bem como o uso de una solução composta de hexametafosfato de sódio $(35,4 \mathrm{~g} / \mathrm{l})$ e sódio carbonato anidro 
(7,94 $\mathrm{g} / \mathrm{l})$ em água destilada - Calgon, em amostras que apresentavam grande quantidade de argila. Após a tentativa de todos estes métodos, foi usada uma combinação destes, ou seja:

Hidratação e defloculação

- $10 \mathrm{~cm}^{3}$ de amostra necessários para a análise foram mergulhados em água por cinco dias até hidratação das argilas e, após esse período, se as amostras ainda apresentassem pelotas de argila endurecidas, eram colocadas na solução de Calgon por mais 24 hs para desagregação das argilas.

Lavagem, Secagem (Ataque Ácido) e Flotação

- A lavagem do material foi realizada através das peneiras 0,500 e $0,062 \mathrm{~mm}$, sendo colocadas em estufa para secagem abaixo de $60^{\circ} \mathrm{C}$ por 24 hs. Depois de secada a amostra foi submetida ao tetracloreto de carbono para separar os foraminíferos do material arenoso através de flotação repetida.

- Quando a amostra apresentava muito carbonato era submetida ao método do ácido acético antes submetê-la ao tetracloreto de carbono.

Todos esses métodos foram testados no mesmo grupo de amostras para verificação de possíveis resultados diferenciados, o que não foi observado.

\subsection{2 - Tratamento Estatístico das Dados}

As freqüencias percentuais das espécies em cada estação amostrada e profundidade no testemunho estão representadas nas tabelas

Utilizou-se na interpretação conhecimentos autoecológicos das espécies encontradas, tais como freqüencia absoluta, relativa, densidade relativa, abundância, diversidade, constância, dominância e fidelidade (Tinoco 1989).

Para a definição de biofácies de foraminíferos e tecamebas com base nos padrões de distribuição na superfície das bordas lagunares, foi feita a análise de agxupamento (Cluster Analysis) dos dados de frequiência relativa mostrados nas tabelas 7 a 27 , agrupadas em um banco de dados pessoal, divididas em seis grupos maiores, de acordo com as diferentes estações climáticas amostradas. O software usado é o xlSTAT, compatível com excel 5.0, que possui um módulo de cluster analysis 2. Essa análise de agrupamento trata os dados em hierarquia ascendente usando distância Euclidiana para medir a proximidade entre os grupos e o método Ward de ligação é utilizado para arrumar os grupos dentro de um dendrograma hierárquico. Esse 
software foi desenvolvido por Thierry Fahmy para Kovach Computing Services Software e pode ser obtido através do endereço e-mail: info@kovcomp.co.uk. 


\section{CAPÍTULO 5}

\section{5-RESULTADOS}

\section{1 - Seções Topográficas Transversais as Bordas Lagunares}

Algumas seções topográficas transversais das bordas lagunares mö̌traram variações entre o verão e o inverno, principalmente nas lagunas de Araruama e Saquarema.. Tais variações ilustram uma dinâmica nas bordas lagunares, por efeito dos ventos, influências flúvio-pluviais e trocas oceânicas através da estreita comunicação com o mar, quando ocorre aumento no volume de água na bacia lagunar. Nas lagoas, devido à menor evaporação no inverno, observoumse aumento na coluna de água, com relação ao verão.

\subsection{1-Salinidade e pH}

A salinidade é dependente de diversos fatores, sendo os mais importantes a contribuição fluvial da bacia de drenagem (significativa na área de Saquarema), escoamento de águas superficial e subsuperficial e balanço hídrico entre evaporação e precipitação.

A laguna de Araruama apresentou aumento sutil dos valores de salinidade no inverno (Tab.6), com exceção da seção 5, posicionada na extremidade leste do sistema e que apresenta a mais significativa influência fluvial.

\begin{tabular}{|cccccc|ccc|}
\hline Seções & Local & Verão & Hora & $\begin{array}{c}\text { Salinidade } \\
(\%)\end{array}$ & pH & Inverno & Hora & $\begin{array}{c}\text { Salinida } \\
\text { de }(\% \text { ) }\end{array}$ \\
\hline S1 & Araruama & $17 / 02 / 93$ & $10: 15$ & 50 & 8.07 & $27 / 08 / 93$ & $9: 00$ & 54 \\
S2 & Araruama & idem & $11: 45$ & 50 & 8.08 & idem & $10: 15$ & 55 \\
S3 & Araruama & idem & $13: 25$ & 42 & 8.12 & idem & $11: 40$ & 54 \\
S4 & Araruama & idem & $15: 25$ & 50 & 8.23 & idem & $12: 30$ & 55 \\
S5 & Araruama & $18 / 02 / 93$ & $9: 25$ & 55 & 7.82 & idem & $15: 00$ & 48 \\
S6 & B.do Espinho & $17 / 02 / 93$ & $17: 00$ & 95 & 7.82 & idem & $13: 00$ & 39 \\
S7 & L. Vermelha & $18 / 02 / 93$ & $11: 00$ & 54 & 8.45 & idem & $16: 00$ & 40 \\
S8 & Saquarema & idem & $13: 25$ & 27 & 8.40 & $28 / 8 / 93$ & $8: 25$ & 21 \\
S9 & Saquarema & idem & $14: 35$ & 16 & 8.61 & idem & $9: 15$ & 16 \\
S10 & Saquarema & idem & $15: 10$ & 12 & 9.03 & idem & $9: 45$ & 16 \\
S11 & Jacarepiá & idem & $12: 30$ & 0 & 8.69 & & & \\
\hline
\end{tabular}

Tab. 6 - Dados físico químicos relativos ao verão e inverno das amostras superficiais das bordas lagunares.

Para as outras seções analisadas os valores de salinidade da água coletada em suas bordas apresentaram decréscimo, esperado nesta época do ano, quando o clima torna-se mais ameno e a evaporação principalmente nos sistemas fechados é menor. Este fator ecológico condiciona 
verticalmente e horizontalmente as espécies encontradas e será discutido juntamente com os dados faunísticos.

Os valores de $\mathrm{pH}$ foram coletados apenas no verão e mostram o predomínio de condições de alcalinidade, apresentando-se dentro dos valores considerados normais em lagunas abertas, uma vez que a água do mar normalmente possui um $\mathrm{pH}$ de 8,1. Essa variável é determinada pela relação entre $\mathrm{CO}_{2}$ e carbonato ou mais precisamente pela concentração de íon $\mathrm{H}^{+}$, resultante da dissociação dos íons $\mathrm{H}_{2} \mathrm{CO}_{3}^{-}$e da $\mathrm{OH}^{-}$na hidrólise do bicarbonato, com maiores valores encontrados onde muito $\mathrm{CO}_{2}$ foi retirado, alterando o equilíbrio de $\mathrm{CO}_{2}-\mathrm{HCO}_{3}{ }^{-}-\mathrm{CO}_{3}{ }^{2+}$ (Allen e Collinson, 1986). Em estudos com culturas de foraminíferos em laboratório a influência mais expressiva observada refere-se aos baixos valores de $\mathrm{pH}$ sobre os organismos vivos, quando estes se desprendem das tecas ou cessam o crescimento. Valores acima de 7,8 encontrados contribuem para uma melhor conservação das tecas carbonáticas.

\subsection{2 - Assembléias Microfaunísticas de Superfície}

O zoneamento microfaunístico na superfície das bordas lagunares será separado sazonalmente e discutido em três grupos mais amplos de acordo com as semelhanças físicoquímicas entre as lagunas. O primeiro grupo corresponde as seções elaboradas nas bordas lagunares de Araruama, o segundo grupo às seções das Lagoas Vermelha e Brejo do Espinho e o terceiro grupo às seções de Saquarema e Jacarepiá. No final será elaborada uma comparação das biofácies entre grupos e sazonalmente.

Uma vez que este estudo demonstra a importância de se conhecer o padrão de distribuição faunístico e sua relação com a elevação, as amostras estão organizadas nas tabelas das mais altas, mais afastadas do nível da água lagunar, correspondentes às estações 1 para as mais baixas, já dentro da água em cada seção. A amplitude corresponde às altura máximas e mínimas de ocorrência de uma determinada espécie em relação ao nível da água lagunar no momento da amostragem, portanto, nível médio do mar, uma vez que as oscilações devidas à variações no estado da maré são consideradas negligenciáveis dentro do contexto das lagunas. Assim, quando as amplitudes forem positivas devem ser entendidas como acima do nível médio do mar, e se negativos abaixo. Inicialmente o zoneamento será discutido com base nas observações ecológicas, destacando-se as tendências de ocupação das estações iniciais. Em seguida o zoneamento será discutido com base nas tendências mais amplas definidas a partir da análise de agrupamento. 
Das 54 amostras coletadas nas superfícies das bordas lagunares no verão, 7 amostras apresentaram-se estéreis e o número de indivíduos variou de 1 a 87.808 . No inverno, das 53 amostras coletadas na superfície das bordas lagunares 12 apresentaram-se estéreis e o número de indivíduos variou de 1 a 49.159. Ao todo foram identificadas 120 espécies de foraminíferos, cinco espécies de tecamebas, 4 espécies de gastrópodes, 2 gêneros de carófitas e 4 espécies de ostracodes. Todas as espécies deste estudo estão ilustradas nas estampas $1-26$ e descritas no capítulo de Taxonomia.

\subsubsection{1-Veräo}

GRUPO 1 - Laguna Hipersalina - Araruama

Os cinco zoneamentos microfaunísticos elaborados nas bordas lagunares de Araruama estão separados, de acordo com as semelhanças faunísticas entre as seções em: zoneamentos localizados à E do sistema, ou seja, Seção 1 ( Tab. 7, Figs. 7A-C) e Seção 5 (Tab. 11, Figs. 11 AC) e zoneamentos de W, Seções 2, 3 e 4 (Tab. 8, Figs. 8 A-C; Tab. 9, Figs. 9 A-C; e Tab. 10, Figs. 10 A B B respectivamente.

Os zoneamentos localizados à $\mathrm{E}$ do sistema apresentam maior influência flúvio-pluvial evidenciada pela ocorrência de foraminíferos aglutinantes em suas fácies pós-laguna (Fig.3C). Esses foraminíferos são representados pelos Haplophragmoides wilberti e Trochammina inflata. Na estação 1 da seção 1 (Tab. 7), H. wilberti corresponde a única espécie vivente a uma altitude de $0,06 \mathrm{~m}$, a qual corresponde a amplitude da fácies pós-laguna nesta seção. Na seção 5 (Tab.11), essas espécies, estão associadas à foraminíferos calcários, que não são exclusivos desta primeira estação como os aglutinantes, onde ocorrem em amplitude de $0,13 \mathrm{~m}$.

Os zoneamentos das seções à W na laguna de Araruama apresentam o predomínio de assembléias calcárias, sem representante exclusivamente vivente nas primeiras estações das fácies de pós-laguna. No entanto, algumas tendências relativas às seções de $\mathrm{W}$ podem começar a ser traçadas: A primeira corresponde ao aumento na abundância absoluta em $10 \mathrm{~cm}^{3}$ em direção à laguna, geralmente associada ao aumento no número de indivíduos de Pseudotriloculina lecalvezae, Ammonia beccarii f. tepida e Elphidium excavatum f. selseyensis (Seção 2 -tab.8, figs. 8A-C e seção 3-tab. 9, figs. 9A-C); esse aumento no número de indivíduos também é acompanhado pelo aumento no número de espécies que apresentam indivíduos viventes. Outra tendência refere-se a diminuição acentuada no número de indivíduos e espécies na zona de arrebentação da laguna, representada pela estação 5 na seção 2 e estação 4 na seção 3 . Na seção 4 
(Tab. 10, Figs. 10A-B) a zona de arrebentação apresenta-se estéril e o baixo número de espécies e indivíduos não permite uma análise isolada desta seção no verão.

\section{GRUPO II - Lagoas Hipersalinas}

Este segundo grupo é representado pelas seções da sabkha Brejo do Espinho (Seção 6 Tab. 12, Figs. 12 A-C) e Lagoa Vermelha (Seção 7 - Tab. 13, Figs. 13 A-C). Essas duas seções apresentam elevada abundância absoluta em $10 \mathrm{~cm}^{3}$ e ocorrência predominanté de foraminúferos calcários. Estes são representados por Agglutinella martiniiana e Agglutinella sp. A vivas, exclusivos à fácies pós-lagunar com $0,13 \mathrm{~m}$ a $0,08 \mathrm{~m}$ de altitude na seção 6 e 0,1 a $0,07 \mathrm{~m}$ na seção 7. Suas tecas apresentam-se cobertas por grãos de aglutinação secundária (Estampa 3, Figg 3-9).

Na seção 6 a espécie calcária Discorinopsis aquayoi apresenta aumento acentuado em sua freqüência de ocorrência em direção à fácies pós-laguna. A composição da teca, de aspecto calcário granular muito fino, com cimento carbonático, era considerada como aglutinante até 1988 (Scott et al. 1990). Na seção 6 Ophtalmmina sp. apresenta ocorrência exclusiva à estação 1 (pós-laguna) com $0,13 \mathrm{~cm}$ de altitude.

A estação 1 (pós-laguna) da seção 7, apresenta a maior diversidade de espécies desta seção com maior freqüência de organismos calcários como os $P$. lecalvezae e $A$. beccarii, inclusive com representantes vivos, embora ocorram por toda a seção. Também são encontradas Trochammina inflata com baixas porcentages de freqüência. Outras dez espécies com freqüuencias de ocorrência menos expressivas nesta estação da seção 7 são consideradas posteriormente na análise de agrupamento.

De maneira semelhante à Araruama, nas duas seções analisadas, observa-se o aumento de P. lecalvezae em direção à lagoa. Ammonia beccarii f. tepida apresenta aumento na frequiência de ocorrência em direção à fácies pós-laguna, inclusive com representantes vivos.

\section{GRUPO III - Saquarema e Jacarepiá}

As seções 8, 9 e 10 da Laguna de Saquarema, respectivamente Tab.14, Fig.14; Tab.15, Figs.15A-B; Tab.16, Figs.16A-B, foram amostradas em momento de maré alta. Assim sendo, a ocorrência de foraminíferos nas estações posicionadas abaixo do nível lagunar refletem o máximo atingido pela maré alta na fácies pós-laguna. Para estas seções e para a seção 11 da Lagoa de Jacarepiá (Tab. 17, Figs 17A-B) não foi elaborado o gráfico de abundância absoluta devido ao baixo número de indivíduos. A seção 8 de Saquarema foi a que apresentou a mais 
inexpressiva freqüência de ocorrência de todas as seções amostradas, com somente frústulas de diatomáceas e gastrópodes. As seções 9, 10 de Saquarema e 11 de Jacarepiá apresentam somente foraminíferos aglutinantes com fidelidade de $H$. wilberti à fácies pós-laguna. Em Saquarema esta espécie está em associação com Trochammina macrescens e em Jacarepiá, devido a condição de água doce, está associada às tecamebas. A altitude de ocorrência de $H$. wilberti na seçẫo 9 é de - $0,06 \mathrm{~m}$ e seu limite inferior corresponde ao limite de amostragem. As altitudes de ocorrência nas seções 10 e 11 correspondem à $0,02 \mathrm{~m}$ e $0,09 \mathrm{~m}$, respectivamente.

\subsubsection{2 ... Inverno}

GRUPO I - Laguna Hipersalina - Araruama

Foi mantida a separação para efeitos comparativos entre as seções localizadas à $\mathbf{E}$ e $W$ da laguna. Os zoneamentos à E do sistema, ou seja, Seção 1 (Tab. 18, Figs. 18A-C) e Seção 5 (Tab. 22, Figs. $22 \mathrm{~A}-\mathrm{C}$ ) continuam apresentando ocorrência de foraminíferos aglutinantes, mas estes não apresentam-se na estação 1 dessas seções, mas deslocados para a estação 3 na seção 1 e estação 2 na seção 5, sem ocorrência de indivíduos vivos na seção 1.

Para a seção 1, observa-se que houve um acréscimo sedimentar de aproximadamente $30 \mathrm{~cm}$, em relação ao verão, expressando uma variação topográfica significativa da borda lagunar. As estações 1 e 2 representam no inverno a zona vegetada pós- lagunar e a estação 3 corresponde à base da escarpa pós-lagunar, ou seja, é na estação 3 que nesta época do ano encontra-se a fácies comparável a fácies pós-lagunar do verão. Nesta seção a estação 2 não apresenta ocorrência de nenhuma espécie exclusiva à ela, ao contrário da estação 3 com a associação de foraminíferos aglutinantes Trochammina sp., H. wilberti e a espécie de tecameba Centropyxis constricta. A altitude da estação 3 é $0,22 \mathrm{~m}$. A seção 1 apresenta queda no número de espécies e indivíduos na estação 9 que corresponde a linha de arrebentação na laguna e aumento desses números em direção a área lagunar.

A seção 5 (Tab.22, Figs. 22A-C) apresenta a estação 1 com ocorrência das espécies calcárias Rosalina candeiana, Varidentella sp. A vivas e com freqüência de ocorrência exclusiva à esta estação. Outras espécies de ocorrência viva não apresentam-se exclusivas à esta estação. As espécies Bolivina striatula, Miliolinella sp. A, e Pseudotriloculina subgranulata com baixas porcentagens de frequiência totais só ocorrem nesta estação. Com a maior altitude da seção $(0,13$ m) a estação 2 apresenta a primeira ocorrência de aglutinantes com Trochammina inflata, e a espécie calcária Quinqueloculina patagonica exclusivas à esta estação com representantes vivos, as outras espécies calcárias apresentam ocorrência nas estações adjacentes. Os outros 


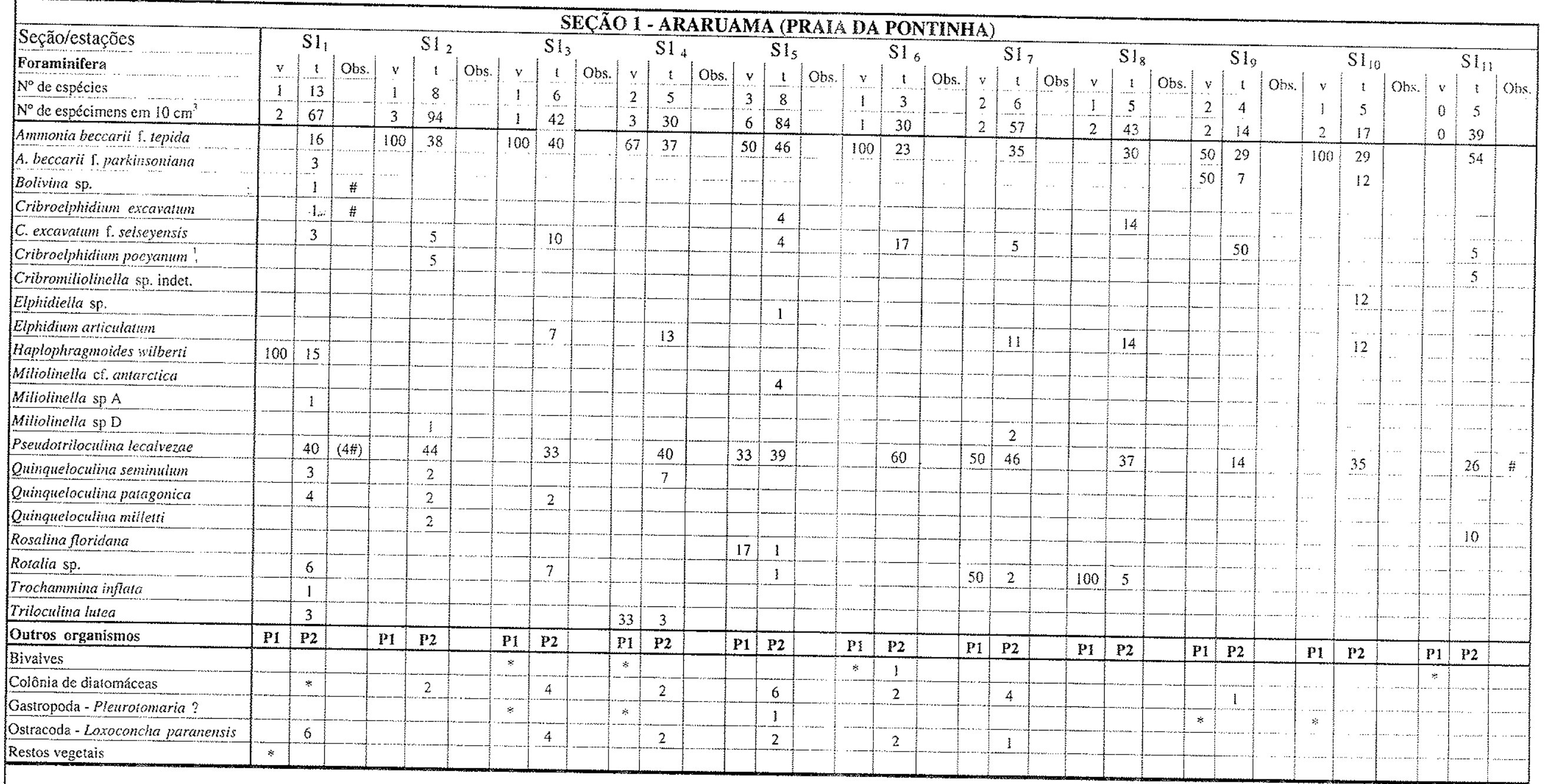

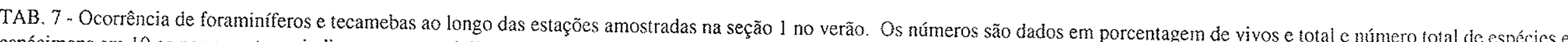

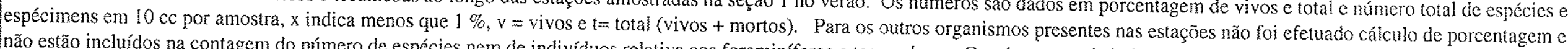

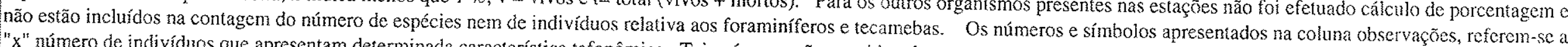

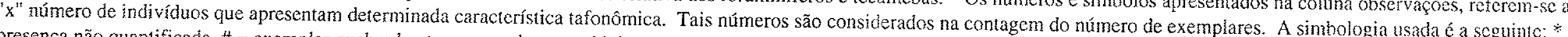

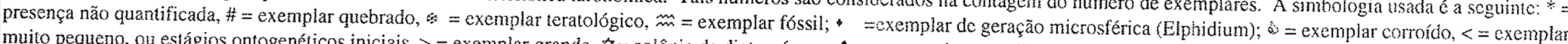

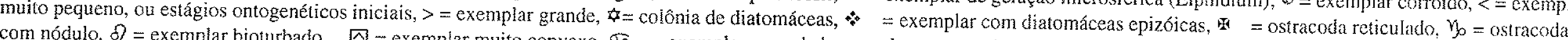

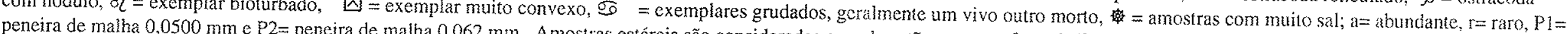
peneira de malha $0,0500 \mathrm{~mm}$ e $\mathrm{P} 2=$ peneira de maha $0,062 \mathrm{~mm}$. Amostras estéreis são consideradas quando estão ausentes foraminíferos em ambas as peneiras. 

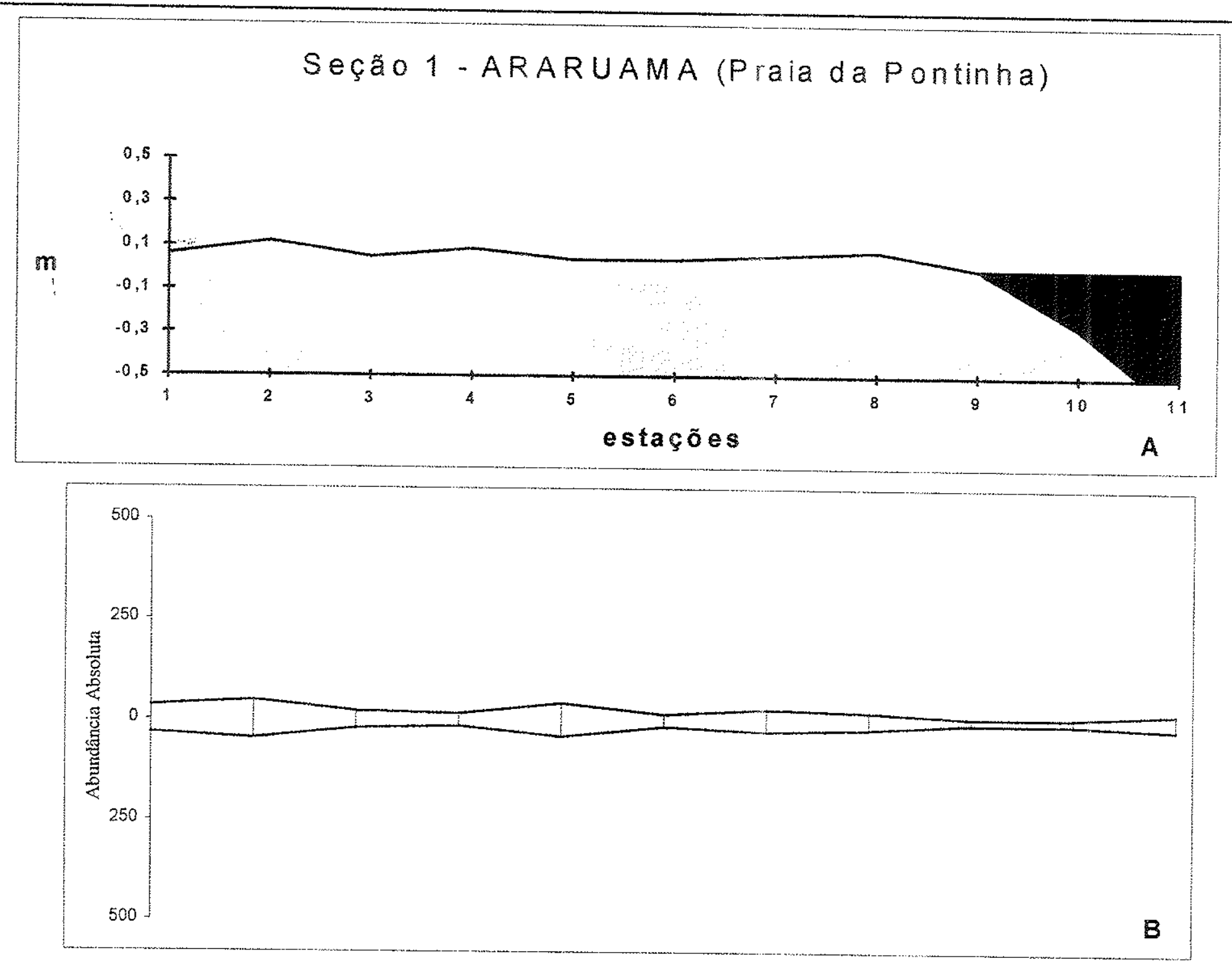

Fig. 7 $\mathrm{B}^{-}$(A) Seção topográfica transversal. O nível de maré indicado corresponde ao momento da coleta e o comprimento total da seção é 16,20 m. (B) Abundância absoluta. O gráfico representa o número total de individuos em $10 \mathrm{~cm}^{3}$. Mais de 1000 indivíduos são por vezes encontrados em cada estação, mas variações significativas parecem ocorrer apenas entre 0 e 1000 (Scott \& Medioli, 1980) dai a escala utilizada. As linhas verticais representam as estações e as horizontais a média interpolada entre as duas estaçôes. 

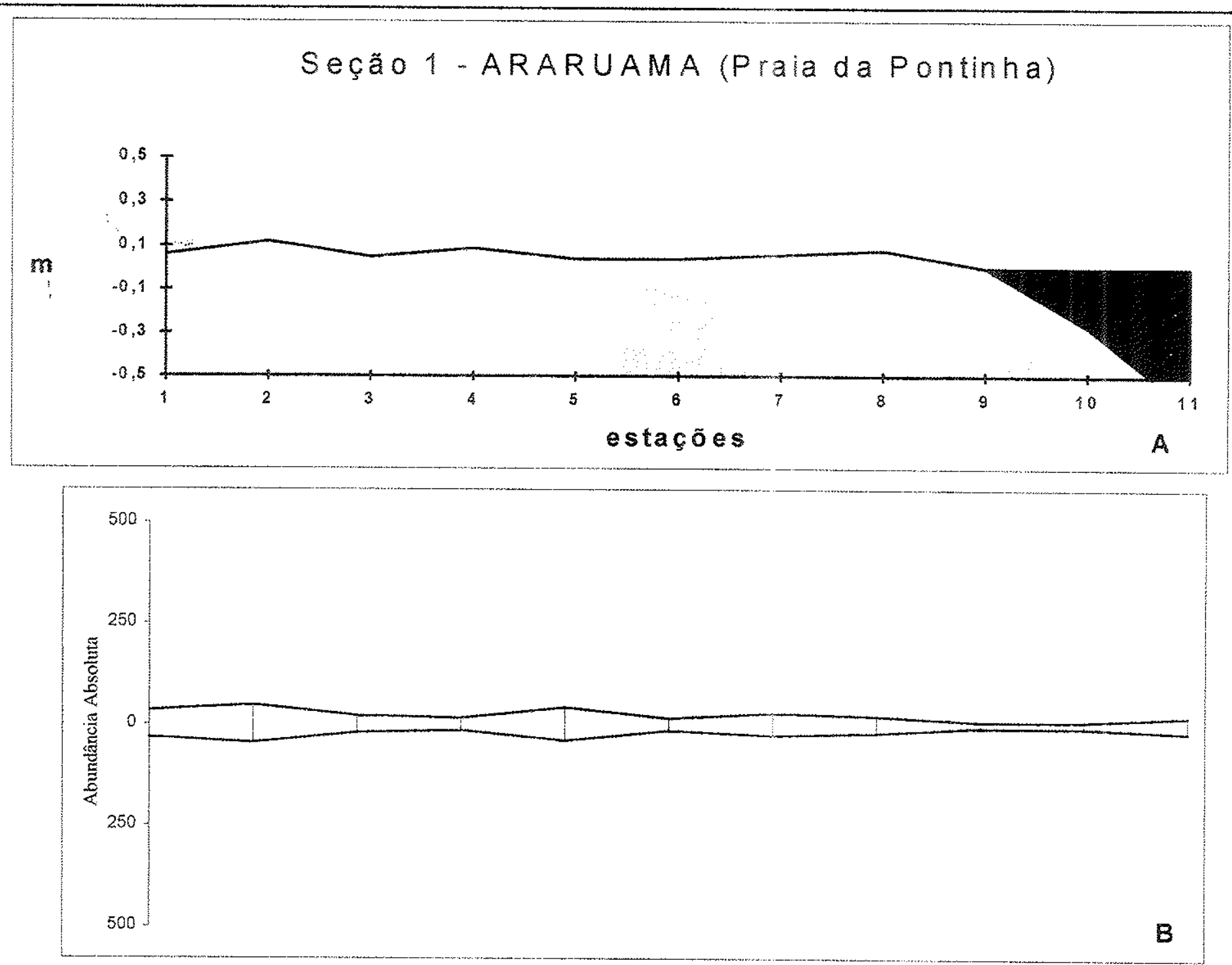

Fig. 7B- (A) Seção topográfica transversal. O nível de maré indicado corresponde ao momento da coleta e o comprimento total da seção é $16,20 \mathrm{~m}$. (B) Abundância absoluta. $O$ gráfico representa o número total de indivíduos em $10 \mathrm{~cm}^{3}$. Mais de 1000 indivíduos são por vezes encontrados en cada estação, mas variações significativas parecem ocorrer apenas entre 0 e 1000 (Scott \& Medioli, 1980) daí a escala utilizada. As linhas verticais representam as estações e as horizontais a média interpolada entre as duas estações. 


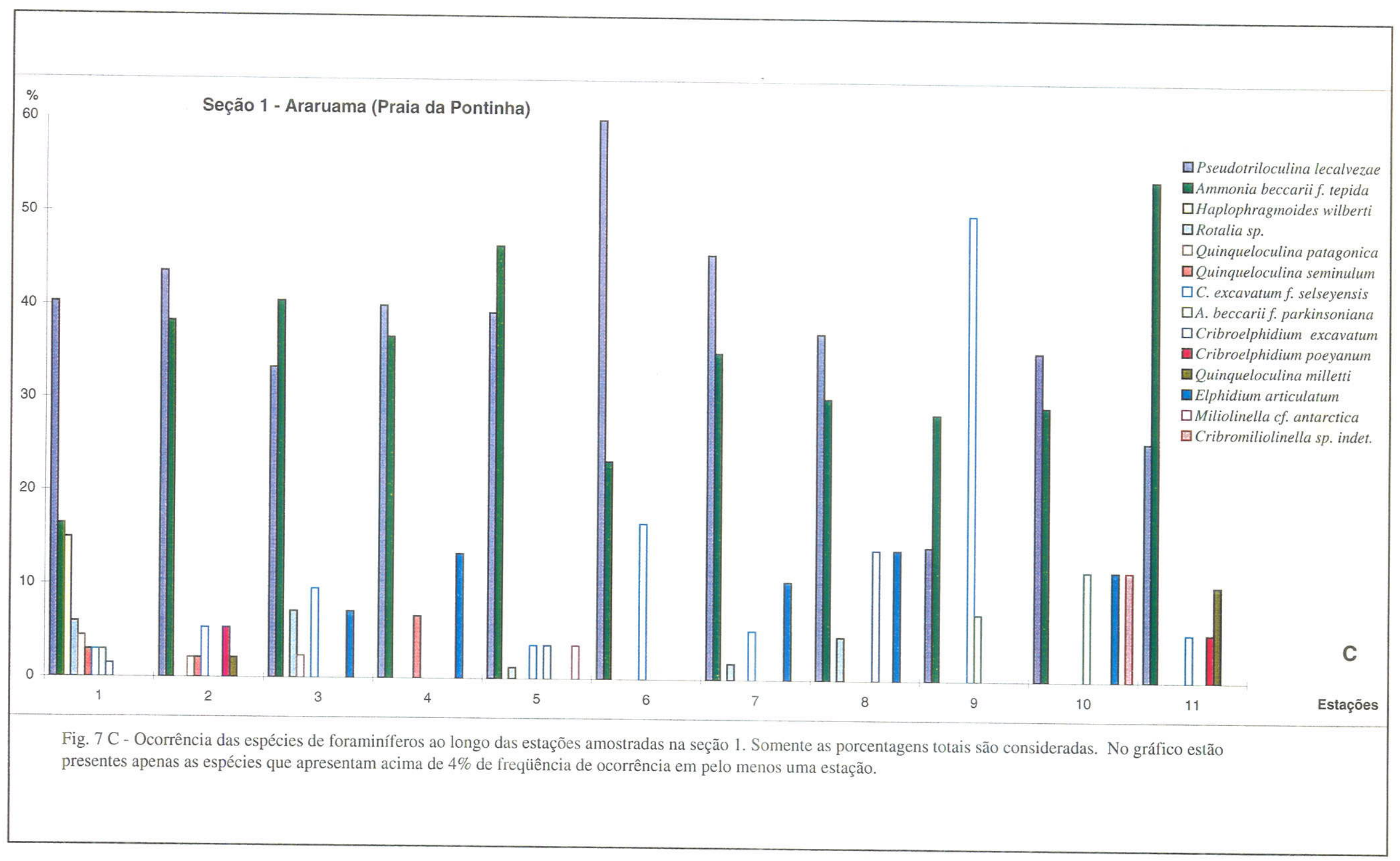




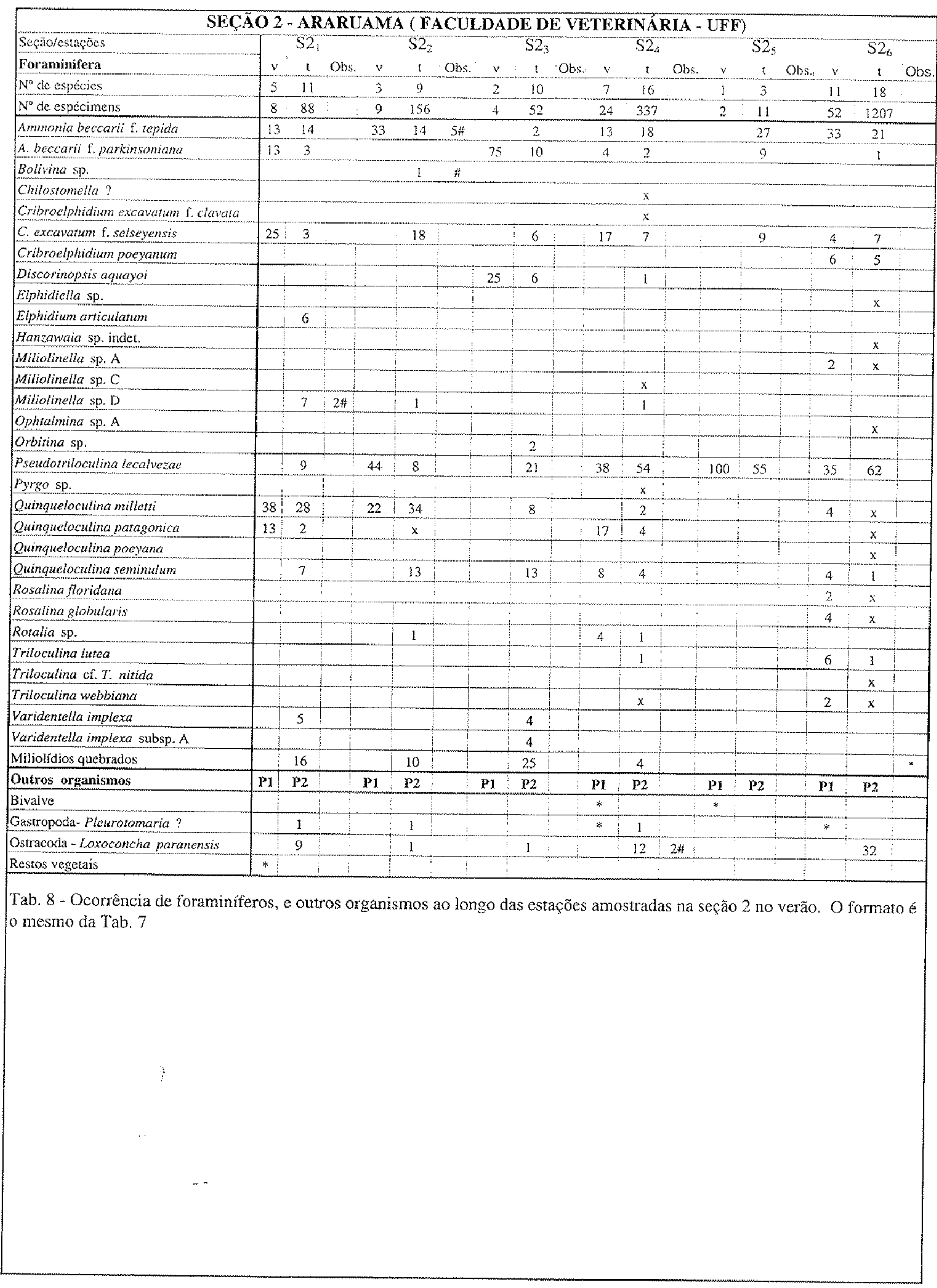


S e ção 2 - AR A R U A M A

( $F$ a culdade de Ve te rinária-UFF)

0,7

m
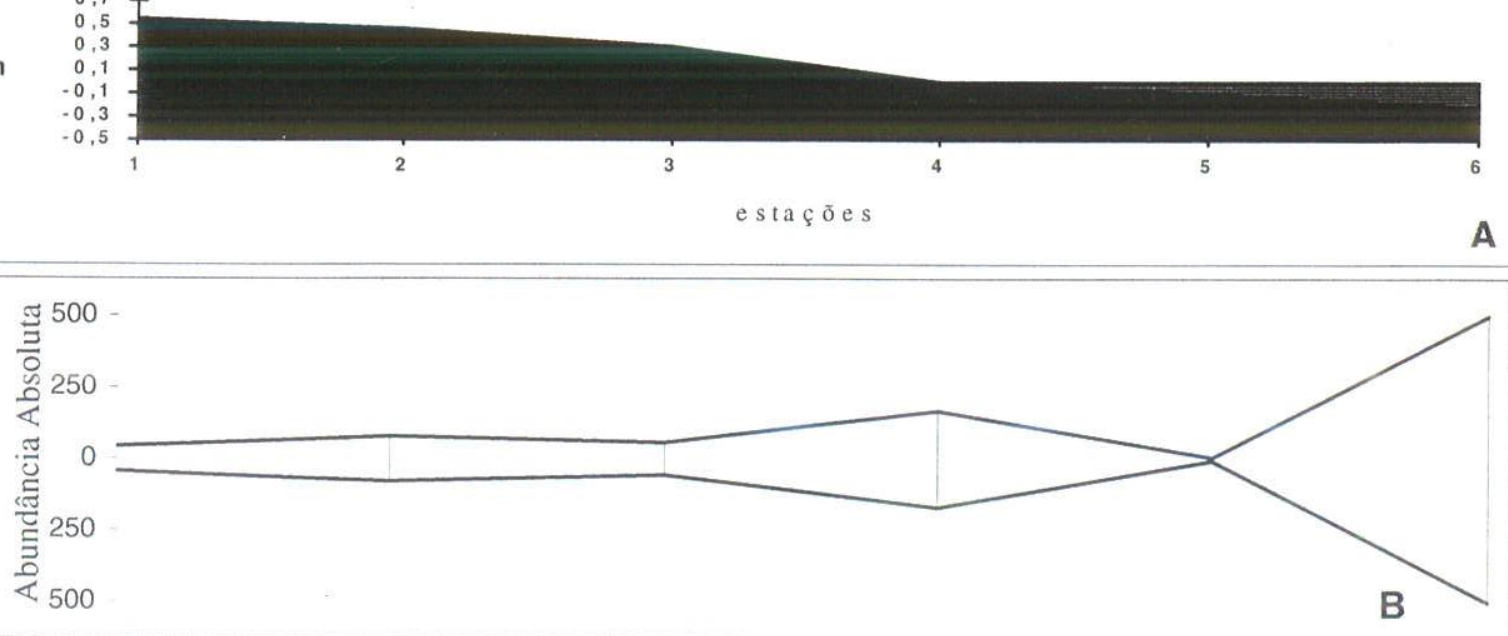

Seção 2 - Araruama (Faculdade de Veterinária-UFF)

\begin{tabular}{|c|c|c|}
\hline & $\square$ Quinqueloculina milletti & Ammonia beccarii f. tepida \\
\hline & $\square$ Miliolídios quebrados & Quinqueloculina seminulum \\
\hline & 圆 Miliolinella sp. $D$ & Elphidium articulatum \\
\hline$\%$ & DC. excavatum $f$. selseyensis & $\square$ Quinqueloculina patagonica \\
\hline & $\square$ Varidentella implexa subsp. A & $\square$ Cribroelphidium poeyanum \\
\hline
\end{tabular}

A. beccarii f. parkinsoniana

$\square$ Pseudotriloculina lecalvezae

$\square$ Varidentella implexa

口Discorinopsis aquayoi

60

50

40

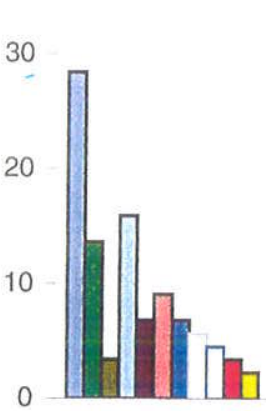

1

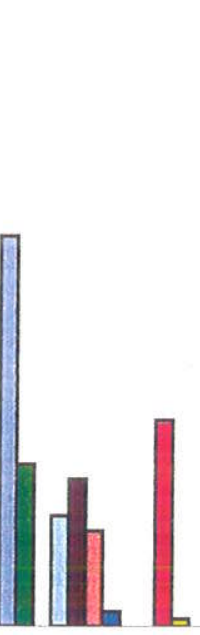

2

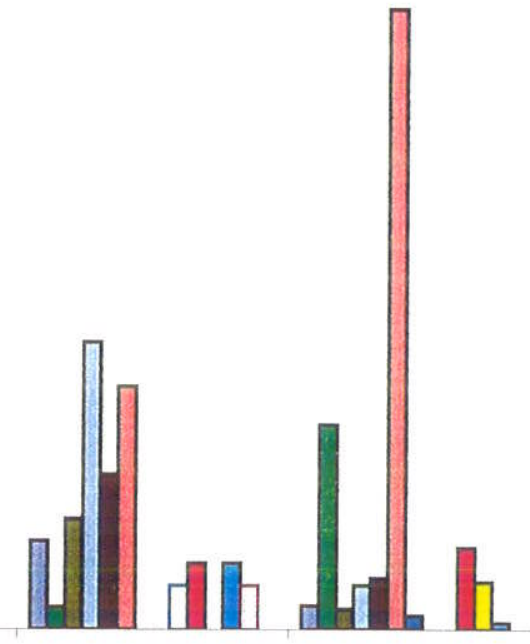

3

4

Estações 


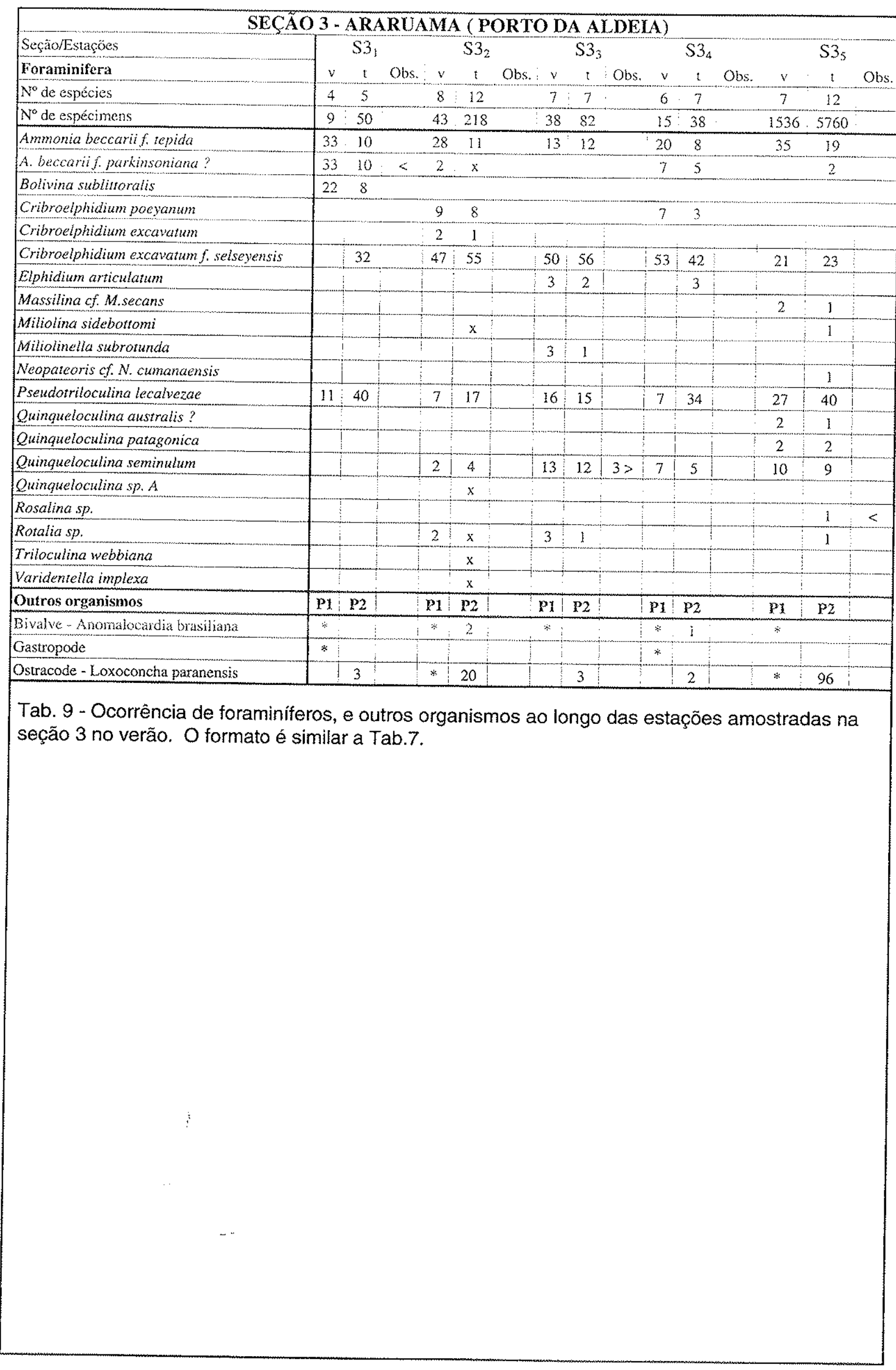




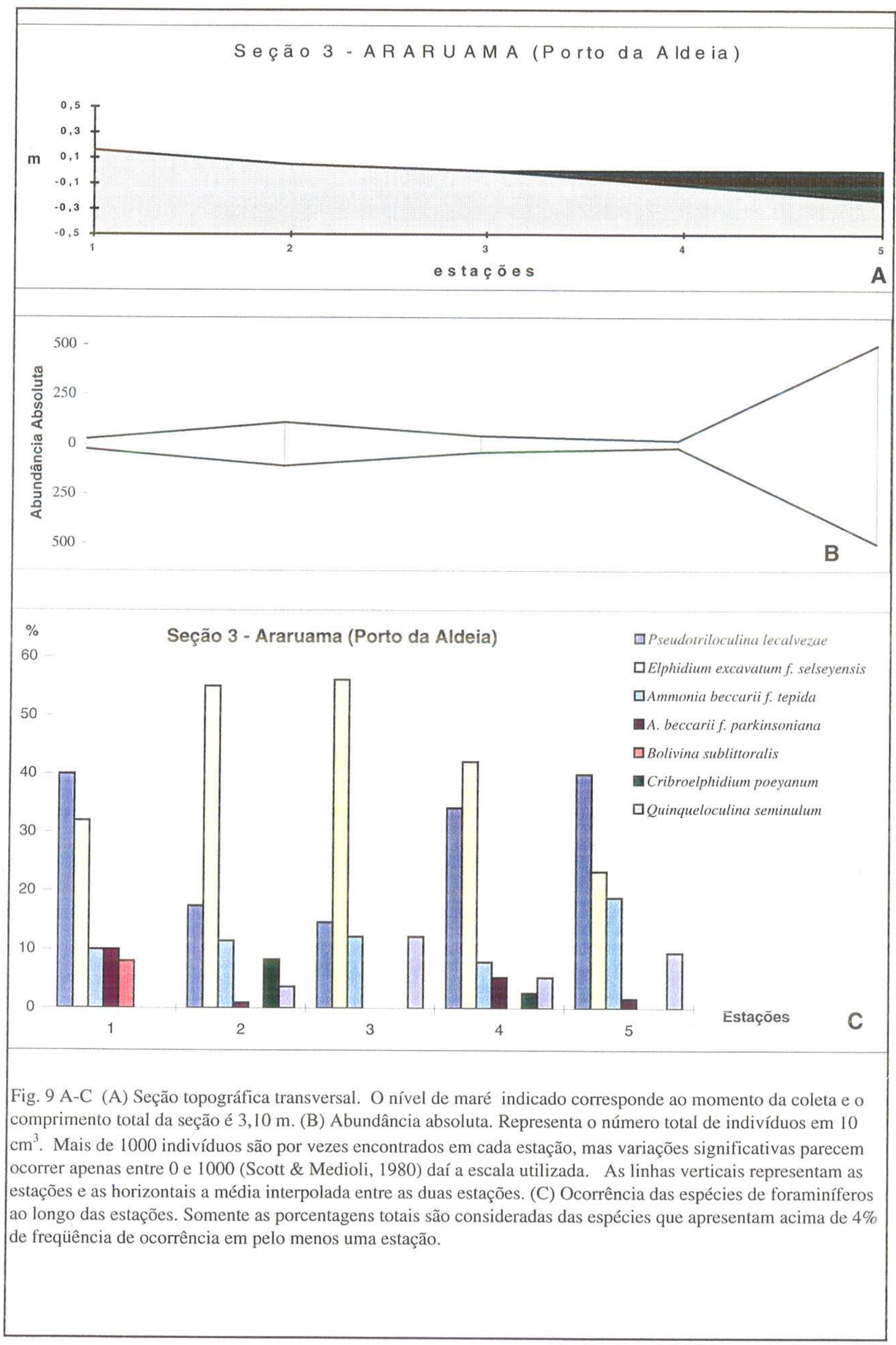




\begin{tabular}{|c|c|c|c|c|c|c|c|c|c|}
\hline \multicolumn{10}{|c|}{ SEÇÃO 4 - ARARUAMA (FIGUEIRA) } \\
\hline \multirow[t]{2}{*}{ Seção/Estações } & \multirow{2}{*}{$\begin{array}{c}\mathrm{S} 4_{1} \\
\text { estéril }\end{array}$} & \multicolumn{3}{|c|}{$\mathrm{S}_{2}$} & \multicolumn{3}{|c|}{$\mathrm{S} 4_{3}$} & \multirow{2}{*}{$\begin{array}{c}\mathrm{S}_{4} \\
\text { estéril }\end{array}$} & \multirow{2}{*}{$\begin{array}{c}\mathrm{S} 4_{5} \\
\text { estéril }\end{array}$} \\
\hline & & $\mathrm{v}$ & $\mathrm{t}$ & Obs. & $\mathrm{v}$ & $\mathrm{t}$ & Obs. & & \\
\hline \multicolumn{10}{|l|}{ Foraminifera } \\
\hline$N^{\circ}$ de espécies & & 0 & 1 & & 0 & 2 & & & \\
\hline$N^{\circ}$ de espécimens & & 0 & 1 & & 0 & 2 & & & \\
\hline Quinqueloculina milletti & & & 100 & & & 50 & & & \\
\hline Q. seminulum & & & 0 & & & 50 & & & \\
\hline
\end{tabular}

Tab. 10 - Ocorrência de foraminíferos ao longo das estações amostradas na seção 4 no verão. Formato similar a Tab. 7

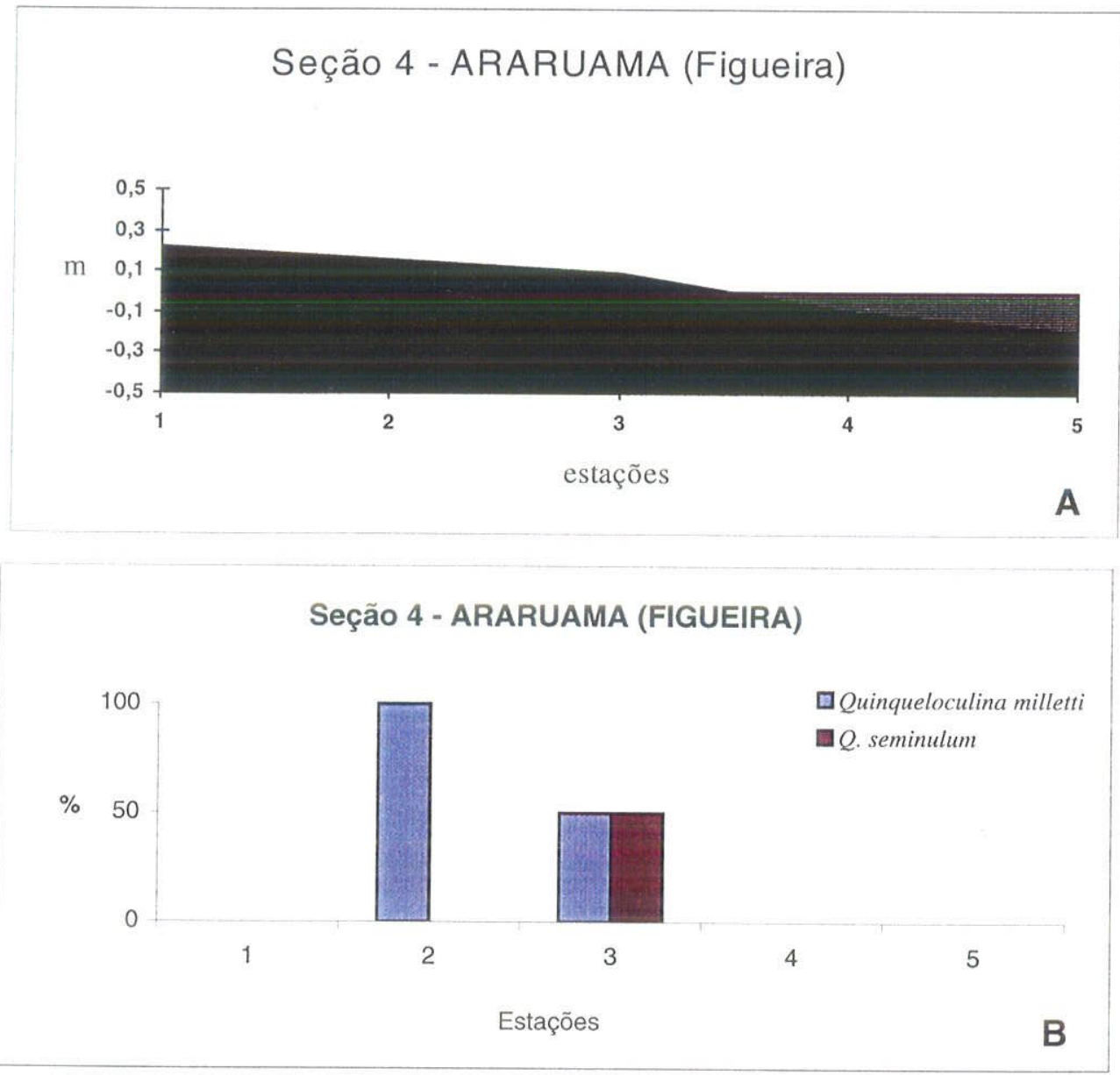

Fig. 10 A-B - (A) Seção topográfica transversal. O nível de maré indicado corresponde ao momento da coleta e o comprimento total da seção é 3,60 m. (B) Ocorrência das espécies de foraminíferos ao longo das estações amostradas na seção 4. Somente as porcentagens totais são consideradas no gráfico. 


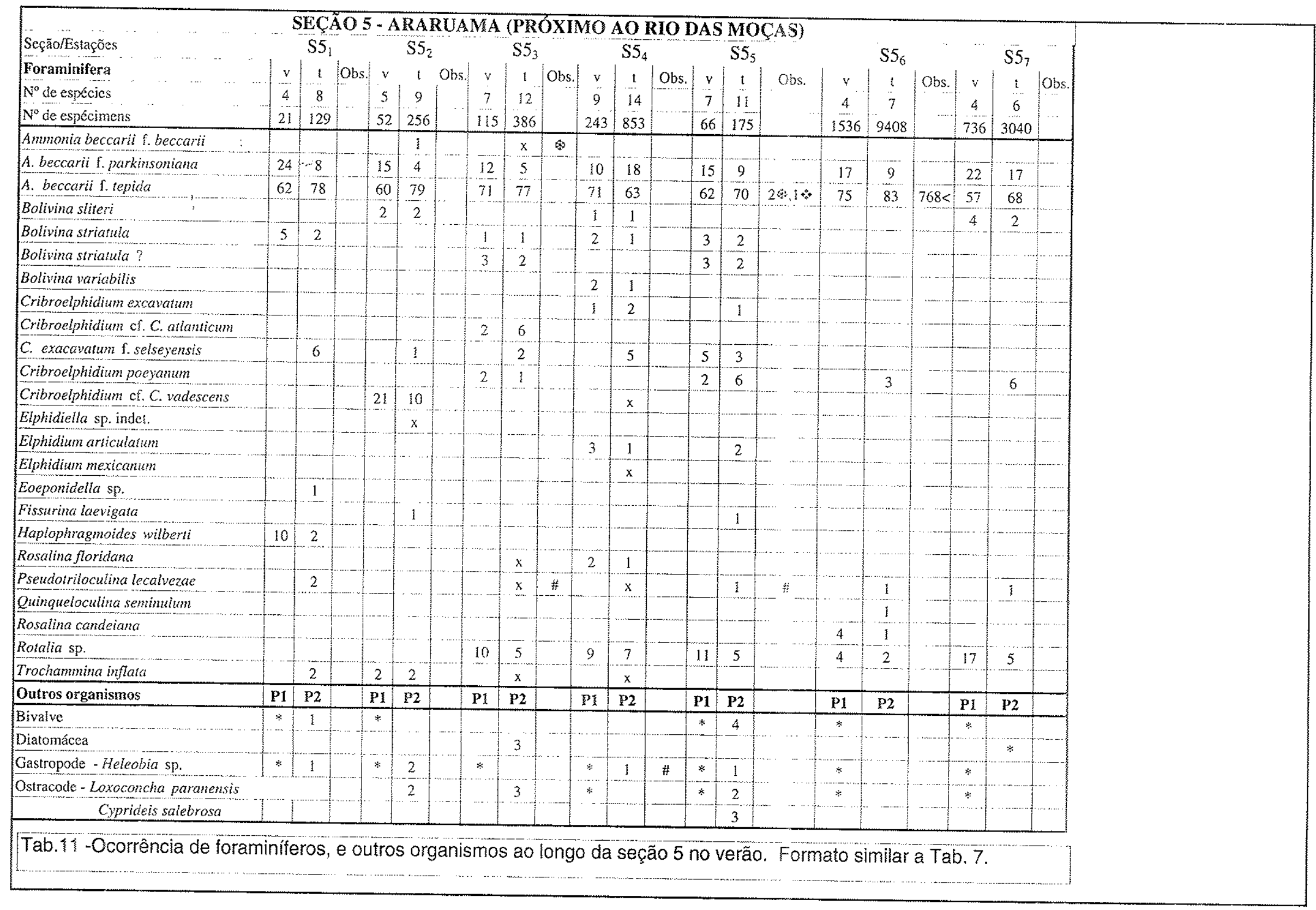




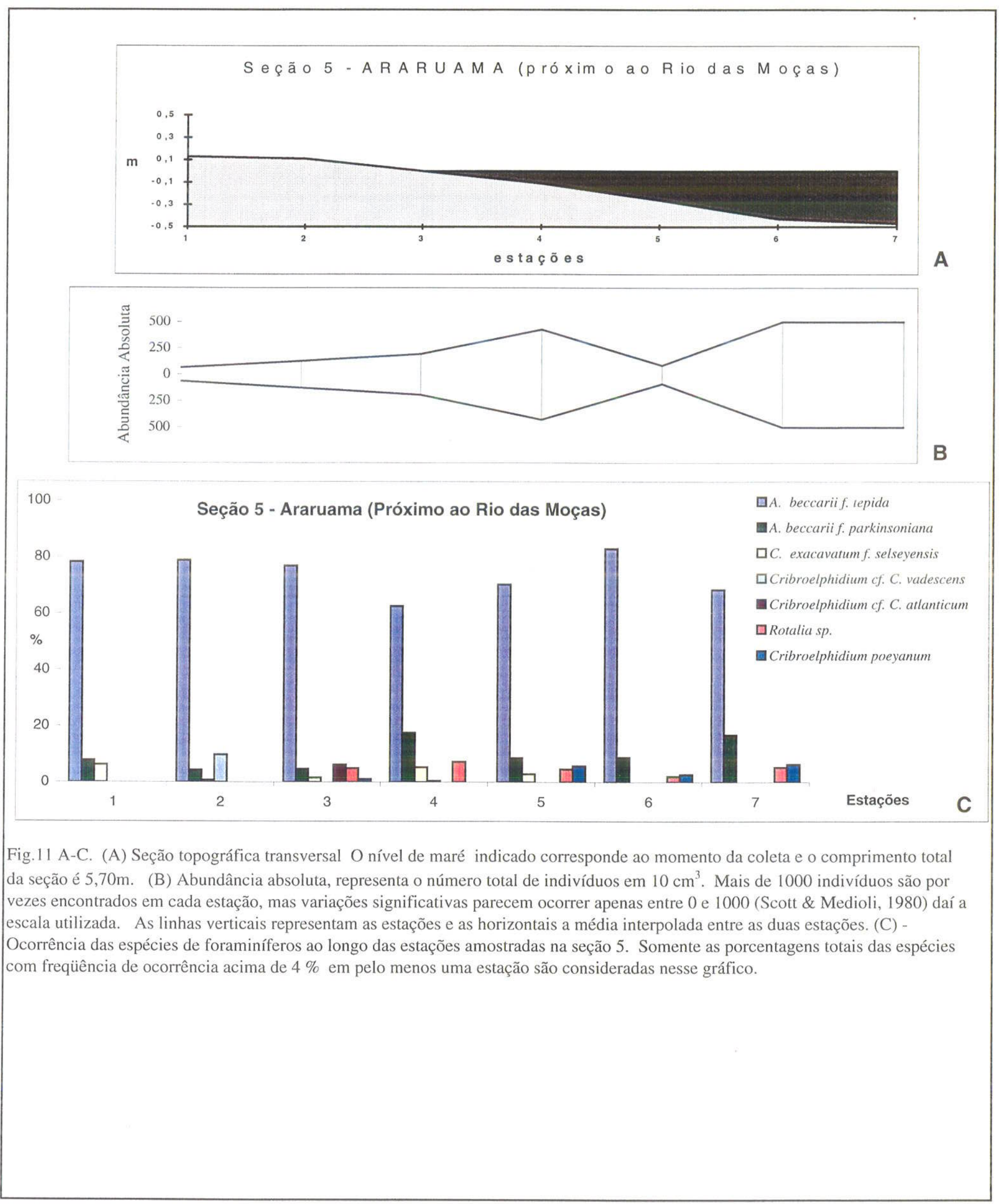




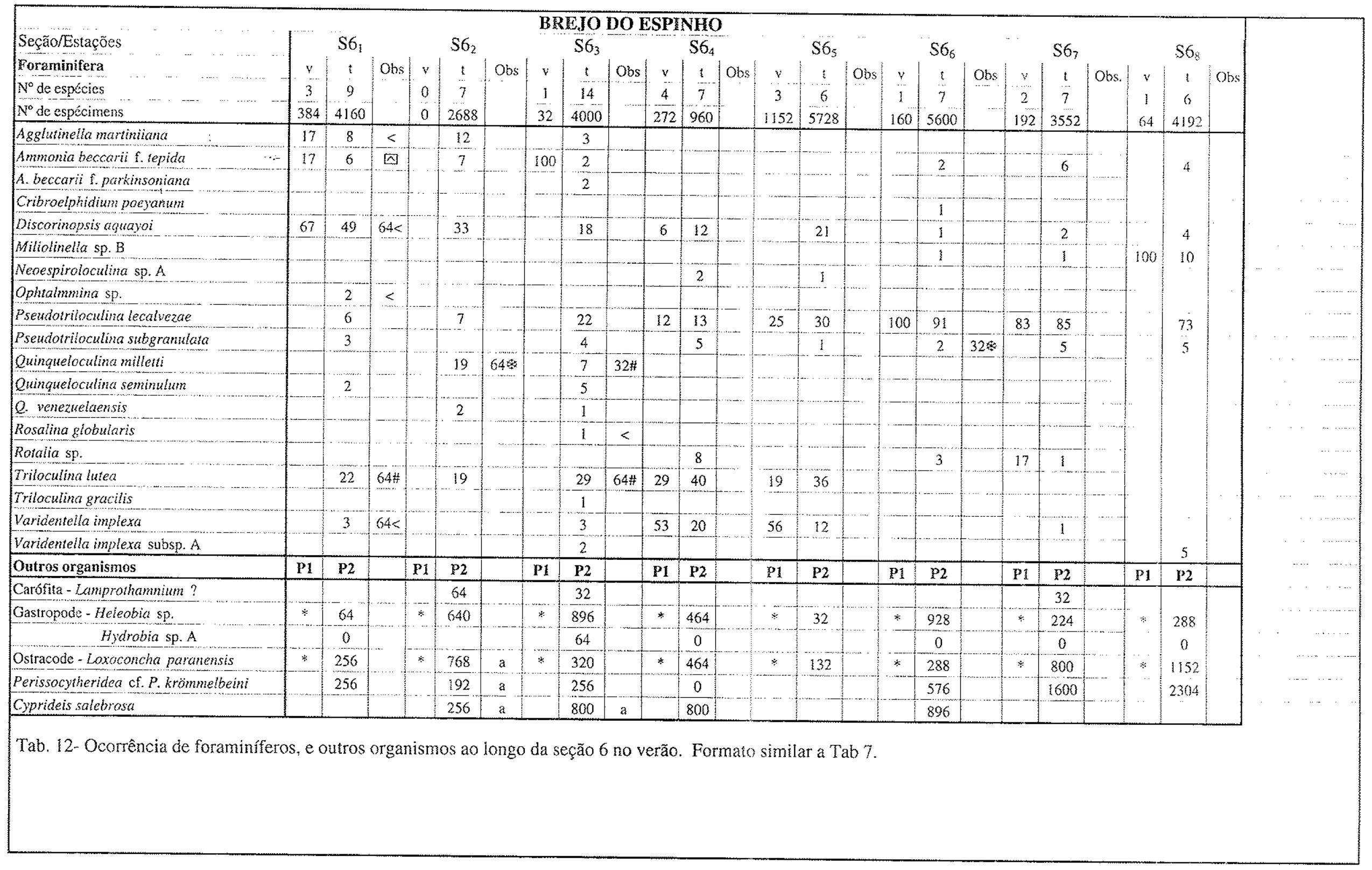




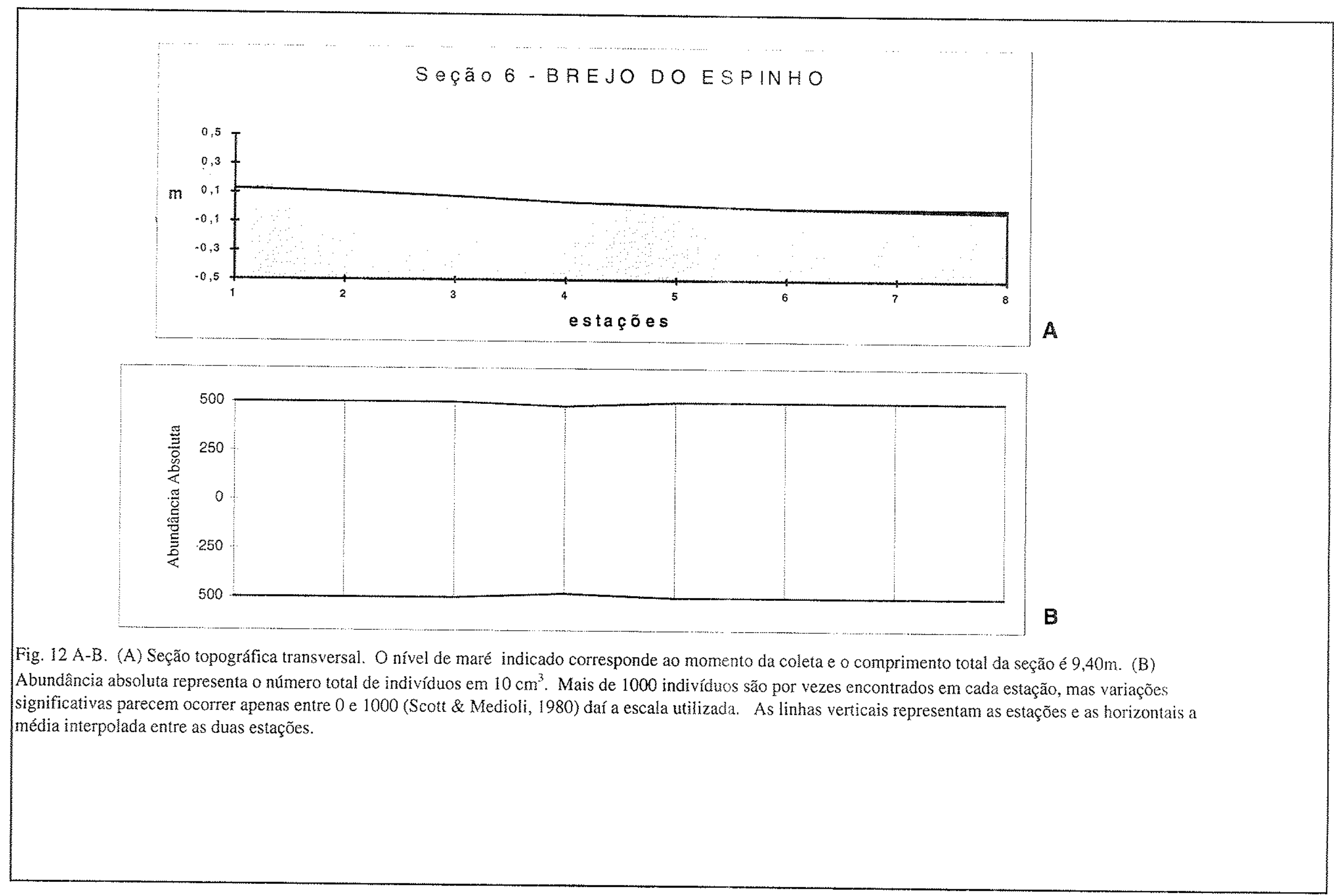




\section{Seção 6 - Brejo do Espinho}

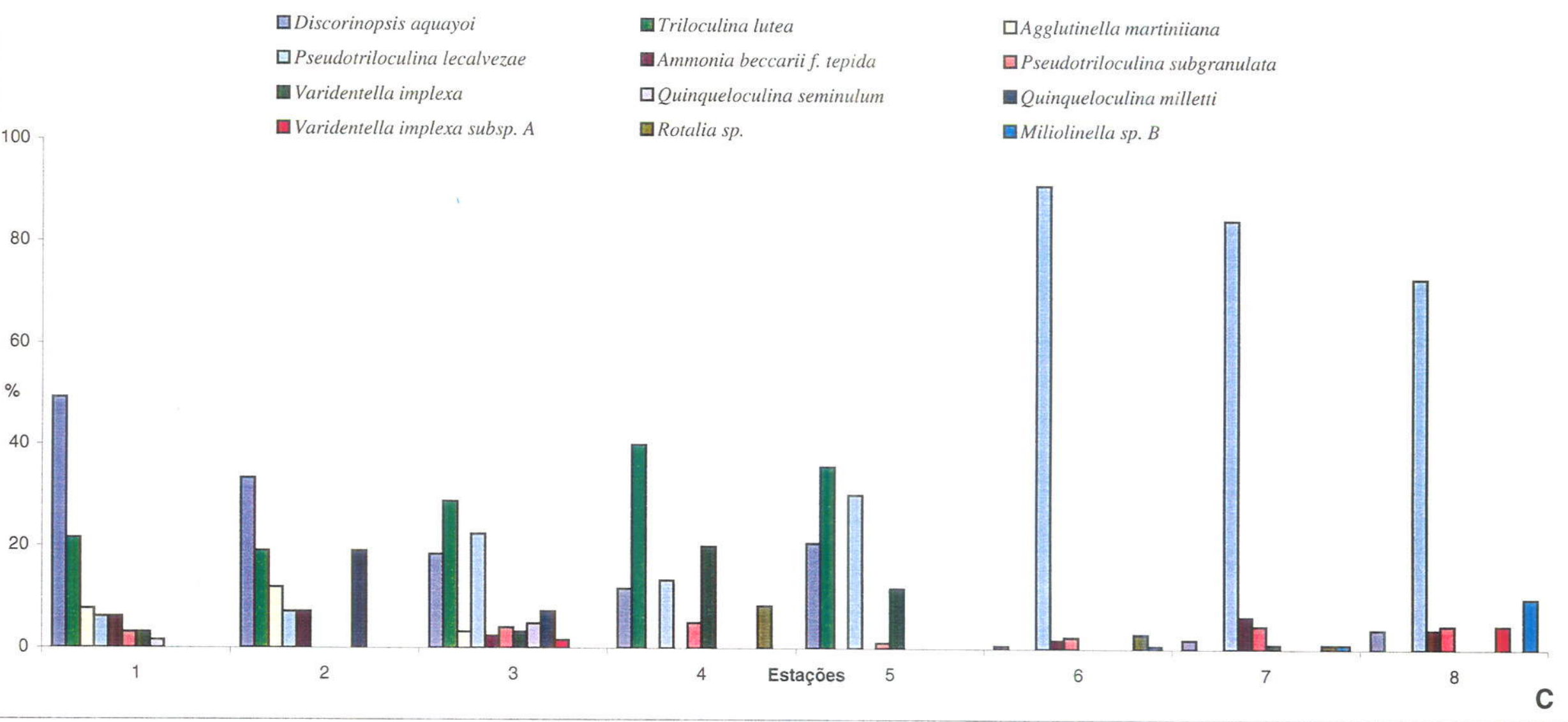

Fig.12 C - Ocorrência das espécies de foraminíferos ao longo das estações amostradas na seção 6. Somente as porcentagens totais das espécies com freqüência de ocorrência acima de $4 \%$ em pelo menos uma estação são consideradas nesse gráfico. 


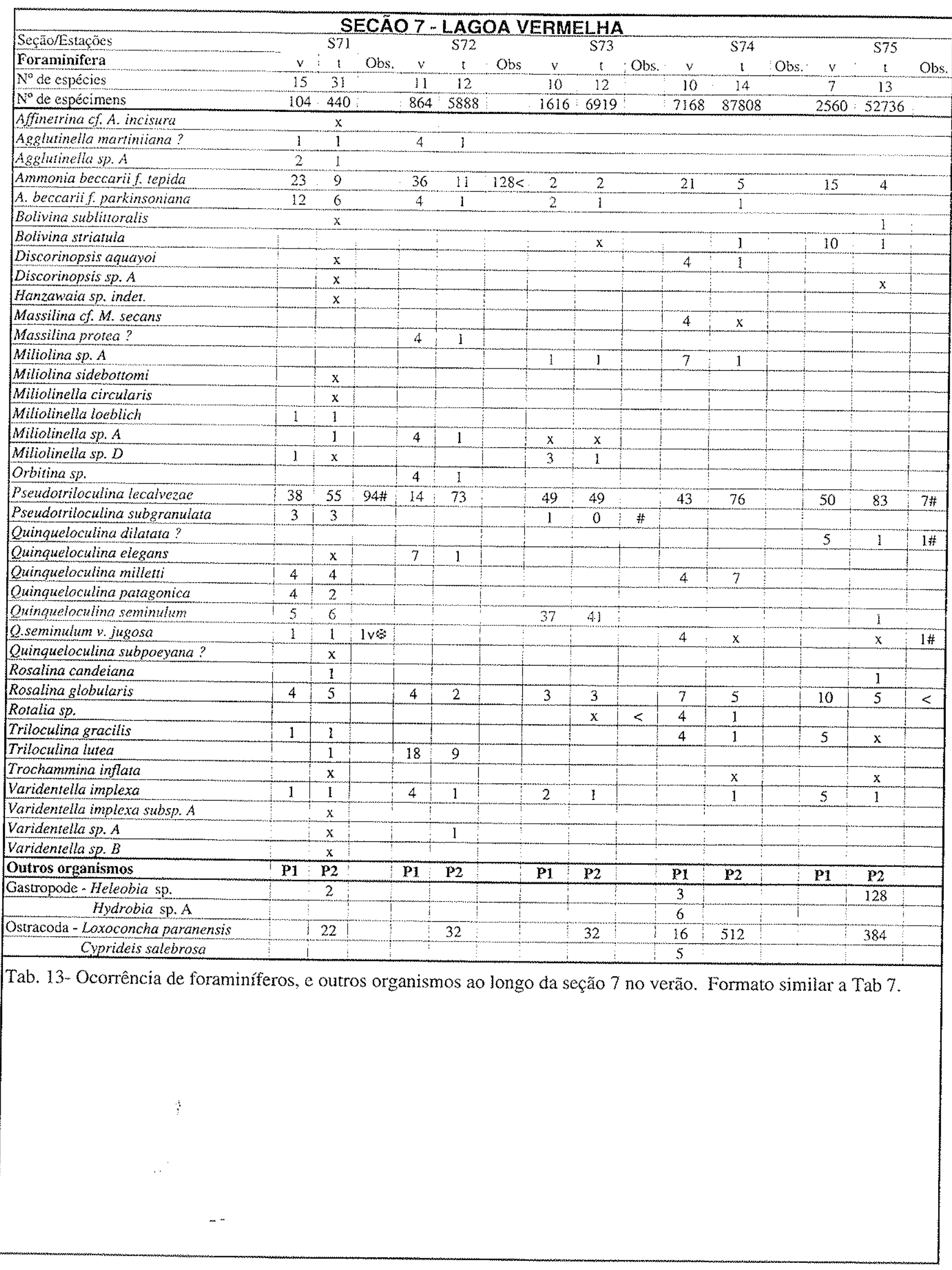



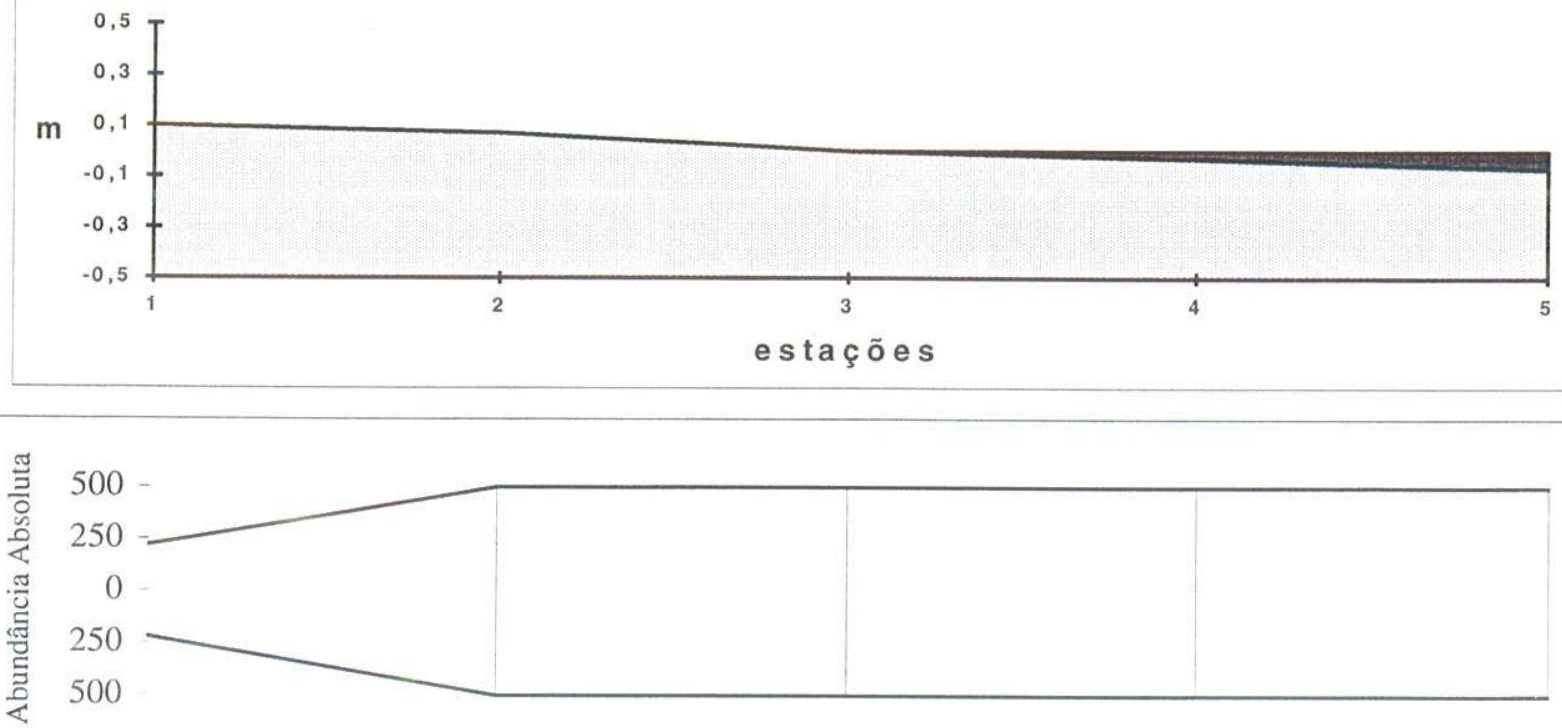

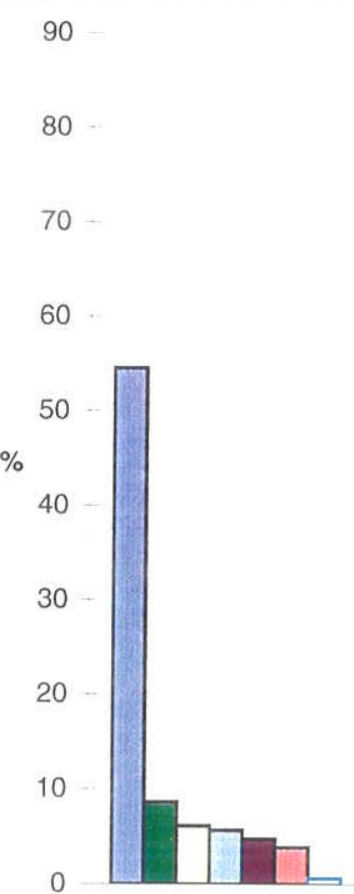

Seção 7 - Lagoa Vermelha

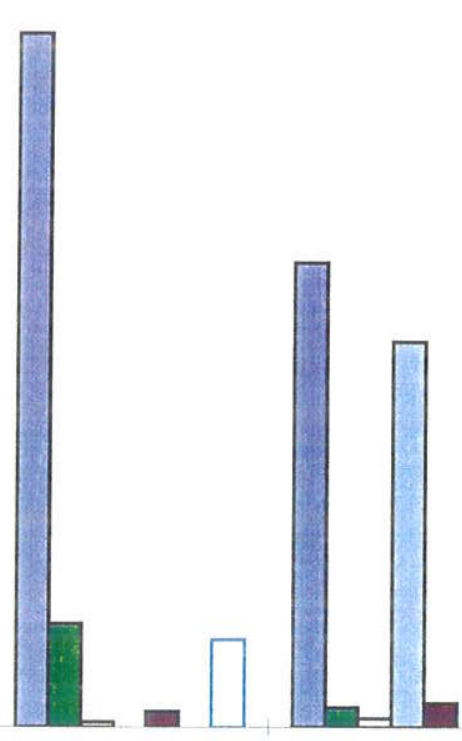

3

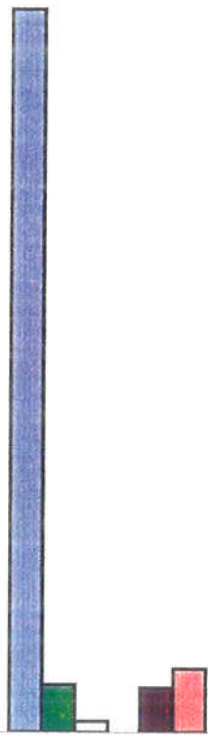

4
口Pseudotriloculina lecalvezae

田Amonia beccarii f. tepida

$\square$ A. beccarii f. parkinsoniana

$\square$ Quinqueloculina seminulum

Rosalina globularis

Quinqueloculina milletti

$\square$ Triloculina lutea

Fig. 13 A-C. (A) Seção topográfica transversal. O nível de maré indicado corresponde ao momento da coleta e o comprimento total da seção é $2,30 \mathrm{~m}$. (B) Abundância absoluta, representa o número total de indivíduos em $10 \mathrm{~cm}^{3}$. Mais de 1000 indivíduos são por vezes encontrados em cada estação, mas variações significativas parecem ocorrer apenas entre 0 e 1000 (Scott \& Medioli, 1980) daí a escala utilizada. As linhas verticais representam as estações e as horizontais a média interpolada entre as duas estações. (C) Ocorrência das espécies de foraminíferos ao longo das estações amostradas na seção 7 . Somente as porcentagens totais das espécies com freqüência de ocorrência acima de $4 \%$ em pelo menos uma estação são consideradas nesse gráfico. 


\begin{tabular}{|c|c|c|c|c|c|c|c|c|c|c|c|c|c|c|c|}
\hline \multicolumn{16}{|c|}{ SAQUAREMA (FORA) } \\
\hline Seção/Estações & & $\mathrm{S} 8_{1}$ & & $\mathrm{~S} 8_{2}$ & & $S 8_{3}$ & & $\mathrm{~S} 8_{4}$ & & $\mathrm{~S} 8_{5}$ & & $S 8_{6}$ & & $\mathrm{~S}_{3}$ & \\
\hline & & & ! & & & & & & $:$ & & & & $v$ & $t$ & Obs. \\
\hline Foraminifera & & estéril & & estéril & $\dot{\vdots}$ & estéril & $\vdots$ & estéril & & estéril & 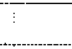 & estéril & & & \\
\hline $\mathrm{N}^{\circ}$ de espécies & & & & & & & & $\vdots$ & & & & & 0 & 1 & \\
\hline$N^{\circ}$ de espécimens & & 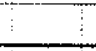 & & 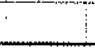 & $\therefore$ & & 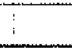 & & & 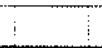 & i & & 0 & 1 & \\
\hline Aglutinante & & & & 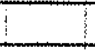 & & & $!$ & & & & 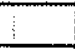 & & & 100 & $\#$ \\
\hline Outros organismos & $\mathbf{P I}$ & $\mathbf{P 2}$ & P1 & $\mathrm{P2}$ & P1 & $\mathbf{P 2}$ & P1 & $\mathbf{P 2}$ & $\mathbf{P 1}$ & $\mathrm{P2}$ & Pl & $\mathrm{P2}$ & $\mathbf{P 1}$ & $\mathbf{P 2}$ & \\
\hline Diatomáceas & & & & $*$ & & & & $*$ & $*$ & $*$ & $*$ & $*$ & & & \\
\hline Gastropode & $*$ & & $*$ & & $*$ & & & & $*$ & & $*$ & & $*$ & & \\
\hline
\end{tabular}

Tab. 14 - Ocorrência de foraminíferos, e outros organismos ao longo da seção 8 no verão. Formato similar a Tab. 7

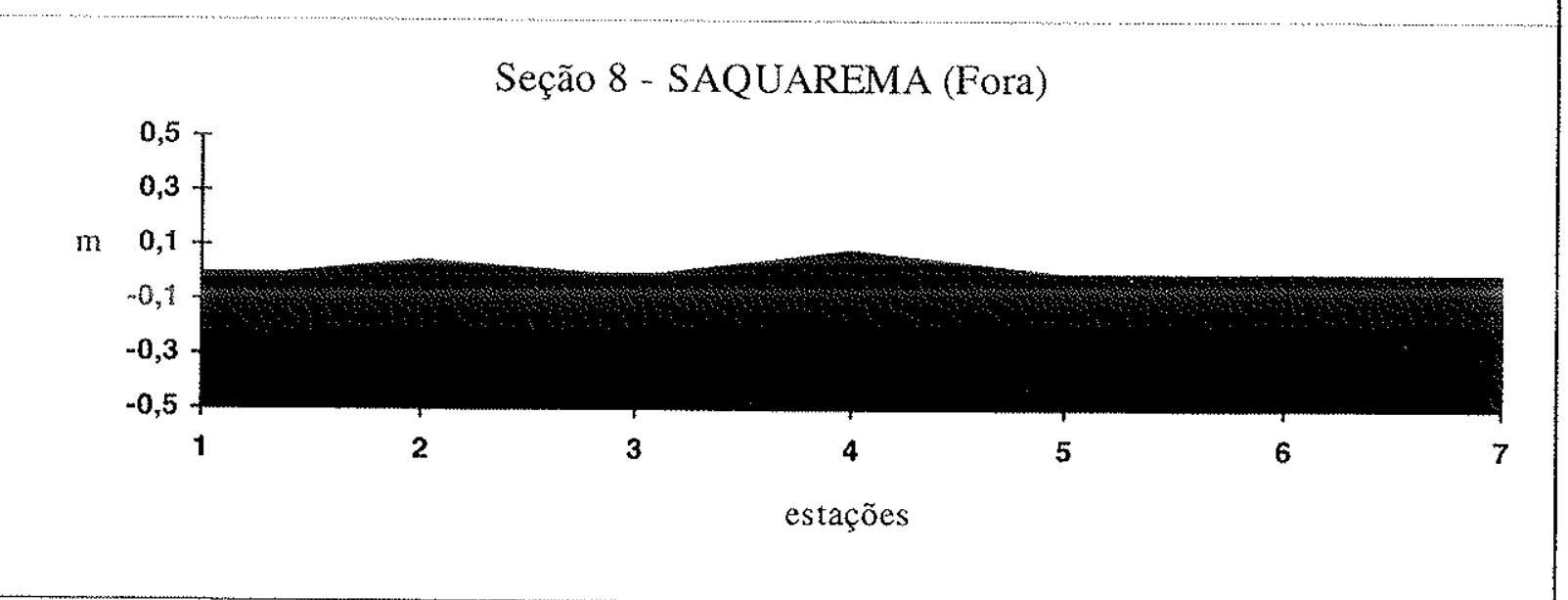

Fig. 14 - Seção topográfica transversal. Os pontos abaixo do perfil topográfico são as estações amostradas. O nivel de maré indicado corresponde ao momento da coleta e o comprimento total da seção é $6,90 \mathrm{~m}$. 


\begin{tabular}{|c|c|c|c|c|c|c|c|c|c|c|c|c|}
\hline \multicolumn{13}{|c|}{ SAQUAREMA (BOQUEIRÃO) } \\
\hline \multirow[t]{2}{*}{ Seção/Estações } & \multicolumn{3}{|c|}{$S 9_{1}$} & \multicolumn{3}{|c|}{$\mathrm{S} 9_{2}$} & \multicolumn{3}{|c|}{$\mathrm{S} 9_{3}$} & \multicolumn{3}{|c|}{$\mathrm{S}_{4}$} \\
\hline & $\mathrm{v}$ & $\mathrm{t}$ & Obs & $\mathrm{v}$ & $\mathrm{t}$ & Obs. & $\mathrm{v}$ & $\mathrm{t}$ & Obs. & $\mathrm{v}$ & $\mathrm{t}$ & Obs. \\
\hline Foraminifera & & estéril & & & estéril & & & estéril & & & & \\
\hline $\mathrm{N}^{\circ}$ de espécies & & & & & & & & & & 2 & 3 & \\
\hline $\mathrm{N}^{\circ}$ de espécimens & & & & & & & & & & 2 & 20 & \\
\hline Haplophragmoides wilberti & & & & & & & & & & 50 & 65 & \\
\hline Trochammina sp. & & & & & & & & & & & 15 & \# \\
\hline Trochammina macrescens & & & & & & & & & & 50 & 20 & $<$ \\
\hline Outros organismos & P1 & P2 & & P1 & P2 & & P1 & P2 & & P1 & P2 & \\
\hline Diatomáceas & & & & & $*$ & & & $*$ & & & & \\
\hline Gastropode & * & & & & & & * & & & * & & \\
\hline Ostracode -Loxoconcha paranensis & & & & & & & & & & & 3 & \\
\hline
\end{tabular}

Tab.15- Ocorrência de foraminíferos, e outros organismos ao longo da seção 9 no verão. Formato similar a Tab. 7.

S eção 9 - SAQUAREMA (Boqueirão)

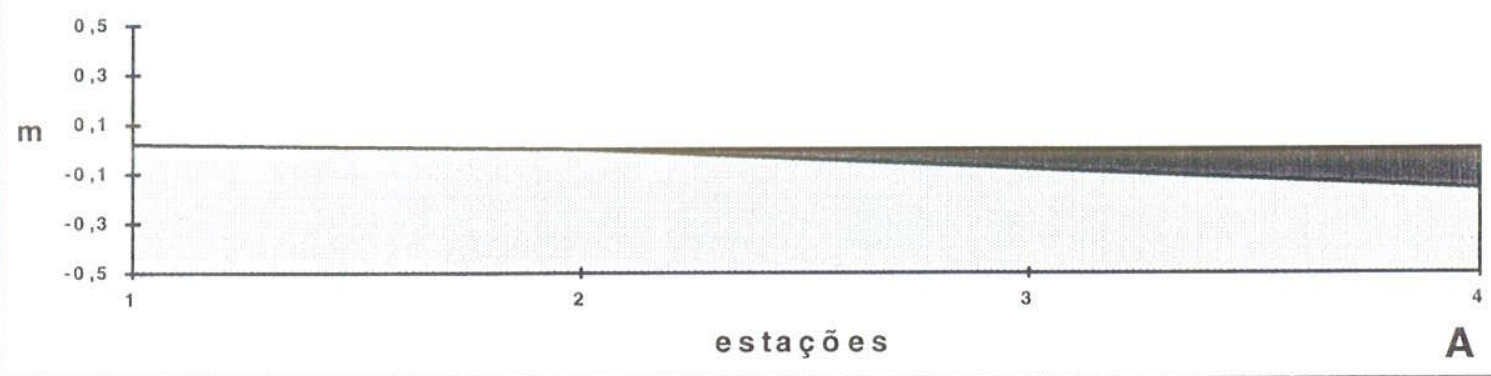

Seção 9 - Saquarema (Boqueirão)

$\% 80$

60

40

20

0

.
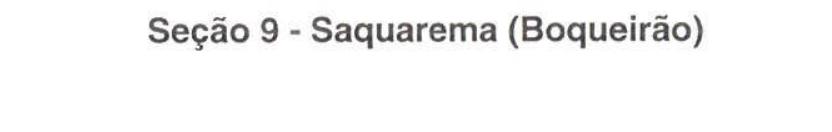
$\square$ Haplophragmoides wilberti
口Trochammina sp.

$\square$ Trochammina macrescens

A

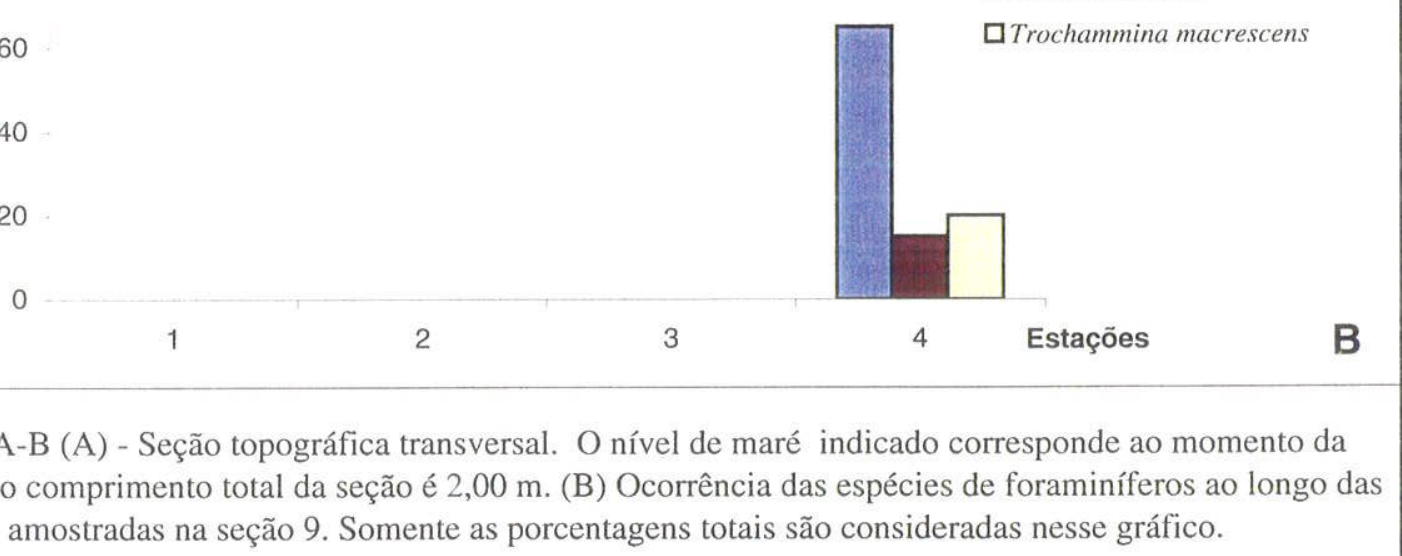

Fig. 15 A-B (A) - Seção topográfica transversal. O nível de maré indicado corresponde ao momento da coleta e o comprimento total da seção é 2,00 m. (B) Ocorrência das espécies de foraminíferos ao longo das estações amostradas na seção 9 . Somente as porcentagens totais são consideradas nesse gráfico. 


\begin{tabular}{|c|c|c|c|c|c|c|c|c|c|c|c|c|}
\hline \multicolumn{13}{|c|}{ SEÇÃO 10 - SAQUAREMA (URUSSANGA) } \\
\hline \multirow[t]{2}{*}{ Seção/Estações } & \multicolumn{3}{|c|}{${\mathrm{S} 10_{1}}$} & \multicolumn{3}{|c|}{$\mathrm{S}_{10} \mathrm{O}_{2}$} & \multicolumn{3}{|c|}{$\mathrm{S}_{10}$} & \multicolumn{3}{|c|}{$\mathrm{S}_{10} \mathrm{H}_{4}$} \\
\hline & $\mathrm{v}$ & $\mathrm{t}$ & Obs & $\mathrm{v}$ & $\mathrm{t}$ & Obs. & $\mathrm{v}$ & $\mathrm{t}$ & Obs. & $\mathrm{v}$ & $\mathrm{t}$ & Obs. \\
\hline Foraminifera & & estéril & & & & & & & & & & \\
\hline$N^{\circ}$ de espécies & & & & 0 & 1 & & 0 & 1 & & 0 & 2 & \\
\hline $\mathrm{N}^{\circ}$ de espécimens & & & & 0 & 1 & & 0 & 1 & & 0 & 4 & \\
\hline Haplophragmoides wilberti & & & & & 100 & \# & & & & & & \\
\hline Trochammina spp. & & & & & & & & & & & 75 & $<$ \\
\hline Trochammina macrescens & & & & & & & & 100 & & & 25 & \\
\hline Outros organismos & P1 & P2 & & P1 & P2 & & P1 & P2 & & P1 & P2 & \\
\hline Diatomáceas & & $*$ & $a$ & & $*$ & $\mathrm{a}$ & $*$ & $*$ & & $\mathrm{r}$ & $*$ & \\
\hline Gastropode & $*$ & & & $*$ & & & & & & * & & \\
\hline Ostracode & $*$ & & & $*$ & & & & & & $*$ & & \\
\hline
\end{tabular}

Tab.16 - Ocorrência de foraminíferos, e outros organismos ao longo da seção 10 no verão. Formato similar a Tab. 7

Seção 10 - SAQUAREMA (Urussanga)

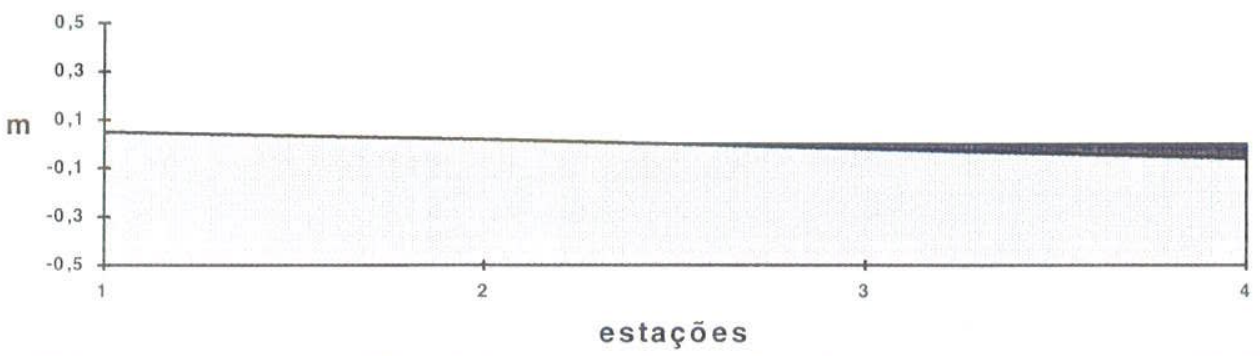

A

\section{Seção 10 - SAQUAREMA (URUSSANGA)}

100
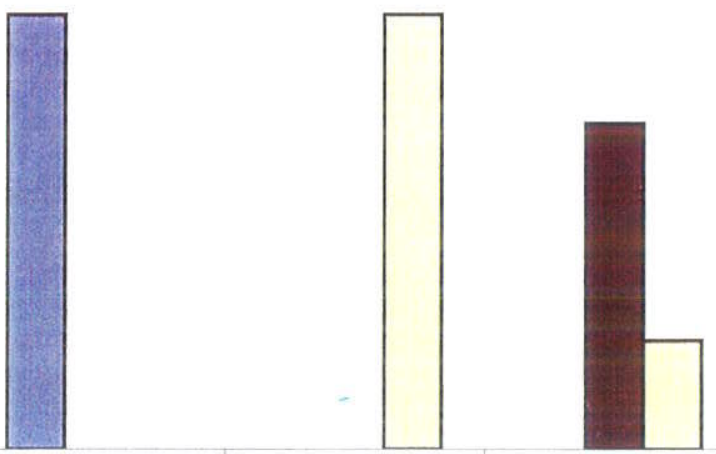

$\square$ Haplophragmoides wilberti

- Trochammina spp.

$\% \quad 40$

20

0

2

Estações

B

Fig.16 A-B. (A) Seção topográfica transversal. O nível de maré indicado corresponde ao momento da coleta e o comprimento total da seção é 2,20 m. (B) Ocorrência das espécies de foraminíferos ao longo das estações amostradas na seção 10 . Somente as porcentagens totais são consideradas nesse gráfico. 


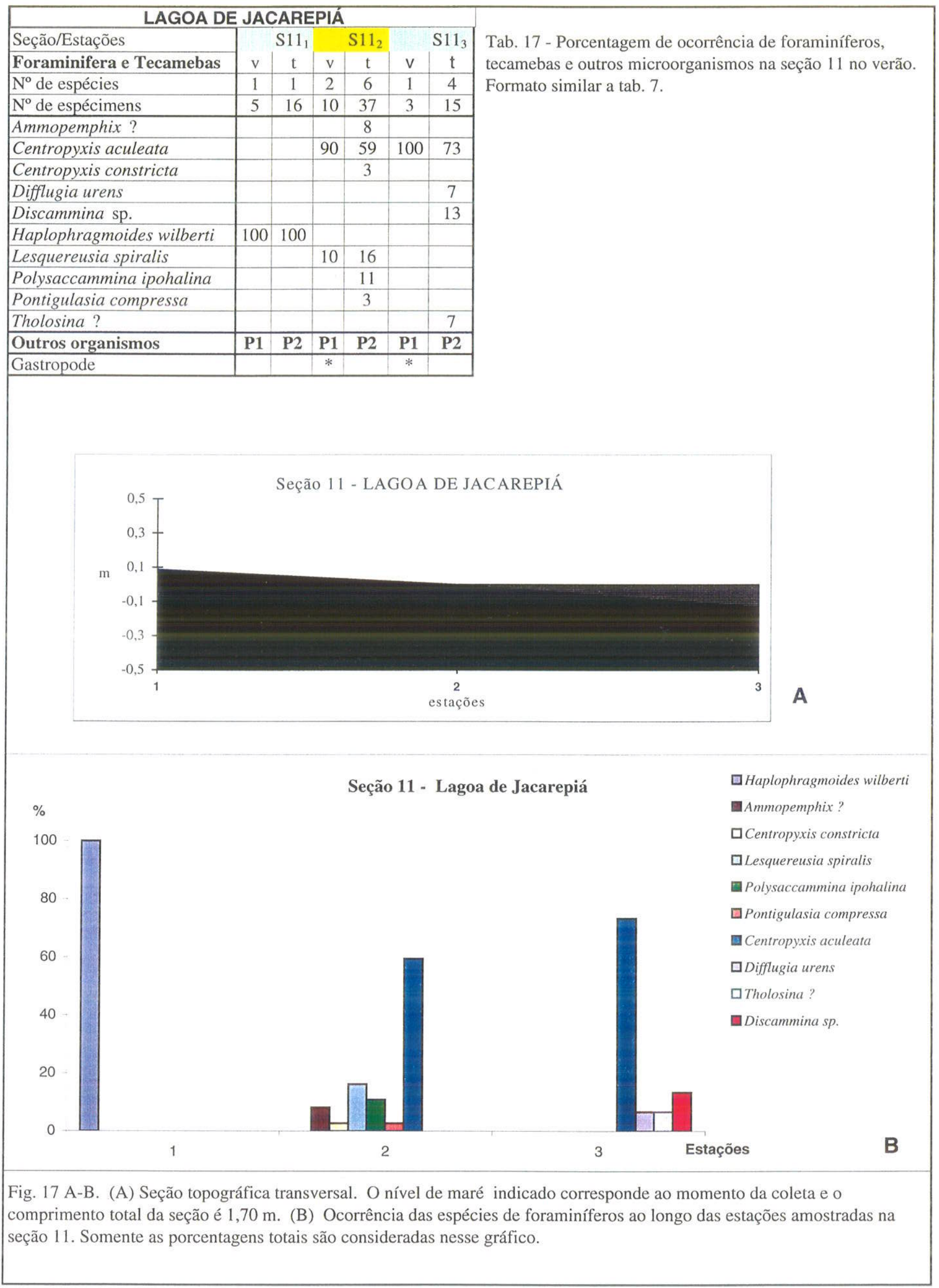


foraminíferos aglutinantes representados por Textularia earlandi ocorrem dentro dos sedimentos de argila orgânica das estações 5 e 6 da face lagunar. A menor abundância absoluta corresponde a zona de arrebentação na laguna (estação 5).

Os zoneamentos à W de Araruama correspondem às Seções 2, 3 e 4 (Tab. 19, Figs. 19 AC; Tab. 20, Figs. 20 A-C; e Tab. 21, Figs.21 A-B), respectivamente. A seção 2 com ocorrência de espécies calcárias ubíqüas, não sugere no inverno, nenhum tipo de zoneamento com aumento da abundância absoluta em direção a área lagunar.

Na seção 3 (Tab. 20, Figs. 20 A-C) a espécie Affinetrina concisa, apresenta maior frequiência na estação 1, inclusive com indivíduos vivos, e baixas freqüências em outras estaçoes. Outros foraminíferos que possuem alta frequiência nesta estação são ubíqüos ao longo da seção, também com altas frequiências, não se caracterizando portanto como bons bio-indicadores da fácies-pós laguna. Foraminífero aglutinante teratológico ocorre na zona de espraiamento da laguna, correspondente a estação 7, sugerindo transporte da teca. Também é nesta estação e em direção à área lagunar que aparece grande quantidade de exemplares e espécies com sinais de bioerosão e ostracodes com nódulos. Esta mudança intraespecífica na ornamentação da carapaça dos ostracodes tem sido relacionada, além da possibilidade de alteração genética dos indivíduos, à reações fisiológicas ao fornecimento de sedimentos terrígenos organo-silicáticos com material húmico degradado na interface água-sedimento de bordas lacustres (Tölderer-Farmer 1985). Embora o substrato das bordas não tenha sido analisado diretamente, ele pôde ser estimado com base nas observações da caderneta de campo e laboratório. Nesta seção é composto por areia fina oxidada, diferente das areias carbonáticas brancas com abundância de grãos biogênicos das outras seções. Nesta seção ocorre também aumento na abundância absoluta de foraminíferos em direção a área lagunar.

A seção 4 (Tab. 21, Figs.21 A-B) apresenta no inverno duas zonas bem marcadas: a primeira corresponde ao zoneamento dos foraminíferos aglutinantes e a segunda ao zonemaneto dos foraminíferos calcários. O primeiro apresenta inclusive tecamebas, nesta porção da laguna de Araruama sem ocorrência fluvial, o que aponta como condicionante destas espécies à fácies póslaguna a influência pluvial. Para a estação I na base da escarpa da praia lagunar, a espécie $T$. inflata corresponde ao indicador, inclusive com ocorrência de indivíduo vivo, acompanhada de H. wilberti como fiéis a esta porção pós-lagunar. Esta estação apresenta $0,31 \mathrm{~m}$ de altitude. Três estações na ante-laguna apresentaram-se estéreis, inclusive quanto a ocorrência de outros organismos. A estação 5 marca a segunda zona desta seção com altitude de $-0,17 \mathrm{~m}$ e ocorrência de Discorinopsis aquayoi com representante vivo e exclusivo à esta estação. Os outros 
foraminíferos calcários ocorrem à partir desta estação em direção a área lagunar, inclusive com indivíduos vivos na estação 6 .

\section{GRUPO II - Lagoas Hipersalinas}

Para a sabkha Brejo do Espinho (Seção 6 - Tab.23, Figs.23 A-B) e Lagoa Vermelha (Seção 7 - Tab.24, Figs.24 A-B) no inverno não foram feitos os gráficos de abundância absoluta devido ao grande número de indivíduos encontrados. Nessas seções ficaram retidos na peneira $0,500 \mathrm{~mm}$ (P1) da estação 2 e 3 (Tab. 23 e 24) algumas espécies com indivíduos muito grandes associados, na seção 6 à ocorrência de carófitas. A ocorrência de indivíduos maiores e de contornos mais alargados pode estar relacionada a temperaturas mais quentes mas, no verão, isso não foi observado. Outro fator importante para a explicação desta ocorrência é a maior disponibilidade alimentar, também expressa pela abundância de indivíduos. Esta alta produção bentônica, certamente está associada ao grande florescimento do tapete algálico de cianofícias e bactérias aeróbicas que thes servem de nutrição na interface águamsedimento das bordas das lagoas.

A seção 6 apresenta na estação 1 altitude de 0,06m, com Discorinopsis aquayoi, Trochammina inflata, e Agglutinella matiniiana com altas pocentagens de frequiencia onde as duas primeiras espécies possuem representantes vivos. Nenhuma dessas espécies apresenta fidelidade a estação 1, mas diminuem na freqüência de ocorrência em direção a área lagunar. Ammonia beccarii f. beccarii também ocorre com maior expressividade nesta estação diminuindo a freqüência em direção a área lagunar embora sem ocorrência de indivíduos vivos.

Na Lagoa Vermelha não foi observada variação na coluna d'água entre o verão e o inverno e suas bordas não parecem apresentar o desenvolvimento de fácies intermaré. A estação 1 apresenta-se na base da vegetação que margeia a lagoa com o maior número de espécies vivas na seção, embora a única espécie que exibe fỉdelidade a estação 1, inclusive com ocorrência viva é Discorinopsis aquayoi, dentre outras espécies com baixas freqüências e somente indivíduos mortos tais como: Affinetrina concisa, Affinetrina sommeri, Cornuloculina sp., Miliolinella williamsoni e Quinqueloculina venezuelaensis. A altitude da estação 1 é de $-0,17 \mathrm{~m}$.

\section{GRUPO III - Saquarema}

As seções 8, 9 e 10 da Laguna de Saquarema, respectivamente Tab.25, Fig.25; Tab.26, Figs.26 A-B; Tab.27, Figs.27A-B, foram amostradas em momento de maré baixa. Para estas seções não foi elaborado o gráfico de abundância absoluta devido ao baixo número de 
indivíduos. A seção 8 de Saquarema foi a que apresentou a mais inexpressiva freqüência de ocorrência de todas as seções amostradas, também no inverno, com somente ocorrência de frústulas de diatomáceas. A seção 9 apresenta somente foraminíferos aglutinantes e na seção 10 estes estão associados a foraminíferos calcários, com ocorrência na área lagunar. A fácies póslagunar apresenta somente $H$. wilberti em ambas as seções encontrando-se associada com Trochammina macrescens e Trochammina inflata em direção a laguna. O limite inferior das amplitudes de ocorrência do marcador da fácies pós-laguna $(H$. wilberti) para a seção 9 e 10 refere-se ao limite da amostragem e corresponde a $0,26 \mathrm{~m}$ e $0,24 \mathrm{~m}$, respectivamente.

\subsection{3 - Biofácies}

Para a definição de biofácies com base nos padrões de distribuição nas superfícies das bordas lagunares foi feita análise de agrupamento das freqüências de ocorrência, mostradas nas tabelas 7 a 27 combinadas (banco de dados pessoal), para os três grupos definidos acima e sazonalmente separados. A análise de agrupamento definiu ao todo 23 biofácies de foraminíferos a partir das freqüências de ocorrência das espécies mais abundantes. Como variações sazonais algumas vezes não foram observadas entre as biofácies definidas pela análise de agrupamento, o resultado foi sintetizado num total 16 biofácies.

Para o GRUPO I -Araruama, no verão, 3 biofácies foram definidas (Fig. 28A) e no inverno 5 biofácies foram definidas (Fig. 28B). Estas foram sintetizadas em seis na tabela de resultado (Fig 28B). A biofácies A. beccarii f. tepida - A. beccarii f. parkinsoniana (I) corresponde a todas as estações da seção 5 com dominância da forma tepida no agrupamento de verão e de inverno, variando de $38 \%$ a $83 \%$ e forma parkinsoniana variando de $0 \%$ a $26 \%$. Cribroelphidium excavatum f. selseyensis ocorre com frequiências de $0 \%$ a $10 \%$. A amplitude vertical das estações nesta biofácies varia de $-0,47 \mathrm{~m}$ a $0,47 \mathrm{~m}$. A única distinção feita pelo agrupamento entre as amostras de verão e inverno dessa biofácies corresponde a estação 7 no inverno, que foi separada devido ao predomínio de $A$. beccarii f. parkinsoniana que ocorre com freqüência de $71 \%$ acompanhada de Miliolinella sp. D e Rotalia sp. Como corresponde a somente uma estação, onde o predomínio ainda é de Ammonia é considerada como uma subdivisão da biofácies I e classificada como biofácies $A$. beccarii $f$. parkinsoniana (II). A biofácies I não apresenta variação sazonal das espécies representativas, embora uma sutil diferença nas freqüências seja observada.

A biofácies Quinqueloculina milleti - Q. seminulum (II) ocorre somente no verão (Fig.28A) onde está incluída toda a seção 4 e as três estações iniciais da seção 2 , sua amplitude vertical é de $-0,19 \mathrm{~m}$ a $0,55 \mathrm{~m}$. 


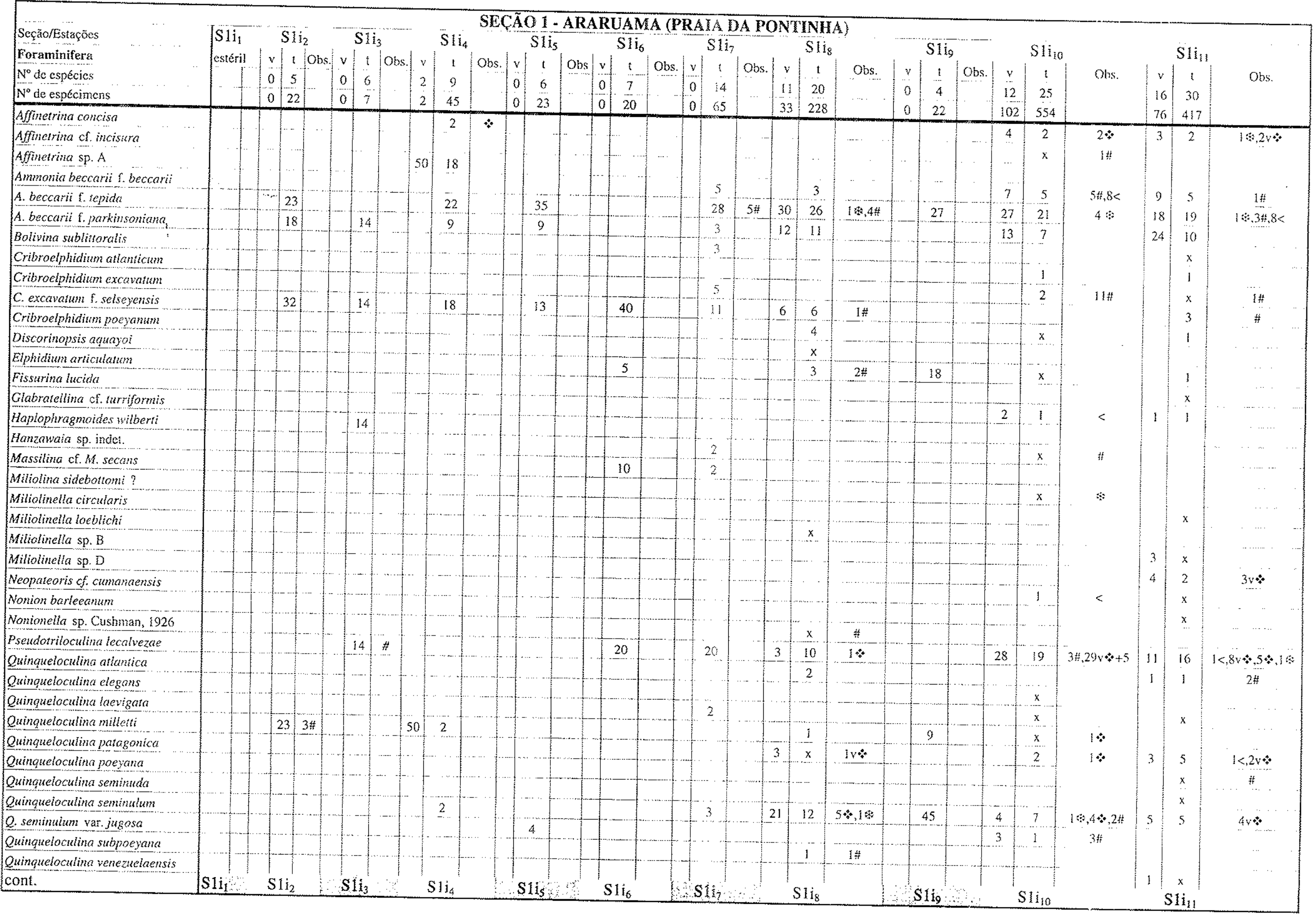




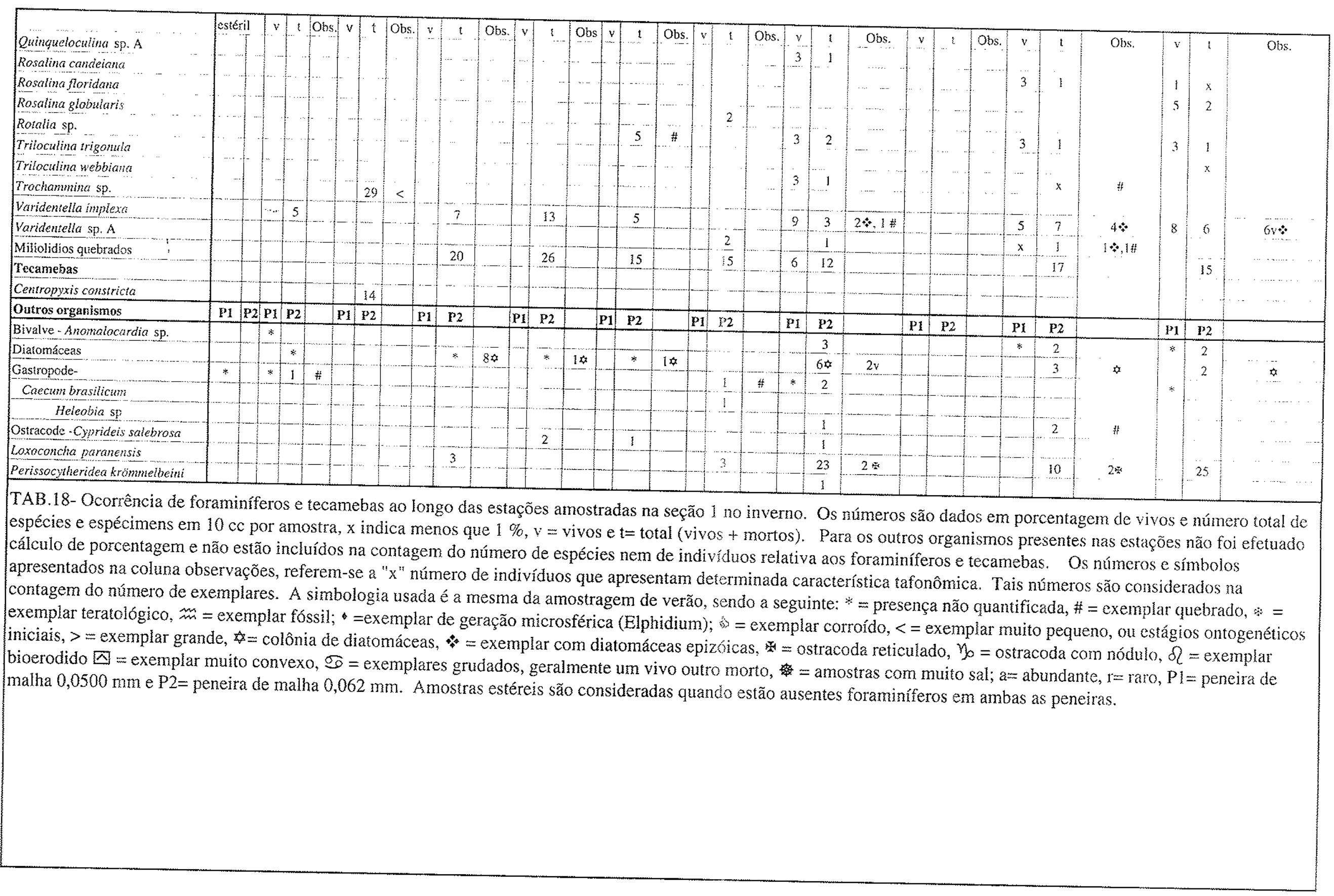




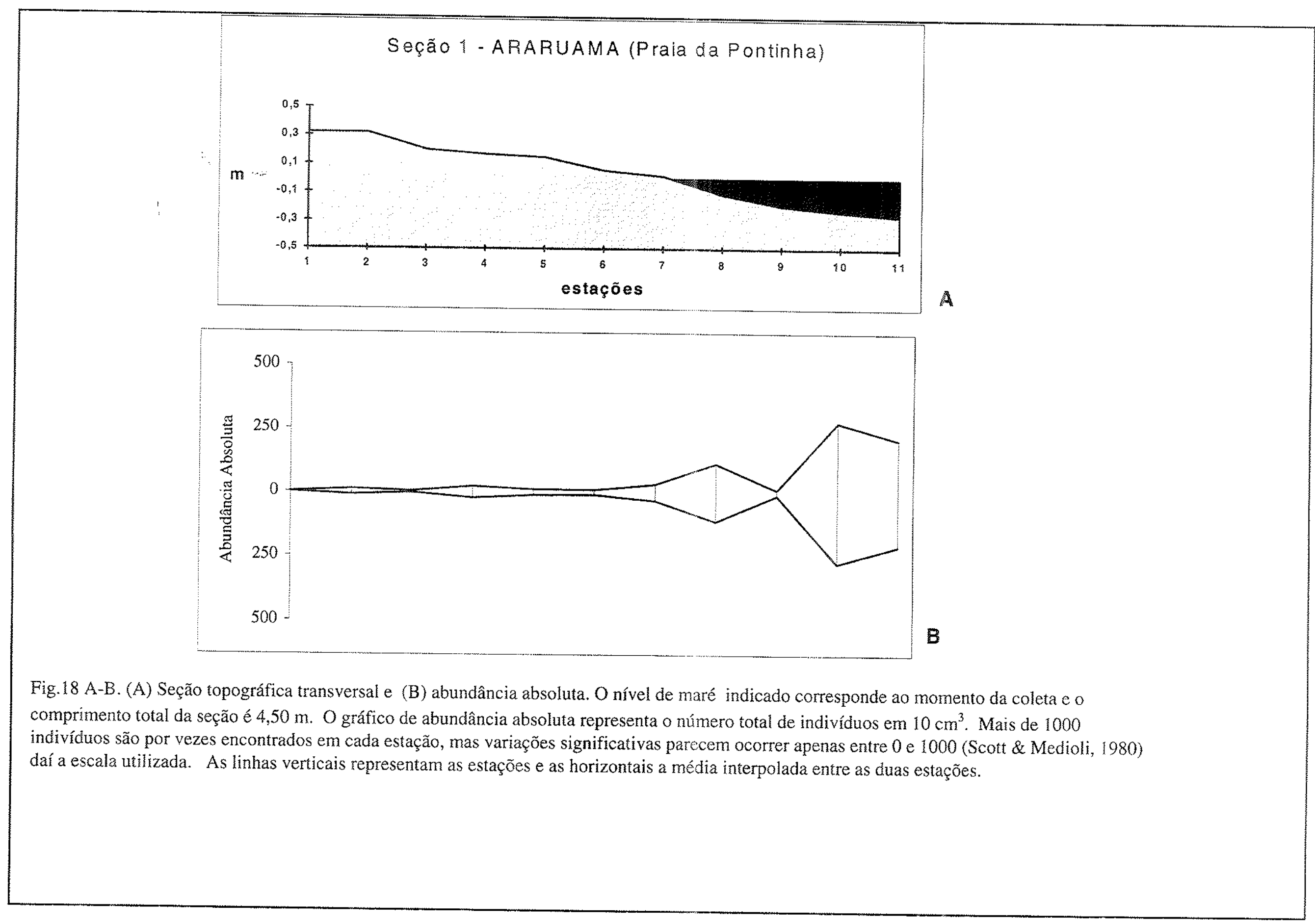




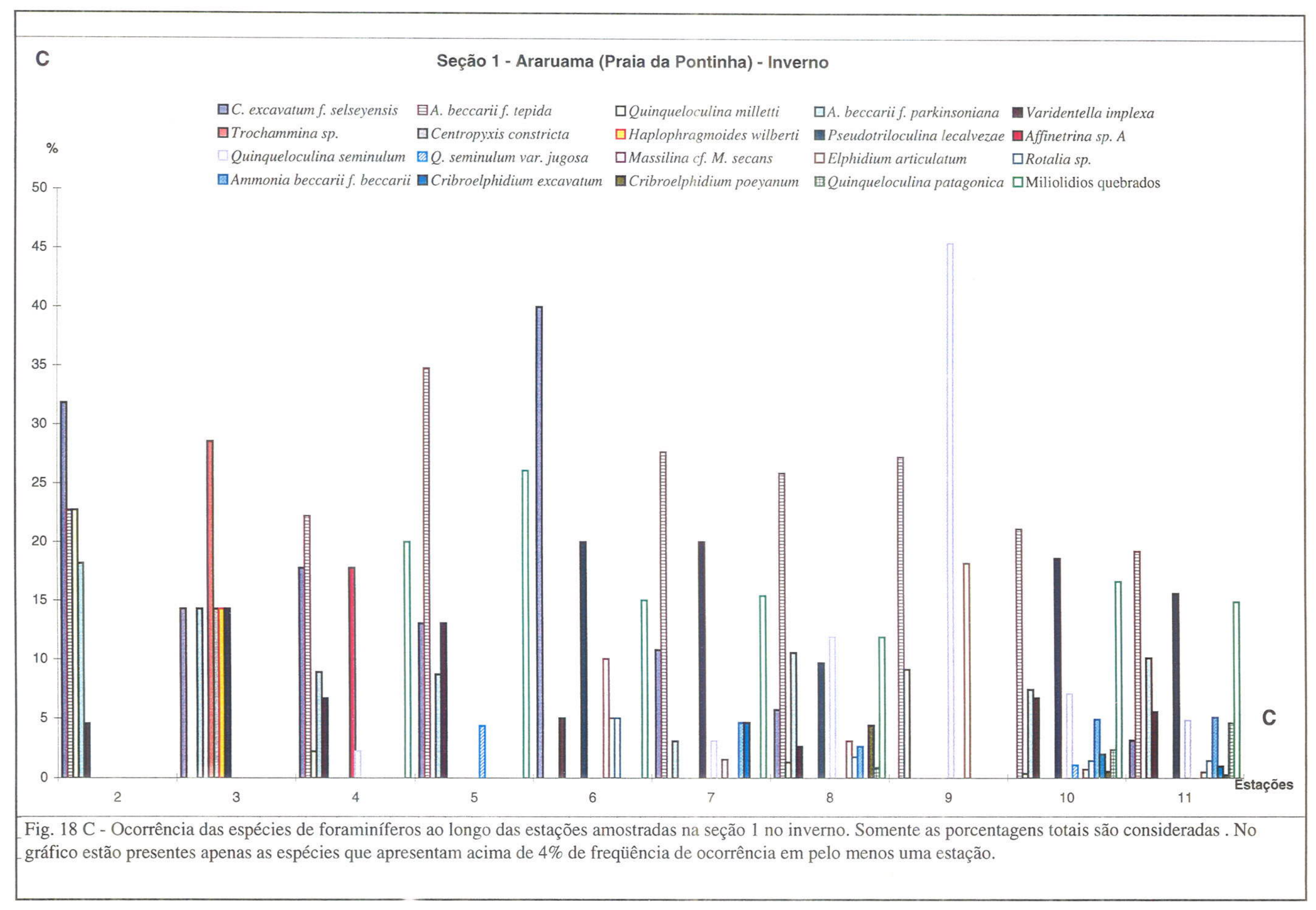




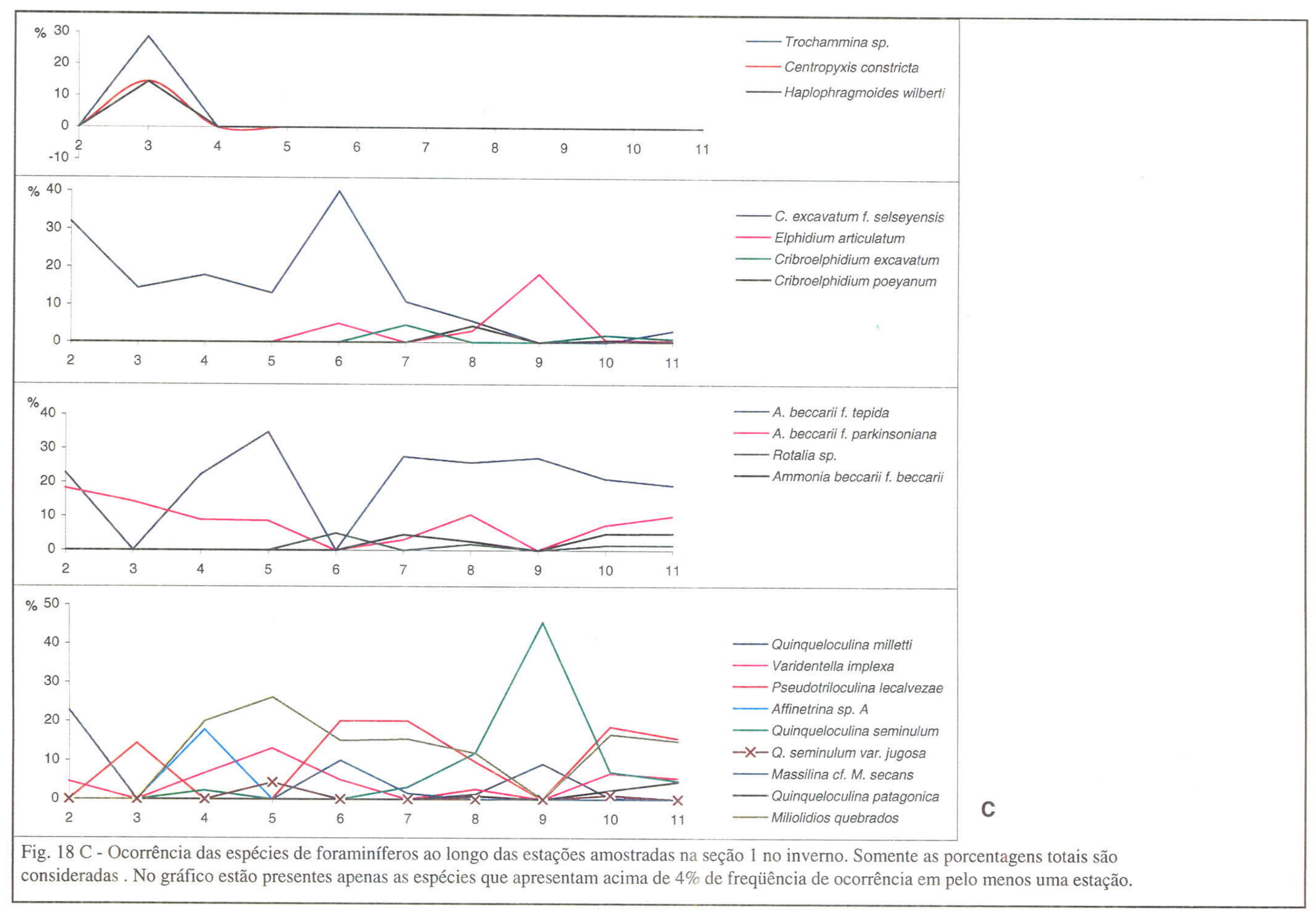




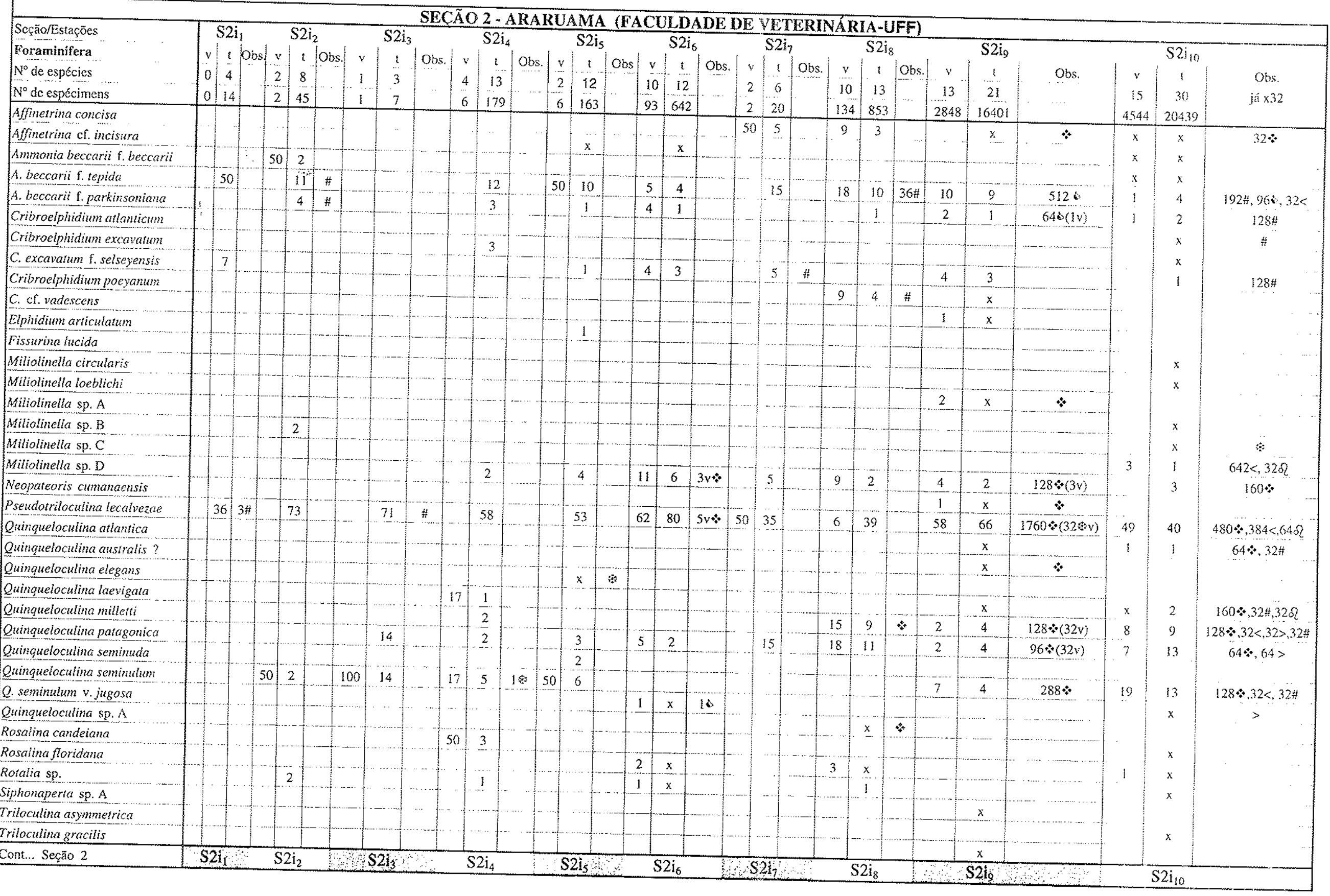




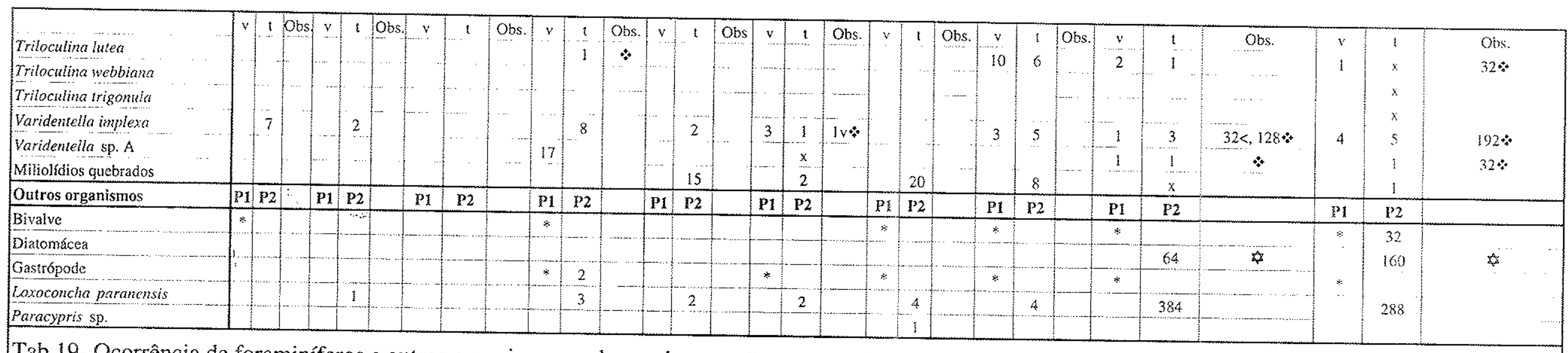

Tab.19- Ocorrência de foraminíferos e outros organismos ao longo das estações amostradas na seção 2 no inverno. Formato similar a Tab. 18

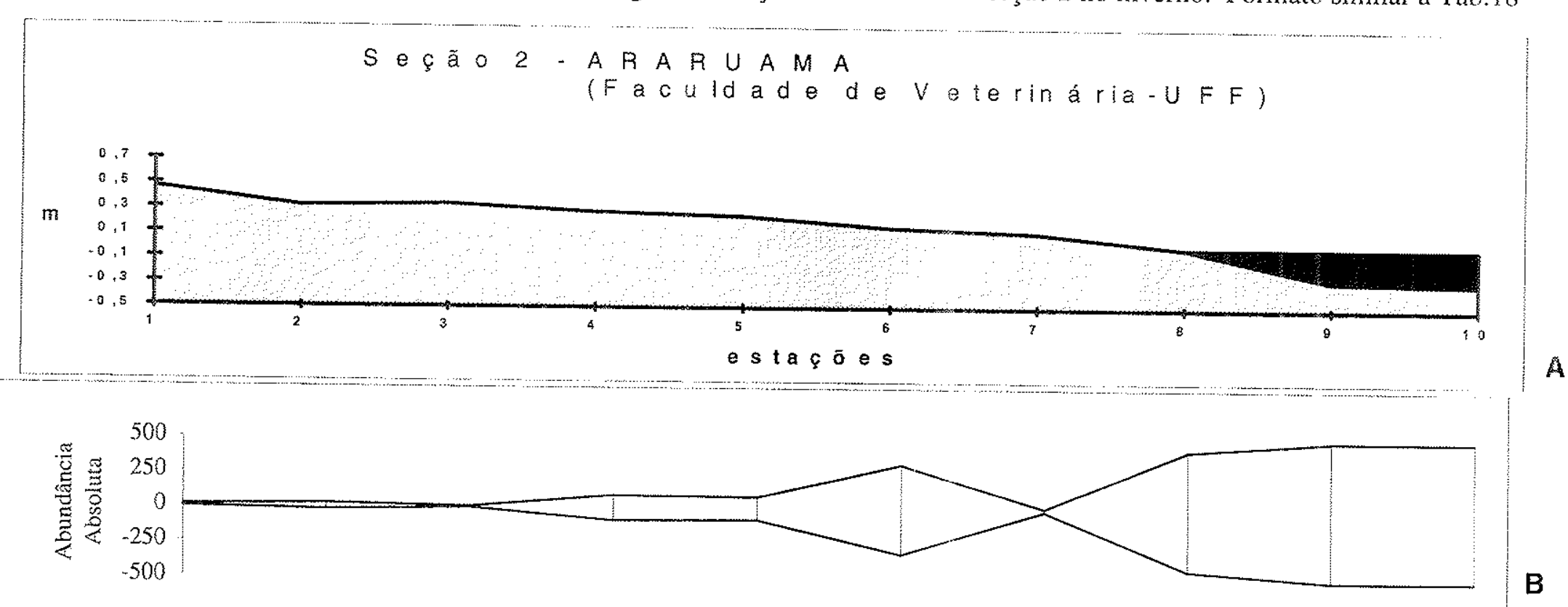

Fig. 19 A-B. (A)Seção topográfica transversal e abundância absoluta.O nível de maré indicado corresponde ao momento da coleta e o comprimento total đảa seção é $6,50 \mathrm{~m}$. (B) O gráfico de abundância absoluta representa o número total de indivíduos $\mathrm{em} 10 \mathrm{~cm}^{3}$. Mais de 1000 indivíduos são por vezes encontrados em cada estação, mas variaçōes

significativas parecem ocorrer apenas entre 0 e 1000 (Scott e Medioli, 1980) daí a escala utilizada. As linhas verticais representam as estações e as horizontais a média interpolada 


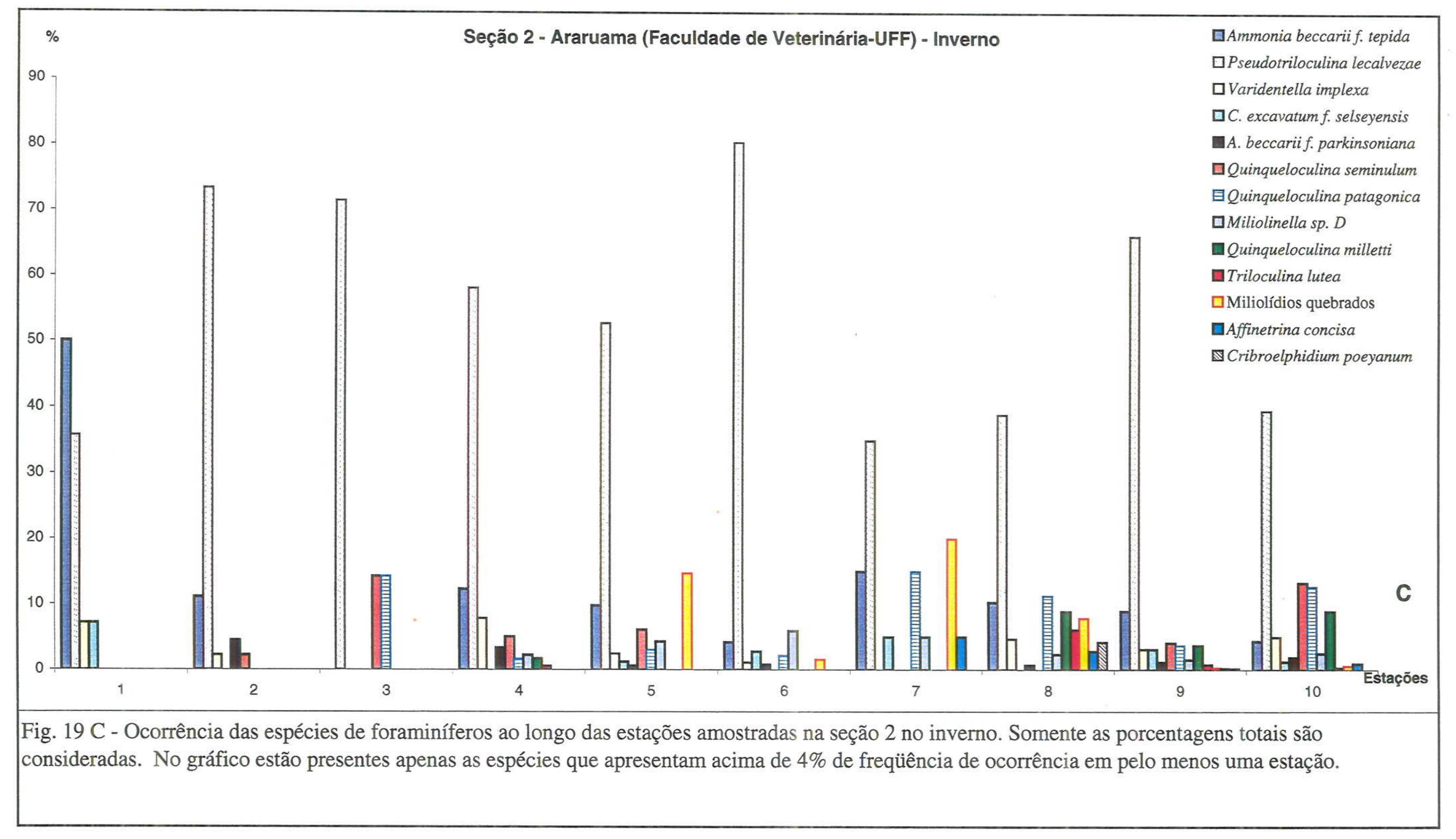




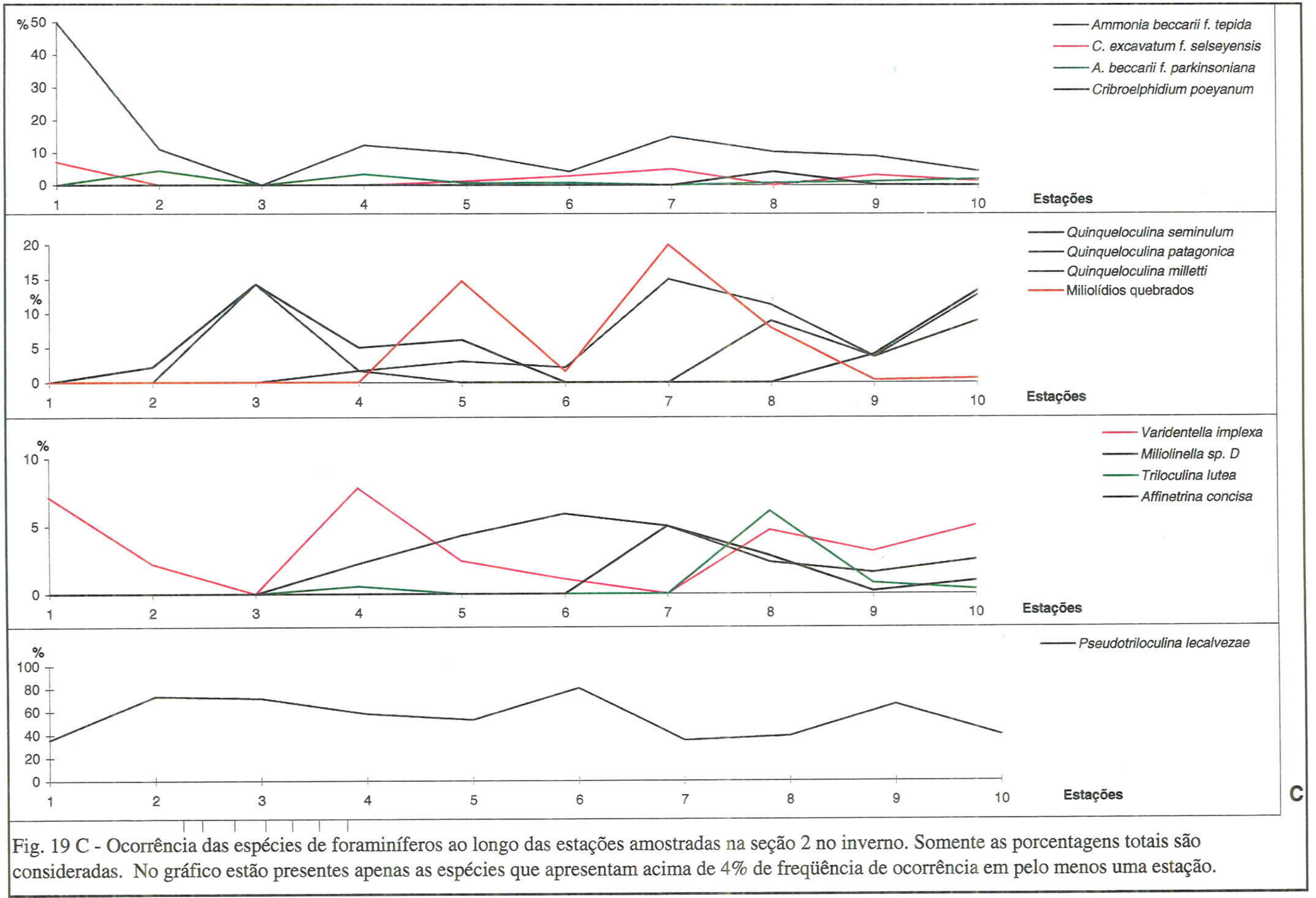




\begin{tabular}{|c|c|c|c|c|c|c|c|c|c|c|c|c|c|c|c|c|c|c|c|c|c|c|c|c|}
\hline & & & & & & & & & & Cि̃ & & POR & TO & $\mathrm{DA} A$ & LDE & & & & & & & & & \\
\hline Seção/Estaçōes & & $\mathrm{S} 3 \mathrm{i}_{\mathrm{I}}$ & & & $S 3 i_{2}$ & & & $\mathrm{~S} 3 \mathrm{i}_{3}$ & & & $\mathrm{~S}_{3} \mathrm{i}_{4}$ & & & $\mathrm{~S} 3 \mathrm{i}_{5}$ & & & $\mathrm{~S}_{3} \mathrm{i}_{6}$ & & & $\mathrm{~S} 3 \mathrm{i}_{7}$ & & & S3is & \\
\hline Foraminifera & $v$ & $\mathrm{t}$ & Obs. & v & $\xi$ & Obs. & $y$ & t & Obs. & v & $\mathrm{t}$ & Obs. & v & $t$ & $08:$ & Y & 1 & Obs. & $v$ & 1 & Obs. & $v$ & $t$ & Obs. \\
\hline $\mathrm{N}^{\circ}$ de espécies & 4 & 12 & & 3 & 8 & & 3 & 11 & & 4 & 7 & & 9 & 15 & & 12 & 24 & & 15 & 27 & & 15 & 24 & \\
\hline$N^{\circ}$ de espécimens & 4 & 143 & & 10 & 142 & & 11 & 207 & & 16 & 68 & & 106 & 604 & & 111 & 515 & & 1024 & 4494 & & 424 & 2424 & \\
\hline $\begin{array}{l}\text { Aglutinante } \\
\text { Affinetrina concisa }\end{array}$ & & & & & & & .. & 1 & & $\ldots$ & $\ldots$ & $\ldots$ & & $\omega_{1}$ & & $x$ & 1 & & & $x$ & $\%$ & & & \\
\hline $\begin{array}{l}\text { Affinetrina concisa } \\
\text { Affinetrina sp. } A\end{array}$ & 25 & 10 & & & & & & 1 & & & 3 & & & & & $x$ & 1. & & & $x$ & $\#$ & & 1 & \\
\hline Ammonia beccarii f tepida & 25 & 5 & & 40 & 17 & & 73 & 15 & & 31 & 16 & & 28 & 10 & & 44 & 17 & & 28 & 15 & $320 \#$ & 34 & 14 & \\
\hline A. beccarii f parkinsoniand & & 3 & & & & & & $x$ & & - & & & & & & 19 & 6 & & 9 & 3 & $64 \#$ & 4 & 1 & \\
\hline Bolivina sublittoralis & & 2 & $2 \#$ & $\ldots$ & & & & & & & & & & & & & & & & & & & & \\
\hline Cornuloculina $\mathrm{sp}$. & & & & & & & & & & & & & & & & & & & & $x$ & & & & \\
\hline Cribroelphidium excavatum & & & & & 2 & & & 1 & & & & & & & & & 1 & & & 1 & $\#$ & 2 & 1 & \\
\hline C. excavatum fo selseyensis & 25 & 6 & & 30 & 45 & & 9 & 39 & $6 \#$ & 31 & 32 & & 15 & 13 & & 13 & 15 & & 17 & 20 & $448 \#$ & 11 & 11 & \\
\hline C. vadescens & & & & & & & & & & & & & & & & & & & & 1 & \# & & & \\
\hline Elphidium articulatum & & & & & & & & & & & & & & & & & 1 & & & & & & & \\
\hline Elphidium gunteri & & 1 & & & & & & & & & & & 5 & 4 & & & & & & 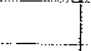 & & & & \\
\hline Elphidium mexicanum & & & & & & & & & & & & & 1 & 1 & & & & & & & & & & $\ldots$ \\
\hline Massilina secaris & & & & & & & & & & & & & & & & & & & 3 & 1 & & & & 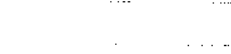 \\
\hline Massilina crescentensis & & & & & & & & & & & & & & & & & & & & $x$ & & & & \\
\hline Miliolinella of Mannarctica & & & & & & & & & & & & & & & & & & & & & & 2 & $x$ & \\
\hline Miliolinella circularis & & 1 & \# & & & & & & & & & & & & & & & & & & & & & \\
\hline Miliolinella cf. M. hybrida & & & & & & & & & & & & & & & & & & & & $x$ & $<$ & & & \\
\hline Miliolinella loeblichi & & & & & & & & & & & & & & & & & $x$ & & & & & & & \\
\hline Miliolinella sp. A & & & & & & & & & & & & & & & & & & & & 1 & & & & \\
\hline Miliolinella sp. C & & & & & & & 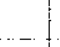 & & & & & & & & & & 1 & & & & & & $x$ & \\
\hline Miliolinella sp. D & & & & & & & $\ldots$ & & & & & & & & & & $\mathrm{x}$ & & & & & & & \\
\hline Veoespiroloculina sp. & & & & & & & & & & & & & & $x$ & 䇣 & & & & & & & & & \\
\hline seudotriloculina lecalvezae & 25 & 34 & $18 \$$ & & 19 & & & 20 & & 6 & 25 & & 33 & 57 & $1 \mathrm{~s}$ & 10 & 17 & $6 \mathrm{v}$ & 16 & 23 & $160 *, 640,326$ & 17 & 23 & $8 v+32 \approx$ \\
\hline Seudotriloculina subgranulata & & & & & ....... & & & & & & & & & & & & & & 2 & 1 & & & & \\
\hline Quinqueloculina aflantica & & & & & . & & $\ldots$ & & & & & & & 1 & $\ddot{n}$ & & $x$ & & 2 & 2 & $16>16 \Omega$ & & & \\
\hline Quinqueloculina australis & & & & & & & $\ldots$ & & & & & & & $\mathrm{x}$ & & & & & & & & & & \\
\hline Quinqueloculina dilatata? & & & & & & & & & & & & & & & & & $x$ & & & & & & & \\
\hline Quinqueloculina elegms & & & & & & & & & & & & & & & & & & & 3 & 3 & $32 v * 0,32 \#, 32>$ & 4 & 1 & $16 \times \mathrm{i}^{2}$ \\
\hline Suinqueloculina laevigata & & & & & & & & & & & & & & & & 3 & 1 & & 2 & 2 & $32 v *$ & & 1 & $8<$ \\
\hline Quinqueloculina lamarckiana & & & & & $\ldots \ldots$ & & & & & & & & & & & & & & & 1 & & & & \\
\hline Tainqueloculina microcostata & & & & & & & & & & & & & & & & & & & & & & & & \\
\hline 2uinqueloculina milleti & & & & & 1 & & & & & & & & & & & 2 & 4 & & 3 & 9 & $80 \#, 16 *$ & 4 & 9 & $8<, 87,24 *$ \\
\hline Quinqueloculina patagonica & & 6 & & & 4 & & $\ldots$ & 2 & & 25 & 16 & & 4 & 4. & & & 5 & lv & 2 & 2 & $16 v 0 \Omega$ & 6 & 5 & 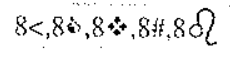 \\
\hline Quinqueloculina poeyana & & & & & & & & & & & & & $\mathrm{x}$ & 1 & & $x$ & $x$ & & & & & & & \\
\hline
\end{tabular}




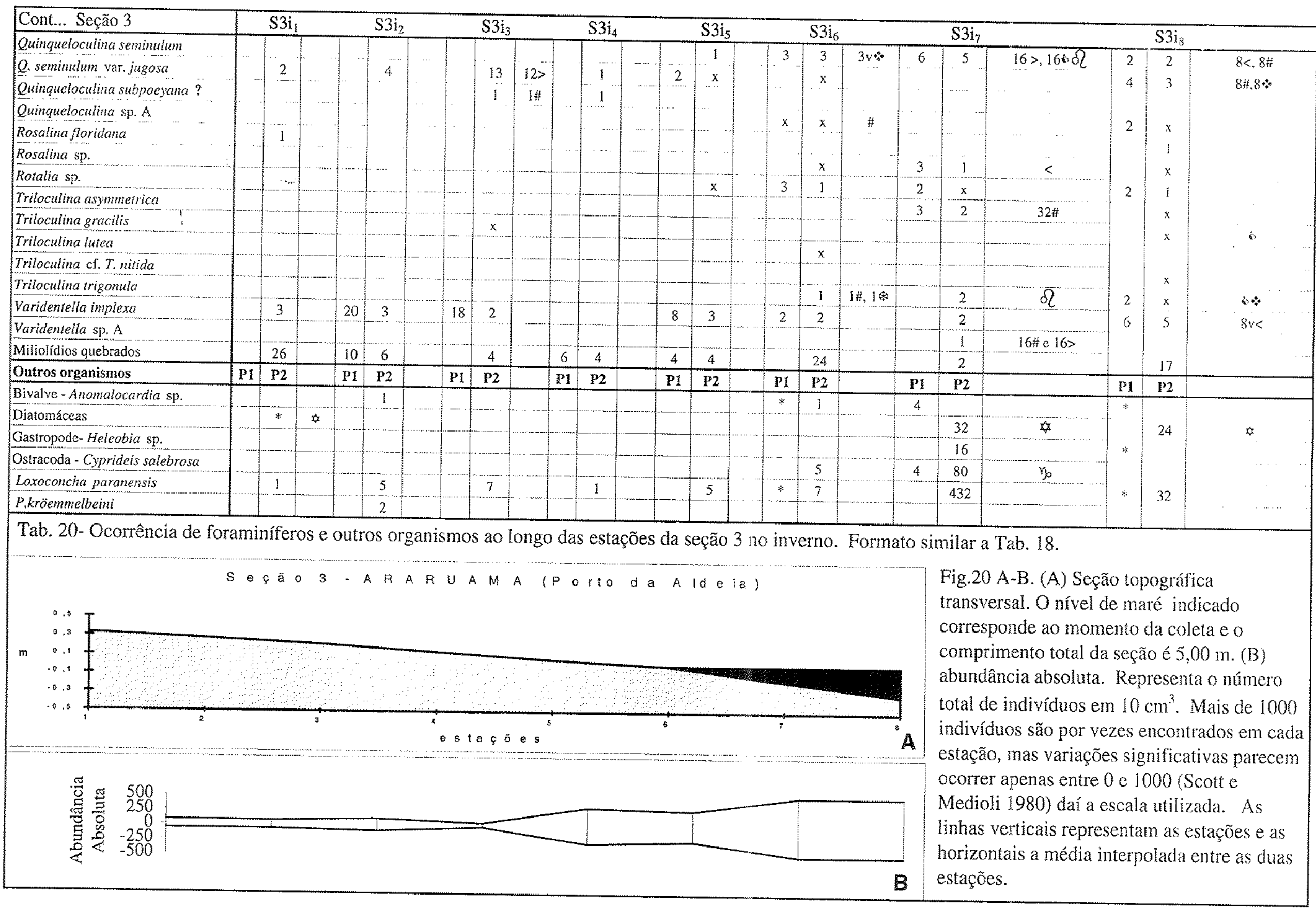




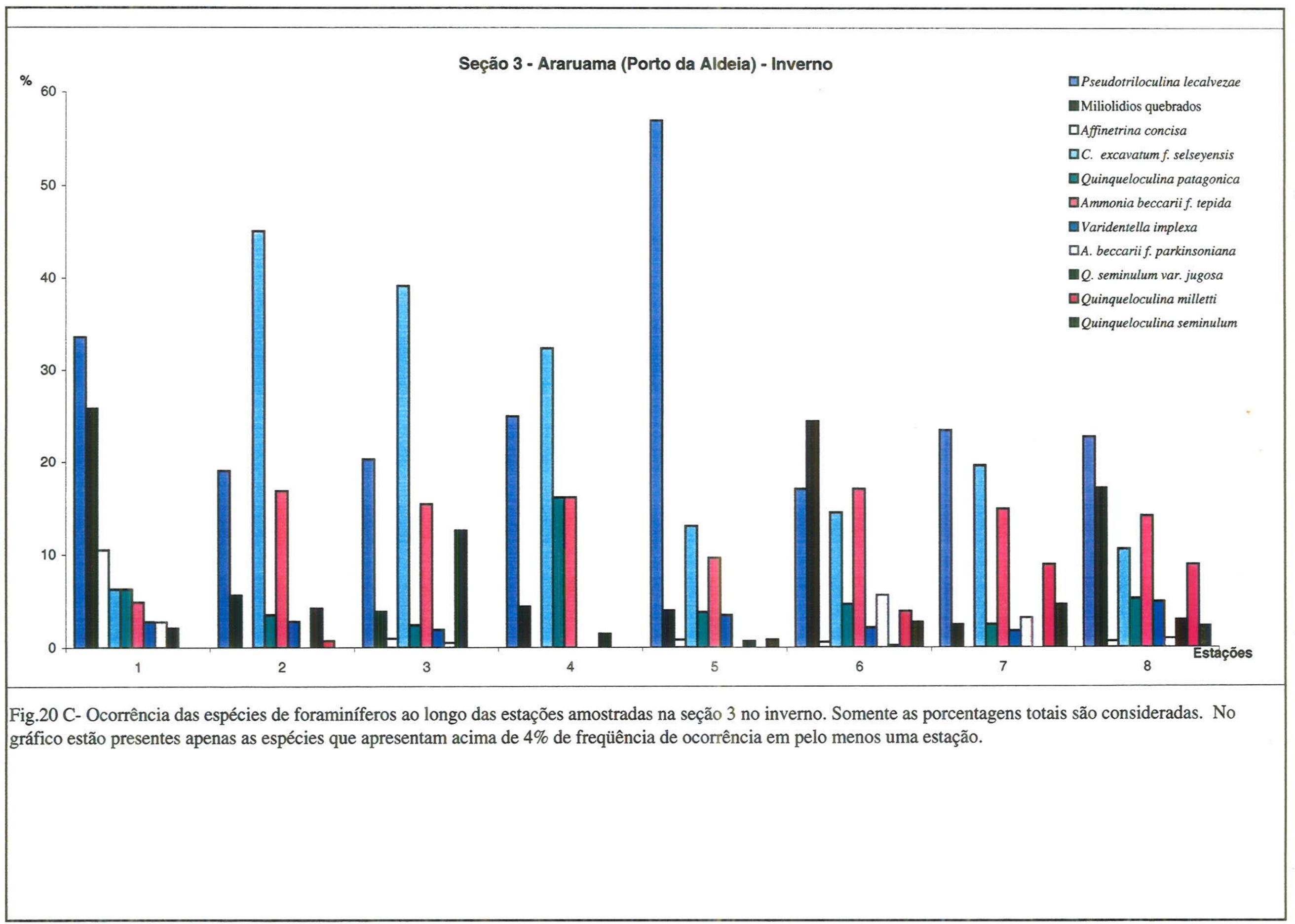




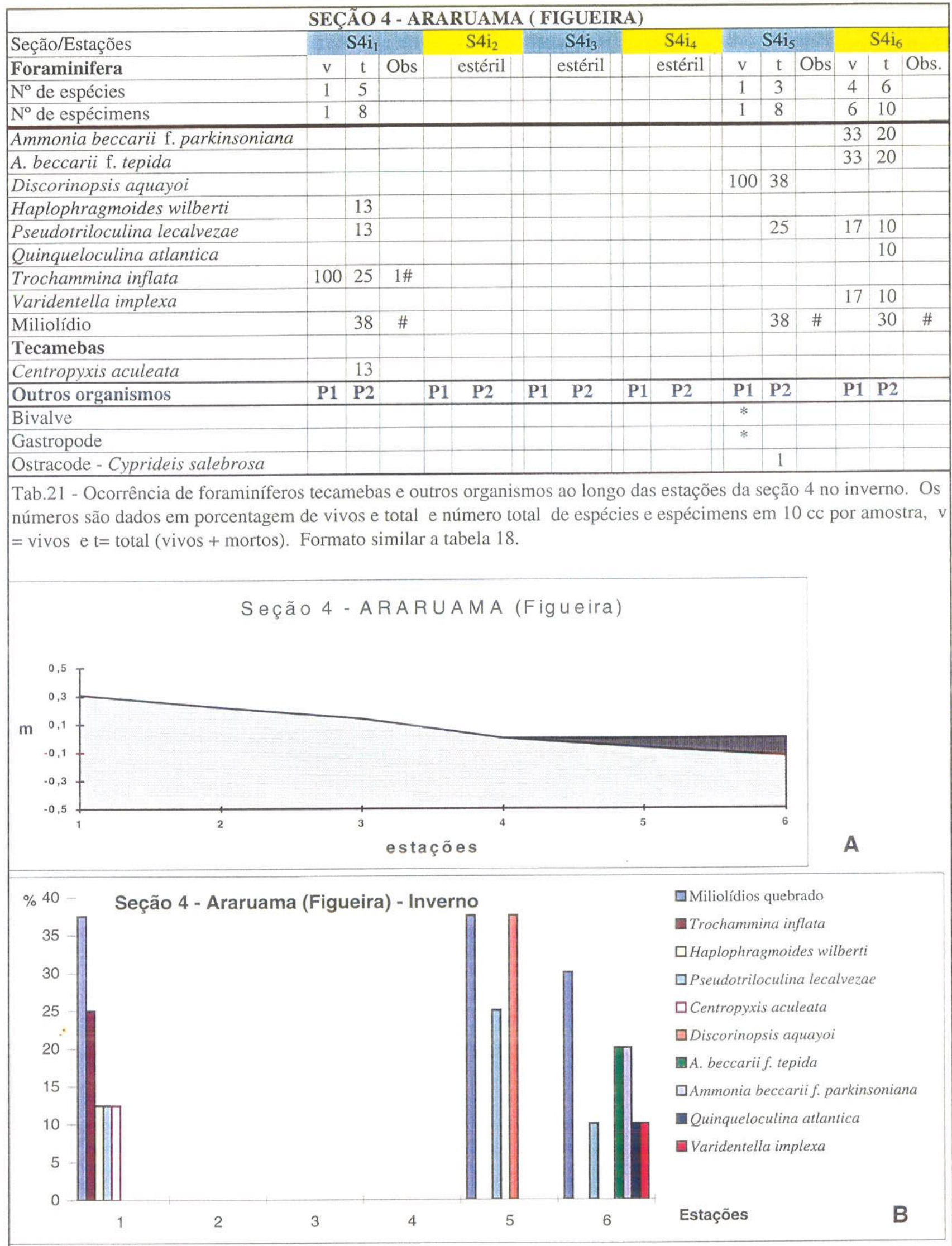

Fig. 21 A-B. (A) Seção topográfica transversal. O nível de maré indicado corresponde ao momento da coleta e o comprimento total da seção é 4,30 m. (B) Ocorrência das espécies de foraminíferos ao longo das estações amostradas na seção 4 no inverno. Somente as porcentagens totais são consideradas. 


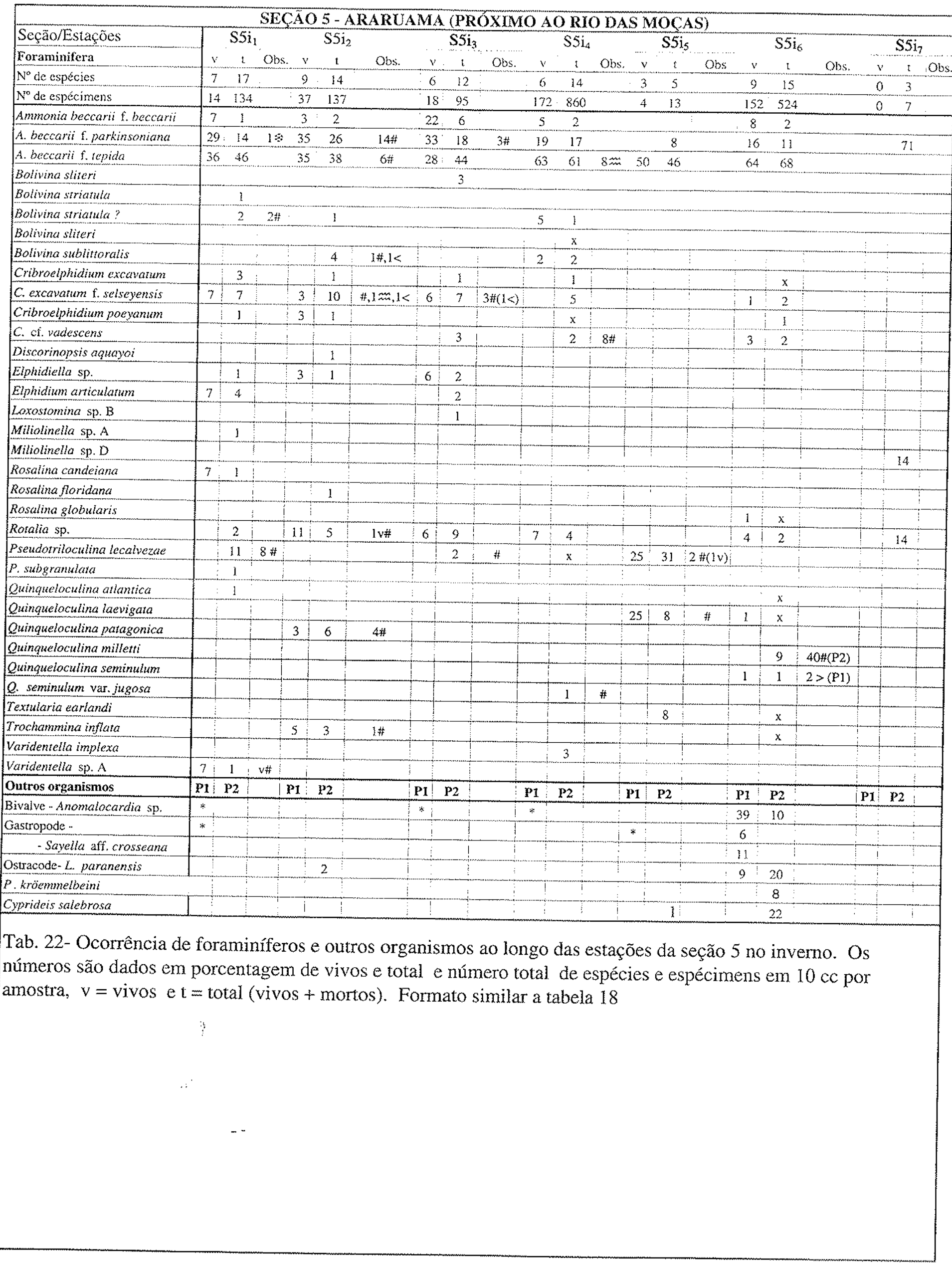


S eção 5 - ARARUAMA (próximo ao Rio das $M$ oças)
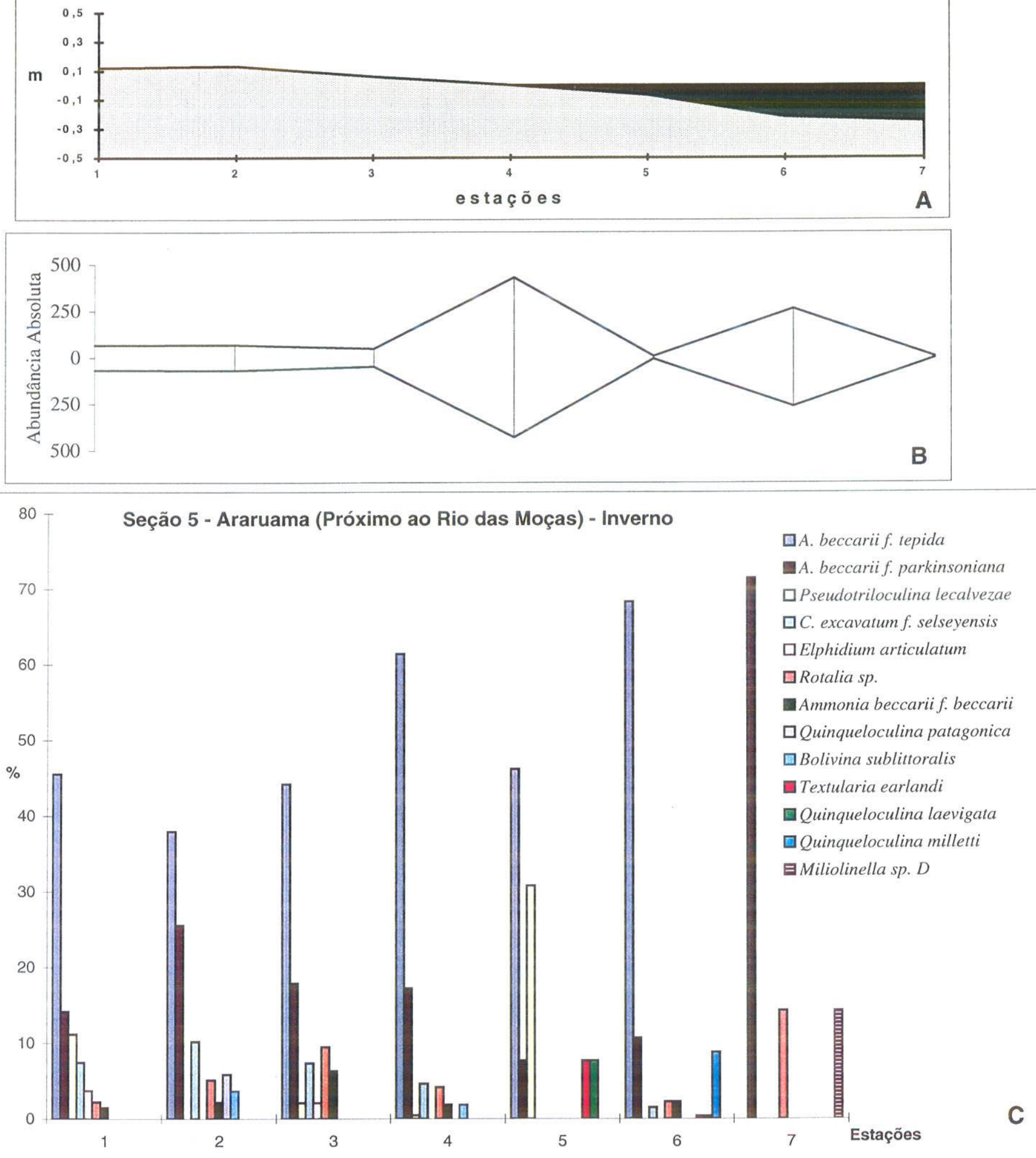

Fig.22 A-C. (A) - Seção topográfica transversal. O nível de maré indicado corresponde ao momento da coleta e o comprimento total da seção é 4,00 m. (B) - Abundância absoluta do total de indivíduos em $10 \mathrm{~cm}^{3}$. As linhas verticais representam as estações e as horizontais a média interpolada entre duas estações. (C)- Ocorrência das espécies de foraminíferos ao longo das estações amostradas na seção 5 no inverno. Somente as porcentagens totais são consideradas. No gráfico estão presentes apenas as espécies que apresentam acima de $4 \%$ de freqüência de ocorrência em pelo menos uma estação. 


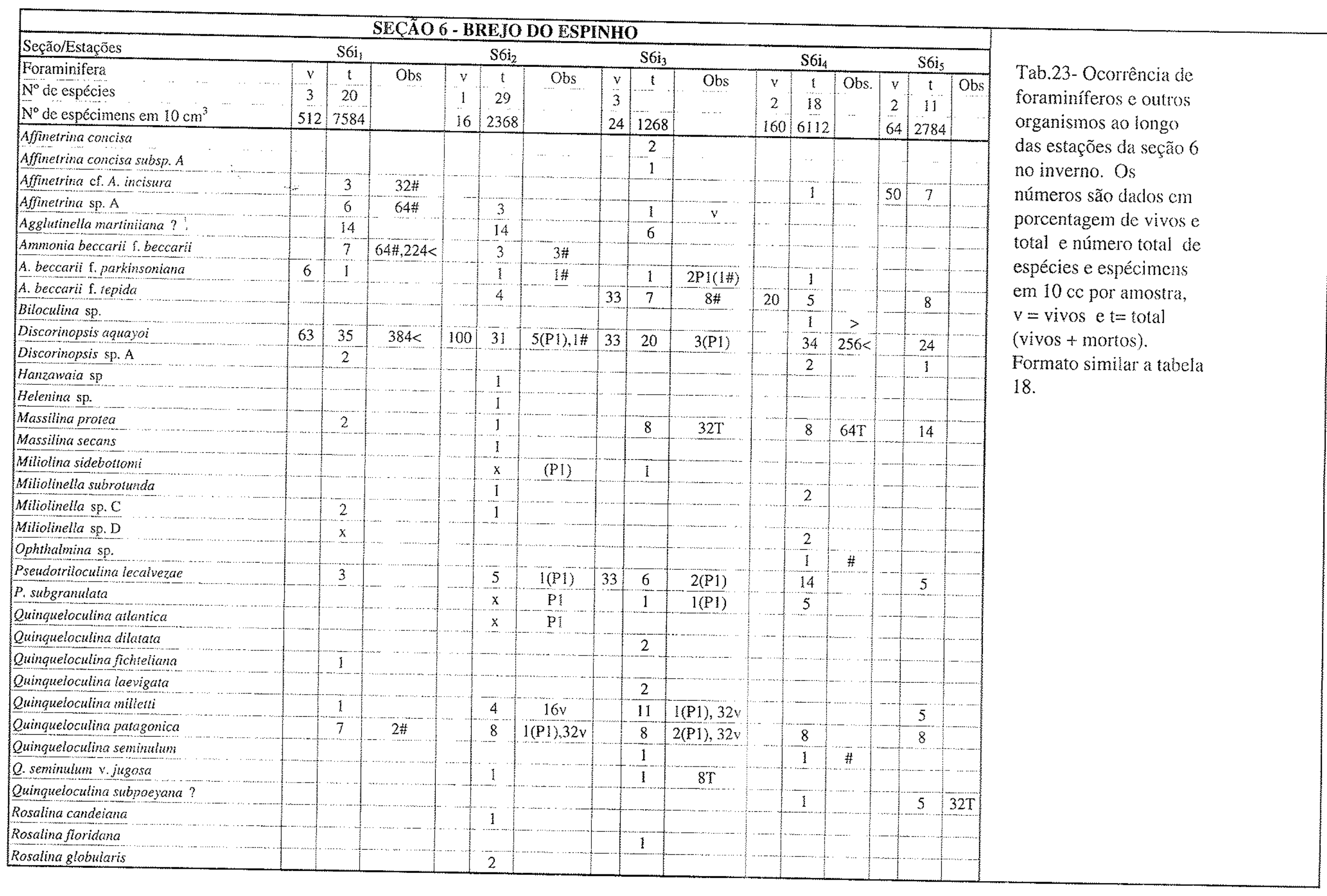




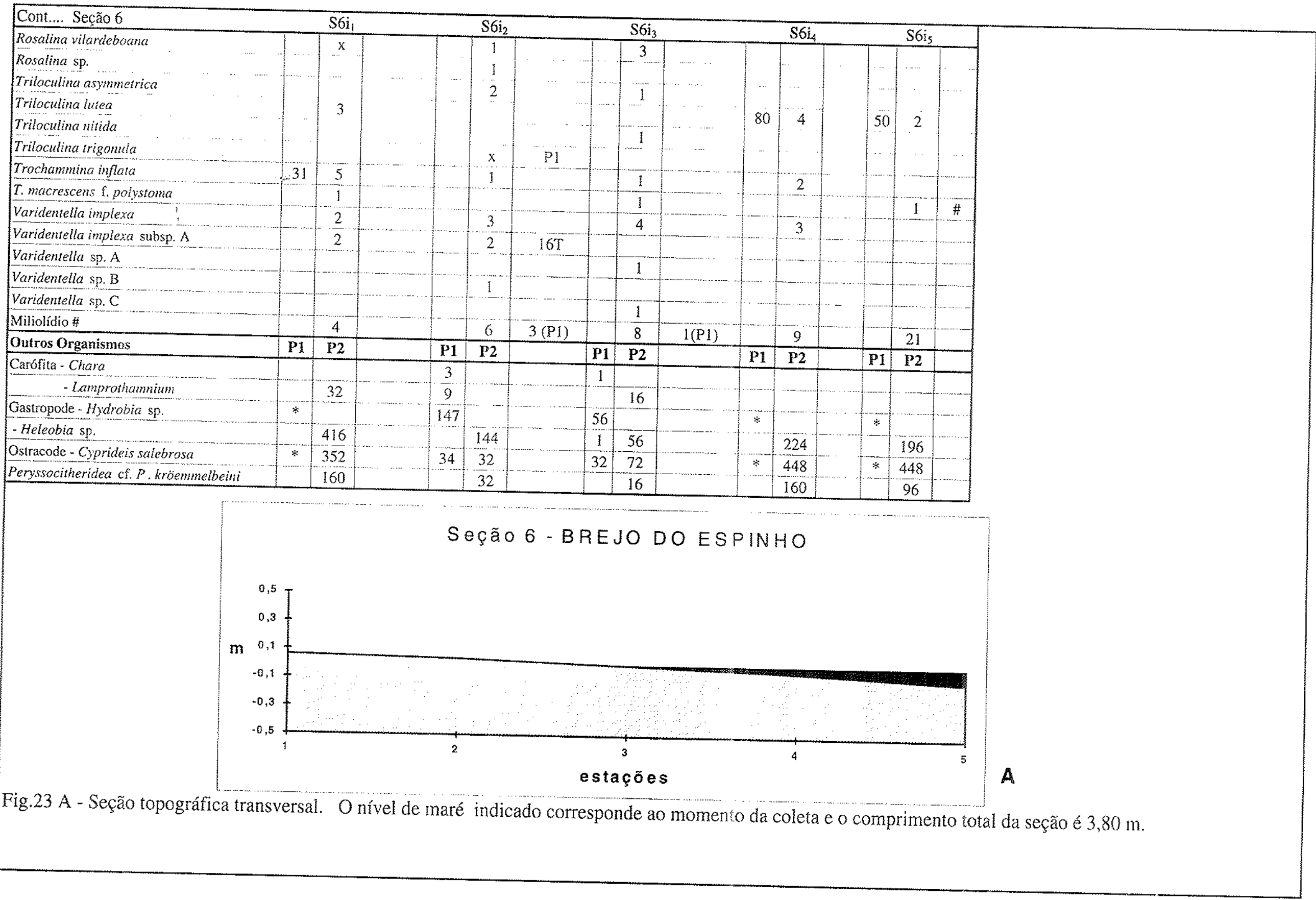




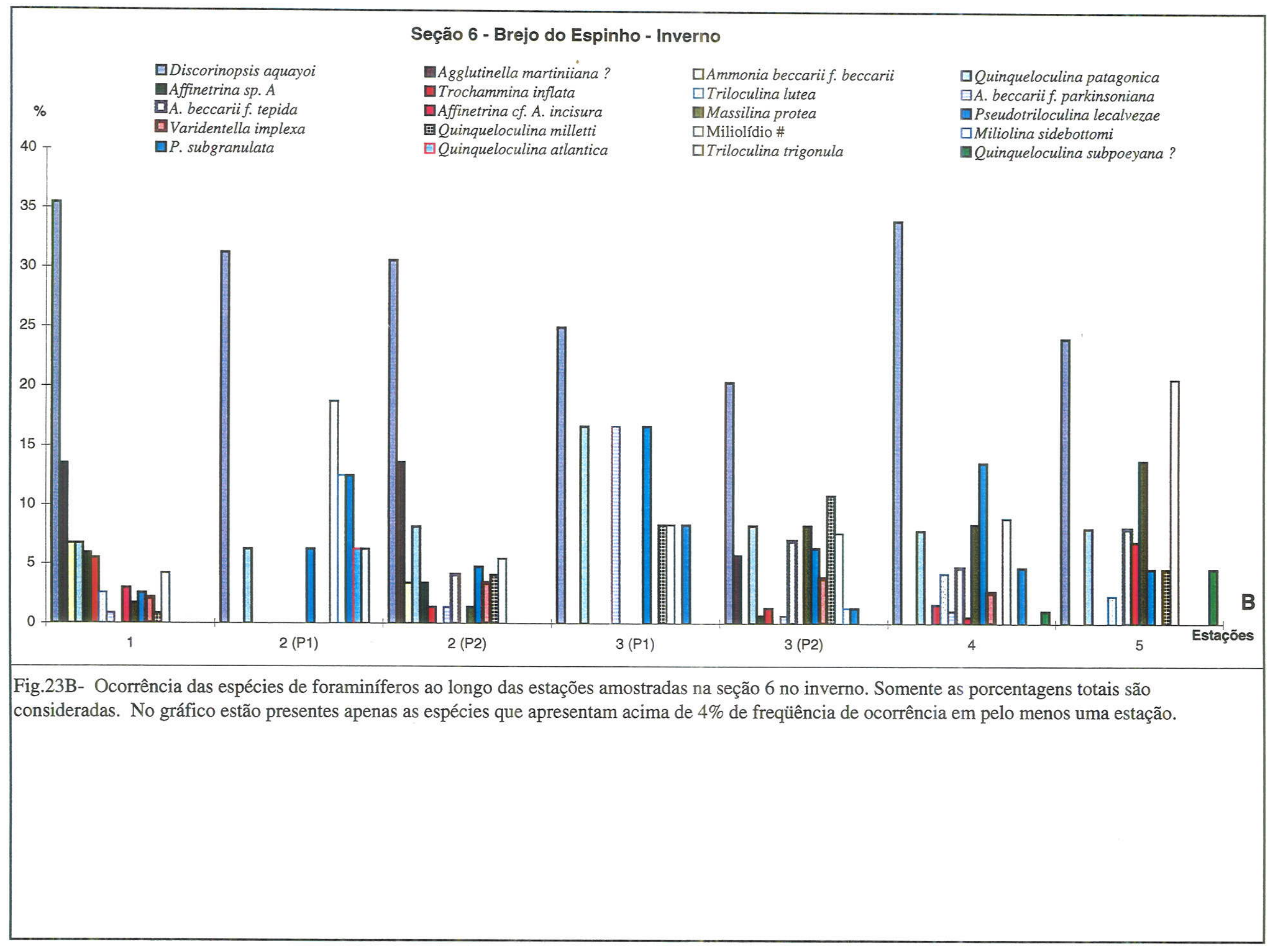




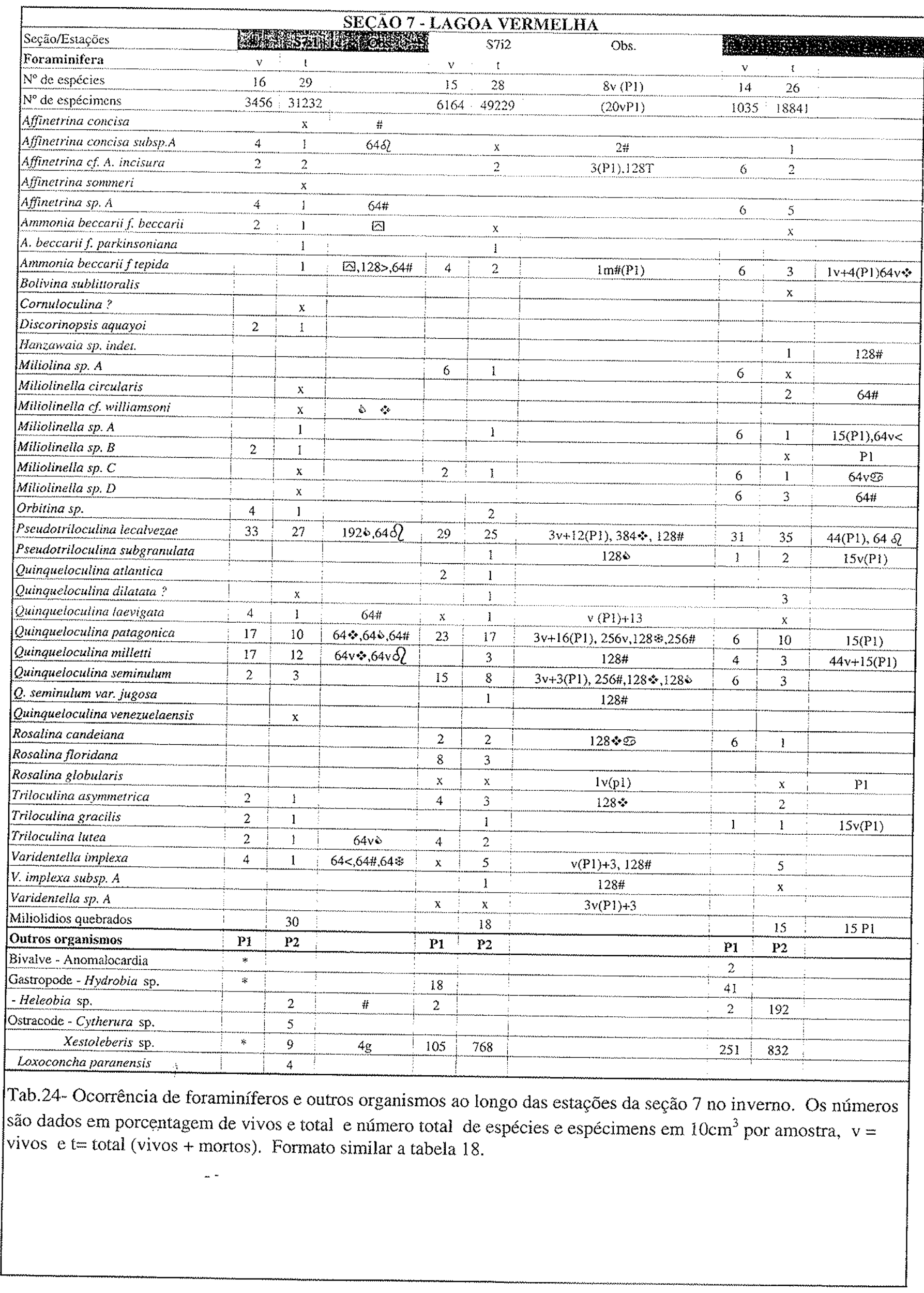




\section{Seção 7 - LAGOA VERMELHA}

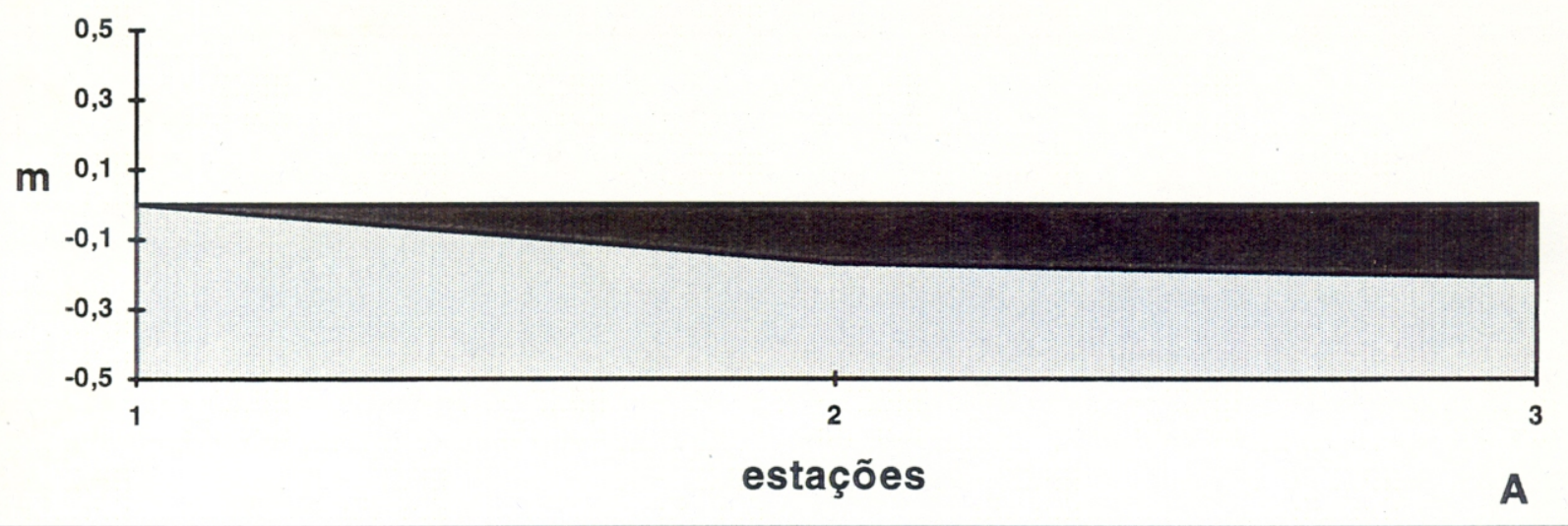

$\square$ Miliolídios quebrados

$\square$ Quinqueloculina patagonica

$\square$ Triloculina gracilis

$\square$ Affinetrina sp. A

- Varidentella sp. A
- Pseudotriloculina lecalvezae

Q Quinqueloculina seminulum

$\square$ Quinqueloculina laevigata

$\square$ Miliolinella sp. $B$

- Pseudotriloculina subgranulata

\section{$\square$ Quinqueloculina milletti}

$\square$ Affinetrina $c f$. A. incisura

⿴囗十 Varidentella implexa

$\square$ Miliolinella sp. A
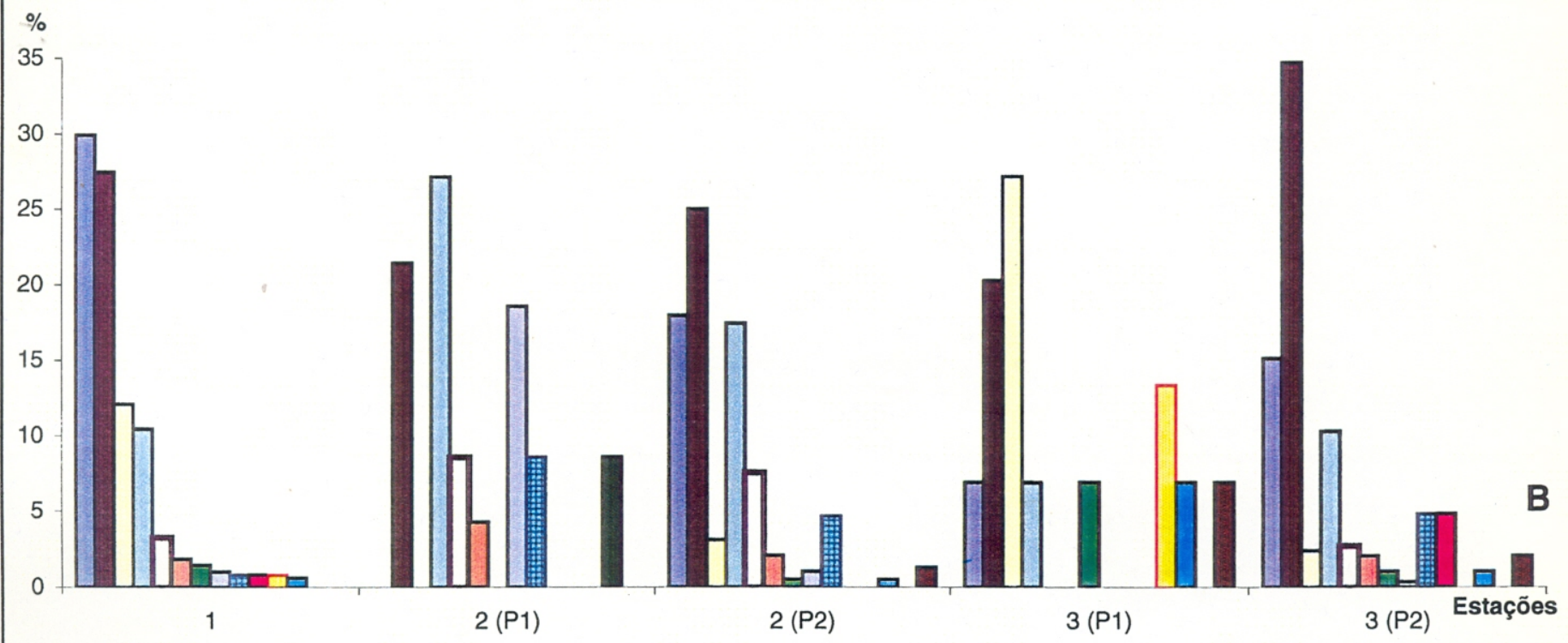

Fig.24 A-B. (A) - Seção topográfica transversal. O nível de maré indicado corresponde ao momento da coleta e o comprimento total da seção é 2,25 m. (B) Ocorrência das espécies de foraminíferos ao longo das estações amostradas na seção 7 no inverno. Somente as porcentagens totais são consideradas. No gráfico estão presentes apenas as espécies que apresentam acima de $4 \%$ de freqüência de ocorrência em pelo menos uma estação. 


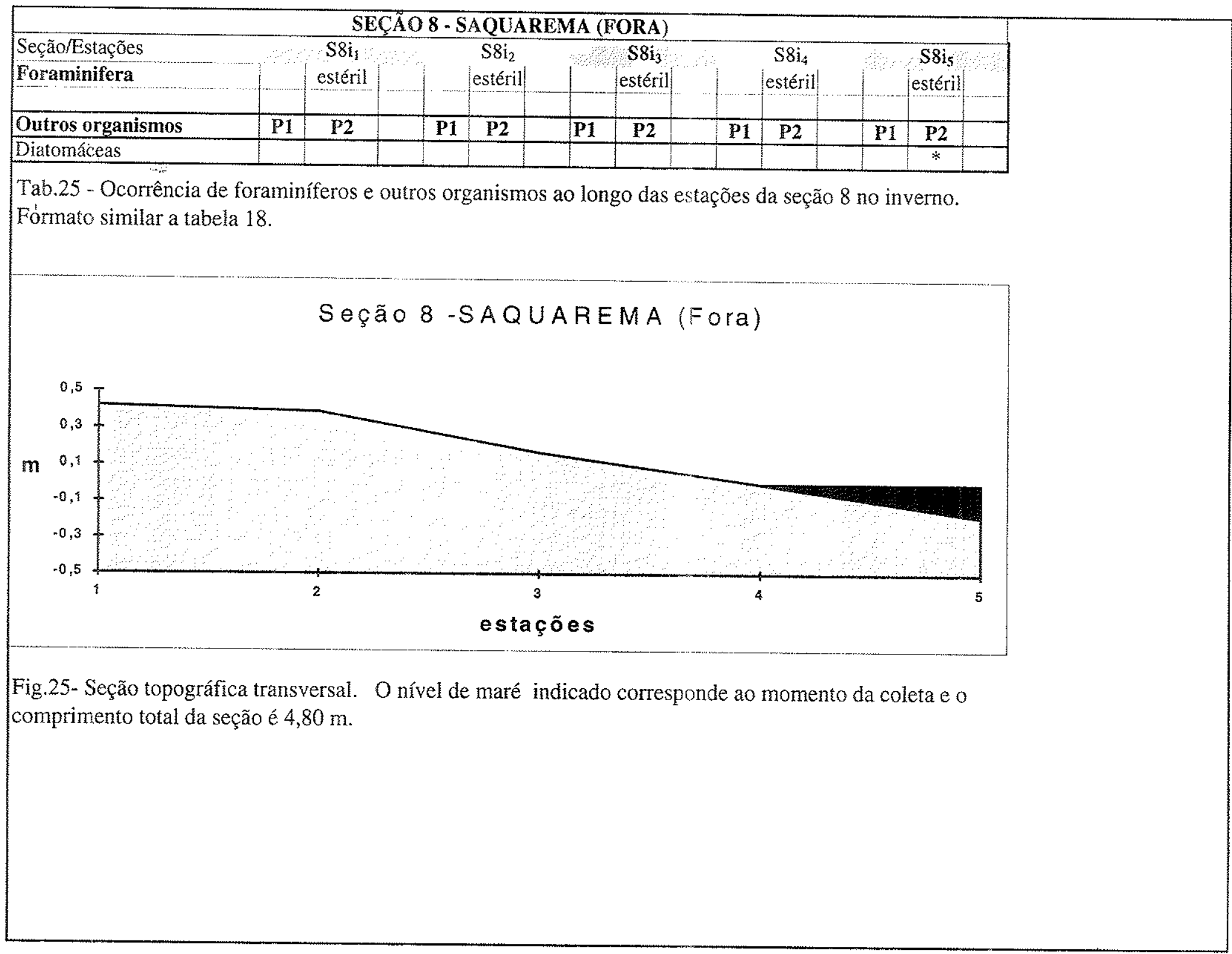




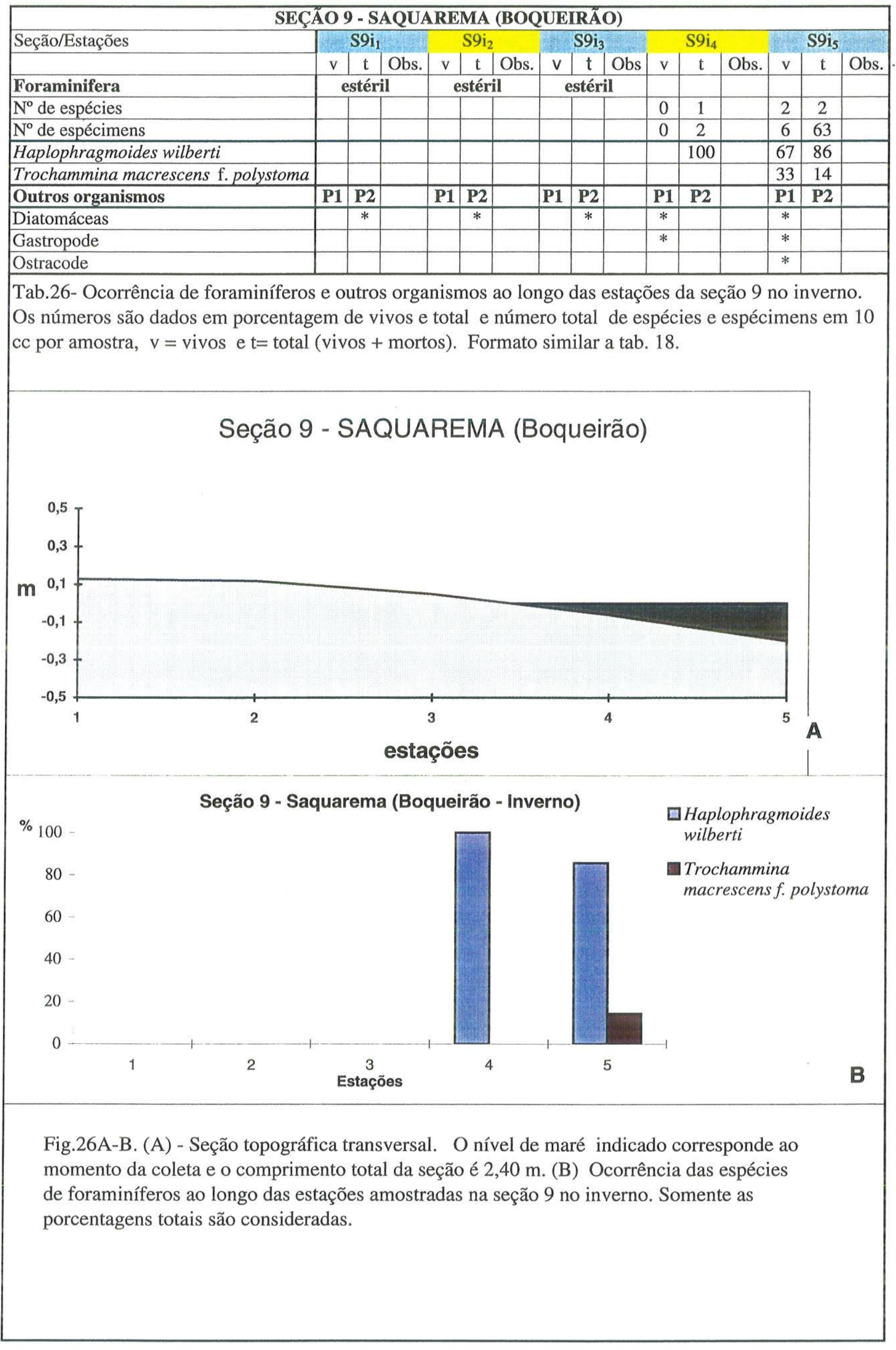




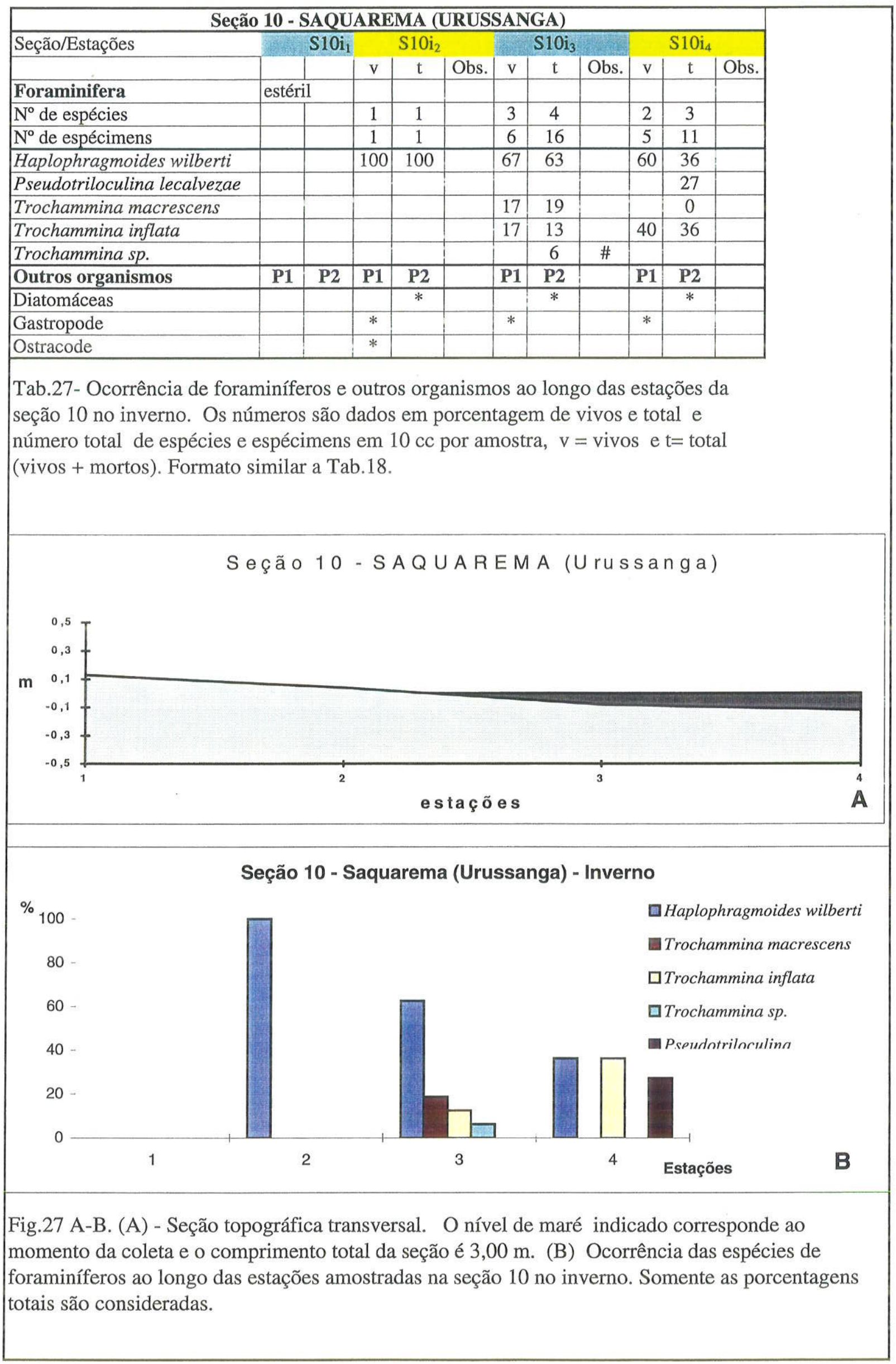


A biofácies $P$. lecalvezae-A.beccarii f. tepida no verão inclui toda a seção 1 e 3 além das estações 4, 5 e 6 da seção 2. Embora as frequiências de A. beccarii f. tepida sejam semelhantes à biofácies I, é diferenciada pela ocorrência de P. lecalvezae com $14 \%$ a $62 \%$. Esta biofácies é comparável a biofácies $P$. lecalvezae-A. beccarii f. tepida do inverno, que inclui praticamente todas as amostras da seção 2 e 4, e também neste caso, foram agrupadas em uma mesma biofácies na tabela de resultado, denominada biofácies (III), embora, com algúma variação nas frequiências. A altitude das amostras varia de $-0,65 \mathrm{~m}$ a $0,33 \mathrm{~m}$.

A biofácies $C$. excavatum $\mathrm{f}$. selseyensis - P. lecalvezae (IV) definida no inverno inclui amostras da seção 3 e 1. C. excavatum f. selseyensis aparece pela primeira vez nesta biofácies com abundância variando de $32 \%$ a $45 \%$. A. beccarii f. tepida está ainda entre as outras espécies presentes com $0 \%$ a $17 \%$ de abundância relativa, juntamente com Quinqueloculina patagonica $\operatorname{com} 2 \%$ a $16 \%$. Esta biofácies possui uma amplitude vertical de $0,06 \mathrm{~m}$ a $0,28 \mathrm{~m}$ e corresponde a única biofácies definida pela análise de agrupamento para a laguna de Araruama a apresentar ocorrência na zona supralitorânea da laguna.

A biofácies A. beccarii f. tepida-Varidentella implexa (V) é encontrada nas amostras da seçäo 3,1 e na mais baixa da seção 4 definida no inverno. Embora todas as estações incluídas nesta biofácies apresentem dominância de $A$. beccarii f. tepida, as abundâncias variam de $10 \%$ a $35 \%$, em associação a Varidentella implexa com $0 \%$ a $13 \%$ de abundância relativa. Esta biofácies possui uma amplitude vertical de $-0,31 \mathrm{~m}$ a $0,32 \mathrm{~m}$.

Para o GRUPO II - Lagoa Vermelha e Brejo do Espinho, no verão foram definidas 4 biofácies (Fig. 29A) e no inverno 3 biofácies (Fig. 29B). Neste caso não pôde ser feita a tabela de resultado devido a abundância de Triloculina lutea na zona supralitorânea no verão e de Agglutinella martiniiana que marca a bioecozona pós-lagunar no inverno.

A biofácies $P$. lecalvezae $Q$.seminulum (VI) é dominada por miliolídios representados por $P$. lecalvezae com $49 \%$ de abundância acompanhada de Q.seminulum com $41 \%$. Esta biofácies com ocorrência apenas na estação 3 da seção 7, está ao nível médio do mar.

A biofácies VII ainda apresenta abundância de $P$. lecalvezae com $55 \%$ a $91 \%$ de frequência com menores porcentagens de A. beccarii f. tepida ( $2 \%$ a $9 \%$ ) e D. aquayoi $(0 \%-4 \%)$, outros organismos presentes correspondem a $V$. implexa com baixas porcentagens $(1 \%)$. Esta biofácies abrange todas as outras estações da seção 7 com amplitude vertical de $-0,1 \mathrm{~m}$ a $0,07 \mathrm{~m}$.

A biofácies VII marca a ante-laguna da zona supralitorânea da seção 6 e apresenta abundância de T. lutea com $29 \%$ a 40\%. P. lecalvezae, apesar de apresentar abundância consideravelmente reduzida (13\% a 30\%) também marca esta biofácies. Outros organismos 
também são definidores por apresentarem abundância em todas as estações da biofácies como $D$. aquayoi (12\%-21\%), V. implexa (3\%-20\%) e Pseudotriloculina subgranulata (1\%-5\%). Esta biofácies apresenta altitudes variando de 0,02 a $0,08 \mathrm{~m}$

A biofácies DX marca a bioecozona pós-lagunar na seção 6 com abundância de $D$. aquayoi $(33 \%$ a $49 \%$ ) e $T$. lutea (19\% a 22\%). Outros organismos presentes nas estações 1 e 2 , que marcam esta biofácies correspondem a A. martiniiana ( $8 \%$ a 12\%), A.beccarii f. tepida (6\% a $7 \%$ ) e $P$. lecalvezae (6\% a 7\%). Esta biofácies apresenta amplitude vertical de $0,13 \mathrm{~m}$ a $0,11 \mathrm{~m}$.

As biofácies de inverno para o GRUPO 11 definidas no dendrograma da Fig. 29B, estâo separadas claramente entre as seções 6 e 7. A biofácies X corresponde a toda seção 7 com abundância de miliolídios, como na biofácies VI definida no verão. Normalmente os miliolidios vivem associados a vegetação submersa e algas (Basson e Murray 1995). No entanto, estas biofácies não puderam ser colocadas em uma tabela de resultado devido a abundância de $Q$. patagonica (10\% a $17 \%$ ) no inverno que, juntamente com $P$. lecalvezae (25\% a $45 \%$ ) definem esta biofácies. Outros organismos presentes em todas as estações no inverno correspondem a $Q$. milletti $(3 \%$ à $12 \%$ ) Q. seminulum $(3 \%$ a $8 \%$ ) e V. implexa (1\% a $5 \%$ ). A amplitude desta biofácies corresponde a aplitude da seção 7 e seu limite inferior foi definido pelo limite da amostragem, variando de $-0,21 \mathrm{~m}$ ao nível médio do mar.

A biofácies XI corresponde a zona ante-laguna supralitorânea da seção 6 e está marcada por abundância de D. aquayoi (20\% a 34\%) e Massilina protea ( $8 \%$ a 14\%). P. lecalvezae (5\% a $14 \%)$ apresenta abundância reduzida nesta biofácies, acompanhado de $Q$. patagonica $(8 \%) Q$. milletti (5\% a $11 \%$ ) e A. beccarii f. tepida (5\% a $8 \%$ ). A amplitude desta biofácies é de $-0,1$ ao nível médio do mar

A biofácies XII corresponde a zona pós-lagunar da seção 6 e apresenta abundância de $D$. aquayoi (31\% a $36 \%$ ) acompanhada de A. martiniiana com $14 \%$. Outros organismos ocorrem nas estações representadas nesta biofácies como A. beccarii f. beccarii (4\% a 7\%), Affinetrina sp. A $(3 \%$ a $6 \%), Q$. patagonica $(7 \%$ a $8 \%), V$. implexa $(2 \%$ a $3 \%)$ e a espécie de foraminífero aglutinante Trochammina inflata (1\% a 6\%). A amplitude desta biofácies varia de 0,04 a $0,06 \mathrm{~m}$.

A biomassa (número de indivíduos vivos em $10 \mathrm{~cm}^{3}$ ) não mostra de forma óbvia nenhum padrão de mudança e permite afirmar que a redução no número de indivíduos vivos no grupo II só ocorre no Brejo do Espinho no verão, onde, mesmo assim os números são altos (12-512) (Tabs. 12, 1323, 24). 


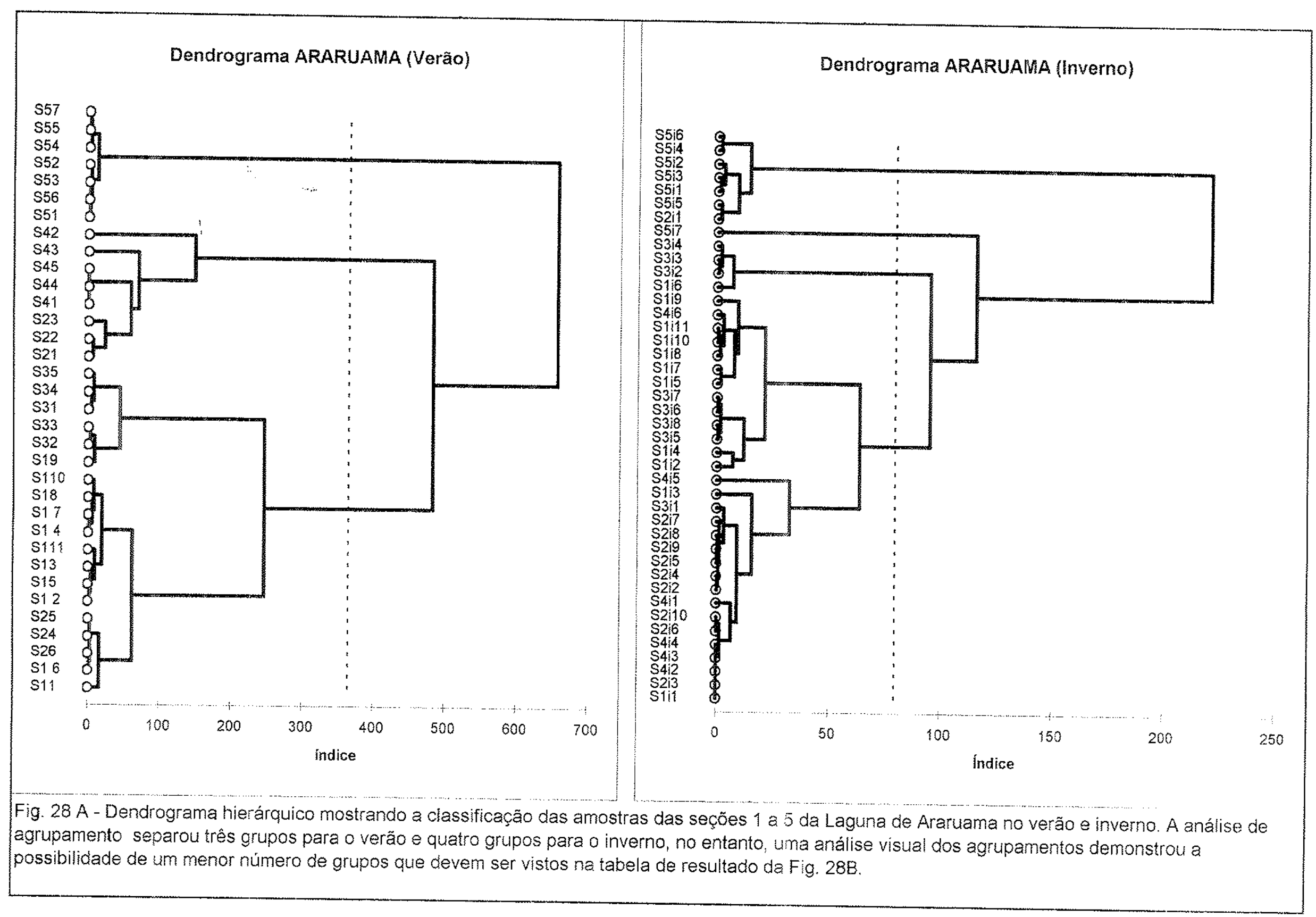




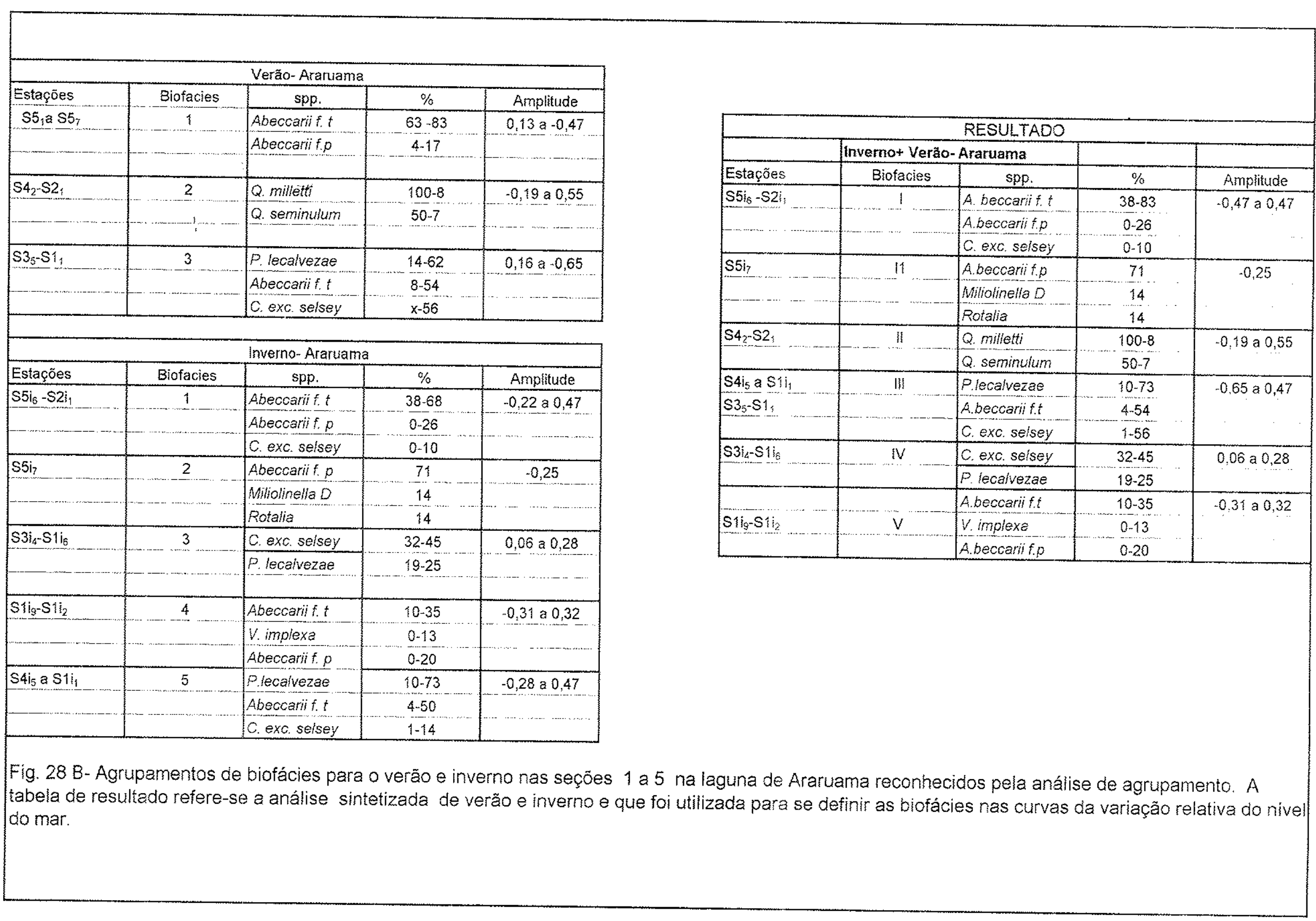




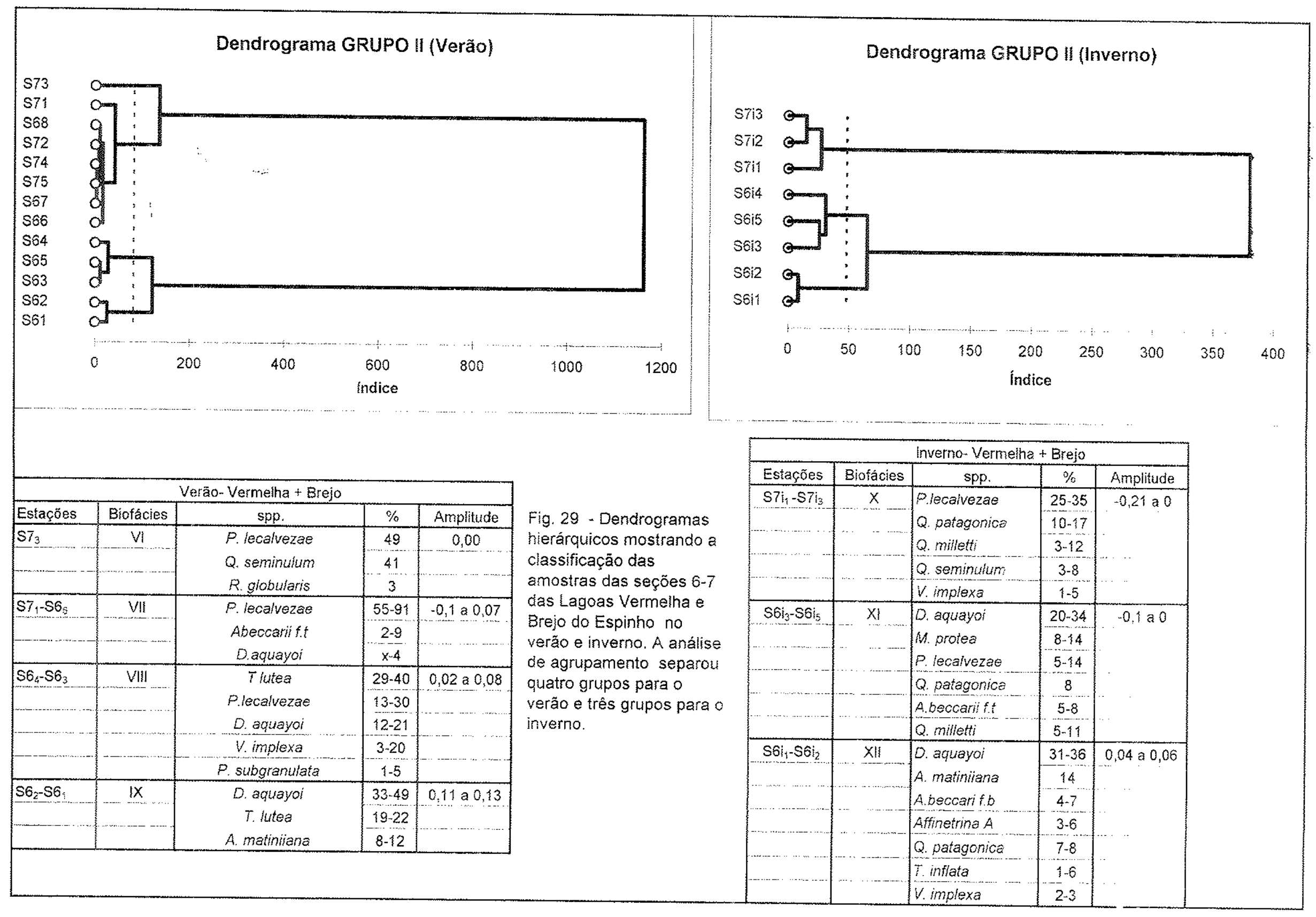




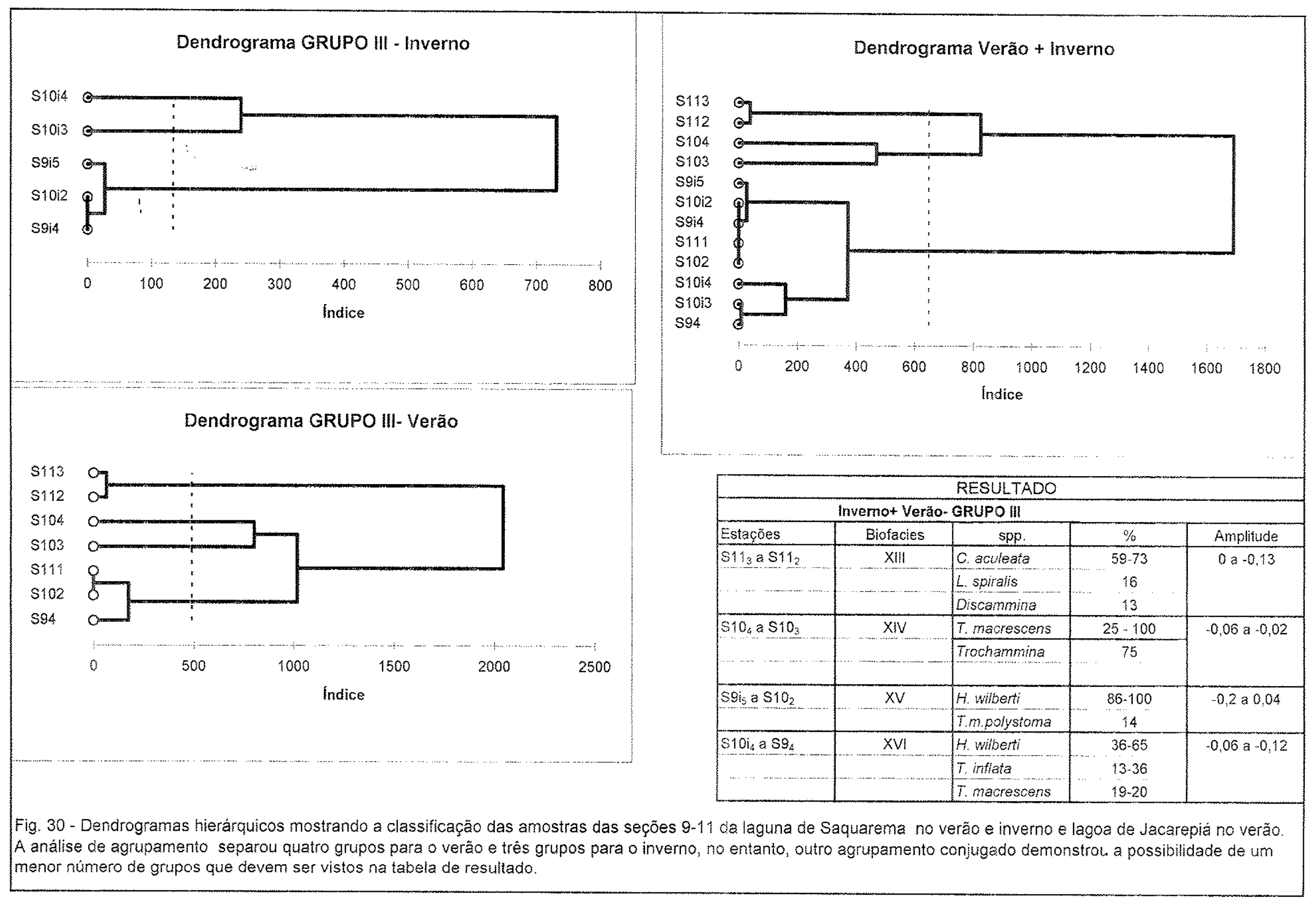


Para o GRUPO III, Laguna de Saquarema e Lagoa de Jacarepiá (Fig. 30), a análise de agrupamento corrobora as observações ecológicas realizadas no grupo II. Embora tenham sido definidas 4 biofácies para o verão e 3 biofácies para o inverno estas foram agrupadas em 4 biofácies na tabela de resultado, devido a ausência de variação sazonal.

A biofácies XIII corresponde as estações 2 e 3 da Lagoa de Jacarepiá com tecamebas abundantes, representados em sua borda por Centropyxix aculeata (59\% a 73\%), Lesquereusia spiralis (16\%), e menor abundância de Discammina sp. (13\%) e P. ipohalina (11\%). A amplitude inferior desta biofácies está limitada pela amostragem, variando de $-0,13 \mathrm{~m}$ ao nível médio do mar.

A biofácies XIV ocorre nas estações 3 e 4 da seção 10 , sendo caracterizada por Trochammina macrescens (25\% a $100 \%$ ) e Trochammina sp. (75\%) com amplitude de $-0,06$ a $0,02 \mathrm{~m}$.

A biofácies XV corresponde as estações $\mathrm{S} 9 \mathrm{i}_{5}, \mathrm{~S} 10 \mathrm{i}_{2}, \mathrm{~S} 10_{2}, \mathrm{~S} 9 \mathrm{i}_{4}$ e $\mathrm{S} 11_{1}$ e apresenta abundância de H. wilberti (86\% a $100 \%)$ e T. macrescens f. polystoma (14\%). Sua amplitude é de $-0,2$ a $0,09 \mathrm{~m}$.

A biofácies XVl corresponde as estações $\mathrm{S9}_{4}, \mathrm{S1Oi}_{3}$ e $\mathrm{S10}$, apresenta abundância de $H$. wilberti $(36 \%$ a $65 \%)$ e Trochammina inflata (13\% a 36\%) acompanhadas de $P$. lecalvezae (27\%) e T. macrescens (19\% a $20 \%$ ). Sua amplitude varia de - 0,12 a $-0,06 \mathrm{~m}$.

\section{2 - Testemunhos}

Três testemunhos foram analisados: LV-89/19 (Fig. 31), LV-4 (Fig. 32) obtidos na Lagoa Vermelha e LBE 89/2 (Fig. 33) no Brejo do Espinho. Onze litofácies foram identificadas nos três testemunhos por feições características observadas como tamanho dos grãos, cor, estruturas sedimentares, litologia e fósseis. As lâminas delgadas examinadas, com ênfase nos intervalos carbonáticos, estão identificadas por letras maiúsculas nas figuras supracitadas, Fig. 34 e respectivas descrições.

Amostras para estudos microfaunísticos foram coletadas a intervalos de $10 \mathrm{~cm}$. Das dezesseis biofácies reconhecidas pela análise de agrupamento, seis foram identificadas para as três zonas batimétricas litorâneas - submaré, intermaré e supramaré.

Serão fornecidas descrições de cada litofácies e posteriormente das biofácies, seguidas por uma discussão das correlações observadas entre unidades litofaciológicas e biofaciológicas. A interpretação da associação de fácies observada nos testemunhos será feita com base nessas relações. 


\subsection{1 - Litofácies}

As descrições dos testemunhos são feitas da base para o topo e ao fim, é apresentada uma breve discussão sobre os dados isotópicos de $\delta^{18} \mathrm{O}$ e $\delta^{13} \mathrm{C}$ obtidos do carbonato total, sobre o carbonato $\left(\mathrm{CaCO}_{3}\right)$, matéria orgânica (M.O), nitrogênio total (NOT) e do carbono orgânico total (COT) para os testemunhos.

\section{89-19}

\section{Fácies 1}

É representada por lama orgânica de cor marrom escura que corresponde à base do testemunho entre $108 \mathrm{~cm}$ e $116 \mathrm{~cm}$ com recorrência cíclica entre $104 \mathrm{~cm}$ e $107 \mathrm{~cm}$ e $98 \mathrm{~cm}$ a $101 \mathrm{~cm}$ intercalada com calcário tipo lamito calcimudstone (Fig. 31). A espessura total é de $18 \mathrm{~cm}$. A estratificação é plano paralela com presença de nível pouco espesso de conchas a $111 \mathrm{~cm}$, onde a laminação apresenta-se levemente bioturbada. A matéria orgânica, no intervalo $110-115 \mathrm{~cm}$, forneceu idade de $3.700 \pm 80$ A.P pelo ${ }^{14} \mathrm{C}$. O estudo de lâmina delgada do calcário tipo lamito (calcimudstone) no intervalo $102-104 \mathrm{~cm}$ (A) revelou rara ocorrência fossilífera (gastrópodes), algas estratiformes intercaladas com níveis de intraclastos, presença de gretas de ressecação e brechação in situ, evidenciando exposição subaérea. O contato superior, com a fácies 2 , a $98 \mathrm{~cm}$, é gradual, e marcado por início da precipitação de carbonatos.

\section{Fácies 2}

É caracterizada por camada carbonática de cor marrom clara com contato inferior gradual com a fácies 1 . O início da deposição está a $98 \mathrm{~cm}$ e o contato superior é gradual a $36 \mathrm{~cm}$ do testemunho totalizando uma espessura de $62 \mathrm{~cm}$. Apresenta-se em geral laminada com níveis concrecionais de cor bege clara, de até $8 \mathrm{~cm}$ de espessura, entremeados por lâminas de cor marrom variegada. Não foi constatada a ocorrência de conchas ou bioturbação. A estrutura predominante é a laminação microbial ou tapete microbial (microbial lamination ou microbial mat- anteriormente chamada cripto-algálica, ${ }^{\dagger}$ quando não se conhecia a natureza biológica de sua gênese), estratiforme, com porosidade fenestrada (fenestral) ${ }^{*}$ e ocorrência intercalada à areias carbonáticas entre 40 e $80 \mathrm{~cm}$. Abaixo dessas laminaçōes são observados grãos carbonáticos escuros devido a condições redutoras. O tipo de tapete algálico é determinado pela intensidade

\footnotetext{
"Entende-se por lamito cripto-algálico (crypt-algal laminites) quando o lamito apresenta-se laminado, irregular, inicialmente ligado por algas. O termo laminito foi sugerido por A. Knopf em substitutição a ritmito de modo a evitar a implicaçäo de periodicidade perfeita na recorrência das lâminas (Sander, B., AAPG, p. 135, 1951).
} 
de dessecação e pelo índice de sedimentação da planície de maré, parecendo corresponder no caso a um tapete pelicular (film mat) que ocorre em áreas raramente inundadas e de baixo índice de sedimentação (Hoffman 1976 in Schreiber 1986). O tapete microbial geralmente é composto por uma variedade de cianobactérias filamentosas e cocóides e bactérias, que são responsáveis pela laminação de escala milimétrica exibida. A lâmina delgada do intervalo $51-53 \mathrm{~cm}$ (B) mostrou calcário tipo lamito (calcimudstone) com intercalações algálicas, e ocorrência de intraclastos.

\section{Fácies 3}

Esta fácies ocorre de $36 \mathrm{~cm}$ ao topo, com $36 \mathrm{~cm}$ de espessura e contato inferior gradacional. É composta de lama síltica de coloração marrom clara bioturbada de 36 a $20 \mathrm{~cm}$, seguida de lama orgânica preta sem fósseis ou estruturas sedimentares visíveis de $20 \mathrm{~cm}$ ao topo. Apresenta dois níveis conchíferos um a $30 \mathrm{~cm}$ e outro a $20 \mathrm{~cm}$, sendo que este último separa a lâma síltica da lama orgânica.

\section{Resultados geoquímicos e isotópicos em LV89/19}

A análise do isótopo de $\delta^{13} \mathrm{C}$ (Fig.31B), mostra que ocorre na base do testemunho, a $109 \mathrm{~cm}$ de profundidade, dentro da litofácies de lama orgânica escura (1) - um aumento da continentalidade expressa por valores mais negativos. Os valores do isótopo de $\delta^{18} \mathrm{O}$ na fácies 1 não expressam aparentemente nenhuma variação de temperatura, apresentando-se bastante homogêneos. A fácies 1 também mostra aumento nos valores de COT e matéria orgânica (Fig. 31 A) nas porções da lama orgânica escura. As oscilações correspondem a ciclicidade entre as fácies 1 e 2 observada na base do testemunho. Os valores de $\mathrm{CaCO}_{3}$ ilustram um aumento em direção ao topo da fácies 1 .

A fácies 2 apresenta valores de $\delta^{13} \mathrm{C}$ menos negativos em seu topo e base, e os valores mais negativos acompanhando a ocorrência do tapete algálico. A curva dos valores de nitrogênio acompanham às de COT e M.O, com tendência de aumento em direção ao topo do testemunho. A fácies 3 registra queda acentuada nos valores de $\mathrm{CaCO}_{3}$ em direção ao topo com o aumento de sedimentos siliciclásticos. A diminuição da continentalidade, ou aumento da oceanicidade, ocorre nas transições faciológicas (1-2 e 2-3). De uma maneira geral $\mathrm{CaCO}_{3}$ apresenta-se inversamente simétrico aos demais dados.

\footnotetext{
* Presença de poros de tamanho milimétrico a centimetrico em forma de lençol subhorizontais formados por vazios ligados pelo tapete microbial ou gerados por mofo de decomposiçâo.
} 
Fig. 31 - Fotomontagem da associação de litofácies paleolagunar do testemunho LV 89/19, mostrando estruturas sedimentares, descrições litofaciológicas, datações e identificação das lâminas delgadas (A,B). A descrição está
detalhada no texto. 
LV-89/19

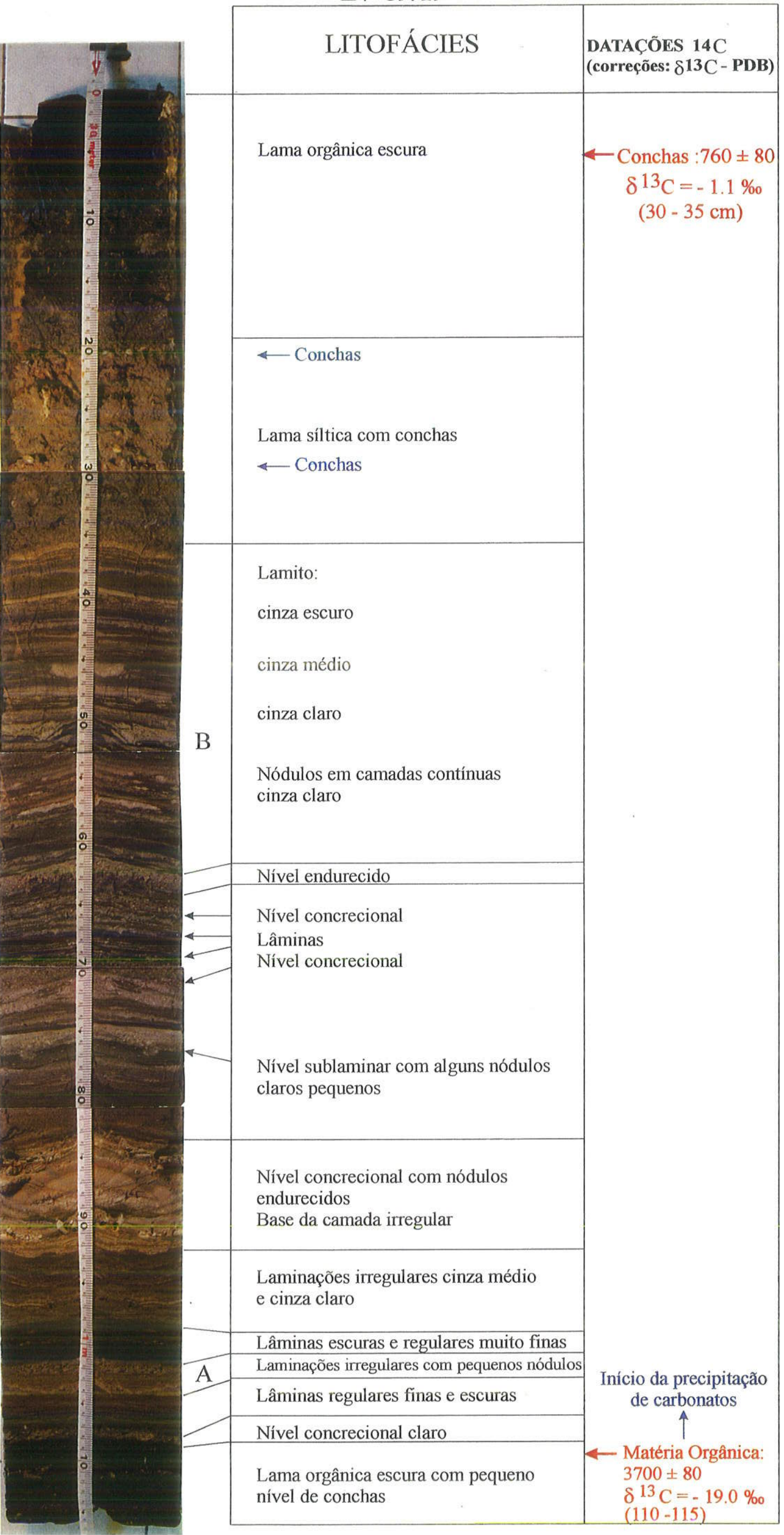




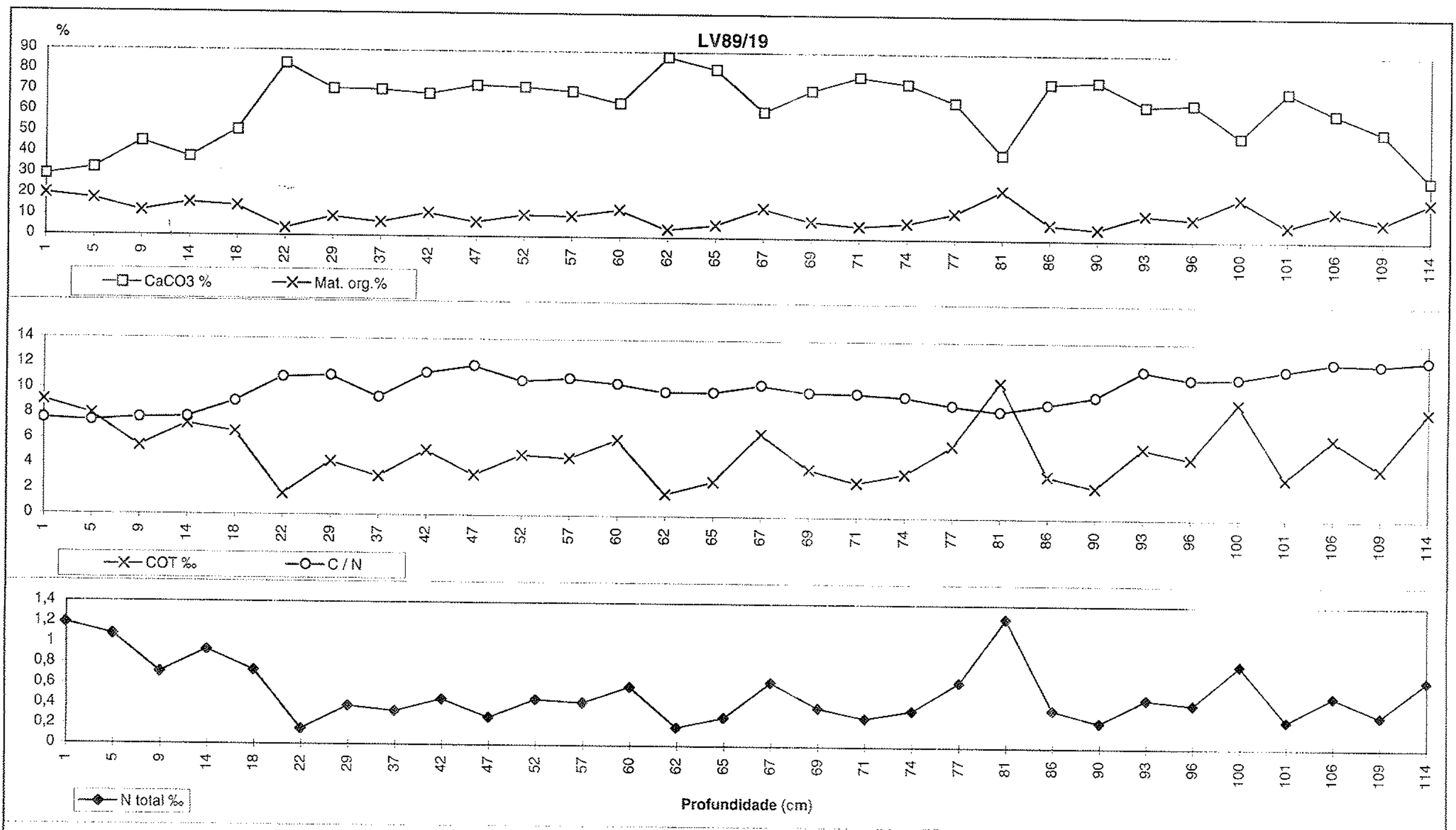

Fig. $31 \mathrm{~A}$ - Porcentagem de $\mathrm{CaCO}_{3}$, matéria orgânica, e teores de carbono orgânico total e nitrogênio total em ppm, com relação carbono/nitrogênio para o tetemunho LV $89 / 19$. 


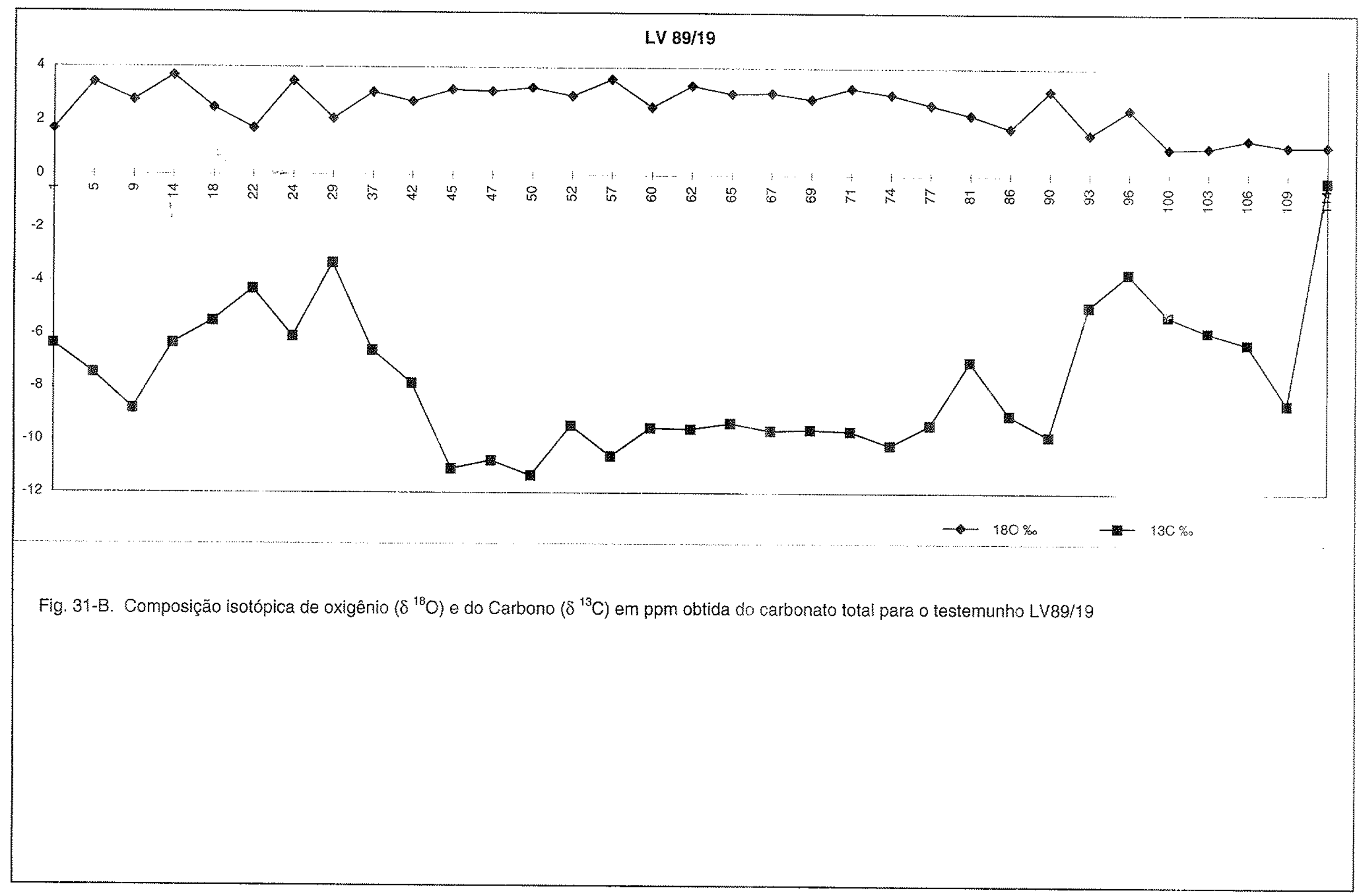




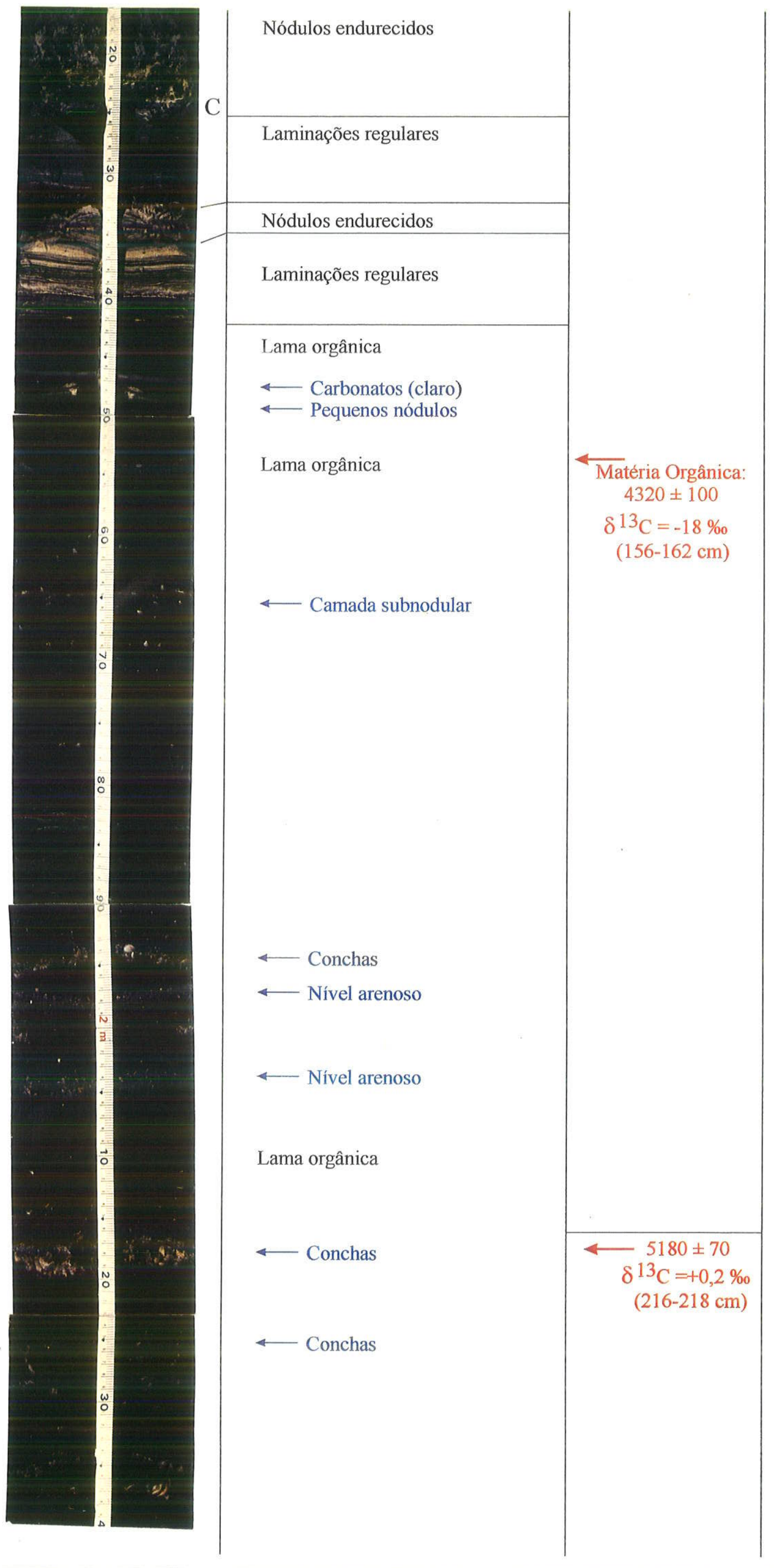




\begin{tabular}{|c|c|c|c|c|c|c|c|c|c|}
\hline \multicolumn{7}{|c|}{ LV 89-19 } & \multicolumn{3}{|c|}{ Carbonato Total } \\
\hline Prof. $\mathrm{cm}$ & Prof. $\tilde{x}$ & $\mathrm{CaCO}_{3} \%$ & Mat. org. $\%$ & COT \% & $N$ total $\%$ & $\mathrm{C} / \mathrm{N}$ & Prof. $\bar{x}$ & $\delta^{18} 0 \%$ & $\delta^{13} \mathrm{C} \%$ \\
\hline $00-02$ & 1 & 28,87 & 19,84 & 9,02 & 1,19 & 7,56 & 1 & 1,7 & $-6,37$ \\
\hline $04-06$ & 5 & 32,18 & 17,51 & 7,96 & 1,08 & 7,39 & 5 & 3,41 & $-7,48$ \\
\hline $08-10$ & 8 & 45,15 & 11,86 & 5,39 & 0,71 & 7,64 & 9 & 2,76 & $-8,82$ \\
\hline $13-15$ & 14 & 37,84 & 15,82 & 7,19 & 0,93 & 7,71 & 14 & 3,67 & $-6,34$ \\
\hline $17-19$ & 18 & 50,95 & 14,45 & 6.57 & 0,73 & 8,97 & 18 & 2,49 & $-5,5$ \\
\hline $21-23$ & 22 & 83,31 & 3,52 & 16 & 0,15 & 10,91 & 22 & 1,73 & $-4,3$ \\
\hline $28-30$ & 29 & 71 & 9,24 & 4,2 & 0,38 & 11,05 & 24 & 3,47 & $-6,09$ \\
\hline $36-38$ & 37 & 70,7 & 6,67 & 3,03 & 0,33 & 9,33 & 29 & 2,09 & $-3,32$ \\
\hline $41-43$ & 42 & 68,87 & 11,24 & 5,11 & 0,45 & 11,28 & 37 & 3,07 & $-6,61$ \\
\hline $46-48$ & 47 & 73 & 6,95 & 3,16 & 0,27 & 11,86 & 42 & 2,72 & $-7,87$ \\
\hline $51-53$ & 52 & 72,34 & 10,47 & 476 & 0,45 & 10,67 & 45 & 3.17 & $-11,1$ \\
\hline $56-58$ & 57 & 70,39 & 9,99 & 4,54 & 0,42 & 10,87 & 47 & 3,11 & $-10,79$ \\
\hline $59-61$ & 60 & 64,7 & 13,24 & 6,02 & 0,58 & 10,47 & 50 & 3,25 & $-11,35$ \\
\hline 61.63 & 62 & 87,62 & 3,83 & 1,74 & 0,18 & 985 & 52 & 2,95 & $-9,45$ \\
\hline $64-66$ & 65 & 81,65 & 6.03 & 2,74 & 0,28 & 9,84 & 57 & 3.57 & $-10,61$ \\
\hline $66-68$ & 67 & 61,03 & 14,41 & 6,55 & 0,63 & 10,44 & 60 & 2,54 & $-9,54$ \\
\hline $68-70$ & 69 & 71,45 & 8,25 & 3,75 & 0,38 & 9,87 & 62 & 3,34 & $-9,58$ \\
\hline $70-72$ & 71 & 78,58 & 6,03 & 2,74 & 0,28 & 98 & 65 & 3,04 & $-9,36$ \\
\hline $73-75$ & 74 & 75,1 & 7.59 & 3,45 & 0,36 & 9,58 & 67 & 3,07 & $-9,65$ \\
\hline $76-78$ & 77 & 66,18 & 12,5 & 5,68 & 0,64 & 8,92 & 69 & 2,84 & $-9,6$ \\
\hline $80-82$ & 81 & 41,02 & 23,67 & $10, \overline{6} \overline{6}$ & 1,27 & 8,46 & 71 & 3,25 & $-8,66$ \\
\hline $85-87$ & 86 & 75,67 & 7,37 & 3,35 & 0,37 & 9,04 & 74 & 3,02 & $-10,2$ \\
\hline $89-91$ & 80 & 76,7 & 5,39 & 2.45 & 0,25 & 9,68 & 77 & 2,64 & $-9,43$ \\
\hline $92-94$ & 93 & 64,95 & 12,32 & 5,6 & 0.48 & 11,75 & 81 & 2,27 & $-7,03$ \\
\hline $95-97$ & 96 & 66,04 & 10,47 & 4,76 & 0,43 & 11,11 & 86 & 1,78 & $-9,05$ \\
\hline $99-101$ & 100 & 50,17 & 20,2 & 9,18 & 0,82 & 11,19 & 90 & 3,17 & $-9,86$ \\
\hline $102-104$ & 101 & 71,95 & 7,04 & 3,2 & 0,27 & 11,86 & 93 & 1,55 & $-4,92$ \\
\hline $105-107$ & 106 & 61,49 & 13.99 & 6,36 & 0,51 & 12,47 & 96 & 2,48 & $-3,68$ \\
\hline $108-110$ & 109 & 52,55 & 8,73 & 3,97 & 0,32 & 12,34 & 100 & 1,04 & $-5,27$ \\
\hline $113-115$ & 114 & 29,15 & 18,74 & 8,52 & 0,67 & 12,65 & 103 & 1,08 & $-5,87$ \\
\hline \multirow{2}{*}{\multicolumn{7}{|c|}{$\begin{array}{l}\text { TAb. } 31 \text { - Porcentagem de } \mathrm{CaCO}_{3} \text { e Matéria Orgânica; Carbono Orgânico Total e Nitrogênio Total } \\
\text { expressas em ppm e relação } \mathrm{C} / \mathrm{N} \text {. Composição isotópica de oxigênio }\left(\delta^{18} \mathrm{O}\right) \text { e do Carbono }\left(\delta^{13} \mathrm{C}\right) \\
\text { em ppm, medida sobre o carbonato total para o testemunho LV } 89 / 19 .\end{array}$}} & 106 & 1,38 & $-6,32$ \\
\hline & & & & & & & 109 & $\frac{1,13}{114}$ & $\begin{array}{l}-8,62 \\
-02\end{array}$ \\
\hline
\end{tabular}




\section{$L V-4$}

\section{Fácies 1}

A fácies 1 é composta de sedimentos de granulação fina impregnados com matéria orgânica de coloração escura, possuindo espessura de $176 \mathrm{~cm}$ (Fig. 32). Apresenta tênue laminação plano horizontal, quase não perceptível em alguns níveis, sem evidência de bioturbação e com lentes arenosas acompanhadas de valvas inteiras e fragmentadas de lamelibrânquios. As conchas são comuns por toda a fácies 1, apresentando-se também de forma esparsa e concentrada nos intervalos $315-318 \mathrm{~cm}, 216-219 \mathrm{~cm}, 203-205 \mathrm{~cm}, 197-199 \mathrm{~cm}$ e 193 . $194 \mathrm{~cm}$.

A fácies 1 pode corresponder a fácies basal da laguna e a datação pelo ${ }^{14} \mathrm{C}$, de sua matéria orgânica no intervalo $317-322 \mathrm{~cm}$, forneceu uma idade de $6530 \pm 100$ A.P.

Essa fácies siliciclástica apresenta contato gradacional com a fácies 2 , a partir da qual a predominância passa a ser de precipitação de carbonatos a $148 \mathrm{~cm}$.

\section{Fácies 2}

Apresenta ao início de sua deposição, a $148 \mathrm{~cm}$, precipitação carbonática acompanhada de pequenos nódulos carbonáticos e laminações plano-horizontais regulares de lama orgânica intercalada com níveis carbonáticos mais claros, seguidos por níveis mais espessos onde aparecem nódulos endurecidos, caracterizando um contato basal gradacional. A análise de lâmina delgada do intervalo $122-126 \mathrm{~cm}$ (C) ilustra ocorrência de laminações interrompidas, descontínuas, com intercalaçöes algálicas e lamitos (calcimudstone) com alguns intraclastos, sendo rara a ocorrência de fósseis de ostracodes. Nesta associação carbonática e nodular, não é verificada macroscopicamente a ocorrência de fósseis, estando separada por paleossolo, encontrado a cerca de $114 \mathrm{~cm}$, de sua porção superior semelhante. Este paleossolo constitui um marcador faciológico, a partir do qual a associação apresenta recorrência cíclica de lama carbonática com espessas camadas de nódulos e laminações regulares até sua porção superior, apresentando alguns raros níveis de conchas. Esta fácies, de cor mais variada que a primeira, apresenta tonalidades entre o cinza escuro (maior enriquecimento de matéria orgânica) e o ocre (carbonatos).

O paleossolo presente nessa fácies sugere ter sido compactado, uma vez que se encontra deformado pelo peso dos sedimentos superpostos, possuindo 1 a $4 \mathrm{~cm}$ de espessura. Pode ser composto por uma unidade concrecional pedogenética (calcrete) rica em carbonato, indicando que neste momento houve pouca ou nenhuma deposição, onde o lençol freático estava mais baixo e a planície costeira em emersão, correspondendo portanto a um marcador de ambiente 
deposicional supralitorâneo. A análise de lâmina delgada do intervalo $110-115 \mathrm{~cm}$ (D) apresenta textura deposicional tipo lamito com textura olho-de-pássaro (birds eye) sem ocorrência fossilífera. Os nódulos podem estar associados a radículas carbonatadas e fragmentos de plantas (Collinson, 1986).

As outras lâminas delgadas elaboradas apresentaram as seguintes características:

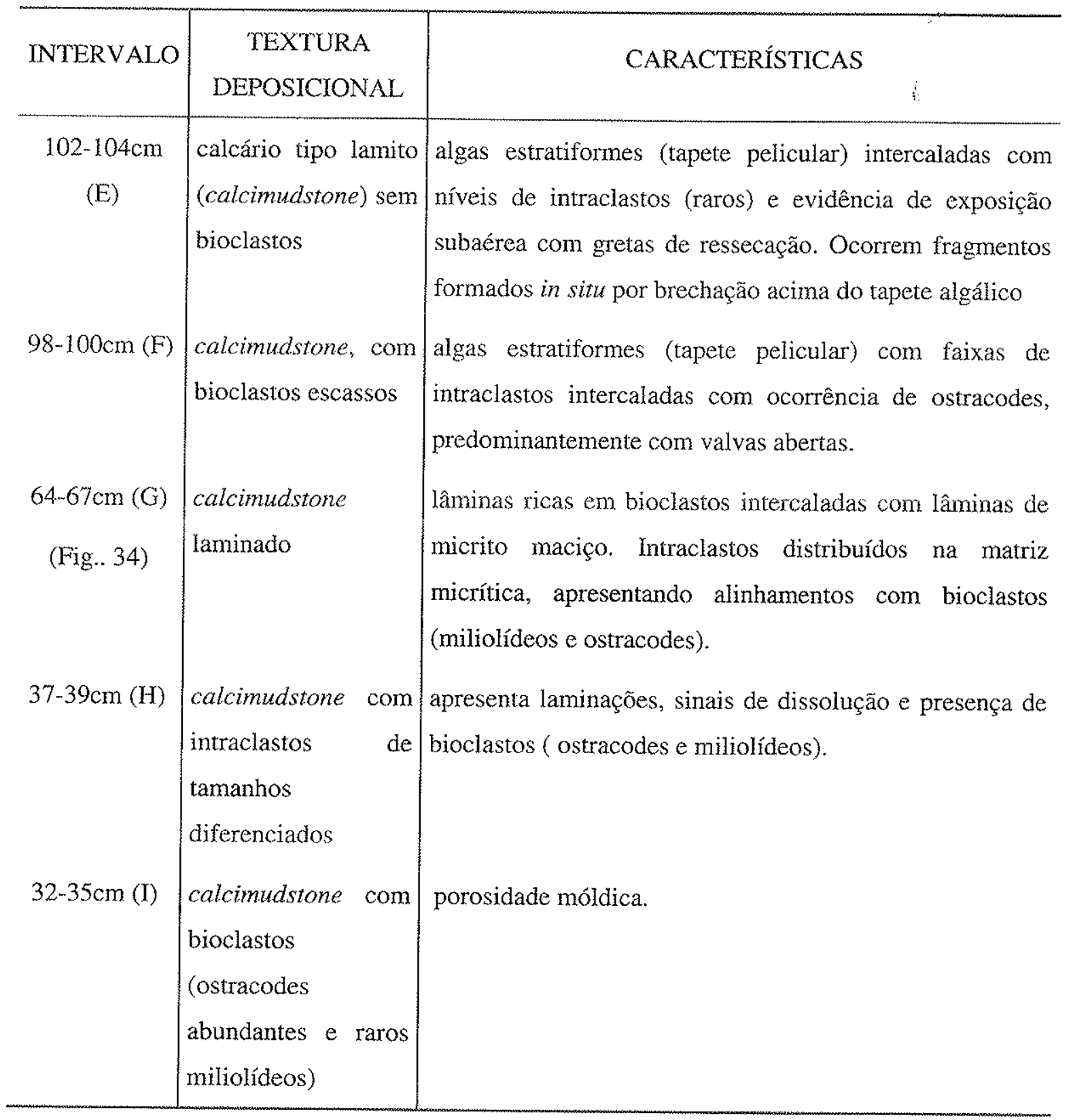

\section{Resultados geoquímicos e isotópicos em LVA}

A curva dos valores isotópicos de $\delta^{18} \mathrm{O}$ neste testemunho (Fig. 32B) registra aumento progressivo com registro máximo a $1 \mathrm{~m}$ de profundidade, associada a ocorrência da sucessão nodular e de paleossolo. Os valores mais negativos da razão $\delta^{13} \mathrm{C}$ na fácies 2 são acompanhados da ocorrência de tapete algálico, exatamente como no testemunho LV89/19. 
A ocorrência da fácies 2 é marcada pela rápida subida dos valores de $\mathrm{CaCO}_{3}$ a $148 \mathrm{~cm}$ (Fig. 32A) acompanhada de uma tendência de decréscimo dos valores de N, COT, e M.O em direção ao topo da associação.

\section{LBE 89/2}

\section{Fácies 1}

Esta fácies é composta por areia de cor marrom escura impregnada com ácidos húmico e/ou fúlvico, apresentando discordância erosiva com a fácies superposta localiząa a $340 \mathrm{~cm}$ (Fig. 33). É observada estrutura sedimentar maciça, sem fósseis, sugerindo a ausência de transporte por tração durante a deposição, de forma muito rápida a partir de suspensão ou de dispersões sedimentares concentradas, ou mesmo recristalização diagenética. Esta fácies corresponde a Formação Cananéia.

\section{Fácies 2}

Corresponde a fácies arenosa de cor cinza que ocorre a partir da discordância erosiva da base a $340 \mathrm{~cm}$, onde são observadas conchas inteiras e fragmentadas de bivalves, seguidas por areia marrom finamente laminada sobreposta por camada com intensa biouturbação e deposição conchífera. Notar a presença de transição marcante na base entre esta e um lamito orgânico marrom (Fácies 3) a $315 \mathrm{~cm}$. Esta fácies arenosa possui $24 \mathrm{~cm}$ de espessura nesta parte e recorrência ao longo da fácies 3 nos intervalos 309, 299-302, 294, 289, 286, 248, 234 e $225 \mathrm{~cm}$. Esta fácies é marcada por discordância erosiva na base e no topo e presença de fósseis.

\section{Fácies 3}

Corresponde a fácies de lama orgânica com contato concordante na base e erosivo com a fácies 4. Apresenta $84 \mathrm{~cm}$ de espessura nesta primeira ocorrência, com estratificação lenticular acompanhada de conchas dispersamente distribuídas na vasa orgânica e recorrências de níveis de areia cinza correspondentes à fácies 2 . A $248 \mathrm{~cm}$ aparecem estruturas de sobrecarga em uma das intercalações da areia cinza da fácies 2 , sobrejacente ao lamito orgânico, chegando a destacar pseudonódulos arenosos que ficam isolados dentro da lama.

A segunda recorrência da lifácies 3 , se dá a partir de $203 \mathrm{~cm}$ do contato concordante na base com a fácies 4 até $167 \mathrm{~cm}$ no topo, com o surgimento dos primeiros nódulos carbonáticos. Este segundo ciclo apresenta $36 \mathrm{~cm}$ de espessura e estratificação lenticular associada a fragmentos de conchas, com maior intensidade de recorrência de lentes arenosas (da fácies 2?) comparativamente ao primeiro ciclo, até o final. 
Fig. 32 - Fotomontagem da associação de litofácies paleolagunar do testemunho LV 4, mostrando estruturas sedimentares, descrições litofaciológicas, datações e identificação das lâminas delgadas $(\mathrm{C}, \ldots \mathrm{I})$. As lâminas delgadas $\mathrm{E}$ e $\mathrm{G}$ estão ilustradas e a escala equivale a $750 \mu \mathrm{m}$ e o aumento é de $2,5 \mathrm{x}$, nicóis cruzados. A descrição está detalhada no texto. 


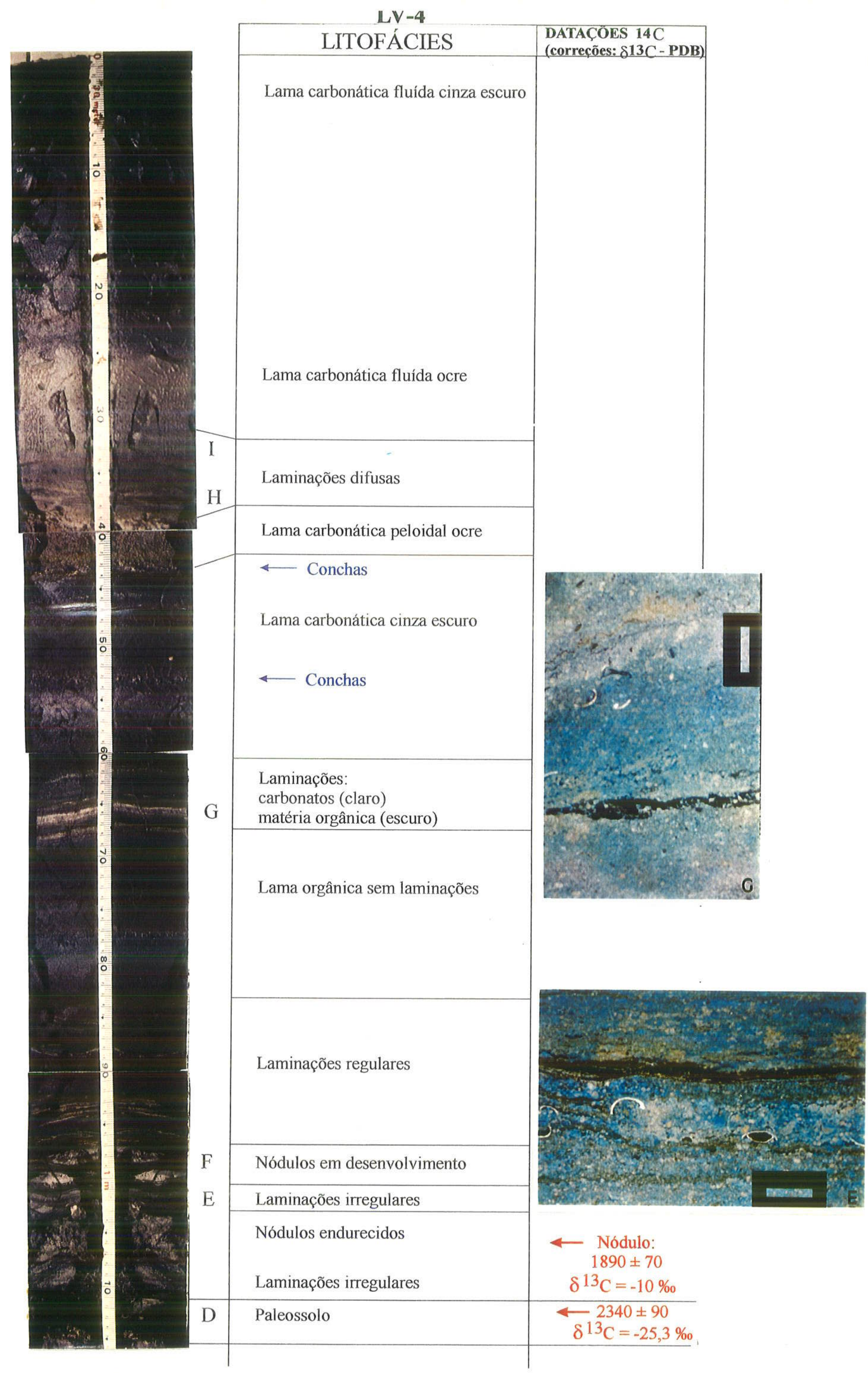




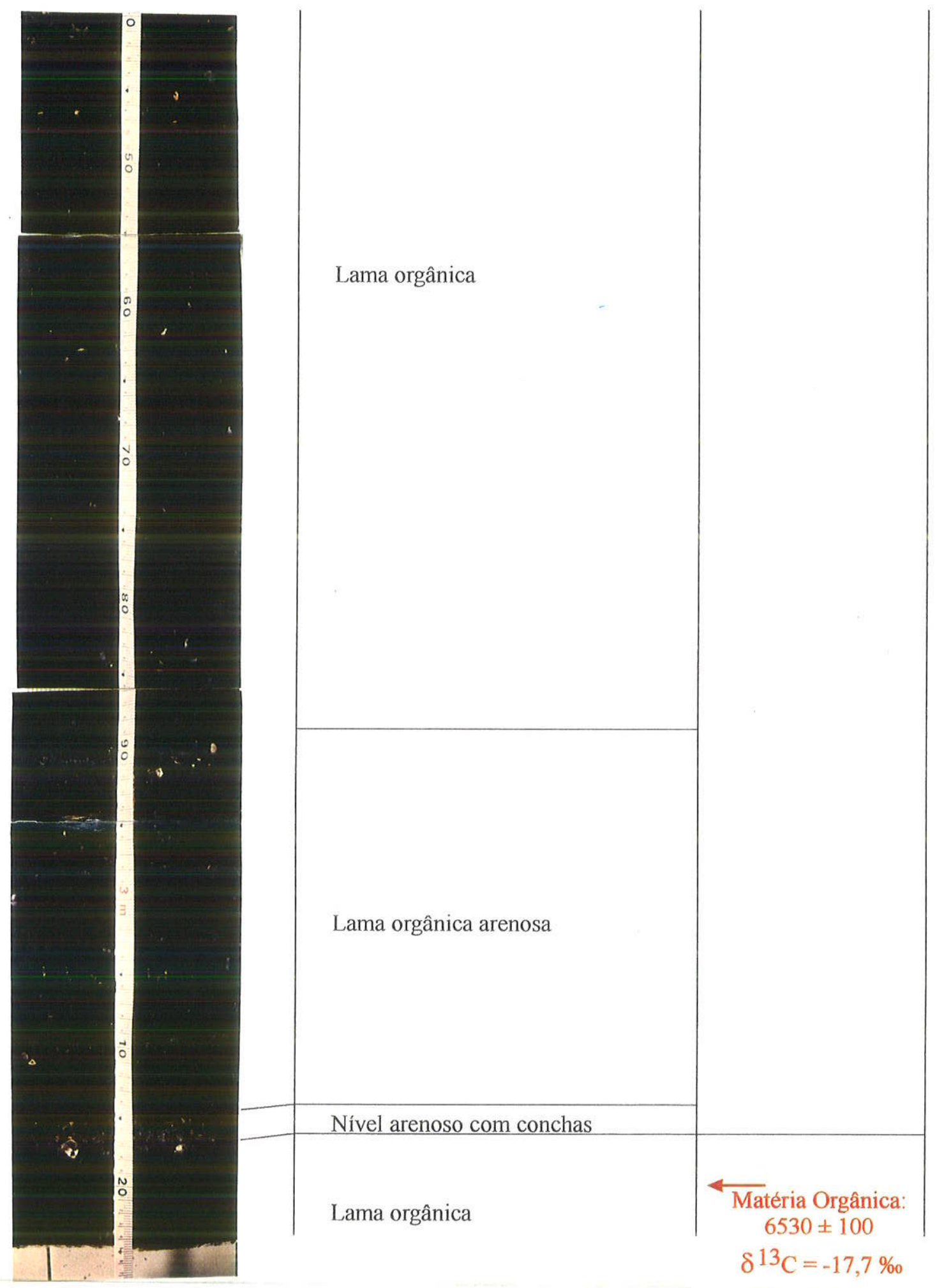



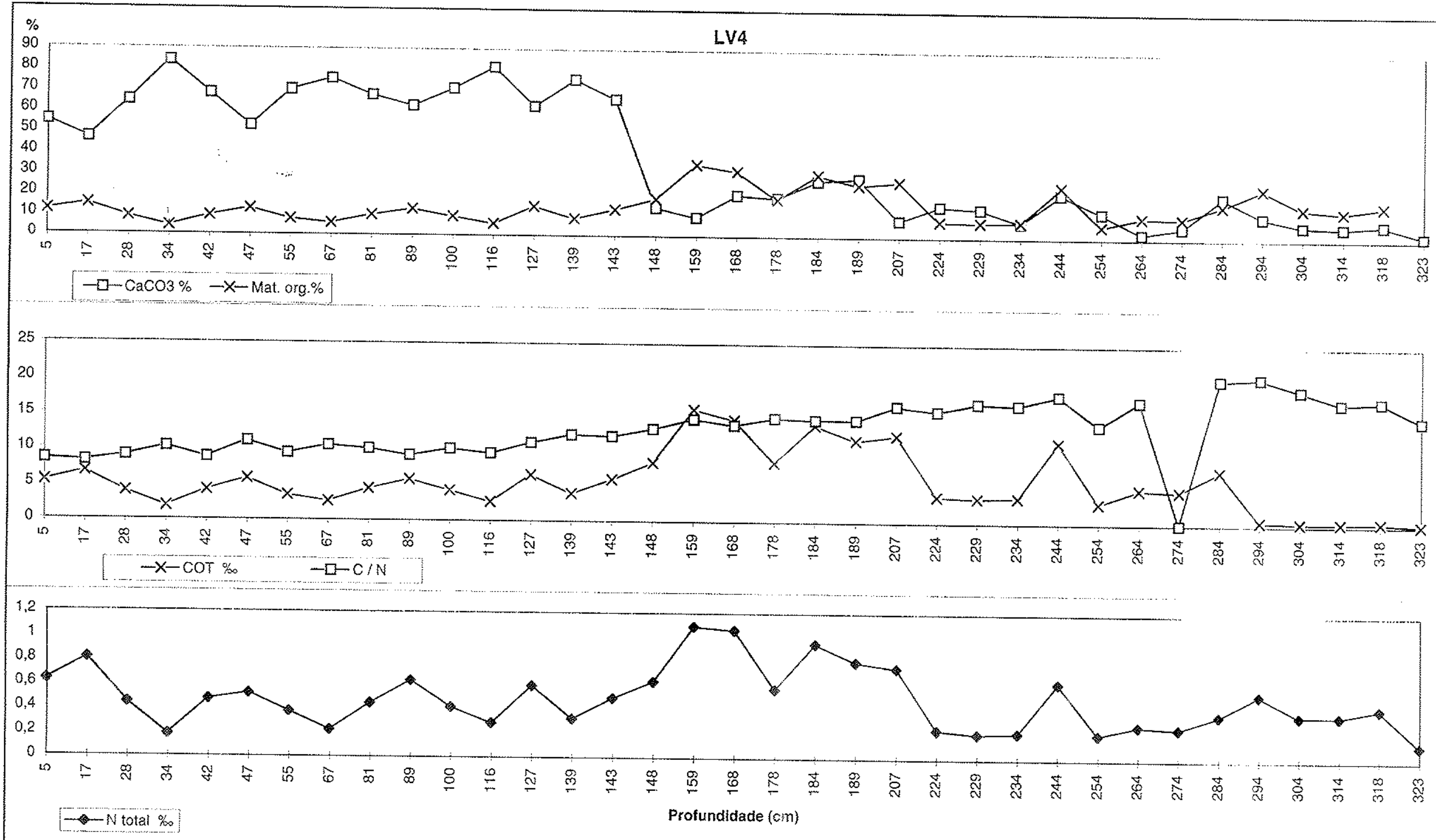

Fig. $32 \mathrm{~A}$ - Porcentagem de $\mathrm{CaCO}_{3}$, matéria orgânica, e teores de carbono orgânico total e nitrogênio total em ppm, com relação carbono/nitrogênio para o tetemunho LV4 


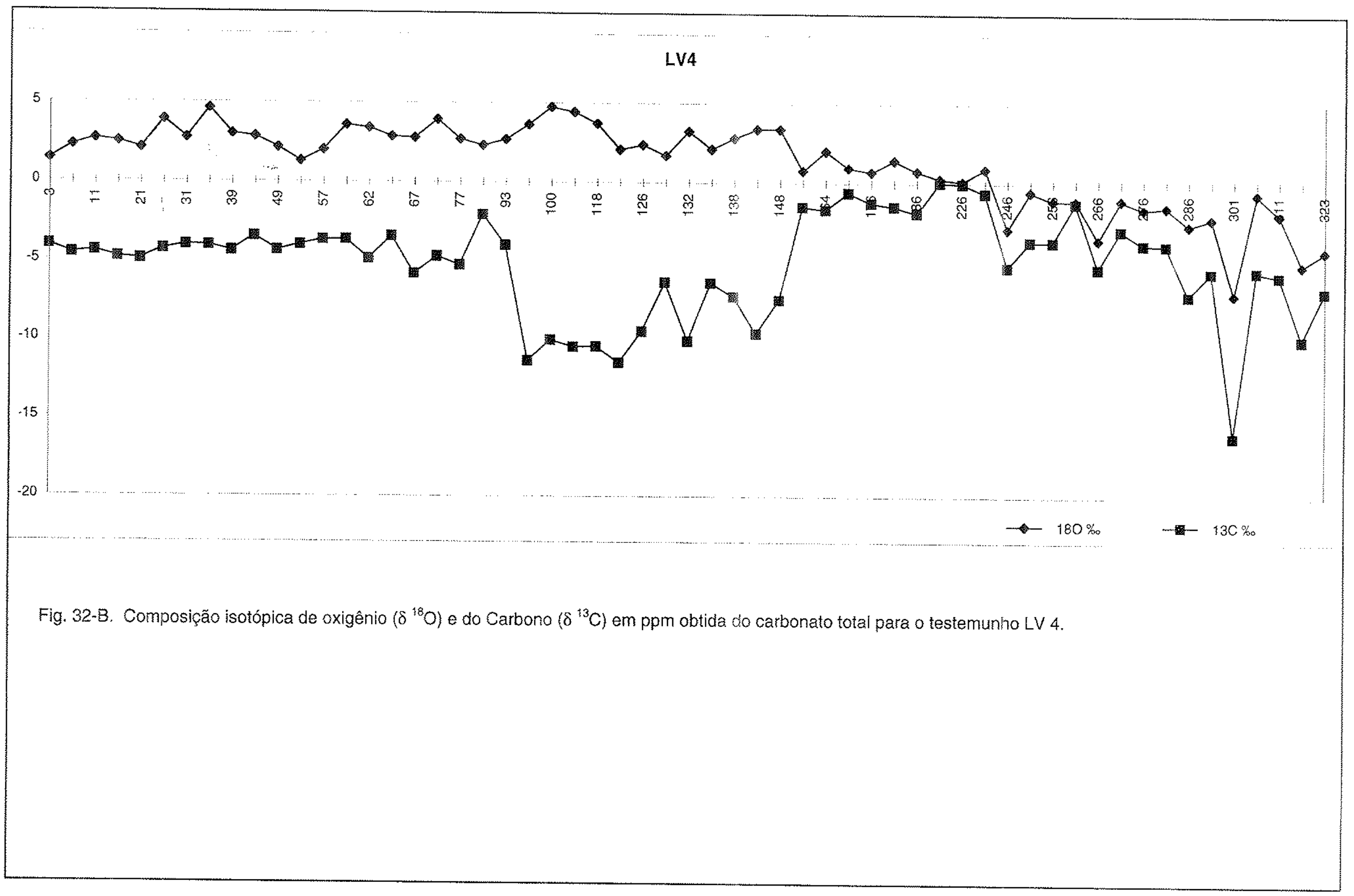




\begin{tabular}{|c|c|c|c|c|c|c|c|c|c|}
\hline \multicolumn{7}{|c|}{ L.V 4} & \multicolumn{3}{|c|}{ Carbonato Total } \\
\hline Prof. cm & Prof. $\bar{x}$ & $\mathrm{CaCO}_{3} \%$ & Mat. org. \% & COT \% & $\mathrm{N}$ total $\%$ & $\mathrm{C} / \mathrm{N}$ & Prof. $\vec{x}$ & $\delta{ }^{18} 0 \%$ & $\delta{ }^{13} \mathrm{C} \%$ \\
\hline $16-18$ & 17 & 46,5 & 14,6 & 6,64 & 0,81 & 8,17 & 6 & 2,28 & $-4,58$ \\
\hline $27-29$ & 28 & 64,5 & 8,6 & 3,91 & 0,44 & 8,95 & 11 & 2,68 & $-4,43$ \\
\hline $33-35$ & 34 & 83,75 & 3,94 & 1,79 & 0,18 & 10,23 & 15 & 2,52 & $-4,81$ \\
\hline $41-43$ & 42 & 68,13 & 9,02 & 4,1 & 0,47 & 8,73 & 21 & 2.1 & $-4,93$ \\
\hline 4648 & 47 & 52,5 & 12,67 & 5,76 & 0,52 & 11,07 & 26 & 3,89 & $-4,31$ \\
\hline $54-56$ & 55 & 70 & 7,58 & 3,45 & 0,37 & 9,37 & 31 & 2,75 & $-4,04$ \\
\hline $66-68$ & 67 & 75,32 & 5,72 & 2,6 & 0,22 & 10,48 & 36 & 4,6 & $-4,07$ \\
\hline $80-82$ & 81 & 67,53 & 9,69 & 4,4 & 0,44 & 10,03 & 39 & 3,02 & $-4,41$ \\
\hline $88-90$ & 89 & 62,34 & 12,61 & 5,73 & 0,63 & 9,1 & 45 & 2,85 & $-3,48$ \\
\hline $99-101$ & 100 & 70,78 & 9,17 & 4,17 & 0,41 & 10,06 & 49 & 2,16 & $-4,36$ \\
\hline $115-117$ & 116 & 81,17 & 5,77 & 2,62 & 0,28 & 9,47 & 52 & 1,31 & $-4,01$ \\
\hline $126-128$ & 127 & 62,34 & 14,15 & 6,43 & 0,59 & 10,99 & 57 & 2,02 & $-3,68$ \\
\hline $138-140$ & 139 & 75,32 & 8,44 & 3,84 & 0,32 & 12,14 & 59 & 3,59 & $-3,67$ \\
\hline $142-144$ & 143 & 66,01 & 12,89 & 5,86 & 0,49 & 11,95 & 62 & 3,4 & $-4,89$ \\
\hline $147-149$ & 148 & 14 & 18,14 & 8,24 & 0,63 & 13,02 & 65 & 2,87 & $-3,46$ \\
\hline $158-160$ & 159 & 9,43 & 34,76 & 15,8 & 1,09 & 14,44 & 67 & 2,79 & $-5,83$ \\
\hline $167-169$ & 168 & 20,19 & 31,68 & 14,4 & 1,06 & 13,64 & 72 & 3,94 & $-4,73$ \\
\hline $177+179$ & 178 & 19,03 & 18,28 & 8,31 & 0,57 & $\{4,63$ & 77 & 2,71 & $-5,27$ \\
\hline $183-185$ & 184 & 27,18 & 30,09 & 13,68 & 0,95 & 14,41 & 85 & 2,32 & $-2,08$ \\
\hline $188-190$ & 189 & 28,48 & 25,36 & 11,53 & 0,8 & 14,41 & 93 & 2,7 & $-4,02$ \\
\hline $206-208$ & 207 & 8,46 & 26,94 & 12,25 & 0,75 & 16,42 & 98 & 3,65 & $-11,39$ \\
\hline $223-225$ & 224 & 15,38 & 8,14 & 3,7 & 0,24 & 15,75 & 100 & 4,73 & $-10,05$ \\
\hline $228-230$ & 229 & 14,23 & 7,72 & 3,51 & 0,21 & 16,87 & 108 & 4,43 & $-10,5$ \\
\hline $233-235$ & 234 & 7,69 & 7,92 & 3,6 & 0,22 & 16,66 & 118 & 3,72 & $-10,47$ \\
\hline $243-245$ & 244 & 21,54 & 25,1 & 11,41 & 0,63 & 18,03 & 122 & 2,09 & $-11,5$ \\
\hline $253-255$ & 254 & 12,69 & 6,35 & 2,89 & 0,21 & 13,81 & 126 & 2,38 & $-9,5$ \\
\hline $263-265$ & 264 & 2,69 & 10,7 & 4,86 & 0,28 & 17,31 & 130 & 1,73 & $-6,35$ \\
\hline $273-275$ & 274 & 5,77 & 10,18 & 4,63 & 0,26 & 17,66 & 132 & 3,25 & $-10,12$ \\
\hline $283-285$ & 284 & 20,58 & 16,48 & 7,49 & 0,37 & 20,41 & 136 & 2,13 & $-6,38$ \\
\hline $293-295$ & 294 & 11,19 & 24,62 & 0,54 & 0,54 & 20,73 & 138 & 2,83 & $-7,28$ \\
\hline $303-305$ & 304 & 6,96 & 15,31 & 0,37 & 0,37 & 19,02 & 146 & 3,4 & $-9,63$ \\
\hline $313-315$ & 314 & 6,29 & 13,84 & 0,37 & 0,37 & 17,18 & $\{48$ & 3,4 & $-7,47$ \\
\hline 318 & 318 & 7,56 & $\{6,63$ & 0,43 & 0,43 & 17,46 & 155 & 0,77 & $-1,51$ \\
\hline 323 & 323 & 1,99 & & 0,13 & 0,13 & 14,74 & 164 & 2,03 & $-1,68$ \\
\hline \multirow{22}{*}{\multicolumn{7}{|c|}{$\begin{array}{l}\text { Tab. 32- Porcentagem de } \mathrm{CaCO}_{3} \text { e Matéria Orgânica, Carbono } \\
\text { Orgânico Total, Nitrogênio Total e relação C/N expressas em ppm. } \\
\text { Composição isotópica de oxigênio }\left(\delta^{18} \mathrm{O}\right) \text { e do Carbono }\left(\delta^{13} \mathrm{C}\right) \text { em } \\
\text { ppm, medida sobre o carbonato total para o testemunho LV } 4 \text {. }\end{array}$}} & 171 & 0,97 & $-0,6$ \\
\hline & & & & & & & 176 & $0,7 i$ & $-1,24$ \\
\hline & & & & & & & 181 & $\{, 46$ & $-1,47$ \\
\hline & & & & & & & 186 & 0,76 & $-1,91$ \\
\hline & & & & & & & 202 & 0,3 & 0,06 \\
\hline & & & & & & & 226 & 0,13 & $-0,01$ \\
\hline & & & & & & & 231 & 0,92 & $-0,62$ \\
\hline & & & & & & & 246 & $-2,93$ & $-5,34$ \\
\hline & & & & & & & 251 & $-0,54$ & $-3,71$ \\
\hline & & & & & & & 256 & $-1,08$ & $-3,74$ \\
\hline & & & & & & & 261 & $-1,1$ & $-1,25$ \\
\hline & & & & & & & 266 & $-3,59$ & $-5,41$ \\
\hline & & & & & & & 271 & $-1,05$ & -3 \\
\hline & & & & & & & 276 & $-\{, 61$ & $-3,89$ \\
\hline & & & & & & & 281 & $-1,48$ & $-3,94$ \\
\hline & & & & & & & 286 & $-2,67$ & $-7,14$ \\
\hline & & & & & & & 296 & $-2,23$ & $-5,64$ \\
\hline & & & & & & & 301 & $.7,08$ & $-16,16$ \\
\hline & & & & & & & 306 & $-0,65$ & $-5,56$ \\
\hline & & & & & & & 311 & $-1,98$ & $-5,86$ \\
\hline & & & & & & & 320 & $-5,19$ & $-9,96$ \\
\hline & & & & & & & 323 & $-4,29$ & $-6,88$ \\
\hline
\end{tabular}




\section{Fácies 4}

Corresponde a expressiva camada arenosa com conchas abundantes possuindo $19 \mathrm{~cm}$ de espessura entre $203 \mathrm{~cm}$ e $222 \mathrm{~cm}$ aproximadamente. O contato é erosivo na base com presença de pseudonódulos arenosos dentro da lama orgânica da fácies 3 e concordante no topo, com mudança textural para lama orgânica. A lâmina delgada do intervalo $207-210 \mathrm{~cm}(\mathrm{~J})$ mostrou unicamente quartzo e fósseis de bivalves.

\section{Fácies 5}

Apresenta predominantemente nódulos carbonáticos de cor marrom variegada intercalados na lama orgânica marrom, por toda extensão da fácies que possui $90 \mathrm{~cm}$ espessura. Seu contato basal é descontínuo marcado por nódulo carbonático precipitado a $167 \mathrm{~cm}$. No topo, esta fácies apresenta contato gradacional inclinado com lama bege clara concrecional a $7 \% \mathrm{~cm}$.

As laminações da lama orgânica apresentam algumas interrupções marcantes na litoestratigrafia. Por volta de $102 \mathrm{~cm}$, a precipitação carbonática entre camadas de lamito produz estrutura semelhante a laminação convoluta e, entre $85-95 \mathrm{~cm}$ conchas de bivalves interceptam o acamamento.

\section{Fácies 6}

Corresponde a fácies de lamito carbonático de cor marrom clara variegada com laminação plano paralela e espessura de $77 \mathrm{~cm}$. O contato basal é gradacional e inclinado pela ocorrência de laminação convoluta entre $70-77 \mathrm{~cm}$. Entre $66-70 \mathrm{~cm}$ há recorrência da fácies 5 interdigitada com $4 \mathrm{~cm}$ de espessura. A lâmina delgada do intervalo $65-67 \mathrm{~cm}$ (L) mostrou a ocorrência de calcário tipo lamito (calcimudstone) com bioclastos de poucos ostracodes e raros representantes da subordem Miliolina.

A lâmina delgada do intervalo $62-65 \mathrm{~cm}$ apresenta calcário tipo lamito (calcimudstone) com textura olhos-de-pássaro (birds eye) e alguns poros alongados (porosidade fenestrada) por dissolução, com rara ocorrência de ostracodes.

A estratificação entre $53-56 \mathrm{~cm}$ apresenta contato lateral, sugerindo corresponder a tubos (pipes) de dissolução em pequena escala. A lâmina delgada nesse intervalo (M) (Fig. 34), mostrou ocorrência de calcário tipo lamito (calcimudstone) com bioclastos (ostracodes e miliolídeos raros) e escassos cristais de anidrita. No intervalo de $51-53 \mathrm{~cm}$ (N) (Fig. 34), a lâmina delgada mostrou calcário tipo lamito (calcimudstone) com estruturas maciças e laminadas intercaladas, passando no intervalo $49-51 \mathrm{~cm}(\mathrm{O})$ para calcimudstone, aparentemente maciço. 
No intervalo $47-49 \mathrm{~cm}$ (P) (Fig. 34) a lâmina delgada mostrou calcimudstone com intercalações maciças interrompidas lateralmente por gretas de ressecação com ocorrência vertical alternada entre faixas mais laminadas e rara ocorrência de bioclastos, representados unicamente por ostracodes.

O intervalo 41-43cm (Q) (Fig. 34), apresenta calcimudstone maciço sem fósseis intercalado verticalmente entre porções mais laminadas, estreitas, com gretas de ressecação. No intervalo $35-37 \mathrm{~cm}(\mathrm{R})$ o calcimudstone mostra bioturbação e no intervalo $32-35 \mathrm{~cm}(\mathrm{~S})$ (Fig. 34), porções mais oxidadas do que outras (sem fósseis). Apresenta pouca variação à $28-30 \mathrm{~cm}(\mathrm{~T})$ (Fig. 34), com calcimudstone maciço composto por uma micrita grumosa com fósseis raros.

\section{Resultados geoquímicos e isotópicos em LBE-89/2}

Os valores mais negativos da razão $\delta^{13} \mathrm{C}$ (Fig. 33B), estão associados a ocorrência dos nódulos carbonáticos, os quais marcam o final da segunda recorrência da fácies 3 a $167 \mathrm{~cm}$, $148 \mathrm{~cm}$ e $70 \mathrm{~cm}$. A anidrita observada em lâmina a aproximadamente $57 \mathrm{~cm}$, está associada a ocorrência dos valores mais positivos do $\delta^{18} \mathrm{O}$. De fato, a nucleação deste mineral requer temperaturas sazonais acima de $35^{\circ} \mathrm{C}$, e só é preservado onde a temperatura média excede $20^{\circ} \mathrm{C}$ (Kinsman 1976).

Existe uma redução progressiva nas razões do $\delta^{18} \mathrm{O}$ e do $\delta^{13} \mathrm{C}$ de $57 \mathrm{~cm}$ em direção ao topo acompanhada pela concentração na curva de $\mathrm{CaCO}_{3}$.

Os valores de COT, M.O e $\mathrm{N}$ diminuem acentuadamente em direção ao topo da associação mostrando a passagem de condições redutoras, na base, para oxidantes, impostas ao ambiente lagunar com o início da ocorrência da fácies 6.

\subsection{2 - Assembléias Microfaunísticas nos Testemunhos}

As porcentagens de frequiência de foraminiferos referentes aos testemunhos LV89/19, LV4 e LBE 89-2 podem ser vistas nas tabelas 28, 29 e 30 respectivamente. A composição microfaunística de cada amostra do testemunho foi comparada às biofácies definidas pela análise de agrupamento (Fig. 28A e B e Fig. 29), de modo a que as biofácies pudessem ser reconhecidas nos testemunhos. A análise de agrupamento efetuada para as Lagoas de Saquarema e Jacarepiá não foi utilizada por năo haver ocorrência nos testemunhos de foraminíferos aglutinantes preservados, o que limitou o uso dessas biofácies.

Uma biofácies somente foi atribuída a uma amostra do testemunho quando a composição das espécies dominantes e a frequência de ocorrência destas, correspondesse ao encontrado na 
Fig. 33 - Fotomontagem da associação de litofácies paleolagunar do testemunho LBE 89-2, mostrando estruturas sedimentares, descrições litofaciológicas, datações e identificação das lâminas delgadas $(\mathrm{J}, \ldots \mathrm{T})$. A lâmina delgada $\mathrm{J}$ está ilustrada e a escala equivale a $750 \mu \mathrm{m}$ e o aumento é de 2,5x, nicóis cruzados. A descrição está detalhada no texto. 


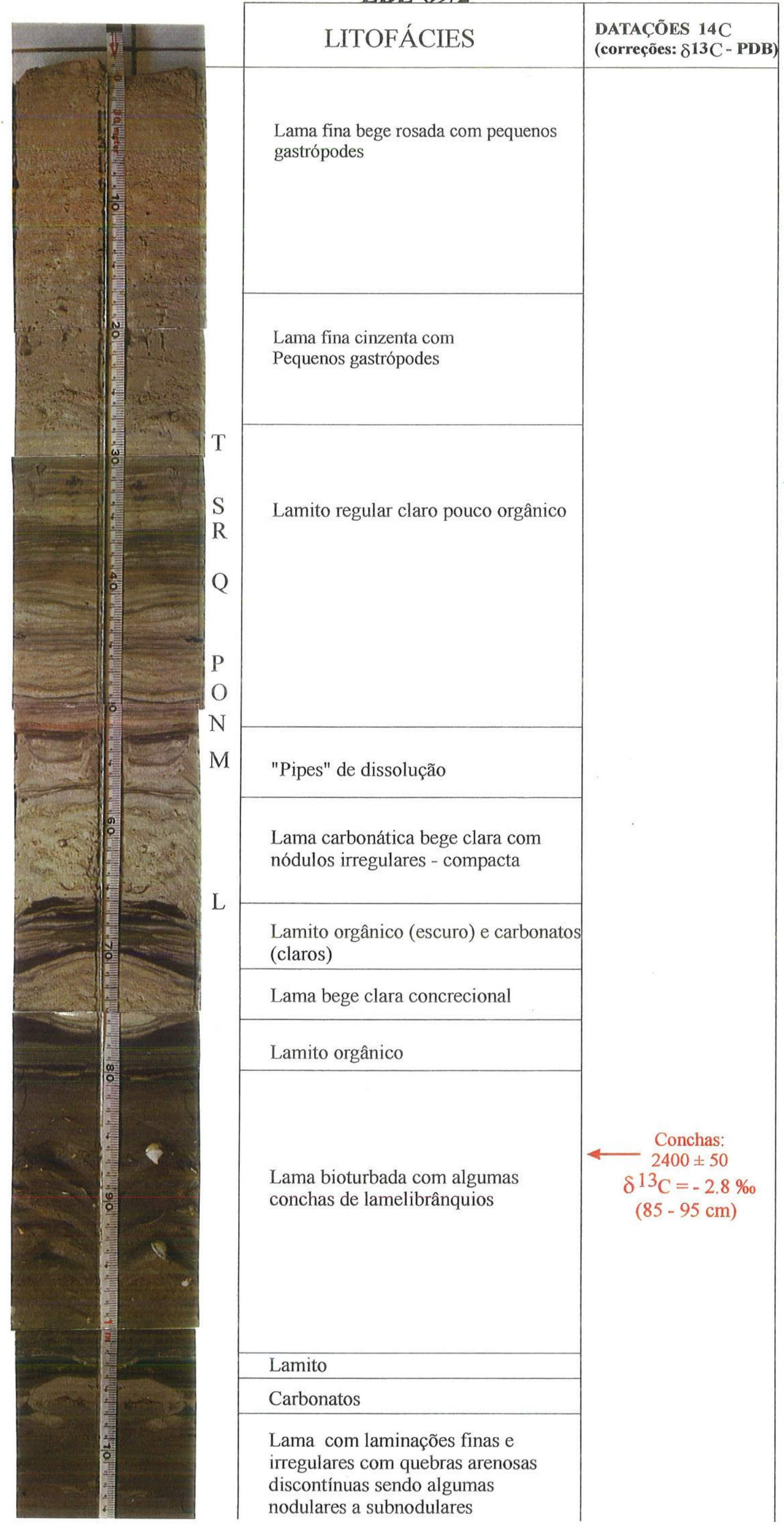




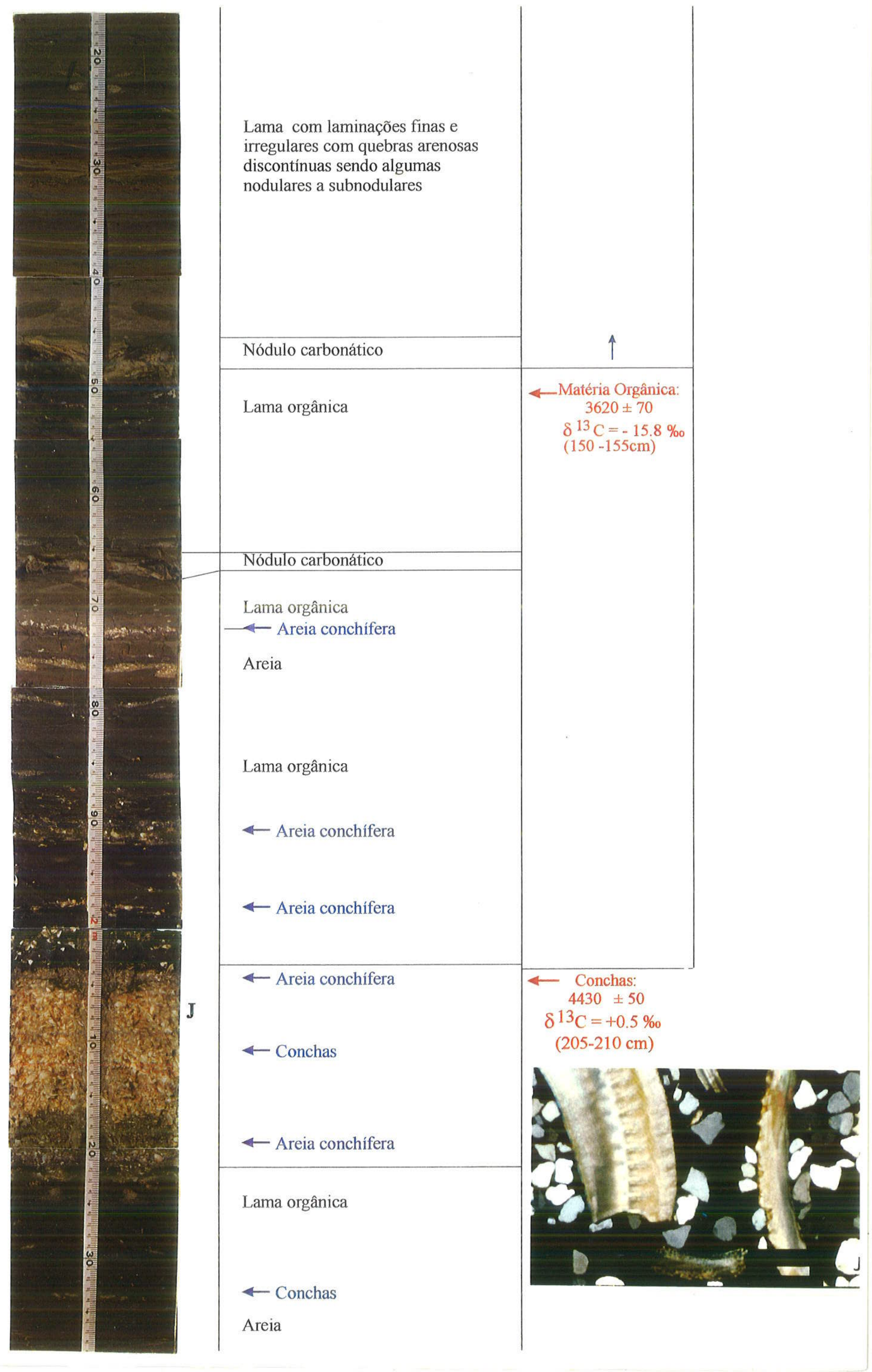




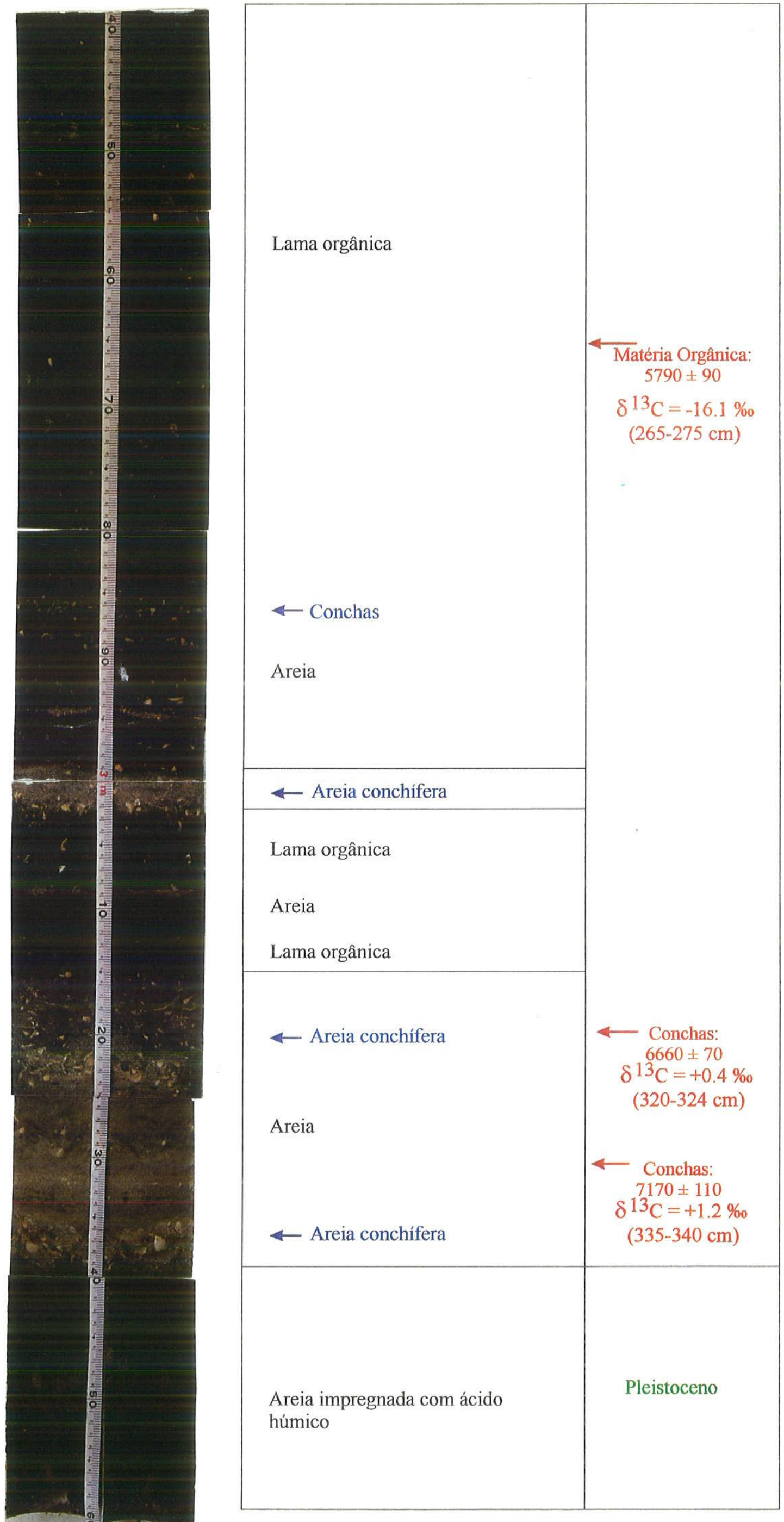




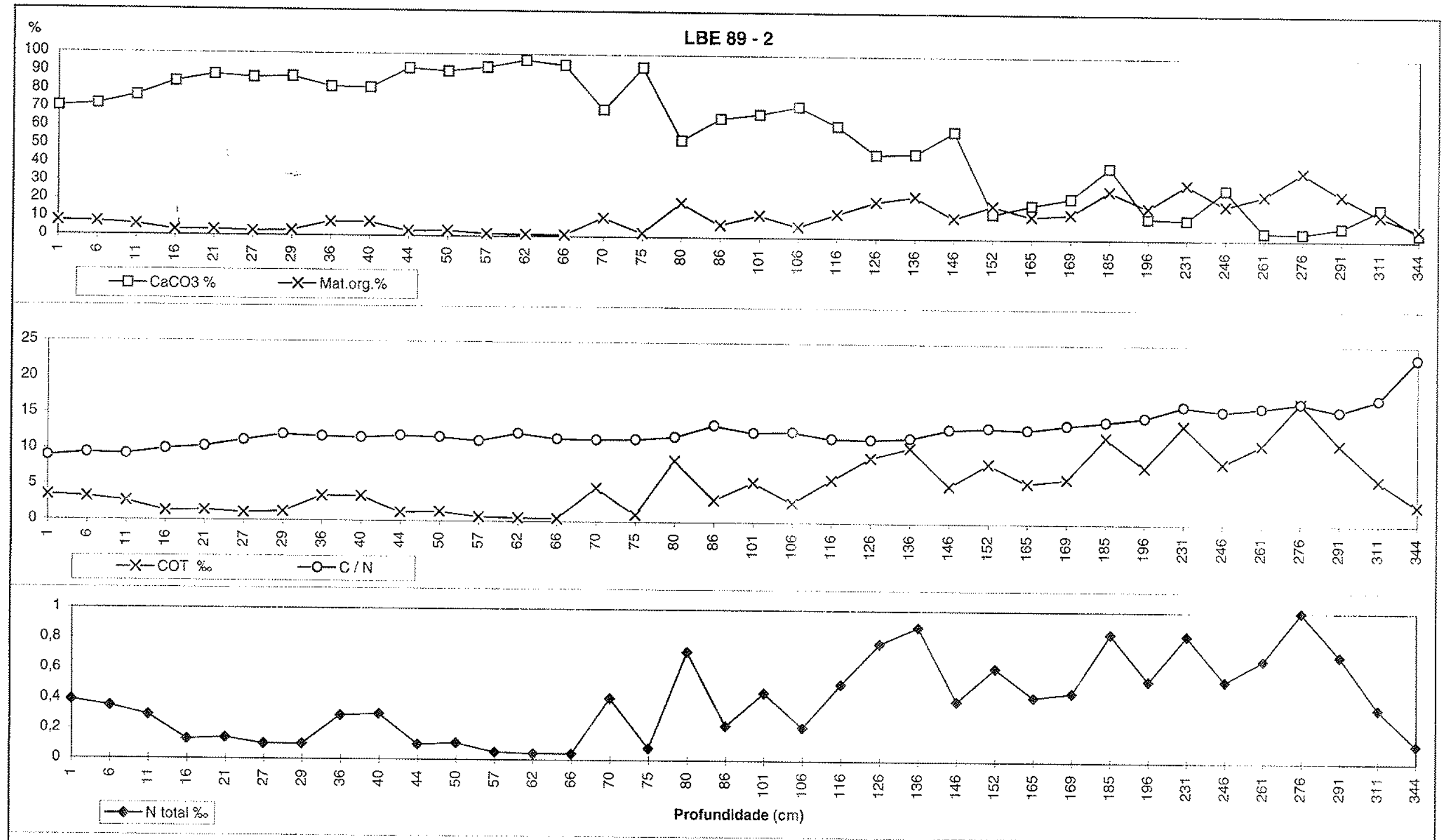
Fig. $33 \mathrm{~A}$ - Porcentagem de $\mathrm{CaCO}_{3}$, matéria orgânica, e teores de carbono orgânico total e nitrogênio total em ppm, com relação carbono/nitrogênio para o
tetemunho LBE 89 -2. 


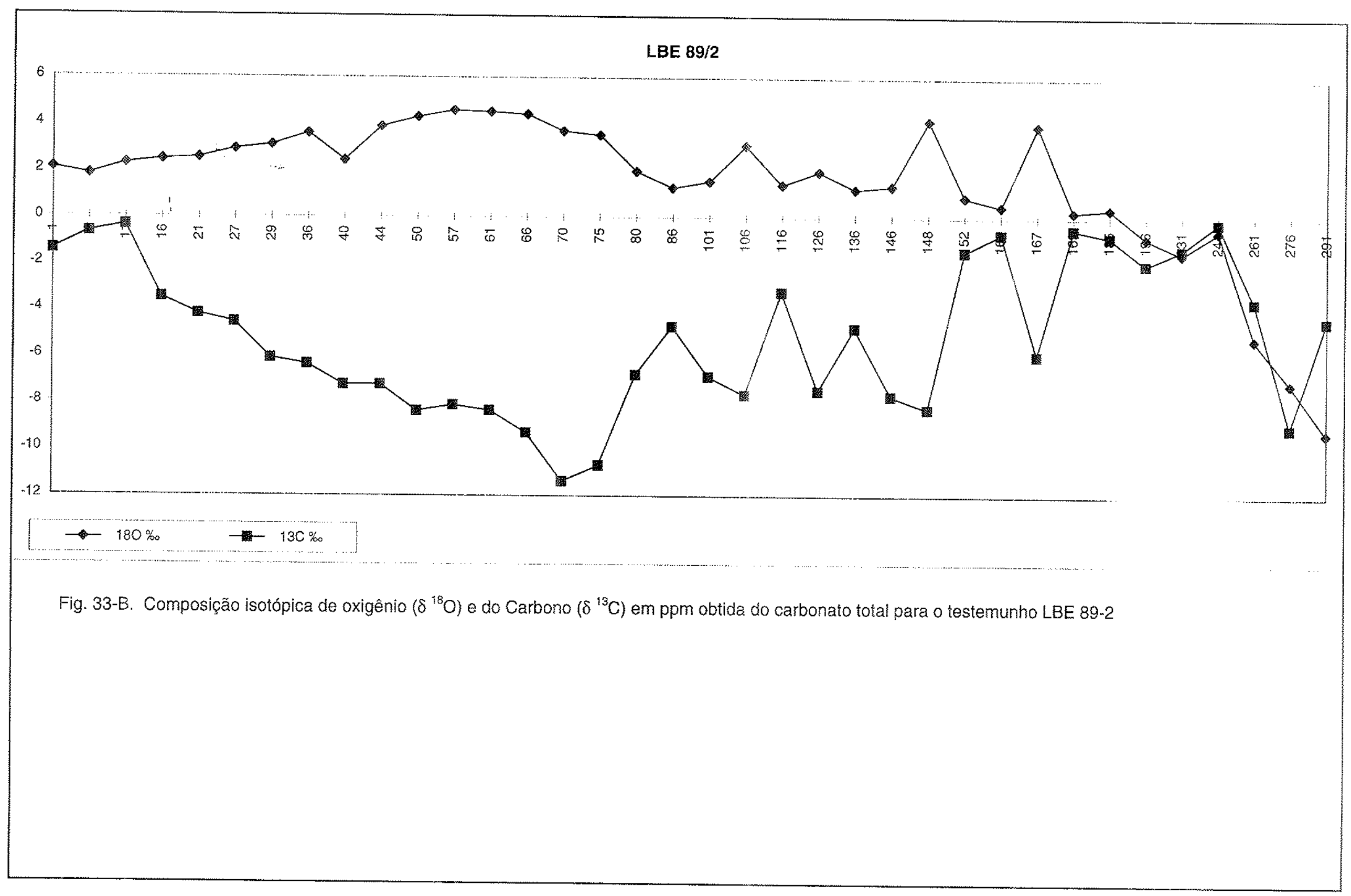



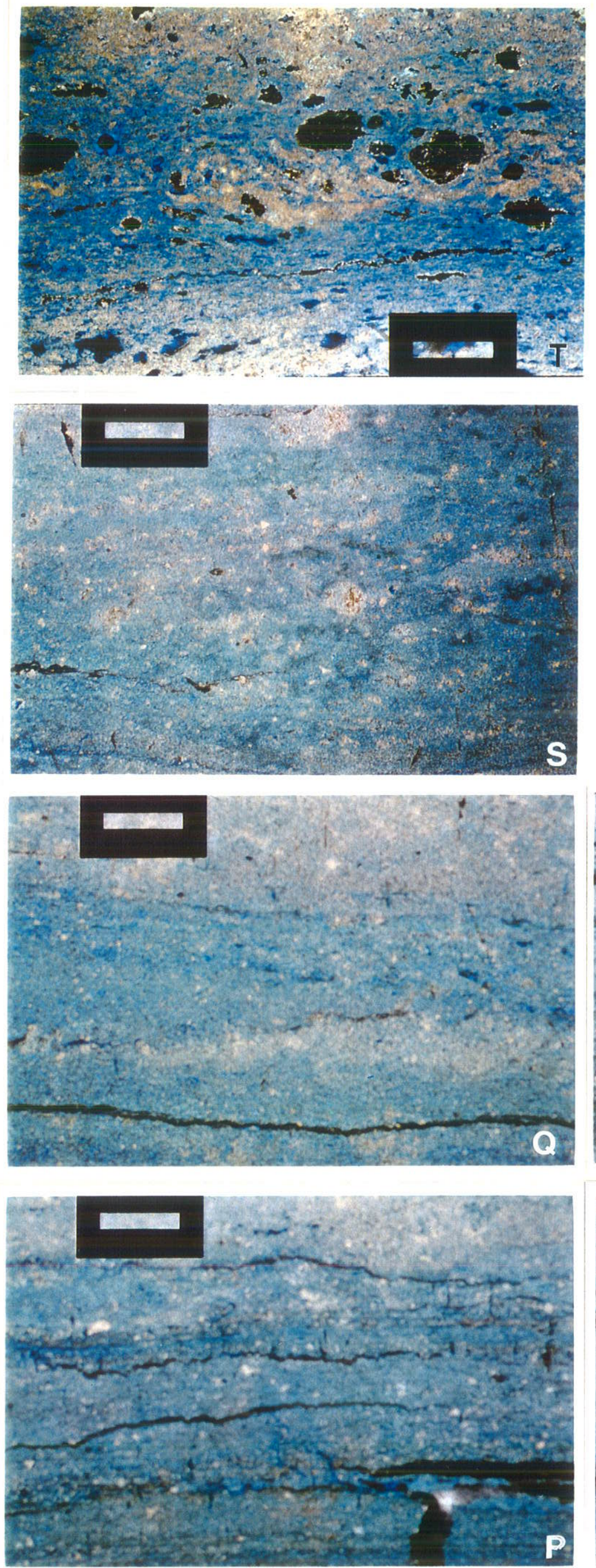

Fig. 34 - Fotografias das lâminas delgadas dos intervalos $\mathrm{M}, \mathrm{N}, \mathrm{P}, \mathrm{Q}, \mathrm{S}$, $\mathrm{T}$ (da base para o topo) da fácies 6 do testemunho LBE 89-2 A localização no testemunho deve ser vista na Fig. 33. A escala de todas as fotos equivale a $750 \mu \mathrm{m}$ e o aumento é de $2,5 \mathrm{x}$. Nicóis x's.

$\Delta$

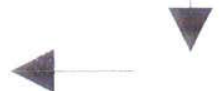

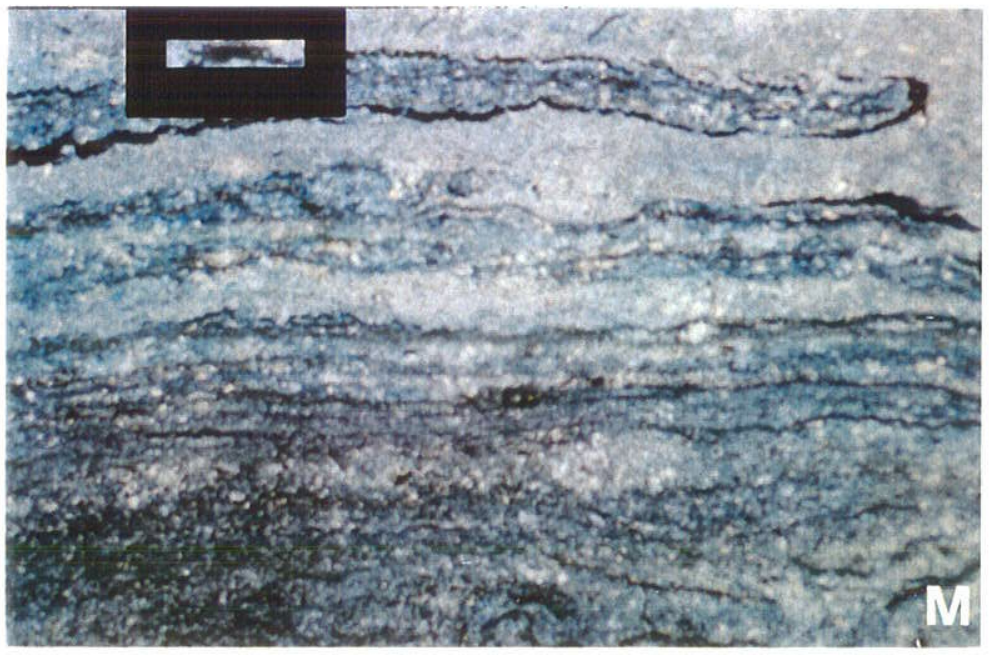

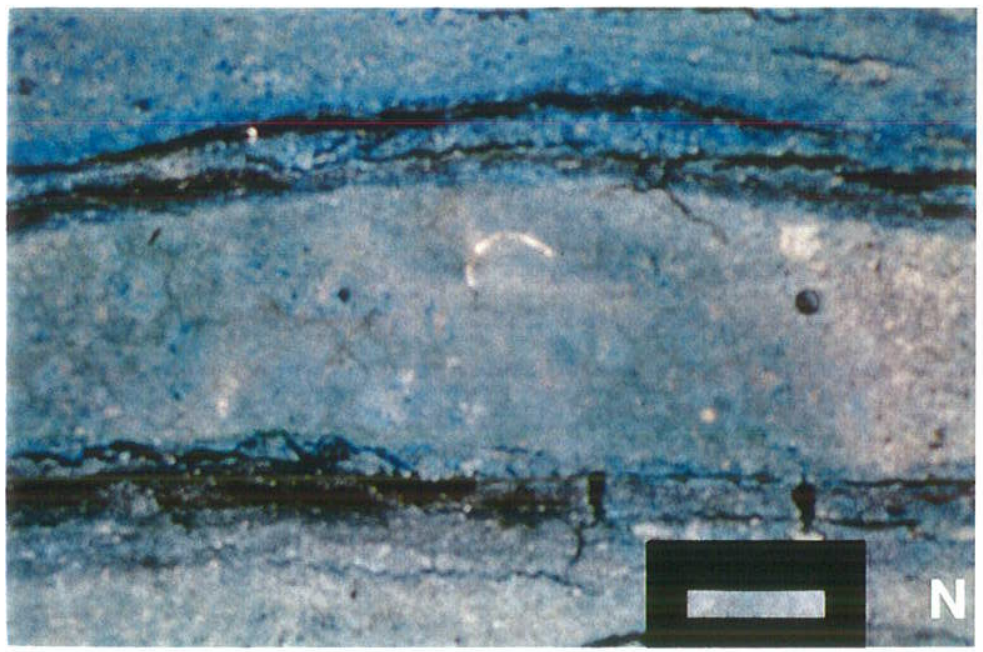




\begin{tabular}{|c|c|c|c|c|c|c|c|c|c|c|}
\hline \multirow[b]{2}{*}{ Prof. $\mathrm{cm}$} & \multicolumn{6}{|c|}{ LBE 89-2 } & \multicolumn{3}{|c|}{ Carbonato Total } & \\
\hline & Prof. $\bar{x}$ & $\mathrm{CaCO}_{3} \%$ & Mat.org. $\%$ & COT $\%$ & N total $\%$ & $\mathrm{C} / \mathrm{N}$ & Prof. $\bar{x}$ & $\delta^{18} 0 \%$ & $\delta^{13} \mathrm{C} \%$ & \\
\hline $0-2$ & 1 & 70,65 & 7,65 & 3,48 & 0,39 & 8,96 & 1 & 2,1 & $-1,44$ & \\
\hline $5-7$ & 6 & 71,97 & 7,21 & 3,28 & 0,35 & 8,39 & 6 & $1 . \overline{82}$ & $-0,68$ & \\
\hline $10 \cdot 12$ & 11 & 76,8 & 5,92 & 2,69 & 0,29 & 9,24 & 11 & 2,28 & $-0,38$ & \\
\hline $15-17$ & 16 & 84,41 & 2,85 & 1,3 & 0,13 & 9,96 & 16 & 2,45 & $-3,5$ & \\
\hline $20-22$ & 21 & 88,24 & 3,07 & 1,4 & 0,14 & 10,34 & 21 & 2,52 & $-4,22$ & \\
\hline $26-28$ & 27 & 86,85 & 2,38 & 1,08 & 0,1 & 11,18 & 27 & 2,9 & $-4,56$ & \\
\hline $28-30$ & $29:$ & 87,3 & 2,73 & 1,24 & 0,1 & 12,04 & 29 & 3,08 & $-6,1$ & \\
\hline $35-37$ & 36 & 81,93 & 7,56 & 3,44 & 0,29 & 11,77 & 36 & 3,58 & $-6,37$ & \\
\hline $39-41$ & 40 & 81,5 & 7,55 & 3,43 & 0,3 & 11,64 & 40 & 2,43 & $-7,26$ & \\
\hline $43-45$ & 44 & 92,04 & 2,59 & 1,18 & 0,1 & 11,89 & 44 & 3,88 & $-7,25$ & \\
\hline $49-51$ & 50 & 90,58 & 2,89 & 1,31 & 0,11 & 11,72 & 50 & 43 & $-8,39$ & \\
\hline $56-58$ & 57 & 92,83 & 1,31 & 0,6 & 0,05 & 11,23 & 57 & 4,58 & $-8,13$ & \\
\hline $60-63$ & 62 & 96,74 & 1 & 0,46 & 0,04 & 12,3 & 61 & 4,52 & $-8,36$ & \\
\hline $65-67$ & 66 & 94,23 & 0,89 & 0,41 & 0,04 & 11,57 & 66 & 4.42 & $-9,31$ & \\
\hline $69-71$ & 70 & 70,01 & 10,37 & 4,72 & 0,41 & 11,47 & 70 & 3,7 & $-11,37$ & \\
\hline $74-76$ & 75 & 93,3 & 2,11 & 0,96 & 0,08 & 11,54 & 75 & 3,52 & $-10,7$ & \\
\hline 79.81 & 80 & 53,48 & 18.87 & 8.58 & 0,72 & 11,91 & 80 & 2 & -68 & \\
\hline $85-87$ & 86 & 65,44 & 6,86 & 3,12 & 0,23 & 13,55 & 86 & 1,3 & $-4,71$ & \\
\hline $100-102$ & 101 & 67,99 & 12,27 & 5,58 & 0.45 & 12,53 & 101 & 1.57 & $-6,88$ & \\
\hline $105-107$ & 106 & 72,36 & 6,03 & 2,74 & 0,22 & 12,68 & 106 & 3,1 & $-7,67$ & \\
\hline $115-117$ & 116 & 61,8 & 13,16 & 5,98 & 0.51 & 11,78 & 116 & 1,43 & $-3,22$ & \\
\hline $125-127$ & 126 & 46,28 & 20,04 & 9,11 & 0,78 & 11,65 & 126 & 2 & $-7,49$ & \\
\hline $135-137$ & 136 & 46,85 & 23,25 & 10,57 & 0,89 & 11,8 & 136 & 1.25 & $-4,77$ & \\
\hline $145-147$ & 146 & 58,94 & 11,51 & 5,23 & 0,4 & 13,14 & 146 & 1,38 & $-7,71$ & \\
\hline $151-153$ & 152 & 13,86 & 18,37 & 8,35 & 0,62 & 13,38 & 148 & 4,18 & $-8,28$ & \\
\hline $164-166$ & 165 & 18,71 & 12,52 & 5,69 & 0,43 & 13,12 & 152 & 0,91 & $-1,46$ & Tab. 33-Porcentagem de $\mathrm{CaCO}_{3}$ e \\
\hline $168-170$ & 169 & 22,5 & 13,81 & 6,28 & 0,46 & 13,8 & 165 & 0,51 & $-0,69$ & Matéria Orgânica, Carbono Orgânico \\
\hline $184-186$ & 185 & 39,68 & 26,66 & 12,12 & 0,85 & 14,32 & 167 & 3,97 & $-5,94$ & Total, Nitrogênio Total e relaçăo $\mathrm{C} / \mathrm{N}$ \\
\hline $195-197$ & 196 & 11,85 & 17,56 & 7,98 & 0,54 & 14,92 & 169 & 0,29 & $-0,48$ & expressas em ppm. Composição \\
\hline $230-232$ & 231 & 11,11 & 30,46 & 13,85 & 0,84 & 16,52 & 185 & 0,42 & $-0,8$ & isotópica de oxigênio $\left(\delta^{18} \mathrm{O}\right)$ e do \\
\hline $245-247$ & 246 & 27,73 & 18,86 & 8,57 & 0,54 & 15,84 & 196 & $-0,85$ & $-1,99$ & Carbono $\left({ }^{13} \mathrm{C}\right)$ em ppm, medida sobre o \\
\hline $260-262$ & 261 & 4,34 & 24,59 & 11,18 & 0,68 & 16,34 & 231. & $-1,52$ & $-1,33$ & carbonato total para o testemunho LBE \\
\hline $275-277$ & 276 & 3,97 & 37.65 & 17,11 & 1 & 17,04 & 241 & $-0,55$ & $-0,17$ & $89 / 2$ \\
\hline $290-292$ & 291 & 7,2 & 24,77 & 11,26 & 0,71 & 15,92 & 261 & $-5,23$ & $-3,61$ & \\
\hline $310-312$ & 311 & 17.68 & 13,78 & 6,26 & 0,36 & 17,59 & 276 & $-7,14$ & $-9,06$ & \\
\hline $343-345$ & 344 & 3,87 & 5,98 & 2,72 & 0,12 & 23,25 & 291 & $-9,29$ & $-4,44$ & \\
\hline
\end{tabular}


análise de agrupamento. Dessa forma, poucas amostras puderam ser correlacionadas fielmente à biofácies definida no agrupamento. Algumas biofácies não puderam ser reconhecidas em sua totalidade devido a ausência de uma ou duas espécies suplementares ou quando a frequiência de ocorrência não correspondia completamente às definidas. Desta forma, foram indicadas por traços pontilhados.

As biofácies e suas amplitudes de ocorrência foram utilizadas conjuntamente para a construção da curva de variação relativa do nível do mar. Por exemplo, uma amostra do testemunho LV89/19 a uma profundidade de $29 \mathrm{~cm}$ estava a $1,79 \mathrm{~m}$ abaixo do nível do mar atual e foi classificada como biofácies $P$. lecalvezae- $Q$. patagonica $(\mathrm{X})$, de acordo com seu conteúdo faunístico, o que sugere ter sido formada entre $-0,21$ e o nível do mar; assim sendo, o nível relativo do mar foi interpretado como tendo estado entre $1,79 \mathrm{~m}$ a 2,00 abaixo do atual quando a amostra foi depositada.

O resultado da análise de agrupamento das seções reflete a pequena variação nas condições ambientais, que pode levar ao agrupamento de todas as estações de uma seção em uma única biofácies, como foi o caso das seções $1,3,4,5$, no verão e 7 no inverno. Esta ausência de zoneamento foi condicionada pela baixa amplitude de maré local, contribuição fluvial insignificante, ausência de vegetação na fácies intermaré e hipersalinidade.

Para a laguna de Araruama, os contrastes ambientais só permitem observar duas zonas: a supramaré correspondente aos foraminíferos aglutinantes $H$. wilberti e $T$. inflata, não preservável e não reconhecida pela análise de agrupamento devido às baixas freqüiências no verão e inverno; e uma mais generalizada, cobrindo a fácies intermaré e submaré, dominada por foraminíferos calcários que correspondem às mesmas espécies no verão e inverno $(P$. lecalvezae, Ammonia spp. e C. excavatum ), embora com alguma alternância em termos de frequiência e dominância. A análise de agrupamento reconheceu somente uma biofácies com amplitude acima do nível lagunar para Araruama (biofácies IV no inverno), apontando baixo potencial de resolução com pequenas amplitudes de deposição em amostras de testemunho.

No zoneamento das lagoas hipersalinas, as variações sazonais, embora marcantes devido à oscilações na coluna d'água, não são capazes de mascarar as biofácies definidas pela análise de agrupamento para a zona pós-lagunar, onde há dominância de $D$. aquayoi no inverno e verão, com variação para a dominância de T. lutea na fácies intermaré de verão, sugerindo esta espécie como possível bioindicador climático desse subambiente.

Foram feitos dois tratamentos quantitativos da fauna ocorrente ao longo dos testemunhos. O primeiro refere-se a plotagem gráfica da abundância absoluta dos indivíduos e da abundância relativa das espécies com freqüencias acima de $4 \%$, em pelo menos uma profundidade. O 
segundo corresponde a plotagem gráfica das biofácies, em uma proposta de curva de variação do nível relativo do mar para a área em estudo.

A má conservação dos testemunhos e a possibilidade de compactação do material podem fazer com que algumas espécies não tenham sido preservadas e levar à algum erro na confecção da curva. Tais hipóteses não foram tratadas por não serem facilmente quantificáveis.

\section{LV89/19}

A interpretação da fauna de foraminíferos ocorrente ao longo do testemunho será conjugada, sempre que possível, com outras variáveis registradas, de modo a sintetizar informações.

O testemunho, de $1,16 \mathrm{~m}$ de comprimento, foi coletado no centro da Lagoa Vermelha (Fig. 1)gradando de uma associação litorânea aberta na base para uma pós lagunar, submaré e intermaré em direção ao topo. Da base ao topo do testemunho(Tab. 28, Fig. 35 A-F), as amostras contém tecas de foraminíferos com abundância variável associadas a ostracodes. Apresentam baixa diversidade de espécies, tecas frágeis, pequenas, algumas vezes deformadas e com diatomáceas epizóicas, indicando condições restritas do meio físico. A espécie $P$. lecalvezae é dominante em quase todo o testemunho, a exceção do intervalo $60-69 \mathrm{~cm}$ quando desaparece. A. base e o topo do testemunho apresentam a maior diversidade de espécies e maior número de indivíduos. A observação das espécies sugere condições mais redutoras na base e no topo com a ocorrência de Bolivina spp. As diferentes espécies de Cribroelphidium spp. e Elphidium mexicanum somente na base, indicam condição lagunar aberta sob condições anóxicas.

O intervalo $50-69 \mathrm{~cm}$ apresenta a menor abundância absoluta de todo o testemunho (Fig. 35 A), com ocorrência das espécies Agglutinella martiniiana, Agglutinela sp. A e Agglutinella sp. indet. e D. aquayoi indicando condições pós lagunares concordando com a ocorrência de tapetes algálicos microbiais. A baixa abundância absoluta registrada no gráfico está associada a valores mais negativos do $\delta^{13} \mathrm{C}$, juntamente à elevação na razão do $\delta^{18} \mathrm{O}$ e ocorrência de $Q$. patagonica, associada a ocorrência de Miliolinella sp. D, Orbitina sp, Disconorbis williamsoni e Fissurina compressa, que defininem a biofácie $X$ de inverno. Outros organismos analisados na Tab. 28, também não apresentam preferência por este tipo de subambiente. Ostracodes, bivalves e diatomáceas ocorrem em pequena quantidade e em geral apresentam aumento em seus números fora deste intervalo. Os gastrópodes marcadamente só passam a ocorrer com o término dessa deposição litofaciológica. 


\section{Flutuações do Nivel Relativo do Mar e Índices de Sedimentação em LV 89/19}

A biofácies III indica condição litorânea aberta com comunicação com o mar na base do testemunho a aproximadamente $3.700 \pm 80$ anos A.P., quando o nível relativo do mar estava a 2,66m. A curva (Fig. 38) mostra tendência regressiva ou de progradação da-planície de maré com ocorrência da biofácies XII, que indica condições pós-lagunares refinando o nível relativo do mar em $2,19 \mathrm{~m} \pm 10 \mathrm{~cm}$ abaixo do atual. A biofácies $\mathrm{X}$, que atualmente possui uma amplitude de 0 a $0,21 \mathrm{~m}$, está posicionada na curva $2 \mathrm{~cm}$ acima da idade de radiocarbono de $760^{\vdots} \pm 80$ anos A.P., e fornece a indicação de que o nível do mar estava entre $1,79 \mathrm{~m}$ a $2,00 \mathrm{~m}$ abaixo do atual. A diferença entre a datações da base e esta última junto com suas profundidades relativas (115$30 \mathrm{~cm}$ ), mostra que em 2.940 anos houve um acúmulo de sedimento de $0,85 \mathrm{~m}$ o que significa dizer que o índice de sedimentação neste intervalo foi de $0,29 \mathrm{~mm} / \mathrm{ano}$, qnquanto que o nível do mar variou de $-2,66$ a $-1,79 \mathrm{~m}$ ou seja, $0,87 \mathrm{~m}$. A diferença é de $2 \mathrm{~cm}$ entre variação do nível relativo do mar e taxa de sedimentação.

A recorrência da biofácies $X$ em direção ao topo do testemunho à $29 \mathrm{~cm}$ e a $9 \mathrm{~cm}$ evidencia um equilibrio entre sedimentação e flutuação do nível do mar para o período representado. A ocorrência da biofácies VII, que atualmente tem uma amplitude de $-0,1$ a $0,07 \mathrm{~m}$, a $1 \mathrm{~cm}$ abaixo do fundo lagunar atual, ou seja a $-1,51 \mathrm{~m}$ indica pequena oscilação nas condições lagunares para esta profundidade.

A interpretação do comportamento geral da curva de flutuação do nível relativo do mar é suportada pelo tipo de biofácies presente, ou seja, para o testemunho LV 89/19 da base para o topo, as biofácies mostram a passagem de ambiente de baía rasa com comunicação marinha para condições cada vez mais restritas, com baixa energia. Condições mais secas na bacia lagunar se deram a aproximadamente $69 \mathrm{~cm}$ de profundidade quando o nível do mar estava a $-2,18 \mathrm{~m} \pm$ $10 \mathrm{~cm}$, interpretado a partir da ocorrência da biofácies XII. As biofácies são indicadoras de ambiente perimaré com hemiciclos submaré, supramaré e intermaré, preservados nesta ordem.

\section{LV4}

A distribuição de foraminíferos e outros organismos ao longo do testemunho LV4 apresenta tendências bem marcadas (Fig. 36 A-E). O gráfico de abundância absoluta (A) demontra decréscimo no número de indivíduos por volta de $245-265 \mathrm{~cm}$ (litofácies de lama orgânica da base) e a $85-112 \mathrm{~cm}$ (litofácies nodular).

A base do testemunho é representada por ocorrência quase exclusiva de Ammonia beccarii (Fig. 36 B) até $213 \mathrm{~cm}$, a partir daí há dominância em direção ao topo de P. lecalvezae, 


\begin{tabular}{|c|c|c|c|c|c|c|c|c|c|c|c|c|c|c|c|c|c|c|c|c|c|c|c|c|}
\hline 1) 89110 & & & & & & & & & & & & & & & & & & & & & & & & \\
\hline Profundidade (cm) & 商 & Obs & 1 & Obs & 18 & Obs & 29 & Obs & 3 & Obs & 60 & Obs & 60 & Obs. & 6 & Obs & 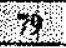 & Obs & 90 & Obs & 98 & Obs & 116 & Obs \\
\hline $\mathrm{N}^{\circ}$ de espécies & 16 & & 17 & & 13 & & 19 & & 13 & & 4 & & 5 & & 4 & & 11 & & 20 & & 15 & & 18 & \\
\hline$N^{\circ}$ de especimens $\mathrm{cm} 10 \mathrm{~cm} 3$ & 244 & & 654 & & 42944 & & 201984 & & 1120 & & 27 & & 7 & & 9 & & 194 & & 714 & & 322 & & 22848 & \\
\hline Wbditodentrix cf A subercavata & & & & & & & $x$ & & & & & & & & & & & & & & & & & \\
\hline Affinetrina concisa & & & & & & & & & & & & & & & & & 9 & 14 & & & 4 & & & \\
\hline Affonetrina of incisura & 1 & & & & & & & & & & & & & & & & & & & & 4 & & & \\
\hline Affnetrina sommeri & 2 & & & & & & $x$ & & & & & & & & & & 3 & & 34 & & 6 & & $x$ & \\
\hline Agghatinella marimiana? & & & & & ... & & & & & & & & & & 44 & & 1 & & 15 & & & & & \\
\hline Agghutimellesp. A & & & & & & & & & & & & & 14 & & 22 & & & & & & & & & \\
\hline Agglutinella sp. indet. & & & & & & & & & & & & & & & 22 & & & & & & 1 & & & \\
\hline A. beccarif parkinsoniana & 11 & $9<$ & 7 & $13<13$ & 1 & $2<$ & $x$ & & 1 & $2 \leq$ & & & 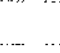 & & & & & & - & & & & 37 & 53 \\
\hline 4. beccariff repida & 11 & & 4 & & 5 & & $x$ & & 1 & & & & & & & & & -- . & .... & & 1 & & 33 & $42: t$ \\
\hline Bolvina sliteri & & & & & & & & & & & & & & & & & & & & & & & 5 & \\
\hline Bolivina stratula? & & & 2 & 4 & $x$ & & & & & & & & & & & & & & 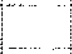 & & & & . & \\
\hline Bolivina sublittoralis & 2 & $\#$ & & & & & $\mathrm{x}$ & $2 \#$ & & & & & & & & & & & & & & & . & \\
\hline Bolivinasp. is & & & & & $x$ & & & & $x$ & & & & & & & & & & & & & & 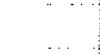 & \\
\hline Cribroelphidium exconatum & & & & & & & & & & & & & & & & & & & 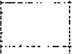 & & & & 3 & $2 \sharp$ \\
\hline C. excruatm f selseyensis & & & & . & & & & & & & & & & & & & 2 & & ... & & & & 3 & $1 H$ \\
\hline Cribroelphitium poeyanm & & & & & & & & & & & & & & & & & & & & & & & 8 & $5 t$ \\
\hline Disconorbis williamsoni & & & & & $5-$ & & & & & & & & & & & & 3 & $<$ & 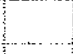 & & & & & \\
\hline Discorinopsis aquanoi & 1 & & 1 & & & & & & $x$ & & 4 & $2 H<$ & 14 & $\leq$ & 11 & $?<$ & & & .... & & $!$ & & 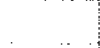 & $\cdots$ \\
\hline Elphidium mexicanm & & & & & $\ldots$ & & & & & & & & & & & & & & 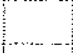 & & & & $x$ & \\
\hline Eoeponidella maroconica & & & & & $\ldots-\ldots$ & & & & & & & & & & & & & & & & & & 1 & $\ldots .$. \\
\hline Eoeponiciella sp.A & & & & & & & & & & & & & & & & & & & 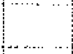 & & & & $x$ & \\
\hline Fissurina conpressa & & & $\ldots$ & & & & & & & & & & & - & & & 1 & & & & & & $\ldots$ & ......... \\
\hline Glabratellina of G. urriformis & & & & & 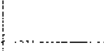 & & $x$ & & & & & & & & & & & & 2 & & & & & 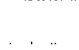 \\
\hline Loxostominasp 4 & & & & & $\mathrm{x}$ & & & & & & & & & & & & & & & & & & & \\
\hline Massilina protea & & & & & & & $\mathrm{x}$ & & & & & & & & & & & & 2 & 15: & & & 1 & 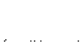 \\
\hline Miholina st. $A$ & 1 & & 1 & & & & & & 9 & 25 & & & & & & & & & 12 & & 11 & & & \\
\hline Miliolinasp. $B$ & & & $x$ & & & & & & & & & & & & & & & & 7 & & & & & \\
\hline Miliolinella cf wi. antarctica & & & & & & & & & & & & & & & & & & & & & & & 1 & \\
\hline Miliolinella subrotunda & & & & & & & & & & & & & & & & & & & 1 & & & & & \\
\hline Miliolinella cf. $M$. willicmsoni & & & & & & & & & & & & & & & & & & & 1 & & & & & \\
\hline Mifiolinella sp. D & 1 & & $x$ & & & & & & & & & & & & & & 4 & $k$ & 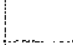 & & & & & \\
\hline Neopatearis of $N$. cumancensis & & & & & & & & & & & & & & & & & & & 6 & & 2 & & $\ldots$ & \\
\hline Orbitina sp. & 1 & & $\ldots$ & & 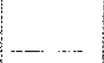 & & & & & & & & & & & & 4 & $<$ & 1 & & 1 & & $x$ & \\
\hline Psendotriloculina lectliezae & $5 \mathrm{I}$ & & 44 & & 64 & $54<, 26 ; x$ & 51 & 250 & 70 & & 78 & & & & & & 4 & $1 \%$ & 1 & & 57 & & 5 & \\
\hline Oninqueloculina dilatata? & 2 & $i<$ & 2 & $3<$ & & & & & 2 & & & & 14 & $?$ & & & & & 4 & & 4 & & & . \\
\hline Quinqueloculina patagonica & 3 & & 22 & & 12 & & 26 & & & & 11 & & 14 & $? \%$ & & & 61 & $27 ?<$ & 1 & & & & 1 & \\
\hline
\end{tabular}




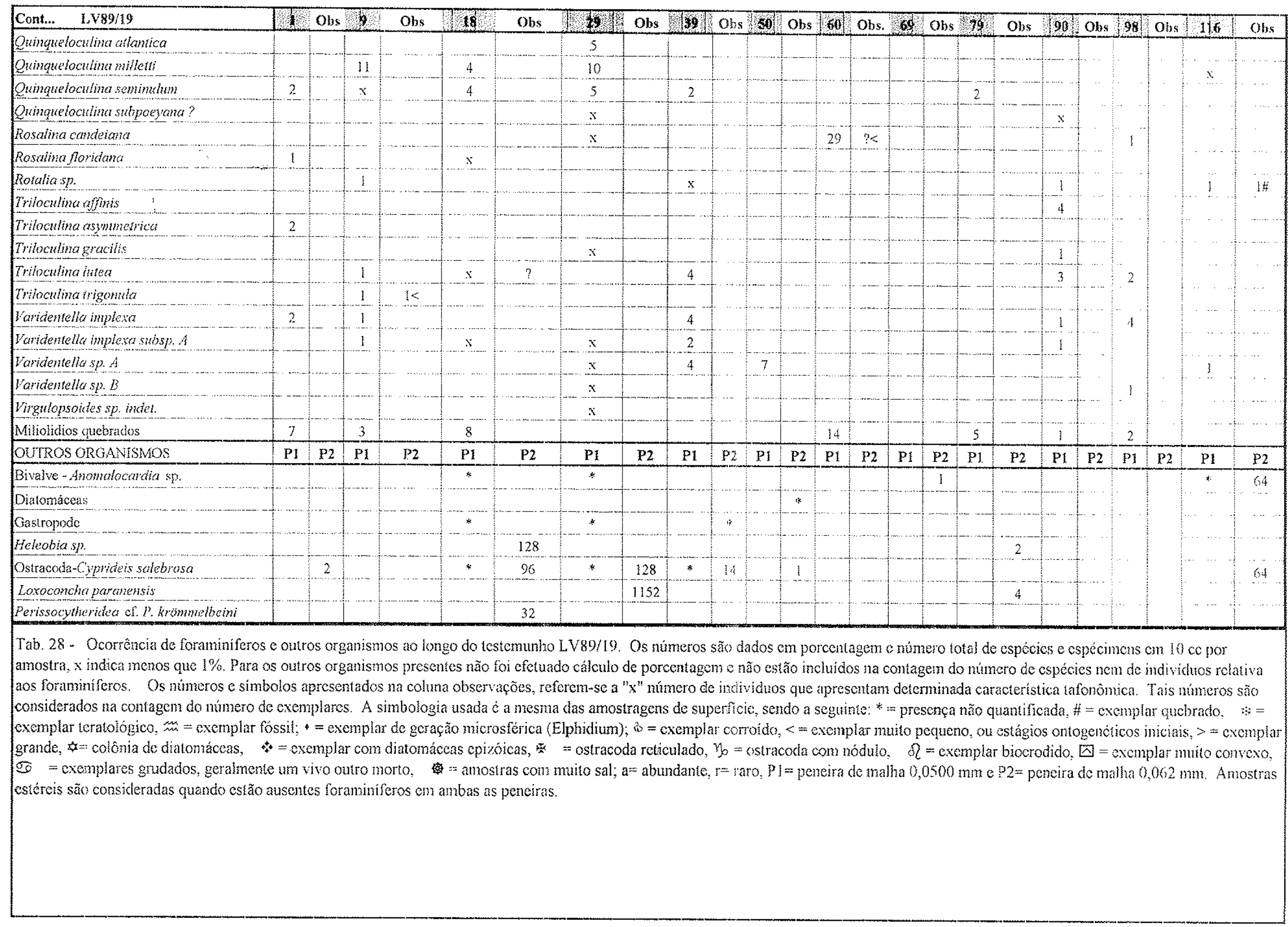




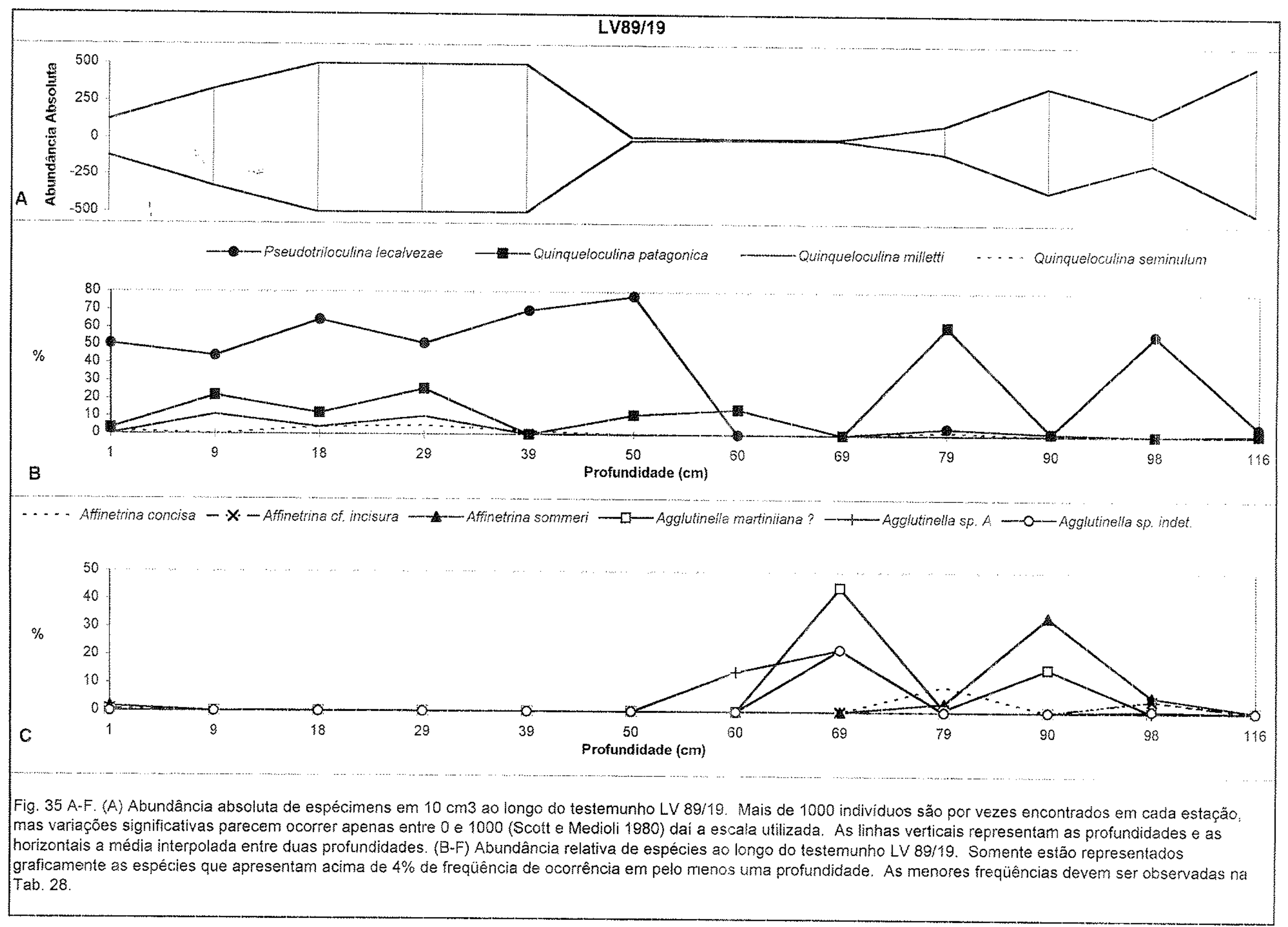




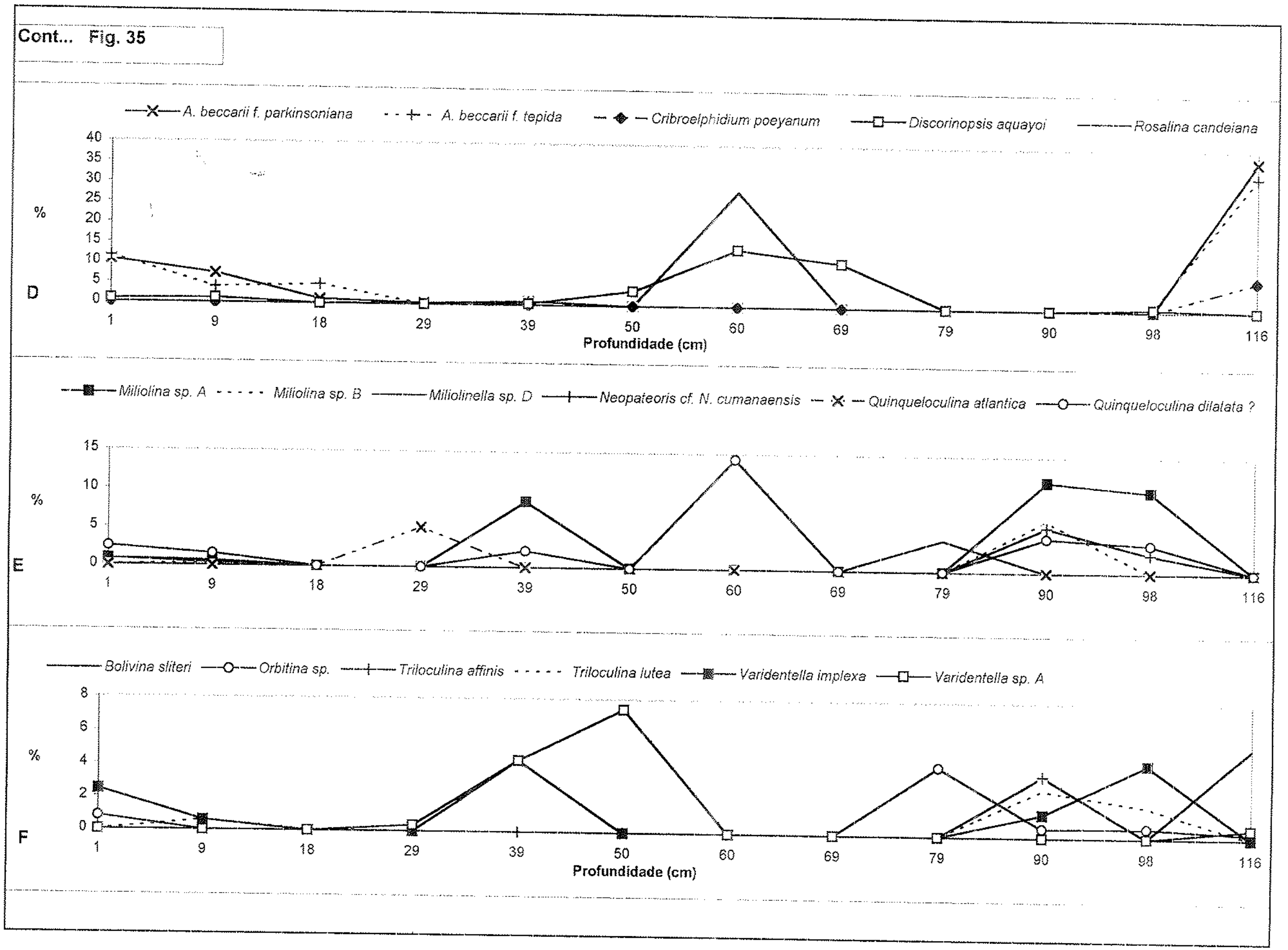




\section{LV $89-19$}

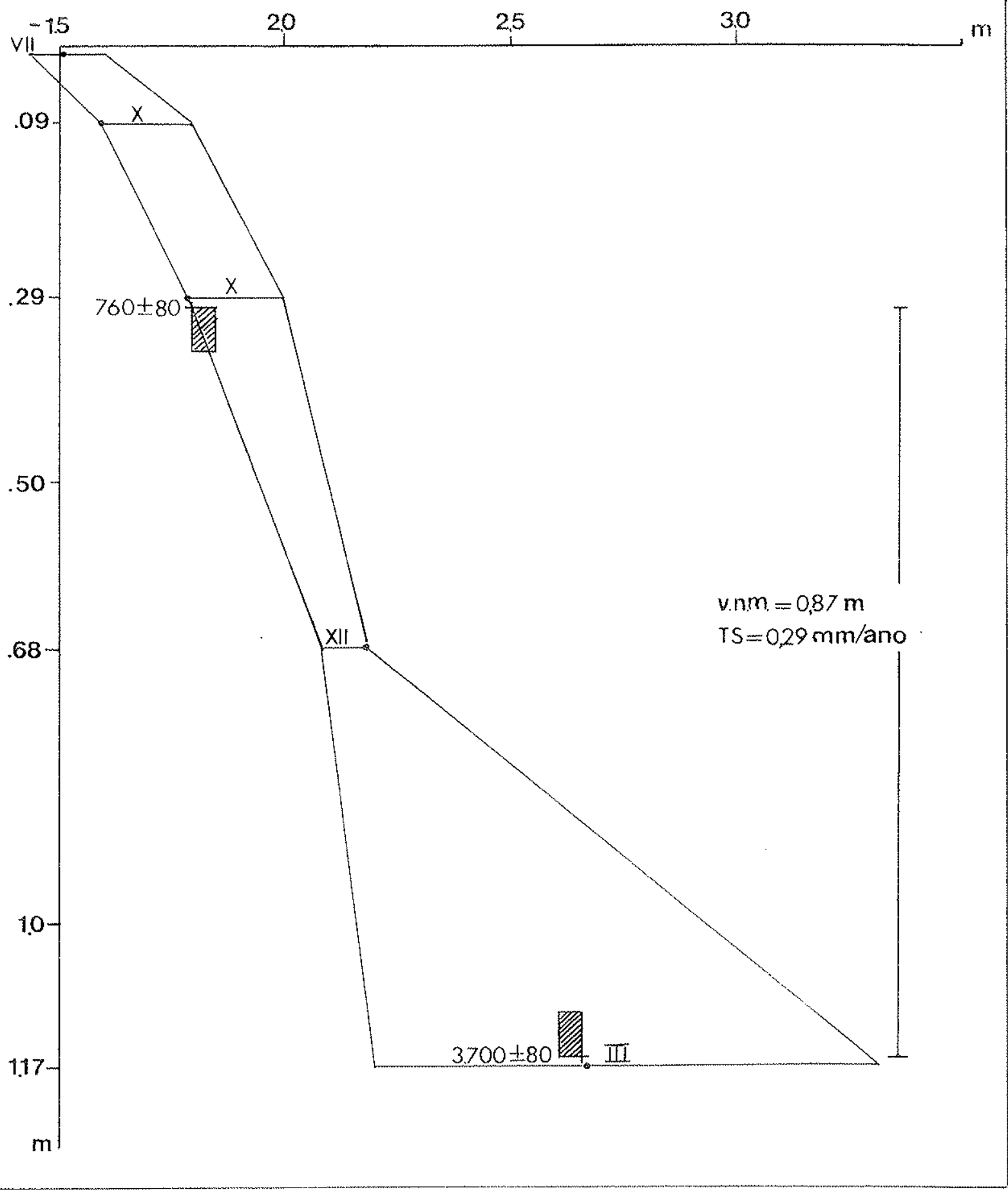

Fig. 38 - Curva de variação do nivel relativo do mar para a região de Cabo frio com base em biofácies de foraminiferos definidas no testemunho LV 89/19 da Lagoa Vemelha. A área hachurada corresponde a amostra de datação de radiocarbono e a cruz ao ponto tomado como medida: os números em romanos indicam as biofácies; e os círculos pretos indicam o nivel médio do mar. TS =taxa de sedimentação e v.n.m = variação do nível relativo do mar. A curva inicia-se à profundidade de $1,50 \mathrm{~m}$, fundo da lagoa na época da amostragem. O eixo $\mathrm{x}$ representa a variaçào do nível relativo do mar e o eixo $y$ a profundidade no testemunho. 
Q. patagonica e Q. milletti (Fig. 36C). Diferentes espécies de Elphidium e Cribroelphidium ocorrem próximo à base do testemunho entre $213-275 \mathrm{~cm}$ e entre $145-174 \mathrm{~cm}$, marcando condições lagunares submaré associadas a ocorrência de Ammonia spp. O pico de aumento de freqüência de Bolivina spp. em $235 \mathrm{~cm}$, associado a outras espécies com baixas freqüências de ocorrência, tais como Brizalina sp.A, Buliminella elegantissima, Globocassidulina subglobosa, Abditodentrix rhomboidalis, Virgulopsoides sp. indet. e Loxostomina sp. B (Tab. 29) indica ambiente litorâneo aberto e com sedimentação de lama, muitas vezes sob condições anóxicas. A morfologia alongada da maioria das tecas favorece a movimentação através dos sedimentos muito finos, e é mais eficiente energeticamente pois mantém o volume enquanto minimiza a área da seção transversal (Lipps 1983). As curvas de matéria orgânica, NOT e COT tem valores mais altos a $244 \mathrm{~cm}$, reforçando esta indicação.

A alternância de dominância de taxas com hábito infauna na base, como as Ammonia, Elphidium e Bolivina para os miliolídios a partir de $224 \mathrm{~cm}$, pode marcar a passagem para condições mais rasas, sob domínio de algas e pradarias submersas (seagrass), onde normalmente ocorrem miliolídios. Microforaminíferos (tecas com tamanhos menores que $0.100 \mathrm{~mm}$ ) pertencentes a subordem Rotalina, como Eoeponidella spp., Microglabratella sp. e Rotalia sp., Rotaliina pequenos que não algumas vezes não puderam ser classificados, ocorrem também a partir de $235 \mathrm{~cm}$ em direção ao topo do testemunho ( Fig. $36 \mathrm{H}$ ). Esses foraminíferos tem sido encontrados epifitados à algas litorâneas (Pawlowski and Lee 1991).

\section{Flutuações do Nivel Relativo do Mar e Índices de Sedimentação em LV 4.}

A biofácies I, indicativa de condição litorânea aberta ocorre na base do testemunho $(6.530$ \pm 100 anos A.P.), quando o nível relativo do mar estava a $-4,24 \mathrm{~m}$. A repetição da ocorrência desta biofácies demonstra um equilíbrio entre taxa de sedimentação e flutuação do nível relativo do mar, com highstand ?/stillstand ? preservado entre $295-285 \mathrm{~cm}$ de profundidade, marcado pela verticalidade da curva. (Fig. 39)

Esta mostra também tendência regressiva ou de progradação da planície de maré quando o nível do mar estava posicionado a aproximadamente $-3,65 \mathrm{~m}$ com a ocorrência da biofácies III, indicativa de condições rasas em laguna aberta. A taxa de sedimentação que abrange a ocorrência das biofácies I e III foi calculada para o intervalo entre $5180 \pm 70$ e $6.530 \pm 100$ anos A.P. como sendo de $0,74 \mathrm{~mm} / a n o$ com variação do nível do mar de $-4,14$ para $-3,14 \mathrm{~m}$. A evidência de equilíbrio é corroborada pela variação de $1 \mathrm{~m}$ de flutuação do nível relativo do mar para o intervalo com $1 \mathrm{~m}$ de sedimento depositado. 
A biofácies $\mathrm{X}$, que atualmente possui uma amplitude de 0 a $-0,21 \mathrm{~m}$, inicia sua ocorrência a $213 \mathrm{~cm}$, um pouco acima da idade de radiocarbono de $5180 \pm 70$ anos A.P., e fornece a indicação de que o nível do mar estava a $-3,12 \mathrm{~m}$ abaixo do atual. A recorrência desta biofácies é interrompida à $174 \mathrm{~cm}$ pela biofácies $\mathrm{II}$, reaparecendo novamente até $145 \mathrm{~cm}$ do testemunho. Outra datação, a $156 \mathrm{~cm}$ de profundidade (4.320 100 anos A.P.), marca essa transição entre biofácies X e III e determina um índice de sedimentação de $0,80 \mathrm{~mm} / \mathrm{ano}$, quando o nível do mar passou de $-3,12$ a $-2,44$, ou seja, indicando $68 \mathrm{~cm}$ de sedimentação e $68 \mathrm{~cm}$ de variação do nível do mar.

Entre $156 \mathrm{~cm}$ de profundidade, $(4.320 \pm 100$ anos A.P.) e o paleossolo a (2.330 \pm 90 anos A.P.), transcorreram-se 1990 anos com deposição de $42 \mathrm{~cm}$ de sedimento, ou seja $0,21 \mathrm{~mm} / \mathrm{ano}$

Outra evidência de estabilidade entre taxa de sedimentação e variação do nível relativo do mar está na recorrência da biofácies VII. O início destas a $133 \mathrm{~cm}$ de profundidade apresenta o nível relativo do mar a $-1,31 \mathrm{~m}$, passando em direção ao topo para $-1,55 \mathrm{~m}$. Esta biofácies com $0,17 \mathrm{~m}$ de amplitude é marcada por paleossolo a $114 \mathrm{~cm}$ de profundidade. A datação na litofácies nodular (1890 170 anos A.P.) acima do paleossolo (2330 \pm 90 anos A.P.) mostra que em 440 anos foram depositados $14 \mathrm{~cm}$ de sedimento, ou $0,3 \mathrm{~mm} / \mathrm{ano}$.

Da biofácies VII para a biofácies X há um período de higstand?/stillstand? indicado pela verticalidade da curva entre 55 e $43 \mathrm{~cm}$.

A biofácies X ocorre em direção ao topo do testemunho, exatamente como em LV89/19 e marca a ocorrência de biofácies submaré.

A interpretação do comportamento geral da curva de flutuação do nível do mar é suportada pelo tipo de biofácies presente, ou seja, para o testemunho LV 4 da base para o topo as biofácies mostram condições cada vez mais restritivas do meio físico, com baixa energia, onde a maior continentalidade na bacia lagunar se deu a aproximadamente $114 \mathrm{~cm}$ de profundidade quando o nível do mar estava a $-2,14 \mathrm{~m} \pm 17 \mathrm{~cm}$, interpretado a partir da ocorrência da biofácies

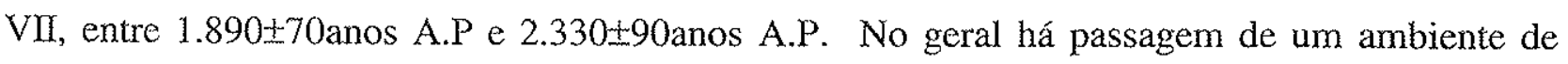
baía rasa com comunicação marinha para condições restritas, com associação de biofácies indicadoras de ambiente perimaré e três hemiciclos intermaré-submaré, preservados. 


\begin{tabular}{|c|c|c|c|c|c|c|c|c|c|c|c|c|c|c|c|c|c|c|c|c|c|c|}
\hline$L \sqrt{4}$ & & & & & & & & & & & & & & & & & & & & & & \\
\hline Profundidade $(\mathrm{cm})$ & 3 & Obs & 13 & Obs & 25 & Obs & 33 & Obs & 43 & Obs & 55 & Obs & 65 & Obs & 74 & Obs & 85 & Ohs & 95 & Obs & 107 & Ons \\
\hline$N^{\circ}$ de espécies & 11 & & 3 & & 10 & & 11 & & 16 & & 8 & & 14 & & 15 & & 13 & & 10 & & 6 & $\therefore . .$. \\
\hline $\mathrm{N}^{\circ}$ de espécimsens em $10 \mathrm{~cm}^{2}$ & 8280 & & 1644 & & 15024 & & 1952 & & 13648 & & 169472 & & 12752 & & 3368 & & 336 & & 534 & & 22.4 & \\
\hline Abditodentrix thomboidalis & & & & & & & & & & & $\cdots \cdots$ & & & & & & & - . . & & & & \\
\hline Abditodentrix subexcavata & & & & & & & & & & & & & & & $\mathrm{x}$ & & & - & & & & $\cdots$ \\
\hline Abditodentrix cf A, subexcavata & & & & & $x$ & & & & & & $\ldots \ldots$ & & . & & $x$ & & & $\ldots$ & $x$ & & & $\ldots$ \\
\hline Af́netrina concisa & & & & & $x$ & & & & $\ldots$ & & $\ldots . .$. & & & & & & 2 & . & $x$ & \# & & \\
\hline & & & & & $\bar{x}$ & & $\mathrm{x}$ & & & & $\ldots \ldots$ & & & & & & $x$ & - n & & & & $\ldots$. \\
\hline $\begin{array}{l}\text { Affinetrina sp. A } \\
\text { Ammonia becconi } \text { f becauri }\end{array}$ & & & & & & ........... & & & & & $-\ldots . .$. & & & & & & ....... & $\ldots \ldots \ldots \ldots$ & & & & $\ldots .$. \\
\hline A. beccarii f. perkinsonicuna & ....... & & & …. & & ...... & .. & & & & $\cdots \cdots \cdots$ & & $\frac{x}{1}$ & & $\frac{1}{1}$ & & 2 & 4 & 2 & & 2 & $\ldots$. \\
\hline A. beccari f tepida & $2 \overline{2}$ & $376<, 85$ & 20 & $84<+\#$ & 7 & $176<$ & 11 & $40<76 \#$ & $x$ & & $x$ & & 1 & & 2 & & 8 & $106010<$ & 17 & $380,1 \div 14<$ & 2 & \\
\hline Bolivina dontezi & & & & & & & & & & & & & $\ldots$ & & & & & 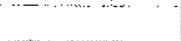 & & & & \\
\hline Bolivina lepida & & & & & & & 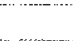 & & & & & & & & & & & $-(-2)$ & & & & $\cdots$ \\
\hline Bolivina aff lepida & & & & & & & & & & & $\ldots \ldots . .$. & & & & & & & 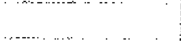 & & $\cdot$ & & $\cdots \cdots$ \\
\hline Bolivina sliteri & & & & & & & & & & & $\cdots$ & & & & & & & $\ldots$ & & $\ldots$ & & \\
\hline B. sliteri subsp asperoides & & & & & & & & & & & ...... & & & & & & & - & & $\cdots$ & & \\
\hline Bolivina striatala? & & & & & & & & & & & & & & & & & & 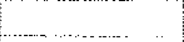 & & & & \\
\hline Bolivina sublittoralis & $x$ & 164 & & & & & & & $x$ & & & & & & & & & $\ldots \ldots \ldots \ldots . . . . . .$. & & & & . \\
\hline Bolivina variabilis & & & & & & & 1 & & & & & & & & & & & 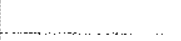 & & & & 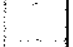 \\
\hline Bolivina sp. A & & & & ...... & & & & & $x$ & & $\ldots$ & & $\ldots$ & ..... & 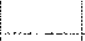 & & & $\ldots \ldots \ldots \ldots . . .$. & & & & \\
\hline Bolivina sp. B & & & & . & & & & & & & & & & & & & & $(\ldots \ldots \ldots \ldots \ldots \ldots$ & & $\begin{array}{ll}\cdots & \ldots\end{array}$ & & ....... \\
\hline Bolivina sp. C & & & & ......... & & & & & & & & & & & 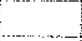 & & & .._- & & $\ldots .$. & & ........ \\
\hline Bolivina spp & & & $\cdots$ & 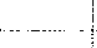 & $\ldots$ & ..... & $\ldots$ & & 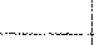 & & 3 & $\#$ & & & $x$ & & & $\ldots-\ldots \ldots \ldots$ & & .. & & ....... \\
\hline $\begin{array}{l}\text { Brizalina sp. A } \\
\text { Buliminelia elegantissina }\end{array}$ & & & ... & & & & ... & & & & $\ldots \ldots$ & & 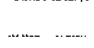 & & & & & 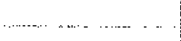 & & $\ldots$ & $\cdots$ & $\ldots$ \\
\hline $\begin{array}{l}\text { Bullininelia elegantissima } \\
\text { Cassitelina cf. spinescens }\end{array}$ & & & & 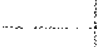 & ... & & & & & & $\ldots \ldots$ & & $\ldots . .$. & & & & & $\ldots$ & & & & $\ldots .$. \\
\hline $\begin{array}{l}\text { Cassidelina cf spinescens } \\
\text { Cribroelpinditm excavatum }\end{array}$ & & & & & & & $\ldots$ & & & & $\ldots \ldots . .$. & & ....... & & & & & $(-\ldots \ldots \ldots \ldots$ & & .. & & \\
\hline $\begin{array}{l}\text { Cribroelphiditm excavatum } \\
\text { Cribroelphictium poeyanum }\end{array}$ & & & & & & & 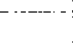 & & & & ......... & & $\cdots$ & & & & & . & & & & \\
\hline C. exacavium f. clavata & & & & & & & & & & & & & $-\ldots$ & & .... & & & $\cdots+\cdots \cdots \cdots$ & .. & .. & & $\cdots$ \\
\hline C. exacavtum $\mathrm{C}$ selseyensis & & & & & & & & & & & $\cdots \cdots$ & & & & & & & & & . & & ...... \\
\hline Cribroelphidium of adescens & & & & & & & & & & &.-- & & & & & & & & & ..... & & \\
\hline Cribromiliolinella sp. indet. & & & & & & & & & $x$ & & ....... & & 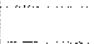 & & - & & & $\ldots$ & & & & $\cdots \cdots$. \\
\hline Discorinopsis aquayoi & & 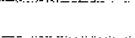 & & & & & - & & $x$ & & & & $x$ & & 1 & & $\mathrm{x}$ & - n n.......... & 1 & - & & \\
\hline Elphiditiella $\mathrm{sp}$ & & & & & & & & & & & & & & & & & & …….......... & & & & $\cdots$ \\
\hline Elphidium articulahm & $x$ & & & & & & 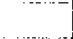 & & & & ....... & & $\cdots$ & & & & & $\cdots \cdots$ & & & & \\
\hline Eiphidium sp. & & & & & & & 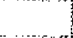 & & & & . & & & & & & & - n & & $\cdots$ & & …. \\
\hline Eocponidella nenoconica & & & & & & & & & & & $\cdots$ & & $\ldots$ & & & & & (n) & & & & \\
\hline Eoeponidella sp A & & & & & & & & & & & me & & & & (n) & . & & $\cdots$ & & $\cdots$ & & \\
\hline Eissurina incida & & & & & & & & & & & 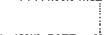 & & & & & & & 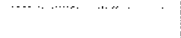 & & & & \\
\hline Floresina seminuta & & & & & & & & & & & & & & & - & & & (n) & & & & \\
\hline Globocassidulina subglobosa & & & & & $-\ldots+2>$ & & & & & & & & & & & & & & & & & \\
\hline Hanzawata sp. indel. & .... & $\ldots \ldots . . . . . . . .$. & & & & & $x$ & & $x$ & & & & & & & & & wara & & $\cdots$ & & \\
\hline Loxostomina sp. B & & & & & & & & & & & & & & & & & & 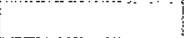 & & & $\mathrm{x}$ & H \\
\hline Massilina crescentensis & - & $\ldots . . . . . .$. & & & & & & & $x$ & & & & $x$ & & & & & 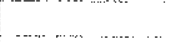 & & . & & \\
\hline Massilina protea & & & & & & & & & & & $x$ & & $x$ & & $x$ & & & $\ldots$ & & .. & & \\
\hline Mfiliolinella cf M antarctica & & & & & & & & & & & & & & & & & & $\ldots \ldots \ldots \ldots \ldots$ & & $\therefore$ & & \\
\hline Ailiolinella circularis & & & & & & & & & & & & & & & & & & $\ldots \ldots \ldots \ldots$ & & & & \\
\hline $\begin{array}{l}\text { Miliolinella subrotwnda } \\
\text { Miliolinella cf } M \text {. williamsoni }\end{array}$ & & & & & $\cdots \cdots$ & & & & & & 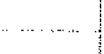 & & $\ldots$ & $\ldots$ & ......... & & & 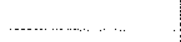 & & & & \\
\hline 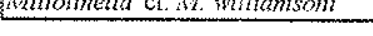 & & & & & & & & & & & & & & & & & $\mathrm{x}$ & & & & & \\
\hline
\end{tabular}




\begin{tabular}{|c|c|c|c|c|c|c|c|c|c|c|c|c|c|c|c|c|c|c|c|c|c|c|c|c|c|c|}
\hline $\begin{array}{r}\text { Cont... LV } 4 \\
\end{array}$ & 112 & Obs & 124 & Obs & 133 & Obs & 145 & Obs & 153 & Obs & 166 & Obs & 274 & Obs & 184 & Obs & 194 & $\mathrm{Obs}$ & 204 & Obs & 213 & Obs & 224 & Obs & 235 & Ons \\
\hline Massilina d M secrans & & ..... & & & & & & & $\mathrm{x}$ & & & & & & & & & & .... & & ...... & & & & $\ldots$ & \\
\hline Miliolina sideboitomi & & & $x$ & & & & $\mathrm{x}$ & & & & & & & & & & & & & & & & & & & \\
\hline Miliolina $\mathrm{sp}$ A & 1 & -_ & $\ldots$ & & 1 & & $\mathrm{x}$ & & & & & _. & & & $\mathrm{x}$ & & & & $x$ & $8: 5$ & $\mathrm{x}$ & & & & & \\
\hline Milioininella sp. B & & - & ....... & 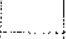 & $\cdots$ & & & & & & & ...- & $\ldots$ & & & & & & & & & & & & & \\
\hline Miliolinella sp. C & & $\ldots$ & $\ldots$ & & & & & & & & & & & & & & & & $x$ & & $x$ & & 3 & & 1 & \\
\hline Miloolinella sp. D & & &.... & & $x$ & & $x$ & $\#$ & & & & 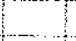 & $x$ & $\ldots$ & $-x$ & & $x$ & & & & $\ldots \ldots . .$. & & & & & \\
\hline Neopatcoris cumanaensis & w. & $\ldots$ & & & 2 & & $x$ & & & & & $\ldots$ & & & $\ldots$ & $\ldots$ & & & & & $\ldots . . .$. & & & & & \\
\hline Neopateoris sp. $A$ & & 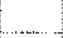 & $x$ & & & $\ldots$ & & & & & & & & & & ........ & & & & & ......... & & & & & \\
\hline Neospiroloculina sp.A & & & $x$ & & & & & & & & & & & & & & & & & & & & & & $\ldots$ & \\
\hline Orbitina sp. & ............... & & & & & & & & & & & & 1 & & 1 & & $x$ & & & & 1 & $2 !$ & $x$ & ... & $x$ & \\
\hline Pseudotriloctilina lectivezac & 54 & & 63 & & 84 & & 55 & & 36 & & 79 & & 77 & 204 & 45 & $10 \mathrm{~A}$ & ]1 & 325 & 31 & & 32 & & 3 & .. & 2 & \\
\hline Pseatotriloculina swbgramentuta & & & $x$ & ........ & & & & & & & & & & & & & - & & - no & & & & & & & \\
\hline Quinquelocutina artica & & & & & & & & & & & & - & $\ldots$ & & 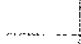 & & ….... & 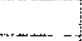 & & & $x$ & & $\ldots$. & & $\ldots$ & \\
\hline Quingteloculina allantica & & $\ldots$ & ......... & -. & & & & & & & & 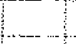 & $\ldots$ & & & & $\ldots \ldots$ & & 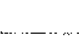 & & & & . & & & \\
\hline Qumandocntina dilatata? & & & $\ldots$ & & & & & & & & & & $\ldots$ & & & & & & & & & & & . & & $\ldots$ \\
\hline Quinqueloculina paragonica & 18 & 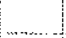 & $\ldots$ & $\ldots$ & 8 & & 27 & & 27 & & & - & $\ldots$ & & 45 & & 64 & & 62 & 8 & 63 & & $\mathrm{x}$ & . & & \\
\hline Quinqueloculina miletti & & -_ & 33 & 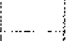 & & $\ldots . .$. & & & & & & 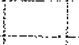 & ....... & & ..... & & 16 & & .............. & & & & $\ldots$ & . & 3 & $56 \%$ \\
\hline Quinquelocnlina seminulum & & & & 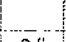 & & $\ldots$ & $\ldots . .$. & & & & & .... & $\ldots . .$. & & $\ldots$ & & $\ldots$ & & $\cdots-$ & & $\ldots$ & & & . & & \\
\hline Q. semimulkm var jugosa & & & $x$ & $2 \mathrm{H}$ & $\ldots$ & . & . & & & & & $\ldots$ & $\ldots$ & & 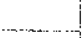 & & 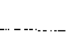 & & & & & & & & & \\
\hline Quinqueloculina stbpoevana? & 1 & $\ldots$ & 1 & $4 \%$ & & $\ldots$ & $\ldots .$. & & & & & 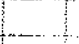 & $\ldots$ & & $\ldots$ & & . & & & & & & & & $\because$ & \\
\hline Quinquelocnilina venezulaelaensis var A & 1 & - . . & $x$ & & $x$ & $\ldots$ & ....... & $\ldots$ & & & & ......... & $\ldots$ & & & & $\ldots$ & - & $x$ & $8 f$ & $\ldots$ & & & & $\ldots$ & \\
\hline Rosulina candeiuma & & 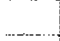 & & & & $\ldots$ & $\ldots$ & & & & & $\ldots$ & & & $x$ & & .......... & & $\ldots$ & - & $\ldots$ & & & $\ldots$ & & \\
\hline Rosalina foridarata & & $\ldots$ & $x$ & & & $\ldots$ & $\ldots$ & & & & & $\ldots$ & 2 & & 1 & & $x$ & & $\ldots$ & & & & & & & \\
\hline Rosaling globularis & 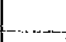 & & & & & & & & & & & $\ldots$ & $\ldots$ & & & $\ldots . .$. & $x$ & & $\ldots$ & & $\ldots$ & & & $\ldots$ & ... & \\
\hline Rotalicasp. & $\ldots$ & $\ldots$ & $x$ & & & $\ldots \ldots$ & $\ldots$ & & $x$ & 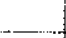 & & ...... & $\ldots . .$. & $\cdots$ & $\ldots \ldots$ & & 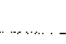 & & $x$ & & ... & & & & & .. \\
\hline "Triloculina" ficheliana & & & $x$ & & & $\ldots$ & ...... . & & & & & $\ldots . .$. & $\ldots$. & & 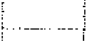 & $\ldots$ & ....... & & $\ldots$ & & 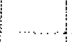 & & $\cdots$ & & $\ldots .$. & $\ldots$ \\
\hline Triboculina lutea & 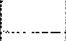 & ......... & $\ldots \ldots$ & & & $-\ldots \ldots$. & $\ldots .$. & $\ldots \ldots \ldots$ & & & & $\ldots \ldots$ & $\cdots$ & ....... & $\ldots-\cdots$ & $\ldots \ldots \ldots$ & $\ldots$ & & & & ... & & & & & \\
\hline Tribculina ef T nitida & & & & & & …- &. & $\ldots \ldots$ & & & & -..... & $\cdots$ & & $(\ldots \ldots \ldots . . .$. & $\ldots \ldots \ldots$ & $\ldots$ & $\ldots$ & $x$ & $8 i$ & $\ldots$. & & & & & \\
\hline Triboculima sidebottomi & & & $x$ & & & & & & & & & - & 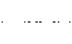 & & $\ldots$ & $\ldots$ & $\ldots$ & & $\ldots . .$. & $\ldots$ & $\ldots$ & & & & $\ldots$ & $\cdots$ \\
\hline Triloculina rigonita & & & $\cdots$ & & & $\cdots$ & & & $\ldots$ & & $\ldots$ & $\cdots$ & $\cdots \cdots$ & & $\cdots$ & $\ldots$ & $x$ & $<$ & $\ldots$ & & $\ldots$ & & & & $\ldots$ & \\
\hline Tritoculina yebbianct & 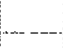 & 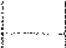 & $\ldots-$ & & & & & & & $\ldots$ & & 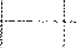 & $-\cdots$ & & 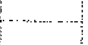 & & $\cdots-$ & & & & $\cdots$ & & . & & & $\ldots$ \\
\hline Varidentella implexa & & & . & & & 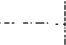 & 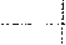 & & & & & 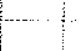 & $\cdots \cdots$ & & ….... & & $x$ & & 8 & & $\ldots$ & & & $\ldots$ & .. & \\
\hline Vuridentella implexs stesp A & 18 & $\ldots$ & $x$ & 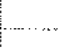 & & …. & 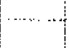 & & $x$ & $\ldots$ & -- & -....... & $\cdots$ & & & & $x$ & & & & ..... & & & & . & $\cdots$ \\
\hline $\begin{array}{l}\text { Varidentella sp C } \\
\text { Firgulopsoides sp. indet. }\end{array}$ & & & & & & 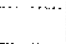 & & & 8 & & & & $-\cdots$ & & w........ & $\ldots \ldots$ & $\cdots$ & & & & . & & & & & \\
\hline $\begin{array}{l}\text { Vingulopsoides sp. indet } \\
\text { Rotaliina < indet. }\end{array}$ & & & & & & & & & & & & & $\cdots$ & -1 & & & $x$ & 100 & & & $\ldots$ & & $\ldots$ & . & $x$ & $\cdots$ \\
\hline $\begin{array}{l}\text { Rotalinin < indet } \\
\text { OUTROS ORGANSSMOS }\end{array}$ & pl & $p_{2}$ & $p 1$ & $p 2$ & P1 & P2 & $P_{1}$ & P2 & $P 1$ & $\mathbf{P 2}$ & $\mathbf{P 1}$ & P2 & $\mathrm{P1}$ & $P 2$ & $P 1$ & $\$ 2$ & 1 & P2 & 1 & P2 & $\bar{p}_{1}$ & $p 2$ & $p_{1}$ & $P 2$ & $\mathrm{Pt}$ & $\mathrm{p}_{2}$ \\
\hline $\begin{array}{l}\text { OUTROS ORGANYSMOS } \\
\text { Bivalve-Anomalocirdiat } \mathrm{sp}\end{array}$ & & & 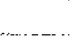 & & & & $\ldots$ & & & & & & ...... & & & & & 32 & 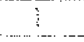 & 8 & & & & .. & & $\ldots$ \\
\hline Diatomáceas & & & & & & & & & & & & & $\ldots . . . . .$. & & & & & & - & & & & & & & $\ldots$ \\
\hline Gasitophde & & & & & & & & & & & & & $\ldots$ & $\ldots$ & $\cdots$ & & & & & & 1 & &. & 64 & 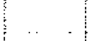 & . \\
\hline Heleobia $\mathrm{sp}$ - & & & & 1 & & & & & & & & & & & & & & & & & & & $\cdots$ & & .. & .. \\
\hline Sayella aft crosseana & & & & & & & & & & & & & & & & & & & & & & & & & $\ldots$ & \\
\hline Dstracoda-Cyprideis sclebrosa & & 1 & & & & & & & & 14 & & & & & & & * & 160 & $*$ & & & & $*$ & $\%$ & & \\
\hline Loxoconcha parangssis & & $\cdots$ & & & & & $\cdots$ & & & & & & $\ldots . . . .$. & 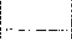 & & & & 32 & & 32 & & 4 & $\ldots$ & 6.1 & & 16 \\
\hline Perissogytheridea cS. P. Kormmelboini & & & & & & & & & & & & & & & & & & & & & & & & & & \\
\hline
\end{tabular}




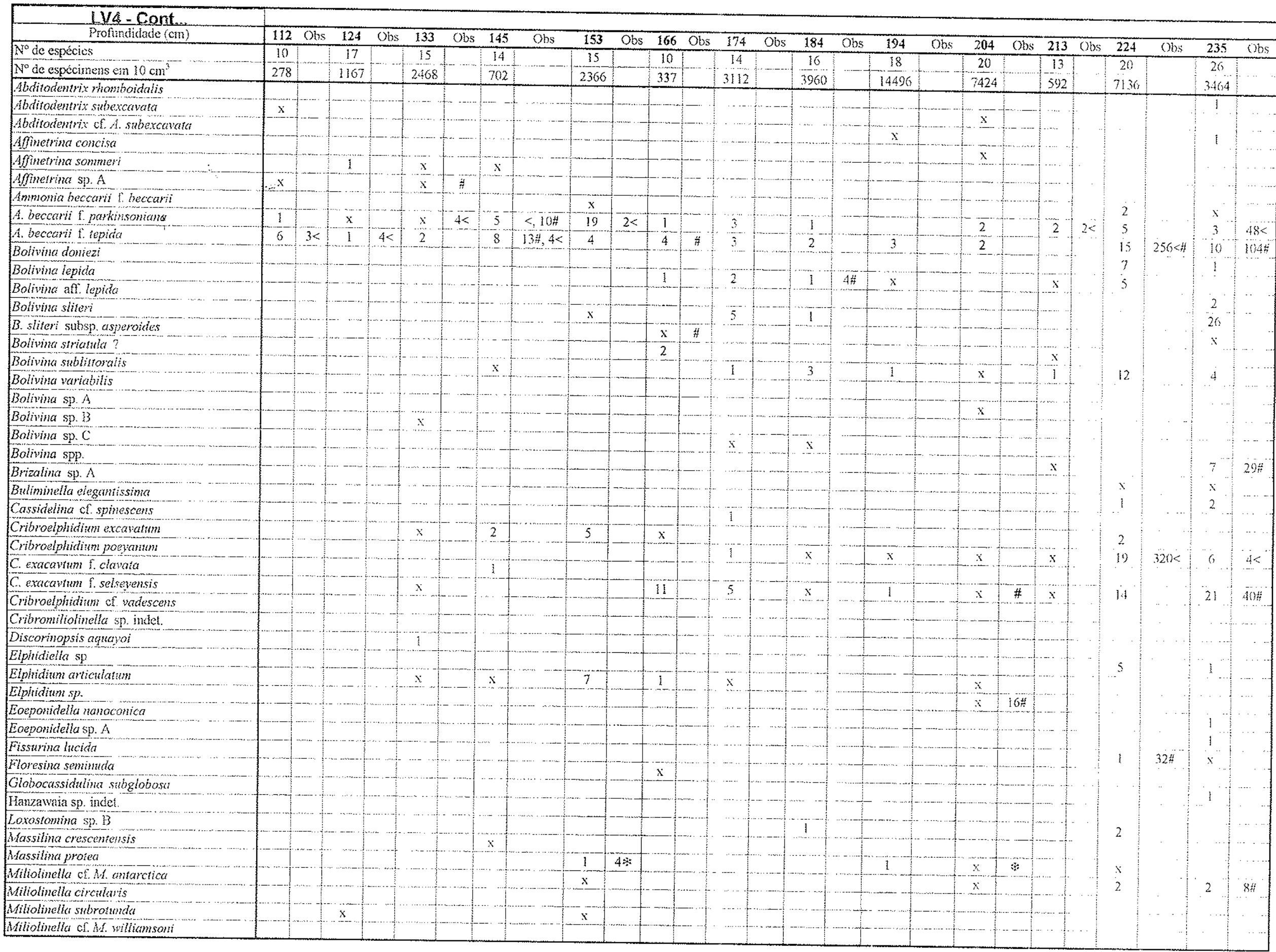




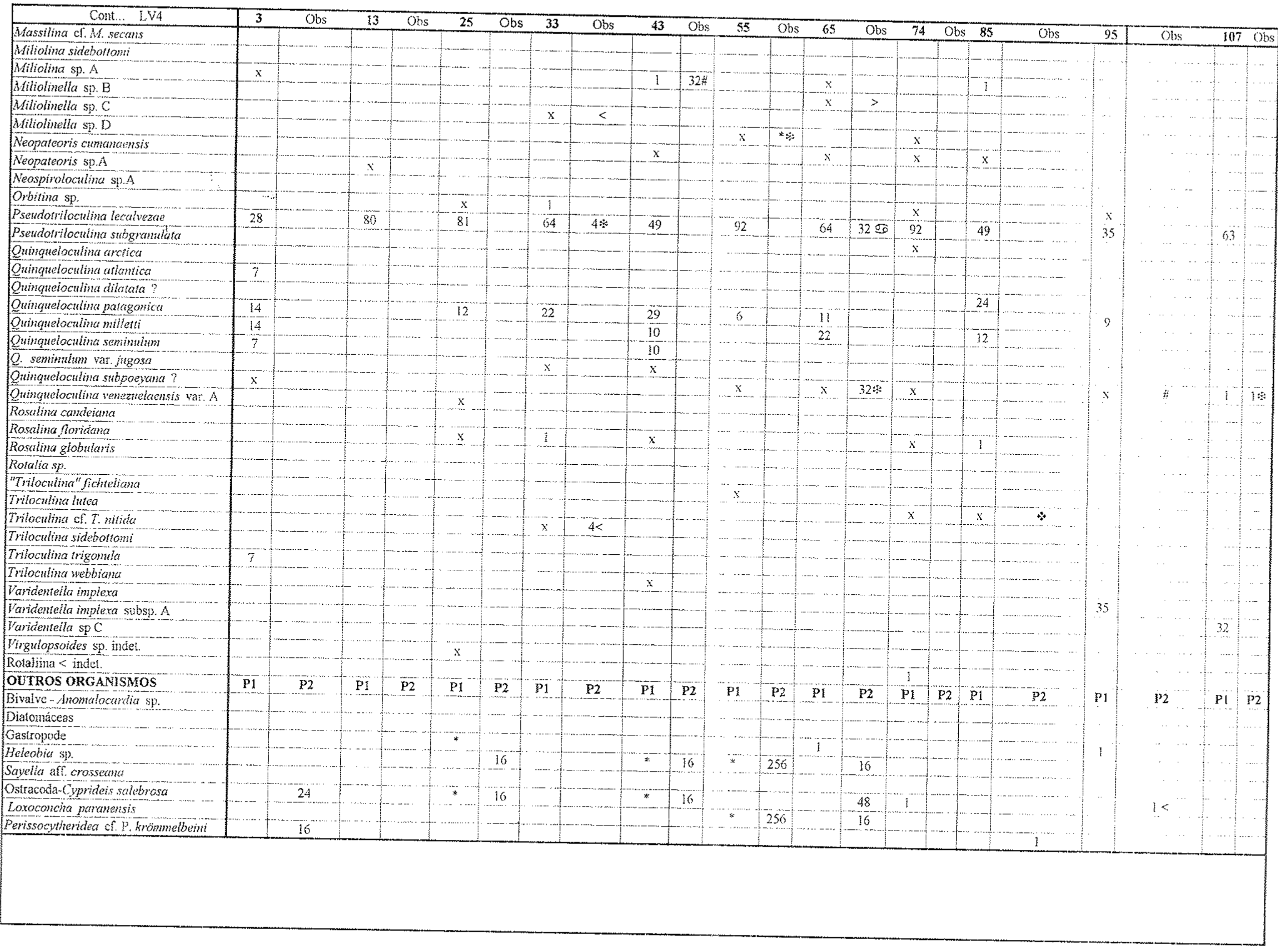




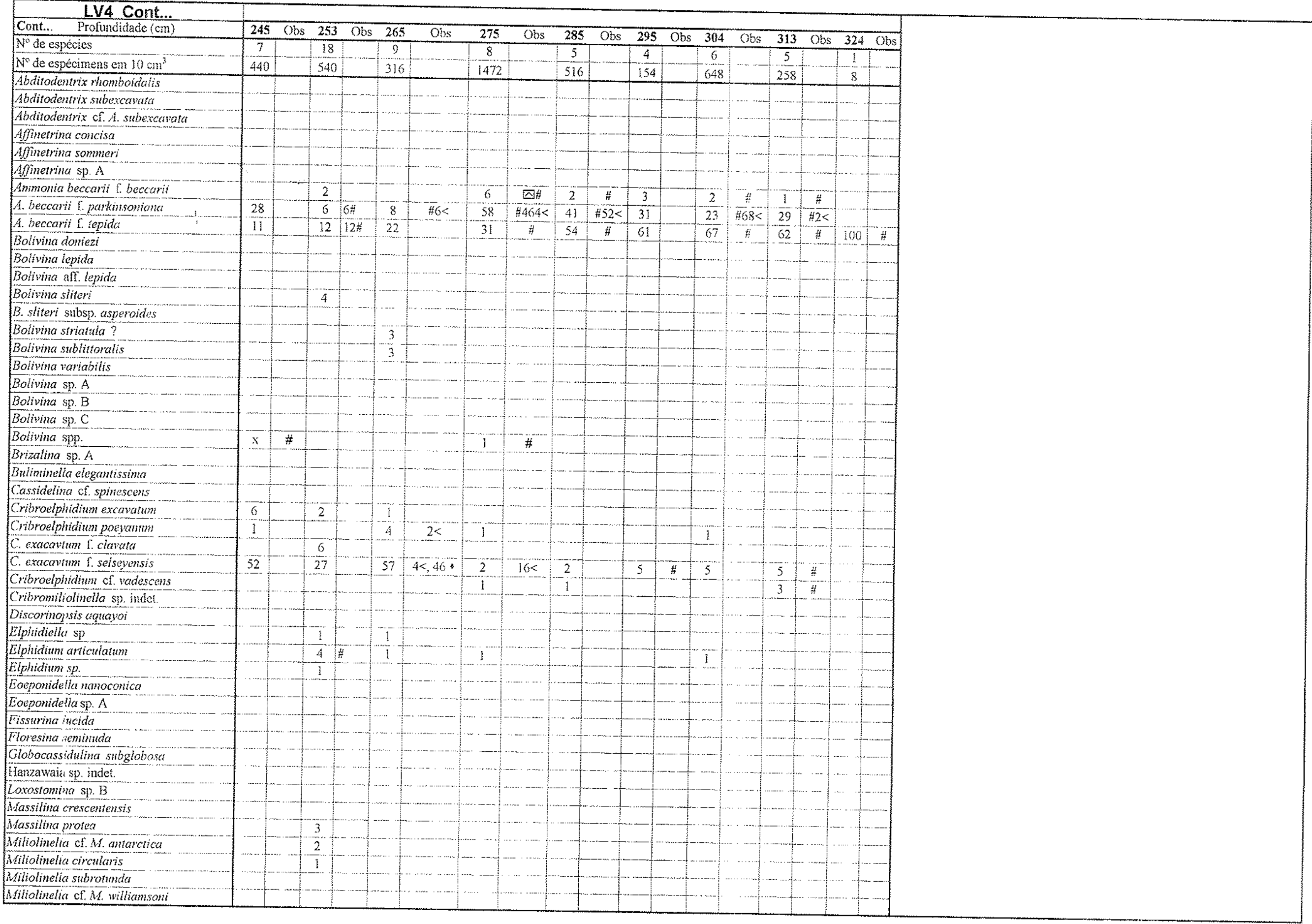


Cont... IV 4

Massilina cf. M. secans

Miliolina sidebottoni

Miliolina sp. A

Miltolinella sp. B

Miliolinellis sp. C

Miliolinella sp. D

Neopateoris cumanacensi

Neopateoris sp. A

Neospiraloctima sp. A

Orbitina sp.

pseidotritoculina lecalvez

Psendatriloc

Quinquetoculina arcica

Ininqueloculina atianici

Ouinqueloculina dilostata?

Guinquelocrlina potago

Orinquelocnlina putagonica

Quingueloculina milletit
Oninqueloculina seminutilum

Q. seminuitum var. jugosa

Oninqueloculina subpocyana?

Outinqueloculina yentezielacensis var. A

Rosatinas candeicunce

Rostima floridana

Rosalina globalaris

Rotalia sp.

"Triloculina" ficheliana

Triloculina kutea

Trilocuina of $T$. nitida

Triloculina sidebotiomi

Triloculina trigonuia

Triloctlina vebbiana

Varidentella implext

Varidentella implesu subsis.

Varidentella $\mathrm{SpC}$

Virmlonsoides Sp indet

Rotaliin < indet.

OUTROS ORGANTSOS -.........

OUTROS ORGANISMOS

Bivalve-Anomatocardia si?

Diatomáceas

Gastopkie

Heicobia sp.

Sayella aff crosseanc

Ostracola-Cyprideis salebro

Loxoconcha paranensis

Perissocytheridea ci. P. krommolbani

\section{Obs 253 Obs 265 Obs 275 Obs 285 Obs 295 Obs 364 Obs 313 Obs 324 Obs}

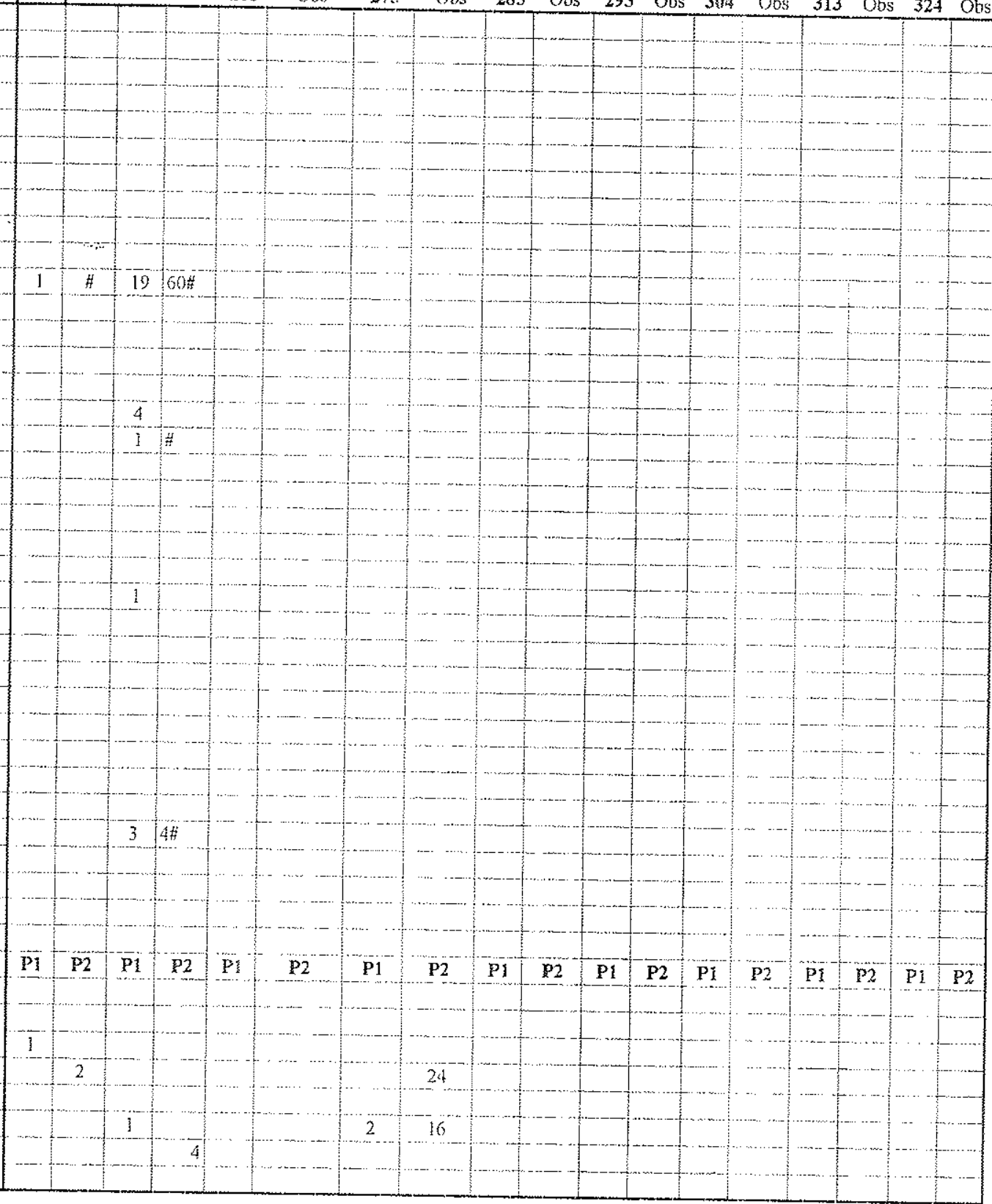

Tab. 29 - Ocortencia do foraminiferos e outros organismos ao longo do testemunho LV4. Os nimeros são dados em porcentagem e mimero total de espécies e espécimens em $10 \mathrm{cc}$ por amostra, $\mathrm{x}$ indica menos que $1 \%$ Para os outros organismos presentes não foi efetuado cálculo de porcentagem e não estão incluidos na contagen to número de espécies nem de indivíduos relativa aos foraminiferos. Os numeros e simbolos apresentados na coluna observações, referen-se a " $x$ " numero de indivídnos que apresentam determinada característica tafonômica. Tais números são considerados na contagem do número de exemplares. A simbologia usada è a mesma das amostragens de superffice, sendo a seguinte:

$*=$ presença não quantifícada, $\#=$ exemplar quebrado,

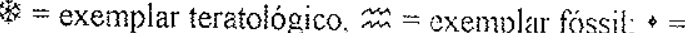
exemplar de geração microsférica (Elphidium); $\dot{b}:=$ exemplar corroido, $<=$ exemplar muto pequeno, ou estágios ontogenéticos iniciais, $>:=$ exemplar grancie, $=$ colônia de diatomáceas, : exemplar com diatomáceas epizóicas, $=$ ostracoda reticulado, $\eta_{0}=$ ostracoda com nódulo, $\quad \mathcal{Q}=$ exemplar bioerodido, $\mathrm{Q}$ =: exemplar mito convexo, $\sigma=$ exemplares grudados, geralmente um vivo outro morto, amostras com muito sal; $a=$ abundante $F$ raro, $P 1=$ peneira de malha 0,0500 mm e $P 2=$ peneira de malha $0,062 \mathrm{~mm}$. Amostras estereis são consideradas cuando estão ausentes foraminíferos em ambas as peneiras. 


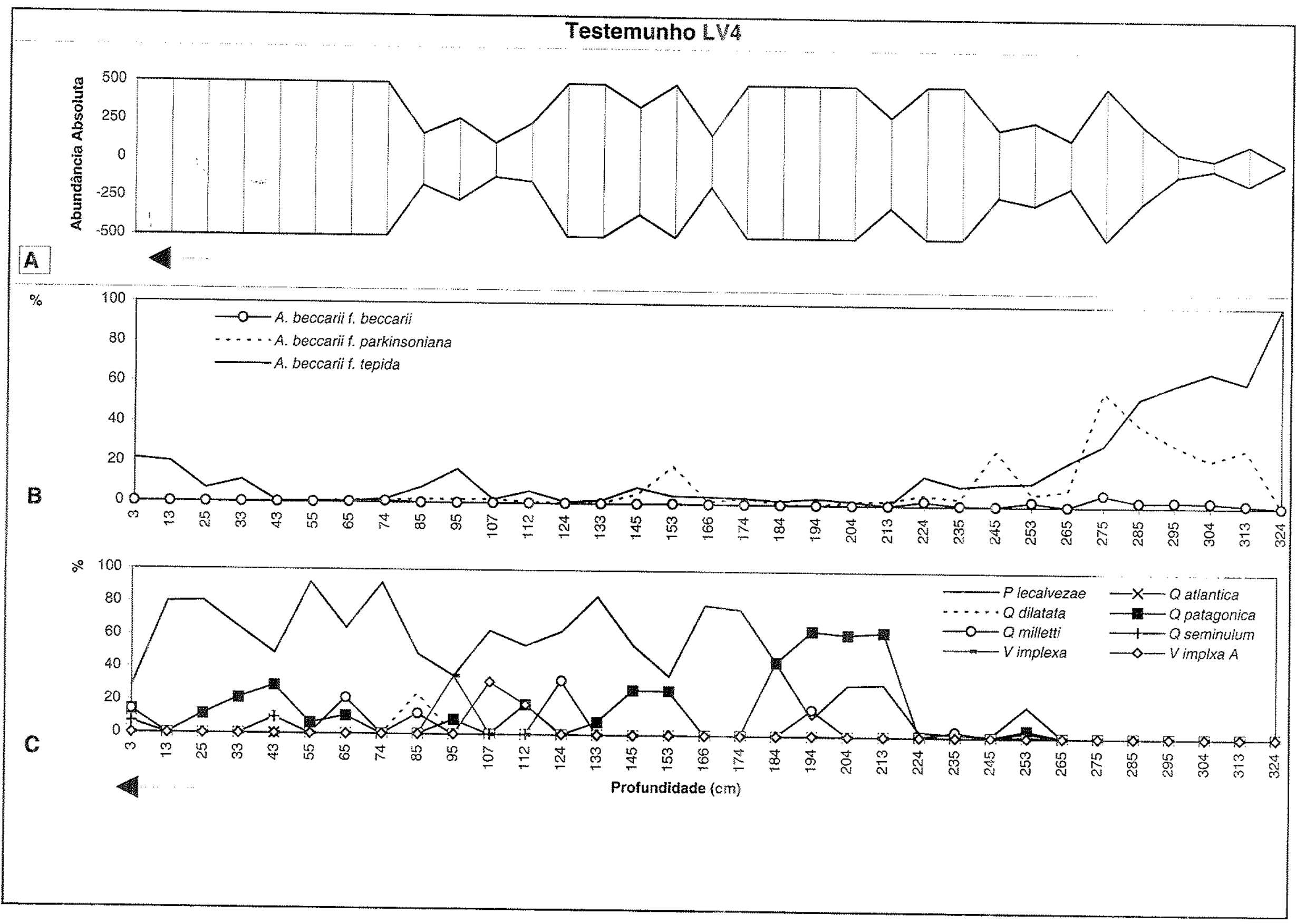




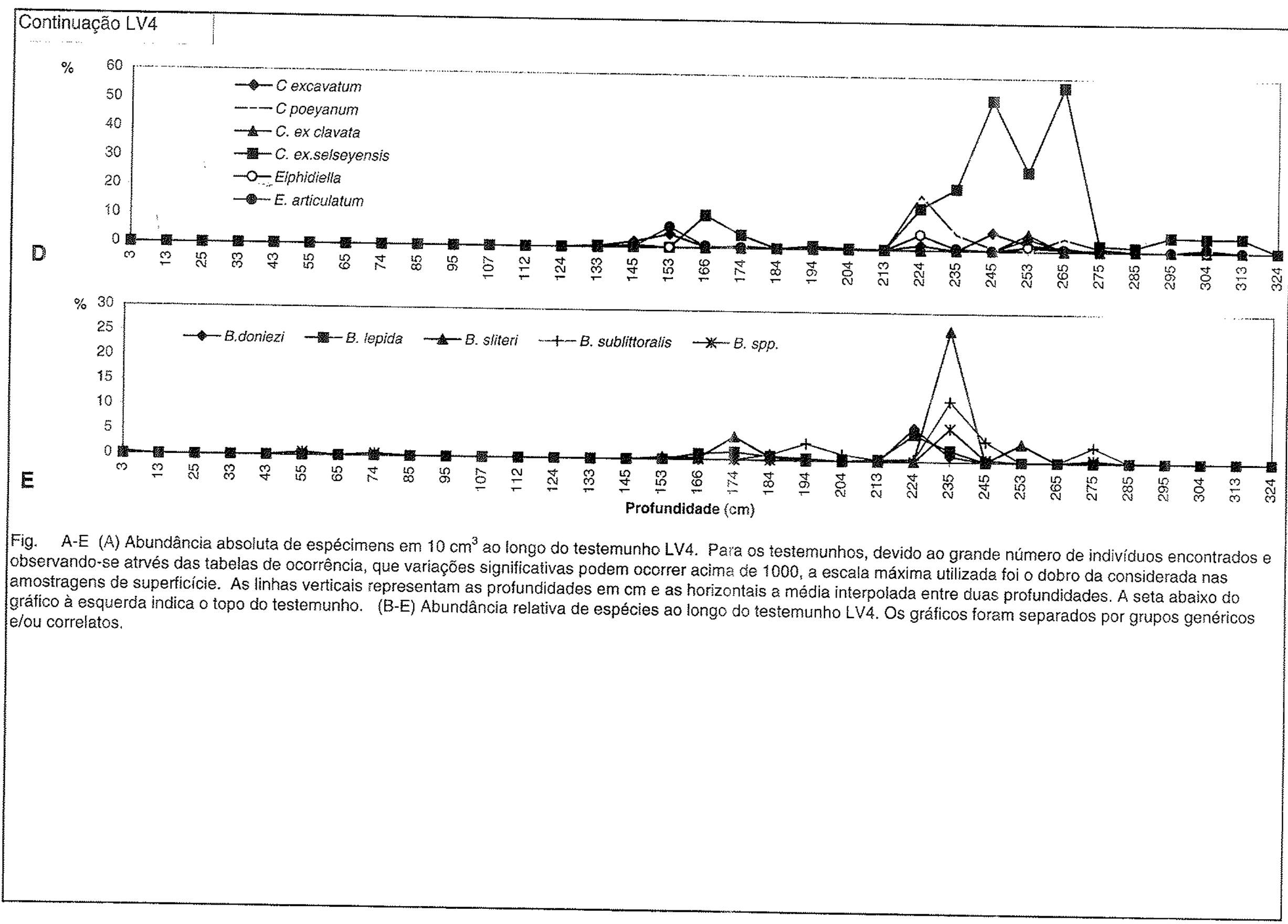




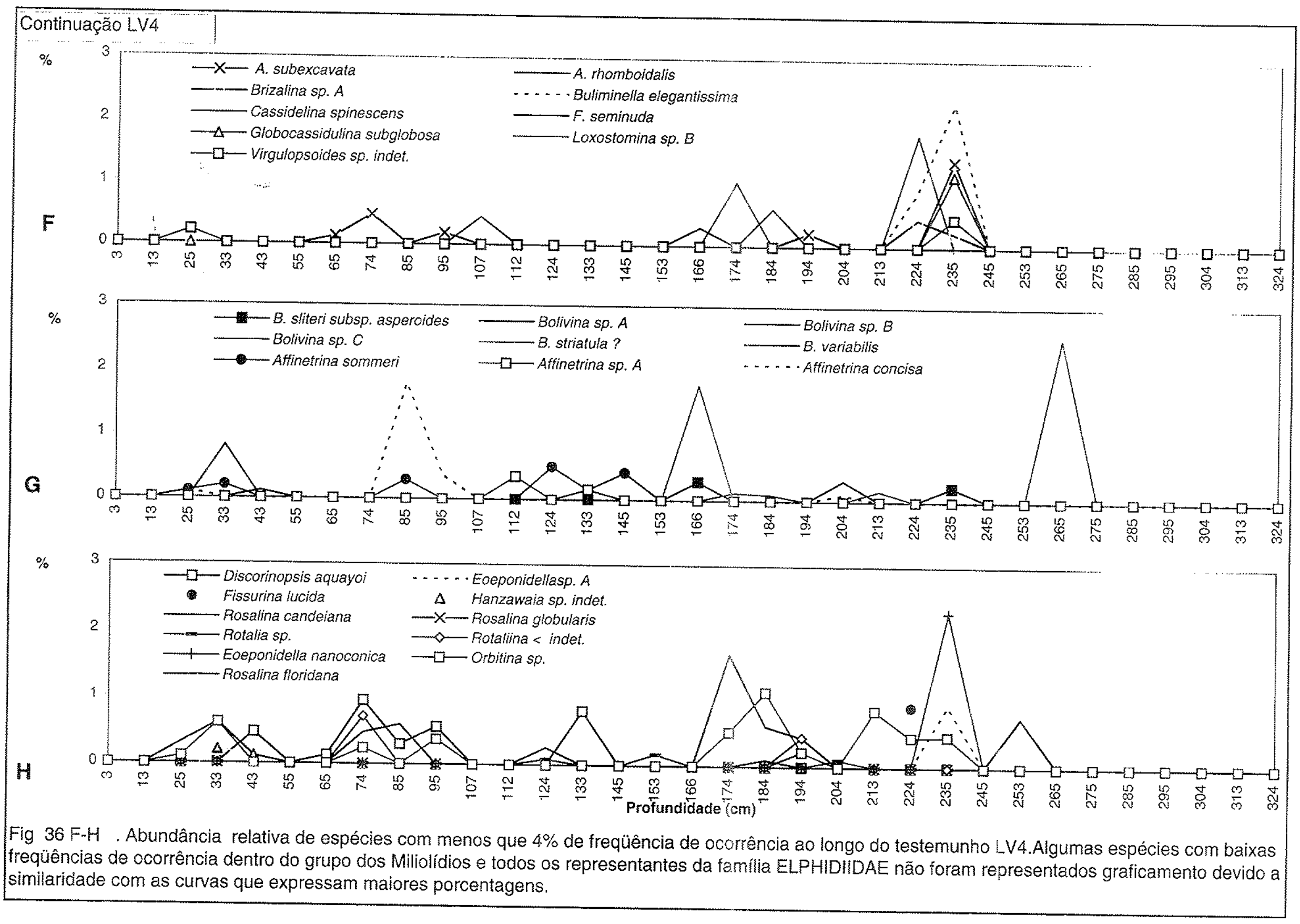




\section{4}

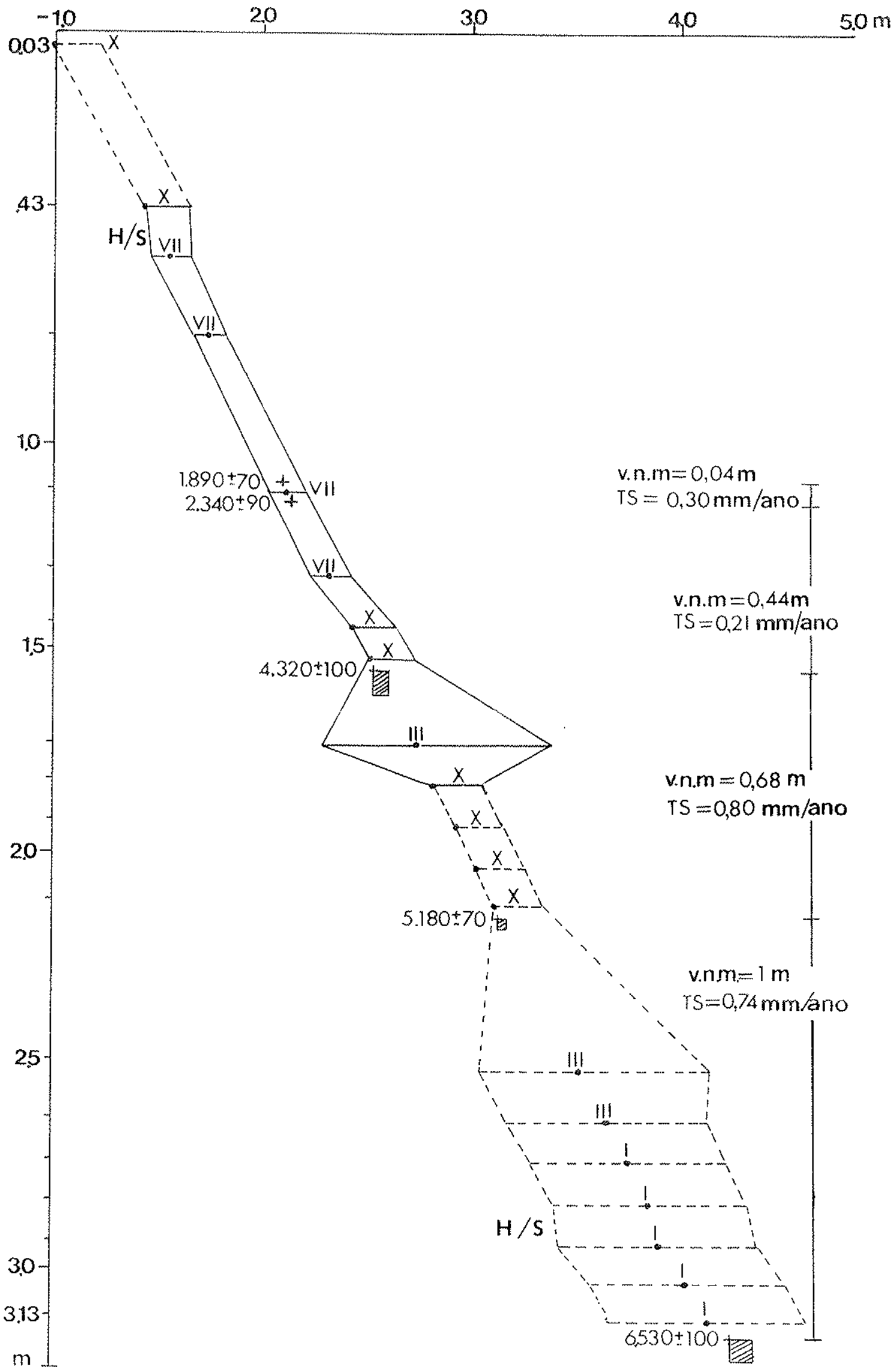

Fig. 39 - Curva de variaçâo do nível relativo do mar para a região de Cabo frio com base em biofácies de foraminiferos definidas no testemunho LV 4 da Lagoa Vermelha. A área hachurada corresponde a amostra de dataçầo de radiocarbono e a cruz ao ponto tomado como medida: os números em romanos indicam as biofácies; e os circulos pretos indicam o nivel médio do mar. TS = taxa de sedimentação e v.n.m = variação do nível relativo do mar. A curva inicia-se à profundidade de $1,00 \mathrm{~m}$, fundo da lagoa na época da amostragem. O eixo $\mathrm{x}$ representa a variação do nivel relativo do mar e o eixo $v$ a profundidade no testemunho. $\mathrm{H} / \mathrm{S}=$ Highstand/ Stillstand.(?) 


\section{LBE 89-2}

Este testemunho, de $3,60 \mathrm{~m}$ de comprimento, possui associação de fácies similares aos testemunhos anteriormente analisados. No entanto, por apresentar maior comprimento, sua base apresenta areias estéreis impregnadas por ácidos úmicos. O início de ocorrência de foraminíferos preservados se dá a $323 \mathrm{~cm}$.

O gráfico de abundância absoluta (Figg. 37A), mostra grandes oscilações no número de indivíduos com decréscimo acentuado a $233-201 \mathrm{~cm}$ e $80-33 \mathrm{~cm}$. O primeiro corresponde a litofácies de conchas e o segundo à ocorrência de tapete algálico microbial. A litofácies de conchas fragmentadas, limitada por contato erosivo na base, expressa uma concentração em momento de alta energia sob condições erosivas, com ausência de suprimento sedimentar (sediment starvation). Esta litofácies é marcada pela ocorrência de infauna de C. excavatum f. selseyensis, A. beccarii e Bolivina sublittoralis. A abrasão mecânica pode reduzir significativamente a preservação de spécimens de foraminíferos, como a observada atualmente nas zonas de arrebentação da laguna de Araruama.

A diminuição de indivíduos na litofácies de tapete algálico também foi observada bern como a dominância de miliolídios, representados principalmente por $P$. lecalvezae, dissociada da ocorrência de A. beccarii f. tepida e forma parkinsoniana e familia Elphidiidae da base (Fig. 37), de maneira análoga ao testemunho LV4. A transição entre essas duas faunas dominantes se dá a $148-140 \mathrm{~cm}$, a partir da segunda recorrência de nódulos. A ocorrência de miliolídeos em direção ao topo, acompanha o domínio da precipitação da lama carbonática diferentemente da base siliciclástica.

Outros organismos apresentam abundância a partir de $23 \mathrm{~cm}$ em direção ao topo, marcadamente quando encerra a ocorrência de tapete algálico, o qual apresenta apenas a espécie de ostracode Cyprideis salebrosa, mandíbula de Neritidae (poliqueta) e carófitas.

\section{Flutuações do Nível Relativo do Mar e Índices de Sedimentação em LBE89-2}

A datação das conchas na base do testemunho a profundidade de $335-340 \mathrm{~cm}$ (não da base com ocorrência de fauna preservada) é de $7170 \pm 110$ anos A.P. Este nível de conchas apresenta discordância erosiva na base, correspondente a ambiente marinho indicado pela razão isotópica $\delta$ ${ }^{13} \mathrm{C}$ de $+1.2 \%$. Deste nível até a primeira ocorrência de biofácies, em $6.660 \pm 70$ anos A.P., foram depositados $12 \mathrm{~cm}$ de areias, com índice de sedimentação de $0,23 \mathrm{~mm} / \mathrm{ano}$.

A curva elaborada para o testemunho LBE 89-2 (Fig. 40) mostra em sua base a ocorrencia de biofácies 1, exatamente como em LV4, indicativa de condição litorânea aberta com 
comunicação com o mar a $6.660 \pm 70$ anos A.P., quando o nível do mar estava a $-4,26 \mathrm{~m}$. A $270 \mathrm{~cm}$ do testemunho, outra datação (5.790 \pm 90 anos A.P.), permite reconstruir um índice de sedimentação de $0,60 \mathrm{~mm} / \mathrm{ano}$, quando o nível do mar variou em $0,56 \mathrm{~m}$, passando de $-4,26 \mathrm{~m}$ para $-3,70 \mathrm{~m}$.

A $233 \mathrm{~cm}$ do testemunho, a ocorrência da biofácies III indica condição litorânea aberta, quando o nível do mar estava posicionado a aproximadamente $-3,32 \mathrm{~m}$. Acima desta biofácies

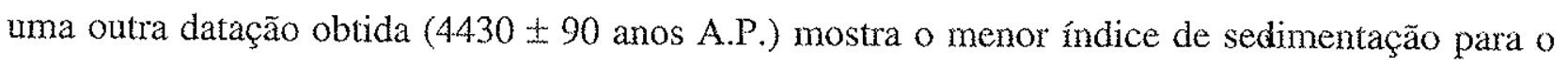
testemunho entre $270-205 \mathrm{~cm}$ como sendo de $0,48 \mathrm{~mm} / \mathrm{ano}$, quando o nível do mar apresentava-se em transgressão variando de $-3,70 \mathrm{~m}$ para $-3,04 \mathrm{~m}$.

A $201 \mathrm{~cm}$ do testemunho a biofácies $\mathrm{V}$, igualmente indicativa de ambiente intermaré, ocorre posicionada $4 \mathrm{~cm}$ acima da datação de $4430 \pm 90$ e marca uma variação do nível relativo do mar de $-3,32 \mathrm{~m}$ (da biofácies $\mathrm{mI}$ ) para $-3,12 \mathrm{~m}$ com variação de $0,20 \mathrm{~m}$. A $153 \mathrm{~cm}$ do testemunho outra datação obtida (3.620 70 anos A.P.) demonstra, para o intervalo que abrange a biofácies $\mathrm{V}$ um aumento no índice de sedimentação, entre $205-153 \mathrm{~cm}$ como sendo de $0,64 \mathrm{~mm} / \mathrm{ano}$.

A biofácies $X$, que atualmente possui uma amplitude de 0 a $-0,21 \mathrm{~m}$, inicia sua ocorrência na curva a $89 \mathrm{~cm}$, marcada com a idade de radiocarbono de 2.400 anos \pm 50 A.P., e fornece a indicação de que o nível do mar estava a $-1,88 \mathrm{~m}$. Para o intervalo entre $153 \mathrm{e} 89 \mathrm{~cm}$, o índice de sedimentação calculado foi de $0,52 \mathrm{~mm} / \mathrm{ano}$, com variação do nível do mar de $-2,53 \mathrm{~m}$ para $1,88 \mathrm{~m}$, ou seja $0,65 \mathrm{~m}$. A recorrência desta biofácies até $63 \mathrm{~cm}$ do testemunho corrobora a estabilidade entre taxa de sedimentação e variação do nível do mar sugerida para o período.

Outra evidência de estabilidade entre taxa de sedimentação e variação do nível relativo do mar está na recorrência da biofácies VII até $3 \mathrm{~cm}$ de profundidade. $O$ início, a $13 \mathrm{~cm}$ apresentava o nível relativo do mar a $-1,22 \mathrm{~m}$ passando em direção ao topo para $-1,08 \mathrm{~m}$

A biofácies X ocorre em direção ao topo do testemunho, exatamente como em LV89/19 e LV4 e marca a ocorrência de biofácies submaré.

A interpretação do comportamento geral da curva de flutuação do nível do mar é suportada pelo tipo de biofácies presente, ou seja, da base para o topo as biofácies mostram condições cada vez mais restritivas do meio físico, com alta energia na base, diminuindo a partir da ocorrência da biofácies $V$.

A maior continentalidade na bacia lagunar se deu a aproximadamente $70 \mathrm{~cm}$ de profundidade quando o nível do mar estava a $-1,70 \pm 21 \mathrm{~cm}$, interpretado a partir da ocorrência da biofácies X e valor da razão isotópica de $\delta^{13} \mathrm{C}-11,37 \%$. No geral passou de um ambiente de 
litorâneo raso com comunicação marinha para condições restritas, com biofácies indicadoras de ambiente perimaré e dois hemiciclos intermaré-submaré, preservados nesta. 


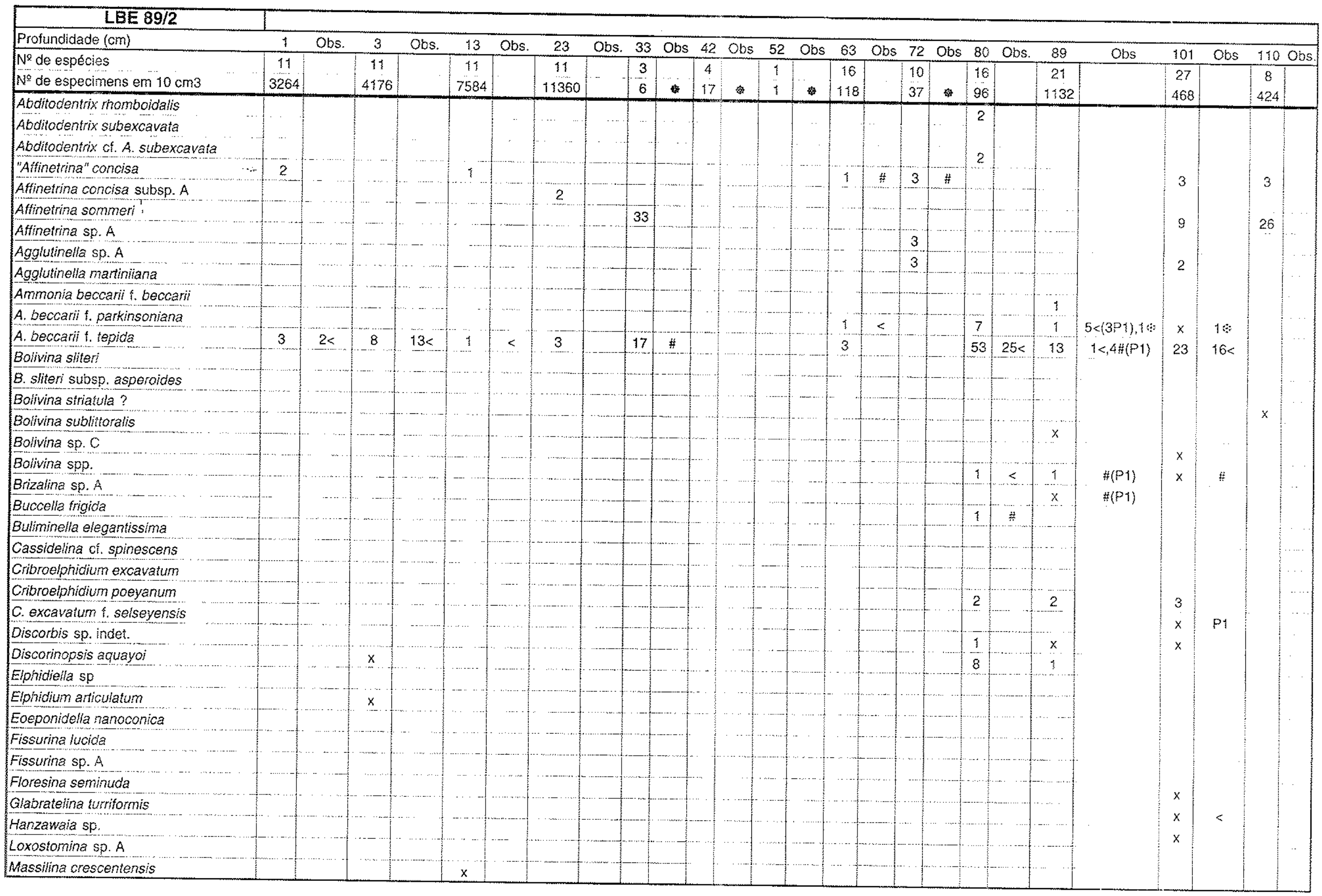




\begin{tabular}{|c|c|c|c|c|c|c|c|c|c|c|c|c|c|c|c|c|c|c|c|c|c|c|c|c|c|c|}
\hline Cont... LBE $89 / 2$ & 1 & Obs. & 3 & Obs. & 13 & Obs. & 23 & Obs. & 33 & Obs & 42 & Obs & 52 & Obs & 63 & Obs & 72 & Obs & 80 & Obs. & 89 & Obs & 101 & Obs & 110 & Obs. \\
\hline $\begin{array}{l}\text { Massilina protea } \\
\text { Miliolina sp. A }\end{array}$ & 1 & $1 \#, 19$ & & & 1 & $1 \%$ & $x$ & $2 *$ & & & & & & & & $\ldots$ & & & & & 7 & & 1 & & 8 & $4 \%$ \\
\hline Milolinella cf. M. antarctica & ${ }^{x}$ & & & & & & & $\ldots$. & $\cdots$ & & & & .. & & & . & & & $\ldots$ & & & & 1 & & 8 & \\
\hline Miliolinella hybrida & & & & & & & & & . & $\ldots .$. & & & & & & & & & & & $x$ & & & & & \\
\hline Miliolinella loeblichi & & & & & & & & & & $\cdots$ & & & & & 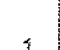 & & & . & & $\ldots$ & & & & & & \\
\hline Miliolinella subrotunda & $x$ & & $\ldots$ & & & & 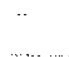 & & & & & & & & ? & & & $\ldots$ & & & & & & & & \\
\hline Miliolinella sp. A & & ...... & & & & & & & & & & & & & & & & & & & $\cdots \cdots \cdots$ & & $y$ & & & $\ldots$ \\
\hline Milolinella sp. C & 2 & & 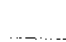 & & & & & & & & & & & & & & & & 1 & & 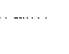 & & $x$ & & & \\
\hline Miliolinella sp. D & & & 2 & $\#$ & $x$ & & 5 & & & & & & & & 2 & & 3 & & & & . & & 1 & & & \\
\hline Neopateoris cumanaensis & & & & - . & $\ldots$ & & & & & & & & & & & & & & & & & & & & $x$ & \\
\hline Neospiroloculina sp.A & & & 2 & ..... & $x$ & & & & & & & & & & & & & 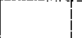 & & & 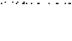 & & & & & \\
\hline Ophthalmina sp. A & & & & $\ldots$ & & & & & & & & & & & & & & 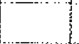 & & & 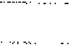 & & 3 & $k<$ & & \\
\hline Orbitina sp. & & & & & & & & & & & & & & & & & & & & & $x$ & & & & & \\
\hline Pseudotriloculina lecalvezae & 51 & & 51 & $\ldots$ & 85 & & 59 & & 50 & $1 \#$ & 24 & 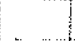 & & & 34 & & 32 & $1 \#$ & 6 & $1 \#$ & 24 & & 15 & $3<$ & 54 & \\
\hline Pseudotriloculina subgranulata & & & & & & & & & & & & & & & & & & & - & & & & $x$ & & & \\
\hline Quinqueloculina arctica & & & & & & & & & & & & 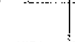 & & & & & & & 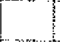 & & 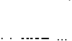 & & & & & \\
\hline Quinqueloculina atlantica & & & $\ldots$ & & & & - & & & & & .......... & & & 2 & & 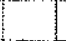 & & 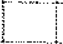 & & $\hat{i}$ & & $x$ & >\# & & \\
\hline Quinqueloculina australis? & & .. & ...... & $\ldots \ldots$ & $\ldots$ & $\ldots$ & ..... & & 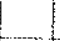 & & & - & & & & & 3 & $\#$ & & & 2 & & & & & \\
\hline Quinqueloculina dilatata? & & & & & $\ldots$ & & - & & & & & & & & 1 & & - & & ...... & & 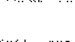 & & & & & \\
\hline Quinqueloculina fichteliana & & & & & & & $\ldots$ & & & & & & & & & & 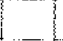 & & 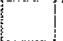 & & & & & & & $\cdots$ \\
\hline Quinqueloculina patagonica & 25 & & 17 & $10,1 \#$ & 8 & $1<$ & 16 & $1 a$ & & & 35 & & & & 11 & & 24 & 1 \# & 1 & & 29 & & 5 & & & \\
\hline Quinqueloculina poeyana & & & & ................. & & & 1 & & & & & & & & & & ..... & & $\ldots$ & & $\ldots$ & & & & & \\
\hline Quinqueloculina laevigata & & & 4 & $\ldots \ldots$ & & & 2 & & & & & & & & & & 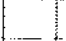 & & 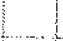 & & & & & & & \\
\hline Quinqueloculina milletti & 10 & & 2 & $\ldots . . . . .$. & 2 & & 5 & & & & 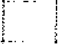 & & & & 5 & & 14 & $2 \#$ & 1 & $\cdots$ & & & & & & \\
\hline Quinqueloculina seminulum & 1 & & $\ldots$ & 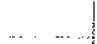 & 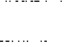 & $\ldots$ & & & & & & & & & 6 & & 3 & & 2 & $\ldots$ & 13 & & & & & \\
\hline Q. seminulum var jugosa & & & 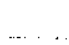 & $\ldots$ & $x$ & ... & & & & & & $\ldots$ & $\ldots$ & & & & & & .... & & $\ldots$ & & 1 & & & \\
\hline Quinqueloculina subpoeyana? & & & 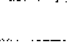 & $\ldots$ & & & & & & & & $\ldots$ & 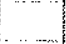 & & 1 & $>$ & & & & & & & & & & \\
\hline Q. venezuelaensis var. A & & & & & & & & & & & $\ldots$ & & & 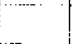 & & & & & & & $x$ & & & & & \\
\hline Rosalina candeiana & & & & & & & & & & & & & & & & & & & & & & & & & & \\
\hline Rosalina floricana & & & & & & & & & & & & & & & & & & & 1 & & $x$ & & & & & \\
\hline Rotalia sp. & & & & 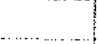 & & & & & & & 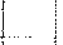 & & & $\ldots$ & 3 & $3<$ & & & 1 & $\#$ & & & & & & \\
\hline Triloculina asymmetrica & & $\ldots . .$. & & 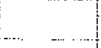 & & & & & & & & & & & 3 & & & & & & & & 2 & & & \\
\hline Triloculina fichteliana & & 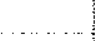 & &.$\ldots$ & & & & & & & 6 & $<$ & & & 2 & & & & & & $\ldots$ & & 1 & & & \\
\hline Triloculina gracilis & & & & & & & 5 & & & & & & & & & & & & & & 1 & & & & & \\
\hline Triloculina lutea & & & 2 & & $\ldots-\ldots$ & & & & & & & & & & & & 3 & \# & & & & & & & & \\
\hline Triloculina sidebottomi & & & & & & & & & & & & & & & & & & & & & & & & & 1 & \\
\hline Triloculina trigonula & & & & & & & 2 & & & & & & & & & & & & & & & & & & & \\
\hline Uvigerina sp. & & & & & & & & & & & & & & & & & & & & & & & & & & \\
\hline Varidentella implexa & 1 & & 2 & & $x$ & & & & & & 12 & & & & 1 & & & & & & 3 & & 1 & & & \\
\hline Varidentella implexa subsp. A & & & & & & & & & & & & & & & & & & & & & & & 3 & $2<$ & & \\
\hline
\end{tabular}




\begin{tabular}{|c|c|c|c|c|c|c|c|c|c|c|c|c|c|c|c|c|c|c|c|c|c|c|c|c|c|c|}
\hline Cont.. Prof. $(\mathrm{cm})$ & 1 & Obs. & 3 & Obs. & 13 & Obs. & 23 & Obs. & 33 & Obs & 42 & Obs & 52 & Obs & 63 & Obs & 72 & Obs & 80 & Obs. & 89 & Obs & 101 & Obs & 110 & Obs \\
\hline $\begin{array}{l}\text { Virgulopsoides sp. indet. } \\
\text { Miliolidios quebrados }\end{array}$ & 2 & $<$ & 8 & & $i$ & & 1 & $\ldots$. & & $\cdots$ & 24 & $\therefore$ & 100 & & 25 & & & & & & 2 & & 19 & $28 \# 16<$ & & \\
\hline $\begin{array}{l}\text { Rotaliina < indet. } \\
\text { OUTROS ORGANISMOS } \\
\text { Bivaive - Anomalocardia sp. }\end{array}$ & P1 & P2 & P1 & $\mathrm{P}_{2}$ & P1 & P2 & $P 1$ & P2 & $P !$ & P2 & $p_{1}$ & $P 2$ & P1 & P2 & Pi & P2 & $P 1$ & P2 & 8 & P2 & $p_{1}$ & P2 & $P_{1}$ & P2 & Pf & P2 \\
\hline $\begin{array}{l}\text { Bivalve - Anomalocardia sp. } \\
\text { Carbfitas -Chara sp. }\end{array}$ & 4 & & 2 & & 26 & 4 & 10 & ...... & & & & & & $\ldots .$. & 2 & & & & & & & & $? 1 ?$ & & & \\
\hline Diatomáceas & & & $\ldots$ & & & & & & & & & & & & & & & 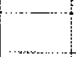 & 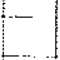 & & & & & & & \\
\hline Gastropode -Heleobia sp. & & 5 & & 2 & & 1 & & 4 & & & & $\ldots$ & & & & & - & 1 & & & & & & & & \\
\hline Hydrobia sp. & 23 & & 11 & & 55 & 4 & 31 & & & & & & & ..... & & & & & & & 3 & & & & 1 & \\
\hline Pleurotomaria??? & & & & 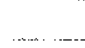 & & & & & & & & & & 䇚敒敒 & $\ldots$ & & & & & & & & & & & \\
\hline Sayella aff. crosseana & & & & & & & & & & & & & & & & & & & & & & & 2 & & & \\
\hline Ostracoda-Cyprideis salebrosa & 12 & 3 & & 2 & & 24 & 9 & & & & & 4 & & & & 4 & & 1 & 2 & & & & $? 3 ?$ & & 1 & 1 \\
\hline Loxoconcha paranensis & 8 & & 3 & & 45 & 2 & 5 & & & & & & & & & & & & 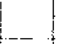 & & & & 1 & & & \\
\hline Perissocytheridea of. P. krömmelbeini & & 4 & & 4 & & & 9 & & & & & & & & & & & & & & & & & & & \\
\hline Poliqueta -Mandibula de Neritidae & & & & & & & & & & & & & & 1 & & & & & & & & & & & & \\
\hline
\end{tabular}

Tab.30- Ocorrência de foraminíferos e outros organismos ao longo do testemunho LBE 89/2. Os números são dados em porcentagem e número total de espécies e espécimens em $10 \mathrm{cc}$ por amostra, $x$ indica menos que $1 \%$. Para os outros organismos presentes não foi efetuado cálculo de porcentagem e não estão incluídos nà contagem do número de espécies nem de indivíduos relativa aos foraminíferos. Os números e símbolos apresentados na coluna observações, referem-se a "x" número de indivíduos que apresentam determinada característica tafonômica. Tais números são considerados na contagem do número de exemplares. A simbologia lisada é a mesma das amostragens de superfície, sendo a seguinte: * = presença não quantificada, \#= exemplar quebrado, $=$ exemplar teratológico, m $=$ exemplar fóssil; $*=$ exemplar de geração microsférica (Elphidium); colônia de diatomáceas, =exemplar com diatomáceas epizóicas, $=$ ostracoda reticulado, $\eta_{\circ}=$ ostracoda com nódulo, $\Omega=$ exemplar bioerodido, $\Theta=$ exempla muito convexo, $\sigma=$ exemplares grudados, geralmente um vivo outro morto, amostras com muito sal; a abundante, $\mathrm{r}=\mathrm{raro}, \mathrm{P} 1=$ peneira de malha $0,0500 \mathrm{~mm}$ e P2 = peneira de malha $0,062 \mathrm{~mm}$. Amostras estéreis são consideradas quando estão ausentes foraminiferos em ambas as peneiras e correspondem aos seguintes intervalos: $250-252,260-262,270-273,281-283,330-335,340-342,350-355,355-360$ 


\begin{tabular}{|c|c|c|c|c|c|c|c|c|c|c|c|c|c|c|c|c|c|c|c|c|c|c|c|c|c|c|c|c|c|c|c|c|}
\hline LEE B9/2 & & & & & & & & & & & & & & & & & & & & & & & & & & & & & & & & \\
\hline Profundidade $(\mathrm{cm})$ & 120 & Obs. & 130 & Obs. & 140 & Obs & $\{48$ & Obs & 160 & Obs. & 170 & Obs. & 181 & Obs. & 191 & Obs & 201 & Obs & 211 & Obs. & .223 & Obs & 233 & Obs. & 241 & Obs. & 291 & Obs & 3000 & Obs & 3230 & Obs \\
\hline № de espécies & 10 & & 13 & & 16 & & 27 & & 1 & & 13 & & 16 & & 19 & & 9 & & 7 & & 3 & & 20 & & 22 & & 2 & & 5 & & $9 /$ & \\
\hline № de especimens em $10 \mathrm{~cm} 3$ & 614 & & 1264 & & 1344 & & 336 & & 4 & & 236 & & 272 & & 1004 & & 49 & & 31 & & 12 & & 242 & & 436 & $a<$ & 4 & & 312 & & 98 & \\
\hline Abditodentrix momboidalis & & & & & & & & & & & & & & & & & & & & & & & & & & & & & & & & \\
\hline $\begin{array}{l}\text { Abditodentrix subexcavata } \\
\text { Abditodentrix cf. A. subexcavata: }\end{array}$ & & & & & & & 1 & & & & & & 2 & & & & & & & & & & & & $i$ & & & & & & & \\
\hline "Abditodentrix af A. subexcavata : & & & & & & & & & & & $x$ & & & & $x$ & & & & & & & & & & 1 & & & & & & & \\
\hline "Affinetrina" concisa & $3 \cdots$ & & 4 & & 1 & & 1. & & & & & & & & & & & & & & & & & & & & & & & & & \\
\hline Affinetrina concisa subsp. A & & & & & & & & & & & & & & & & & & & & & & & & & $x$ & & & & & & & \\
\hline Affinetrina sommeri & 11 & & 7 & & 5 & & 26 & & & & & & $x$ & & & & & & & & & & & & & & & & & & & \\
\hline Affinetrina $\mathrm{sp} . \mathrm{A}$ & & & & & & & & & & & & & & & & & & & & & & & & & & & & & & & & \\
\hline Agglutinella sp. A & & & & & & & 1 & .... & & & & & & & & & & & & & & & & & & & & & & & & \\
\hline Agglutinella martiniana & & & & & ...... & & 2 & & & & & & & & & & & & & & & & & & & & & & & & & \\
\hline Ammonia beccarii t. beccarii & & & & & & & $i$ & \# & & & & & 1 & & 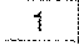 & & 12 & & & & 17 & & 4 & & 1 & & & & 2 & & 3 & \\
\hline A. beccarii f parkinsoniana & & & & & & & 11 & $13<$ & 100 & $<$ & 14 & $23<$ & 20 & $31<4$ & 4 & $1<$ & 29 & $1<$ & 19 & & 17 & $1<, 1$, & 18 & $|30<1 \mathrm{a}|$ & 2 & $4<$ & & & 10 & $3<$ & 16 & $2<$ \\
\hline A. beccarii f tepida & & & 1 & & & & 2 & & & & 8 & 9\# & $x$ & & 10 & 3P & 14 & & 13 & $\#$ & 67 & $3 \#$ & 14 & & 2 & & 25 & $\therefore$ & 28 & 54 & 62 & i \\
\hline Bolivina sliteri & & & & $\ldots$ & & $\ldots . .$. & . & & & & & & & & 2 & & & & & & & & 7 & & 5 & & & & & & & \\
\hline B. sliteri subsp. asperoides & & & & & & & & & & & & & & & - & & & & & & & & 1 & 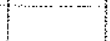 & & & & & & & & \\
\hline Bolivina striatula? & & & & & & & 1 & & & & & & & & . & & & & & & & & & & & & & & & & .. & \\
\hline Bolivina sublittoralis & & & & & $\ldots$ & $\ldots$ & & & & & 5 & & & & & & & & 6 & $\#$ & & & 4 & & 4 & & & & & & & \\
\hline Bolivina sp. C & & & ............ & & 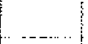 & 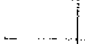 & 1 & $\#$ & & & & & $x$ & & & & & & & & & & & & & & & & & & & \\
\hline Bolivina spp. & & & & & $\ldots$ & $\ldots$ &. & & & & & & 1 & 专 & & & 2 & $\#$ & & & & $\ldots$ & 5 & \# & 3 & & & & & & & \\
\hline Brizalina sp. A & & & & & $\ldots$ & 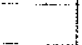 & & _ & & & & & & & $x$ & & & & & & & 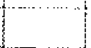 & & & & & & & & & $i$ & \\
\hline Buccella frigida & & & & & & & $\xi$ & & & & & & & & & & & & & & & & & & & & & & & & & \\
\hline Buliminella elegantissima & & & & & 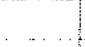 & $\ldots \ldots$ & & & & & 1 & & & & 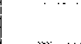 & & 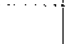 & & & & & $\ldots$ & 1 & & & & & & & & & \\
\hline Cassideina cf. spinescens & & & & & & & & & & & & & & & $\underline{x}$ & & ........ & & & & & $\ldots$ & & & & & & & & & & \\
\hline Cribroelphidium excavatum & & & & & & & & & & & & & 12 & & $\overline{2}$ & & 8 & & 16 & & & & & 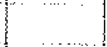 & 3 & 3非 & & & 2 & & & \\
\hline Cribroelphidium poeyanum & & & & & & & 1 & & & & 8 & & 8 & & 24 & $2 P_{1}$ & 10 & & 10 & & & & 4 & $1<$ & 27 & & & & & & 4 & $1 \#$ \\
\hline C. excavatum f. selseyensis & & & & & $\ldots$ & & & & & & 39 & & 39 & $49<4$ & 45 & $5 \mathrm{P} 1$ & 14 & & 32 & & & & 5 & . & 30 & $8<$ & 75 & 3 & 58 & & 3 & \\
\hline Discorbis sp. indet. & & & & & & & $\ldots$ & & & & & & & & & & & & & & & & & & & & & & & & & \\
\hline Discorinopsis aquayol & & & & & & & & & & & & & & & & & & & & & & & & .. .. & & & & & & & & \\
\hline Elphidiella sp & & & & & & & $\ldots$ & & & & 2 & & 6 & & 2 & & 2 & & & & & & & & 1 & & & & & & 1 & \\
\hline Elphidium articulatum & & & & & & & & & & & 15 & & 7 & & 3 & & 8 & & 3 & & & & 2 & & 12 & & & & & & 4 & \\
\hline Eoeponidella nanoconica & & & & & & & & & & & 3 & & 1 & $<$ & $x$ & & & & & & & & & & & & & & & & & \\
\hline Fissurina lucida & & & & & & & & & & & 2 & & & & & & & & & & & & & & & & & & & & & \\
\hline Fissurina sp. A & & & & & & & & & & & 3 & & & & & & & & & & & & & & & & & & & & & \\
\hline Floresina seminuda & & & & & & & 1 & & & & & & & & & & & & & & & & & & & & & & & & & \\
\hline Glabratelina turriformis & & & & & & & & & & & & & & & 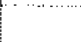 & & & & & & & & & & & & & & & & & \\
\hline Hanzawaia sp. & & & & & & & & & & & & & & & - & & & & & & & & & & & & & & & & & \\
\hline Loxostomina sp. A & & & & & & & & & & & & & & & & & & & & & & & & & 1 & & & & & & & \\
\hline Massilina crescentensis & & & & & & & & & & & & & & & & & & & & & & & & & & & & & & & & \\
\hline
\end{tabular}




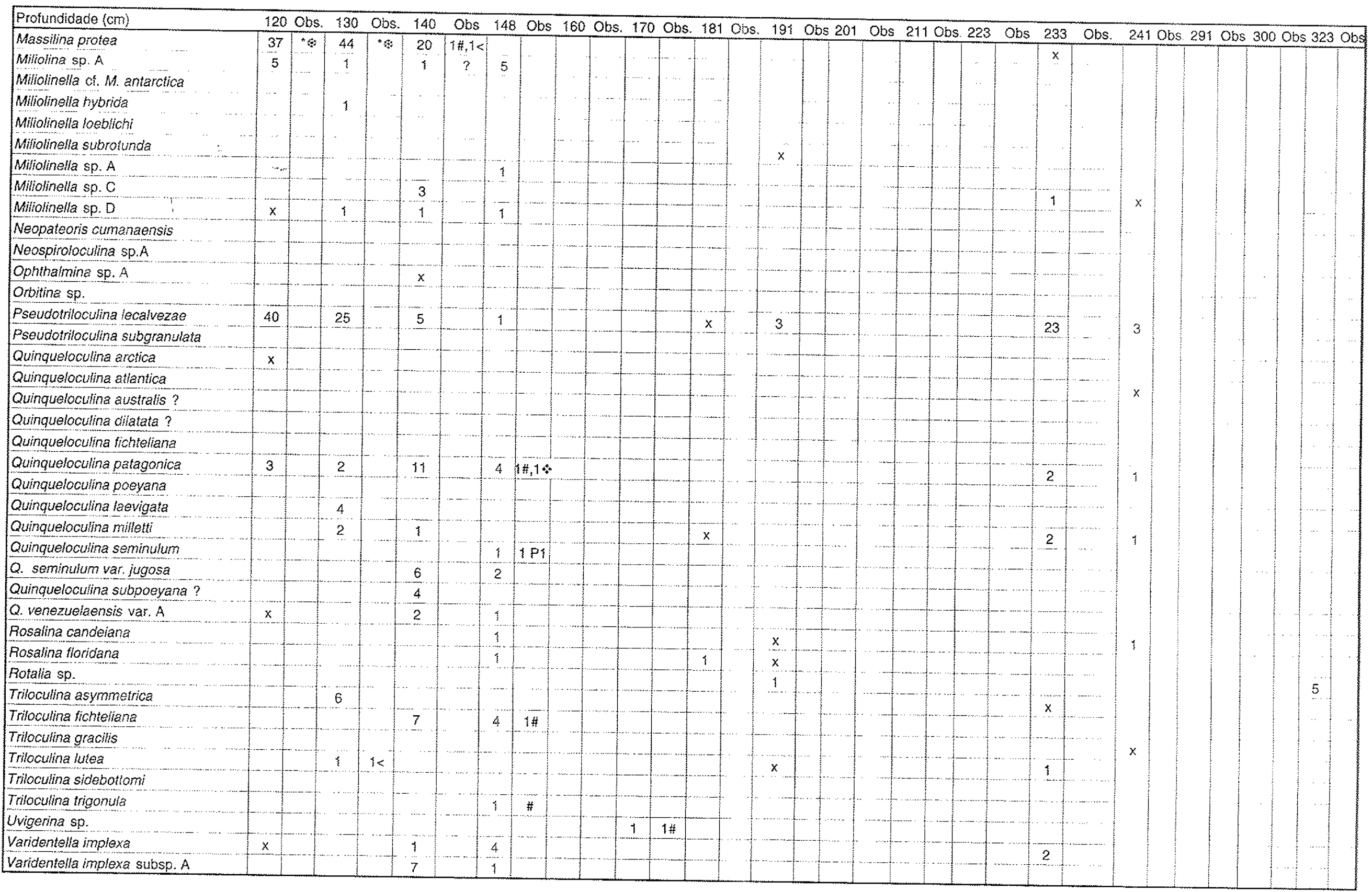




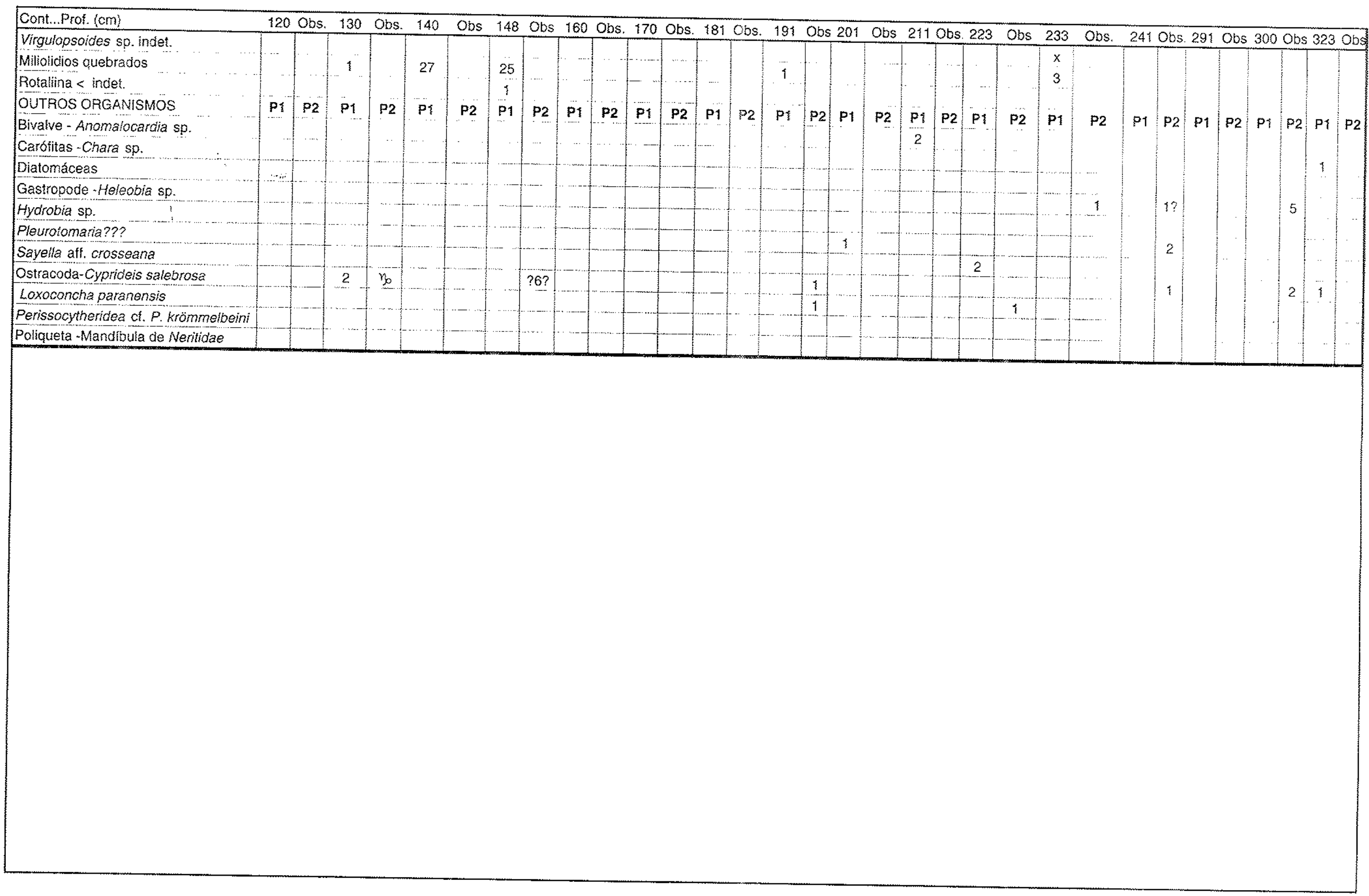




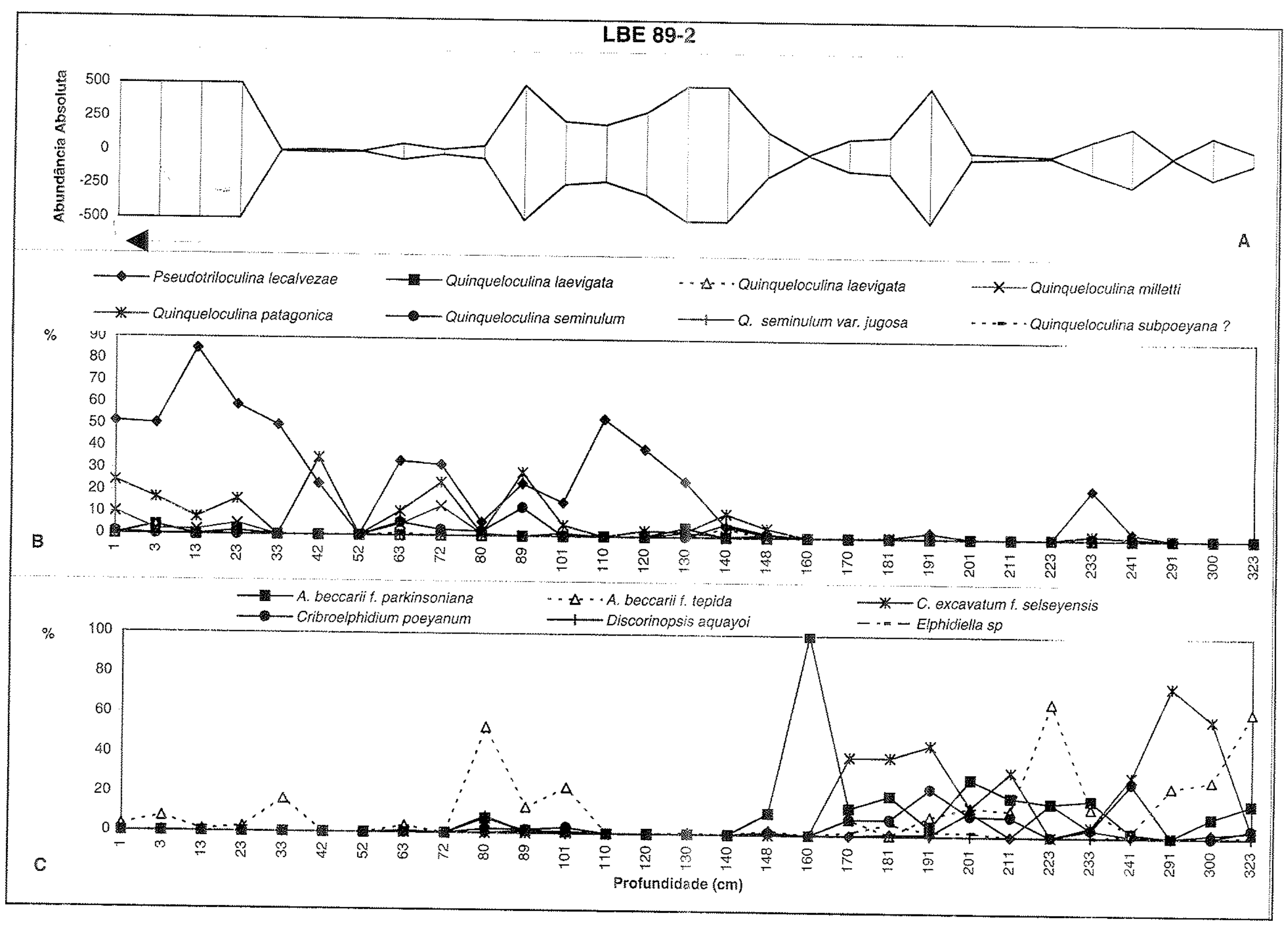




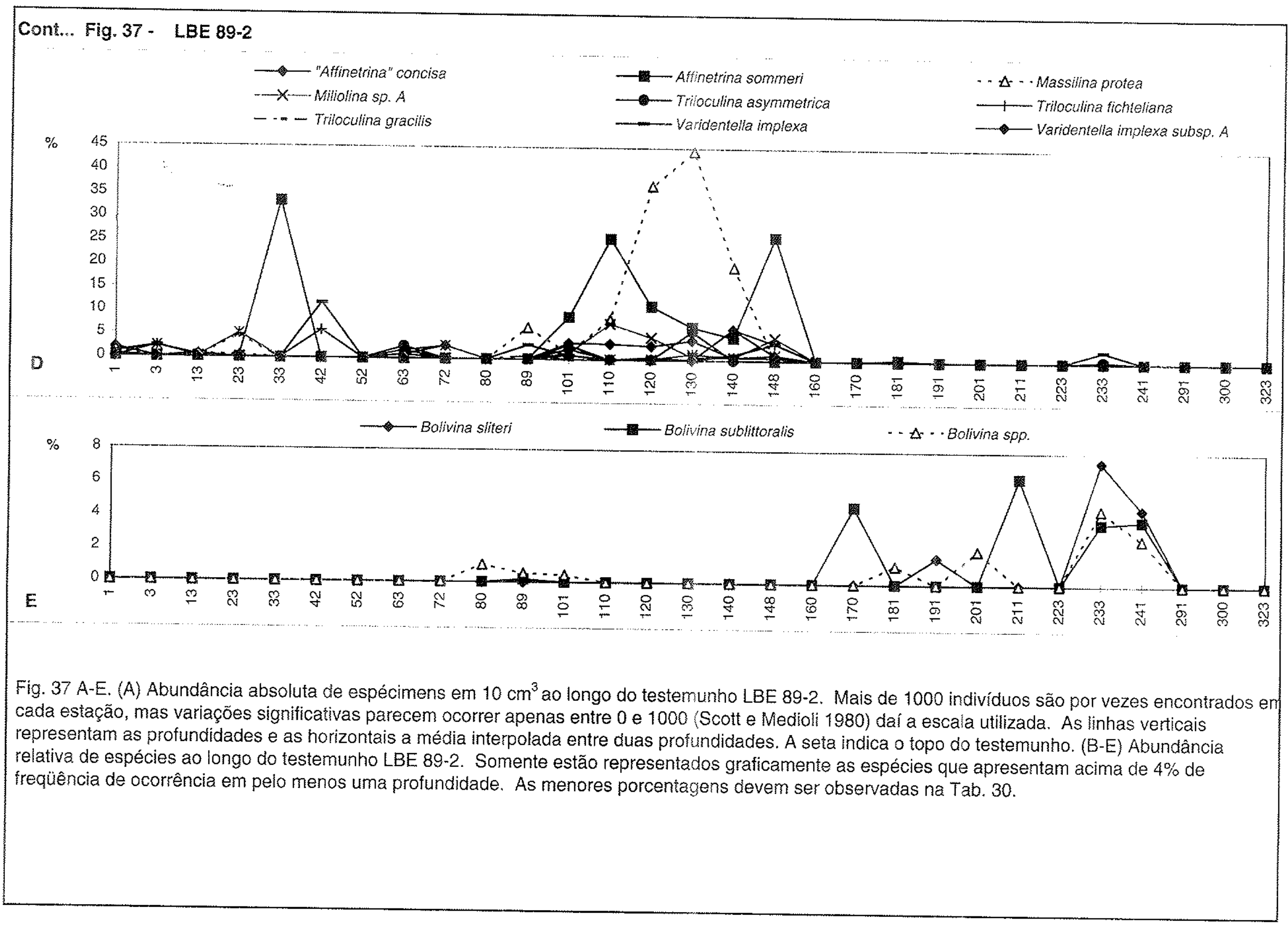




\section{LBE 89-2}

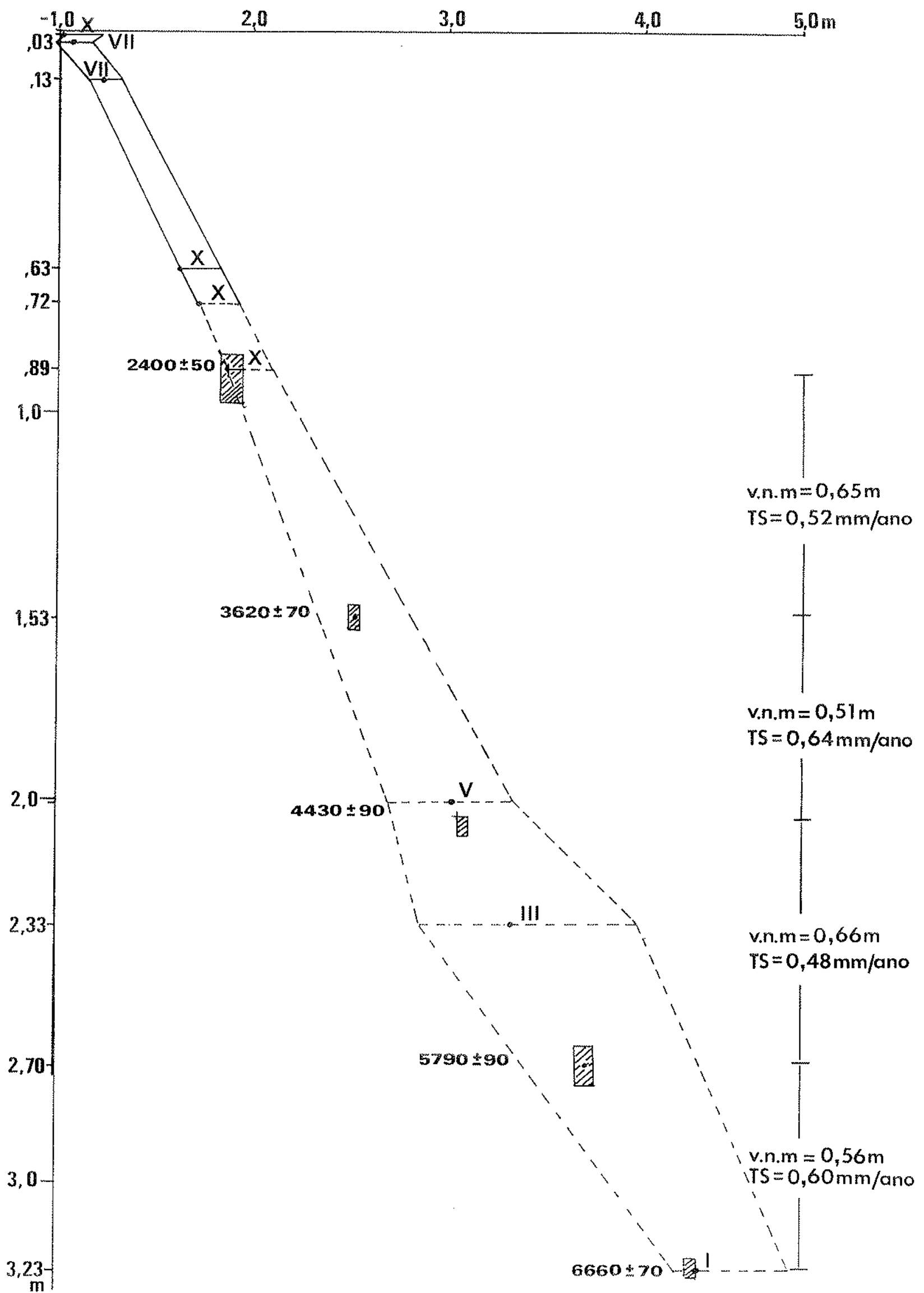

Fig. 40 - Curva de variação do nível relativo do mar para a região de Cabo frío com base em biofácies de foraminíferos definidas no testemunho LBE 89-2 da Lagoa Brejo do Espinho. A área hachurada corresponde a amostra de datação de radiocarbono e a cruz ao ponto tomado como medida: os números em romanos indicam as biofácies; e os circulos pretos indicam o nivel médio do mar. TS = taxa de sedimentação e v.n.m :- variação do nivel relativo do mar. A curva inicia-se à profundidade de $1,00 \mathrm{~m}$, fundo da lagoa na época da amostragem. O eixo x representa a variação do nivel relativo do mar e o eixo y a profundidade no testemunho 


\section{CAPÍTULO 6}

\section{6 - INTERPRETAÇÕES E DISCUSSÃO}

Esta porção da costa do Rio de Janeiro apresenta-se particularmente interessante em termos de estudos microfamnísticos devido a grande diversificação físico-química dos ecossistemas em curto espaço, a grande intensidade da produtividade bentônica na laguna de Araruama e Lagoas Vermelha e Brejo do Espinho, a ocorrência de corrente de ressurgência de águas frias, hipossalinas e ricas em nutrientes, na região costeira adjacente, e ao clima semi-árido (representativo de $67 \%$ das áreas costeiras brasileiras).

Inicialmente serão tratados todos os resultados das amostragens atuais e de que forma estes definiram bioindicadores.

Pela primeira vez, com este estudo é registrada a ocorrência de foraminíferos aglutinantes representados pelas espécies $H$. wilberti e $T$. inflata na bioecozona pós-lagunar de ambientes hipersalinos e mixohalinos aqui tratados. Estes, reforçam os resultados de Barbosa (1991), onde, estas mesmas espécies ocorrem ern áreas supramaré dos manguezais no sul do Brasil. A. diferença é que no caso atual, as porcentagens são baixas, embora caracterizem-se algumas vezes com as únicas espécies viventes nesta bioecozona. O baixo potencial de preservação desses organismos faz com que seu uso em análises biofaciológicas e de subsuperfície seja bastante limitado, pelo menos nas áreas de antigas planícies de maré.

A área hipersalina de Mustang Island, no Texas (Williams 1994), e a planície deltáica do Mississippi (Scott et al. 1991), também apresentam zoneamentos representativos de condições submersas, de grande amplitude devido a baixa amplitude de maré e baixo conteúdo orgânico nos sedimentos. Devido ao baixo potencial de preservação dos foraminíferos aglutinantes em sedimentos de subsuperfície, procurou se buscar o zoneamento a partir das faunas bentônicas carbonáticas das bordas lagunares, que são mundialmente pouco estudadas apesar de apresentarem bom potencial de preservação.

Isto só foi possível a partir do refinamento taxonômico obtido neste estudo, poisassembléias carbonáticas que marcam bioecozonas de ambientes transicionais hipersalinos não foram obtidas mundialmente até o momento, talvez devido a tendência atual para análise de morfogrupos e tratamento genérico dos organismos, onde muitas vezes estes são definidos simplesmente como miliolídeos, ou erroneamente classificados como Quinqueloculina seminulum. A classificação em nível específico da subordem Miliolina é complexa, exigindo tempo e auxílio de microscopia eletrônica.O zoneamento de foraminíferos calcários, embora 
mais representativos de condições submersas do que de planícies de maré ou bioecozonas póslagunares, também mostram tendências interessantes, como a ocorrência de $D$. aquayoi, Agglutinela matiniiana, Agglutinella sp. A e T. lutea como marcadores das zonas emersas e bordas lagunares, e mais ainda, com pequena amplitude vertical e excelente potencial de preservação em subsuperfície. Deve-se ressaltar no entanto, que estes bioindicadores são representativos das lagoas Vermelha e Brejo do Espinho onde foram observados principalmente no verão, sob condições de exposição pronunciada da fácies intermaré e domínio de tapete algálico microbial. $\mathrm{O}$ gênero Agglutinella, vivente no ambiente atual e no registro dos testemunhos, mostra recobrimento carbonático secundário da teca (Estampa 3, Figs. 3-9).

Na sabkha Brejo do Espinho, além de foraminíferos, foram observadas carófitas na superfície atual e imediatamente abaixo do topo do testemunho. Esta ocorrência é curiosa, considerando-se ambientes hipersalinos dessa magnitude, estando certamente associada aos momentos de cheia pluvial.

Na lagoa de Jacarepiá ocorrem tecamebas e foraminíferos aglutinantes com tecas orgânicas e outros com aglutinação de material muito grosso marcando a zona de água alta.

$\mathrm{Na}$ laguna de Araruama a zona supramaré, atingida nos momentos de cheia lagunar, é marcada por Haplophragmoides wilberti. Como essa espécie é típica de ambientes mixohalinos, confirma-se a influência pluvial e fluvial no zoneamento desse ambiente lagunar hipersalino. Em momentos de cheia lagunar a água doce flui acima das águas hipersalinas, favorecendo a ocorrência dessa espécie aglutinante, com representantes vivos na zona supramaré. Entretanto o condicionamento a baixas salinidades não pode ser isolado como único fator que explica a ocorrência de Haplophragmoides wilberti na zona supramaré, uma vez que esta se encontra posicionada nesta mesma zona em praticamente todas as seções lagunares analisadas neste estudo, independente da salinidade predominante. Dessa forma, o potencial de resolução para o zoneamento da laguna de Araruama está na definição de biofácies submaré e intermaré inferior, devido a grande produtividade bentônica do fundo lagunar e baixo potencial de preservação de H. wilberti.

A laguna de Saquarema é o único dentre os ambientes analisados, com características hidrológicas essencialmente mixohalinas e manguezais esparsamente distribuídos em sua borda e, de maneira análoga à laguna de Araruama, apresenta ocorrência de H. wilberti marcando a zona supramaré. Estes são altamente adaptados às condições de rápida alternância entre águas doces e mixohalinas, ou até hipersalinas como em Araruama, onde também ocorrem na bioecozona supramaré. Infelizmente, testemunhos de Araruama e Saquarema não foram estudados e representantes dessa espécie preservados em subsuperfície não são conhecidos. 
Provavelmente as condições de pH levariam à corrosão e destruição das tecas aglutinantes, típicas das zonas supramaré e baixas salinidades desses ambientes.

Foram também observados nas bordas da laguna de Araruama, associadas ao conteúdo biótico, micro-concreções $(50 \mu \mathrm{m})$ de cálcio e magnésio epifitadas por diatomáceas, como ilustrado na estampa 21, figs. 1 6; assim como pelotas siliciclásticas (neste caso sem diatomáceas) para a Laguna de Saquarema e Lagoa de Jacarepiá (Estampa 21, figs. 10-12). Aparentemente não há registro destes tipos de micro-concreções ou pelotas na literatura, como confirmado por P. Mallock-Muller e J. Lee (comunicação pessoal).

Quanto às diatomáceas epizóicas nas carapaças de foraminíferos, sabe-se que os foraminíferos comem diatomáceas e alguns parecem cultivá-las ao redor das aberturas, antes de serem ingeridas. Na verdade, diatomáceas epizóicas foram observadas sobre tecas vivas e mortas. Nas tecas mortas, parecem corresponder à habitat para fixação dessas microalgas. O enriquecimento de frústulas de diatomáceas sobre tecas de foraminíferos também pode corresponder a escudos contra a dissolução.

\section{1 - Interpretação Paleoambiental e das Flutuações do Nível do Mar}

A associação de fácies será interpretada e discutida com base em todos os dados analisados, da base para o topo dos testemunhos LV89/19, LV4, e LBE89-2, corroborados pelo zoneamento atual nas superfícies das bordas lagunares.

Os indicadores das condições químicas dos ambientes à época de sua formação, tais como razões isotópicas de oxigênio e carbono, permitem algumas inferências sobre a variação no nível do mar. As razões isotópicas foram medidas para o carbonato total, que apesar de envolver diferentes tipos carbonáticos, tem demonstrado respostas consistentes (Azevedo 1995). Dados geoquímicos referentes ao carbono orgânico total (C.O.T.), nitrogênio total, concentração de $\mathrm{CaCO}_{3}$ e matéria orgânica, são significativamente relacionados com a produtividade biológica, devido a remoção de $\mathrm{CO}_{2}$ e aumento da concentração principalmente do carbonato total. Os foraminíferos definem fatores ambientais específicos, pois a diversidade e abundância são bons indicadores da "saúde" da fábrica carbonática, por fornecerem informações sobre a consistência do substrato e circulação da água, principalmente para o caso de lagunas restritas, com salinidades altas. Outros organismos poderão ser incorporados na análise na medida em que mostrem sinais para a interpretação paleoambiental. 
Os testemunhos LV89/19, LV4,e LBE89-2 aparentemente registram cinco fases evolutivas:

\section{FASE I}

Da base a 2,85m: Sugere ocorrência de um litoral com praia e instalação de um meio lagunar. Os testemunhos LV4 e LBE89-2 nesta profundidade, registram uma vasta baía, protegida, relativamente rasa, com sedimentos de lama orgânica arenosa escura, sob domínio de $A$. beccarii spp e C. excavatum f. selseyensis (biofácies I). Bivalves, gastrópodes e ostracodes com ocorrência menos expressiva, colonizaram este meio onde havia entrada de âgua doce que permitia a ocupação por Ammonia beccarii f. parkinsoniana. A alta relação $\mathrm{C} / \mathrm{N}$ sugere influência de vegetais superiores em seus arredores.

As datações de conchas neste intervalo indicam idades de $6.660 \pm 70$ e $7.170 \pm 110$ na sabka Brejo do Espinho e de $6530 \pm 100$ na Lagoa Vermelha, mostrando que a laguna e alguma barreira externa que fornecia a proteção indicada, já existia antes de 6.000 anos (Martin e Flexor 1989).

Muđanças alogênicas (Kidwell e Jablonski 1983) estão expressas neste intervalo, e referem-se a processos físicos como determinantes das mudanças na comunidade. Podem estar relacionadas ao baixo potencial de preservação dos foraminíferos carbonáticos na litofácies lama orgânica arenosa, devido a oxidação das tecas e intensidade de processos físicos (com a preservação somente das tecas mais resistentes). Praticamente todas as espécies analisadas possuiam tecas quebradas, teratológicas e pequenas. A grande quantidade de tecas pequenas, juvenis, indica período de sobrevivência prolongada e reprodução favorável à espécie Ammonia beccarii. A temperatura tem sido apontada como uma variável importante na reprodução dessa espécie, podendo ocorrer por aclimatação, em culturas de laboratório, a temperaturas de 17 a 25 ${ }^{\circ} \mathrm{C}$ (Schnitker comunicação escrita in Walton e Sloan 1990).

Estágios ontogenéticos de Ammonia spp. (Estampa 17), encontrados em abundância na base do testemunho, são facilmente confundidos em lupa com foraminíferos plantônicos que, se encontrados, sugerem condições ambientais bem diferentes, em ambiente de plataforma aberta ou sob ação intensa de correntes oceânicas. Talvez os foraminíferos plantônicos interpretados por Rodrigues et al. (1981) em testemunhos das lagoas Salgada e das Ostras e por Madeira e Carvalho (1992) na Lagoa de Araruama näo correspondam a Globigerina sp. e sim à estes estágios ontogênicos de Ammonia spp. 
O sedimento arenoso na base do testemunho LBE, impregnado por ácido húmico, corresponde a Fm. Cananéia que aflora nos Estados de São Paulo e Paraná e no delta do rio Paraíba do Sul. Provavelmente essa variação na continuidade lateral pode refletir diferentes intensidades de atuação de processos erosivos, como também a heterogeneidade lateral na morfologia costeira e da plataforma.

Os resultados isotópicos de oxigênio e carbono no testemunho LV4 (Fig. 32B), e LBE (Fig. 33B) apresentam comportamento análogo, os quais mostram a tendência de aumento da temperatura expressos na razão $\delta^{18} \mathrm{O}$ e aumento da influência oceânica da base ao fim desta fase. Esta passagen de valores negativos para valores positivos na razão $\delta^{18} \mathrm{O}$, pode näo necessariamente ilustrar uma variação de temperatura, por corresponder a um período climático interglacial, mas podem ser interpretados em termos de variação de salinidade (Pratt 1984) ou mudanças de temperatura na água de superfície.

\section{FASE II}

De $2,85 \mathrm{~m}$ a $1,60 \mathrm{~m}$. A laguna se instala definitivamente e os aportes de água doce amenizam a salinidade, distinguindo-se duas etapas: de $2,85 \mathrm{~m}$ a $2,65 \mathrm{~m}$ a assembléia de $A$. beccarii $f$. parkinsoniana aumenta significativamente sua freqüência suplantando à $A$. beccarii f. tepida. De 2,65m a 2,13m em LV4, ocorre a dominância do gênero Cribroelphidium spp. e Bolivina spp. Essa fase apresenta maior espessura em LBE, (até 1,60m), com sedimentação de lama orgânica, ocorrência de alguns níveis arenosos do espessura variável e predomínio das mesmas espécies.

Esta fase é datada em $5.790 \pm 90$ para a base na LBE e $5.180 \pm 70$ e $4320 \pm 100$ para o final na lagoa Vermelha.

Os altos índices de matéria orgânica gerando anoxia e laminações escuras na laguna são corroborados pela ocorrência de diferentes espécies de Bolivina spp. com tecas apresentando poros grandes e riqueza de ornamentação, bem como Ammonia spp e Cribroelphidium excavatum $\mathrm{f}$. selseyensis. Corresponde a um período de alternância com deposição siliciclástica variável e os picos máximos estreitos e distintos na curva de carbonato (Figs. 32Ae 33A), e valores mínimos amplos e cêncavos, o que indica alta diluição terrígena devido a ampla espessura da camada pobremente carbonática.

A litofácies de conchas fragmentadas(4) em LBE, limitada por contato erosivo na base, expressa uma concentração em momento de alta energia, sob condições erosivas de transgressão e ausência de suprimento sedimentar (sediment starvation). A abrasão mecânica pode reduzir 
significativamente a preservação de espécimens de foraminíferos, como a observada atualmente nas zonas de arrebentação da laguna de Araruama. Esta litofácies é marcada pela ocorrência de infauna de C. excavatum f. selseyensis, A. beccarii e Bolivina sublittoralis. A concentração de conchas durante eventos erosivos são derivadas segundo Kidwell e Jablonski (1983) de: 1) exumação de material previamente enterrado; 2) produção biológica in situ, contemporânea a erosão e 3) distribuição de partes duras alóctones de áreas adjacentes. De uma forma geral essas acumulações conchíferas caracterizam margens de água rasa de bacias onde ocorrem ciclos transgressivos-regressivos. O controle com a datação de radiocarbono e ausência de conchas em posição de vida sugerem o terceiro fator como explicátivo da ocorrência na área de estudo.

De fato, há evidência através da razão isotópica de $\delta^{13} \mathrm{C}$ de maior influência oceânica na bacia lagunar, cuja finalização da deposição conchífera está em 4.430 anos A.P. O índice de sedimentação na LBE mostra o menor valor de todo o testemunho neste momento. Espécies com menor frequiência de ocorrência, representadas por Globocassidulina subglobosa, Brizalina sp. A, Abditodentrix rhomboidalis e Bolivina sliteri subsp. asperoides (Fig. 36 F-H), apesar de estatisticamente insignificantes, sugerem maior profundidade na bacia lagunar e corroboram a diéia de momento transgressivo nesta fase, com ápice em $213-245 \mathrm{~cm}$, ou seja, 5.180 anos A.P. em LV4 e em LBE, marcada pela discontinuidade erosiva na base da mais espessa fácies de conchas..

\section{FASE III}

De $1,60 \mathrm{~m}$ a $0,80 \mathrm{~m}$.É marcada pela ocorrência de nódulos carbonáticos, relacionados a saturação carbonática da água do mar na zona intermaré e supramaré, típica de planícies costeiras sob regime semi-árido. Tais concreções de carbonato ocorrem geralmente em camadas distintas e como resultado da cimentação apresentam alto conteúdo de carbonato. Os valores isotópicos de ${ }^{13} \mathrm{C}$ muito negativos sugerem grande influência continental, possivelmente sob condições de erosão e redeposição. É evidente nesta fase a mudança na propriedade física e química da água, bem como sua profundidade e energia, pois os sedimentos passam de fácies submaré para intermaré, como corroborado pela mesma tendência em relação as biofácies em LV4. A grande lacuna de interpretação biofaciológica nesta fase em LBE, não permite afirmar o mesmo para este testemunho. A chamada de lama concrecional pode corresponder à estruturas em forma de montículos (mound-like struciures, Höhn et al. 1986) referidas por Vasconcelos (1988) como sendo estromatolitos na Lagoa Vermelha. Desenvolvem tapetes algálicos em sua volta, de mesma composição dos tapetes peliculares da borda, e, de acordo com os primeiros autores, consistem 
de raízes de Acrosticum aureum. Podem estar representados nos testemunhos a profundidades de 0,82-0,92m em LV89/19 e 1,00-1,10m em LV4. Possivelmente a mesma estrutura ocorre em LBE $(0,59-0,65 \mathrm{~m}$ e $0,70-0,77 \mathrm{~m}$.

Esta fase corresponde a uma associação de fácies perimaré a partir da camada transgressiva na base, mostrando em sua evolução faciológica, condições lagunares progressivamente mais rasas (shallowing upward), culminando com planície de maré e paleossolo, capeador desta sucessão perimaré em $L V 4$ a $114 \mathrm{~cm}$ (2.340 190 años A.P.). A razão isotópica do $\delta^{13} \mathrm{C}$ entre $98-146 \mathrm{~cm}$ em LV4 (Fig. 32B) e a $70 \mathrm{~cm}$ em LBE (Fig. 33B), apresentam valores muito negativos, indicativos de uma maior continentalidade na bacia lagunar, com allta produtividade orgânica, expressa também nos gráficos de abundância absoluta para esta fase. A lâmina delgada (E) mostra exposição subárea com gretas de ressecação.

Estas feições mostram que houve nesta fase uma queda do nível do mar. No entanto esta queda não parece ter sido brusca por não ter erodido as várias fácies previamente depositadas.

Três ritmos expressam diferentes input deposicionais que podem ser diferenciados pela variação nas curvas do $\mathrm{CaCO}_{3}$ e C.O.T. O primeiro, na base, entre 1,60-1,48cm, (Figs. $32 \mathrm{~A} \mathrm{e}$ 33A) corresponde a alternâncias com deposição silicática variável, com o máximo da curva de carbonato estreito e distinto e o mínimo amplo e côncavo. Neste momento a diluição terrígena do carbonato é grande e seu conteúdo ainda é pequeno. O segundo tipo, corresponde a deposição de carbonato variável, quando a curva de carbonato tem valores máximos amplos, convexos e valores nas camadas mínimas côncavos e estreitos, devido ao maior índice de sedimentação e acréscimo carbonático nas camadas mais ricas. A $81 \mathrm{~cm}$ parece haver uma alternância, com deposição de matéria organica variável, com o conteúdo de carbonato afetado pela quantidade de matéria orgânica. Isto só ocorre quando o conteúdo de carbonato é alto (Ricken 1991).

Este perído reflete também uma grande produtividade biológica, expressa pelos gráficos de abundância absoluta. Basicamente ocorrem mudanças autogênicas (Kidwell e Jablonski 1983), que expressam processos biológicos como modificadores na composição da comunidade. A litofácies nodular e de tapete algálico microbial pode estar relacionada a mudanças autogênicas nos processos tafonômicos (postmortem) atuantes no material carbonático, que podem corresponder a alta produção bentônica e a mortalidade em massa geradora de acumulação de tecas e partes duras carbonáticas. Esse acúmulo, que pode servir de substrato para outras espécies e até mesmo à fixação de estromatolitos, atua também como inibidor ao desenvolvimento de infauna por alterar a textura do substrato, facilitando a ocorrência de algumas espécies, muito bem adaptadas que proliferam em número de indivíduos. Os miliolídeos com ocorrência abundante nos tapetes algálicos, geralmente apresentam as tecas alongadas, de 
modo a facilitar o movimento através do sedimento. A intensa produção bentônica está registrada no tapete algálico das lagoas Vermelha e Brejo do Espinho atualmente, onde 21 amostras apresentaram em $10 \mathrm{~cm}^{3}$ variação de 960 a 7584 indivíduos de foraminíferos na seção 6 (LBE) e de 440-87808 para a Lagoa Vermelha.

Em LBE as espécies com maiores freqüências são representadas apenas pelo subgrupo Miliolina ( $P$. lecalvezae, Massilina protea, Affinetrina sommeri) (Fig. 37 A-E) e em LV4 por $P$. lacalvezae, A. sommeri e D. aquayoi (Fig. 36 A-H).

O empobrecimento geral do número de espécies, com abundância de $P$. lecalvezae e Affinetrina sommeri evidencia restrição e desfavorecimento ambiental. Neste momento, a laguna se individualiza de um sistema lagunar mais amplo, restringindo-se em área, onde a sedimentação, até então predominantemente de lama orgânica, passa a precipitação carbonática com as condições de hipersalinidade do meio lagunar limitando o desenvolvimento de algumas espécies.

Entre $0,80-0,89 \mathrm{~m}$ em LBE89-2, a $2.400 \pm 50\left(\delta{ }^{13} \mathrm{C}=-2.8 \%\right.$ a bacia lagunar, antes de seu fechamento definitivo, foi invadida por águas muito frias, proveniente da corrente de ressurgência com ocorrência adjacente e alcance na área costeira. Estas correntes trazem nutrientes que estão abaixo da zona fótica e incentivam a produção biológica. Em todos os testemunhos está registrada maior oceanicidade na bacia lagunar neste momento e a esta profundidade. As águas de ressurgência, mais freqüentes no verão e outono, registram à esta profundidade a última ocorrência em direção ao topo, de Bolivina spp., Abditodentrix spp. Cribroelphidium spp. (também a 79-116cm em LV89/19) única ocorrência de Buccela frigida e Miliolinella antarctica (também a $116 \mathrm{~cm}$ em LV89/19). A grande abundância absoluta, juntamente com a queda nos teores de $\mathrm{CaCO}_{3}$, registra nesta fase, um fechamento à profundidade de $85 \mathrm{~cm}$ e mais uma invasão oceânica a 45-50cm em LV4 e $29 \mathrm{~cm}$ em LV89/19, encontrada registrada apenas em Lagoa Vermelha.

O fato da lagoa Vermelha apresentar outra invasão oceânica, inclusive com ocorrência de highstand registrado na curva, pode ser devido à menor altura do cordão externo à época, ou a menor taxa de sedimentação, se comparada à LBE.

\section{FASE IV}

De 0,80 a 0,30m - Esta fase apresenta menor espessura de litofácies nos testemunhos LV89/19 e LV4 - de 0,80 a 0,35m, marcando a associação de fácies carbonáticas de ambiente perimaré raso, em planícies lamosas, com desenvolvimento acentuado de tapetes algálicos. Apresenta variação 
na profundidade da água, expressa pelo decréscimo na ocorrência da fácies de tapete algálico, de aproximadamente $57 \mathrm{~cm}$ até 30 ou $35 \mathrm{~cm}$. Está refletida também na sucessão de biofácies em todos os testemunhos, gradando de biofácies intermaré e supramaré na base para submaré no topo da fase. Apresenta a menor abundância absoluta nos testemunhos LV89/19 e LBE, onde os tapetes algálicos apresentam maior espessura. Em LV4 não apresenta-se de forma distinta como nos outros testemunhos, e as menores abundâncias estão na fase III com a ocorrência dos nódulos (mais espressivamente representados neste testemunho).

Sobre este aspecto, cabe aqui uma discussão quanto a diferença observada entre a grande abundância absoluta nos tapetes algálicos atuais e a inexpressiva abundância observada nos testemunhos, onde estes tapetes apresentam desenvolvimento acentuado.

Os mecanismos específicos de destruição das tecas de foraminíferos em ambientes carbonáticos de água morna tem sido desenvolvidos por Martin e Liddell (1991) e Kotler et al. (1992), dentre outros. O impacto das bactérias degradativas de carbonato biogênico tem sido considerado em alguns estudos, mas poucos trabalhos (Freiwald 1995) tem fornecido evidência de remoção de carbonato por meio de bactérias. Este impacto é controlado pela composição microestrutural da teca e pela distribuição e fomecimento de compostos orgânicos, dentro e sobre a teca. $\mathrm{O}$ ecossistema algálico forma um depósito natural de $\mathrm{CO}_{2}$, impedindo uma queda do $\mathrm{pH}$ para condições ácidas. No entanto, o processo respiratório das bactérias aeróbicas leva a hidratação de $\mathrm{CO}_{2}$ e conversão em ácido carbônico, favorecendo a dissolução do carbonato.

Os foraminíferos observados, principalmente na base desta fase, correspondem aos mesmos encontrados atualmente no tapete algálico, marcando a fácies intermaré e supramaré, ou seja, em LV89/19 aparecem Agglutinella martiniiana, D. aquayoi, Varidentella sp. A e Quinqueloculina dilatata (Fig. 35 A-F); em LV4, P. lecalvezae e D. aquayoi (Fig. 36 A-H) e em LBE, $P$. lecalvezae e $Q$. patagonica. A adaptação à este tipo faciológico, está expressa nas paredes das tecas com aglutinações secundárias (Aglutinella) que podem permitir um melhor potencial de preservação, bem como a presença de poros grandes em $D$. aquayoi que demonstra adaptação desta espécie a baixos teores de oxigenio.

A ocorrência de T. lutea entre $74-85 \mathrm{~cm}$ em LV4 e a $72 \mathrm{~cm}$ em LBE, marca a base desta fase mais quente.

Dos outros organismos considerados na análise, praticamente todos estão ausentes na fácies de tapete algálico, a exceção de Cyprideis salebrosa. Este ostracode tem sido encontrado em ambiente de água doce e mixohalino e raramente em salinidade marinha normal, existindo apenas um caso onde as carapaças vazias foram recuperadas de sedimentos depositados em ambiente hipersalino (lago Enriquillo, República Dominicana, 49\%o), mas nesse caso, 
correspondia a uma tanatocenose, uma vez que a espécie nunca havia sido encontrada vivendo atualmente no lago (J.C. Coimbra, comunicação escrita). No presente estudo, apresentam registro atual na laguna de Araruama, lagoa Vermelha e Brejo do Espinho. Os gastrópodes nitidamente não ocorrem nesta fácies em nenhum testemunho. Os bivalves, caracterizados por Anomalocardia brasiliana, acompanham a litofácies de lama orgânica ou níveis arenosos no meio da lama, geralmente na base dos testemunhos quando a entrada de águas oceânicas era mais freqüente e no topo, somente em LV89/19, com níveis bem marcados, que podem corresponder a invasões esporádicas de águas oceânicas.

A alternância de cores nas litofácies do tapete algálico expressam pequeno ciclo rediox, onde os períodos climáticos com maior oxigenação das águas mostram camadas de coloração mais clara com alto conteúdo de carbonato, enquanto períodos caracterizados por deficiência de oxigênio correspondem a laminações mais escuras. O ritmo das variações de $\mathrm{CaCO}_{3}$ e C.O.T, ilustra, no início da fase, deposição de carbonato dominante, com as curvas apresentando máximas amplas e convexas, alternadas com deposição variável de carbono orgânico, principalmente ao fim desta fase.

Os valores de $\delta^{13} \mathrm{C}$ mais negativos acompanham a ocorrência do tapete algálico, o que mostra a absorção e fixação do ${ }^{12} \mathrm{C}$ na matéria orgânica através do processo de fotossíntese do tapete algálico, elevando a concentração de ${ }^{13} \mathrm{C}$ dos carbonatos da fácies intermaré. Os valores menos negativos dessa razão isotópica estão no topo e base desta litofácies, expressiva em LV89/19.

A estratificação entre $53-56 \mathrm{~cm}$ na LBE apresenta contato lateral, sugerindo corresponder a tubos (pipes) de dissolução em pequena escala. Esses tubos de dissolução geralmente ocorrem por ocasião de cheia na bacia lagunar após a fase seca, quando ocorre a dissolução ao longo das margens verticais dos cristais de halita (parte mais solúvel do cristal), precipitados nas camadas subjacentes das gretas de ressecação, sendo posteriormente preenchidos por novos cristais de halita de fases secas subseqüentes. A laminação escurecida acima dos tubos pode corresponder a evidência de cheia na bacia lagunar. De acordo com Shearman (1970), camadas sucessivas de halita são produzidas por entradas de águas marinhas e, posterior concentração de halita de seu resíduo. Esta invasão de água marinha pode ter correspondido, à mais fraca influência registrada em LBE, devido a maior taxa de sedimentação, da segunda entrada de águas frias de ressurgência, (primeira à $80 \mathrm{~cm}$ ), cujo highstand está registrado na lagoa Vermelha.

A anidrita observada em lâmina a aproximadamente $57 \mathrm{~cm}$, está associada a ocorrência dos valores mais positivos do $\delta^{18} \mathrm{O}$. De fato, a nucleação deste precitado mineral requer 
temperaturas sazonais acima de $35^{\circ} \mathrm{C}$, só sendo preservado onde a temperatura média excede 20 ${ }^{\circ} \mathrm{C}$ (Kinsman 1976).

\section{FASE V}

De $0,30 \mathrm{~m}$ ao topo. Continua o domínio de $P$. lecalvezae acompanhado permanentemente, a partir de $0,43 \mathrm{~m}$, por $A$. beccarii f. tepida, $Q$. patagonica, $A$. sommeri e $B$. variabilis, $\mathrm{O}$ aparecimento desta última espécie, sugere que a salinidade tornou-se normal, mas com baixos teores de oxigênio dissolvido, entrada de águas marinhas e isolamento temporário, capaz de provocar forte diminuição da população e da diversidade de foraminíferos.

A redução na cobertura vegetal nos arredores (baixa relação $\mathrm{C} / \mathrm{N}$ ) sugere erosão, abrasão e transporte do silte e argilas terrestre para as lagunas. Todos os testemunhos apresentam lama orgânica carbonática bioturbada. Nessa região de clima semi-árido, mudanças climáticas sazonais podem gerar flutuaçôes no input terrígeno, com o transporte eólico e de $\mathrm{CO}_{2}$ devido a decomposição da biomassa terrestre, transferido para as lagoas. Se ao mesmo tempo o input de argilas terrestres for alto, pode se formar a lama carbonática e ocorrer à dissolução do carbonato.

O ritmo evidenciado pela variação na curva de $\mathrm{CaCO}_{3}$ e C.O.T. refere-se a input deposicional com alternâncias de deposição silicática variável, onde o máximo de carbonato é estreito e distinto e o mínimo é amplo e côncavo, observável principalmente em LV89/19, o que corrobora a alta diluição terrígena causando o aumento da espessura da camada pobremente carbonática. A queda acentuada nos valores de $\mathrm{CaCO}_{3}$ em direção ao topo da fácies é observada em LV4 e em LBE.

\section{2 - As Flutuações do Nível do Mar}

Foram definidas nos testemunhos quatro biofácies intermaré (I,III,V,VII), uma submaré (X) e uma supramaré (XII). As biofácies supramaré definem com precisão o alcançe máximo do nível do mar e conseqüentemente correspondem a bons indicadores de níveis pretéritos. No entanto, as batimetrias submaré e intermaré mostram melhor potencial de preservação, provavelmente por não apresentarem seu registro exposto aos processos erosivos. A biofácies $\mathrm{X}$ apresentou o melhor potencial de preservação. O registro biofaciológico não apresenta os ciclos supramaré, intermaré e submaré $(A, B, C)$ completos, e desta forma correspondem a hemiciclos em LBE (B,C,B,C); em LVA (B,C,B,C,B,C) e em LV89/19 (B,A,C,B). Somente no testemunho LV89/19 foi possível o reconhecimento de uma biofácies supramaré. 
O limite erosivo descontínuo na base dos testemunhos marca a passagem de condições de corpo aquoso com mistura (oligomítico) para permanentemente estratificado (meromítico), a aproximadamente 6.660 anos A.P., passando igualmente de condições pobres em termos de nutrientes (oligotrófico), para maior riqueza em nutrientes e algas (eutrófico). A eutrofização observada atualmente nas lagoas fechadas intercordão já ocorre desde aproximadamente 4.300 anos A.P. Todas as litofácies carbonáticas apresentam maior espessura e melhor potencial de preservação no testemunho LBE, que mostrou também para esta fase carbonátiça, o maior índice de sedimentação. A litofácies de lama orgânica e lama carbonática estão melhor preservadas e com maior espessura em LV4. Isto parece ilustrar, de forma geral, que a lagoa Vermelha apresentavarse como um depocentro (devido ao tipo de sedimento) da laguna maior em que estava inserida até a fase III, quando se individualiza.

A associação de fácies lagunares iniciamse em $7.170 \pm 110$ a partir de uma discontinuidade erosiva, que a separa dos sedimentos da Fm. Cananéia, na base dos testemunhos. Os testemunhos LV4 e LBE apresentam as mesmas biofácies intermaré na base (passando da I para III). A $6.660 \pm 70$ anos A.P., a biofácies I registra o nível do mar a $-4,26 \mathrm{~m} \pm 0,94 \mathrm{~m}$ a $323 \mathrm{~cm}$ de profundidade.

Há registro de highstand ?/ stillstand? delineado pela biofácies I na curva LV4 a 295$285 \mathrm{~cm}$ de profundidade, quando o nível do mar esteve a $-4,90 \mathrm{~m}$.

A aproximadamente $5.180 \pm 70$ A.P. passa a ocorrer, a $213 \mathrm{~cm}$ de profundidade, a biofácies submaré $X$ quando o nível do mar esteve a $-3,12 \pm 0,21 \mathrm{~m}$, registrando neste período um aumento do nível relativo do mar, que aparentemente manteve em equilíbrio sua taxa de subida com a taxa de sedimentação até aproximadamente $174 \mathrm{~cm}$ (interrompida com a deposição da biofácies III). A biofácies X reaparece entre $153-145 \mathrm{~cm}$., registrando uma nova oscilação. Este registro sugere a ocorrência de uma variação de intensidade para a última grande transgressão Holocênica, se comparada à curva elaborada para o Estado da Bahia (Fig. 2), que tem sido adotada no Estado do Rio de Janeiro.

A recorrência da biofácies submaré $X$ a $3 \mathrm{~cm}$ de profundidade acima da datação de 4.320 \pm 100 anos A.P. registra um nível relativo do mar de $-2,52 \mathrm{~m} \pm 0,21 \mathrm{~m}$, mostrando que ocorreu uma segunda subida do nível relativo do mar, com menor intensidade que a anterior, em concordância com o comportamento da curva de Martin et al. (1979) na mesma época (Fig. 2).

Outro registro da biofácie intermaré III na curva em LV89/19, a $3.700 \pm 80$ anos A.P., indica um nível relativo do mar a aproximadamente $-2,66 \mathrm{~m}$. No entanto, não se constitui um bom marcador já que esta biofácie possuir uma amplitude muito grande $(1,12 \mathrm{~m})$. 


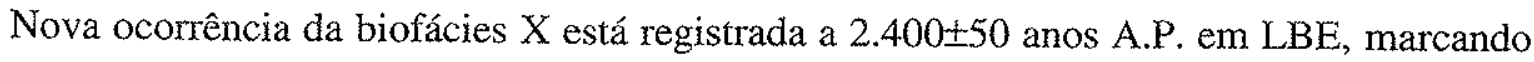
uma subida do nível relativo do mar em $-1,88 \mathrm{~m} \pm 0,21 \mathrm{~m}$, iniciando sua ocorrência a $89 \mathrm{~cm}$. A recorrência desta biofácies até $63 \mathrm{~cm}$ do testemunho corrobora a estabilidade entre taxa de sedimentação e variação do nível relativo do mar no período. Comparando-se com a curva de Martin et al. (1979), a intensidade de subida foi aparentemente menor também neste período.

O paleossolo registrado em LV4 a $2.340 \pm 90$ representa o ápice de um ciclo progressivamente mais raso (shallowing upward). Dois centímetros acima deste, está representada a biofácie VII que define o nível do mar a $-2,14 \mathrm{~m} \pm 17 \mathrm{~cm}$, também em acordo com a curva de Martin et al (1979).

Um tipo de adaptação notável é o tamanho da fauna; microforaminíferos pertencentes a subordem Rotaliina ocorrem a partir de $235 \mathrm{~cm}$ em direção ao topo do testemunho LV4 (Fig. 36 H) e corroborando com a interpretação de águas mais rasas. 


\section{CAPÍTULO 7}

\section{CONCLUSÕES}

Dezesseis assembléias de foraminíferos (biofácies) são diferenciadas em cinco áreas lagunares na região de Cabo Frio, Rio de Janeiro; seis delas foram utilizadas na interpretação do paleoambiente deposicional e das flutuações do nível relativo do mar por apresentarem-se nos três testemunhos analisados. A grande amplitude vertical de algumas biofácies definidas, principalmente em Araruama, para o ambiente submaré e intermaré inferior, não as qualifica como boa refinadoras da curva, embora apresentem bom potencial de preservação. Isto ocorre devido a ausência de diferenciações ambientais nas bordas lagunares hipersalinas, causada pela ausência de vegetação e influência fluvial, abundância de sedimentos biogênicos e baixos valores de matéria orgânica, que fazem com que as diferenciações das associações de foraminíferos sejam muito sutís. No entanto, biofácies com amplitudes mais restritas foram obtidas nas lagoas Vermelha e Brejo do Espinho, correspondendo aos foraminíferos carbonáticos Agglutinella matinitana, Aglutinella sp. A, e Discorinopsis aquayoi.

Essas biofácies em conjunto com dados litofaciológicos, isotópicos, geoquímicos e datações permitiram uma boa resolução na interpretação da sucessão perimaré caracterizada por fácies progressivamente mais rasas, em salinidade marinha normal na base dos testemunhos, passando à valores acima da normal em direção ao topo.

Os paleoambientes submaré raso e intermaré inferior foram diferenciados pelo tipo de biofácie e pela presença de material conchífero de organismos bentônicos, tapetes algálicos e lamas carbonáticas, algumas vezes bioturbadas, com variação de energia, sob regime de micromaré $(<$ que $2 \mathrm{~m}$ ). Os paleoambientes supramaré (que também podem apresentar tapetes algálicos) foram bem marcados pela presença de nódulos carbonáticos, paleossolo e precipitados de anidrita.

Cinco fases evolutivas estão registradas para o paleoambiente deposicional, conjugandose indicações fornecidas pelos três testemunhos:

A fase I apresenta misturas de águas (oligomítica) sob domínio de deposição siliciclástica e marcada pelas espécies de Ammonia spp. Cribroelphidium excavatum f. selseyensis. As

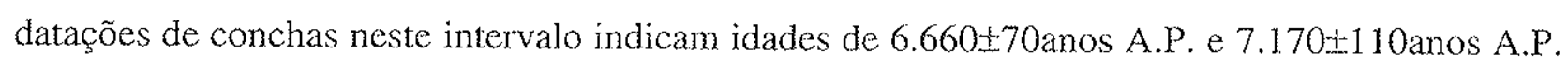
na sabka Brejo do Espinho e de 6530t100anos A.P. na Lagoa Vermelha. Sedimentos predominantemente arenosos, conchas de Anomalocardia brasiliensis e seus fragmentos, e as 
espécies de foraminíferos, indicam uma laguna ampla, com comunicação oceânica, sob condições óxicas, mas com presença de ilha ou ilhas barreiras à frente.

Na fase $I$ a laguna se instala definitivamente e já mostra uma diminuição acentuada na energia do meio físico, onde os aportes de água doce amenizam a salinidade, sob condições anóxicas, marcada pelos gêneros Ammonia spp. Cribroelphidium spp e Bolivina spp., com poros

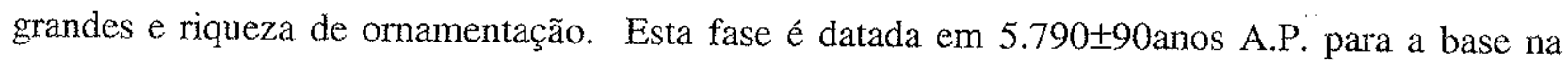

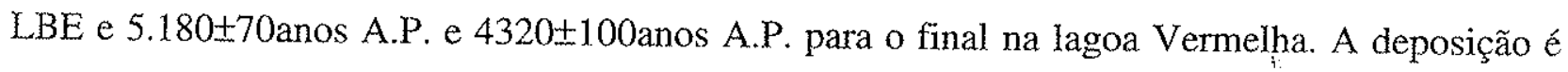
siliciclástica variável, com lama orgânica e litofácies de conchas fragmentadas, com contato erosivo na base.llustra distribuição de partes duras alóctones de areas adjacentes, sob condiçôes erosivas de transgressão (com ápice a 5.180 anos A.P.) corroborada pelo menor índice de sedimentação na LBE e pelas espécies Globocassidulina subglobosa, Brizalina sp. A, Abditodentrix rhomboidalis e Bolivina sliteri subsp. asperoides.

$\mathrm{Na}$ fase $\mathrm{II}$ as lagunas se individualizam de um sistema lagunar mais amplo, restringindose em área caracterizada por condições meromíticas do corpo aquoso, com deposição silicática variável na base passando a precipitação de carbonato variável no topo. A passagem de fácies submaré para intemrnaré é acompanhada pela mesma tendência regressiva em relação as biofácies em LV4. As espécies $P$. lecalvezae e Affinetrina sommeri são comuns aos testemunhos LV4 e LBE, acrescentando-se $D$. aquayoi ao primeiro e Massilina protea ao último. A alta produtividade biológica (abundância absoluta) não é acompanhada pelo número de espécies. A associação de fácies perimaré é marcada pela ocorrência de nódulos carbonáticos e paleossolo (2.340 \pm 90 anos A.P.). A razão isotópica do $\delta^{13} \mathrm{C}$ indica uma maior continentalidade e queda do nível do mar. A bacia lagunar, antes de seu fechamento definitivo, foi invadida por águas muito frias a $2.400 \pm 50$ anos A.P provenientes da corrente de ressurgência adjacente registrada pela presença de Buccela frigida e Miliolinella antarctica.

A Fase IV marca a associação de fácies carbonáticas de ambiente perimaré raso, com desenvolvimento de tapetes algálicos gradando de biofácies intermaré e supramaré na base para submaré no topo. Há menor abundância absoluta nos testemunhos LV89/19 e LBE, onde os tapetes algálicos apresentam maior espessura. A presença de anidrita, juntamente com $\delta^{18} \mathrm{O}$ ilustra que a temperatura média excedia $20^{\circ} \mathrm{C}$. Os foraminúferos observados ^a base são os mesmos encontrados atualmente no tapete algálico, e em LV89/19, correspondem a Agglutinella martiniiana, D. aquayoi, Varidentella sp. A e Quinqueloculina dilatata. Ém LV4, correspondem a $P$. lecalvezae e $D$. aquayoi e em LBE, P. lecalvezae e $Q$. patagonica. A ocorrência de T. lutea entre $74.85 \mathrm{~cm}$ em LV4 e a $72 \mathrm{~cm}$ em LBE, marca a base desta fase mais quente. Cyprideis 
salebrosa embora com baixos números está presente na fácies de tapete algálico. Os gastrópodes e bivalves não ocorrem nesta fácies. A deposição é dominantemente carbonática, e os tubos (pipes) de dissolução seguidos por laminação escurecida sugerem momento de cheia na laguna.

A fase $\mathrm{V}$ é marcada por deposição de lama orgânica carbonática bioturbada com o domínio de $P$. lecalvezae, acompanhado por $A$. beccarii f. tepida, $Q$. patagonica, $A$. sommeri e $B$. variabilis, e por salinidade acima da marinha normal, com entrada esporádica dé águas marinhas e baixos teores de oxigênio dissolvido, capaz de provocar forte diminuição da população e diversidade de foraminíferos.

Estas cinco fases possuem estreita correlação com cada pacote faciológico e biofaciológico, mostrando assinatura distinta quanto aos dados geoquímicos e isotópicos, possibilitando o reconhecimento de associação de fácies carbonáticas perimaré correlacionáveis ao Quatemário, inclusive de outras regiões. As litofácies aqui definidas poderão ser utilizadas na interpretação de ambientes perimaré de outros períodos geológicos, uma vez que tais sequiências em ambientes de águas rasas e planícies lamosas, correspondem às mais eminentes fácies carbonáticas no registro rochoso.

As curvas de variação do nível relativo do mar ilustram também a subida deste no registro oceanográfico dos últimos três centímetros dos testemunhos (aproximadamente 100 anos A.P.), como indicada pela ocorrência da biofácies submaré X seguida da biofácies intermaré VII.

O padrão de empilhamento dos sedimentos mostra uma expressão parcial das fácies transgressivas até 5.180 anos A.P., devido à discontinuidade erosiva que dá início a associação de fácies litorâneas na base dos testemunhos, com a perda das fácies mais oceânicas e preservação somente a partir da proteção exercida pela(s) ilha(s) barreira(s) já presente(s) a 7.170 \pm 110 anos A.P. anos A.P., aparentemente de baixo relevo e com bancos intermarés. Esta sucessão perimaré, progressivamente mais rasa, apresenta-se lateral e verticalmente discontínua no tempo, com fácies supramaré pobremente preservadas. Expressam variações locais e regionais e condições hidrográficas que sugerem similaridade com o modelo de ilhas de planícies de maré desenvolvido por Pratt e James (1986) para o Grupo St. George no Ordoviciano Inferior de Newfoundland.

São possíveis desdobramentos e aplicações deste trabalho a comparação com os outros modelos biofaciológicos, aprimorando esta ferramenta para análise paleoambiental; a quantificação das observações ecológicas realizadas, examinando variações das diferentes fases ou litofácies e a comparação destes dados com sequências perimaré de outros locais e em outros períodos geológicos. 


\section{REFERÊNCIAS BIBLIOGRÁFICAS}

ALLEN, P. A. e COLLINSON, J. D.1986. Lakes. In: READING, H. G. (Ed.) Sedimentary Environments and Fácies. 2a. Ed., Oxford, Blackwell Scientific Publ., p. 63-94.

ANDRE, D.L., OLIVEIRA, M.C. e OKUDA, T. 1979. Estudo preliminar sobre as condições hidroquímicas da Lagoa de Araruama - Rio de Janeiro. Instituto de Pesquisas da Marinha. Relatório Interno, Março, 1979, p. 1-30

ARAÚUO, D.S.D. de e HENRIQUES R.P. B. 1984. Análise florística das restingas do Estado do Rio de Janeiro. In: LACERDA,L.D. et al.(Orgs.) Restingas: Origem, Estruturas, Processos. CEUFF, Niterói, p: $159-193$.

ASSUNÇÃO, M.; NETO, C.M.D.; BERROCAL, J.; ANTEZANA, R.; FRANÇA, H.; ORTEGA, R. 1980. Sismicidade do Sudeste do Brasil. In: CONGRESSO BRASILEIRO DE GEOLOGIA, 31. Camboriú, 1980, Camboriú, Anais... Camboriú, SBG, v. 2, p. 1075-1092.

AZEVEDO L.S.P. 1984 Considerações geoquímicas das lagunas do litoral leste do Estado do Rio de Janeiro. In: LACERDA, L.D. de et al. (Orgs.) Restingas: Origem, Estruturas, Processos. CEUFF, Niterói, p. 123-135.

BARBIÉRE, E.B. 1975 Ritmo climático e extração do sal em Cabo Frio. Revista Brasileira de Geografia, Rio de Janeiro, v. 37, n. 4.p. 23-109.

BARBIÉRE, E.B. 1981 O fator climático nos sistemas territoriais de recreação. Análise subsidiária ao planejamento na faixa litorânea do Estado do Rio de Janeiro. Revisia Brasileira de Geografia, Rio de Janeiro, v. 43, n. 2, p. 145-265.

BARBIÉRE, E.B. 1984 Cabo Frio e Iguaba Grande, dois microclimas distintos a um curto intervalo espacial In: LACERDA, L.D. de et al. (Orgs.) Restingas: Origem, Estruturas, Processos. CEUFF,Niterói, 1984. p: 3-12.

BARBIÉRE, E.B. 1985.Condições climáticas dominantes na porção oriental da Lagoa de Araruama (RJ) e suas implicações na diversidade do teor de salinidade. Caderno de Ciências da Terra, São Paulo, v. 59, p. $3-35$.

BARBIÉRE, E. B. (No prelo) Flutuações climáticas em Cabo Frio.

BARBOSA, C.F. 1991. Caracterização biossedimentológica quantitativa do sistema estuário - manguezal da Baía de Guaratuba, P.R. Dissertação (Mestrado em Geologia Sedimentar) Instituto de GeociênciasUSP, inédito.1991

BARBOSA, C. F. No Prelo Zoneamentos de Foraminifera e Arcellacea ("Thecamoebia") nos pântanos salinos de Guaratuba, Paraná, Brasil. Anais Academia Brasileira de Ciências.

BARROSO, L. V. 1987. Diagnóstico ambiental da Lagoa de Araruama - RJ. Bol. FBCN - (Fundação Brasileira para a Conservação da Natureza), Rio de Janeiro, 22: 30-65.

BASSON, P.W. E MURRAY, J.W. 1995 Temporal variations in four species of intertidal foraminifera, Bahrain, Arabian Gulf. Micropaleontology, vol. 41,n. 1, p. 69-76. 
BLOOM, A. L.; BROECKER, W.S.; CHAPELL, J.; MATTHEWS, R.K.; MESOLELLA, K.J. 1974. Quaternary sea-level fluctuations on a tectonic coast: new ${ }^{230} \mathrm{Th} /{ }^{234} \mathrm{U}$ dates from the Huon peninsula, New Guinea. Quaternary Research, 4: 185-205.

BOLTOVSKOY, E. 1965. Los Foraminiferos Recientes. Biología, métodos de estudio, aplicación oceanográfica. Buenos Aires, Eudeba. 510 pp.

BOLTOVSKOY, E. e WRIGHT, R. 1976. Recent Foraminifera. Dr. W. Junk b.v. Publ., The Hague, 515 p.

BRADSHAW, J.S. 1968. Environmental parameters and marsh foraminifera: Limnology and Oceanography, v.13, n.1, p. 26-38.

BRANCO, P.C.M.P.A. e RAMALHO, R. 1984. Projeto Lagoa de Araruama/ Relatório Final de Pesquisa de conchas calcárias. CNA-Companhia Nacional Álcalis/CPRM- Companhia de Pesquisa de Recursos Minerais, Contrato CNA no. 362-5, vol. 1 e 2, Rio de Janeiro.

BURNE, R. V.; BAULD, J.; DE DECKKER, P. 1980. Saline lake charophytes and their geological significance. J. of Sedim. Petrol., v. 50 n. 1, p. 281-293.

CARMOUZE, J.P. e BARROSO, L.V. 1989 Recent environmental modification of the lagoon of Saquarema and its watershed. INTERNATIONAL SYMPOSIUM ON GLOBAL CHANGES DURING THE QUATERNARY. São Paulo. Extended Abstract: 65-69.

CHAPELL, J. 1983. A revised sea-level record for the last 300,000 years from Papua New Guinea. Search, 14: 99-101.

CHAPMAN, V.J.1960. Salt marshes and Salt Deserts of World: London, Leonard Hill LTP, 392 p.

COE NETO, R. 1984. Algumas considerações sobre a origem do sistema lagunar de Araruama. In: "SIMPÓSIO SOBRE RESTINGAS BRASLLERAS", Niterói, Proc., p. 61-63.

CULVER, S. J. 1990 Benthic Foraminifera of Puerto Rican Mangrove-Lagoon Systems: Potential for Paleoenvironmental Interpretations. Palaios, v. 5, p. 34-51.

De SÁ, C, F,C 1993. Florística e Fitossociologia em área de floresta de restinga após seis anos de sucessão secundária. Dissertação (Mestrado em Ciências Biológicas -Botânica) UFRJ, 167 p.

De VERNAL, A.; LORTIE,G.; LAROUCHE,A.; SCOTT,D.B.; RICHARD, P.J.H. 1984. Évolution d'un milieu littoral et remonteé du niveau relatif de la mer à l'Holocene supérieur au nord de l'ile du CapBreton, Nouvelle-écosse. Can. J. Earth Sci.,22:315 323.

De RIJK, S. 1995. Salinity control on the distribution of salt marsh foraminifera (Great Marshes. Massachusetts). J. of Foram. Res, v. 25, n.2, p.156-166.

DIRETORIA DE HIDROGRAFIA E NAVEGAÇÃO - DHN 1993 Tábuas de Marés - Costa do Brasil e Alguns Portos Estarngeiros, Marinha do Brasil, Publ. Anual

DIAS, G. T. M.; SILVA, C. G. 1984. Geologia de depósitos arenosos costeiros emersos - exemplos ao longo do litoral fluminense. In: LACERDA, L.D. DE; ARAÚJO, D. S. D. DE; CERQUEIRA, R.; TURCQ, B. (org.) Restingas: Origem, Estrutura, Processos. CEUFF, Niterói, 1884. p: 15-25.

DIAS, G.T.M.; RODRIGUEZ, M.A.; VALLADARES, C.S. 1983. Contribuição à evolução sedimentar dos depósitos deltaicos do rio Pará́ba do Sul (com base em foraminíferos). CONGRESSO BRASILEIRO DE PALEONTOLOGIA, 8. Resumo da Comunicaçōes. Rio de Janeiro, SBP. Academia Brasileira de Ciências. 
DIAS, G.T.M.; SILVA, C.G.; MALSCHITZKY, I.H.; PIRMEZ, C. 1984. A planície deltáica do rio Paraíba do Sul - sequiencias sedimentares subsuperficiais. XXXII CONGR. BRAS. DE GEOL. ANAIS..., Rio de Janeiro, SBG, RJ, 1984, vol. 1, p: 98-104.

DINIZ, A.B.; DAMASCENO,R.N. e FIGUEIREDO, A.G. 1989. Distribuição de carbonato e matéria orgânica nos sedimentos da Lagoa de Saquarema. In: SIMPÓIO SOBRE OCEANOGRAFIA, 1. São Paulo, 1989. Resumo..., São Paulo, IOUSP, p. 60.

DOMINGOS, P., VASCONCELOS, P. de A. e CARMOUZE, J-P. 1989 Efeito de intrusões marinhas na Lagoa de Saquarema, RJ, sobre as atividades biológicas e a comunidade fitoplantônica. SIMPÓSIO SOBRE OCEANOGRAFIA, 1., São Paulo, 1989. Resumos..., São Paulo, IOUSP, p. 82

DREWS, M.G.P. 1995 Projeto Arraial do Cabo, RJ.Eletrorresistividade para Estudos de Fundaçóes e Aquíferos. Convênio de Cooperação Técnico-Científica CPRM-PMAC, SUREG/BH, Relatório Interno, $5 \mathrm{pp}+56$ figs.

FERREIRA DA SILVA, L.C.; MEDEIROS DE ALBUQUERQUE, C.A.; CAVALHEIRO, W.W.; PASSERI HANSEN, C.M. 1984.Gabarito tentativo para as massas de água da costa Sudeste brasileira. Separata dos Anais Hidrográficos da Diretoria de Hidrografia e Navegação da Marinha, Tomo XLI, 28 pp.

FREIWALD, A. 1995. Bacteria-Induced Carbonate Degradation: A Taphonomic Case Study of Cibicides lobatulus From a High-Boreal Carbonate Setting. Palaios, v. 10, p. 337-346.

GAMMA DE ALMEIDA, E. e TANAKA, K. 1981 Acompanhamento de Fenômenos Oceanográficos da Costa Sul do Brasil por Sensoriamento Remoto à Distância Orbital. Publicação do instituto de Pesquisas Espaciais, 1975-RPE/280, 34 pp.

GEHRELS, W.R. 1994 Determining relative Sea-level change from salt-marsh foraminifera and plant zones on the coast of Maine, U.S.A. Journal of Coastal Research, v.10, n.4: 990-1009.

GLENN, C. R. e KELTS, K. 1991 Sedimentary rhythms in lake deposits. In: EINSELE, G., RICKEN, W. e SEILACHER, A. (Eds.) Cycles and Events in Stratigraphy. Springer-Verlag. 943 p.

HALFMAN, J.D. E JOHNSON T. C. 1988. High-resolution record of cyclic climatic change during the past 4 ka from Lake Turkana, Kenya. Geology 16, p. 496-500

HÖHN, A.; TOBSCHALL, H.J.; MADDOCK, J.E.L. 1986. Biogeochemistry of a hypersaline lagoon east of Rio de Janeiro, Brazil. The Science of the Total Environment, 58, p. 175-185.

HOFFMAN,P. 1976. Stromatolite morphologies in Shark Bay, Western Australia. In: Stromatolites (Ed. by M.R. Walker) Elsevier, Amsterdan, pp. 261-272.

HSÜ, K.J. e SIEGENTHALER, C. 1969. Preliminary experiments on hydrodynamic movement induced by evaporation and their bearing on the dolomite problem. Sedimentology, 12, 11-25.

JARDINE, W.G. 1986. Determination of altitude. In: VAN DE PLASSCHE, O. (Ed.) Sea-level Research: a manual for collection and evaluation of data. Free Univ. Amsterdam. Geo Books, Norwich: 569.590.

JENNINGS, A.E. E NELSON, A. R.1992. Foraminiferal assemblage zones in Oregon tidal marshes relation to marsh floral zones and sea level. J. Foram. Res., v. 22,n.1:13-29.

JENNINGS, A.E; NELSON, A.R.; SCOTT, D.B.; ARAVENA, J.C. 1995. Marsh foraminiferal assemblages in the Valdivia Estuary, South-Central Chile, relative to vascular plants and sea-level. Journal of Coastal Research 11,n.1: 107-123 
KIDWELL, S.M. e JABLONSKI, D.1983. Taphonomic Feedback Ecological Consequences of Shell Accumulation. In TAVESZ,M.J.S. e Mc CALL, P.L., Biotic Interactions in Recent and Fossil benthic Communities. Plenum Press, N.Y.and London.pp.195- 248.

KINSMAN, D.J.J. 1976. Evaporites relative humidity control on primary mineral facies. J. Sedimentary Petrology, v. 46, p. 273-279.

KJERFVE, B. 1986. Comparartive oceanography of coastal lagoons. In: Estuarine variability. D.A. Wolfe (ed.) Academic Press, New York, pp. 63-81.

KJERFVE, B.; KNOPPERS, B. A. 1991.Tidal choking in a coastal lagoon. In: PARKER, B. B. (Ed.) Tidal Hydrodynamics. John Wiley e Sons, Inc. p. 169- 181.

KJERFVE, B.; KNOPPERS, B. A.; MOREIRA, P.; TURCQ, B. 1990. Hydrological regimes in Lagoa de Guarapina, a shallow Brazilian coastal lagoon. Acta Limnologica Brasiliensia III: 931-949.

KJERFVE, B. e MAGILL, K. E. 1989. Geographic and hydrodynamic characteristics of shallow coastal lagoons. Marine Geology, 88: 187-199.

KJERFVE, B.; SCHETTINI, C.A.F.; KNOPPERS, B.; LESSA,G.; FERREIRA, H.O. 1995. Hydrology and Salt Balance in a Large Hypersaline Coastal Lagoon: Lagoa de Araruama, Brazil. Estuarine, Coastal and Shelf Science.

KNOPPERS, B.; KJERFVE, B.; CARMOUZE, J-P. 1991. Trophic state and water turn-over time in six choked coastal lagoons in Brazil. Biogeochemistry 14: 149-166.

KOWSMANN, R. O. e COSTA, M.P.A. 1979. Evidence os Late Quaternary sea level stillstandson the Upper Brazilian continental margin: a synthesis. In SUGUIO et al (Eds) INTERNATIONAL SYMPOSIUM ON COASTAL EVOLUTION IN THE QUATERNARY, 1979, São Paulo, p. 170192.

KOTLER, E., MARTIN, R.E. e LIDDELL, W.D. 1992. Experimental analysis of abrasion and dissolution resistance of modern reef-dwelling foraminifera: Iplications for the preservation of biogenic carbonate: Palaios, v. 7, p. 244-276.

LABOREL, J. 1979. Fixed marine organisms as biological indicators for the study of recent sea level and climatic variations along the brazilian tropical coast. In SUGUIO, K. et al. (Eds) INTERNATIONAL SYMPOSIUM ON COASTAL EVOLUTION IN THE QUATERNARY. Proceedings..., 1978, São Paulo, p. 193-211.

LESSA, G.C. 1989. Considerações sobre o comportamento hidráulico do Canal de Itajurú - Laguna de Araruama (RJ). In: III SIMP. GEOGRAFIA FÍSICA APLICADA, Anais...,1989, Nova Friburgo, RJ, p: 334.347 .

LESSA, G.C. 1990. Hidráulica e Sedimentação do Canal de Itajuru - Laguna de Araruama (RJ). Dissertaçäo (Mestrado, Departamento de Geografia) UFRJ 90p.

LETHIERS, F. e CRASQUIN- SOLEAU, S. 1988. Comment extraire les microfossiles à tests calcitiques des roches calcaires dures. Revue de micropaléontologie, v. 31,n.1, p.56-61.

LIPPS, J.H. 1983. Biotic Interactions in Benthic Foraminifera. In TAVESZ,M.J.S. e Mc CALL, P.L., Biotic Interactions in Recent and Fossil Benthic Communities. Plenum Press, N.Y.and London.pp.331- 376. 
MACEDO, J.M. 1990 Evolução tectônica da Bacia de Santos e áreas continentais adjacentes. In RAJA GABAGLIA,G.P. e MILANI, E.J. (Coords.) Origem e Evolução de Bacias Sedimentares. Petrobrás, RJ, p. 361-376.

MADEIRA, C. V. e CARVALHO, M.G.P. de 1992. Foraminíferos bentônicos da Lagoa de Araruama RJ: Uma Abordagem Ecológica. III CONGRESSO ABEQUA. Anais..., 1992, Belo Horizonte,p. 249. 293.

MARTIN, L; BITTENCOURT; A.C.S.P.; VILAS-BOAS, G.S. 1982 Primeira ocorrência de corais pleistocênicos da costa brasileira: Datação do máximo da penúltima transgressão. Ciências da Terra, Salvador, 1: 16-17.

MARTIN, L.; FLEXOR J. M. 1989. Terraços marinhos Pleistocênicos da região Norte do Estado do Rio de Janeiro, II CONGRESSO DA ASSOCIAÇÃO BRASILEIRA DE ESTUDOS DO QUATERNÁRIO, Publ. Esp. , 1, Resumos.

MARTIN, L.; FLEXOR J. M.; VALENTIN, J. L. 1988.Influence du Phénomène Océanique Pacifique, El Niño, sur L'Upwelling et le Climat de la Région du Cabo Frio, sur la côte Brésilienne de L'État de Rio de Janeiro. C. R. Acad. Sci. Paris, Tomo 307, série II, 1101-1115

MARTIN, L.; FLEXOR J. M.; VILAS BOAS, G. DA S., BITTENCOURT, A.C. DA S.P. E GUIMARÃES, M.M.M. 1979. Courbe de Variation du Niveau relatif da La Mer au Cours des 7.000 dernières annés sur un secteur homogène du littoral brésilien (Nord de Salvador- Bahia). In: Suguio et al. (Eds) Proceedings of the 1978 International Symposium on Coastal Evolution in the Quaternary, São Paulo, Brasil (1979). p: 264-274.

MARTIN, L.; MÖRNER, N. A.; FLEXOR, J.M.; SUGUIO, K. 1986 Fundamentos e reconstrução de antigos níveis marinhos do Quaternário. Bol. IG/USP, Publ. Esp. 4, 161 pp.

MARTIN, L.; SUGUIO, K. 1989. São Paulo. Special Publication no.2. Excursion route along the Brazilian coast between Santos (State of São Paulo) and Campos (North of State of Rio de Janeiro) INTERNATIONAL SYMPOSIUM ON GLOBAL CHANGES IN SOUTH AMERICA DURING THE QUATERNARY. 1989, 136p.

MARTIN, L.; SUGUIO, K.; FLEXOR, J.M.L.; AZEVEDO, A.E.G.,1984. Evolução da Planície Costeira do rio Paraíba do Sul $(\mathrm{RJ})$ durante o Quaternário: influência das flutuações do nível do mar. CONGRESSO BRASILEIRO DE GEOLOGIA, 33. Rio de Janeiro, 1984. Anais... Rio de Janeiro, SBG, v. 1, p. 84-97.

MARTIN, R.E. e LIDDELL, W.D. 1991. The taphonoy of foraminifera in modern carbonate environments: Implications for the formation of forainiferal assemblages: In DONOVAN, S.K. (Ed.), The Processes of Fossilization: Colubia University Press, New York, p. 170-193.

MEADE, R. H. 1969 Landward transport of bottom sediments in estuaries of the Atlantic Coastal Plain. J. Sed. Petrol., 39: 222-234.

MIOTO, J. A. 1984 Mapa de Risco Sísmico do Sudeste do brasileiro I. Publ. no. 1563. IPT - Monografias 10. $48 \mathrm{p}$.

MOREIRA DA SILVA, P. C. 1977. Upwelling and its biological effects in southern Brazil. Publ. do Inst. de Pesq. da Marinha, 112, 6. pp.

MOREIRA, A.L.C. 1989. Estados tróficos da Lagoa de Saquarema (RJ) num ciclo anual. Dissertação (Mestrado, Instituto de Química, UFF. Niterói, RJ.91 p. 
MUEHE, D. e CORREAA, C. H. T. 1989. The coastline between Rio de Janeiro and Cabo Frio. In: Neves, C. (ed.) Coastlines of Brazil., American Society of Civil Engineers. New York, p: 110-123.

MURRAY, J.W. 1971. Living foraminiferids of tidal marshes: A review. Journal of Foraminiferal Research, v. ,n. 4, p. 153-161.

MURRAY, J.W. 1973. Distribution of living benthic foraminiferids: Heinemann; London, 274 p.

NICHOLS, M.M.; JOHNSON, G.H.; PEEBLES, P.C.,1991. Modern sediments and fácies model for a microtidal costal plain estuary, the James Estuary, Virginia. J. Sed. Petrol., v.61, n.6:883-899.

PALACIOS, J.R.A. 1993 Estudo espectral do fenômeno da ressurgência de Cabo Frio (R.J., Brasil). Dissertação (Mestrado- Depto. de Geofísica do Observatório Nacional do C.N.Pq.

PATCHINEELAM, S. R.; REBELLO, A. de L.; MOREIRA, Y., 1984. Ocorrencia de dolomita diagenética numa lagoa hipersalina. ANAIS XXXIII CONGR. BRAS. DE GEOL., Rio de Janeiro, 1984, p. 245-253.

PAWLOWSKI, J. e LEE, J.J.,1991. Taxonomic notes on some tiny, shallow water foraminifera from the northern Gulf of Elat (Red Sea). Micropaleontology, v. 37, n. 2, p. 149-162.

PETRUCCI, F.; MEDIOLI, F.S.; SCOTT, D.B.; PIANETTI, F.A.; CAVAZZINI, R., 1983. Evaluation of the usefulness of foraminifera as sea level indicators in the Venice Lagoon (N. Italy) Acta Naturalia de l'Ateneo Parmense, v.19 n.3:63-77.

PHLEGER, F. B., 1965. Living Foraminifera from a coastal marsh, south-western Florida. Boletin Sociedad Geologica Mexicana, v.28 n.1, p. 45-60

PHLEGER, F. B., 1966. Patterns of living marsh foraminifera in south Texas coatal lagoons: Boletin de la Sociedad Geológica Mexicana, t. 28, n.1, p. 1-44.

PHLEGER, F. B., 1967. Marsh foraminiferal patterns, Pacific Coast of North America. An. Inst. Biol. Univ. Nal. Autónoma México 38, Ser. Cienc. del Mar y limnología (1): 11-38.

PHLEGER, F. B., 1970. Foraminiferal populations and marine marsh processes. Limnology and Oceanography, v. 15 (4), p. 522-534.

PHLEGER, F. B. e BRADSHAW, J.S., 1966. Sedimentary Environments in a Marine Marsh. Science, 23 , v. 154 n. 3756,p. 1551-1553.

POAG, W.C., 1978. Paired foraminiferal ecophenotypes in Gulf Coast estuaries: Ecological and paleoecological implications. Transactions - Gulf Coast Association and Geological Societies. vol. XXVIII, p. 395-421.

PONÇANO, W.L.; FÚLFARO, J.V.; GIMENEZ, A. F., 1979 PROC. SIMP. REG. DE GEOL., 2, Rio Claro, v. 1, p. 291-304.

PRATT, B.R. e JAMES, N.P., 1986. The St. George Group (Lower Ordovician) of western Newfoundland: tidal flat islands model for carbonate sedimentation in shallow epeiric seas. Sedimentology, v.33,p.313-343.

PRATT, L. M. (1984) Influence of paleoenvironmental factors on preservation of organic matter in Middle Cretaceous Greenhorn Formation, Pueblo, Colorado. Am. Assoc. Perrol. Geol. Bull., 68:11461159. 
REINECK, H.-E. e SINGH, I.B. (1986) Depositional Sedimentary Environments with reference to Terrigenous Clastics. Springer-Verlag, 2a. Ed. 551p.

RIBAS, L.B. (1969) Foraminíferos Bentônicos da Costa entre o Espírito Santo e Cabo Frio. Inst. Pesq. da Mar., Publ. 32.

RIBAS, L.B. (1973) Contribuição ao conhecimento dos foraminíferos de sèdimentos recentes da Paltaforma Continental do Estado do Rio de Janeiro. (Enseada dos Anjos e Adjacências - Cabo Frio). Dissertação de Mestrado. Instituto de Geociências, UFRJ. 50 p.

RICKEN, W, 1991 Variation of Sedimentary Rates in Rhythmically Bedded Sediments. Distinction Between Depositional Types. In EINSELE et al. (Eds.) Cycles and Events in Stratigraphy. Springer Verlag, Heidelberg, p. 167 187.

RODRIGUES, M.A.; de CARVALHO, M. da G.; DLAS, G. T. de M. 1981 Interpretação paleoambiental das lagoas Salgada e das Ostras (RJ) Brasil, com base em foraminíferos. ANAIS II CONGR. LATINO-AMERICANO PALEONTOLOGIA, Porto Alegre, Abril, 1981: 893-906.

SCHREIBER, B.C., 1986. Arid Shorelines and Evaporites. In: READING, H.G. (Ed.) Sedimentary Environments and Fácies. 2nd. Edition. Blackwell Scientific Publicatioons.Oxford. p. 189-228.

SCOTT,D.B.,1976. Quantitative studies of marsh foraminiferal patterns in southern California and their application to holocene stratigraphic problems. Maritime Sediments, Sp. Publ.,1: 153-170.

SCOTT, D.B.,1977. Distributions and population dynamics of marsh-estuarine foraminifera with applications to relocating Holocene sea-level. Halifax,252, phD Dissertation/Dalhousie Univ.

SCOTT, D. B. e MARTINI, I.P. 1982 Marsh foraminifera zonation in Western James and Hudson Bays. Naturaliste Can. (Rev. Écol. Syst.), 109: 399-414.

SCOTT, D.B. e MEDIOLI, F.S.,1978. Vertical zonations of marsh foraminifera as accurate indicators of former sea levels. Nature 272 (5653):528-531

SCOTT, D.B. e MEDIOLI, F.S., 1980. Quantitative studies of marsh foraminiferal distributions in Nova Scotia: Implications for sea level studies Cush. Found. Foram. Res., Sp. Publ., 17: 1-58

SCOTT, D.B. e MEDIOLI, F.S., 1982. Micropaleontological documentation for early Holocene fall of relative sea level on the Atlantic coast of Nova Scotia. Geology, 10: 278-281.

SCOTT, D.B. e MEDIOLI, F.S., 1986. Foraminifera as sea-level indicators. In: VAN DE PLASSCHE, O. (ed.) Sea-level Research: a manual for collection and evaluation of data. Free Univ. Amsterdam. Geo Books, Norwich: 435-455.

SCOTT, D.B.; PIPER, D.J.W.; PANAGOS, A. G.,1979. Recent salt marsh and intertidal mudflat foraminifera from the western coast of Greece. Rivista Italiana Paleontologia e Estratigrafia, 85 (1): 243-266.

SCOTT,D.B.; SCHNACK,E.J.; FERREIRO,L.; ESPINOSA, M.; BARBOSA, C. F., 1990. Recent marsh foraminifera from the east coast of South America: Comparison to the Northern Heemisphere. In HEMLEBEN C. et al. (eds) Paleoecology, Biostratigraphy, Paleoceanography and Taxonomy of Agglutinated Foraminifera, Kluwer Acad. Publ., 717-737.

SCOTT,D.B., SUTER, J.R. e KOSTER.S, L., 1991. Marsh Foraminifera and Arcellaceans of the lower Mississippi delta: Controls on Spatial Distributions. Micropaleontology, v.37, n.4,p. 373-392. 
SCOTT, D. K. e LECKIE, M.R., 1990. Foraminiferal zonation of Great Sippewissett Salt Marsh (Falmouth, Massachusetts). Journal of Foraminiferal Reseach, v.20, n.3, 248-266.

SHEARMAN, D. J., 1970. Recent halite rock, Baja California, Mexico. Trans. Inst. Min. Metall. B, 79, 155-162.

SMITH, D.A.; SCOTT, D.B.; MEDIOLI, F.S., 1984. Marsh foraminifera in the" Bay of Fundy: modern distribution and application to sea-level determinations. Maritime Sediments and Atlantic Geology, 20: $127-142$.

STEINECK, P.L. e BERGSTEIN, I., 1979. Foraminifera from Hommocks Salt-marsh, Larchmont Harbor, New York. Journal of Foraminiferal Research, v. 9,n.2, p. 147-158.

SUGUIO, K. e TESSLER, M.G., 1984. Planícies de cordões litorâneos quatemários do Brasil: Origem e Nomenclatura. In: LACERDA, L. D. et al. (Orgs.) Restingas: Origem, Estrutura, Processos. CEUFF, Niterói, 1984, p. 15-25.

SUGUIO, K. (1992) Dicionário de Geologia Marinha. T.A. Queiroz, São Paulo. p. 171.

SVERDRUP, H.U.; JONHSON, M.W.; FLEMING, R.H. 1942 The Oceans. Prentice Hall.

TANAKA, K., 1985. Comparação dos dados de temperatura obtidos da Comissão Oceanográfica Rio de Janeiro II com os dados do satélite SMS-2 na Região de Cabo Frio. Publicação do Instituto de Pesquisas Espaciais, 3440-PRE/697, 26 pp.

TWNOCO, L. de M., 1955. Foraminíferos recentes de Cabo Frio, Estado do Rio de Janeiro. Departamento Nacional de Produção Mineral, Bol. 159.Rio de Janeiro, 51 p.

TINOCO, I. de M., 1958. Observações sobre a fauna de Foraminíferos da Lagoa de Araruama. An. Acad. Bras. de Ci., v. 30 , n.4, p: 576-585.

TINOCO, I de M., 1989, Introdução ao Estudo dos Componentes Bióticos dos Sedimentos Marinhos Recentes. Recife, Ed. Universitária da UFPE, PROED, 220 p.

TÖLDERER-FARMER, M., 1985. Causalite des variations morphologiques de la carapace chez les ostracodes. Essai d'interpretation sur des populations actuelles et fossiles. Université de Bordeaux I. Thèse de Doctorat en Oceanologie. p. 285 plus planches et annexes.

TORRES, Jr. A. R., 1995. Resposta da Ressurgência costeira de Cabo Frio a Forçantes Locais. Dissertação (Mestrado - Coordenação dos Programas de Pós-Graduação COPPE)- UFRJ, 143 pp.

TURCQ, B.; COE-NETO, R.; FROIDEFOND,J.M., 1986. Variability of beach ridges on the coast of Maricá (rio de Janeiro, Brazil). In: RABASSA, J. (ed.) Quaternary of South America and Antarctic Peninsula. Rotterdam, A.A. Balkema. v. 4, p: 45-57.

TURCQ, B.J.; MARTIN, L.; FLEXOR, J-M.; SUGUIO, K.; PIERRE, C.; TASAYCO-ORTEGA, L. (INÉDITO) Origin of the Quaternary coastal plain between Guaratiba and Cabo Frio, Sate of Rio de Janeiro, Brazil.

VASCONCELOS, C. de O., 1988. Sedimentologia e Geoquímica da Lagoa Vermelha Um exemplo de formação e diagênese de carbonatos. Dissertação (Mestrado, Instituto de Química, Departamento de Geoquímica) UFF, Niterói, 87 p.

VASCONCELOS, C.; MCKENZIE, J; BERNASCONI, S.; GRUJIC, D.; TIEN, A.J., 1995. Microbial mediation as a possible mechanism for natural dolomite formation at low temperatures. Nature, vol. 377 , p. $220-222$. 
WILLIAMS, H.F., 1989. Foraminiferal zonations on the Fraser River delta and their application to paleoenvironmental interpretations. Palaeogeography, Palaeoclimatology, Palaeoecology, 73: 39-50.

WILLIAMS, H. F. L., 1994. Intertidal benthic foraminiferal biofacies on the central Gulf Coast of Texas: modern distribution and application to sea-level reconstruction. Micropaleontology, v.40, n.2, pp. 169-183. 


\section{CLASSIFICAÇÃO E TAXONOMIA}

Para as denominações supra-específicas foi adotado o trabalho de Loeblich e Tappan (1988). Na classificação de alguns gêneros e espécies, além dessa publicação, foi consultada a descrição original no catálogo Ellis e Messina (1940ss), ou quando possível,os artigos originais com as descrições das espécies. Outros trabalhos foram adotados, principalmente aqqueles que trazem formas cenozóicas da plataforma continental interna brasileira, argentina, lagunas costeiras, Golfo do México e Mar Mediterrâneo por apresentarem semelhança faunística com os exemplares identificados neste estudo.

A classificação de subordens de foraminíferos aqui empregadas segue a ordenação sugerida por Loeblich e Tappan (1988), bem como as familias e subfamilias. Os gêneros estão apresentados em ordem alfabética bem como as espécies descritas dentro de cada um, com as nomenclaturas abertas ao final.

As sinonímias apresentam somente a referência das espécies originais ou tabalhos mais relevantes. As descrições referem-se a algumas observações morfológicas relativas ao material analisado e ilustrado. As espécies que permaneceram indeterminadas caracterizam-se por tecas quebradas, muito pequenas ou com as feiçōes externas muito desgastadas. Os sinais cf., ?, e sp. A, B, foram utilizados de acordo com a terminologia sugerida por Bengtson, (1988).

MEV refere-se a microscópio eletrônico de varredura e EDS a análise de espectometria da energia dispersiva de raios- $x$.

Procedência: refere-se ao exemplar fotografado [entre colchetes] e sua respectiva identificação de campo e laboratório.

Dimensões: os exemplares fotografados correspondem a média representativa da população amostrada. 


\section{LISTAGEM DAS ESPÉCIES ENCONTRADAS}

\section{TECHAMOEBIA}

Centropyxis aculeata

Centropyxis constricta

Difflugia sp.

Lesquereusia spiralis

Pontigulasia compressa

FORAMINIFERA - AGLUTINANTES

Ammopemphix?

Discammina sp.

Discorinopsis aquayoi

Discorinopsis sp. A

Haplophragmoides manilaensis

Haplophragmoides wilherti

Polysaccammina ipohalina

Portatrochammina sp. indet.

Textularia earlandi

Tholosina?

Trochammina inflata

Trochammina macrescens f. polystoma

\section{FORAMINIFERA - CALCARIOS}

Abditodentrix rhomboidalis

Abditodentrix subexcowata

Abditodentrix cf. subexcavata

Affinetrina concisa

Affinetrina concisa subsp. A

Affinetrina cf. incisura

Affinetrina sommeri

Affinetrina sp. A

Agglutinella martiniiana?

Agglutinella sp. A

Ammonia beccarii

Ammonia beccarii f. beccarii?

Ammonia beccarii f. parkinsoniana

Ammonia beccarii f. tepida

Bolivina doniezi

Bolivina lepida

Bolivina aff. lepida

Bolivina sliteri

Bolivina sliteri subsp. asperoides

Bolivina striatula

Bolivina striatula?

Bolisina sublittoralis

Bolivina variabilis

Bolisina sp. A

Bolivina sp. $B$

Bolivina sp. C

Bolivina sp. D

Brizalina sp. A

Buliminella elegantissima

Cassidelina of spinescens

Cormuloculina sp.

Cribroelphidium of atlanicum

Cribroelphidium excovatum

Cribroelphidium excavatum f. clavata
Cribroelphidium excavatum f. selseyensis

Cribroelphidium poeyanum

Cribroelphidium of. vadescens

Cribromiliolinella sp. indet.

Disconorbis williamsoni

Discorbis

Eoeponidella nanoconica

Eoeponidella sp. A

Elphidiella sp.

Elphidium articulatum

Elphidium mexicanum

Fissurina compressa

Fisssurina lucida

Fissurina sp. A

Floresina seminuda

Glabratellina cf. tumiformis

Globocassidulina subglobosa

Hanzowaia sp. indet.

Helenina sp.

Loxostomina sp. A

Loxostomina sp. B

Massilina crescentensis

Massilina protea

Massilina cf. M. secans

Miliolina

Miliolina sidebottomi

Miliolina sp. A

Miliolinella of. antarctica

Miliolinella circularis

Miliolinella of. M. hybrida

Miliolinella loeblichi

Miliolinella subrotunda

Miliolinella cf. williamsoni

Miliolinella sp. A

Miliolinella sp. $B$

Miliolinella sp. C

Miliolinella sp. D

Neopateoris cf. N. cumanaensis

Neopateoris.sp. A

Neospiroloculina sp. A

Nonion barleeanum

Ophthalmina sp. A

Orbitina sp.

Pseudoeponides falsobeccarii?

Pseudotriloculina lecalvezae

$P_{\text {seudotriloculina subgranulata }}$

Quinqueloculina arctica

Quinqueloculina atlantica

Quinqueloculina australis?

Ouinqueloculina elegans

Quinqueloculina dilatata?

Quinqueloculina laevigata

Ouinqueloculina lamarckiana

Oningueloculina microcostata

Ouinqueloculina milletti

Quinqueloculina patagonica

Ouinqueloculina poeyano 


\author{
Quinqueloculina seminuda \\ Quinqueloculina seminulum \\ Quinqueloculina seminulum var, jugosa \\ Quinqueloculina subpoeyana? \\ Ouinqueloculina venezuelaensis var. A \\ Quinqueloculina sp. A \\ Rosalina candeiana \\ Rosalina floridana \\ Rosalina globularis \\ Rosalina vilardeboana \\ Siphonaperta sp. A \\ Triloculina asymmetrica \\ "Triloculina"fichteliana \\ Triloculina gracilis \\ Triloculina lutea \\ Triloculina cf. nitida \\ Triloculina trigonula \\ Triloculina webbiana \\ Varidentella implexa \\ Varidentella implexa subsp. A
}

Varidentella sp. A

Varidentella sp. $B$

Varidentella sp. $C$

Virgulopsoides sp. indet.

\section{OSTRACODA}

Cyprideis salebrosa

Loxoconcha paranensis

Paracypris sp.

Perissocytheridea cf. P. krömmelbeini

\section{GASTROPODA}

Caecum brasilicum

Hydrobia sp. A

Heleobia sp.?

Sayella aff. crosseana

CHAROPHYTES (Taxonomia a ser confirmada) Charc

Lamprothamminom? 


\author{
ARCELLACEA ("THECAMOEBIA") \\ Subfilo SARCODINA Schmarda, 1871 \\ Classe RHIZOPODEA von Siebold, 1845 \\ Subclasse LOBOSA Carpenter, 1861 \\ Ordem ARCELLINIDA Kent, 1880 \\ Superfamília ARCELLACEA Ehrenberg, 1830 \\ Familia CENTROPYXIDIDAE Jung, 1942 \\ Gênero Centropyxis Stein, 1859
}

Centropyxis aculeata Ehrenberg, 1832

(Est. 1, Fig.1)

Arcella aculeata Ehrenberg, 1832 b (ab Ehrenberg, 1830, p. 60, nomen nuadum; ou Ehrenberg, 1832 a, p.40, nomen nudum), p. 91

Centropyxis aculeata (Ehrenberg) Stein, 1859, p.43. Medioli e Scott, 1983, p. 39, est.7, figs.10-19

Descrição: Teca pequena, arredondada, discóide, comprimida; parede anterior, lisa, brilhante, muito fina e polida, com intussuscepção da abertura em posição subcentral anterior; material mais grosso, e pseudo espinhos ao longo da margem posterior-lateral.

Procedência: $\mathrm{SI}_{3}$

Obs: Esta espécie apresenta-se na borda da Lagoa de Tramandaí -RS (Closs e Madeira, 1967) sendo denominada Centropyxis (Cyclopyxis) arenata (Cushman); no estuário de Guaratuba (PR) foi observada principalmente nas áreas localizadas às margens dos manguezais (Barbosa 1991; no prelo).

\section{Centropyxis constricta Ehrenberg, 1843}

(Est. 1, Fig.2)

Arcella constricta Ehrenberg, 1843, p. 410, est.4, fig. 35; est. 5, fig. 1.

Centropyxis constricta (Ehrenberg). Deflandre, 1929 p.340, fig. $60-67$.

Centropyxis constricta (Ehrenberg). Medioli e Scott, 1983, p. 41, est..7, figs. 1-9.

Descrição: Teca pequena, comprimida, elíptica em vista posterior, intussuscepção da abertura em posição antero-marginal. Teca orgânica, variável em forma e tamanho.

Procedência: $\mathrm{S}_{1} l_{2}$

Obs: Sua ocorrência em áreas brasileiras está descrita e ilustrada em Closs e Madeira $(1962,1967)$, respectivamente para o Arroio Chuí e Lagoa de Tramandaí. Também foi observada no estuário de Guaratuba, por Barbosa (1995).

\section{Familia HYALOSPHENIIDAE Schulze, 1877 \\ Gênero Lesquereusia Schlumberger, 1845 \\ Lesquereusia spiralis ( Ehrenberg) \\ (Est.1; Figs. 3-4)}

Difflugia spiralis Ehrenberg, 1840, p.199

Lesquereusia spiralis (Ehrenberg). Patterson et al.,1985, p. 135, est. 2, figs.9,10

Descrição: Teca pequena, autógena, construída com idiossomas que däo uma forma vermicular, assimétrica, piriforme, comprimida lateralmente e com constrição na parede da teca. Abertura terminal circular. Idiossomas (para fixação ?) presentes no "fundus" da teca.

Procedência: $\mathrm{S}_{1} 1_{2}$ 
Obs: O espécie Lesquereusia spiralis está ilustrada em Patterson et al. (1985) e o gênero Lesquereusia está descrito e ilustrado em Medioli e Scott (1988), p. 372, est. II, 12-16.

A constrição presente na teca desta espécie pode ser devida a enrolamento ou presença de diafragma interno na base do pescoço, como em Pontigulasia compressa Carter, sendo as duas espécies muito similares no microscópio ótico e somente distintas ao MEV (Microscópio Eletrônico de Varredura). Seria interessante a análise detalhada da estrutura interna para sabermos se correspondem realmente a gêneros distintos.

Sua ausência em estudos que tratam de tecamebas no Brasil, talvez se deva ã esse problema, uma vez que a figura ilustrada em Closs e Madeira (1967), como Pontigulasia compressa é muito semelhante a Lesquereusia spiralis. 
Ordem FORAMINIFERIDA Eichwald, 1830

Subordem TEXTULARIINA Delage \& Hérouard, 1.896

Superfamília ASTRORHIZACEA Brady, 1881

Família POLYSACCAMMINIDAE Loeblich \& Tappan, 1984

Subfamília SACCAMMINA Brady 1884

Gênero Polysaccammina Scott, 1976

\section{Polysaccammina ipohalina}

(Est. 1, fig. 5)

Polysaccammina ipohalina Scott, 1976, p.319, figs. 4a-c, est. 2, figs 1-4.

Descrição: Teca média, livre; aproximadamente 20 câmaras pequenas, as iniciais são unisseriais, com torção no enrolamento, a partir da onde as câmaras apresentam arranjo bisserial; periferia arredondada; parede aglutinante com partículas muito finas; suturas distintas, comprimidas; e abertura em fenda, pequena, só observada ao MEV.

Procedência: $\mathrm{S}_{1} \mathrm{H}_{2}$

Obs: Na descrição original, apesar de citar o arranjo e forma irregular e extremamente variável da carapaça, Scott (1976) não menciona nenhum tipo de torção. Assim sendo, resta a dúvida se o exemplar fotografado, dentre outros espécimens de $P$. ipohalina típicos encontrados, corresponde ou não a essa espécie.

Família HEMISPHAERAMMINIDAE Loeblich \& Tappan, 1961

Subfamília HEMTSPHAERAMMININAE Loeblich \& Tappan, 1961

Gênero Ammopemphix Loeblich, 1952

\section{Ammopemphix ?}

(Est. 1, figs. 6-7)

Descrição: Teca fixa; por volta de quatro câmaras semi-esféricas de tamanho aproximadamente igual; enrolamento trocoespiral (?), indistinto devido a natureza heterogênea do material aglutinado; periferia arredondada; parede aglutinante com material grosso e irregular; suturas deprimidas; abertura arredondada, terminal, com borda e dente valvular.

Procedência: $\mathrm{S}_{1} 1_{2}$

Obs: Na descrição genérica de Loeblich \& Tappan (1988) não é feita menção a borda ou a nenhum tipo de dente na abertura, além de mencionar a característica muito fina do material aglutinado, o que não foi observado nos exemplares encontrados.

Gênero Tholosina Rhumbler, 1895

Tholosina?

(Est. 21, figs. 10-12)

Descrição: Teca livre, semi-esférica, irregular; periferia arredondada; parede aglutinante com areia muito fina, um tanto friável; aberturas numerosas, irregulares, pequenas, com as maiores distribuídas aleatoriamente; cor marrom claro.

Procedência: $\$ 11_{3}[10-11]$, Saquarema [12]

Obs: Os exemplares apresentam afinidade com a descrição de Tholosina, no entanto não parecem possuir o hábito fixo descrito para este gênero. Uma vez que até mesmo a classificação genérica desses indivíduos é duvidosa, foram feitas algumas análises de espectometria da energia dispersiva de raios-x (EDS) para verificar a composição química da tecá, sendo seus resultados descritos abaixo. 


\begin{tabular}{|c|c|c|c|c|c|c|c|}
\hline \multicolumn{3}{|c|}{ Fig. 10-11 } & \multicolumn{4}{c|}{ Fig. 12} \\
\hline Elementos & Fórmula & \multicolumn{2}{|c|}{ Peso \% } & Elementos & Fórmula & \multicolumn{2}{c|}{ Peso \% } \\
\hline $\mathrm{Ca}$ & $\mathrm{CaO}$ & 16.80 & 21.62 & $\mathrm{Ca}$ & $\mathrm{CaO}$ & 19.06 & 9.51 \\
\hline $\mathrm{Si}$ & $\mathrm{SiO} 2$ & 22.84 & 22.93 & $\mathrm{Si}$ & $\mathrm{SiO} 2$ & 30.14 & 38.31 \\
\hline $\mathrm{K}$ & $\mathrm{K} 20$ & 22.94 & 17.17 & $\mathrm{~K}$ & $\mathrm{~K} 20$ & 7.35 & 3.94 \\
\hline
\end{tabular}

O restante da porcentagem, para completar $100 \%$ é relativo ao elemento Au usado para metalização. Os dois valores de percentuais de peso obtidos em cada exemplar, correspondem aos resultados de dois pontos selecionados para análise, em cada teca. A maior porcentagem do elemento Si evidencia a natureza aglutinante dos exemplares.

Superfamília LITUOLACEA de Blainville, 1827

Família HAPLOPHRAGMOIDIDAE Maync, 1952

Gênero Haplophragmoides Cushman, 1910

Haplophragmoides wilberti Andersen, 1953

(Est. 1, figs. 9-16)

Haplophragmoides wilberti Andersen 1953, p.21, est. 4, fig. 7 a,b. Closs, 1962, p. 33, fig. 7, est. 6, figs. 22 a-c. Boltovskoy e Vidarte 1977, p. 39, est. 3, fig. 3. Zaninetti et al., 1977, est. 1, figs. 12,13. Scott et al., 1990 p. 731, est. 1, figs. 8a,b.

Haplophragmoides manilaensis Andersen, 1953, p. 22, est. 4, fig. 8a,b

Haplophragmoides bonplandi Todd e Brönnimann, 1957, p. 23, est. 2, fig. 2; Scott e Medioli, 1980a, p. 40 , est. 2 , figs. 4,5 .

Descrição: Teca média, livre; enrolamento planoespiral involuto, biumbilicado; 7- 8 câmaras na última volta, suavemente infladas, aumentando gradualmente em tamanho; periferia arredondada; parede finamente aglutinante; suturas distintas, comprimidas, retas; abertura em arco equatorial, com lábio, na base da face septal da última câmara.

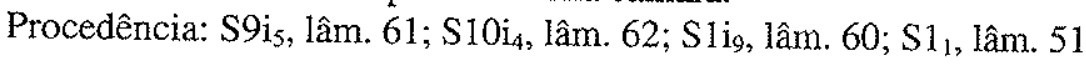

Obs: Esta espécie está descrita por Closs e Madeira (1966) em área próxima a ilha das Laranjeiras, na Baía de Paranaguá (PR). Parece apresentar preferência de habitat no manguezal superior, como encontrado em Guaratuba por Barbosa 1991 e Barbosa (no prelo).

Obs: Considera-se neste trabalho H. manilaensis, Andersen, 1953 como sinonímio júnior de $H$. wilberti, uma vez que em amostras com grande quantidade desses indivíduos, torna-se difícil a distinção entre essas espécies.

Familia DISCAMMINIDAE Mikhalevich, 1980

Gênero Discammina Lacroix, 1932

Discammina sp.

(Est. 1, fig. 8)

Descrição: Teca pequena, planoespiral suavemente evoluta, comprimida; quatro câmaras visíveis, a última maior que as demais; periferia arredondada; parede aglutinante com grãos de quartzo; suturas distintas; abertura arredondada, ampla e baixa, equatorial, interiomarginal.

Procedência: $\mathrm{S}_{3}$

Superfamilia TROCHAMMINACEA Schwager, 1877

Famúlia TROCHAMMINIDAE Schwager, 1877

Subfamília TROCHAMMININAE Schwager, 1877

Gênero Portatrochammina Echols, 1971 


\section{Portatrochammina sp. indet.}

(Est. 1, figs. 17-18)

Descrição: Teca pequena, trocoespiral, baixa; cinco câmaras visíveis na última volta; periferia arredondada; suturas distintas comprimidas, retas; umbílico coberto por um flap da última câmara; parede do proloculum de proteína, sem partículas aglutinantes como no restante da teca; abertura em arco interiomarginal baixo, na base da face septal, com lábio.

Procedência: $\mathrm{S}_{3}$

Obs: A espécie-tipo Portatrochammina eltaninae Echols, foi identificada em sedimentos do Mar da Escócia no continente Antártico, correspondendo portanto, a um gênero adaptado a baixas temperaturas.

Gênero Trochammina Parker \& Jones, 1859

Trochammina inflata Montagu, 1808

(Est. 1, figs. 19-20; Est. 2, figs. 1-2)

Nautilus inflata Montagu, 1808 , p. 8 b, est. 18 , fig. 3

Trochammina inflata (Montagu) Boltovskoy e Vidarte, 1977, p.39, est. 4, figs. 11, 14; Zaninetti et al. 1977, est. 1, figs. 1,2.

Siphotrochammina elegans Zaninetti et al., 1977, est. 2, figs. 8,10,11.

Descrição: Teca média, livre, trocoespiral, baixa; seis câmaras na última volta, aumentando suavemente em tamanho conforme somadas; periferia arredondada; parede aglutinante fina; suturas radiais; abertura interiomarginal, umbilical/extraumbilical com lábio.

Procedência: $\$ \mathrm{Si}_{1}$

Obs: Alguns exemplares com abertura interiomarginal desenvolvem uma terminação em forma de sifão na última câmara, direcionado para a frente no sentido do enrolamento.A espécie ilustrada como $S$. elegans Zaninetti et al.é idêntica a $T$. inflata, apresentando se dentro da amplitude de variabilidade que esta última apresenta. Zaninetti et al. definiu essa nova espécie sem descrição do material amostrado, sendo portanto difícil considerá-la uma nova espécie. Com isso, existe a necessidade de revisão profunda do gênero Siphotrochammina e algumas espécies definidas dentro desse gênero.

Trochammina macrescens Brady, 1870

Trochammina macrescens f. polystoma Bartenstein \& Brand, 1938

(Est. 2, figs. 3-4)

Trochammina inflata (Montagu) var. macrescens Brady, 1870, p. 290, est. 11, figs. 5a-c

Jadammina polystoma Bartenstein \& Brand, 1938, p. 38, figs. 1a-c, 2a-1

Trochammina macrescens Brady. Phleger \& Walton,1950, p.281, est.2, figs 6,7; Boltovskoy \& Vidarte, 1977 , p. 39 , est. 4, figs. 12,13

Trochammina irregularis Cushman \& Brönnimann. Zaninetti et al., 1977, est. 1, figs. 10,11.

Descrição: Teca de tamanho médio, livre, trocoespiral muito baixo tendendo a plano-espiral em espécimens adultos; seis câmaras ná última volta, aumentando de tamanho a uma taxa mediana; periferia arredondada; parede aglutinante; suturas radiais; abertura em fenda interiomarginal, equatorial, abertura areal suplementar logo acima da abertura principal, com lábio circundante.

Procedência S9i 5

Obs: Trochammina macrescens $f$. polystoma tem sido relacionada a altas salinidades, ao contrário de sua forma macrescens. A montante do estuário de macromarés de Gironde, Pujos (1984) documenta a migração sazonal de Jadammina polystoma Bartenstein \& Brand na porção oligohalina e de forte 
turbidez estuarina, juntamente com Haplophragmoides wilberti, alternando sua biofácies de ocorrência sazonal com a população de tecamebas. Infelizmente o trabalho não apresenta descrição do indivíduo considerado como $J$. polystoma. Assim não há certeza se realmente corresponde a atual f. polystoma ou f. macrescens.

\author{
Superfamília TEXTULARIACEA Ehrenberg, 1838 \\ Familia TEXTULARIDAE Ehrenberg, 1838 \\ Subfamília TEXTULARIINAE Ehrenberg, 1838 \\ Gênero Textularia Defrance, 1824
}

Textularia earlandi Parker, 1952

(Est. 2, fig. 5)

Textularia earlandi Parker, 1952, p. 458, est. 2, figs. 4-5

Texiularia paranaguaensis Closs \& Madeira, 1966, p. 147, est.1, fig. 2, est.2, fig. 1.

Descrição: Teca grande, livre;aproximadamente doze câmaras suavemente infladas, aumentando lentamente, em altura e largura para os últimos estágios ontogenéticos; periferia semi-retangular com bordas arredondadas e amplas; alongada, enrolamento bisserial, apresentando-se ao terceiro par de câmaras e somente aí, trisseriada; aglutinante, heterogêneo em forma e natureza; tecas de cores castanhas; suturas distintas, comprimidas, quase perpendiculares ao eixo do enrolamento, retas; abertura em arco baixo, com evidência de canaliculi, interiomarginal.

Procedência: $\mathrm{S} 7 \mathrm{i}_{\mathrm{S}}$

Obs: A dificuldade na distinção entre membros finais de $T$. earlandi e $T$. paranaguaensis, de acordo com as diferenças ressaltadas por Closs e Madeira, 1966 nos levou a considerar esta última sinonimio junior de T. earlandi.

\title{
Família VALVULAMMINIDAE Loeblich \& Tappan, 1986 \\ Gênero Discorinopsis Cole, 1941
}

Discorinopsis aquayoi (Bermudez)

(Est.2, figs. 6 - 15)

Discorbis aquayoi Bermudez, 1935, p. 204, est. 15, figs. 10-15.

Discorinopsis aquayoi (Bermudez) Parker, Phleger \& Pierson, 1953, p. 7, est. 14, figs. 23-24. Boltovskoy \& Hincapié de Martinez, 1983, p. 218, est. II, Figs. 8,9. Scott et al., 1990, p. 730, est. 1, figs. $6 \mathrm{a}, \mathrm{b}$.

Discorinopsis vadescens (Cushman \& Brönnimann). Boltovskoy \& Vidarte, 1977, p. 38, est. 2, figs. 8, 10.

Descrição: Teca pequena a média, com enrolamento trocoespiral baixo; seis câmaras na última volta, crescentes, resultando em uma teca auriculiforme; lado espiral convexo, baixo; poros grandes distribuídos na porção central das câmaras, apenas na face septal da última câmara, lado umbilical côncavo imperfurado; periferia arredondada; suturas pouco distintas, lisas, umbilicais radiais profundas na direção do umbílico; abertura principal indistinta abaixo do flap umbilical que apresenta diferentes graus de desenvolvimento, gerando aberturas suplementares.

Procedência: LV4 (64-67; 73 -75, lâm. 69; 94-96 cm, lâm. 70); S7, lâm. 15.

Obs: Na descrição de Loeblich e Tappan (1988) o gênero é referido a tecas com partículas calcárias aglutinantes com cimento calcário. Podemos caracterizar diferentes graus de conservação da teca, que podem confundir a aparência calcária desses indivíduos sob lupa binocular. 
Obs: Estes indivíduos diferem dos anteriormente descritos por apresentarem lado convexo dorsal perfurado densamente com poros distribuídos em toda sua extensão, com exceção das suturas que são limbadas. Seu lado ventral apresenta perfurações que se projetam de seu umbílico mas não alcançam a margem periférica ventral, com suturas indistintas cobertas por flaps camerais lisos e imperfurados.

Procedência: S7, lâm. 15

\author{
Subordem MILIOLINA Delage \& Hérouard, 1896 \\ Superfamília CORNUSPIRACEA Schultze, 1854 \\ Família OPHTHALMIDIIDAE Wiesner, 1920
}

Gênero Cornuloculina Burbach, 1886

\title{
Cornuloculina?
}

(Est. 26, fig 1-2)

Descrição: Teca de tamanho médio, semi-triangular em vista lateral, achatada lateralmente; arranjo milioliniforme, prolóculo globular com crescimento ontogenético posterior indistinto e somente as três últimas câmaras definidas, sendo a últina maior e mais larga que as precedentes; periferia arredondada; parede calcária porcelanosa brilhante, abertura estreitada no final đa última câmara por placa dental.

Procedência: S3i7, lâm. 38

Obs: Os exemplares observados foram inicialmente colocados neste gênero devido às características gerais da teca. Na descrição de Loeblich e Tappan 1988 este gênero apresenta carena, o que não foi observado em nosso material.

Gênero Ophthalmina Rhumbler, 1936

Ophthalmina sp. A

(Est. 3, fig. 1)

Descrição: Teca muito pequena; enrolamento plano espiral, comprimida lateralmente, discóide; três câmaras visíveis, sendo as últimas duas mais largas na base do que na extremidade; arranjo milioliniforme; periferia arredondada; parede calcária, porcelanosa, perolada, imperfurada, brilhante; últimas suturas distintas; abertura semi-arredondada, simples no final da última câmara, sem dente.

Procedência: LBE 89/2 (100-102 cm), lâm. 121

Obs: O exemplar fotografado mostra as duas câmaras finais praticamente completando a teca e pontos de corrosão na parede (?).

Superfamília MUIOLACEA Ehrenberg, 1839

Família SPIROLOCULINIDAE Wiesner, 1920

Gênero Neospiroloculina Mc Culloch, 1977

\section{Neospiroloculina sp. A}

(Est. 3, fig. 2)

Descrição: Teca grande, achatada; arranjo milioliniforme; cinco câmaras visíveis, sendo a última com a base mais larga que a extremidade e maior que as câmaras anteriores; periferia arredondada; parede calcária imperfurada, porcelanosa, superfície lisa, mas não polida, grossa; oval en perfil; terminação da abertura estendendo-se para além da linha mediana da teca, visível apenas en um dos lados; abertura terminal semi-arredondada, sem dente. 
Procedência: LV4 (122-126 cm), lâm. 72; LV4 (64-67), lâm. 69; LBE 89-2 (2-5) lâm. 132.

Obs: Embora o indivíduo fotografado tenha superfície da teca grossa, alguns exemplares, principalmente os menores, apresentam-na hialina e transparente.

Família HAUERINIDAE Schwager, 1876

Subfamília SIPHONAPERTINAE Saidova, 1975 .-

Gênero Agglutinella El-Nakhal, 1983

Agglutinella martiniiana?

(Est.3, fig.3-8)

Triloculina martiniiana d'Orbigny, 1839. Tomo 2, pt. 2, Est. 3, figs. 16-18.

Descrição: Teca pequena, oval, oblonga; arranjo pseudotriloculiforme; três câmaras visíveis, distintas, alongadas, mais largas na base, englobantes, sendo as iniciais oblíquas; periferia arredondada; parede calcária, com cobertura superficial de grãos muito finos, homogêneos em origem e forma; suturas sinuosas, comprimidas, fortemente oblíquas. Abertura grande, oval com peristoma espesso, elevado, às vezes como um pescoço, possuindo dente largo em forma de barra, com extremidade mais larga que a base, acompanhando o desenho lateral do formato do lábio e praticamente preenchendo a abertura.

Procedência: LV 89/19 (89-91 cm), lâm. 99; S6ì , lâm. 43

Obs: T. martiniiana apresenta parede lisa, brilhante e acuminada na base. A espécie parece apresentar variação no formato do dente e abrangência da última câmara. Alguns exemplares nas amostras atuais não parecem apresentar aglutinação de grãos, cmborá o formato geral da teca seja idêntico. Uma questão permanece sem resposta, esta cobertura de grâos (dolomita ?) é natural da espécie ou é ambiental?

$\mathrm{Obs}_{2}$ : Alguns exemplares apresentam-se mais alongados em vista lateral e a abertura apresenta dente longo, irregular, como no gênero Affinetrina descrito mais adiante. Diferem de "Quinqueloculina" sp. A Hottinger et al., 1993, por não apresentar periferia aguda; talvez correspondam a uma nova espécie, como sugerido por estes autores. Diferem de Miliolina chrysostoma Chapman, 1909 por apresentarem-se totalmente alongadas e ovais e não moderadamente larga e com dente tão proeminente.

Agglutinella sp. A

(Est. 3, fig. 9; Est. 26, fig.3)

Descrição: Teca pequena, alongada, sub-elíptica em vista lateral; três câmaras visíveis no exterior com arranjo pseudotriloculiforme; lateralmente comprimida; periferia arredondada; parede calcária, coberta com camada de material aglutinado muito fino, homogêneo em origem e forma; suturas pouco marcadas; abertura terminal subelíptica com dente fino e simples.

Procedência: $S 7_{1}$, lâm. 15 .

Gênero Siphonaperta Vella, 1957

Siphonaperta sp. A Hottinger et al. 1993

(Est. 26, Fig. 4-5)

Quinqueloculina cf. wiesneri Parr. Haig, 1988, p.234, pl.8, figs. 29-31.

Siphonaperta sp. A Hottinger, Halicz e Reiss, 1993, p. 64, pl. 64, figs. 7-12

Descrição: Teca média, porcelânica; subelíptica em vista lateral, mais alta que larga;arranjo quinqueloculiforme; cinco câmaras visíveis pouco infladas; periferia arredondada; parede com microestrias anastomosadas longitudinais, com distintas irregularidades transversais que produz depressões externas generalizadas, dando aspecto grosso a teca e de grãos aglutinados; suturas deprimidas; abertura terminal suboval ao final de um percoço curto com dente bipartido e borda peristomal com lábio. 


\author{
Subfamília HAUERININAE Schwager, 1876 \\ Gênero Massilina Schlumberger, 1893
}

Massilina crescentensis Hamlin, 1960

(Est. 3, figs. 10-13)

Massilina crescentensis Hamlin, 1960, vol. 11, pt.3, p. 87, est. 14, fig. 1 a-d, 2 a-d.

Descrição: Teca porcelanosa, achatada lateralmente, mais larga que alta; arranjo milioliniforme; cinco câmaras visíveis, infladas; periferia arredondada; parede com estrias muito finas e irregulares; suturas distintas; abertura subarredondada, com peristoma espesso, antero-escavado, com dente simples. Exemplares mais desenvolvidos podem apresentar dente secundário estendendo-se do topo da abertura.

Procedência: LV4 (4I-45 cm), lâm. 68

Obs: Diferem de Neopateoris Bermúdez \& Seiglie, por não apresentarem dente terminalmente bipartido. Os exemplares ilustrados 12 e 13 foram referidos com a designação informal (?) por não apresentarem- se elípticos em vista lateral e sim arredondados, podendo corresponder a outra espécie.

\title{
Massilina protea Parker, 1953
}

(Est. 3, figs. 14-18)

Massilina protea Parker, Phleger e Peirson, 1953, n. 2, p.10, est. 2, figs. 1-4

Descrição: Teca média a grande, comprimida lateralmente, mais longa que larga; arranjo milioliniforme; cinco câmaras aparentes; periferia arredondada; parede grossa com costelas longitudinais variáveis, baixas, truncadas; suturas deprimidas e quase indistintas; abertura um pouco destacada, semi-circular com lábio polido, espesso e dente largo a muito largo, curto e bipartido.

Procedência: LV4 (223-225 cm), lâm. 80; LBE 89/2 (109-111, 129-131 cm) lâm. 107 e 109 respectivamente.

Obs: Essa espécie apresenta-se bastante irregular, com alguns exemplares retorcidos. Esta variabilidade, descrita para a espécie-tipo, é marcante também nos exemplares estudados no presente trabalho. Embora não haja menção sobre pescoço para a espécie-tipo, no presente estudo, algumas vezes exemplares teratológicos apresentam «se com pescoço nítido; outras vezes o pescoço está torcido, quase acompanhando o contorno da teca. As outras características, no entanto, não deixam dúvida quanto a espécie $M$. protea, não se parecendo com nenhuma outra espécie descrita. Os indivíduos das figuras 16-18, foram designados informalmente como (?) por possuirem pescoço.

Acredito que a tendência ao desenvolvimento de pescoço nas espécies do presente estudo possa estar ligada a hábitos alimentares herbívoros ativos, uma vez que os pseudópodos não são rígidos e necessitam de suporte.

Difere de Q. stalkeri Loeblich \& Tappan, 1953 por esta apresentar a superfície com material aglutinado de granulação muito fina e $Q$. subpoeyana Cushman, 1922 apresenta abertura com lábio

- muito fino e dente simples.

Massilina cf. $M$. secans (d'Orbigny)

(Est. 4, Figs. 1-3)

Quinqueloculina secans d'Orbigny, 1826, p. 303, n. 43, modelos, n. 96.

Massilina secans (d'Orbigny) Schlumberger, 1893, p. 218 , est. 4, figs. 82,83 . Cushman, 1929, p. 37 , 38 , est. 7 , figs. 3,4 .

- Descrição: Teca de tamanho médio, subcircular em lista lateral; arranjo quinqueloculiforme; cineo câmaras aparentes, a menor câmara aparente projeta-se na forma de crista suavemente acuminada; periferia arredondada passando a aguda e carenada nos estágios ontogenéticos finais; parede lisa, 
porcelanosa, brilhosa com aparência enrrugada na última câmara; suturas distintas, comprimidas; abertura arredondada, ampla com peristoma e dente fino bipartido.

Procedência: $\mathrm{S}_{3 i}$, lâm. 38

Obs: Os exemplares desse estudo apresentam a última câmara com aparência enrrugađa, talvez devido a estágios de crescimento, como em $M$. australis Cushman, 1932, mas diferencia-se desta por apresentar abertura mais larga e dente bipartido, arranjo diferenciado e câmaras mais infladas.

Difere de $M$. brodiei Hedley, Hurdle \& Burdett, 1967 por esta possuir abertura alongada, com dente grande, no entanto, esses autores descrevem e ilustram dente variável de simples a bipartido, com alguns indivíduos mais inflados.

Difere de Q. catalinensis Natland, 1938 por esta possuir teca com aparência grossa, e abertura suavemente destacada da teca com margem espessa.

Difere de $Q$. planciana d'Orbigny, 1839 por esta ser mais alongada, possuir à penúltima câmara carenada e última arredondada (ao contrário dos exemplares deste estudo) e dente alongado.

Difere de $Q$. vulgaris d'Orbigny, 1826 por esta, apresentar penúltima câmara carenada e última arredondada e ter uma aspecto mais grosso. Infelizmente d'Orbigny não descreveu a espécie-tipo nem forneceu ilustrações, que foram posteriormente figuradas por Parker, Jones \& Brady, 1871 e Fornasini, 1902, sendo descrita e ilustrada por Cushman, 1917. Cushman, 1929 descreve a abertura como alongada, usualmente com dente simples o que a difere de nossos exemplares além de não haver menção sobre crenulaçōes ou qualquer outro tipo de ornamentação diferenciada em sua última câmara.

O exemplar ilustrado (3) apresenta-se com arranjo quinqueloculiforme o que nos leva a questionar o gênero Massilina, posteriormente designado e consagrado para esta espécie. Talvez d'Orbigny estivesse certo em incluir sua espécie no gênero Quinqueloculina. O número escasso desses indivíduos não permitiu a determinação de sua variabilidade.

\section{Gênero Quinqueloculina d'Orbigny, 1826}

Quinqueloculina arctica Cushman, 1933

(Est. 4, figs. 6-7)

Quinqueloculina arctica Cushman, 1933. v.89, n.9, p.2, est. 1, fig. 3

Quinqueloculina arctica Cushman. Boltovskoy et al. 1988, p. 45, Est. 26, figs 18-20

Descrição: Teca pequena, robusta, lateralmente pouco achatada; periferia arredondada; quatro a cinco câmaras visíveis no exterior, um pouco angulosas; parede calcária, porcelanosa, com grãos extremamente finos aglutinados sobre a parede lisa dando um aspecto fosco a teca e crenulado ao MEV, aparência áspera; suturas pouco distintas; abertura arredondada com lábio espesso, proeminente, liso e dente simples, largo, retangular ou terminalmente bipartido.

Procedência: LBE 89/2 (119-121 cm), lâm. 108; LV4 $(212-215 \mathrm{~cm})$, lâm. 79, exemplar bioturbado proveniente de sedimento de lama orgânica.

\section{Quinqueloculina atlantica Boltovskoy, 1957}

(Est. 4, Fig.14)

Quinqueloculina sp. b. Tinoco, 1955, Bol. 159, p.17, est. 1, fig.8.

Quinqueloculina atlantica Boltovskoy, 1957 . vol. 6, n.1, p.25, est.5, figs. $2-6$

Descrição: Teca pequena-média, oblonga, vista lateral subelíptica, vista apical semi-triangular; periferia arredondada; cinco câmaras visíveis, mais largas na base do que na extremidade; parede lisa, brilhante, porcelanosa; suturas nítidas, comprimidas; abertura redonda com borda e dente simples e longo, na extremidade da última câmara, na base da abertura, observa-se un afundamento muito sutil diferenciando a abertura do restante da câmara.

Procedência: $\mathrm{S} 1 \mathrm{i}_{\mathrm{g}}, \mathrm{lâm} .22$

Obs: Difere de $Q$. patagonica d'Orbigny por possuir câmaras com largura igual, abertura oval e dente curto. 


\section{Quinqueloculina australis?}

(Est. 4, Figs. 10-11)

Quinqueloculina australis Parr, 1932. vol. 44, p.7, Est. 1, fig. 8 a-c.

Descrição: Teca média semi-arredondada, estágios finais não dispostos em um mesmo plano; periferia semi-angulosa; quatro a cinco câmaras visíveis na última volta, inicialmente oblíquas; parede porcelanosa, lisa, polida; suturas distintas mas não comprimidas; abertura anipla semi-retangular com peristoma e dente bipartido pequeno.

Procedência: $\mathrm{S} 3 \mathrm{i}_{5}$, lâm. 16

Obs: Na descrição de Parr a abertura é semi-circular, com dente da mesma forma, o que não corresponde aos exemplares deste estudo. A forma torcida da teca lhe confere un aspecto similar aos espécimens denominados neste estudo de Varidentella implexa, mas diferencia-se desta pela presença de dente.

\section{Quinqueloculina dilatata?}

(Est. 4, Fig.15; Est. 26, figs.6-7)

Quinqueloculina dilatata d'Orbigny, 1839 , p. 192, est. 11, figs. 28-30

Quinqueloculina dilatata d'Orbigny. Cushman, 1929, Bull. 104, p. 26, est. 2, figs. 5a, b.

Descrição: Teca média, semi-arredondada, lateralmente comprimida; periferia arredondada; quatro a cinco câmaras visíveis na última volta, sendo a última mais larga e abrangente na base; parede calcária, porcelanosa, lisa, polida; suturas pouco distintas, comprimidas; abertura semi-circular, alongada, com borda peristomal fina e dente pequeno com extremidade alargada.

Procedência: LV4 $(84-86 \mathrm{~cm})$, lâm. 70

Obs: O exemplar ilustrado por Cushman apresenta abertura em fenda não condizente com a descrição do material que deveria apresentar abertura oval, alongada, com dente.

\section{Quinqueloculina elegans d'Orbigny, 1878}

(Est. 5, Figs. 9-10)

Quinqueloculina elegans d'Orbigny, 1826 [ nom. nud.],p.135, n.12, est. III, figs. I a-d

Quinqueloculina elegans d'Orbigny.Fornasini, 1902, sér. 5, tomo 10, p. 24, fig. 19

Descrição: Teca de tamanho médio, irregular, lateralmente pouco comprimida, semi-arredondada em vista lateral, com porção lateral-central convexa; quatro câmaras visíveis na última volta, lateralmente abrangente (câmaras com porção basal mais larga que a extremidade); enrolamento quinqueloculiniforme indistinto e tendência final plano-espiral; ornamentação com costelas longitudinais bem marcadas, as quais se fundem na periferia produzindo uma linha de carena ("bladelike carina"); abertura terminal semi-arredondada, com borda lisa, sem dente ou com dente simples. Procedência: $\mathrm{S} 3 \mathrm{i}_{7}$

Obs: Difere de Q. costata d'Orbigny, 1878 por esta ser mais alongada e não possuir carena.

\section{Quinqueloculina laevigata d'Orbigny, 1826}

(Est. 26, fig. 8)

Quinqueloculina laevigata d'Orbigny, 1826, vol.7, p. 301,no. 6

Descrição: Teca pequena a média, oblonga, quatro a cinco câmaras aparentes na última volta, enrolamento quinqueloculiniforme; periferia arredondada, parede porcelanosa, fina, brilhante e polida com superfície que não é integralmente lisa mas mostra suaves traços longitudinais não aparentes em

primeiro plano; suturas pouco comprimidas; abertura arredondada e pequena, com dente fino.
Procedencia: LBE 89-2 
Quinqueloculina lamarckiana d'Orbigny, in De la Sagra, 1839, p.189, pl.11, figs.14,15

Quinqueloculina lamarckiana d'Orbigny in Cushman, 1921, vol.59,p.65, pl.15, figs13,14

Descrição: Teca média, vista lateral arredondada, triangular em seção transversal, quatro a cinco câmaras distintas na última volta; enrolamento quinqueloculiniforme;-periferia com ângulos subagudos; parede calcária, porcelanosa lisa e brilhante; suturas deprimidas; abertura arredondada com dente fino e alongado. Em alguns exemplares a abertura se eleva, mas não chega a formar pescoço.

Procedência: $\mathrm{S} 3 \mathrm{i}_{7}$, lâm. 38 .

\section{Quinqueloculina microcostata Natland, 1938}

(Est. 5, figs. 7-8)

Quinqueloculina microcostata Natland, 1938. vol.4, n.5, p.142, est. 4, fig. 6amc

Descrição: Teca média a grande, fusiforme, suavemente convexa; quatro a cinco câmaras distintas; enrolamento quinqueloculiniforme; periferia angulosa; parede porcelanosa, ornamentada com estrias longitudinais muito finas, irregulares; suturas deprimidas; abertura terminal, oval, com lábio liso e fino e dente fino na base e bipartido-inflado na extremidade.

Procedência: $\mathrm{S} 3 \mathrm{i}_{2}$, Lâm. 18

Obs: Difere de $Q$. lamarckiana d'Orbigny por possuir ornamentação da teca com estrias.

Quinqueloculina milletti (Wiesner)

(Est. 4, figs. 4-5, Est. 26, fig.12)

Miliolina milletti Wiesner, 1912. Arch. Protistenk., v.25, p.220-237

Quinqueloculina milletti (Wiesner) Boltovskoy et al. 1980, p. 46, est. 28, figs. 13-17.

Descrição: Teca pequena, elíptica, lateralmente comprimida; quatro a cinco câmaras visíveis na última volta, inicialmente oblíquas; periferia amplamente arredondada; enrolamento quinqueloculiniforme; parede lisa, calcária, brilhante; suturas distintas; abertura semi-arredondada, terminal, com peristoma espesso, dente pequeno, simples ou indistinto.

Procedência: $\mathrm{S} 7_{1}$, lâm. 15

Obs: São comuns exemplares com arranjo e forma de sutura como ilustrado na estampa 26.

Quinqueloculina patagonica d'Orbigny, 1839

(Est. 4, figs.16-20)

Quinqueloculina patagonica d'Orbigny, 1839. d'Orbigny, p.74, est.4, figs. 14-16.

Quinqueloculina patagonica d'Orbigny. Boltovskoy, Giussani, Watanabe \& Wright, 1980, p. 46, est. 28 , figs. 18-21.

Descrição: Teca média, alongada, subelíptica em vista lateral e periférica, subtriangular em vista apical; cinco câmaras visíveis; periferia arredondada; enrolamento quinqueloculiniforme; parede porcelanosa, lisa; suturas distintas, comprimidas; abertura terminal arredondada, com borda e dente bipartido de base larga.

Procedência: S7, lâm. 15; S3is, lâm. 16; LV4 $(212-215$ cm), lâm. 79

Obs: Difere de $Q$. milletti (Wiesner) por não apresentar abertura com dente simples. Difere de $Q$. atlantica Boltovskoy por não apresentar abertura estreita alongada com dente fino e longo. Difere de Q. seminulum (Linné) por não apresentar câmaras com diâmetro uniforme. 
Quinqueloculina poeyana d'Orbigny, 1839, p.191, vol. 8, est. 11, figs. 25-27

Quinqueloculina poeyana d'Orbigny. Cushman, 1929, Bull. 104, p. 31, est. 5, figs. 2 a-c.

Descrição: Teca média, oblonga, suavemente comprimida; quatro câmaras pouco distintas na última volta; periferia arredondada; enrolamento quinqueloculiniforme; superfície ornamentada com numerosas costelas longitudinais bem marcadas, contínuas, que se fundem na periferia; suturas pouco comprimidas; abertura oval com borda peristomal muito discreta, dente simples e estreito.

Procedência: $\mathrm{S} 3 \mathrm{i}_{5}$, lâm. 16.

Obs: Difere de Q. costata pela forma oblonga e suturas menos marcadas. Na descrição original de d'Orbigny a abertura não possui peristoma; já em Cushman, encontramos lábio pouco marcado ("lip slight"). Existe a necessidade de exame das espécies-tipo de $Q$. costata e $Q$. poeyana para saber se realmente correspondem a diferentes espécies ou a variantes da espécie $Q$. poeyana, sendo muitas vezes đifícil a diferenciação entre os dois membros finais.

\section{Quinqueloculina seminuda Reuss}

(Est. 26, figs.13-15)

Quinqueloculina seminuda Reuss in Cushman 1929. Foraminifera of the Atlantic Ocean. Bull.104. part 6, pg. 33, pl.6, Figs 6a-c.

Descrição: Teca média a grande, mais larga que longa em vista lateral, triangular em vista apical; mais que cinco câmaras visíveis na última volta; arranjo quinqueloculiniforme; periferia aguda limitada por costelas longitudinais bem marcadas, com distribuição irregular e nunca muito abundante; suturas pouco distintas; abertuira terminal, arredondada, com lábio e dente pequeno.

Procedência: $\mathrm{S} \mathrm{i}_{11}$, lâm. 24

Obs: Difere de $Q$. funafutiensis (Chapman) por possuir a periferia bem marcada por costelas e ser mais achatada. Reuss descreveu originalmente esta espécie para o Oligoceno da Alemanha, mas outros autores tem estendido sua ocorrência ao Holoceno, como Heron-Allen e Earland (região de Clare Island na Irlanda) e Oeste da Escócia. Earland registra esta espécie nas áreas costeiras de Bagnor, Sussex e Cushman para o Atlantico ( costa dos EUA- Golfo do México e Mar do Caribe).

\section{Quinqueloculina seminulum (Linné)}

(Est. 4, figs.12-13)

Serpula seminulum Linné,1767.p. 1264, n. 791.

Quinqueloculina seminulum (Linné) Boltovskoy et al., 1980, est. 29, figs, 7-13

Descrição: Teca média, oval em vista lateral, oblonga, vista lateral desigualmente convexa; cinco câmaras visíveis, alongadas e de largura uniforme; arranjo quinqueloculiniforme; periferia semi. arredondada; parede porcelanosa, lisa; suturas distintas; abertura semicircular com dente bipartido curto em forma de U.

Procedência: S3in , lâm. 17

\section{Quinqueloculina seminulum (Linné) var. jugosa Cushman, 1944}

(Est.5, figs.1-4)

Quinqueloculina seminulum (Linné) var. jugosa Cushman, 1944, n. 12, p. 13, est. 2, fig. 15

Descrição: Teca de tamanho médio, subelíptica em vista lateral, semi-triangular em vista apical; cinco câmaras visíveis no exterior; arranjo quinqueloculiniforme; estreitando-se longitudinalmente em direção a abertura; periferia arredondada; parede calcária, porcelanosa, ornamentada com costelas 
longitudinais, bem marcadas e irregulares; suturas indistintas; abertura terminal arredondada com peristoma e dente bipartido.

Procedência: LV4 (41-45 cm), lâm. 67 [1 - 2]; S3i 4, lâm. 16 [3 - 4].

Obs: Nossos exemplares [3 - 4],são extremamente similares em vista lateral a ilustração de $Q$. poeyana d'Orbigny subsp. victoriensis Collins, 1974, mas distingue-se desta subespécie pela forma da abertura, descrita como estreita, de lados paralelos quase totalmente preenchida por dente reto e longo.

Difere de $Q$. poeyana d'Orbigny por esta possuir dente simples e não possuir peristoma.

\section{Quinqueloculina subpoeyana?}

(Est. 5, figs. 11-14)

Quinqueloculina subpoeyana Cushman, 1922. Cushman, 1929, Bull. 104, p.31, est. 5, figs. 3 a-c.

Descrição: Teca média a grande, alongada; quatro câmaras visíveis no exterior; periferia arredondada; arranjo quinqueloculiniforme; parede calcária, porcelanosa, superfície com costelas longitudinais desgastadas mas nítidas, truncadas, irregulares, dando uma aparência grossa à teca; suturas distintas; abertura terminal, arredondada, produzida ao final de um pescoço que acompanha o enrolamento, circundada por lábio virado para fora, com dente bipartido curto ou marginal simples e muito pequeno.

Procedência: [11-12] - Lv4 (54-56 cm), lâm. 69; [13 14] - S7 , lâm. 15

Obs: $O$ dente bipartido não é típico de $Q$. subpoeyana a qual possui dente simples. Difere de $Q$. costata por possuir dente bipartido e lábio. Difere de $Q$. poeyana por possuir costelas irregulares, lábio e pescoço. No geral, os exemplares não apresentam pescoço muito desenvolvido.

\section{Quinqueloculina venezuelaensis Bermúdez \& Seiglie var. A}

(Est. 5, figs. 5-6)

Quinqueloculina venezuelaensis Bermúdez \& Seiglie, 1963. vol. 2,n. 2, p.142,143, Est. 9, fig. 7a,b.

Descrição: Teca de tamanho médio, alargada em sua parte equatorial, triangular em vista apical; quatro câmaras visíveis apresentando costelas longitudinais regular e contímua, espessas; periferia subangulosa; arranjo quinqueloculiniforme; parede porcelanosa, branca; suturas profundas; abertura terminal, semi oval, elevada, com lábio bem definido, transbordante, dente internamente bipartido, abaixo da superfície labial, dando externamente, a aparência de ser pequeno simples e um pouco alargado.

Procedência: LV4 (110-115 cm), Lâm. 71

Obs: As tecas analisadas apresentam as partes iniciais centrais convexas desgastadas.

\section{Quinqueloculina sp. A}

(Est. 4, figs. 8-9)

Descrição: Teca de tamanho médio, alongada, comprimida lateralmente, porção equatorial da teca mais alargada; cinco câmaras visíveis, última câmara envolve as prévias em sua base; arranjo quinqueloculiniforme; periferia semi-angulosa; parede lisa porcelanosa; suturas pouco distintas; abertura arredondada, com borda espessa, dente bipartido, largo, ocupando metade da abertura.

Procedência: S3 $3_{2}$, Lâm. 14

Obs: Embora o formato lateral da teca seja semelhante a Miliolina cultrata Brady, esta năo possui dente. 


\section{Subfamília MILIOLINELLINAE Vella, 1957 \\ Gênero Affinetrina Luczkowska, 1972}

"Affinetrina" concisa (Cushman)

(Est. 6, fig. 5; Est. 26, figs.13-14)

Triloculina concisa Cushman, 1944. n.12, p.16, est.2, fig. 24 a-b.

Descrição: Teca média, alargada, comprimida lateralmente, semi-arredondada, três câmaras distintas, sendo a última abrangente; periferia arredondada; parede lisa, polida; suturas quase indistintas, abertura oval alongada, peristoma; dente único e longo, estreito na base e alargado na extremidade.

Procedência: $\mathrm{S} 3 \mathrm{i}_{5}$, lâm. 16

Obs: Foi inicialmente colocada no gênero Affinetrina pela forma da teca e pelo tipo de dente magro, longo e terminalmente inflado ou bipartido que define este gènero, diferenciando-o de Triloculina. No entanto, parece apresentar mais que três câmaras aparentes, em sua parte central, posicionadas perpendicularmente à orientação das últimas câmaras.

\section{"Affinetrina" concisa (Cushman) subsp. A}

(Est. 26, figs. 15-16)

Obs: Difere de "Affinetrina" concisa (Cushman) por apresentar sua parte central aprofundada e longitudinal à orientação lateral dos últimos estágios ontogenéticos com extremidade do dente bifurcada.

Procedência: S7i, lâm. 40

\section{Affinetrina cf. incisura (Todd)}

(Est. 6, figs. 1-4)

Triloculina incisura Todd. Todd, 1957, p. 308, est. 86, fig. 18.

Quinqueloculina cf. Q. incisura (Todd). Haig, 1988, p. 233, est. 6, figs. 11-14.

"Quinqueloculina" eburnea (d'Orbigny). Hottinger et al. 1993, p. 59, pl.53, figs. 9-11, pl. 54, Figs. 15 .

Descrição: Teca pequena a média, oblonga, oval em vista lateral e comprimida; três câmaras visíveis, com base da última câmara abrangendo as precedentes; enrolamento pseudotriloculiniforme; periferia arredondada; parede porcelanosa, lisa, polida; suturas distintas, curvadas e levemente sinuosas; abertura terminal, comprimida lateralmente, borda peristomal lisa; dente alongado, magno, em forma de barra, projetando-se de forma arqueada e acompanhando o contorno apical da teca, as terminações basais e distais do dente possuem a mesma largura e praticamente preenchem a abertura.

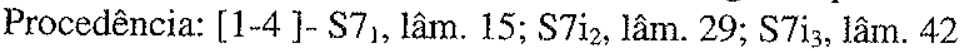

Obs: Difere de Triloculina eburnea d'Orbigny por não possuir dente com extremidade alargada lateralmente como na forma de um "T". Hottinger et al. (1993), denomina de "Quinqueloculina"eburnea (d'Orbigny), embora seus exemplares não apresentem o dente característico da espécie T. eburnea, sendo muito semelhante aos espécimens deste estudo. Hottinger et al. (1993) considera que esta espécie possa corresponder a um novo gênero, devido ao arranjo, ausência de abertura com lábio virado para fora e dente bipartido.

Nossos exemplares apresentam largura do dente variada, mas uniforme em sua parte basal e distal como na Triloculina bermudezi Acosta, 1940, mas diferenciam-se desta por não apresentar a teca com extremidade apical comprimida, dando aspecto piriforme. 


\section{Affinetrina sommeri (Tinoco)}

(Est. 6, figs. 6-8)

Triloculina sommeri Tinoco, 1955. p. 24, est. 2 , figs. 8 a-c, 9 a-c.

Descrição: Teca pequena, arredondada, longitudinalmente achatada, semicircular em vista apical; três câmaras visíveis; periferia amplamente arredondada; parede porcelanosa, um pouco irregular, sugerindo a aglutinação de grãos carbonáticos muito finos cobrindo a parede lisa; suturas deprimidas apresentando-se retas no lado biloculado e sinuosas no lado oposto; abertura pequena, oval, lateralmente comprimida com dente em forma de barra, simples e pequeno, o qual, observado em exemplares mais desenvolvidos apresenta base estreita e extremidade alargada.

Procedência: [6-7]-LV4 (122-126 cm), lâm. 72; [8]- LBE 89/2 (100-102 cm)

Obs: Esta espécie foi definida na região de Cabo Frio. Alguns de nossos exemplares não apresentam o dente tão curto como na descrição do holótipo. A forma do dente é típica do gênero Affinetrina e não Triloculina.

\section{Affinetrina sp. A}

(Est. 6, figs. 15-16)

Descrição: Teca de tamanho médio, elíptica em vista lateral e oval em vista apical, formato pseudotriloculiniforme; três câmaras visíveis; periferia arredondada; parede calcária, imperfurada, porcelanosa branca a perolada; suturas indistintas, abertura arredondada à oval; dente oval quase completando a abertura.

Procedência: $\mathrm{S} 3 \mathrm{i}_{4}$, lâm. $16 ; \mathrm{S} 7 \mathrm{i}_{3}$, lâm. 42

Obs: Presença de diatomáceas epizóicas sobre o exemplar fotografado. Alguns exemplares podem apresentar a abertura elevada, mas não chegando a formar um pescoço.

Esta espécie necessita maior detalhamento, uma vez que não foi possível observar se todos os exemplares apresentam frústulas de diatomáceas epizóicas, ou se pode corresponder a algum tipo de aglutinação secundária, como nas Agglutinella. Devido a dificuldade para determinação de suturas e conseqüentemente do número de câmaras, foi colocada inicialmente sob este gênero, pela forma do dente.

\section{Gênero Cribromiliolinella Saidova, 1981}

\section{Cribromiliolinella sp. indet}

(Est.6, figs. 13-14)

Descrição: Teca de tamanho médio, pouco achatada lateralmente mais longitudinalmente; três câmaras visíveis, com larguras equivalentes, semi-oval em vista apical; periferia arredondada; parede porcelanosa, lisa, suturas deprimidas, abertura terminal com flap miliolineliforme que acompanha 0 eixo de enrolamento.

Procedência: LV4 $(41-45 \mathrm{~cm})$, lâm. 68

Obs: O exemplar fotografado aparentemente apresenta sua abertura com quebra e regeneração adaptativa. O tipo de abertura ilustrada, desconhecida pela autora até então, não deve corresponder a um tipo comum, pois estranha-se o fato de não ter sido identificada até a presente data. Observar forâmen como um processo retral acompanhando o enrolamento da teca, circundado por "ponticuli". Assim sendo, pode corresponder a uma variação ecofenotípica ou até uma nova espécie. Difere de $T$. sommeri Tinoco por não apresentar dente. 
Obs: Este gênero é considerado por Loeblich \& Tappan (1988) sinônímio júnior de Triloculina d'Orbigny, 1826. No entanto, a definição de Miliolina não se baseia na idéia de um número rígido de três câmaras como as Triloculina. Este fato limita a classificação de indivíduos com número superior de câmaras, dente simples e não bipartido como nas Triloculina e Quinqueloculina. Desta forma Miliolina difere em sua descrição pelo número variável de câmaras e dente simples, o que me leva a considerá-lo distinto destes. Difere de Miliolinella por esta ser lateralmente achatada com arranjo final planoespiral e possuir aba na abertura.

\section{Miliolina sidebottomi (Rasheed)}

(Est. 5, figs. 17-18)

Triloculina sidebottomi Rasheed, 1971. Sec. B, vol. 37-38 (1967-1968), pp.38,39.

Descrição: Teca média, lútea, oval em vista lateral, semi-triangular em vista apical, comprimida lateralmente; quatro câmaras visíveis no exterior, abrangentes na porção aboral; periferia arredondada; parede com omamentação de estrias espessas e irregulares, desgastadas, dando aparência grossa; suturas distintas; abertura semi-triangular, arredondada, ao final de um pescoço curto; lábio espesso e virado para fora; dente cilíndrico curto.

Procedência: LV4 ( 144-146 cm), lâm. 73

Obs: Difere de T. littoralis Collins, 1958 por esta possuir dente grande e fino, com apenas três câmaras visíveis no exterior.

\section{Miliolina sp. A}

(Est. 6, figs. 9-12)

Descrição: Teca pequena, oblonga, não equiilateral; periferia arredondada; parede porcelanosa; suturas deprimidas; abertura semi-oval, presença de peristoma, dente simples e longo, em forma de barra, com extremidade inflada e irregular.

Procedência: $[9-10,11-12]$ - LV4 $(41-45,132-135 \mathrm{~cm})$, lâminas 68 e 72 respectivamente.

Obs: Os exemplares sub-fósseis ilustrados, apresentam superfície da teca fosca, irregular, com sinais de corrosão.

Gênero Miliolinella Wiesner, 1931

Obs: ver observação de $M$. subrotunda

Miliolinella cf. antarctica Kennet, 1967

(Est. 7, Figs. 9-10)

Miliolinella antarctica Kennet, 1967. vol. 18, pt.3, pp. 133,134, Est. 11, figs. 1 a-c, 2,3

Descrição: Teca pequena, semi-oval, alongada, pouco comprimida; quatro câmaras visíveis, sendo a última mais ampla na base do que na extremidade; periferia arredondada; parede calcária, lisa, imperfurada; suturas mais distintas no lado bicamerado; abertura em arco crescente, com dente em forma de flap, largo, grosso e semi circular, que se projeta um pouco para fora da abertura.

Procedência: S7, lâm. 53 
Obs: $M$. antarctica Kennet apresenta a abertura mais fechada por um flap sólido, que acompanha o contorno periférico apical da teca, ao contrário de nossos exemplares, nos quais o flap se projeta. Difere de Miliolinella sp. A. Hottinger et al. 1993, porque esta é mais redonda e apresenta flap fino.

\section{Miliolinella circularis (Bornemann)}

(Est. 7, figs. 5-6)

Triloculina circularis Bornemann, 1855, vol. 7, p. 349. Cushman, 1929, Bol. 104, p. 58, est. 13, figs. 6,7 ; est. 14, figs. 1,2 .

Descrição: Teca média, semi-arredondada, lateralmente comprimida; três a quatro câmaras visíveis no exterior, infladas, a última abrange as anteriores; periferia amplamente arredondada; parede calcária, porcelanosa, lisa, polida, ao MEV observa-se a presença de micro-estrias; suturas suavemente curvadas, comprimidas, aberiura terminal, em arco crescente, estreito; peristoma espesso e flap basal escavado.

Procedência: S7i 3 , lâm. 42; S2i ${ }_{10}$, lâm. 37 .

\section{Miliolinella cf. $M$. hybrida (Terquem)}

Quinqueloculina hybrida Terquem, 1878. Terquem, p. 79, pl.9, fig.23.

Miliolina hybrida (Terquem) Wiesner, 1923. Wiesner, p. 71, pl. 13, figs. 171-175.

Mililinella labiosa (d'Orbigny). Said, 1950, p.5, pl.1, fig 10

Miliolinella australis (Parr) subsp. labiosa (d'Orbigny) Baccaert, 1987, p. 140, pl. 61, figs. 4-6.

Miliolinella cf. hybrida (Terquem). Hottinger et al., 1993, p. 52, pl. 39, figs. 16.

Descrição: Teca pequena, semi-oval, mais larga que alta; três a quatro câmaras aparentes, com rápido aumento de tamanho e lateralmente abrangente, torcidas; periferia arredondada; parede calcária, lisa, hialina, suturas distintas; abertura terminal em forma de arco, arredondada e irregular com flap escavado.

\section{Miliolinella loeblichi Bermúdez \& Seiglie, 1963}

(Est. 7, figs. 11-13)

Miliolinella loeblichi Bermúdez \& Seiglie, 1963, vol. 2,n.2, p.100, est. 136, fig. 8 a-c, 9 a-c.

Descrição: Teca de tamanho médio, larga; três câmaras visíveis no exterior; periferia arredondada; parede porcelanosa, lisa, com algumas estrias fracamente esboçadas na borda periférica da última câmara; suturas pouco visíveis, marcadas pelo intumescimento cameral; abertura semi-arredondada, com peristoma e dente bipartido aberto pouco desenvolvido.

Procedência: $\mathrm{S} 7_{1},[11-12]$ lâm. $15 ; \mathrm{S}_{4}$, [13] lâm. 3

Obs: Diatomáceas epizóicas sobre alguns exemplares dessa espécie. O exemplar ilustrado [13] da amostra $\mathrm{S}_{4}$ parece apresentar um tipo de abertura secundária acompanhando a sutura posterior da última câmara, na base da abertura principal. Ver também estampa 21 [7], correspondente ao mesmo exemplar.

\section{Miliolinella subrotunda (Montagu)}

(Est. 7, figs. 3-4)

Vermiculum subrotundum Montagu, 1803

Miliolinella subrotunda (Montagu) Loeblich \& Tappan, 1988, p.93, 340, est. 350, fig. 9,10,11. 
Descrição: Teca média, semi-arredondada em vista lateral, achatada lateralmente; três câmaras visíveis no exterior, acrescentadas alternadamente como em Massilina, com enrolamento planoespiral, sendo a última abrangente; periferia sulcada com inserção da borda periférica, formando uma carena incisa; parede porcelanosa com ranhuras; suturas deprimidas; abertura triangular; lábio peristomal virado para fora e dente curto e simples.

Procedência: LV4 (152-154 cm), lâm. 74

Obs: O exemplar estudado é muito similar ao exemplar descrito na sirionímia (apresentado em Loeblich \& Tappan) no entanto, Miliolinella, não apresenta dente em sua descrição, mas aba na abertura. Como este gênero tem incluído espécies com variadas formas de dente e até mesmo sem ele, e sendo a teca de nossos exemplares composta de três câmaras e arranjo muito similar ao ilustrado por estes autores, foram incluídos nesta espécie, até que estudos mais detalhados reorganizem o conceito perdido de Vermiculum subrotundum Montagu.

\section{Miliolinella ef williamsoni (Terquem)}

(Est. 7, figs. 1-2)

Triloculina williamsoni Terquem, 1878

Descrição: Teca pequena, semicircular em vista lateral, comprimida lateralmente, subelíptica em vista apical; três câmaras visíveis no exterior; periferia sulcada; parede calcária com ranhuras e aspecto grosso; suturas pouco distintas; abertura em fenda triangular, peristoma espesso, mas não desenvolvendo lábio, estreitada por flap basal triangular, plano.

Procedência: LV4 $(84-86 \mathrm{~cm})$, lâm. 70

Obs: Difere de $M$. subrotunda por não apresentar suturas deprimidas, nem abertura semicircular com dente pequeno.

\section{Miliolinella sp. A}

(Est. 7, figs. 14-15)

Descrição: Teca de tamanho médio, semi-arredondada em vista lateral, semi-oval em vista apical; estágios iniciais quinqueloculiniforme sobressaem lateralmente, finais com tendência plano-espiral; cinco a seis câmaras visíveis no exterior; periferia arredondada porém irregular; parede porcelanosa, lisa; suturas indistintas; abertura semi oval, ampla; peristoma espesso e flap retangular.

Procedência: $S 7_{1}$, lâm. 15

Obs: O exemplar fotografado talvez corresponda a uma forma teratológica de $M$. subrotunda, devido ao intumescimento do estágio quinqueloculiniforme inicial, lembrando Scythiloculina confusa Neagu, 1984, definida no Cretáceo Inferior (Berriasiano Superior ao Aptiano) da Romênia.

\section{Miliolinella sp. B}

(Est. 7, figs. 7-8)

Descrição: Teca média, semi-oval em vista apical e lateral; arranjo quinqueloculiniforme; três câmaras no exterior sendo a última maior e abrangendo lateralmente as anteriores; periferia arredondada; parede porcelanosa, lisa com aparencia granular muito fina ao MEV; suturas distintas, comprimidas; abertura terminal em fenda coberta por borda espessa, baixa.

Procedência: S74, lâm. 53; LV4 (64-67), lâm.69.

Obs: Difere de Triloculinella por ser achatada 
Descrição: Teca grande, semicircular em vista lateral, subtriangular em vista apical, suavemente comprimida; quatro câmaras visíveis, pouco infladas, de largura quase uniforme; periferia arredondada; parede calcária, porcelanosa de aspecto grosso; suturas distintas, sinuosas ao MEV; abertura triangular; placa dental de mesmo formato, mas de tamanho menor e não proeminente.

Procedência: LV4 $(212-215 \mathrm{~cm})$, lâm. 79

\title{
Miliolinella sp. D
}

(Est. 8, figs. 5-8)

Descrição: Teca média, sub-oval em vista lateral com lados quase paralelos, gibosa, subelíptica em vista terminal; quatro a cinco câmaras visíveis, suavemente comprimidas lateralmente, com terminação aboral ampla, abrangendo a terminação oral das câmaras precedentes; periferia arredondada; parede calcária, lisa; suturas suavemente comprimidas; abertura terminal, com borda peristomal, dente simples e largo.

Procedência: [5-6]- $\mathrm{S} 1_{2}$, lâm.5; [7-8]- $\mathrm{S} 2_{4}$, lâm. 3

Gênero Neopateoris Bermúdez \& Seiglie, 1963

Neopateoris cf. N. cumanaensis Bermúdez \& Seiglie, 1963

(Est. 3, figs. 10-11;Est. 7, fig. 18)

Descrição: Teca média, oval, semi-retangular em vista lateral, achatada lateralmente, arranjo miliolineliforme; cinco câmaras no exterior; periferia semi-arredondada; parede calcária, lisa e polida; suturas pouco marcadas; abertura arredondada; peristoma espesso, dente simples e pequeno. Procedência: LV4 $(84-86,94-96$ cm), lâm. 70

\section{Neopateoris sp. A}

(Est. 7, fig. 19)

Descrição: Teca média, achatada; três a cinco câmaras visíveis com arranjo Miliolineliforme; periferia arredondada; parede calcária, opaca, imperfurada, irregularmente estriada, com ranhuras que dão uma aparência grossa a teca; suturas bem marcadas; abertura com lábio espesso, dente curto, largo com tendência a bipartição.

Procedência: LV4 (12-14 cm), lâm. 65

Obs: Diferencia-se de N. cumanaensis Bermúdez \& Seiglie, por não ter a teca lisa e polida.

\author{
Gênero Pseudotriloculina Cherif, 1970 \\ Pseudotriloculina lecalvezae (Kaaschieter) \\ (Est. 8, figs. 9-16)
}

Triloculina laevigata (d'Orbigny) Terquem 1878, ser. 3, tomo 1, n.3, p.57, est. 5, figs 20 a-b, 21 a-b. Triloculina lecalvezae Kaaschieter, 1961, p. 166

Descrição: Teca de tamanho médio, oval en vista lateral e oral; três câmaras aparentes, sendo as iniciais oblíquas ao enrolamento final; periferia arredondada; parede calcária, imperfurada, porcelanosa, lisa, brilhante; suturas distintas; abertura terminal, arredondada;dente terminalmente inflado ou bipartido. 
Procedência: [9-13]- S2 ${ }_{4}$, lâm. 3; [14-15]- S71, lâm. 15; [16]-S3i , lâm. 16

Obs: Difere de Q. seminulum por esta apresentar cinco câmaras visíveis e abertura oval.

\section{Pseudotriloculina subgranulata (Cushman)}

(Est. 8, figs. 18-21)

Triloculina subgranulata Cushman, 1918. Cushman, p. 290, est. 96, fig. 4.

Pseudotriloculina subgranulata (Cushman). Hottinger et al., 1993.p. 56, est. 47, figs. 8-13, est. 48, figs. 1-8

Descrição: Teca alongada, semi-oval em vista lateral e oral; quatro câmaras no exterior, sendo a quarta quase indistinta com base da última câmara sobrepondo-se às precedentes; periferia arredondada; parede porcelanosa, coberta com micro-estrias longitudinais oblíquas, dando aspecto grosso à teca; suturas bem marcadas e irregulares; abertura terminal, semi-arredondada; peristoma apresentando borda basal escavada e lábio peristomal; presença de dente plano, simples e discretamente bipartido em alguns exemplares.

Procedência: [18-21]- LV4 (73-75 cm), lâm. 69

\section{Triloculina d'Orbigny, 1826}

Triloculina asymmetrica Said, 1949

(Est. 26, figs. 17-18)

Triloculina asymmetrica Said, 1949. Said, p. 18, pl.2, fig.11

Descrição: Teca de tamanho médio, suboval em vista oral, mais larga que alta em vista lateral; três câmaras aparentes, sendo a última abrangente e mais larga que as demais; periferia amplamente arredondada; parede porcelânica com superfície suave e em alguns exemplares com microestrias quase indistintas, longitudinais; suturas bem marcadas; abertura terminal, suboval; lábio peristomal e dente bipartido curto.

Procedência: $\mathrm{S} 3 \mathrm{i}$ ?

\section{"Triloculina" fichteliana (d'Orbigny)}

(Est. 26; figs 19-22)

Triloculina fichteliana d'Orbigny, 1839. d'Orbigny, p. 171, pl. 9, figs. 8-10.

Descrição: Teca média, mais larga que alta, subcircular em vista lateral; três a cinco câmaras visíveis; periferia arredondada; parede calcária, porcelânica, branca com estrias longitudinais que dão uma aparência grossa a teca; suturas distintas; abertura oblíqua ao enrolamento, cercada por lábio peristomal liso; dente simples, largo e pequeno.

Obs: Os exemplares observados apresentam geralmente quatro a cinco câmaras e por isso foram designados informalmente "Triloculina".

Difere de $T$. webbiana pelo tipo de dente e posicionamento da abertura oblíquo à teca. A espécie ilustrada por Hottinger et al. (1993) como T. fichteliana, p. 65, pl. 66, corresponde à $T$. webbiana. $O$ tipo de dente descrito e ilustrado por estes autores ("bifid spur-like tooth"), dente bipartido em forma de espora, é característico da espécie T. webbiana, bem como a ornamentaçäo com estrias mais irregularmente đistribuídas. T. fichteliana não apresenta dente bipartido e as estrias säo uniformemente distribuílas, na descrição original de d'Orbigny.

Procedência: LBE 89-2 
Triloculina gracilis d'Orbigny in De la Sagra, 1839 , p. 159, est. 11, figs. 10-12 Triloculina gracilis d'Orbigny. Cushman, 1929, part. 6. p. 59, est. 14, fig. 4 a-c.

Descrição: Teca média, alongada, delgada, lateralmente mais larga na porção equatorial da teca; três câmaras visíveis; periferia arredondada; parede calcária porcelanosa, lisa, algumas vezes com aparência granular, e fosca; suturas quase indistintas; abertura terminal, arredondada, no final de um pescoço curto cilíndrico; peristoma, dente largo e terminalmente bipartido com extremidade inflada, ocupando praticamente toda a abertura.

Procedência: LV89/19 (28-30 cm), lâm. 95

Obs: Difere de Q. granulosa Natland, 1938 por esta apresentar periferia subaguda. Difere de $Q$. granuliformis Zheng, 1988 por apresentar apenas três câmaras visíveis na última volta e suturas indistintas. Na descrição original desta última consta presença de lábio vistoso

Triloculina lutea d'Orbigny, 1839

(Est. 8, figs. 1-2)

Triloculina lutea d'Orbigny, 1839. Tomo 5, pt. 5, p. 70, est. 9, figs 6-8

Descrição: Teca pequena-média, ovato-oblonga; três câmaras aparentes, flexuosas, convexas, mais estreitas na porção terminal, alargadas e arredondadas na porção basal; periferia arredondada; parede lisa, brilhante, suturas bem marcadas; abertura semicircular com peristoma.

Procedência: $S 7_{1}$, lâm. 15

Obs: As observações dos exemplares, somada a fotomicrografia em MEV da abertura, sugere a ocorrência de dente bipartido. Este detalhe não está descrito por d'Orbigny, pois em lupa parece corresponder a uma abertura muito estreita cercada por lábio espesso, como definido por este autor. Alguns exemplares mostram aglutinação secundária de grãos carbonáticos.

Triloculina cf. nitida d'Orbigny, 1839

(Est. 8, figs. 3 4)

Triloculina nitida d'Orbigny, 1839 , tomo 2 , pt. 2 , p. 141 , est. 3 , figs. $22-24$

Descrição: Teca média, pouco alongada, oblonga, comprimida lateralmente; três câmaras visíveis, infladas; periferia arredondada; parede calcária; suturas distintas, comprimidas; abertura terminal, semiarredondada; peristoma, dente largo, pequeno e terminalmente inflado.

Procedência: LV4 (203-205 cm), lâm. 84

Obs: Os exemplares não são tão alongados como os ilustrados por d'Orbigny. O exemplar fotografado corresponde a estágio ontogenético

Triloculina trigonula (Lamarck)

(Est. 26, figs. 23-25)

Miliolites trigonula Lamarck, 1804, p.351, pl.17, fig 14.

Triloculina trigonula(Lamarck) Cushman, 1929,pl.12, fig 10-11,pl. 13, fig.1,2

Descrição: Teca grande, mais larga q̨ue longa; três câmaras aparentes; periferia arredondada, convexa; parede lisa, porcelanosa, brilhante; suturas deprimidas e distintas; abertura arredondada, ampla, com dente bipartido.

Procedência: $\mathrm{S} 3 \mathrm{i}_{6}-\mathrm{S} 3 \mathrm{i}_{8}$ 
Descrição: Teca quase orbicular em vista lateral; três câmaras visíveis, infladas, arqueadas, mais largas em seção equatorial; periferia amplamente arredondada; parede com costelas longitudinais grossas e bem marcadas, que se estendem da base à extremidade, de forma contínua e regular; suturas profundas; abertura redonda; peristoma e dente largo, saliente, quadrado, com duas dobras na extremidade.

Procedência: $S 2_{4}$, lâm. 3.

\title{
Gênero Varidentella Luczkowska, 1972
}

Varidentella implexa (Terquem \& Terquem)

(Est. 9, figs. 1-6, Est. 26, figs.26-27)

Quinqueloculina implexa Terquem \& Terquem, 1886, vol. 11, p. 335, est. 11, figs 24-26.

Descrição: Teca de tamanho médio, oblonga, alongada; quatro a cinco câmaras visíveis na última volta, sendo a última oblíqua ao plano de enrolamento da teca, formando-se atrás da vista lateral tricamerada, dando à teca, uma aparência torcida; câmaras com diâmetro desproporcional, com base larga envolvendo as câmaras precedentes e extremidade menor; periferia arredondada; parede porcelanosa; suturas pouco nítidas; abertura variável podendo apresentar-se semi-arredondada ou oval, sem dente ou com dois dentes marginais simples e muito pequenos, só visíveis ao MEV.

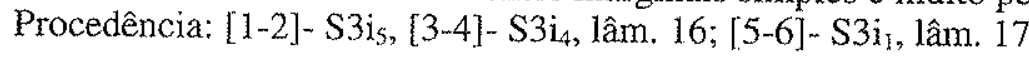

Obs: Difere de $Q$. bosciana d'Orbigny, 1839 por não possuir abertura unidentada. Na descrição de Terquem \& Terquem a abertura não possui dente, realmente, o tipo de dente é imperceptível à lupa.

\section{Varidentella implexa subsp. A}

(Est. 9, Fig. 7)

Obs: Parece corresponder a uma variação da espécie por apresentar estrias longitudinais (visíveis à lupa) dando um aspecto áspero à parede da teca. Em vista lateral não apresenta-se oblonga como os outros exemplares anteriormente descritos e sim com aspecto giboso. Alguns exemplares apresentam câmaras mais infladas. As demais características não deixam dúvida quanto a espécie implexa.

Procedência: $\mathrm{S}_{1}$, lâm. 15 .

\author{
Varidentella sp. A \\ (Est. 9, figs. 8-9)
}

Descrição: Teca média, alongada, gibosa, comprimida lateralmente; quatro câmaras involutas, mais largas na base do que na extremidade, sendo a última abrangente; periferia arredondada; parede calcária, polida, lisá; suturas distintas mas não comprimidas; abertura com terminação truncada, dando um aspecto giboso a teca, sem dente.

Procedência: [8]- S7, lâm. 15; [9]- LV 89/19 (28-30 cm)

Obs: Difere de Miliolina exsculpta Heron-Allen \& Earland, 1915 por não possuir as linhas de sutura profundamente escavadas nem pescoço.

\section{Varidentella sp. B}

(Est. 9, figs. 10-11)

Descrição: Teca média, arredondada em vista lateral, subtriangular em vista apical; três câmaras visiveis; periferia amplamente arredondada; parede porcelanosa; suturas bem marcadas; abertura semi-arredondada, baixa, estreita, sem peristoma e sem dente. 
Procedência: $\mathrm{S} 7$, lâm. 15

Obs: Diferencia-se de Ishamella Buzas \& Severin por não ser biloculina e de Miliolinella circularis (Bornemann) por não possuir dente.

\author{
Varidentella sp. C \\ (Est. 9, figs. 12-13)
}

Descrição: Teca grande, oval em perfil, comprimida; quatro câmaras visíveis aproximadamente da mesma largura; periferia semi-arredondada; parede calcária, porcelanosa, com ornamentação de costelas baixas, longitudinais irregulares, com entumescimentos dando aspecto rugoso a teca; suturas pouco comprimidas e largas; abertura sub-retangular ao final de um pescoço muito curto; peristoma fino; dentes muito pequenos que se projetam da parede lateral, só visíveis ao MEV.

Procedência: LV4 (152-154 cm), lâm. 74; S6i 3 , lâm. 45

\author{
Subordem LAGENINA Delage \& Hérouard, 1896 \\ Superfamília NODOSARIACEA Ehrenberg, 1838 \\ Familia ELLIPSOLAGENIDAE A. Silvestri, 1923 \\ Subfamília ELLIPSOLAGENINAE A. Silvestri, 1923 \\ Gênero Fissurina Reuss, 1850
}

Fissurina compressa (d'Orbigny)

(Est.9, fig. 14)

Oolina compressa d’Orbigny, 1839 , v. 5 , pt. 5 , p.18, est. 5, figs. 1,2

Fissurina compressa (d'Orbigny). Boltovskoy et al. 1980, p. 31, est. 15, figs. 4-6.

Descrição: Teca pequena, unilocular, piriforme em vista lateral, comprimida; parede transparente, hialina, brilhante; periferia arredondada; abertura fusiforme, irregular, com presença de tubo entosolene curto.

Procedência: LV89/19 (78-80 cm)

Obs: O holótipo de d'Orbigny apresenta como localidade tipo a Patagônia e Ilhas Malvinas, correspondendo portanto a uma espécie adaptada a baixas temperaturas.

\title{
Fissurina lucida (Williamson)
}

(Est. 9, fig. 15)

Entosolenia marginata (Montagu) var. lucida Williamson. Williamson, 1848, p. 17, est. 2, fig. 17. Fissurina lucida Williamson. Murray, 1971, est. 39, figs. 1-3. Boltovskoy et al. 1980, p. 32, est. 15, figs. 17-20.

Descrição: Teca pequena, unilocular, piriforme em vista lateral, comprimida na extremidade oral; inflada na porção aboral, com dois nódulos curtos; periferia arredondada; parede calcária, hialina, brilhante, finamente perfurada; abertura terminal, em fenda longa mais alargada nas extremidades, paralela, um pouco elevada da parede da teca e com tubo entosolene curto.

Procedência: LV4 (223-225 cm), lâm. 80

Obs: Difere de $F$. laevigata Reuss, 1850 por possuir os dois nódulos aborais e não possuir carena. 


\section{Fissurina sp. A}

(Est. 9, Fig.16)

Descrição: Teca pequena, unilocular; contorno semicircular; periferia aprofundada em alinhamento com uma fissura marginal, que parte da região aboral, mas não alcança a terminação oral; abertura terminal elíptica, situada dentro da fissura marginal, guarnecida de tubo entosolene curto,

Procedência: LBE 89/2 (170-171 cm), Lâm. 110

Obs: Devido a aglutinação secunđária, na superfície das tecas, maiores detalhes desses indivíduos não puderam ser obtidos, mesmo com microscopia eletrônica.

\section{Subordem ROTALINA Delage \& Hérouard, 1896 \\ Superfamília BOLIVINACEA Glaessner, 1937 \\ Família BOLIVINIDAE Glaessner, 1937 \\ Gênero Bolivina d'Orbigny, 1839}

As definições dos gêneros Bolivina e Brizalina são extremamente semelhantes, somente distintas pela menção de periferia carenada em Brizalina

\section{Bolivina doniezi Cushman \& Wickenden, 1929}

(Est. 10, fig. 1)

Bolivina doniezi Cushman \& Wickenden, 1929, vol. 75, n.9, p.9, est. 4, figs. 3a-b. Buzas et al. 1977 , p.73-74, est. 1, figs. $25-28$.

Descrição: Teca de tamanho médio, comprimida, mais larga na face oral dando à teca uma forma triangular em vista lateral; aproximadamente nove pares de câmaras, com crescimento rápido em direção aos últimos estágios ontogenéticos; parede densamente perfurada, com menor densidade de poros nas câmaras iniciais, presentes somente ao longo das suturas (na margem basal); suturas distintas, oblíquas, comprimidas; bordos agudos; abertura circular comprimida, ná base da última câmara.

Procedência: LV4 (223-225 cm), lâm. 80

Obs: Nossos exemplares (principalmente o ilustrado) correspondem a indivíduos em avançado estágio ontogenético e talvez por isso apresentem a teca de tamanho médio e não pequena como descrita por
Cushman \& Wickenden.

\section{Bolivina lepida Sliter 1969}

(Est. 10; figs. 2-6)

Bolivina lepida Sliter, 1969 ,est. 1, figs. 1-3

Descrição: Teca pequena, pouco comprimida; aproximadamente dez câmaras baixas e amplas; parede calcária transparente com poros grandes, alinhados na base cameral e aleatoriamente distribuídos ao longo das câmaras; margem sutural inferior marcada por poros, formando alinhamento sutural distinto, deprimido e suavemente curvado; periferia semi-arredondada; abertura circular, deprimida, na base da face septal da última câmara, com placa dental.

Procedência: Testemunho LV4 (165-167) - [2 -3], lâm. 75; (173-175) - [4-5], lâm. 76; (183-185 cm) [6], lâm. 78, sendo que o último apresenta periferia mais aguda.

Obs: Esta espécie foi definida em ambiente nerítico raso da Califórnia do Sul. Difere de $B$. doniezi Cushman \& Wickenden por ser mais robusta com parede e poros mais grosseiros. 
Descrição: Teca de tamanho médio, triangular em vista lateral, suavemente comprimida na porção aboral, mais baixa, aumentando em altura a partir da metade superior da teca; câmaras pouco distintas, aproximadamente 7 pares; parede calcária, translúcida; poros esparsamente distribuídos ao longo das suturas na metade inferior da teca; metade superior intensamente perfurada ao longo das câmaras e suturas; suturas com poros grandes na base, porém pouco distintas, comprimidas, retas; eixo central deprimido, com ramificações dicotômicas marcadas por poros nas extremidades; periferia semi-arredondada; abertura circular comprimida na base da última câmara.

Procedência: LV4 (183 - 185 cm)- [8-9], lâm. 77; LV4 (234 -236 cm)- [7], lâm. 81

Obs: B. lepida apresenta morfologia pouco variável de acordo com descrição de Sliter, em termos de brilho, comprimento, largura e forma das câmaras. Os indivíduos aqui ilustrados parecem corresponder a uma variação intraespecífica (conspecíficas?). Diferem da espécie $B$. lepida por possuírem seu eixo central deprimido entre duas costelas longitudinais retas.

Difere de $B$. pseudomplicata Heron-Allen \& Earland, por ser menos robusta, não apresentar costelas longitudinais tão marcadas e por apresentar as ramificações dicotômicas ao invés de poros grandes confinados entre os espaços intercostais.

Difere de $B$. donieze por não conter suturas distintas nem oblíquas. As ramificações dicotômicas, são similares a B.lepida.

\section{Bolivina sliteri Sellier de Civrieux, 1976}

(Est. 10, figs. 10-19)

Bolivina sliteri Sellier de Civrieux, J.M., 1976, n. 5, est.17, figs. 3-9, pp.20,21

Descrição: Teca de tamanho médio; 6 pares de câmaras que aumentam em altura na direção oral, notável nos exemplares mais jovens; periferia arredondada; parede calcária; poros numerosos, mais finos no sentido oral, com face da abertura não perfurada; suturas distintas, levemente curvadas, oblíquas comprimidas, na porção média superior da teca, ornamentadas com estrias longitudinais; na porção inferior, as estrias avançam sobre câmaras e suturas; abertura deprimida com borda fina e placa dental desenvolvida e serrilhada.

Procedência: LVA (152-154 cm)- [18 - 19 ], lâm. 74; (173 -175 cm)-[16-17], lâm. 76; (183 - 185)[14-15], lâm. 77; (234-236 cm)- [10 - 13], lâm. 81 .

Obs: Difere de B. striatula Cushman, 1922 pela periferia menos aguda, poros maiores, irregulares, estrias mais grossas, menor compressão e alargamento da teca. Esta espécie apresenta localidade-tipo em areias lamosas carbonáticas com debris orgânicos pobres em oxigênio da plataforma continental costa afora de Sucre, Venezuela.

Pode-se diferenciar membros finais comprimidos e inflados, não somente através do grau de compressão da teca como também através da forma da abertura. Apresentam ocorrência em sedimentos de lama orgânica.

\section{Bolivina sliteri subsp. asperoides Sellier de Civrieux, 1976} (Est. 10; fig.20)

Bolivina sliteri Sellier de Civrieux subsp. asperoides Sellier de Civrieux, 1976, n. 5, p. 21, est. 18, figs. I-4

Obs: Se diferencia da forma típica (B. sliteri Sellier de Civrieux, 1976) pela presença de espessamento irregular e compacto, escassamente perfurado na metade inferior da teca. As demais características são similares a forma típica.

O holótipo desta subespécie apresenta como localidade-tipo águas mais profundas ( $56 \mathrm{~m}$ ) do que a espécie B. sliteri ( $15 \mathrm{~m}$ ) em sedimentos pobres em oxigênio, costa afora de Marigüitar, Venezuela. Procedência: LV4 (234-236 cm), lâm. 81. 
Bolivina striatula Cushman, 1922, p. 27, est. 3, fig 10.

Descrição: Teca média, alongada, gradualmente cônica; 7 pares de câmaras, infladas na metade superior, comprimidas na porção inferior; ornamentação com estrias contínuas, longitudinais, ocupando grande parte da teca, avançando sobre suturas e câmaras; poros pequenos, escassos, mais finos em sentido apical; periferia arredondada; suturas pouco comprimidas; face da abertura lisa; abertura oval na base da última câmara; borda em apenas um dos lados da abertura, placa dental única com extremidade serrilhada.

Procedência: $\mathrm{S5}_{3}$, lâm. 10

Obs: Muitas espécies de Bolivina tem sido incluídas no gênero Brizalina pela intensidade de ornamentação (Brun et al. 1984; Hottinger et al. 1993), uma vez que a diferenciação entre esses gêneros não é muito clara. Alguns trabalhos já se referem a Brizalina striatula (Cushman) devido a intensa ornamentação presente nessa espécie, independente da presença de carena, que diferencia estes dois gêneros. No material deste estudo, alguns indivíduos são mais inflados do que outros, com. variação muito grande na intensidade de estriamento. Em algumas amostras, podem ser diferenciados dois membros finais quanto a variaçâo no grau de compressão lateral da teca: infladas (aqui consideradas) e comprimidas, colocadas abaixo como B. striatula?

\section{Bolivina striatula?}

(Est.11, figs.2-6)

Descrição: Teca de tamanho médio, comprimida, aumentando suavemente em largura; a metade inferior da teca carece de definiçäo das câmaras e poros, com estrias contínuas; a porção superior apresenta suturas limbadas, com poros diminuindo em diâmetro no sentido da abertura; a transição entre a porção superior e inferior da teca é marcada pôr interrupção das estrias, onde as poucas que avançam para a parte superior estão restritas às suturas; parede lisa, comprimida; abertura oval com lábio, duas placas dentais e depressão peri-apertural.

Procedência: S5 3 [2 4], lâm. 10; LV4 (165 -167 cm)- [5], lâm. 75; LV89/19 (8-10 cm)- [6], lâm. 93.

Obs: Exemplares mais comprimidos, com ausência de distinção das câmaras inferiores, sugerindo corresponder a uma variação da espécie apresentando suturas limbadas e últimas câmaras perfuradas.

Bolivina sublittoralis Sellier de Civrieux, 1976

(Est. 11, figs. 7-11, 16-17)

Bolivina sublittoralis Sellier de Civrieux, 1976, n. 5, p. 24, est. 8, figs. 4-8.

Bolivina lowmani Phleger e Parker subsp. densipunctata Sellier de Civrieux, 1976, n.5, pp.15-16, pl. 9 , figs. 1,2 .

Descrição: Teca de tamanho pequeno a médio; moderadamente comprimida, prolóculo grande, provavelmente de geração macrosférica assexuada, série de 6 pares de câmaras, pouco infladas, aumentando a altura lentamente na direção da abertura; periferia arredondada; parede calcária, lisa, perfurada; poros mais finos para as últimas câmaras, até desaparecimento na face da abertura; suturas distintas, ligeiramente oblíquas, deprimidas, com poucas estrias presentes, tênues, restritas as suturas e bases camerais; abertura oval, com placa dental serrilhada e borda periférica proeminente.

Procedência: LV4 ( $2-4 \mathrm{~cm})$ - [8-9,16], lâm. 64; (173-175 cm)- [17], lâm. 76; (223-225 cm)-[7,10], lâm. $80 ;(234-236 \mathrm{~cm})-[11]$, lâm. 81 .

Obs: Esta espécie, definida em ambiente de laguna de restinga en Isisa de Margarita, na plataforma interna da Venezuela, por Sellier de Civrieux, assemelha-se a espécie B. lowmani subsp. densipunctata, definida pelo mesmo autor, em ambiente de areias carbonáticas na plataforma costa afora do Estado de Sucre na Venezuela. As figuras e descrições das duas espécies são muito 
semelhantes, sendo assim, talvez não correspondam a espécies distintas. Sellier de Civrieux não descreve semelhanças nem diferenças entre essas duas espécies e a única variação observada, é quanto a menção de poros pequenos e finos para $B$. sublittoralis, ao contrário dos poros medianos descritos para B. lowmani subsp. densipunctata. Isto pode estar relacionado a variações ecofenotípicas impostas às tecas, devido a variação de oxigenação e tipo de sedimento, entre os diferentes ambientes. Talvez, as pelo menos 9 espécies novas de Bolivina, descritas por este autor, neste mesmo ano, correspondam somente a oito. Assim sendo, como B. lowmani subsp. densipunctata e B. sublittoralis diferenciam-se de B. lowmani Phleger e Parker, 1951 pela presença de poros densamente distribuídos na superfície da teca, prolóculo imperfurado e tendência a formar estrias na parte inferior da carapaça, considero aqui a espécie $B$. sublittoralis e a subsp. densipunctata passa a sinonímio júnior desta.

\section{Bolivina variabilis (Williamson)}

(Est. 11, figs.12-13)

Textularia variabilis Williamson. Williamson 1858, p.76, est. 6, figs. 162, 163.

Bolivina variabilis (Williamson) Sliter, 1970, p. 166, est. 5, fig. 4, est. 6, figs. 1-3, est. 8, figs. 15, 16.

Descrição: Teca pequena, alongada, suavemente mais larga próximo a abertura; aproximadamente 6 pares de câmaras; parede calcária, lisa ao longo da linha mediana, onde as suturas apresentam-se deprimidas; suturas pouco distintas, suavemente curvadas, definidas por poros grandes, distintos, na periferia arredondada; abertura oval com face lisa, e lábio de um lado e duas placas dentais do outro, separadas da face da abertura por uma depressão peri-apertural.

Procedência: LV4 (32-35 cm), lâm. 67

\section{Bolivina sp. A}

(Est. 11, figs. 14-15)

Descrição: Teca de tamanho médio, alongada; aproximadamente 9 pares de câmaras, aumentando lentamente em altura, porção superior inflada, câmaras inferiores baixas; periferia arredondada; parede calcária, perfurada; poros médios, com maior densidade a partir da metade superior da teca, com áreas distintas, próximas ao eixo central da teca sem ornamentação, face da abertura imperfurada; suturas distintas, suavemente curvadas; abertura oval com lábio circundante, placa dental e depressão peri-apertural.

Procedência: LV4 $(234-236 \mathrm{~cm})$, lâm. 81

\section{Bolivina sp. B \\ (Est.11, figs. 18-20)}

Descrição: Teca oval, média; aproximadamente seis pares de câmaras, não distintas na metade inferior da teca, aumentando lentamente em altura; periferia arredondada; parede calcária, poros grandes, raros na porção inferior, limitados às suturas e na porção superior da teca mais densamente distribuídos, com exceção da face da abertura; parede com duas regiões escavadas ao redor do eixo central da teca; ormamentação acentuada de elevaçóes reticulares marcadamente abaixo do último par de câmaras; suturas distintas somente na metade superior, comprimidas, curvadas, oblíquas; abertura oval com lábio espesso, placa dental serrilhada e depressão peri-apertural.

Procedência: LV 89/19 (12 - 15 cm) - [20], lâm. 94; (38-41 cm)- [18-19], lâm. 96

Obs: Os exemplares diferem de B. subexcavata Cushman \& Wickenden, 1929, pelo formato oval da teca, sendo mais comprimida e possuindo menor densidade de poros. 
Descrição: Teca grande, alongada, suavemente rombóide em vista apical, acima de sete pares de câmaras distintas, pouco infladas, baixas e alongadas com pouca variação na altura em direção apical; parede densamente perfurada, poros distintos e ornamentação com padrão poligonal ao redor; suturas distintas, retas, oblíquas, comprimidas, formando um padrão zig-zag ao longo do eixo central escavado; periferia truncada; abertura oval na porção superior da última câmara, na direção do eixo central.

Procedência: LV4 (183-185 cm), lâm. 77

Obs: Diferencia-se de B. torqueata por não apresentar a teca pequena, torcida, nem suturas limbadas. Diferencia-se de B. rhomboidalis (Millett) pelo tamanho, forma rombóide muito sutil e por não ser cônica em vista lateral.

\author{
Gênero Brizalina Costa, 1856 \\ Brizalina sp. A \\ (Est. 11, figs. 22-23)
}

Descriçâo: 'Teca de tamanho médio, alongada, comprimida, suavemente triangular em vista lateral; cerca de 6 pares de câmaras, indistintas, estreitas, em arranjo bisserial, aumentando medianamente em altura conforme somadas; suturas pouco distintas, oblíquas, curvadas para cima, truncadas na borda periférica; poros médios, aumentando em densidade para as últimas câmaras, as primeiras apresentam poros principalmente ao longo das suturas; periferia aguda; abertura oval, com borda espessa e duas placas dentais dobradas.

Procedência: LV4 ( $223-225$ cm), lâm. 80

Obs: O gênero Brizalina tem sido observado indicando condições marinhas abertas em ambientes redutores, lamosos pobres em oxigênio.

\author{
Gênero Abditodentrix Patterson, 1985 \\ Abditodentrix rhomboidalis (Millett) \\ (Est. 12, figs. 1-2)
}

Textularia rhomboidalis Millett. Millett, 1899, p. 66, est. 7, fig. 4.

Brizalina rhomboidalis (Millett). Murray, 1970, p.63, fig. 10 D, E.

Bolivina rhomboidalis (Millett). Baccaert, p. 180, est. 73, figs. 3-4.

Descrição: Teca rombóide em vista oral e triangular em vista lateral; deprimido, escavado aproximadamente 9 pares de câmaras, periferia subaguda; arranjo bisserial, aumentando rapidamente em tamanho; poros grandes, amplamente distribuídos, cercados por polígonos elevados (cancelado), inclusive na face septal da última câmara; suturas distintas, comprimidas e oblíquas, formando um padrão zig-zag em seu eixo central, abertura precedente triangular com lábio virado para fora.

Procedência: LBE 89/2, lâm. 125

\title{
Abditodentrix subexcavata (Cushman \& Wickenden)
}

(Est. 12, figs. 3-6) Bolivina subexcavata Cushman \& Wickenden, 1929, p. 9, est. 4, fig. 4a -b. Buzas et al. 1977, p. 76 ,
est. 2, figs. 11-22.

Descrição: Teca pequena, lamelar, triangular en vista lateral; eixo central escavado; periferia semiarredondada; 5 a 7 pares de câmaras, iniciais mais baixas, aumentando medianamente; ornamentação cancelada com pequenas pústilas na face septal e apêndices poligonais elevados ao redor dos poros, 
sendo estes distintos, alinhados ao longo das câmaras e na margem; suturas distintas, oblíquas, comprimidas; abertura oval, com lábio espesso, na base da última câmara, com placa dental apresentando borda serrilhada.

Procedência: LV4 (110-115 cm)- [5-6], lâm. 71; (234-236 cm)- [3-4], lâm. 81

Obs: O gênero Abditodentrix Patterson, parece englobar várias espécies de Bolivina que apresentem ornamentação com apêndices poligonais ao redor dos poros e pequenas pústulas, sendo realmente muito distinto de Bolivina.

Na descrição de Patterson (1985) Abditodentrix difere de outros gêneros da família por sua distinta margem truncada, ornamentação de reticulações e placa dental reduzida. Todos os exemplares com trama complexa de reticulações elevadas, sugestiva do gênero Abditodentrix, foram considerados como tal, apresentando algumas vezes ornamentação que se estende para a face da abertura, geralmente com menor intensidade, mas ornamentada até mesmo no lábio e placa dental. Loeblich \& Tappan (1988) cita para a a face apertural ornamentação reduzida, o que não condiz com a descrição original de Patterson nem tampouco com os exemplares desse estudo.

\section{Abditodentrix cf. A.subexcavata (Cushman \& Wickenden)}

(Est. 12, figs. 7-12)

Bolivina subexcavata Cushman \& Wickenden, 1929, p. 9, est. 4, fig. 4a -b.

Obs: Esses exemplares se assemelham a A. subexcavata (Cushman \& Wickenden), apresentando, no entanto, face da abertura sem ornamentação acentuada, e as últimas câmaras com suturas irregulares (plicaturas ?). Diferenciam-se de B. pseudo-plicata (Heron-Allen \& Earland) por não apresentarem costelas longitudinais bem marcadas e plicaturas múltiplas, confinadas aos espaços intercostais.

Procedência: LV4 (24-26 cm) - [8], lâm. 66; (64-67 cm)- [9-10], lâm. 69; (234-236 cm)- [7], lâm. $81 \mathrm{e}$ LV 89/19 (28-30 cm)-[11-12], lâm. 95

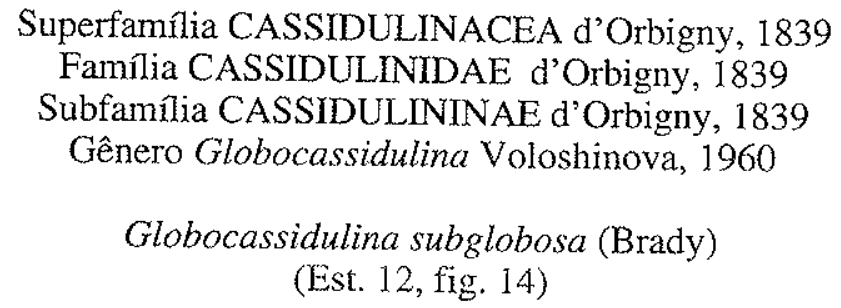

Cassidulina subglobosa Brady, 1884, v. 9, p. 430, est. 54, fig. 17

Globocassidulina subglobosa (Brady) Loeblich \& Tappan, 1988, est. 557, figs 18-23.

Descrição: Teca globosa; arranjo bisserial enrolado, involuto; número de câmaras indistinto; periferia sub-arredondada; parede calcária hialina, lisa, com poros esparsos; suturas radiais, suavemente deprimidas; abertura "tripartite" (quase cruciforme), estendendo seu maior eixo para a face da abertura; borda distal apresentando padrão poligonal; terminação terminal da abertura bordejada por 2 placas dentais (two-tongued toothplate).

Procedência: LV4 (234-236 cm), lâm. 81

Superfamília TURRILINACEA Cushman, 1927

Família STAINFORTHIDAE Reiss, 1963

Gênero Cassidelina Saidova, 1975

Cassidelina cf. spinescens (Cushman)

(Est.12, fig. 13) 
Bolivina spinescens Cushman. Cushman, 1911, p. 46, fig. 76

Bolivina spinescens Cushman. Cushman, 1937, p. 142, est. 18, figs. 17-19.

Descrição: Teca média, alongada, comprimida, na porção aboral e oral; aproximadamente 8 pares de câmaras que crescem suavemente; no adulto, arranjo bisserial, torcido na porção inicial; periferia arredondada, lobulada; parede calcária, hialina, finamente perfurada, exceto na face da abertura; suturas distintas, oblíquas, deprimidas; estrias na porçāo inicial das câmaras da primeira metade da teca; abertura ampla em forma de "U" invertido, com lábio espesso e placa dental.

Procedência: LV4 (173-175 cm), lâm. 76

Obs: $B$. spinescens Cushman parece ser mais inflada e ter a ornamentação composta por pústulas e pseudo-espinhos na porção inicial das câmaras iniciais. Os indivíduos aqui èncontrados contém estrias o que torna a posição sistemática dessa espécie questionável.

\section{Gênero Virgulopsoides Mc Culloch, 1977}

Virgulopsoides sp. indet.

(Est. 12, figs. 15-16)

Descrição: Teca de tamanho médio, alongada, maior volume na porção central da teca ( "bulging"); aproximadamente seis pares de câmaras, somente as últimas infladas; arranjo inicial trisserial passando a bisserial até o final, com torção em relação ao eixo longitudinal na metade da teca; periferia arredondada; parede calcária hialina, distintamente perfurada, com ornamentação de apêndices poligonais ao redor dos poros e pústulas; suturas distintas, deprimidas, oblíquas; abertura oval, comprimida, oblíqua à face da abertura; lábio com borda espessa; duas placas dentais: depressão peri-apertural.

Procedência: LV4 (24-26 cm), lâm. 66

Superfamília BULIMINACEA Jones, 1875

Família SIPHOGENERINOIDIDAE Saidova, 1981

Subfamília SIPHOGENERINOIDINAE Saidova, 1981

Gênero Loxostomina Sellier de Civrieux, 1969

Loxostomina sp. A

(Est. 12, fig. 17)

Descrição: Teca de tamanho médio, alongada, pouco comprimida; bisserial, com tendência a unisserial, no último estágio ontogenético; aproximadamente 7 pares de câmaras aumentando de tamanho conforme acrescentadas; suturas arqueadas para baixo, pouco deprimidas; com tendência a obliqüidade, sendo a última marcadamente oblíqua e reta, a partir da metade superior central apresentam-se limbadas; parede densamente perfurada, hialina; estrias longitudinais muito finas; abertura terminal, oval, estendendo-se para cima da face da abertura, com placa dental.

Procedência: LV 89/19 (12-15 cm), lâm. 94

Loxostomina sp. B

(Est. 12, figs. 18-21)

Descrição: Teca de tamanho médio a grande, três vezes mais longa que larga; prolóculo arredondado; aproximadamente 10 pares de câmaras lentamente aumentando em tamanho, comprimidas com tendência a entumescimento suave na base cameral com lobos crenulados; periferia subaguda; parede hialina, transiúcida, com poros distribuídos por toda a teca, com exceção da face da abertura e periferia da última câmara; tendência a formar estrias muito finas; suturas deprimidas, oblíquas, irregularmente curvadas; abertura oval, com borda espessa e placa dental serrilhada. 
Procedência: LV4 (223-225 cm ) [18], lâm. 80; (183-185 cm)- [19-21], lâm. 77

Obs: Os exemplares encontrados apresentam alguma afinidade com Bolivina petterssoni Parker, 1953, mas diferenciam-se marcadamente por apresentarem câmaras menos infladas, por não apresentarem projeção periférica das câmaras, pela tendência ao arranjo unisserial e à formação de estrias.

\author{
Família BULIMINELLIDAE Hofker, 1951 _. \\ Gênero Buliminella Cushman, 1911
}

Buliminella elegantissima d'Orbigny, 1839

(Est. 12, fig. 22)

Descrição: Teca alongada, enrolamento trocoespiral alto; número de câmaras indistintas, altas, estreitas, suavemente infladas; parede calcária, hialina, finamente perfurada; suturas pouco curvadas e perpendiculares a sutura espiral, suavemente deprimida, abertura teminal na porção deprimida da última câmara, sem placa dental.

Procedência: LV4 $(223-225 \mathrm{~cm})$, lâm. 80

Obs: Revets (1990) faz uma excelênte revisão taxonômica deste gênero e retira da superfamília Buliminacea, uma vez que a familia Buliminellidae Hofker, 1951 passa a incluir Buliminella e Tosaia.

Família TURRILINIDAE Cushman, 1927

Gênero Floresina Revets, 1990

Floresina seminuda (Terquem)

(Fst. 12, figs. 23-24)

Bulimina semi nuda Terquem, 1882, sér. 3, v.3, no. 3, p. 117, est. 12, fig. 21

Bulimina elegantissima var. compressa Millett, 1900 , p. 277 , est. 2, figs. 5a, $5 \mathrm{~b}$

Buliminella seminuda (Terquem) Boltovskoy et al., 1980, p. 21, est. 6, figs $11-15$

Descrição: Teca média, semi-cilíndrica, arredondada, alongada; trocoespiral alto; aproximadamente três voltas, com parte central mais inflada; câmaras alongadas, discóides, mais largas que altas, com face apertural ocupando a terça parte superior da teca; arranjo oblíquo; periferia arredondada; parede calcária hialina, transparente, lisa, brilhosa; suturas indistintas; abertura terminal, arredondada, apresentando ornamentação incisa com sulcos radiais e placa plastogâmica.

Procedência: LBE 89/2 (100-102 cm)- [23] , lâm. 121 e LV4 (165-167 cm)- [24], lâm. 75

Obs: Diferem de Buliminella por apresentarem face apertural fendida por sulcos bem definidos e placa plastogâmica. Assemelhanse a espécie $F$. durrandi Revets, 1990, embora os exemplares deste estudo apresentem mais do que oito fendas na face apertural. Todos os exemplares apresentam-se bioerodidos e corroídos.

O exemplar bioerodido [23], ocorre em sedimentos arenosos na base de camada bioturbada por lamelibrânquios; o exemplar [24], com aparência corroída, ocorre dentro de camada de lama orgânica.

Superfamília: DISCORBACEA Ehrenberg, 1838

Família: DISCORBIDAE Ehrenberg, 1838

Gênero: Disconorbis Sellier de Civrieux, 1977

Disconorbis williamsoni (Chapman \& Parr)

(Est.13, figs. 1-2)

Rotalina nitida Williamson, 1858, p. 54, est. 4, figs. 106-108 [ emend. Discorbis williamsoni

Chapman \& Part, 1932, v. 44, p. 226 ]

Discorbis williamsoni (Chapman \& Parr) Boltovskoy et al. 1980, p. 28, est. 12, figs. 5-12. 
Descrição: Teca pequena, trocoespiral, biconvexa baixa, desigual; lado espiral evoluto, lado umbilical involuto; cinco câmaras na última volta, subtrapezoidais no lado espiral, triangulares no lado umbilical; botão umbilical presente; parede calcária, lisa com aparência granular ao MEV; suturas deprimidas, retas e oblíquas no lado espiral; radiais no lado umbilical; periferia aguda, mas não quilhada, ornamentada com poros grandes; abertura interiomarginal, extraumbilical com lábio pequeno e espesso.

Procedência LV89/19 (78-80 cm), lâm. 98

Obs: Difere de Discorbis por não apresentar borda quilhada, flaps umbilicais e por possuir menor número de câmaras.

\title{
Gênero Orbitina Sellier de Civrieux, 1977
}

Orbitina sp.

(Est.13, figs. 3-13)

Descrição: Teca pequena, trocoespiral, planoconvexa; aproximadamente seis câmaras; umbílico amplo, com botão bem desenvolvido; parede calcária, ornamentada com poros no lado espiral, prolóculo e suturas espirais imperfurados; suturas oblíquas, suavemente curvadas, indistintas no lado umbilical com afundamento na direção umbilical e produzindo espaços interloculares e intraseptais abertos; periferia aguda, demarcando a porção densamente perfurada espiral com a imperfurada umbilical; abertura interiomarginal, extraumbilical, anterior ao folium;abertura sutural suplementar posterior ao folium.

Procedência: LV4 (24-26 cm)- [8-9], lâm. 66; (32-35cm)- [3-5], lâm. 67; (94-96 cm)- [10-11], lâm. 70; (183-185 cm)- [6-7] lâm. 77. LV 89/19 (78-80 cm)- [12-13], lâm. 98.

Obs: Os indivíduos [10-13] parecem não corresponder a mesma espécie dos anteriores, pois apresentam várias feições que os distinguem dos demais.

\author{
Família ROSALINIDAE Reiss, 1963 \\ Gênero Rosalina d'Orbigny, 1826 \\ Rosalina candeiana d'Orbigny \\ (Est. 13, figs. 14-15)
}

Rosalina candeiana d'Orbigny, 1839, p. 97, est. 4, figs. 2-4.

Discorbis candeiana (d'Orbigny) Cushman, 1931, Bull. 104, part.8, p. 19, est. 7, figs. 4a-c.

Descrição: Teca pequena a média, trocoespiral; evoluta e convexa no lado espiral; involuta e côncava no lado umbilical; cinco a seis câmaras na última volta; a última ocupa $1 / 3$ da circunferência da teca; discretamente infladas, subtriangulares no lado umbilical; folium parcialmente perfurado, grande; periferia suavemente lobulada, arredondada; parede calcária, translúcida, densamente e uniformemente perfurada em ambos os lados; umbílico aberto e amplo; suturas deprimidas, curvadas, limbadas, côncavas no lado umbilical; abertura umbiblical-extraumbilical, em arco, na base da última câmara; lábio suave.

Procedência: $\mathrm{S} 7_{1}$, lâm. 15

Obs: Difere de Discorbis Lammarck por possuir umbílico aberto, poucas câmaras por volta, ausência de espaço intraseptal interlocular e periferia arredondada. Difere de D. orientalis Cushman, 1925 por não possuir espessamentos inflados no folium e nas margens camerais ao redor do umbílico. 


\title{
Rosalina floridana (Cushman)
}

(Est. 13, figs. 16-17)

Discorbis floridana Cushman, 1922, Publ. 311, p. 39, est. 5, figs. 11,12.

Descrição: Teca pequena, rotaliforme, côncavo-convexa; seis câmaras na última volta com lado espiral perfurado; umbilical com perfuração apenas na borda do folium da última câmara; periferia arredondada; parede calcária; suturas limbadas na porçâo dorsal apenas nos enrolamentos iniciais; últimas suturas não limbadas mas distintas, deprimidas, suturas umbilicais deprimidas e curvadas; abertura umbilical-extraumbilical, em arco alongado, na base da última câmara; lábio bem marcado.

Procedência: $\mathrm{S}_{3}$, lâm. 10

Rosalina globularis d'Orbigny, 1826

(Est. 13, figs. 18-20)

Rosalina globularis d'Orbigny, 1826, p. 271, est. 13, figs. 1,2.

Discorbis globularis (d'Orbigny) Cushman, 1924. Bull. 104, part. 8, p. 22, est. 4, fig 9 a-c.

Descrição: Teca pequena, trocoespiral, plano-convexa, comprimida; seis câmaras na última volta, última ocupando 1/3 da teca; parede calcária, hialina; suturas espirais deprimidas, oblíquas, curvadas, suavemente limbadas; suturas umbilicais indefinidas, com afundamento na extremidade cameral na direção umbilical, produzindo espaços interloculares e intraseptais abertos; periferia subaguda; lado espiral densamente perfurado; lado umbilical imperfurada; abertura extraumbilical, com fenda interiomarginal e folium com borda distinta.

Procedência: $\mathrm{S} 7$, lâm. 15 .

Obs: Difere de R. bradyi (Cushman) Hottinger et al. 1991 por não apresentar os poros cercados por bordas poligonais sutis, onde ocorrem curtos pseudo-espinhos.

\author{
Superfamília GLABRATELLACEA Loeblich \& Tappan, 1964 \\ Família GLABRATELLIDAE Loeblich \& Tappan, 1964 \\ Gênero Glabratellina Seiglie \& Bermúdez, 1965
}

\section{Glabratellina cf. turriformis (Mc Culloch)}

(Est. 14, figs. 1-3)

Sabinia turriformis Mc Culloch, 1977, p. 312 (non Sabinia Parona, 1909)

Descrição: Teca pequena, lamelar, trocoespiral, plano-convexa; lado espiral cônico, evoluto; lado umbilical involuto, suavemente elevado nas margens e deprimido em sua porção central (centrocôncavo); periferia lobulada, arredondada; parede calcária hialina; aproximadamente seis câmaras visiveis, relativas aos últimos estágios ontogenéticos; suturas umbilicais, radiais, retas e deprimidas, suturas espirais suavemente curvadas e oblíquas, deprimidas, quase tangenciais; poros grandes e distintos no lado espiral; estrias irradiam-se de sua área umbilical; entre algumas estrias e normais a elas, pequenas pústulas alinhadas, preenchem a área umbilical; abertura provavelmente interiomarginal anterior ao flap umbilical.

Procedência: LV89/19 (89-91 cm), lâm. 99

Obs: Houve problema com a metalização de ouro-paladium nesses exemplares, com formação de elevações sobre parte da porção espiral e cobertura sobre a área umbilical, mascarando as pústulas. As fotos foram tomadas de 3 indivíduos distintos, mas da mesma espécie.

Esses exemplares embora também apresentem algumas semelhanças com Discorbinoides Saidova, 1975, diferem deste por não apresentarem carena.

Essa espécie apresenta grande quantidade de espécimens pequenos que podem ser considerados microforaminíferos- tecas com tamanhos menores que 0.100mm (Pawlowski and Lee 1991), e desta forma podem corresponder também a Microglabratella sp., encaixando na descrição e definição fornecida por estes autores. 


\title{
Superfamília ASTERIGERINACEA d'Orbigny 1839 \\ Família ASTERIGERINATIDAE Reiss 1963 \\ Gênero Eoeponidella Wickenden 1949
}

Eoeponidella nanoconica Seiglie, 1965

(Est. 14, figs. 4-5; 10-11)

Eoeponidella nanoconica Seiglie, 1965, p.511-512, est. 5, figs. 12-15.
Eoeponidella nanoconica Seiglie. Pawlowski \& Lee,1991.p. 158, est. 4, figs 4a-b.

Descrição: Teca pequena; lado espiral suavemente convexo; aproximadamente seis câmaras na última volta; periferia arredondada; parede calcária, hialina, fina, com perfurações pęquenas somente no umbílico; suturas deprimidas, curvadas e oblíquas em ambos os lados; umbílico centralmente deprimido, com placas (camaretas foliares?) formando uma série estrelada ao redor do umbílico; suavemente lobulada; abertura em arco alto, umbilical (intraumbilical).

Procedência: LBE 89/2 (170-171 cm)-[4-5], lâm. 110. LV4 (234-236 cm)- [10-11], lâm. 81

Obs: Pawlowski \& Lee (1991) isolaram dois indivíduos dessa espécie de material algálico coletado no Golfo de Elat no Mar Vermelho a uma profundidade de 2-3 m. Para que se possa observar melhor a estrutura desses indivíduos seria melhor utilizar microscópio eletrônico de transmissão e não MEV. Esta espécie corresponde a microforaminífero (tecas com tamanhos menores que $0.100 \mathrm{~mm}$ )

\section{Eoeponidella sp. A \\ (Est.14, figs. 6-9)}

Obs: As características gerais são comparáveis a espécie descrita anteriormente. No entanto, o lado umbilical desses indivíduos apresenta poros somente ao longo das suturas, que são curvadas e oblíquas. Em alguns exemplares as suturas apresentam-se aparentemente preenchidas, não apresentando as placas (camaretas foliares ? ) perfuradas formando a série estrelada. Também corresponde a microforaminífero.

Procedência: LBE 89/2 (159-161 cm)-[8-9], lâm. 110; LV4 (234-236 cm)-[6-7], lâm. 81.

\author{
Superfamília CHILOSTOMELLACEA Brady, 1881 \\ Familia GAVELINELLIDAE Hofker, 1956 \\ Subfamilia GAVELINELLINAE Hofker, 1956 \\ Gênero Hanzawaia, Asano 1944
}

\section{Hanzawaia sp. indet.}

(Est. 14, figs. 12-16)

Descrição: Teca trocoespiral, plano-convexa baixa; lado umbilical convexo involuto com porção umbilical plana; lado espiral plano, parcialmente evoluto; aproximadamente 10 câmaras na última volta; periferia arredondada, lobulada; parede calcária, oticamente granular, densamente perfurada no lado espiral; suturas distintas, deprimidas, em ambos os lados; abertura equatorial em fenda estreita, estendendo-se suavemente para o lado umbilical, abaixo dos flaps umbilicais; aberturas suplementares presentes nas margens internas e externas dos flaps umbilicais.

Procedência: LV4 (41-45 cm)-[12-13], lâm. 67. S71 [14-16], lâm. 15

Obs: Na descrição original do gênero a periferia é subangular o que não é observado em nenhum exemplar desse estudo. O exemplar [16] apresenta-se em avançado estágio ontogenético. 
Superfamília: ROTALIACEA Ehrenberg, 1839

Familia: ROTALIIDAE Ehrenberg, 1839

Subfamília ROTALIINAE Ehrenberg, 1839

Gênero Rotalia Lamark, 1804

\section{Rotalia?}

Rotalia Loeblich \& Tappan, 1988.

(Est. 15, figs. 4-13)

Descrição: Teca pequena, trocoespiral; lado espiral evoluto, convexo; lado umbillical involuto; câmaras subtrapezoidas no lado espiral e triangulares no lado umbilical; algumas vezes possuindo folium grande, com distinta reentrância sutural posterior (entalhe) presente no lado umbilical entre a parede da câmara principal e o folium; periferia arredondada e suavemente lobulada; parede calcítica, finamente e regularmente perfurada em ambos os lados, com exceção de parte do folium, face septal e ao redor das aberturas espirais suturais; suturas no lado espiral retas e oblíquas, no lado umbilical retas, deprimidas e suavemente oblíquas; pústulas poligonais grandes presentes no folium, preenchendo a cavidade umbilical, pústulas muito pequenas e pseudoespinhos presentes na área da abertura, ao longo das margens dos espaços interloculares e no entalhe sutural; abertura em fenda estreita interiomarginal, extraumbilical.

Procedência: S3i $i_{1}-[4-5]$, lâm. 17; S3i - [10], lâm. 16; S5 - [11]; S5 $5_{3}$-[12-13]; S5 - [6-8], lâm. 11; $\mathrm{S}_{5}-[9]$

Obs: A espécie-tipo na descrição de Loeblich \& Tappan, 1988 apresenta periferia angular o que não foi observado no material desse estudo.

\section{Subfamília: AMMONINAE Saidova, 1981}

Obs: Hottinger et al. 1993 considera Familia AMMONIDAE Saidova, 1981 nom. transl. ex AMMONIINAE Saidova, 1981 e descarta todas as denominação de subfamília em seu trabalho.

Gênero: Ammonia Brünnich, 1772

Obs: O gênero Ammonia Brünnich, 1772 foi o primeiro gênero estabelecido na ordem Foraminiferida e muitas descriçōes de variantes do gênero e de sua espécie-tipo Nautilus beccarii (Linnaeus) tem proliferado na literatura desde então. Com isso, uma enorme quantidade de espécies acomodadas nos gêneros Ammonia, Rotalia e Streblus tem transformado a análise desses organismos em um verdadeiro caos.

Alguns trabalhos se destacam dos mais de 250 artigos que tratam da distribuição de foraminíferos em águas marinhas marginais e que citam Ammonia e variantes do gênero (banco de dados gentilmente cedido por Benjamin J. Sloan - University of Texas, Austin).

Schnitker (1974) reconhece diferentes variações morfológicas em culturas clonadas de laboratório de Ammonia beccarii (Linné) e outras espécies, tais como A. parkinsoniana (d'Orbigny), A. advena (Cushman), A. tepida (Cushman), A. sobrina (Schupack), A.pauciloculata (Phleger \& Parker) e A. limnetes (Todd \& Brönnimann) seriam ecofenótipos e portanto sinônimio-júnior de $A$. beccarii. O Dr. E. Boltoskoy (comunicação verbal) considera que A. catesbyiana também é uma variação ecofenotípica de $A$. beccarii.

Outros trabalhos tem se preocupado em reconhecer variações morfológicas impostas por controladores ambientais, especialmente temperatura e salinidade. Pioneiro neste aspecto, Poag (1978), reconhece dois membros finais como ecofenótipos de A. parkinsoniana d'Orbigny, 1839 recomendando o uso das designações informais forma tepida e forma typica. Hofker (1964) e Poag (1978) reconhecem A. beccarii como morfologicamente distintas de A. parkinsoniana, que dominaria o Oeste do Atlântico, enquanto a primeira seria característica do Mediterrâneo e arredores.

Jorissen (1988) diferencia as duas espécies, sendo a primeira caracterizada por exemplares com suturas limbadas no lado espiral e ormamentação em forma de protuberância arredondada ("knobby") em ambos os lados e utiliza-se do nome indicado por Poag (1978)- A. parkinsoniana para a identificação de exemplares menores, lobulados e menos ornamentados. 
Walton \& Sloan (1990) elaboraram uma síntese da distribuição geográfica e variação morfológica dentro do gênero Ammonia. Este trabalho deve ser considerado como ponto de partida para os futuros estudos sobre o táxon. Com o intuito de acabar com a proliferação de nomes específicos, esses autores recomendam o uso do nome $A$. beccarii, sugerindo que $A$. parkinsoniana seja sinonimizada com essa espécie. Seu principal argumento é a grande distribuição geográfica observada no estudo de exemplares típicos de A. beccarii com ornamentação em forma de conta ("beaded") e em forma de sulco arredondado raso ("fluted"), inclusive na parte Oeste do Norte do Atlântico. Para esses autores A. beccarii apresenta três morfotipos: A. beccarii f. tepida, A. beccarii f. parkinsoniana e A. beccarii f. beccarii.

Baseado nisso, especialmente adotando-se a proposta de Waiton \& Sloan (1990), foram adotados no presente estudo os seguintes conceitos:

A. beccarii f. parkinsoniana - corresponde a forma typica de Poag, comi exemplares menos ornamentados, 6 a 11 câmaras na última volta, mais grosseiramente calcários, periferia arredondada e possuindo 1 ou mais botões umbilicais;

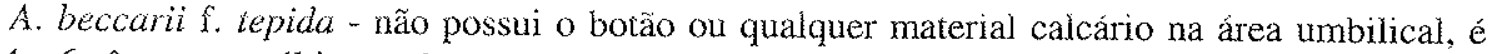
menor, 4 a 6 câmaras na última volta.

A. beccarii f. beccarii - corresponderia a forma inflata de Jorissen, com exemplares maiores e mais robustos, mais que 13 câmaras na última volta e principalmente ocorrência de "beading", "fluting"ou "furrowing" em ambos os lados.

O trabalho de Walkton \& Sloan (1990) foi adotado, como forma de contribuir para a síntese dos conhecimentos, até que mais estudos, com culturas de laboratório, possam determinar de forma mais precisa quais características de $A$. beccarii são genéticas e quais resultam de variações ecofenotípicas.

\section{Ammonia beccarii (Linnaeus) f. beccarii ?}

(Est. 14, figs. 17-20; Est. 15, figs. 1-3)

Ammonia jacksoni Buzas, Smith \& Beem, 1977, est 6, figs. 13-18

Ammonia beccarii f. inflata Jorissen, 1988 , p. 43, 52 est. 5, figs 1-4, est. 6, figs 1-4.

Ammonia beccarii f. beccarii Walton \& Sloan, 1990 , est. 2 , figs. 4-6, est.3, figs. 1-6, e est. 4, figs. 1-5.

Obs: Indivíduos incluídos sob esta designação nas áreas estudadas são muito raros. Diferenciam-se de A. beccarii f. parkinsoniana basicamente por possuirem mais botões no lado umbilical, algumas vezes ornamentação na borda do folium, pústulas diminutas e pseudoespinhos próximos a abertura e ao longo das margens nos espaços interloculares. Não foi identificada em nenhum exemplar a presença de "beading" "fluting" ou "furrowing" no lado espiral, que apresenta geralmente suturas limbadas. No lado umbilical, o que pode ser observado algumas vezes é a terminação irregular dos espaços interloculares e contas.

Procedência: S5 - [14: 20]; S5 - [14: 19; 15: 1 3], lâm. 9; LV4 (152-154 cm)- [14:17-18], lâm. 74

\section{Ammonia beccarii (Linnaeus) f. parkinsoniana Schnitker}

(Est. 15, figs. 14-20; Est. 16, figs. 1-11)

\footnotetext{
"Rotalia"beccarii var. A Parker, Phleger \& Peirson, 1953, p. 13, est 4, figs. 20-22.

Ammonia beccarii var. parkinsoniana Schnitker 1974

Ammonia parkinsoniana f. typica Poag, 1978, p. 397, est 1, figs 5-9, 13-16, 19-21.

Ammonia parkinsoniana f. parkinsoniana Jorissen, 1988 , p. 46,56 , est. 9, figs $1-5$
}

Descrição: Teca lamelar, trocoespiral; lado espiral convexo, evoluto; lado umbilical involuto; cavidade umbilical coberta por botâo produzido por um único pilar de lamela, com ornamentação inflada por pequenas pústulas e/ou pseudoespinhos; sulcos semicirculares ao redor do botão umbilical permanecem abertos e são sucessivamente preenchidos com lamelaçöes secundárias nos enrolamentos iniciais, sem gerar canais espirais; o folium pode se fundir com o botão umbilical; suturas espessas e/ou altas no lado espiral, na última volta, em alguns exemplares; suturas no lado umbilical retas radiais ou suavemente arqueadas e inclinadas com afundamento na direçäo umbilical, produzindo 
espaços interloculares e intraseptais abertos; periferia semi-circular, nunca quilhada; abertura em arco baixo interiomarginal.

Procedência: S5 - [est. 15: 19m20; est. 16: 11]. S5 $5^{-}$[est. 16: 2], lâm. 10. S5 - [est. 15: 14-16; est. 16: 5-6, 7-10], lâm. 11. LV4 (132-135 cm)- [est. 16: 1], lâm. 72; (274-276 cm)- [est. 16: 3-4], lâm. 86. LV89/19 (115-117 cm)-[est. 15: 17-18], lâm. 101.

\title{
Ammonia beccarii (Linnaeus) f. tepida Schnitker
}

(Est. 16, figs. 12-19)

\author{
"Rotalia" beccarii var. B Parker, Phleger \& Peirson, 1953, p. 13, est. 4, figs 25-28. \\ Ammonia aberdoveyensis Haynes, 1973, est 18, fig. 15, p. 185, tf. 38, nos. 1 7 \\ Ammonia beccarii var. tepida Schnitker, 1974 \\ Ammonia parkinsoniana f. tepida Poag, 1978 p. 397, est 1, figs 1-4, 10-12, 17-18. \\ Ammonia parkinsoniana f. tepida Jorissen 1988 , p. 46, 56 est 2, fig. 8a-8b; est 7, figs. 1-4; est. 10, figs \\ $1-3$.
}

Descrição: Teca lamelar, trocoespiral; lado espiral convexo, evoluto; lado umbilical involuto; cavidade umbilical sem botão; lado espiral liso e sem definição de câmaras, com exceção da última volta; suturas deprimidas algumas vezes limbadas no lado espiral; suturas no lado umbilical retas radiais ou suavemente arqueadas e inclinadas com afundamento na direção umbilical, produzindo espaços interloculares e intraseptais abertos; periferia semi-circular, nunca quilhada; abertura em arco baixo interiomarginal.

Obs: A única diferença entre a forma tepida e a anteriormente descrita é a ausência de botão umbilical. Estão ilustrados também os estágios ontogenéticos iniciais de A. beccarii f. tepida uma vez que em lupa binocular, muitas vezes, dependendo do tamanho do material, podem ser confundidos com foraminíferos plantônicos. Através da observação desses diferentes estágios ontogenéticos tenho questionado se correspondem realmente a $A$. beccarii f. tepida ou se o botão só se desenvolve no indivíduo adulto. Caso isso se confirme, esses diferentes estágios ontogenéticos podem corresponder a forma parkinsoniana também.

Procedência: S5 - [16-17], lâm. 11. LV4 (132-135 cm) - [18-19], lâm. 72; (274-276 cm)- [12 15], lâm. 86

Estágios ontogenéticos - LV4 (274-276cm) - [1,3,4,6-8], lâm. 86

LV89/19 (0-2 cm) - [5,9], lâm. 92; (8-10 cm) - [2,10-1 1], lâm. 93

Família: ELPHIDIDAE Galloway, 1933

Subfamilia: ELPHIDINAE Galloway, 1933

Gênero: Cribroelphidium Cushman \& Brönnimann, emend. Voloshinova, 1958

Cribroelphidium cf. atlanticum (Gudina)

(Est. 19, figs. 7-8)

Elphidium atlanticum Gudina in Gudina et al., 1975, p. 107, est. 11, figs. 6-22, est. 12, figs. 1 24

Descrição: Teca de tamanho médio, lateralmente comprimida; enrolamento plano espiral involuto; aproximadamente dez câmaras na última volta; periferia arredondada (algumas vezes irregular); parede hialina, fina e densamente perfurada; suturas retas; ponticuli curtos e largos, presentes nas últimas câmaras, mascarados como poros maiores nas câmaras iniciais; abertura principal cribrada, com as precedentes alinhadas na base da face septal da última câmara; aberturas areais suplementares. Procedência: S5, lâm. 10

Obs: Esta espécie definida para o Holoceno e Pleistoceno do norte da Rússia, apresenta botäo umbilical. Nos exemplares deste estudo, esta feição não foi observada, podendo talvez relacionar-se a gerações de indivíduos microsféricos. 


\section{Cribroelphidium excavatum (Terquem) \\ (Est.18, figs. 1-10)}

(?) Polystomella arctica (Parker \& Jones) Terquem, p.428, est. 2, fig. 1

Elphidium excavatum (Terquem) forma lidoensis Cushman, 1936. Miller et al. 1982, p. 134, est.1, figs. 17-20; est. 4, figs. 7-12; est. 5, fig.9; est. 6, figs. 15,16.

Descrição: Teca planoespiral involuta, área umbilical deprimida; aproximadamente dez câmaras infladas; periferia subcircular parede calcária, com poros muito pequenos; ornamentação composta por pústulas abundantes e pseudo-espinhos na base da face septal e em volta da abertura, nos espaços intercamerais, ao longo do septum, folium e umbílico; presença de canal espiral-umbilical formado abaixo do folium. Em exemplares com face apertural quebrada, observamse flap septal da câmara posterior aderido à face septal precedente, com exceção de suas margens onde uma lacuna intercameral estreita é formada ao longo do septum, estendendo-se em duas placas umbilicais simétricas posicionadas normal ao enrolamento adjacente. Suturas curvadas para trás, deprimidas; folium grande, podendo apresentar-se com extensões em forma de placas irregulares; abertura em arco interiomarginal, na base da face distal, encoberta por pseudo-espinhos; aberturas suplementares
dentro do espaço intercameral.

Procedência: LV4 (144-146 cm) - [7-8], lâm. 73; (223-225 cm) - [3-4], lâm. 80; (24.4-246 cm) - [5-6], lâm. 82; (264-266 cm) - [1-2], lâm. 85; S5 - [9-10], lâm. 11 .

Obs: Difere de Haynesina Banner \& Culver, 1978 por apresentar ponticuli incipientes, fossetas e flaps septais como os rotaliídeos. Por esta mesma razão também diferem de Nonion Montfort, 1808 , além do que a espécie-tipo de Nonion-Nautilus incrassatus -pertence agora ao gênero Anomalinoides, que faz parte de outra família. A nova espécie tipo submetida ao ICZN, designada Nautilus faba diferencia-se dos exemplares aqui descritos por não apresentar ponticuli. Difere de Elphidium por nâo possuir ponticuli extensamente distribuídos

\section{Cribroelphidium excavatum (Terquem) forma clavata Cushman, 1930}

(Est. 18, figs. 11-12)

Elphidium incertum (Williamson) var. clavatum Cushman,1930, p. 20, est. 7, fig. 10 a,b

Descrição: Teca pequena translúcida; frequientemente com botão e canal umbilical incompletos; suturas radiais ou curvadas, não atingindo a periferia da teca; ponticuli raros, estreitos e incompletos.
Procedência: LV4 $(144-146 \mathrm{~cm})$, lâm. 73

Obs: Miller et al. 1982 sugerem algum tipo de variação ecofenotípica, correspondendo a exemplares com região umbilical "pobremente"desenvolvida.

\section{Cribroelphidium excavatum (Terquem) forma selseyensis Heron-Allen \& Earland, 1911}

(Est. 18, figs.13-16; Est. 19, figs. 15-16)

Cribroelphidium excavatum (Terquem) forma selseyensis Heron-Allen \& Earland, 1911. Miller et al., 1982, est. 1, figs. 13-16, est. 5, fig. 10-13, est. 6, figs. 9-13.

Obs: Esta variação apresenta maior número de ponticuli e maior número de câmaras (aproximadamente 13). Difere de $E$. gunteri Cole por este possuir perfuraçöes grosseiras na parede da teca, o que näo é observado nos exemplares desse estudo.

Procedência: LV4 (264-266 cm) - [18:13-14], lâm. 85. S54 * [18:15-16], lâm. l 1

LV4 (132-135 cm) - [19:15], lâm. 72; (193-195 cm) -[19:16], lâm.78 


\section{Cribrolphidium poeyanum (d'Orbigny)}

(Est. 19, figs. 12-14)

Polystomella poeyana d'Orbigny, 1839, p. 55, est. 6, figs. $25,26$.

Descrição: Teca planoespiral involuta; aproximadamente 11 câmaras na última volta, sendo as últimas suavemente infladas; periferia arredondada; parede calcária, oticamente radial; finamente perfurada; ponticuli numerosos; suturas suavemente curvadas e comprimidas; umbílico com sistema de canais verticais fechando, com o folium, a porção umbilical; face apertural lisa,-com abertura principal cribrada na base e aberturas areais suplementares distribuídas na face septal.

Procedência: LV4 (223-225 cm) - [12 13], lâm. 80; LBE 89/2 (180-182 cm) - [14], Jâm 124

\section{Cribroelphidium cf. vadescens Cushman \& Brönnimann, 1948}

$$
\text { (Est.19, figs. 1-5, 9) }
$$

Cribroelphidium vadescens Cushman \& Brönimann, 1948, vol. 24, p. 18, est. 4, figs. 5a,b.

Descrição: Teca de tamanho médio, comprimida; aproximadamente dez, suavemente infladas nos últimos estágios ontogenéticos; parede calcária, densamente perfurada com poros grandes e distintos, com exceção da face septal da última câmara; área umbilical com pseudo-espinhos, pústulas e botões irregulares; suturas retas, pouco distintas, sendo as últimas mais incisas que as primeiras, com poucos ponticuli presentes, espessos; periferia subarredondada, irregular; aberturas cribradas alinhadas na base da face septal da última câmara, alguns exemplares apresentam alinhamento secundário de aberturas.

Procedência: $S 5_{2}-[5] ; S 5_{3}-[3-4] ; S 5_{4}-[1-2]$, lâm. 11; S7i 4 , -[9], lâm. 34.

Obs: Os exemplares desse estudo diferem da descrição original por possuirem menor número de ponticuli ("processos retrais" de Cushman \& Brönnimann). Diferem de E. gunteri Cole por apresentarem menor número de câmaras e não as quatorze descritas para esta espécie.

Gênero Elphidiella Cushman, 1936

Elphidiella sp.

(Est. 19, fig. 6)

Descrição: Teca de tamanho médio a grande, plano-espiral, involuta, bilateralmente simétrica; dez câmaras na última volta; parede calcária, perfurađa, lisa; ponticuli e fossetas não homólogas aos de Elphidium; suturas retas, lisas com fossetas redondas, que aumentam em tamanho em direção as últimas câmaras; ocorrência de canais umbilicais verticais e espirais; periferia arredondada; abertura principal cribrada na base da face septal da última câmara, com aberturas areais suplementares. Procedência: LV4 $(223-225 \mathrm{~cm})$, lâm. 80

Obs: Este gênero apresenta ocorrência em regiões árticas e boreais do Paleoceno ao Holoceno.

Gênero: Elphidium de Montfort, 1808

Elphidium articulatum (d'Orbigny)

(Est. 19, figs. 10-11)

Polystomella articulata d'Orbigny, 1839, v. 5, pt. 5, p. 30, est. 3, fïgs. 9, 10.

Elphidium articulatum (d'Orbigny) Boltovskoy et al. 1980, p. 29 , est. 13, figs. 1-4

Descriçăo: Teca de tamanho médio, biumbilicada, lateralmente comprimida; vista lateral circular; aproximadamente quatorze câmaras visíveis, não infladas; parede calcária, opaca; poros muito finos dando muitas vezes um aspecto granular; suturas retas, com ponticuli retangulares e finos, numerosos; periferia arredondada; abertura em fenda, quase imperceptivel, na base septal da última câmara.

Procedência: S54, lâm. 11 
Elphidium incertum (Williamson) var. mexicanum Kornfeld, 1931, vol. 1, p. 89, est. 16, figs. 1,2. Elphidium mexicanum Kornfeld. Buzas et al. 1985, p. 1087, est. 7, figs. 9-10.

Descrição: Teca planoespiral involuta, lateralmente comprimida; contorno equatorial subcircular, ligeiramente lobulada, principalmente nas últimas câmaras; aproximadamente 10 a 12 câmaras, discretamente curvadas para trás; parede finamente perfurada; aparência oticamente granular, lisa, exceto na área da abertura, ao redor das fossetas e umbílico, onde as pústulas estão presentes; fossetas interseptais arredondadas; botão umbilical largo (megalosférico ?); abertura em fenda, na base septal da última câmara, mascarada por pústulas; folium anterior igualmente marcado por pústulas.

Procedência: $\mathrm{S}_{4}$, lâm. 11

Obs: Difere de E. discoidale (d'Orbigny) por não apresentar periferia angulosa, poros grosseiros e não ser opticamente radial. 


\section{OSTRACODA}

Procedência: $\mathrm{S} 6_{3}$, lâm. 57

Cyprideis salebrosa Bold, 1963.

Procedência: [1-3] LV4 (274-276 cm), lâm. 86; [4-6] LBE89/2, lâm. 112

Procedência: $\mathrm{S} 2_{1}$

Loxoconcha paranensis (Rossi de García), 1966

Proceđência: S2ì, lâm. 26

Paracypris sp.

Perissocytheridea cf. P. krömmelbeini Pinto \& Ornellas, 1970

Procedência: LBE 89/2, lâm. 112

Procedência: LV4 (2-4 cm), lâm. 64

\section{CHAROPHYTES (Carófitas)}

Taxonomia a ser confirmada:

Familia CharaceaE L. CL. Richard, 1815

Subfamília CHAREAE von Leonardi, 1863

Gênero Chara (Vaillant, 1719), Linneo, 1753

Procedência: LBE 89/2 (0-2 cm), lâm. 111

Procedência: $\mathrm{S}_{3}$, lâm. 57

\section{Gênero Lamprothamnium ?}

\section{GASTRÓPODES}

Taxonomia a ser confirmada:

Procedência: LBE 89/2 (0-2 cm), lâm. 111

Hydrobia sp. A

Heleobia sp.?

Procedência: [1, 3] LBE 89/2, lâm. 112; [2] LV4 (41-45 cm), lâm. 68; [4] LV4 (244-246 cm), lâm. 82.

Sayella aff. crosseana

Procedência: LBE 89/2 (100-102 cm), lâm. 119

Procedência: $\mathrm{Sli}_{7}$, lâm. 21

Caecum brasilicum Folin, 1867 


\section{GLOSSÁRIO}

Para facilitar a leitura pertinente à taxonomia foi adotada a terminologia sugerida por Hottinger et al. 1993, somada a contribuições próprias do material analisado, de modo a que as feições morfológicas utilizadas para a descrição dos foraminíferos comecem a ser unificadas, através da versão de alguns termos. Um número muito superior de feições podem ser encontradas no trabalho do referido autor. Os termos listados são seguidos pelo seu uso em inglês acompanhados [entre colchetes] por termos alternativos usados e (entre parêntesis) por termos considerados sinonímios ou usados para feições similares mas que possuem significado taxonômico diferenciado. A numeração apresentada após a descrição refere-se a estampa/ número do exemplar. As abreviações utilizadas na iconografia, estão no final do glossário e em parte apresentadas na Estampa 26 e em algumas estampas.

Abertura, aperture - abertura primária na teca ou entre elementos da teca, pode ser simples ou múltipla (ver também abertura cameral, abertura foliar, abertura suplementar). 16/2 Abertura areal, areal aperture - abertura cameral na parede distal, NÄO NA SUTURA. Pode ser simples
ou múltipla. $2 / 4$

Abertura cameral, cameral aperture - abertura simples ou múltipla na parede da câmara, colocando em comunicação o lumen cameral principal com o exterior e convertido parcialmente ou inteiramente em um foramen intercameral (ver abertura suplementar e abertura foliar). Fig. A, 11/19

Abertura extraumbilical, extraumbilical aperture - abertura cameral primária interiomarginal não conectada com o umbilico. $1 / 18,13 / 2,16 / 14$

bertura extraumbilical-umbilical, extraumbilical-umbilical aperture - abertura primária interiomarginal que se estende do umbilico a periferia, em espécies espirais.13/17

Abertura foliar, foliar aperture - (abertura labial, pars auct.) - abertura primária de um folium ao exterior em posição interiomarginal anterior, posterior ou umbilical (axial) às bordas do folium; entre a parede da câmara principal e o folium ( Iábio foliar, fissura astral); ou dentro do folium propriamente. Uma abertura foliar pode estar em continuação com a abertura cameral primária ou separada desta, mas nunca convertida em foramen intercameral. Pode passar a canal vertical por laminação secundária.
$13 / 19 ; 18 / 1$

Abertura interiomarginal, interiomarginal aperture - abertura situada na sutura entre a parede distal e o enrolamento precedente. $1 / 18$

Abertura primária, primary aperture - ver abertura cameral principal; abertura suplementar

Abertura secundária, secondary apertures - ver aberturas suplementares.

Abertura (s) suplementar (es), supplementary aperture (s) (abertura (s) secundária(s), pars. auct.) aberturas formadas primariamente tanto na face da abertura ("apertural pores") ou ("slit- like") em posição sutural, sempre somando-se a uma abertura cameral principal. Aberturas suturais suplementares não são convertidas em foramina intercameral por causa da sua posição e assim, aparentemente não servem para a passagem do endoplasma funcional entre as câmaras. O mesmo parece ocorrer com as aberturas suplementares múltiplas que, embora situadas no septum, podem estar ausentes nas câmaras iniciais podendo estar ligadas a um instar subseqüente. 19/6,13,14.

Abertura umbilical [intraumbilical], umbilical aperture - abertura primária de uma câmara em direção ao umbílico. $14 / 5,7,9$.

A boral, aboral - Oposto à terminaçăo da abertura [oral]

Apical, apical - refere-se a parte inicial da teca 
Arranjo das câmaras, chamber arrangement - disposiçăo no padrão das câmaras.

Arranjo cameral involuto, involute chamber arrangement - em formas de enrolamento espiral onde devido a forma das câmaras - a lumina cameral em uma volta cobre lateralmente aquelas da volta precedente. $1 / 12 ; 12 / 14 ; 14 / 1-3 ; 19 / 2,4,6,12,18$.

Arranjo cameral planoespiral, planispiral chamber arrangement - arranjo em vottas, onde o índice de translação (índice líquido do movimento ao longo do eixo de crescimento em relação ao índice líquido de movimento para fora do eixo ) é zero. Lados espirais e umbilicais da teca idênticos e simétricos em relação ao plano de simetria bilateral. 2/3,4; Est.18 e 19.

Arranjo trocoespiral, trochospiral arrangement - arranjo cameral em voltas ou enrolamento onde o índice de translação ( índice líquido do movimento ao longo do eixo de crescimento em relação ao índice líquido de movimento para fora do eixo ) é maxs que zero. Lados umbilical e espiral desiguais. Pode ser involuto ou evoluto em ambos os lados.14/1-3; Est. 15

Bisserial, biserial - arranjo cameral trocoespiral com aproximadamente $180^{\circ}$ entre as câmaras consecutivas, produzindo duas fileiras de câmaras.

Borda [borda peristomal], rim - margem espessada de uma abertura (ver também lábio). Ver distal e proximal, $7 / 19 ; 5 / 4,6,18 ; 12 / 14 ; 13 / 17$

Botão umbilical [plug, umbilical plug] - pilar expandido de lamela espessa em posição axial em um umbílico ou em um bowl umbilical. Pode ser simples, composto e/ou canaliculado. 16/1;19/17

Câmaras, loculus, chamber - espaço (s) comprimido entre elementos "esqueléticos" da teca e produzidos durante um único passo de crescimento.

Camaretas, chamberlets - segmentos ou subdivisões de uma câmara.

Camareta foliar, foliar chamberlet - parte da câmara delimitada por um folium. Uma camareta foliar pode ser contínua, com a câmara principal, separada primariamente (e parcialmente ou completamente) da última por uma placa do foramen, por uma placa umbilical, ou secundariamente por uma placa de cobertura ou uma placa selante. Uma camareta foliar comunica-se com o exterior através de aberturas foliares e com seu próprio lumen cameral principal através de aberturas na placa umbilical ou placa de cobertura (quando presente) ou à sua margem. Dependendo da geometria dos elementos da teca, uma camareta foliar pode ser convertida em parte de um canal umbilical espiral secundário bem como parte da cavidade umbilical e a qual se comunica com os espaços interloculares intraseptais. $14 / 5$

Canais verticais, vertical canals - espaços tubulares mais ou menos normais a superfície da teca produzido por laminação secundária (a qual é extremamente afinada) sobre vários enrolamentos. Originam-se das margens dos canais suturais ou fossetas, ou de aberturas foliares que se comunicam com um canal umbilical espiral. 19/12

Canal espiral, spiral canal - ver canal espiral umbilical primário e secundário

Canal umbilical espiral primário, primary spiral- umbilical canal - espaço achatado e tubular comprimido entre as placas umbilicais e a parede precedente do enrolamento adjacente ou entre placas, folia e enrolamento precedente; ou entre placas dentais e o enrolamento precedente; presente na última câmara.18/14

Canal umbilical espiral secundário, secondary spiral-umbilical canal - espaço achatado a tubular contido entre as placas de cobertura e a parede lateral do enrolamento prévio adjacente. $13 / 5 ; 16 / 11$

Cancelado, cancellate - termo adotado da botânica. Mais comumente utilizado nas descrições de plantônicos. Provido de pequenas perfurações ou abertura, cercada de grade ou cancela. Podendo apresentar-se com cristas em forma de favo de mel. $12 / 1-12$ 
Carena, carina - espessamento periférico na teca. Em foraminiferos bilamelares formada pela lamela externa. $11 / 23$

Costelas, costae - elevações alinhadas na superfície da teca. Ver também estrias. 5/3,9,15,19.

Dente(s) miliolina, milioline tooth/teeth - uma ou mais projeções para dentro da porção proximal da parede da câmara para dentro da abertura de espécies miliolina. Pode ter forma de- barra, espatulada, bipartida ou bigorna, T, Y, âncora, espora, pá ou colher. Um dente simples sempre presente em posição interiomarginal; pode estar acompanhado de dente marginal projetando-se da margem oposta à abertura, do "teto" da abertura ou parede lateral. 5/12; 7/1,5,15;9/2

Depressão peri-apertural, adapertural depression - espaço formado por uma placa dental e separado desta parcialmente ou completamente do "lumen" cameral principal. Depressões peri-aperturais interconectadas produzem um canal.11/9,13,19; 12/16.

Dimorfismo, dimorphism - ocorrência na mesma espécie de duas formas distintas, comumente refere-se a gamonte e esquizonte, embora uma teca megalosférica também possa pertencer a um esquizonte. $18 / 1-4$

Distal, distal - o mais afastado do proloculum, na direção do crescimento.

Dorsal ou lado dorsal, dorsal side - ver lado espiral.

Eixo de enrolamento, axis of coiling - linha imaginária ao redor da qual a teca espiral é enrolada.

Enrolamento, whorl, coil - volta única ou evolução da teca espiral em tomo de $360^{\circ}$.

Qnrolamento dextrógiro, dextral coiling - enrolamento na direção horária como visto do lado espiral. $16 / 15$

Enrolamento miliolínico, milioline coiling - em foraminíferos porcelânicos, enrolamentos biloculares onde todas as aberturas terminais são posicionadas em um eixo comum (eixo da abertura); com eixos de enrolamento normais ao eixo da abertura e rotacionados de tal maneira que entre os planos médios das câmaras consecutivas vários ângulos são produzidos, por ex: $72^{\circ}$ (quinqueloculina), $120^{\circ}$ (triloculina) ou $180^{\circ}$ (spiroloculina ou biloculina).

Enrolamento sinistrogiro, sinistral coiling - enrolamento na direção anti-horária, vista do lado espiral. $16 / 12,16$.

Entalhe, notch, notch - reentrância em posição sutural; pode se prolongar num ângulo ou curva interna (Ver também placa do foramen). 13/5,17; 14/18

Espaço interlocular, interlocular space - (lacuna pars auct.) - espaço formado como consequiência de uma sutura profundamente mergulhada entre as paredes de câmaras consecutivas ou entre enrolamentos consecutivos. Ver espaços intraseptais e espirais interloculares. 18/1; Fig. A

Espaço interlocular intraseptal, intraseptal interlocular space - em formas que possuem um flap septal parcialmente não aderido, corresponde ao espaço formado entre a parede bilamelar posterior de uma câmara e a parede bilamelar distal da câmara precedente como resultado de aprofundamento por mergulho da sutura. Espaços intraseptais podem estar abertos para o exterior ao longo de suas margens tanto continuamente ou através de aberturas entre pontos de aderência marginal da parede da câmara lateral consecutiva (canais suturais; fossetas).18/4,8,12

Espécie, species - soma total de indivíduos que partilham os mesmos caracteres de suas tecas, como tamanho, n. de câmaras, ou outro tipo de variação em tamanho e forma de alguns elementos e claramente separáveis de outro grupo com características similares.

Estrias, striae - costelas finas a muito finas. 11/1-3 
Equatorial, equatorial - localizado no plano médio e normal ao eixo de enrolamento.

Face da abertura, apertural face - superfície da parede cameral que contém a abertura cameral principal. Fig. A

Face distal, distal face - última superfície da parede da câmara distal.

Face septal, septal face - superfície da parede da câmara a ser convertida em septum ao subseqüente instar.

Flap basal, basal flap - encerramento mais ou menos escavado espatulado interiomarginal da parede distal que se projeta em uma abertura de tipo miliolina restringindo a. 7/9,15

Flap septal, septal flap - (paries proximus, pars auct.) - parte da lamela interna que cobre a face septal precedente. Pode estar aderido à esta, produzindo neste caso um septum trilamelar em foraminiferos primariamente bilamelares; pode estar separado em parte da face septal precedente ao longo de uma sutura aprofundada e assim coberto pela lamela externa, produzindo um espaço interlocular intraseptal. O flap septal pode estender-se para uma placa umbilical, uma placa do foramen, uma placa de cobertura ou uma placa dental. 18/12

Folium, folium - ( lábio; parte projetante, lobo astral, pars auct. ) - em foraminíferos lamelares espirais corresponde ao contomo mais triangular e geralmente diferenciado texturalmente (porosidade) na porção axial-umbilical da parede da camara lateral. A borda entre a parede da camara lateral principal e o folium pode ser indicada por um entalhe curto ou "notch" ou por uma placa de sutura umbilical. Uma abertura (abertura foliar) está sempre presente entre a margem anterior de um folium e o enrolamento prévio adjacente. Adicionalmente, aberturas umbilicais e /ou posteriores podem estar presentes, dependendo se o folia está livre ou fixado por sua extremidade ou junto a sua margem posterior. En alguns gêneros o folia pode estender-se sobre a câmara precedente e fixar-se à esta, cobrindo parciaimente espaços interloculares intraseptais. Um folium é composto das mesmas camadas daquelas que formam a parede cameral principal. Ver camareta foliar; abertura foliar. 13/15,19; 15/5,6.

Foramen, foramina, foramen, foramina - [intercameral] abertura ou aberturas que colocam em comunicação a Iumina cameral principal fornecendo a passagem para o endoplasma. Pode ser primária, se formada pela abertura da câmara inicial, ou secundária, i.é. formada pela ressorção de partes de um septum. Aberturas camerais convertidas em foramina intercameral podem ser modificadas em forma pela ressorção ou através da restrição pela fixação de uma placa dental, placa do foramen ou placa umbilical. $1 / 5 ; 12 / 6 ; 10 / 5 ; 16 / 14 ; 18 / 10$.

Foramen intercameral, intercameral foramen - ver foramen

Fosseta, fossete - abertura para o exterior de um espaço interlocular intraseptal o qual é subdividido por ponticuli com processos retrais. 19/3,6,8,12,17.

Imperfurada, imperforate - ausência de poros ou paraporos.

Instar, instar - crescimento instantâneo episódico da teca.

Lábio, lip [apertural lip - lábio da abertura] - extensão da parede da câmara virada para fora ao longo da abertura cameral. Pode ser estreito ou amplo, pequeno ou grande. Ver também borda; comparar folium. 11/19;12/14;15/15

Lado espiral, spiral side [dorsal] - o lado da teca em formas trocoespirais que compreendem o proloculus ou a direção no qual o proloculus é deslocado.

$16 / 3,5,12,15$.

Lado umbilical, umbilical side [ventral] - em tecas trocoespirais corresponde ao lado oposto do espiral [dorsal]. $16 / 4,6,8,13,17$.

Lado ventral, ventral side - ver lado umbilical. 
Limbada, limbate - refere-se a borda sutural espessada da câmara; pode ser elevada. 11/2; 12/17; $15 / 14,1617,19 ; 16 / 3$;

Lumen cameral principal, main chamber lumen - cavidade da câmara completa ou segmentada que se comunica com a lumina da câmara precedente e sucessiva através da foramina intercameral (primária ou secundária). Em certos foraminíferos lamelares está separado parcialmente ou completamente de uma canareta foliar ou estrelar, bem como de sistemas de canais por uma placa do foramen, placa dental, placa umbilical, placa de cobertura, ou placa selante, por lamela interna envolvida ou parede lateral produzindo septula.

Megalosféfica, megalospheric - em tecas de espécies dimorficas que possuem um grandeiproloculus ou megalosfera; comumente um gamonte.

Micro-estrias, microstriae - elevações longitudinais miúdas, geralmente anstomosadas na superfície das tecas porcelânicas. Visíveis sob grande aumento, especialmente em MEV.5/7,8

Microsférica, microspheric - em tecas de espécies dimórficas que possuem um pequeno proloculus ou microsfera; comumente um esquizonte.

Oral, oral - da abertura

Ornamentação, omamentation - padrões de modificação externa na espessura e/ou textura da parede (Ver inflada; omamentação incisa).

Ornamentação incisa, incisional omamentation - padrão de porçōes afinadas da lamela externa aprofundada por laminação secundária fina usualmente adjacente a ornamentação inflada. Ver sulcos.

Ornamentação inflada, inflational ornamentation - padrões de espessamento primário freqüentemente em áreas imperfurada da lamela externa tornando-se adicionalmente espessada por laminação secundária (Ver pústulas; pseudoespinhos; costelas; carena).

Parede da câmara, chamber wall (s) - elementos do "esqueleto" formado num único passo fechando a câmara correspondente e coberto por revestimento orgânico interno- inner organic lining (IOL).

Parede lateral da câmara, lateral chamber wall - parede da câmara principal nunca convertida em parte de um septum; razoavelmente separada da periferia da câmara.

Parede porcelânica da teca, porcelaneous test wall - composta de ripas e bastões (rods) opticamente criptocristalinos ou agulhas de calcita. Os bastões são dispostos ao acaso, as ripas são arranjadas em um padrão similar a telhas de um telhado, formando a camada da parede externa. Parede imperfurada mas podendo conter "pits" (perfuraçôes apenas externamente).

Parede principal da câmara, main chamber wall - parede da teca que engloba o lumen cameral principal. A parede principal da câmara pode também incluir uma placa do foramen, placa de cobertura ou uma placa umbilical. Em tecas porcelânicas com ou sem camada externa aglutinada, a parede principal da câmara pode incluir uma extensão da porção da parede mais interna (sempre porcelânica) cobrindo a câmara adjacente (tão chamada assoalho -floor). Em todas as tecas de foraminíferos um revestimento orgânico interno cobre a parede da câmara principal.

Perfurada, perforate - refere-se a parede que possui poros verdadeiros.

Peristoma, peristome [lábio peristomal, borda peristomal]- borda ou tubo elevado ao redor da abertura ou foramen.

Pile, Pile (pilar inflado auct.) - espessamentos lamelares superpostos (pústulas) nas paredes laterais ou folia em enrolamentos consecutivos ou camadas de camaretas consecutivas, produzindo uma estrutura em forma de pilar (pillar). Fig. A 
Pilar, pillar ver pilares interseptais

Pilar inflado, inflational pillar - ver pile

Pilares interseptais, interseptal pillars - em espécies porcelânicas e aglutinantes, as projeções colunares múltiplas da porção interna da parede entre o septum e a parede da câmara distal, paralelo ao fluxo protoplásmico.

Placa da abertura, apertural plate - uma estrutura em forma de placa ao longo da base da abertura interiomarginal e que restringe a última.

Placa de cobertura, cover plate [umbilical cover plate] (retroparies, pars auct.) - extensão mais ou menos dobrada, imperfurada do flap septal dentro da câmara precedente através do foramen intercameral, interceptando - na câmara precedente - o Iumen cameral principal de uma camareta foliar. Usualmente fixada a placa precedente. É uma feição secundária, nunca presente na última câmãa $c$ portanto não homóloga com a placa do foramen primária ou placa umbilical.

Placa dental, toothplate ( sifăo; pilar central pars auct.) - placa retorcida que vai desde o foramen intercameral à abertura, ligada a ambas. Dobrada em espiral simples ou dupla. Dobras (ou línguas) com terminações distais livres e serrilhadas. Uma placa dental separa parcialmente ou inteiramente o lumen cameral principal de um espaço axial (depressão periapertural) em estágios pós embrionários. Placas dentais interconectadas produzem um canal espiral primário. $12 / 16$

Placa do foramen, foramenal plate - (placa dental; paries proximus, pars auct.) - basicamente um encerramento primário ou "inpush" na direção do crescimento da parede cameral posterior"lateral no entalhe sutural e fixado ao foramen intercameral. Uma placa do foramen pode ter a forma de um "dedinho" - ou de uma estrutura fechada exn forma de lobo, em forma de placa curta e reta, aberta marginalmente, dobrada a um angulo com o eixo de enrolamento e fixada ao enrolamento prévio adjacente, ou em forma de túnel, alcançando uma abertura espiral. Uma placa do foramen parcialmente separa um lumen cameral principal da camareta foliar e está em continuação com um flap septal. Pode ou não estar conectada com uma placa de cobertura, a qual separa - na câmara precedente completamente o lumen cameral principal de uma camareta foliar. Compare placa umbilical; placa de cobertura. 16/14

Placa plastogâmica, plastogamic plate - estrutura em forma de placa que cobre o umbílico de indivíduos plastogâmicos. 12/23

Placa umbilical, (placa do foramen; flap umbilical; placa dental; paries proximus; pars auct.) elemento da teca em forma de placa contorcida que pode ser simples ou composto de dois ramos simétricos em alguns gêneros planoespirais, com isto produzindo um ou dois canais umbilicais entre a placa e onrolamento adjacente. $18 / 4,6,10,14$

Plastogamia, plastogamy - fusão de adultos pela superfície umbiblical ao momento da reprodução sexual.

Ponticulus, ponticuli, ponticulus, ponticuli - ponte da parede lateral ligando espaços interloculados interseptais. Pode ser maciço ou possuir buraco, encobrindo um processo retral. 18/14; $19 / 12$

Poro, pore - perfurações tubulares diminutas que atravessam a parede das câmaras sendo cobertas internamente por um revestimento orgânico. Tamanho e forma externa e interna das aberturas dos poros podem ser identicas ( arredondadas ou alongadas) ou diferentes. Fig. A; 2/10,16;16/1; $19 / 1,12$

Processos retrais, retral processes - extensões ordenadas em forma de dedo do lumen cameral coberta por ponticuli presente às margens de um espaço interlocular intraseptal. 18/14

Prolóculo, Proloculus - câmara inicial da teca dos foraminíferos em ambas geraçôes. 17/1

Protoconcha, protoconch - primeira câmara da teca na qual uma deuteroconcha e diferenciada (ver prolóculo). 17/1 
Protoplasma, protoplasm - matéria viva que compreende o corpo celular.

Proximal, proximal - o mais próximo do proloculus. Oposto à direção de crescimento.

Pseudópodes, pseudopodia - projeções ectoplasmáticas do extratálamo semipermanente ou temporária Observado no organismo vivo.

Pseudoespinhos, pseudospine (murica; espinho, pars auct.) - feição ornamentada inflada com estrutura em forma de espinho cônica ou alongada frequientemente sólida, mas algumas vezes oca: 17/6;18/1; $19 / 4$

Pseudoespinose, pseudospine - possuindo pseudoespinhos. 17/6

Pústula, pustule [tubercle; papilla] - protuberância semiesférica a subcônica inflada da lamela externa. (Ver também pseudoespinho). 15/7

Quinqueloculina, Quinqueloculine - que possui arranjo típico de quinqueloculina.

Revestimento orgânico interno, inner organic lining "IOL" - cobertura de mucopolisacarídeo de toda a superfície interna das câmaras, foramina ou stolons que fecham os poros ou pseudoporos. Pode ser mais espesso nas câmaras ontogeneticamente iniciais.

Septum, septum - parede que separa duas luminas de câmaras principais consecutivas.

Sifão, sipho - termo amplamente aplicado tanto para placas dentais fortemente dobradas dos buliminideos e para tubos entosolenes. Aplicado também para abertura foliar estendida das Siphoirochammina. 2/2

Sistema de canais, canal systems - termo coletivamente e amplamente aplicado aos espaços interconectados da teca dos foraminíferos, primariamente ou secundariamente separado da lumina cameral principal, mas com a qual eles podem comunicar no mesmo enrolamento ou em enrolamentos sucessivos através de aberturas que não correspondam a foramina cameral. Os espaços que forman o sistema de canais são delimitados por diferentes elementos da teca: placa umbilical, placa de cobertura ligada a uma placa do foramen (foramenal plate), placa selante (sealing plate), placa dental (toothplate), flap septal, folia, enrolamento prévio bem como lamelas externas consecutivas.

Spiroloculina, spiroloculine - ver enrolamento miliolina

Sulcos, groove - depressões alongadas produzidas por afinamento local externo da lamela externa. Tornando-se aprofundada por laminação secundária fina persistente e conseqüente espessamento adjacente. Levando principalmente para dentro dos espaços intraseptais interloculares e freqüentemente correndo na periferia (corda marginal) ou nas paredes laterais paralelas ao perfil da periferia da câmara (ex. padrão em forma de chevron). Podem ser parcialmente fechados por laminação em estágios de crescimento posterior, produzindo canais. 12/23.

Sutura, suture - linha de aderência das paredes das câmaras a teca previamente formada.

Sutura espiral, spiral suture - sutura correspondente a parede entre os enrolamentos adjacentes. Fig. A

Sutura septal, septal suture - sutura correspondente ao septum. Fïg. A

Teca, test - concha ou componente esquelético de um foraminifero. Pode ser formada de material secretado ou aglutinado ou ambos.

Triloculina, triloculine - ver enrolamento miliolina

Tubo entosolene, entosolenian tube [endosolen] - tubo em forma de estrutura do esquleto interno que se estende da abertura na direção proximal, mais facilmente observado com o exemplar úmido sob lupa binocular ou ao microscópio eletrônico de transmissão. 9/14-16. 
Umbilicado, umbilicate - que possui um umbilico verdadeiro em um lado ou em ambos (biumbilicado).

Umbilico, umbilicus - espaço axial em foraminíferos espirais que se comunicam diretamente através das aberturas com a lumina cameral principal circundante ou camaretas foliares. Pode estar aberto ou retrito por um botão umbilical. 16/1

Dente valvular, valvular tooth - Em foraminiferos aglutinantes corresponde a uma extensão em forma de flap da margem distal da abertura principal, restringindo-a parcialmente. $1 / 7$

Vértice, apex - porção inicial da trocoespira ou da teca cônica. 
Significađo das abreviações utilizadas na iconografia.
A - Abertura
Aa - Abertura areal (não na sutura)
Ac - Abertura cameral
Af - Abertura foliar
As - Abertura suplementar (na sutura)
B - Botão umbilical
Bd $\sim$ Borda distal
Bp-Borda proximal
Ca - Cancelado
Car - Carena
Ce - Canal espiral
$\mathrm{Cv}$ - Canais verticais
Dp - Depressão periapertural
Dv - Dente valvular
Ei - Espaço interlocular
Fa - Face da abertura
Fb - Flap basal
F - Foramen
Fs - Flap septal
Fss - Fossetas
Fo - Folium
L. - Lábio
$\mathrm{N}$ - Notch, entalhe
P-Poro
Pc - Protoconcha
Pd - Placa dental
Pf - Placa do foramen
PI - Prolóculo
Po - Ponticuli
Pp - Placa plastogâmica
$\mathrm{Pr}$ - Processos retrais
Ps - Pseudoespinhos
Pu - Pústula [ tubérculo, papilla]
Pub - Placa umbilical
Ss - Sutura septal
Se - Sutura espiral 


\section{Estampa 1}

1- Centropyxis aculeata. Vista anterior, x 450, 20pm

2- Centropyxis constricta. Vista anterior lateral, x 500, 20 $\mu \mathrm{m}$

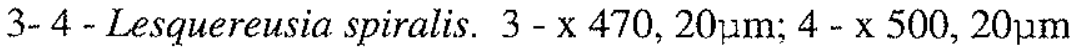

5- Polysaccammina ipohalina, x 120, 100 pm

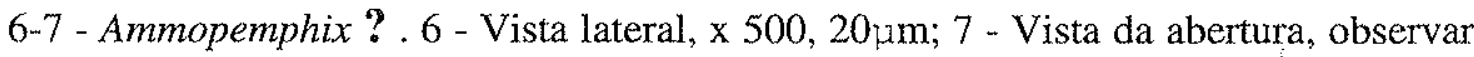
dente valvular, $\times 500,20 \mathrm{um}$

8. Discammina sp. Vista de perfil oblíqua mostrando abertura. $x 600,20 \mathrm{\mu m}$

9-16 - Haplophragmoides wilberti. 9- Vista lateral, x 600, 20 $\mu \mathrm{m} .10$ - Vista da

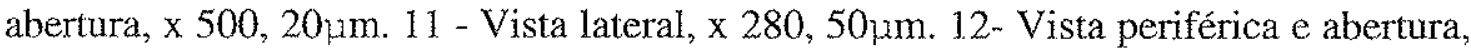

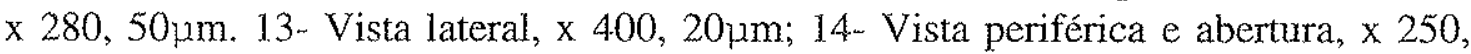
$50 \mu \mathrm{m} ; 15$ - Vista lateral, x 400, 20um; 16- Vista periférica oblíqua e abertura, x 450 , $20 \mathrm{xm}$.

17 -18-Portatrochammina sp. indet. 17 - Vista lateral, x 500, $20 \mu \mathrm{m} ; 18$ - Vista periférica e da abertura, x 500, 20 גm.

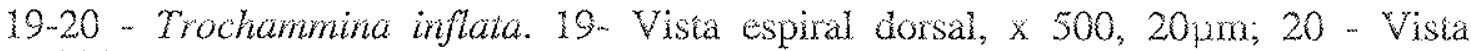

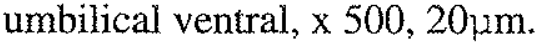




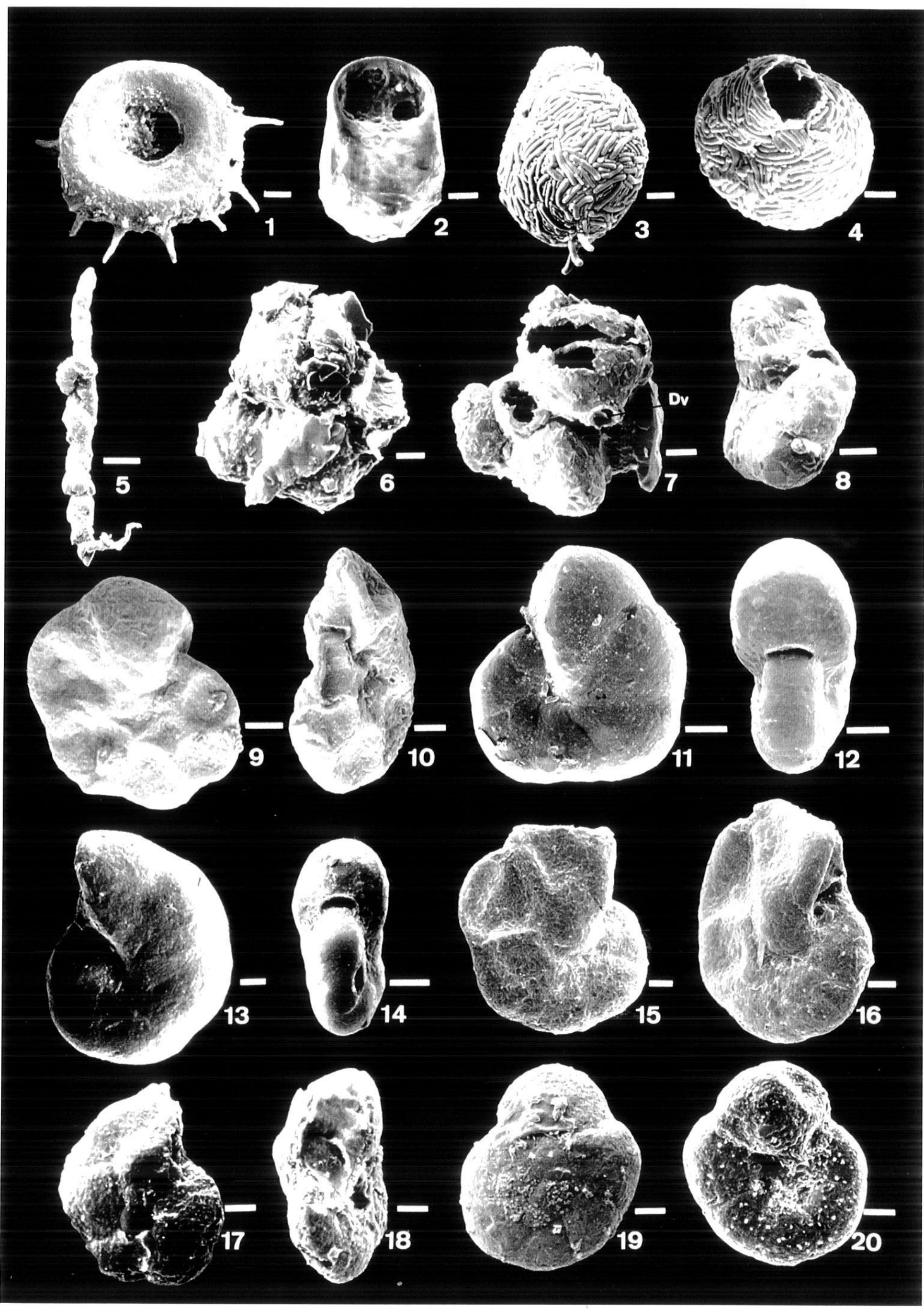




\section{Estampa 2}

1 - 2 - Trochammina inflata. 1 - Vista dorsal, x 700, $20 \mu \mathrm{m} ; 2$ - Vista ventral, x 700, $20 \mu \mathrm{m}$.

3-4 - Trochammina macrescens f. polystoma. 3 - Vista lateral, x 280, $50 \mu \mathrm{m} ; 4$ - Vista periférica e apertural, x 280,50 $\mathrm{m}$.

5 - Textularia earlandi. Vista periférica e apertural, x 290, $50 \mu \mathrm{m}$.

6 - 15 - Discorinopsis aquayoi. 6- Vista dorsal, x 300, $50 \mu \mathrm{m} ; 7$ - Visța periférica mostrando abertura, x 300, $50 \mu \mathrm{m} ; 8$ - Vista ventral, x 300, $50 \mu \mathrm{m} ; 9$ - Vista ventral de exemplar fóssil, x 500, $20 \mu \mathrm{m}$; 10- Vista dorsal, x 500, $20 \mu \mathrm{m}$; 11- Vista ventral, x 500, $20 \mu \mathrm{m}$; 12- Vista dorsal, observar variação do proloculum e perfurações, x 330, $50 \mu \mathrm{m} ; 13$ - Vista ventral, observar aumento das perfurações, x 330, $50 \mu \mathrm{m} ; 14$ - Vista dorsal de exemplar fóssil, com menor número de perfurações, x 390, $20 \mu \mathrm{m} ; 15$ - Vista ventral do exemplar fóssil, x 390, $20 \mu \mathrm{m}$.

16-17 - Discorinopsis sp. A. 16- Vista dorsal, x 280, $50 \mu \mathrm{m} ; 17$ - Vista ventral, x 280, $50 \mu \mathrm{m}$ 

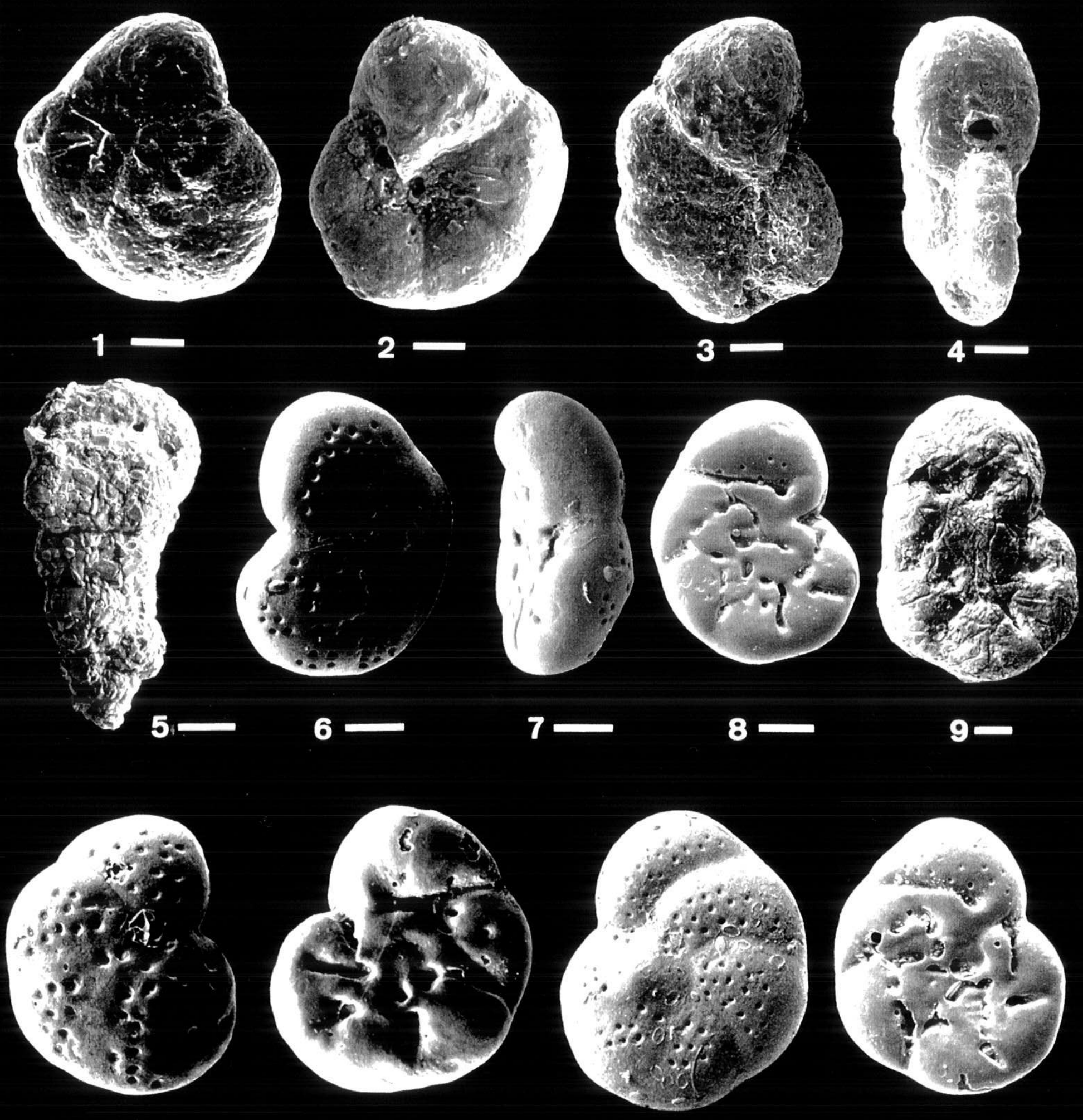

$10-$

11

12
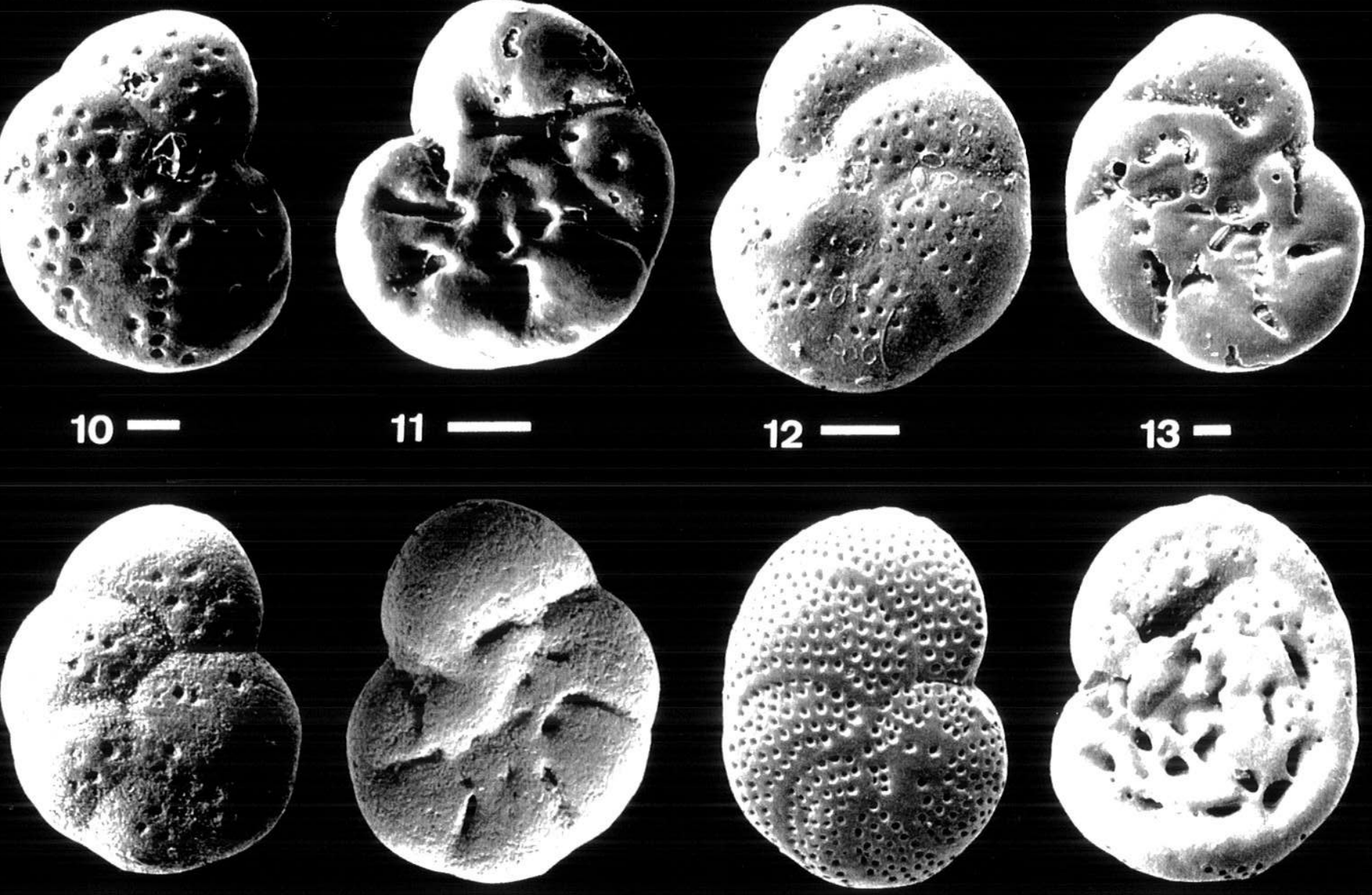

$14=$

15
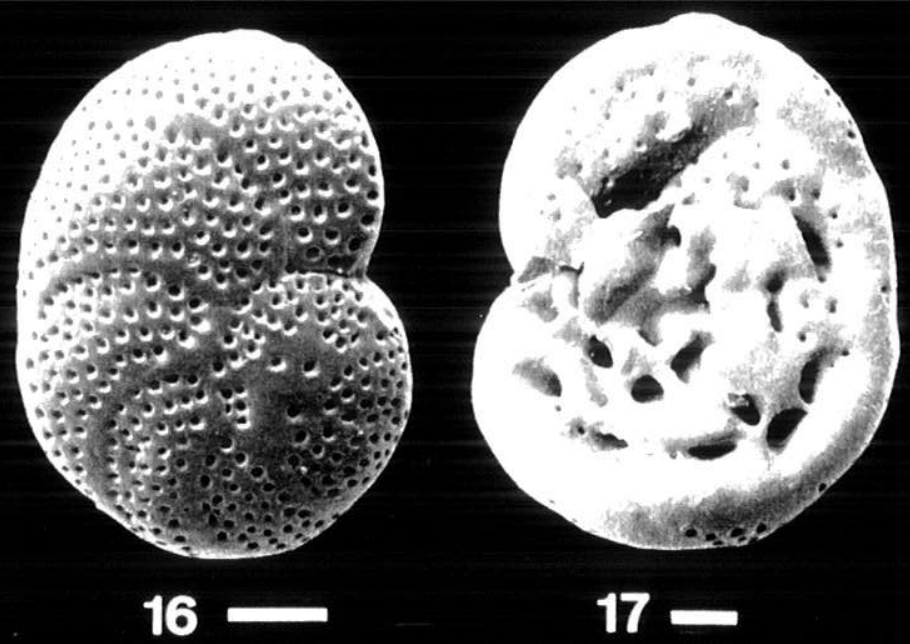


\section{Estampa 3}

1 - Ophthalmina sp. A. Vista lateral ilustrando pontos de corrosão na parede da teca, $\mathrm{x}$ 600 ,

$20 \mu \mathrm{m}$.

2 - Neospiroloculina sp. A. Vista lateral, x 160, 100 $\mu \mathrm{m}$.

3 - 8 - Agglutinella martiniiana ?.3 - Vista lateral e abertura, x 480, $20 \mu \mathrm{m} ; 4$ - Vista

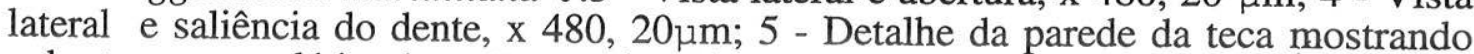
cobertura secundária de grãos carbonáticos, x 1400, $10 \mu \mathrm{m}$; 6- Vista lateral de exemplar com modificação da abertura e evidência da teca carbonática abaixo da

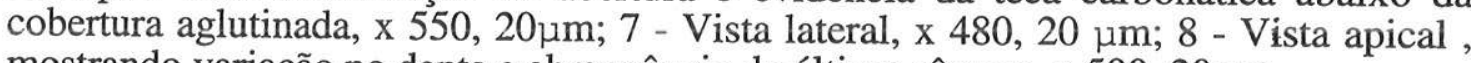

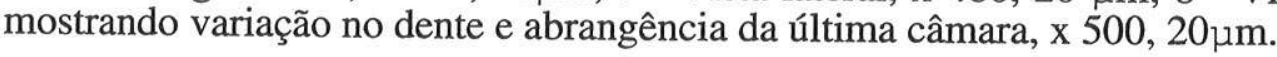

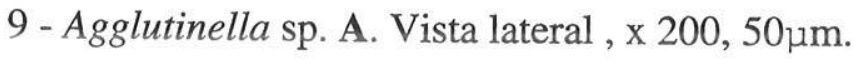

10 - 11 -Neopateoris cf. N. cumanaensis. 10- Vista apical, mostrando dente secundário unido ao dente principal, x 250, $50 \mu \mathrm{m}$. 11- Vista lateral, x 260, $50 \mu \mathrm{m}$.

12-13 - Massilina crescentensis ?. 12 - Vista da abertura, x 230, $50 \mu \mathrm{m} ; 13-$ Vista

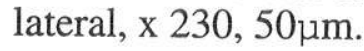

14 - 15 - Massilina protea. 14 - Vista lateral, x 170, $100 \mu \mathrm{m} ; 15$ - Vista da abertura, x 200, 50um;

16 - 18 - Massilina protea ?. 16 - Vista lateral, x 160, $100 \mu \mathrm{m} ; 17$ - Vista da abertura, x 200,50 $\mu \mathrm{m} ; 18$ - Vista lateral e apertural de exemplar teratológico, x 190, $100 \mu \mathrm{m}$. 

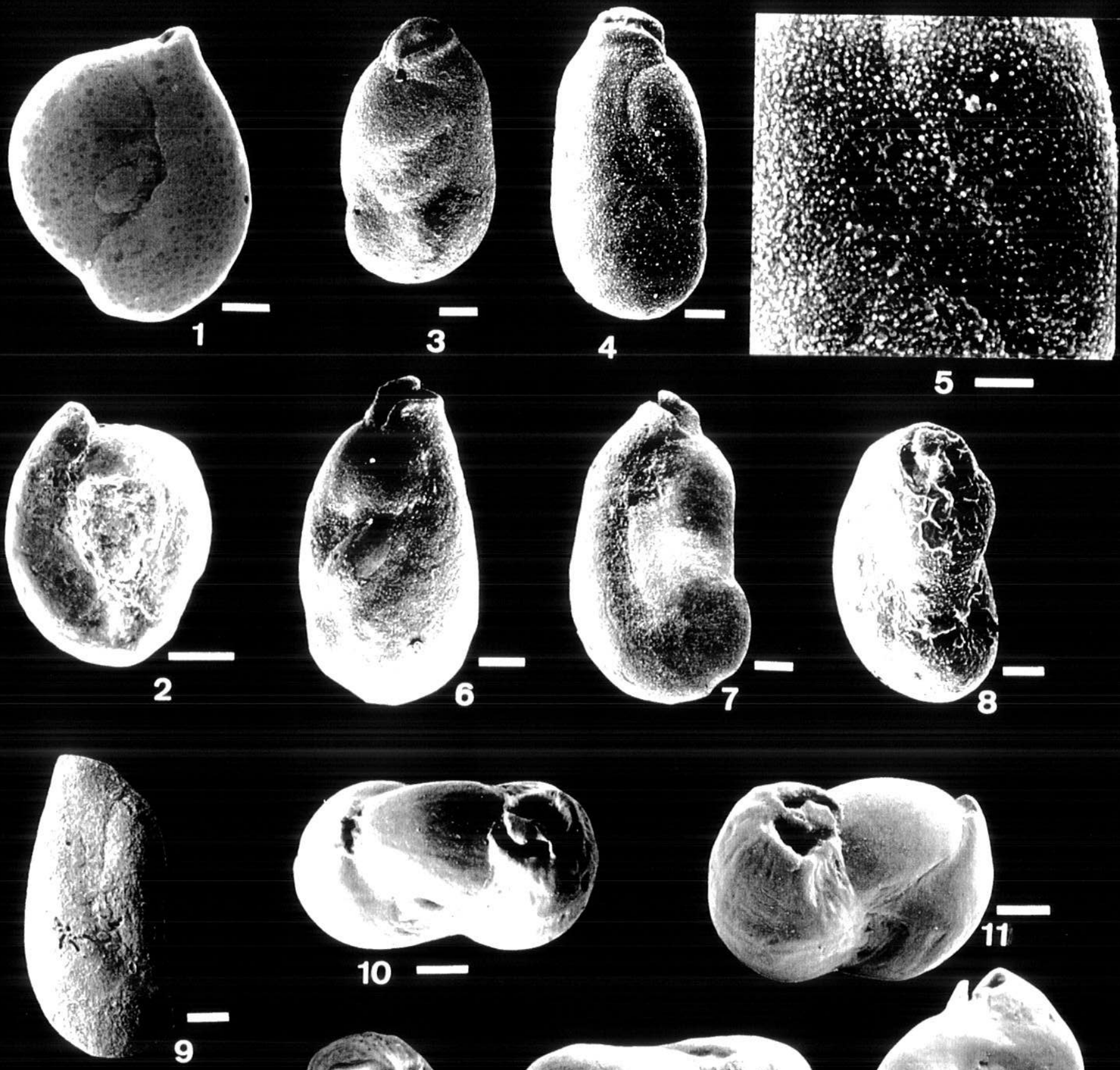

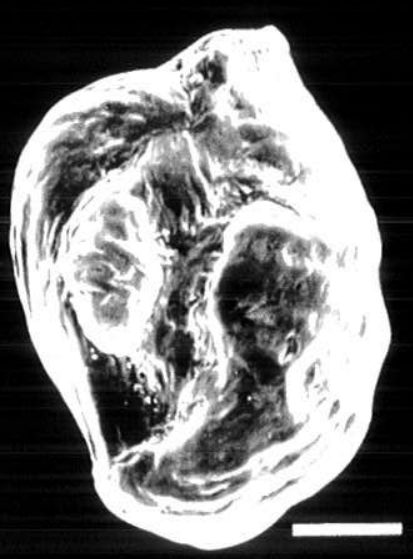

14
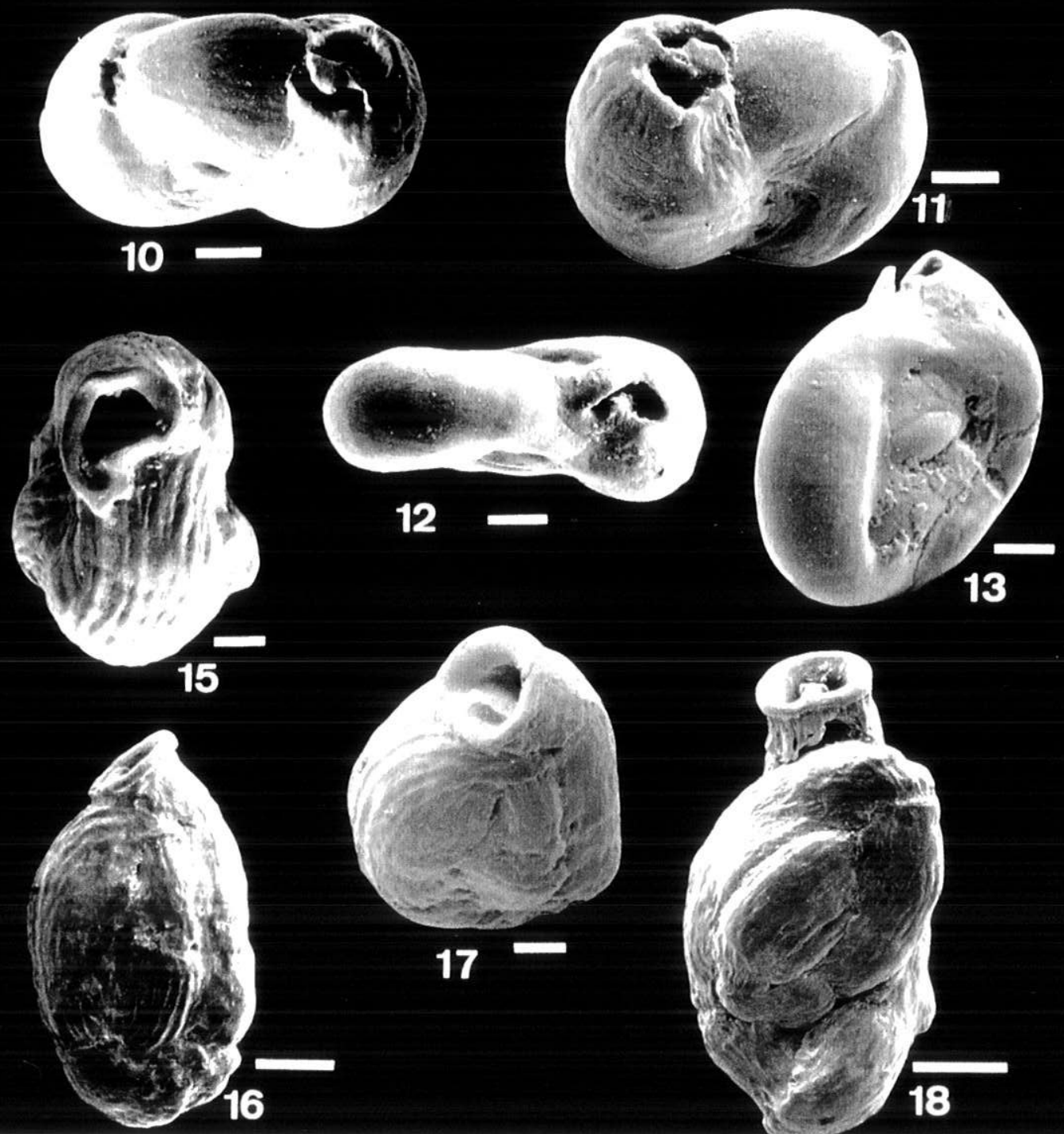


\section{Estampa 4}

1-3 - Massilina cf. M. secans. 1- Vista lateral, x 170, 100 $\mathrm{mm}$; 2- Vista periférica e apertural, x 210, $50 \mu \mathrm{m} ; 3$ - Vista periférica e abertura de outro exemplar com arranjo

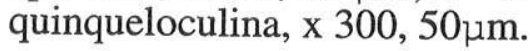

4-5 - Quinqueloculina milletti. 4- Vista apical e da abertura, notar mudança no plano de enrolamento, x 500, 20um; 5 - Vista lateral, mostrando câmara do enrolamento inicial oblíqua, x 350, 50 $\mu \mathrm{m}$.

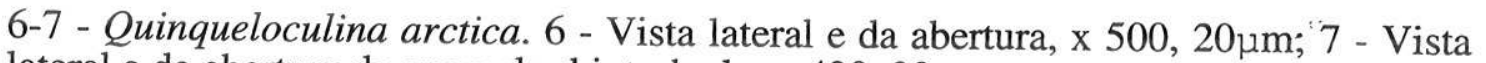
lateral e da abertura de exemplar bioturbado, x 420, 20 $\mu \mathrm{m}$.

8-9 - Quinqueloculina sp. A. 8- Vista da abertura, x 200, 50um; 9 - Vista lateral, x $160,100 \mu \mathrm{m}$.

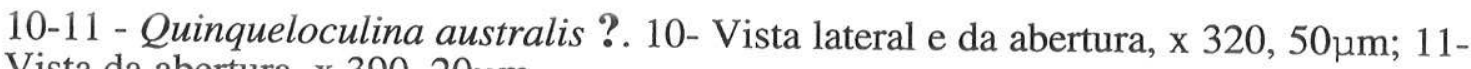
Vista da abertura, x 390, 20 $\mu \mathrm{m}$.

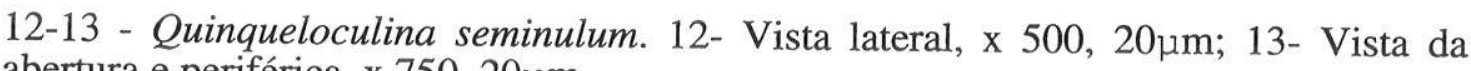
abertura e periférica, x 750, $20 \mu \mathrm{m}$.

14 - Quinqueloculina atlantica. Vista lateral e apertural, x 160, 100 $\mathrm{m}$.

15- Quinqueloculina dilatata?. Vista apertural, x 360, $50 \mu \mathrm{m}$.

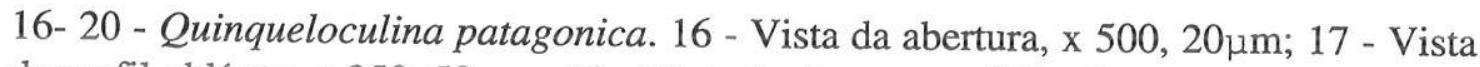

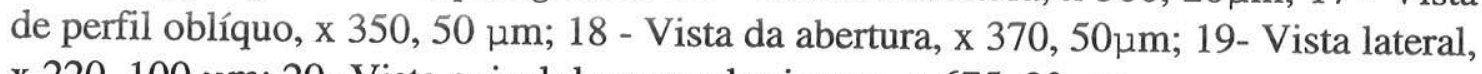
x 220, $100 \mu \mathrm{m}$; 20- Vista apical de exemplar jovem, x 675, 20um. 

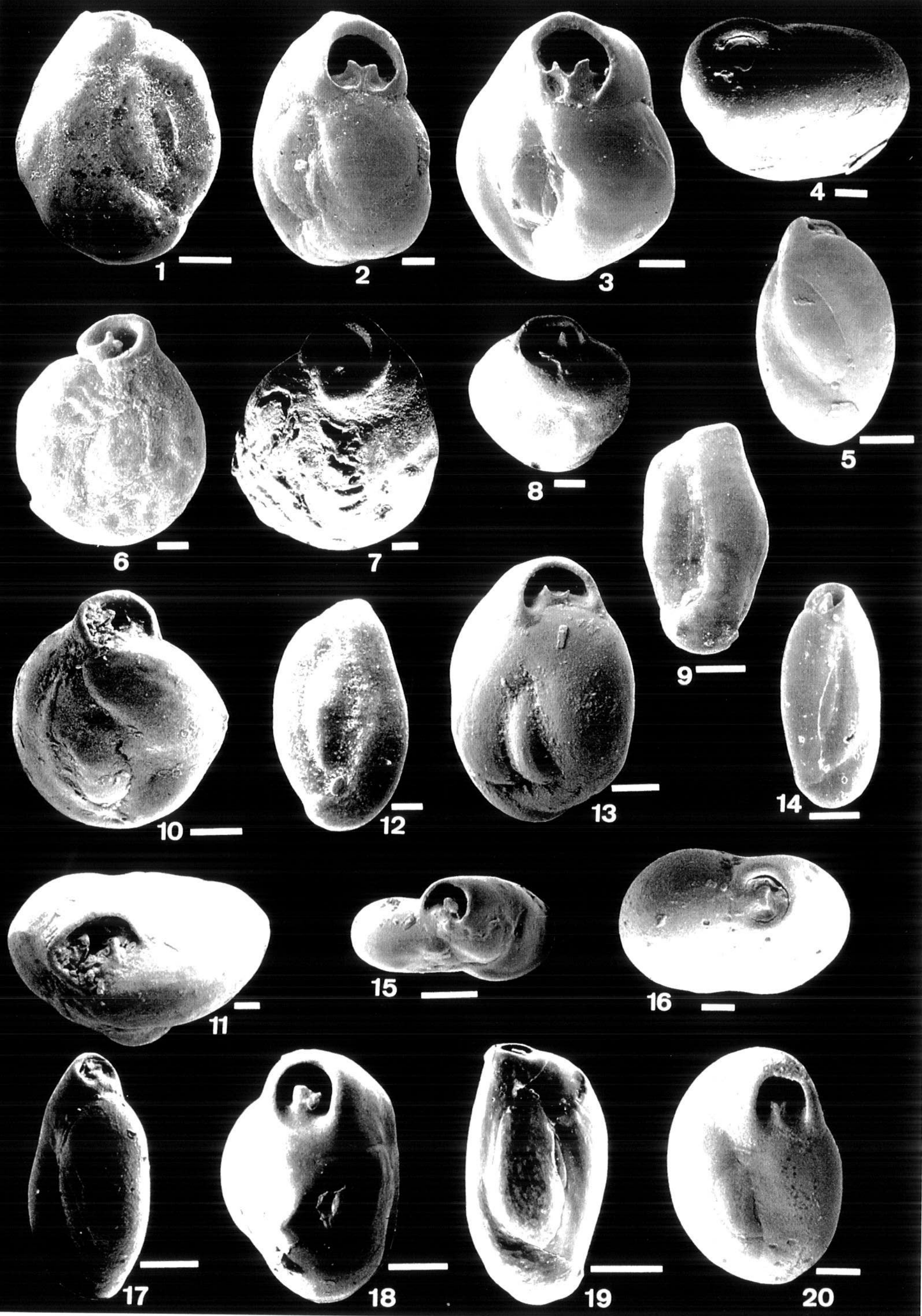


\section{Estampa 5}

1- 4- Quinqueloculina seminulum var. jugosa. 1- Vista lateral oblíqua de exemplar

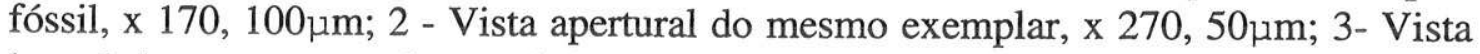
lateral de outro exemplar atual da amostragem de inverno, x 250, 50 $\mu \mathrm{m} ; 4$ - Vista apertural, x 380, $50 \mu \mathrm{m}$.

5-6 - Quinqueloculina venezuelaensis var. A. 5 - Vista lateral, x 180, $100 \mu \mathrm{m}$; 6- Vista terminal mostrando enrolamento quinqueloculina e estrutura de dente bipartido abaixo da superfície labial, x 200, $50 \mu \mathrm{m}$.

7-8 - Quinqueloculina microcostata. 7 - Vista lateral, x 170, $100 \mu \mathrm{m}$; 8- Vista terminal oblíqua, mostrando angulosidade das câmaras, lábio e dente bipartidoinflado, x 230, 50um.

9-10- Quinqueloculina elegans. 9- Vista lateral, x 250, $50 \mu \mathrm{m} ; 10$ - Vista lateral oblíqua mostrando junção de costelas longitudinais, x 300, $50 \mu \mathrm{m}$.

11- 14- Quinqueloculina subpoeyana ?. 11- Vista lateral, x 140, $100 \mu \mathrm{m} ; 12$ - Vista lateral oblíqua e apertural com dentes laterais simples e muito pequenos, x 140, 100 $\mu \mathrm{m} ; 13$ - Vista lateral, x 200, $50 \mu \mathrm{m}$; 14- Vista apertural e periférica, x 200, 50 $\mu \mathrm{m}$.

15-16 - Quinqueloculina poeyana. 15- Vista apertural e periférica com dente simples, $350,50 \mu \mathrm{m}$; 16- Vista lateral mostrando junção de costelas longitudinais $350,50 \mu \mathrm{m}$.

17-18 - Miliolina sidebottomi. 17 - Vista lateral, com lábio de base excavada e virado para fora. Notar estrias irregulares e espessas x 200, $100 \mu \mathrm{m}$; 18- Vista apertural com lábio espesso e dente cilíndrico curto, x 350, $50 \mu \mathrm{m}$.

19- 20 - Triloculina webbiana. 19 - Vista terminal oblíqua de exemplar com última câmara quebrada, observar dente quadrado com duas dobras na extremidade, x 200, $50 \mu \mathrm{m} ; 20$ - Vista lateral mostrando saliência do dente, x 160, $100 \mu \mathrm{m}$. 

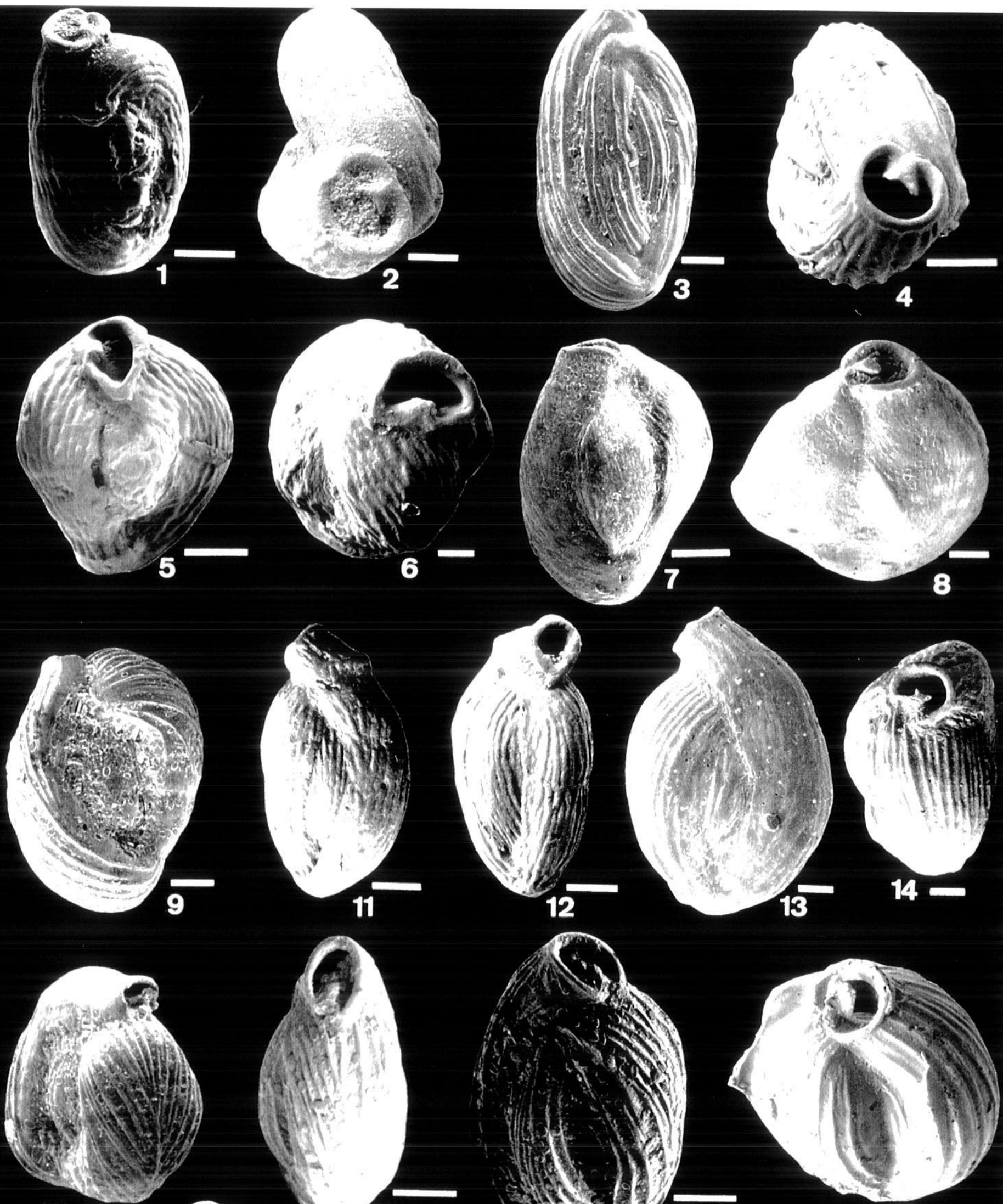

10

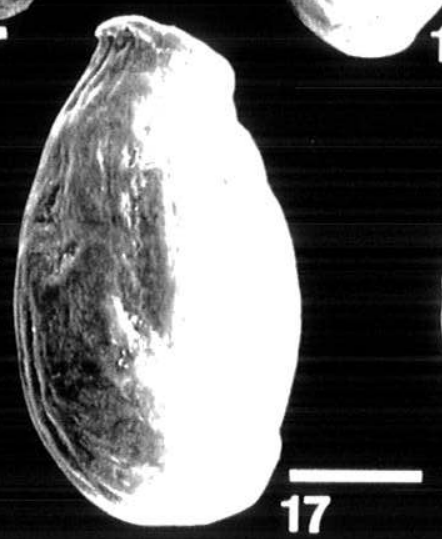

15
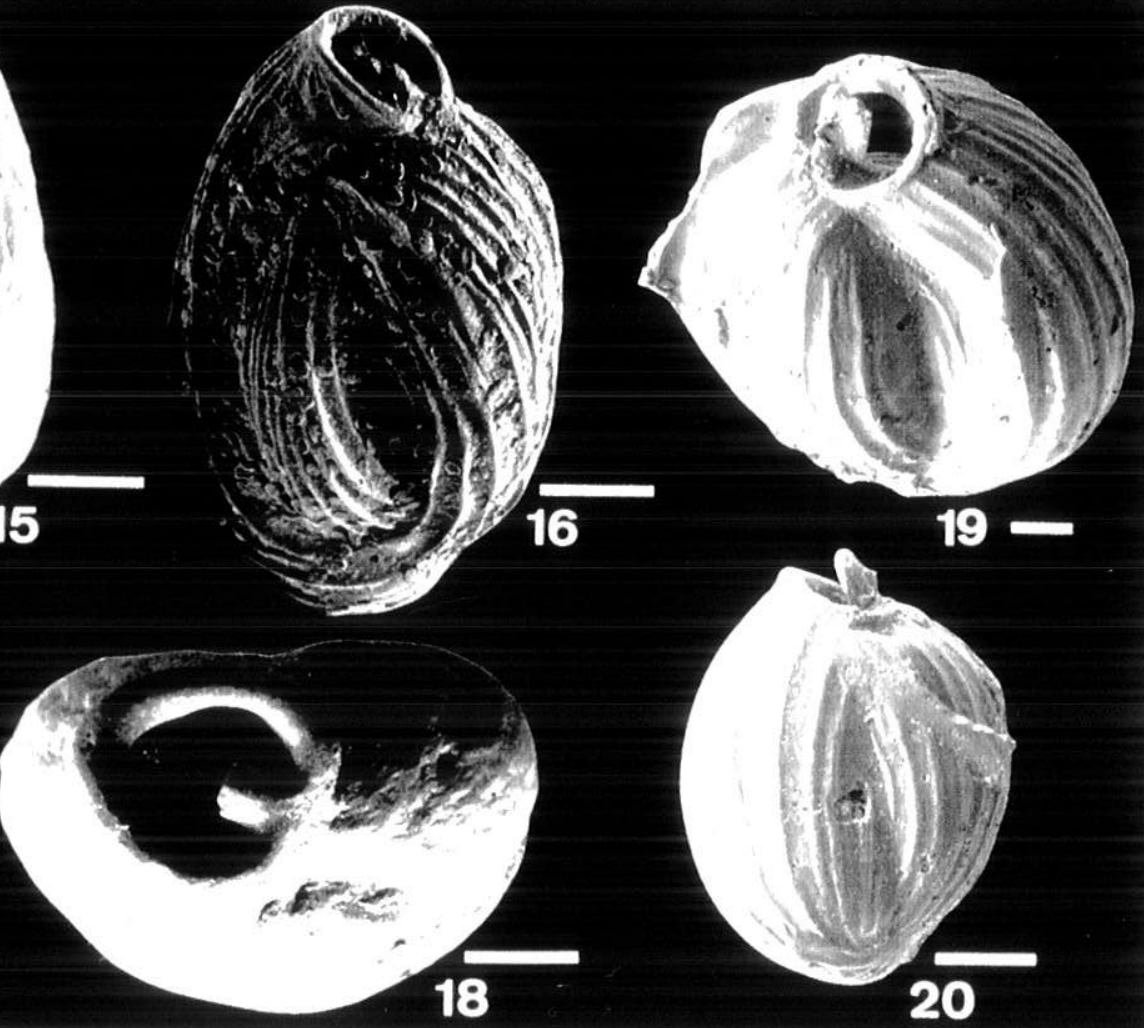


\section{Estampa 6}

1-4 - Affinetrina cf. incisura. 1- Vista apertural, x 600, $20 \mu \mathrm{m}$; 2- Vista lateral, x 460, $20 \mu \mathrm{m}$; 3- Vista apertural mostrando dente magno em forma de barra, quase preenchendo a abertura comprimida, x 300, $50 \mu \mathrm{m}$; 4- Vista lateral, notar projeção arqueada do dente acompanhando o contorno apical da teca, x 220, $50 \mu \mathrm{m}$.

5 - Affinetrina concisa. Vista lateral, x 330, $50 \mu \mathrm{m}$.

6-8 - Affinetrina sommeri. 6 - Vista lateral oblíqua, x 400, $20 \mu \mathrm{m}$; 7- Vista lateral, observar delaminação da parede na base da última câmara, x 370, $100 \mu \mathrm{m} ; 8$ - Vista

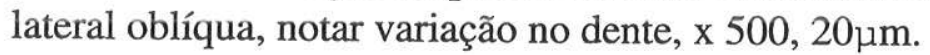

9-12- Miliolina sp. A. 9- Vista lateral, x 430, $20 \mu \mathrm{m}$; 10- Vista terminal, mostrando quatro câmaras aparentes e dente em forma de barra, x 430, $20 \mu \mathrm{m}$; 11- Vista lateral oblíqua, x 330, $100 \mu \mathrm{m} ;$ 12- Vista terminal, mostrando arranjo em planos diferenciados, $\mathrm{x} 450,20 \mu \mathrm{m}$.

13-14- Cribromiliolinella sp. indet. 13- Vista lateral oblíqua com "flap" miliolinellina e foramen, x 250, $50 \mu \mathrm{m}$; 14- Vista terminal, x 250, $50 \mu \mathrm{m}$

15-16 - Affinetrina sp. A. 15- Vista lateral oblíqua e abertura com dente oval, x 350, $50 \mu \mathrm{m} ; 16$ - Vista apertural, de teca colonizada por diatomáceas psamíticas móveis, notar estágio inicial de dissolução, x 350, $50 \mu \mathrm{m}$. 

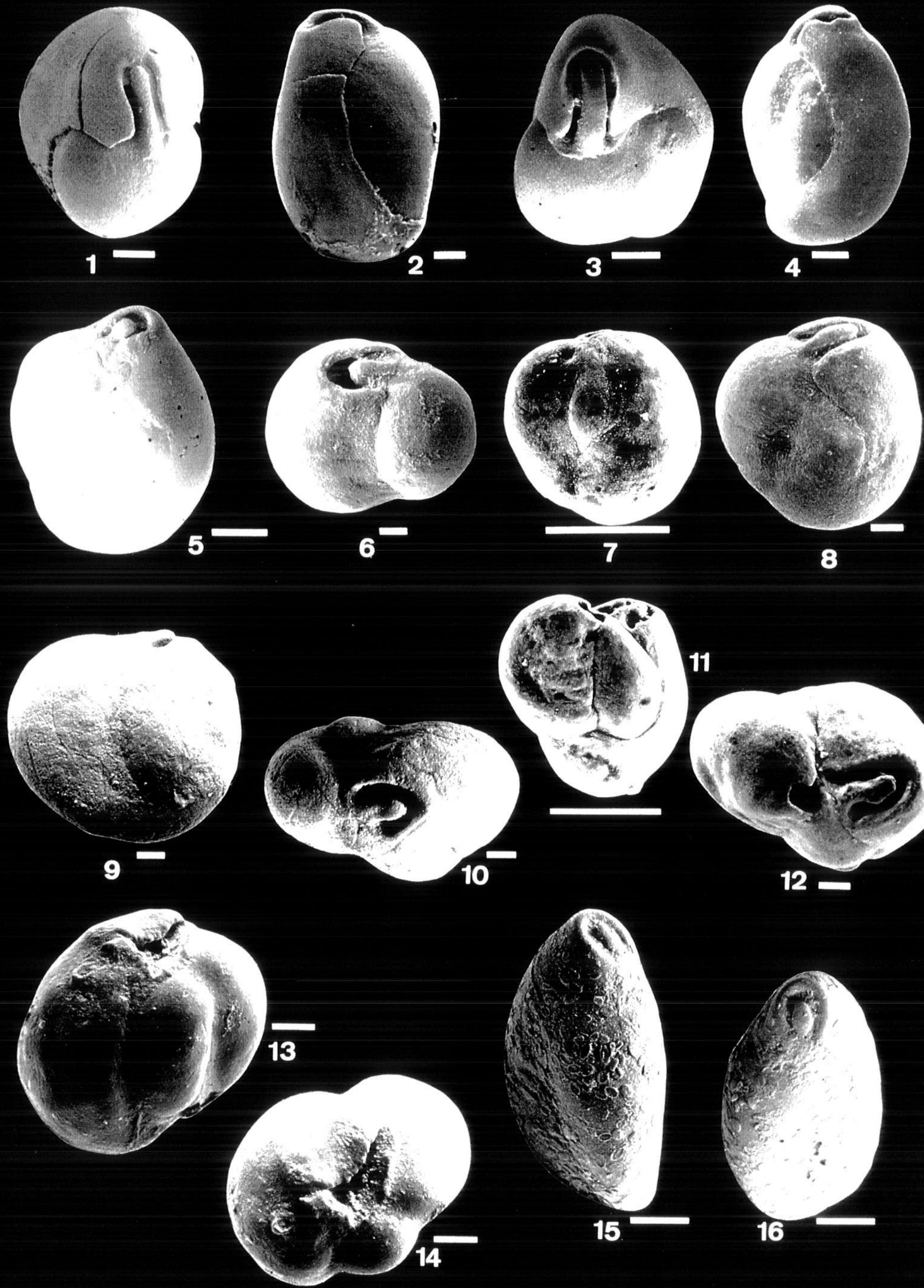

11
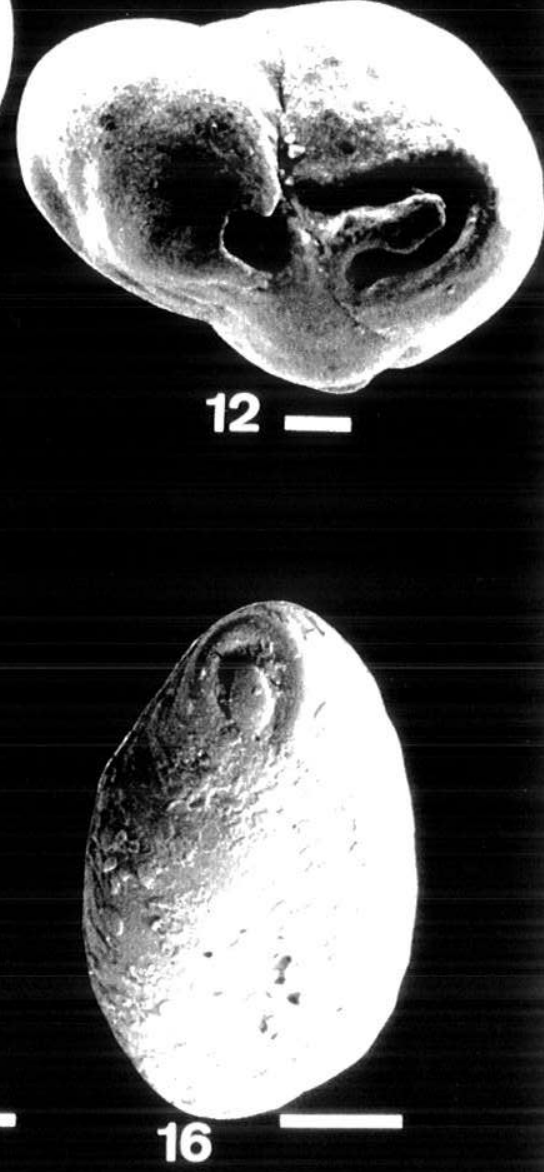


\section{Estampa 7}

1-2- Miliolinella cf. williamsoni. 1- Vista terminal oblíqua e abertura. Notar flap (fl), x 500, $20 \mu \mathrm{m} ; 2$ - Vista lateral, x 500, $20 \mu \mathrm{m}$.

3-4 - Miliolinella subrotunda. 3- Vista terminal oblíqua com abertura alongada, lábio peristomal e dente simples e curto, "carena" inserta, x 200, $50 \mu \mathrm{m}$; 4- Vista lateral, x $170,100 \mu \mathrm{m}$.

5-6- Miliolinella circularis. 5 - Vista terminal oblíqua com flap basal excavado, $\mathrm{x}$ 360, $50 \mu \mathrm{m} ; 6$ - Vista lateral, x 310, $50 \mu \mathrm{m}$.

7-8 - Miliolinella sp. B. 7- Vista apertural, x 200, $50 \mu \mathrm{m} ; 8$ - Vista lateral, x 200, 50 $\mu \mathrm{m}$.

9-10- Miliolinella cf. antarctica. 9 - Vista lateral, x 400, $20 \mu \mathrm{m} ; 10$ - Vista lateral e apertural, x 350, $50 \mu \mathrm{m}$.

11-13- Miliolinella loeblichi. 11- Vista lateral oblíqua e abertura, x 230, $50 \mu \mathrm{m} ; 12$ Vista lateral e periférica mostrando estrias (E) na borda periférica da última câmara, $\mathrm{x}$ 230, $50 \mu \mathrm{m}$; 13- Vista periférica oblíqua, mostrando estrias, abrangência da última câmara e abertura suplementar (também ilustrada na estampa 21 [7-8]), x 220, $50 \mu \mathrm{m}$.

14-15 - Miliolinella sp. A. 14- Vista lateral, notar suturas sinuosas x 250, $50 \mu \mathrm{m} ; 15$ Vista apertural, x 280, $50 \mu \mathrm{m}$.

16-17- Miliolinella sp. C . 16- Vista apertural mostrando enrolamento final planoespiral e placa dental de mesmo formato da abertura, x 200, $50 \mu \mathrm{m} ; 17$ - Vista lateral mostrando sinuosidade das suturas, $\mathrm{x} 170,100 \mu \mathrm{m}$.

18- Neopateoris cf. $N$. cumanaensis. Vista lateral e apertural com dente simples e pequeno, x 360, $50 \mu \mathrm{m}$.

19- Neopateoris sp. A. Vista apertural oblíqua mostrando "pallets" dando aparência estriada a parede da teca e dente bipartido, x 300, 50 um. 

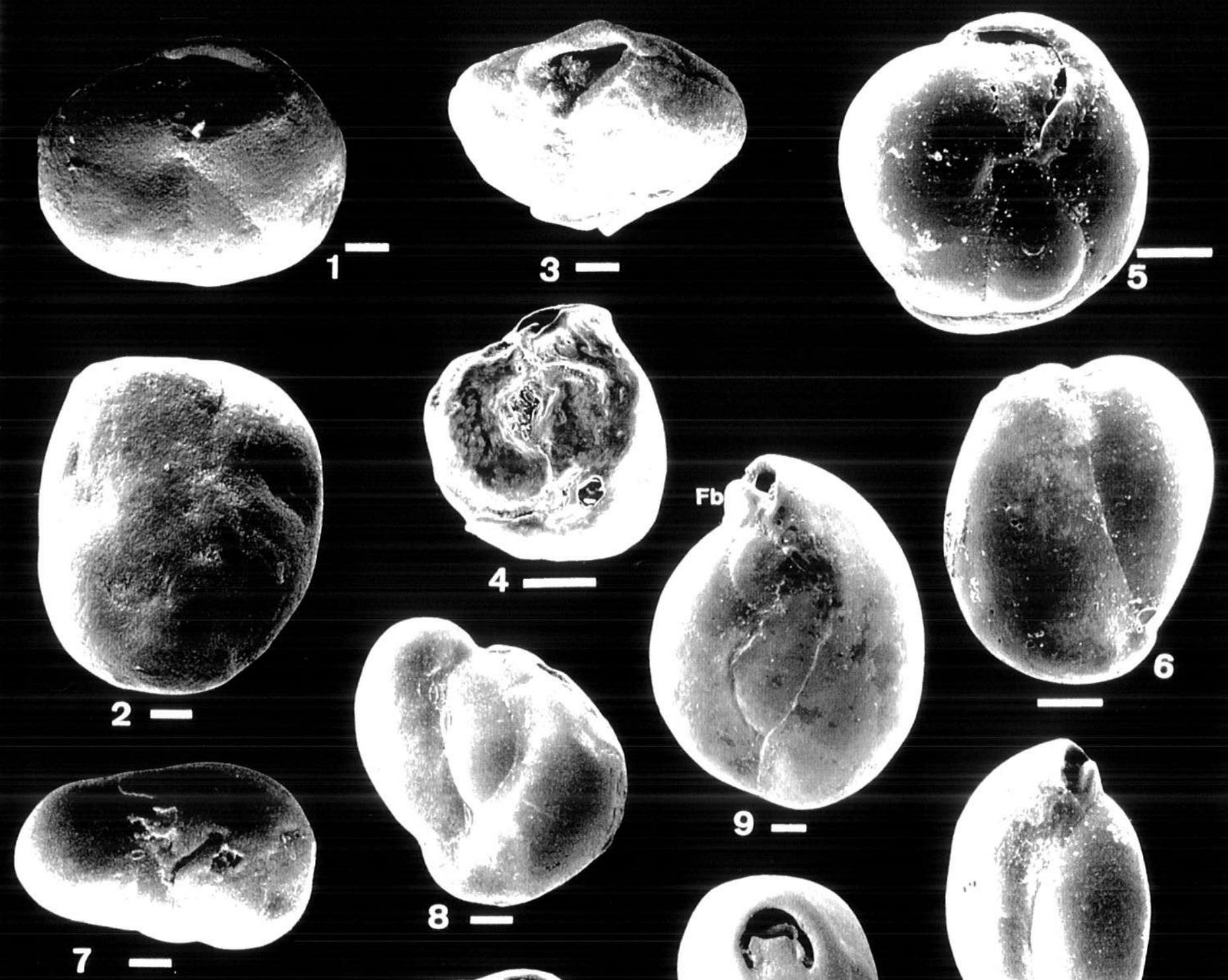


\section{Estampa 8}

1-2- Triloculina lutea. 1- Vista lateral, notar abrangência aboral da última câmara, $\mathrm{x}$ $300,50 \mu \mathrm{m} ; 2$ - Vista terminal com dente bipartido abaixo da placa carbonática, x 500, $20 \mu \mathrm{m}$.

3-4- Triloculina cf. nitida. 3- Vista lateral oblíqua e apertural, x 370, $50 \mu \mathrm{m}$; 4- Vista lateral, x 270, $100 \mu \mathrm{m}$.

5-8 - Miliolinella sp. D. 5- Vista lateral oblíqua, x 400, $20 \mu \mathrm{m} ; 6$ - Vista lateral, x 300, $50 \mu \mathrm{m} ; 7$ - Vista lateral oblíqua, x 230, $50 \mu \mathrm{m} ; 8$ - Vista terminal apertural, x 380, 50 $\mu \mathrm{m}$;

9-16 - Pseudotriloculina lecalvezae. 9- Vista lateral, x 200, $50 \mu \mathrm{m} ; 10$ - Vista lateral, x 230, 50 $\mu \mathrm{m}$; 11- Vista terminal oblíqua, x 380, $50 \mu \mathrm{m}$; 12- Vista lateral, x 230, $50 \mu \mathrm{m}$;

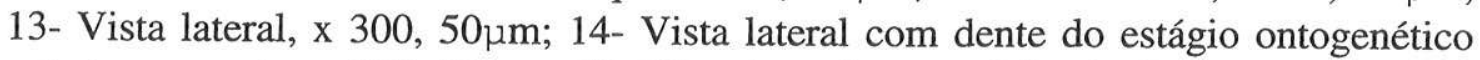
anterior aparente, x 250, $50 \mu \mathrm{m} ; 15$ - Vista lateral com evidência da câmara quebrada na porção aboral, x 250, $50 \mu \mathrm{m}$; 16- Vista lateral de exemplar com última câmara quebrada mostrando último dente e do estágio ontogenético prévio, x 240, $50 \mu \mathrm{m}$.

17- Triloculina gracilis. Vista lateral oblíqua e apertural, x 230, $50 \mu \mathrm{m}$

18-21- Pseudotriloculina subgranulata. 18- Vista terminal oblíqua, x 200, $50 \mu \mathrm{m}$; 19 Vista lateral com quarta câmara indistinta, x 200, 50um; 20- Vista lateral com dente bipartido-planar discreto e quarta câmara quase indistinta, x 240, $50 \mu \mathrm{m} ; 21$ - Vista lateral, x 220, $50 \mu \mathrm{m}$. 

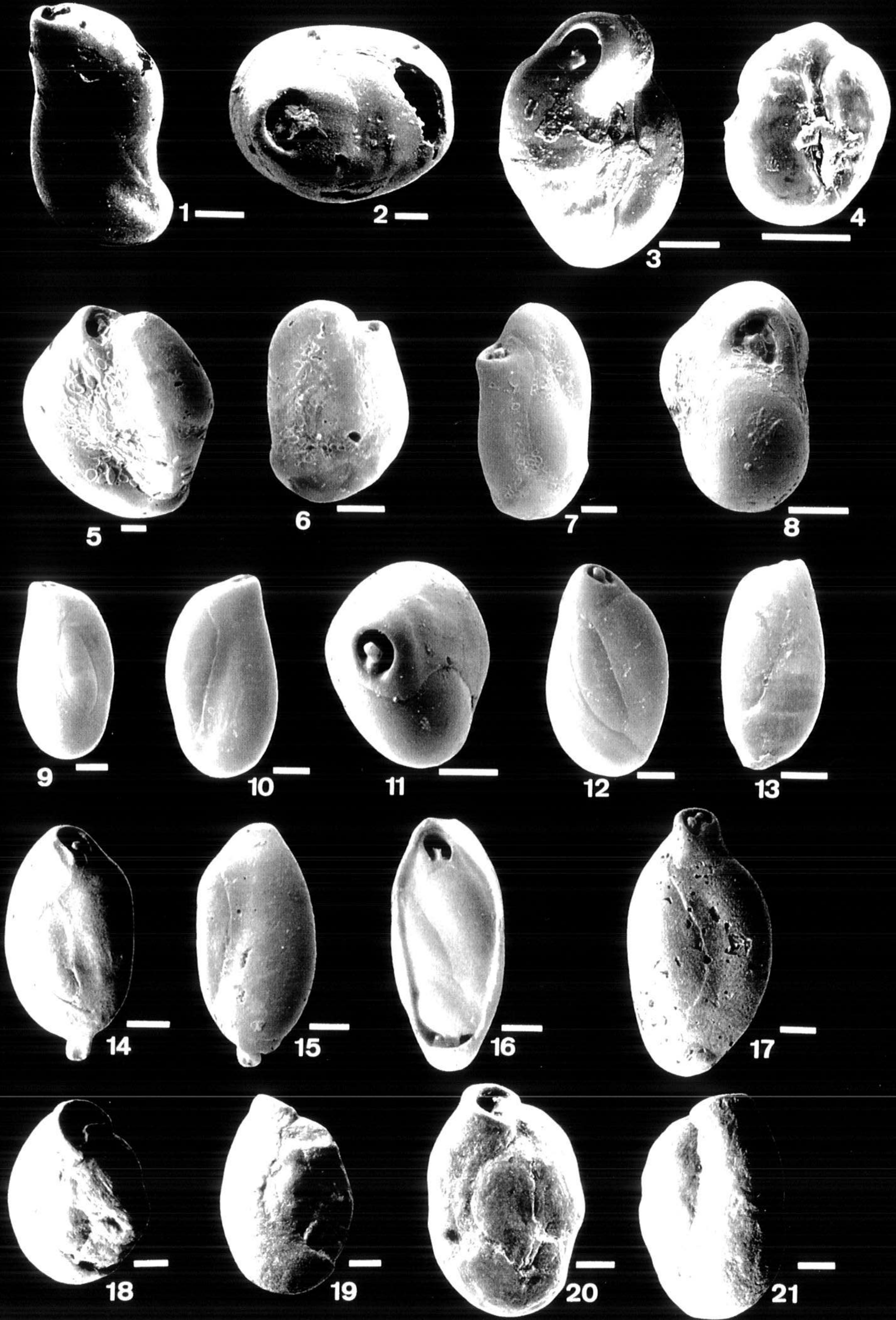


\section{Estampa 9}

1-6 - Varidentella implexa. 1- Vista periférica, x 400, $20 \mu \mathrm{m} ; 2$ - Vista terminal e apertural mostrando dentes simples projetados da parede lateral da abertura, x 450, 20 um; 3 - Vista terminal mostrando última câmara posicionada na porção lateral, x 380 ,

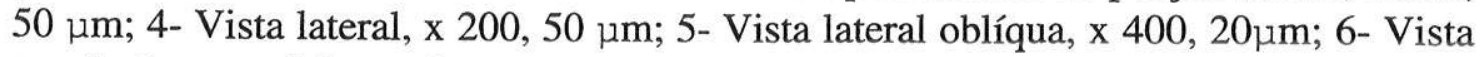
terminal com última câmara na porção lateral diminuindo em diâmetro para a abertura, x 650, $20 \mu \mathrm{m}$.

7- Varidentella implexa subsp. A. Vista lateral de exemplar bioturbado, com teca gibosa de aparência áspera x 180, $100 \mu \mathrm{m}$.

8-9- Varidentella sp. A. 8- Vista lateral, x 270, $50 \mu \mathrm{m}$; 9- Vista lateral oblíqua com abertura sem dente, $\mathrm{x} 240,50 \mu \mathrm{m}$.

10-11-Varidentella sp. B. 10- Vista lateral oblíqua de exemplar bioturbado, x 380, 50 $\mu \mathrm{m}$;

11-Vista periférica e apertural sem dente, x 500, $20 \mu \mathrm{m}$.

12-13 - Varidentella sp. C. 12- Vista lateral da teca rugosa, x 130, 100 $\mathrm{m}$; 13- Vista terminal oblíqua, notar parede lateral da abertura com dente simples que se alonga para o interior da teca, x 170, $100 \mu \mathrm{m}$;

14- Fissurina compressa. Vista apertural oblíqua, x 800, 20um.

15- Fissurina lucida. Vista apertural, x 650, $20 \mu \mathrm{m}$.

16 - Fissurina sp. A. Vista lateral, x 700, $20 \mu \mathrm{m}$. 

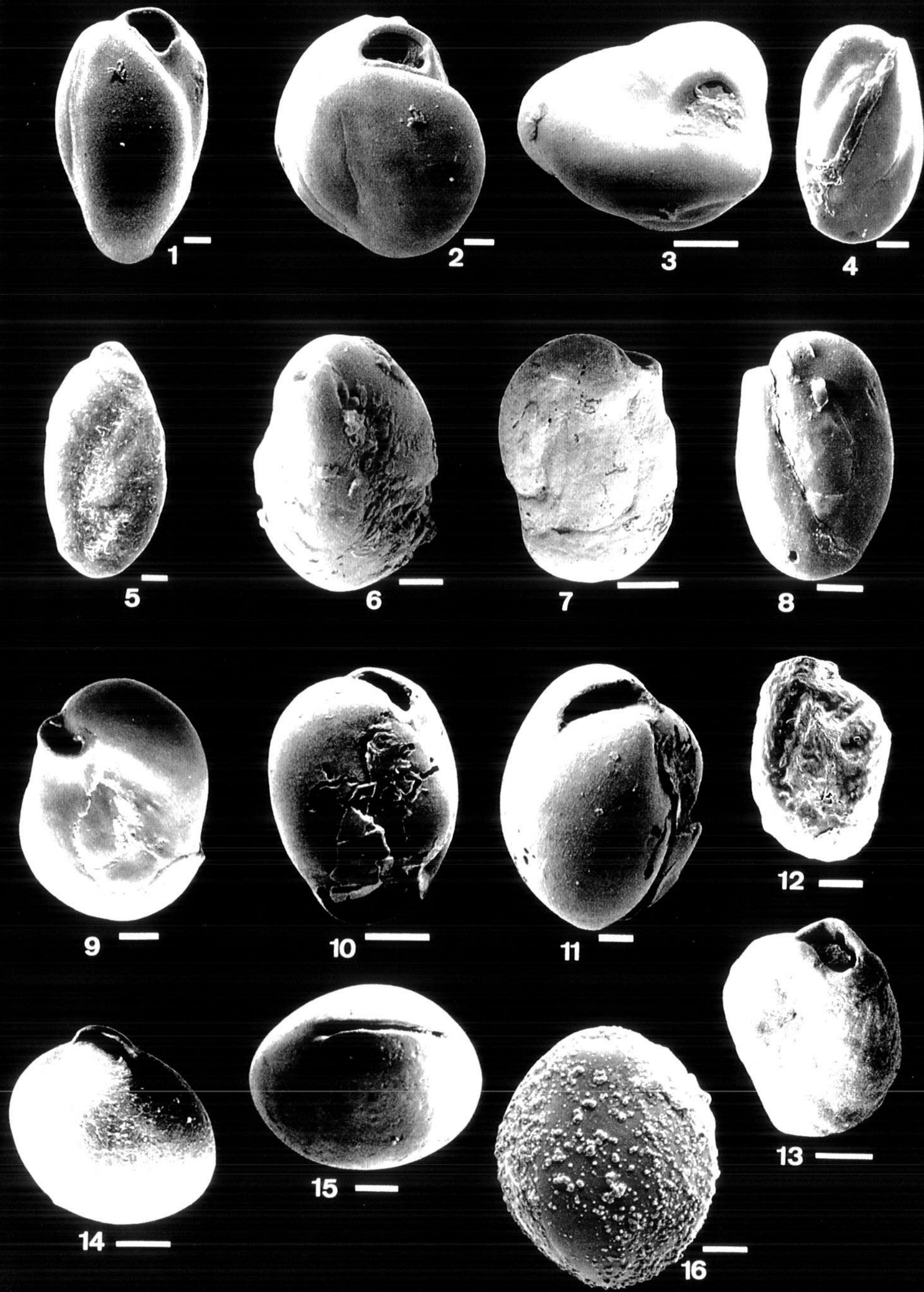


\section{Estampa 10}

1- Bolivina doniezi. Vista lateral x 250, $100 \mu \mathrm{m}$.

2-6- Bolivina lepida. 2- Vista lateral, x 330, $100 \mu \mathrm{m}$; 3- Vista apertural oblíqua, x 400, $20 \mu \mathrm{m}$; 4- Vista lateral, x 450, $10 \mu \mathrm{m}$; 5- Vista apertural oblíqua, x 600, $20 \mu \mathrm{m}$; 6Vista lateral oblíqua de exemplar comprimido, x 500, $20 \mu \mathrm{m}$.

7 - 9- Bolivina aff. lepida. 7- Vista lateral, x 250, $100 \mu \mathrm{m} ; 8$ - Vista lateral de exemplar com ornamentação mais intensificada, x 220, $100 \mu \mathrm{m}$; 9 - Vista da abertura na câmara precedente, x 200, $50 \mu \mathrm{m}$.

10-19 - Bolivina sliteri. 10- Vista lateral, x 350, $100 \mu \mathrm{m}$; 11- Vista lateral periférica, x 450, $10 \mu \mathrm{m} ; 12$ - Vista lateral, x 300, $100 \mu \mathrm{m} ; 13$ - Vista apertural-periférica de exemplar com abertura arredondada, x 300, $50 \mu \mathrm{m} ; 14$ - Vista lateral, x 230, $100 \mu \mathrm{m}$; 15 - Vista apertural de exemplar com abertura comprimida, x 200, $50 \mu \mathrm{m} ; 16$ - Vista apertural-periférica, x 370, $50 \mu \mathrm{m} ; 17$ - Vista lateral, x 400, $10 \mu \mathrm{m} ; 18$ - Vista lateral, x 300, $100 \mu \mathrm{m} ; 19$ - Vista apertural oblíqua, x 400, $20 \mu \mathrm{m}$.

20 - Bolivina sliteri subsp. asperoides. Vista lateral, x 200, $100 \mu \mathrm{m}$. 


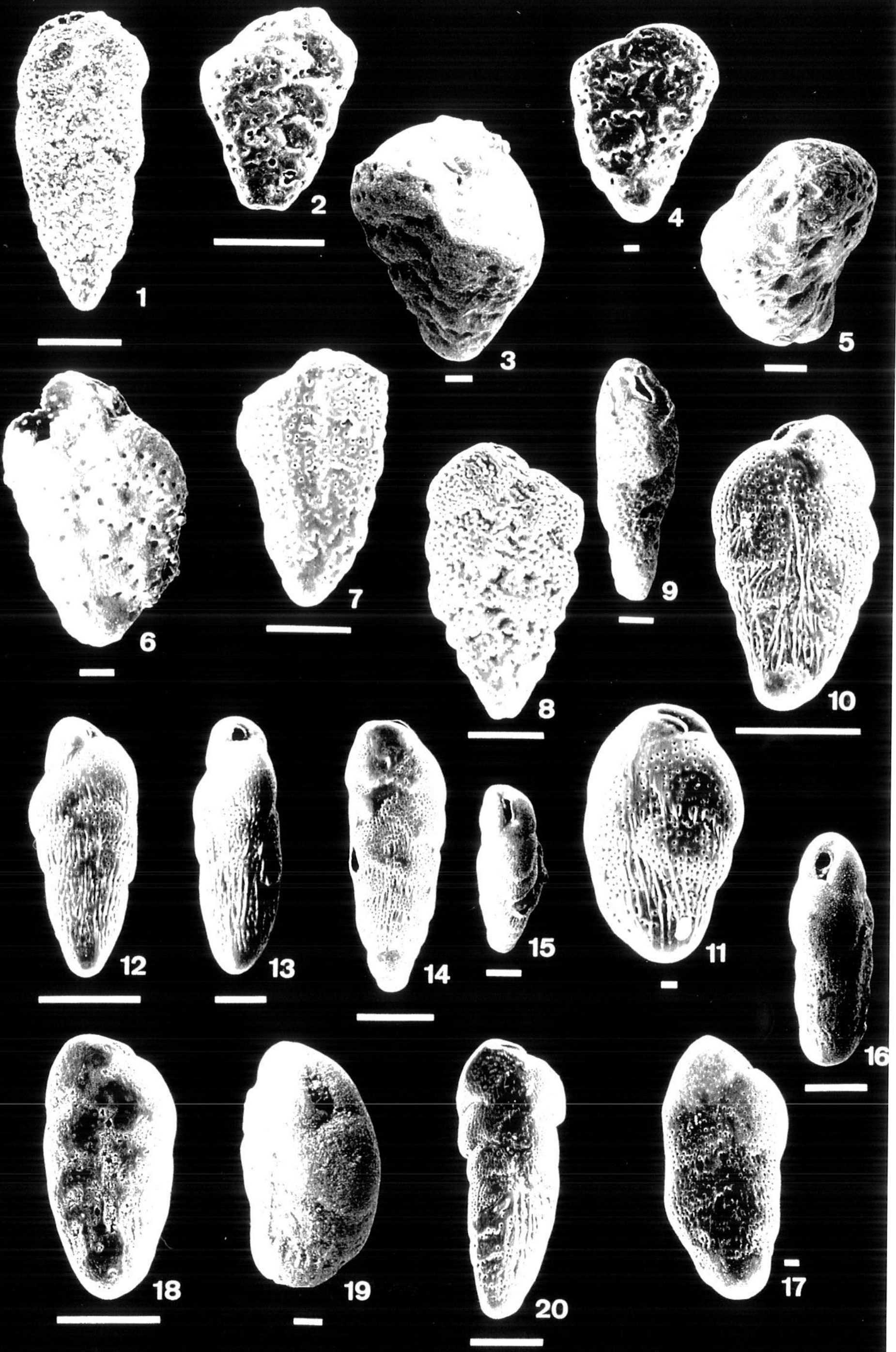




\section{Estampa 11}

1- Bolivina striatula. 1- Vista lateral e da abertura de exemplar inflado, x 260, $50 \mu \mathrm{m}$

2 - 6 - Bolivina striatula? 2- Vista lateral de exemplar comprimido, x 330, $50 \mu \mathrm{m} ; 3$

- Vista lateral do mesmo exemplar comprimido mostrando detalhe das suturas limbadas e estrias avançando sobre câmaras e suturas, x 410, $20 \mu \mathrm{m} ; 4$ - Vista apertural mostrando lábio, duas placas dentais e depressão adapertural, x 700, $20 \mu \mathrm{m}$; 5 - Vista lateral de exemplar comprimido fóssil, x 500, $20 \mu \mathrm{m} ; 6$ - Vista lateral, x 410, $20 \mu \mathrm{m}$.

7 - 11, 16 - 17 Bolivina sublittoralis. 7 - Vista lateral oblíqua de exemplar jovem, x 500, $20 \mu \mathrm{m} ; 8$ - Vista lateral. Notar que estrias são restritas as suturas e não avançam sobre as câmaras x 480, $20 \mu \mathrm{m} ; 9$ - Vista apertural. Notar placa dental serrilhada, depressão adapertural e borda periférica proeminente, x 500, $20 \mu \mathrm{m} ; 10$ - Vista periférica oblíqua de exemplar adulto de geração macrosférica assexuada, x 360, 50 $\mu \mathrm{m} ; 11$ - Vista lateral, x 350, $100 \mu \mathrm{m}$. 16- Vista lateral de exemplar com suturas limbadas deprimidas e ausência de definição das câmaras iniciais, x 460, 20 um; 17 Vista lateral oblíqua, x 360, $50 \mu \mathrm{m}$.

12 -13 - Bolivina variabilis. 12- Vista lateral. Notar ausência de ornamentação ao longo do eixo central da teca, x 460, $20 \mu \mathrm{m} ; 13$ - Vista da abertura com lábio, placa dental e depressão adapertural, x 750, $20 \mu \mathrm{m}$.

14 - 15 - Bolivina sp. A. 14 - Vista lateral, x 300, $100 \mu \mathrm{m} ; 15$ - Vista periféricaapertural com lábio circundante, x 400, 20 um.

18 - 20 - Bolivina sp. B. 18 - Vista lateral, x 480, $20 \mu \mathrm{m} ; 19-$ Vista apertural, x 750, $20 \mu \mathrm{m}$;

20 - Vista lateral de exemplar mais inflado, x 370, $50 \mu \mathrm{m}$.

21-Bolivina sp. C. Vista lateral de exemplar quebrado, x 160, $100 \mu \mathrm{m}$.

22 - 23 - Brizalina sp. A. 22 - Vista lateral, x 220, $50 \mu \mathrm{m} ; 23$ - Vista apertural oblíqua. Notar periferia carenada e abertura com borda espessa e duas placas dentais, x 330, $100 \mu \mathrm{m}$. 

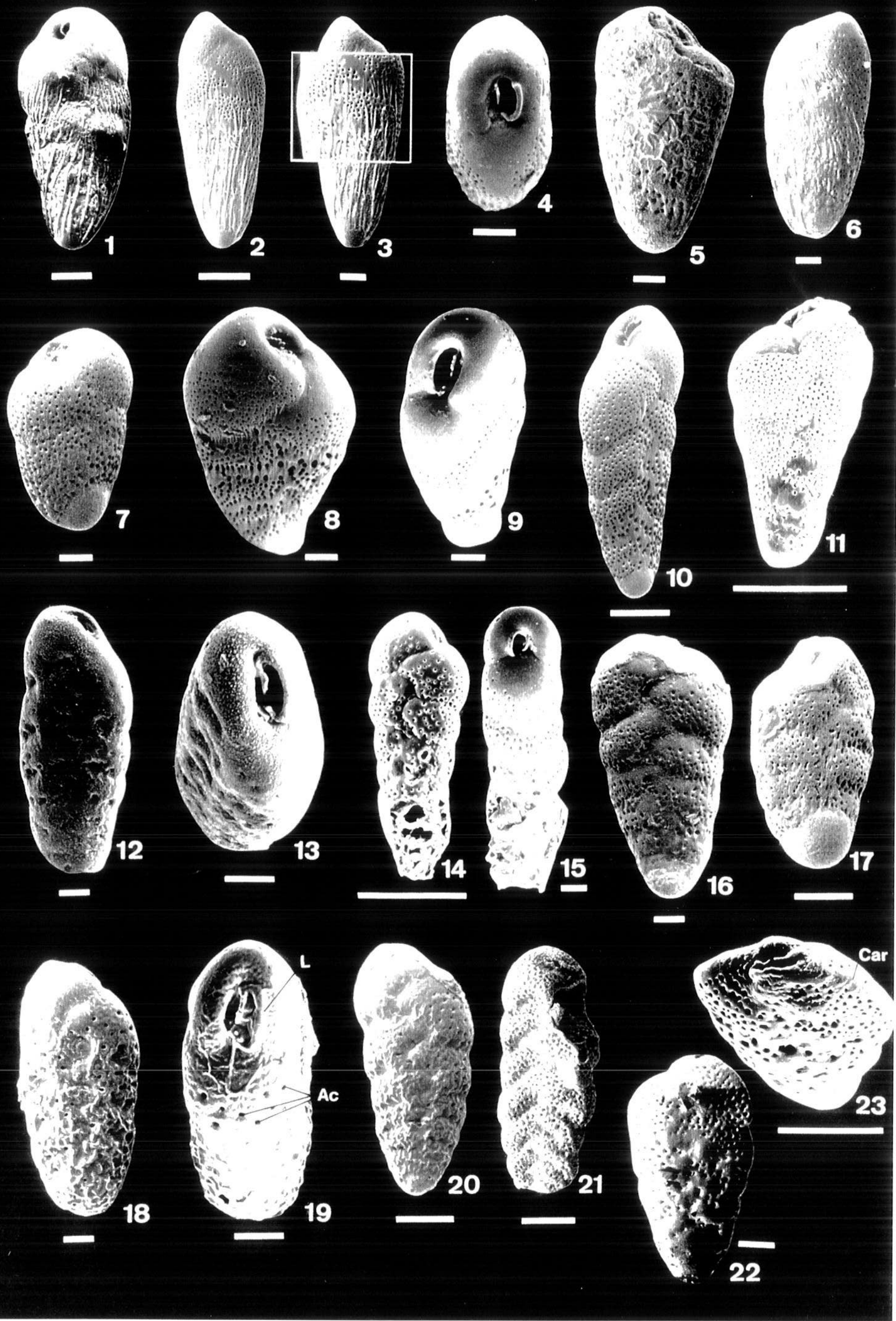


\section{Estampa 12}

1 - 2 - Abditodentrix rhomboidalis. 1 - Vista lateral, x 200, $50 \mu \mathrm{m} ; 2$ - Vista periférica e abertura precedente. Notar aspecto rombóide das câmaras, x 200, $50 \mu \mathrm{m}$.

3 - 6 - Abditodentrix subexcavata. 3 - Vista lateral, x 430, $10 \mu \mathrm{m} ; 4$ - Vista apertural. Notar ornamentação da face apertural se estendendo para o lábio e placas dentais, $\mathrm{x}$ 675, $20 \mu \mathrm{m} ; 5$ - Vista lateral oblíqua, x 320, $50 \mu \mathrm{m} ; 6$ - Vista da face apertural precedente, x 390, $20 \mu \mathrm{m}$.

7 - 12 - Abditodentrix cf. subexcavata. 7 - Vista lateral, x 440, $20 \mu \mathrm{m} ; 8$ - Vista apertural oblíqua, x 350, $50 \mu \mathrm{m}$; 9 - Vista lateral oblíqua, x 600, $20 \mu \mathrm{m} ; 10$ - Vista apertural, x 650, $20 \mu \mathrm{m} ; 11$ - Vista lateral, x 300, $50 \mu \mathrm{m} ; 12$ - Vista apertural, x 500, $20 \mu \mathrm{m}$.

13 - Cassidelina cf. spinescens. Vista periférica oblíqua. Notar abertura com lábio e placa dental e ornamentação de estrias na base das câmaras inferiores, x 240, $50 \mu \mathrm{m}$.

14 - Globocassidulina subglobosa. Vista apertural oblíqua, notar variação entre borda distal ( com padrão poligonal) e terminação proximal (com duas placas dentais), $\mathrm{x}$ $600,20 \mu \mathrm{m}$.

15 - 16 - Virgulopsoides sp. indet. 15 - Vista lateral, notar torção da teca x 280, 50 $\mu \mathrm{m} ; 16$ - Vista apertural oblíqua com grande depressão adapertural (ad), placa dental (p) e lábio (1), x 500, $20 \mu \mathrm{m}$.

17 - Loxostomina sp. A. Vista lateral, x 250, $50 \mu \mathrm{m}$.

18 - 21 - Loxostomina sp. B. Vista lateral, x 185, $100 \mu \mathrm{m} ; 19$ - Vista periférica apertural, x 200, $50 \mu \mathrm{m} ; 20$ - Vista lateral, x 160, $100 \mu \mathrm{m} ; 21$ - Vista apertural mostrando peristoma espesso e placa dental, x 350, $50 \mu \mathrm{m}$.

22 - Buliminella elegantissima. Vista apertural-lateral, x 600, $10 \mu \mathrm{m}$.

23 - 24 - Floresina seminuda. 23 - Vista apertural-lateral mostrando "grooves" radiais e placa plastogamica em exemplar bioturbado, x 320, $50 \mu \mathrm{m} ; 24$ - Vista lateral de exemplar corroído, x 450, $20 \mu \mathrm{m}$. 


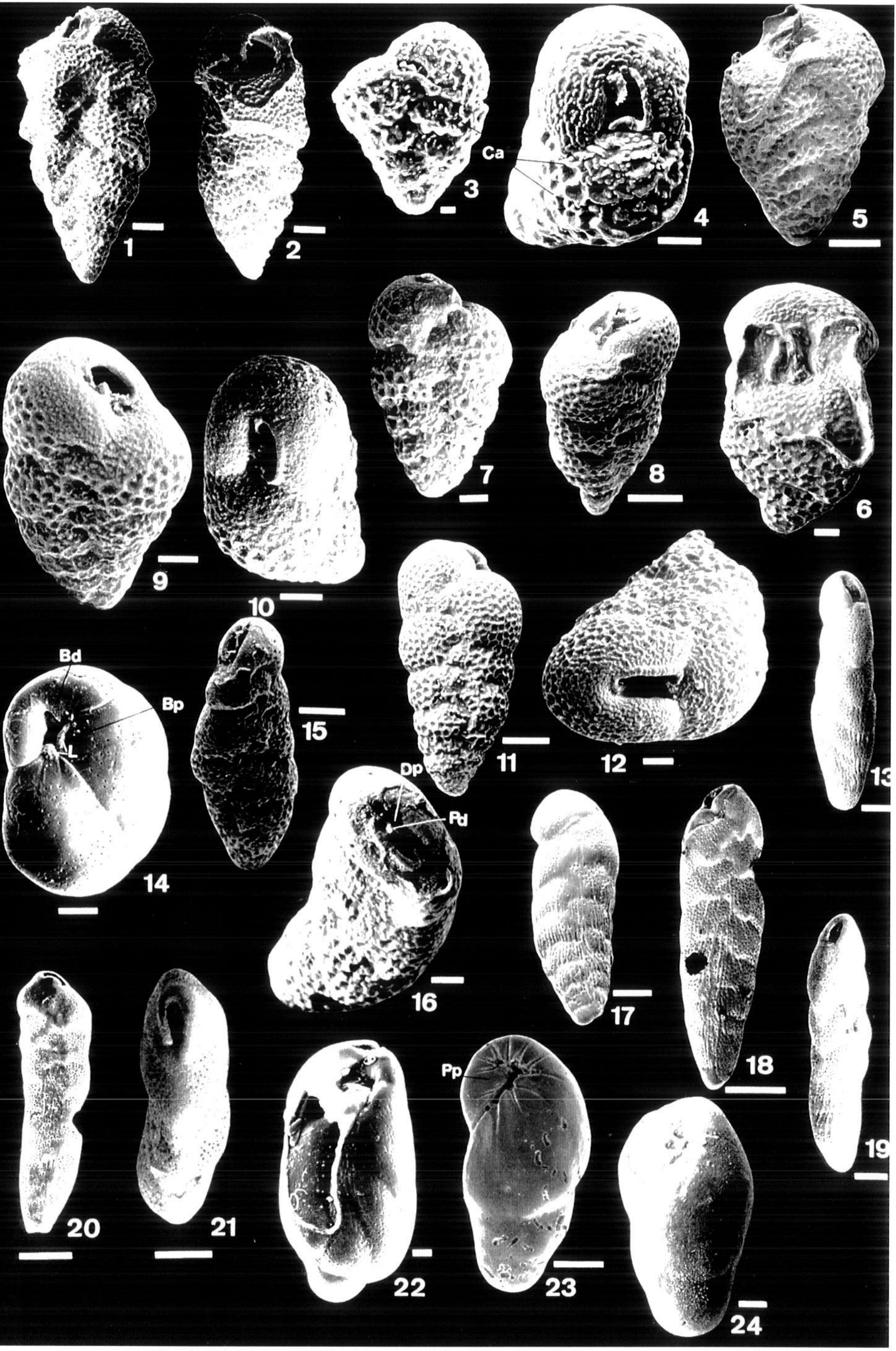




\section{Estampa 13}

1 - 2 - Disconorbis williamsoni. 1 - Vista espiral, x 500, $20 \mu \mathrm{m} ; 2$ - Lado umbilical, x 500, $20 \mu \mathrm{m}$.

3 - 13 - Orbitina sp. 3 - Vista espiral, x 675, $20 \mu \mathrm{m} ; 4$ - Vista periférica, x 675, 20 $\mu \mathrm{m} ; 5$ - Lado umbilical, x 750, $20 \mu \mathrm{m} ; 6$ - Vista espiral, x 430, $10 \mu \mathrm{m} ; 7$ - Lado umbilical, x 550, $20 \mu \mathrm{m} ; 8$ - Lado espiral, x 550, $20 \mu \mathrm{m} ; 9$ - Läđo umbilical de indivíduo com septum quebrado mostrando estrutura interna, x 550, $20 \mu \mathrm{m}$; 10 - Lado espiral, x 500, $20 \mu \mathrm{m} ; 11$ - Lado umbilical. Notar presença de poros, x 500, $20 \mu \mathrm{m} ; 12$ - Lado espiral de indivíduo corroído e com poucos poros, x 750, $20 \mu \mathrm{m} ; 13$ - Lado umbilical, x 750, $20 \mu \mathrm{m}$.

14 - 15 - Rosalina candeiana. 14 - Vista espiral, x 500, $20 \mu \mathrm{m}$; 15 - Vista umbilical, x 500, $20 \mu \mathrm{m}$.

16 - 17 - Rosalina floridana. 16 - Vista espiral, x 420, $20 \mu \mathrm{m} ; 17$ - Vista umbilical, x 400, $20 \mu \mathrm{m}$.

18 - 20 - Rosalina globularis. 18 - Vista espiral, x 280, $50 \mu \mathrm{m} ; 19$ - Vista de perfil mostrando abertura (a) e folium (fo), x 280, $50 \mu \mathrm{m} ; 20$ - Vista espiral, x 250, $50 \mu \mathrm{m}$. 

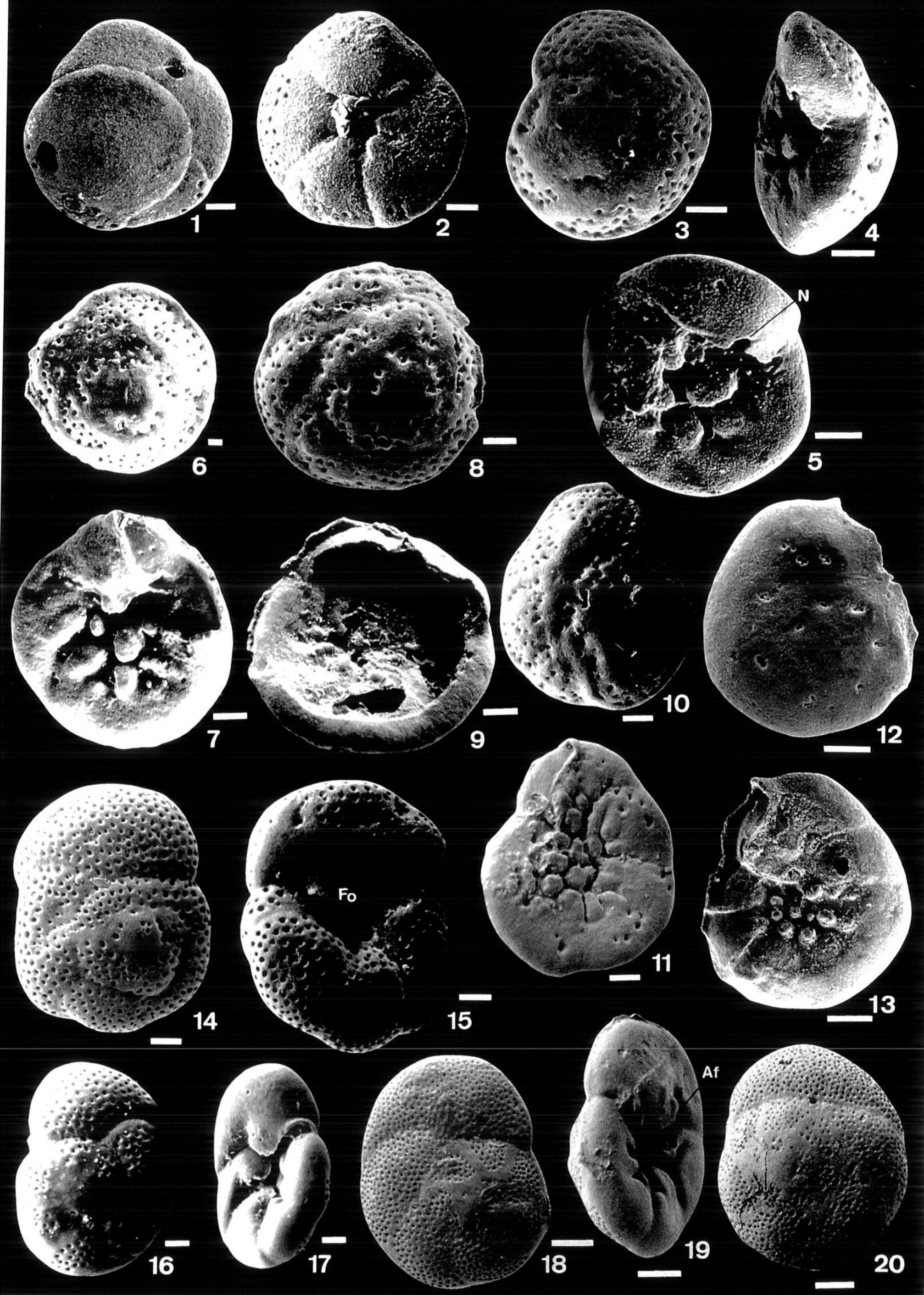

15

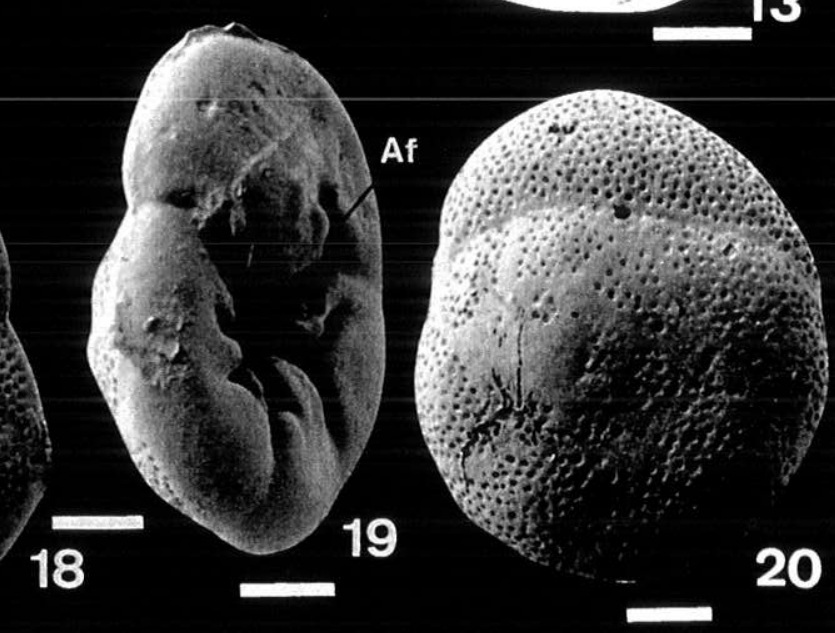




\section{Estampa 14}

1 - 3 - Glabratellina cf. turriformis. 1 - Vista espiral. Notar problema com metalização dos exemplares em 1 e 2 , com ouro formando pontes semelhantes às de ornamentação, ou cobrindo a área umbilical, x 750, $20 \mu \mathrm{m} ; 2$ - Vista umbilical oblíqua, mostrando enrolamento e suturas umbilicais radiais, x 675, $20 \mu \mathrm{m} ; 3$ - Vista

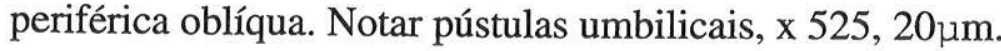

4 - 5 - Eoeponidella nanoconica. 4 - Vista espiral, x 700, $20 \mu \mathrm{m} ; 5$ - Vista umbilical, x 700, $20 \mu \mathrm{m}$.

6 - 9 - Eoeponidella sp. A. 6 - Vista dorsal com mesmo problema de metalização ocorrido em 1 e 2, x 700, $20 \mu \mathrm{m} ; 7$ - Vista umbilical, x 600, $10 \mu \mathrm{m} ; 8$ - Vista dorsal, x 650, $20 \mu \mathrm{m} ; 9$ - Vista umbilical, 725, $20 \mu \mathrm{m}$.

10 - 11 - Eoeponidella nanoconica. 10 - Vista espiral de exemplar com avançado grau de corrosão, x 500, $10 \mu \mathrm{m}$; 11- Vista umbilical, x 600, $20 \mu \mathrm{m}$.

12 - 16 - Hanzawaia sp. indet. 12 - Vista espiral, x 250, $50 \mu \mathrm{m} ; 13$ - Vista periféricaapertural, x 200, $50 \mu \mathrm{m} ; 14$ - Vista oblíqua da espiral, x 200, $50 \mu \mathrm{m} ; 15$ - Vista periférica x 200, $50 \mu \mathrm{m} ; 16$ - Vista ventral, x 200, $50 \mu \mathrm{m}$.

17 - 20 - Ammonia beccarii f. beccarii ?. 17 - Vista espiral, x 200, $50 \mu \mathrm{m} ; 18$ - Vista umbilical, x 200, $100 \mu \mathrm{m} ; 19$ - Vista oblíqua umbilical x 360, $50 \mu \mathrm{m} ; 20$ - Vista oblíqua umbilical, x 440, $20 \mu \mathrm{m}$. 

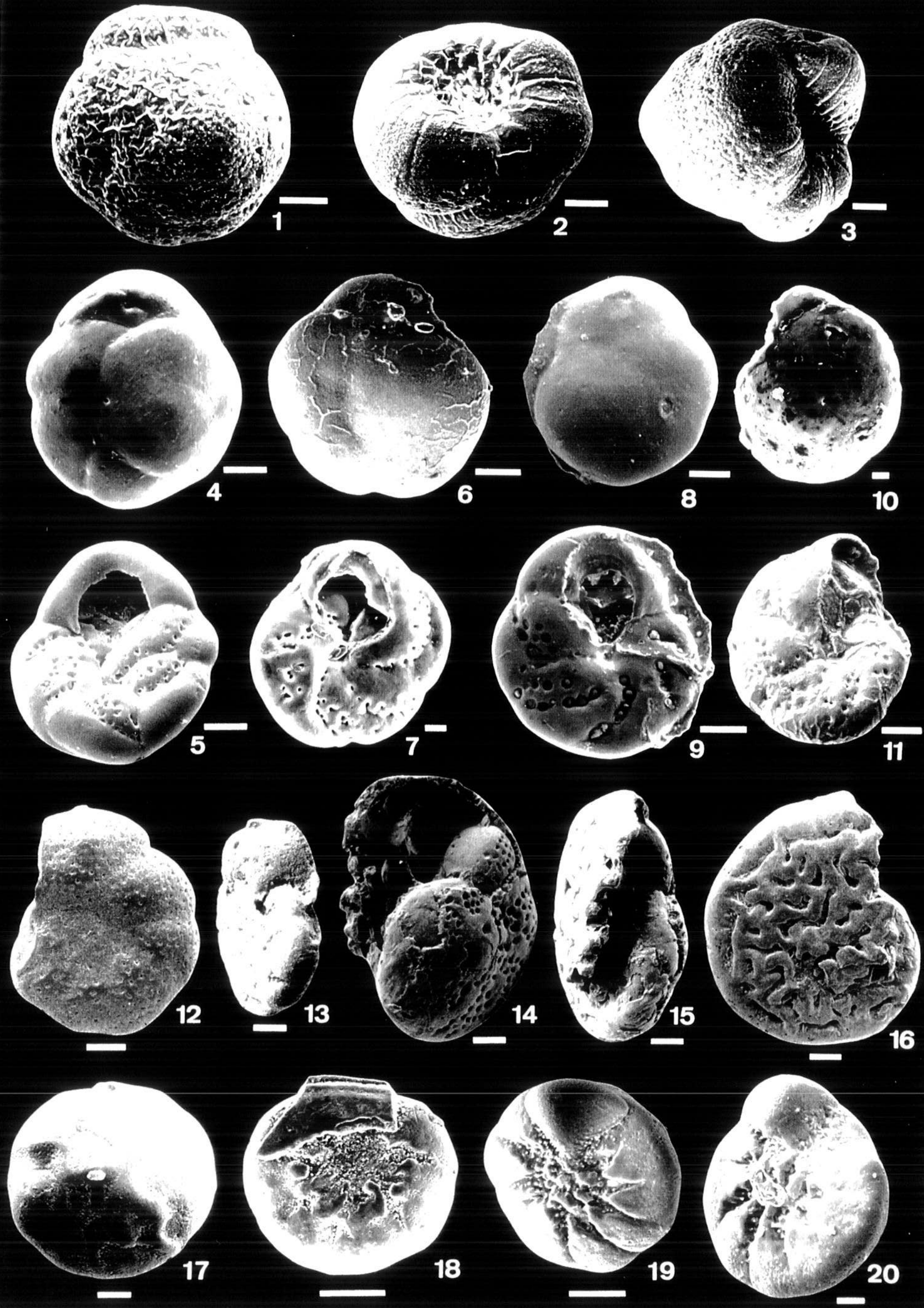


\section{Estampa 15}

1- 3 - Ammonia beccarii f. beccarii ? 1- 2 Vista umbilical e retângulo de detalhamento, x 500, $20 \mu \mathrm{m} ; 3$ - Detalhe de ornamentação da borda do folium, x 500, $20 \mu \mathrm{m}$.

4 - 13 Rotalia ? 4 - Vista espiral, x 400, $20 \mu \mathrm{m}$; 5 - Vista umbilical, x 400, $20 \mu \mathrm{m} .6$ - Vista espiral, x 300, $50 \mu \mathrm{m} ; 7$ - Vista umbilical oblíqua, x 300, $50 \mu \mathrm{m} ; 8$ - Vista de perfil, x 300, $50 \mu \mathrm{m} .9$ - Vista de perfil, x 500, $20 \mu \mathrm{m}$. 10 - Vista umbilical, x 460, 20 $\mu \mathrm{m} .11$ - Vista umbilical, x 290, $50 \mu \mathrm{m}$. 12 - Vista espiral, x 400, $20 \mu \mathrm{m}$; 13 - Vista periférica oblíqua, x 500, $20 \mu \mathrm{m}$.

14 - 20 - Ammonia beccarii f. parkinsoniana. 14 - Vista espiral, x 400, $20 \mu \mathrm{m} ; 15$ Vista umbilical, x 400, $20 \mu \mathrm{m}$; 16 - Vista de perfil e abertura, x 400, $20 \mu \mathrm{m}$. 17 - Vista espiral, x 300, $50 \mu \mathrm{m} ; 18$ - Vista umbilical oblíqua, x 300, $50 \mu \mathrm{m} .19$ - Vista espiral, x 380, $50 \mu \mathrm{m} ; 20$ - Vista de perfil, x 380, $50 \mu \mathrm{m}$. 

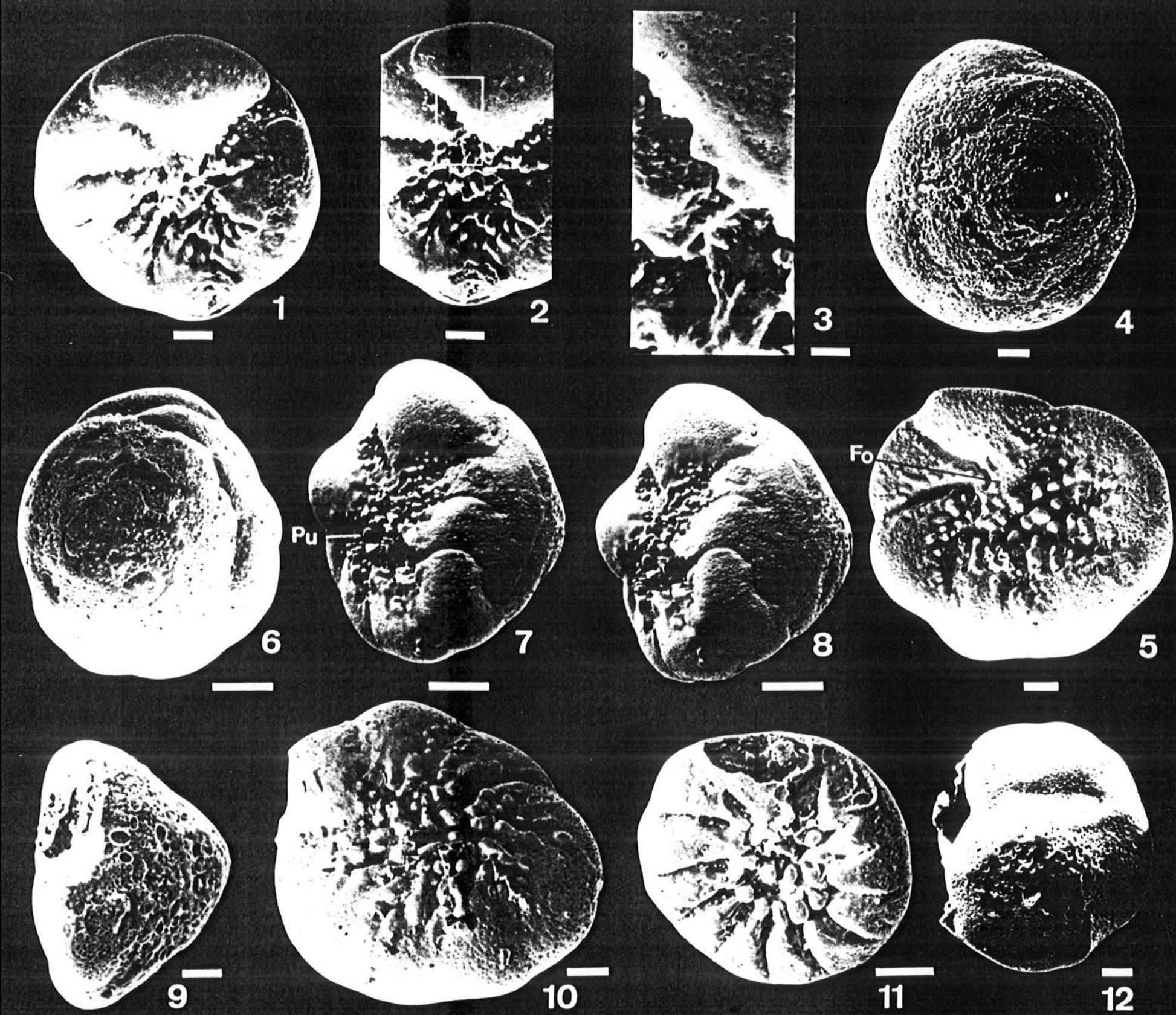

Hor
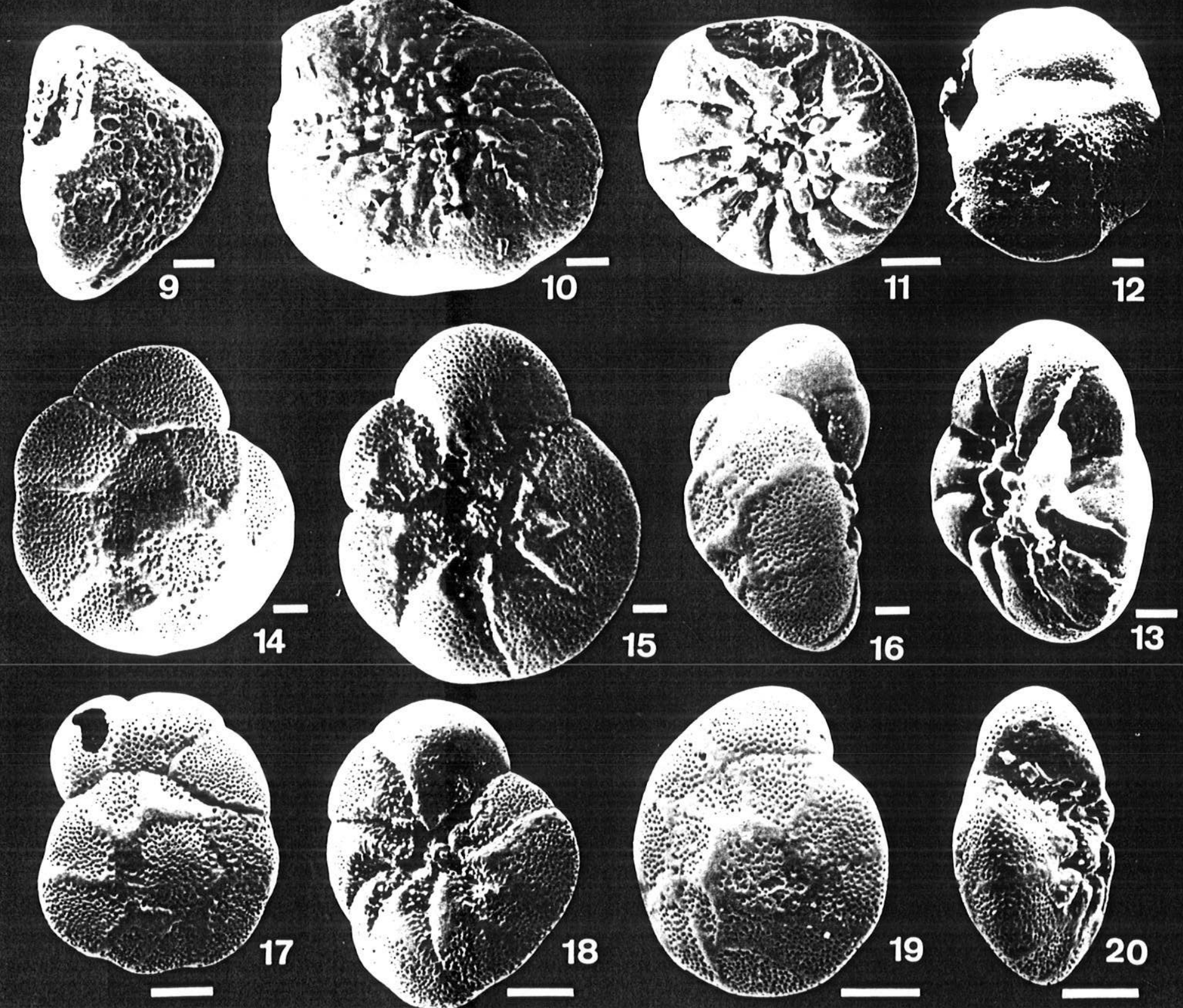


\section{Estampa 16}

1 - 11 - Ammonia beccarii f. parkinsoniana. 1 - Vista umbilical, x 500, $20 \mu \mathrm{m} .2$ Vista periférica oblíqua, x 360, $50 \mu \mathrm{m}$. 3 - Vista espiral, x 240, $50 \mu \mathrm{m} ; 4$ - Vista umbilical, x 190, $100 \mu \mathrm{m} .5$ - Vista espiral, x 550, $20 \mu \mathrm{m}$; 6 - Vista umbilical, x 550, $20 \mu \mathrm{m} .7$ - Vista espiral, x 525, $20 \mu \mathrm{m} ; 8$ - Vista umbilical, x 525, $20 \mu \mathrm{m} .9$ - Vista espiral, x 650, $20 \mu \mathrm{m} ; 10$ - Vista umbilical, x 650, $20 \mu \mathrm{m}$. 11 --Vista umbilical oblíqua, x 400, $20 \mu \mathrm{m}$.

12 - 17 - Ammonia beccarii f. tepida. 12 - Vista espiral, x 200, $50 \mu \mathrm{m} ; 13$ - Vista umbilical, x 200, $50 \mu \mathrm{m} ; 14$ - Vista da periferia e abertura, notar placa foramenal, $\mathrm{x}$ 200, $50 \mu \mathrm{m} .15$ - Vista espiral, x 200, $50 \mu \mathrm{m} .16$ - Vista espiral, x 575, $20 \mu \mathrm{m}$; 17 Vista umbilical, x 575, $20 \mu \mathrm{m} .18$ Vista espiral de exemplar fóssil, x 330, $100 \mu \mathrm{m} ; 19$ - Vista umbilical, x 360, $50 \mu \mathrm{m}$. 

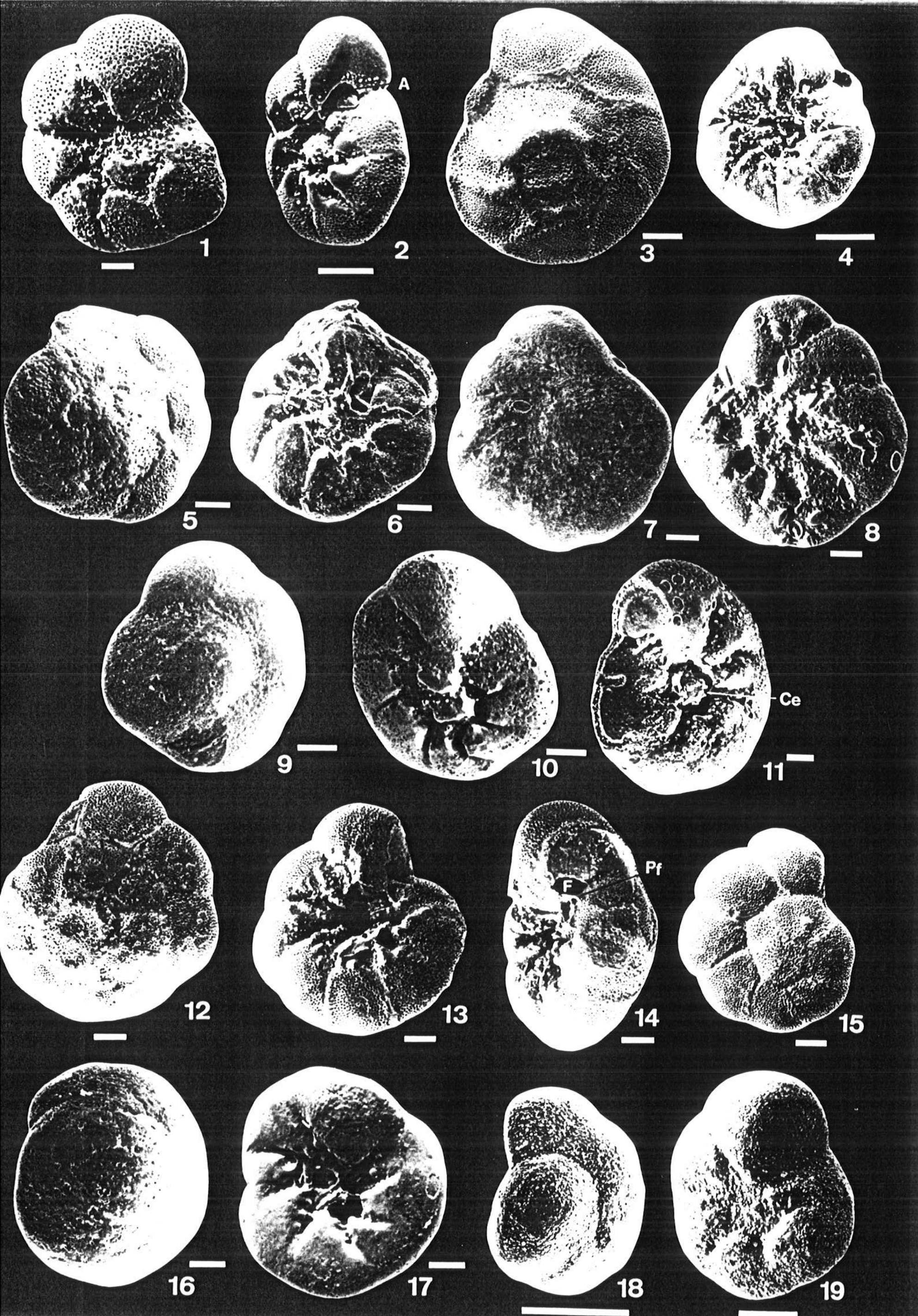


\section{Estampa 17}

1 - 11 - Estágios ontogenéticos de Ammonia beccarii. Observar nestes exemplares: Prolóculo (Pl); Protoconcha (Pc); e pseudoespinose já nos estágios iniciais. 1 - x 550, $20 \mu \mathrm{m} ; 2$ - x 600, $20 \mu \mathrm{m} ; 3$ - x 500, $20 \mu \mathrm{m} ; 4$ - x 550, $20 \mu \mathrm{m} ; 5$ - x 700, $20 \mu \mathrm{m} ; 6$ - x $500,20 \mu \mathrm{m} ; 7$ - x 430, $20 \mu \mathrm{m} ; 8$ - x 500, $20 \mu \mathrm{m} ; 9$ - x 700, $20 \mu \mathrm{m} ; 10$ - x 600, $20 \mu \mathrm{m}$; 11-x 600, $20 \mu \mathrm{m}$. 

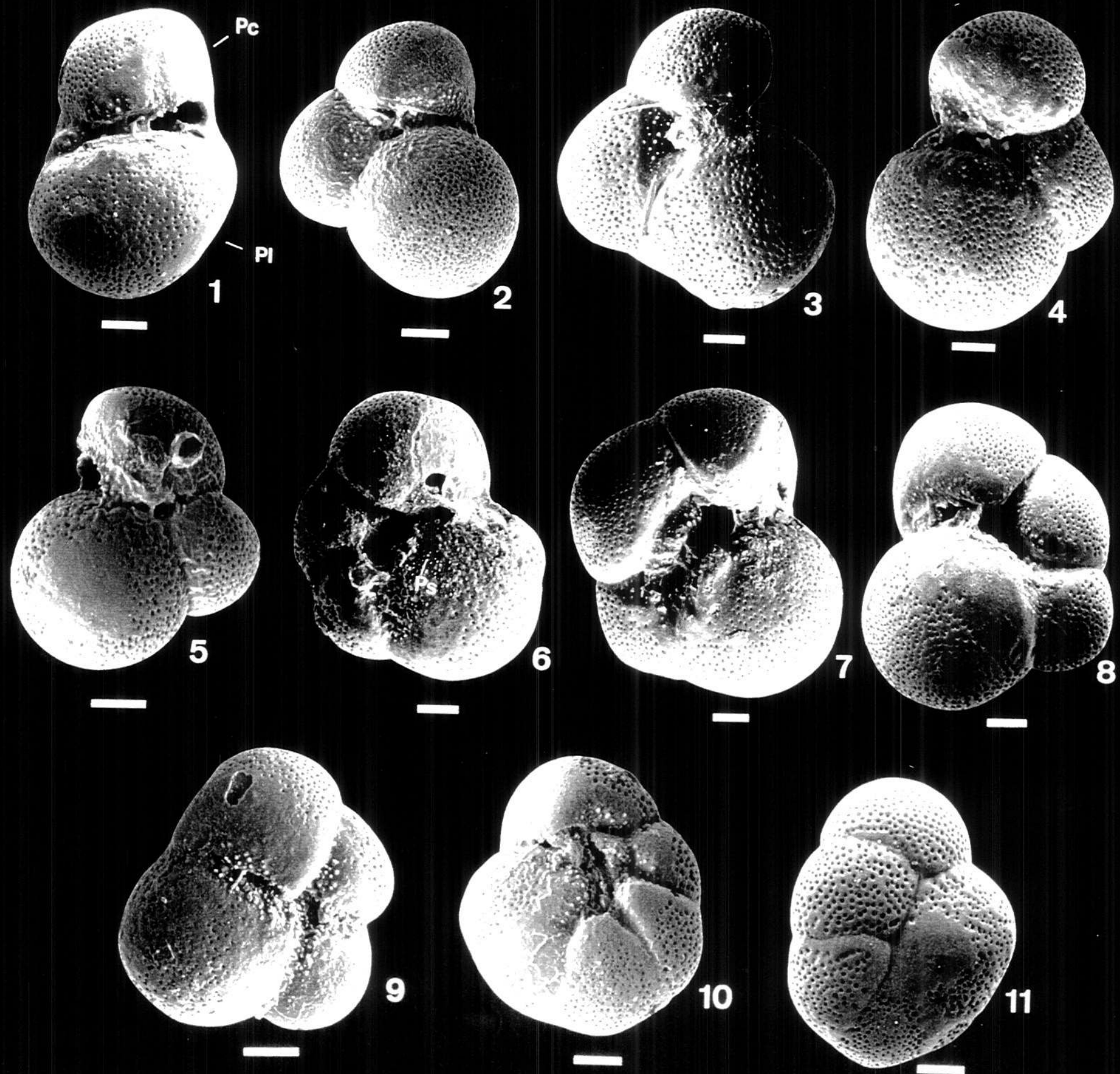


\section{Estampa 18}

1 - 10 - Cribroelphidium excavatum. 1 - Vista lateral da ornamentação de pústulas e pseudoespinhos sobre folium e ao longo dos espaços interloculares intraseptais (Ei), notar ponticuli (po) x 430, $10 \mu \mathrm{m} ; 2$ - Vista periférica e apertural mostrando foramen (f) erncoberto por pústulas e pseudo espinhos, x 500, $20 \mu \mathrm{m}$. 3 - Vista lateral, x 370, $100 \mu \mathrm{m} ; 4$ - Vista de perfil mostrando foramen das câmaras precedentes, canal umbilical espiral (ce) abaixo da placa umbilical (pu), flap septal (fs), espaço interseptal (is), x 450, $20 \mu \mathrm{m} ; 5$ - Vista lateral, x 300, $100 \mu \mathrm{m}$; 6 - Vista apertural oblíqua, x 400, $20 \mu \mathrm{m}$. 7 - Vista lateral, x 400, $10 \mu \mathrm{m} ; 8$ - Vista apertural oblíqua, x 450, $20 \mu \mathrm{m}$. 9 - Vista lateral de exemplar recente, x 350, $50 \mu \mathrm{m} ; 10$ - Vista da periferia, x 350, $50 \mu \mathrm{m}$.

11- 12 - Cribroelphidium excavatum f. clavata. 11 - Vista lateral com "ponte" para o proloculum, x 330, $100 \mu \mathrm{m} ; 12$ - Vista de perfil, x 360, $50 \mu \mathrm{m}$.

13 - 16 - Cribroelphidium excavatum f. selseyensis. 13 -Vista lateral de exemplar fóssil, x 270, $100 \mu \mathrm{m} ; 14$ - Vista de exemplar quebrado com flap septal, processos retrais (pr), ponticuli (po) e canal umbilical bilateral (ce), x 270, $50 \mu \mathrm{m}$. 15 - Vista lateral de exemplar recente, x 200, $50 \mu \mathrm{m} ; 16$ - Vista da periferia, x 200, $50 \mu \mathrm{m}$. 

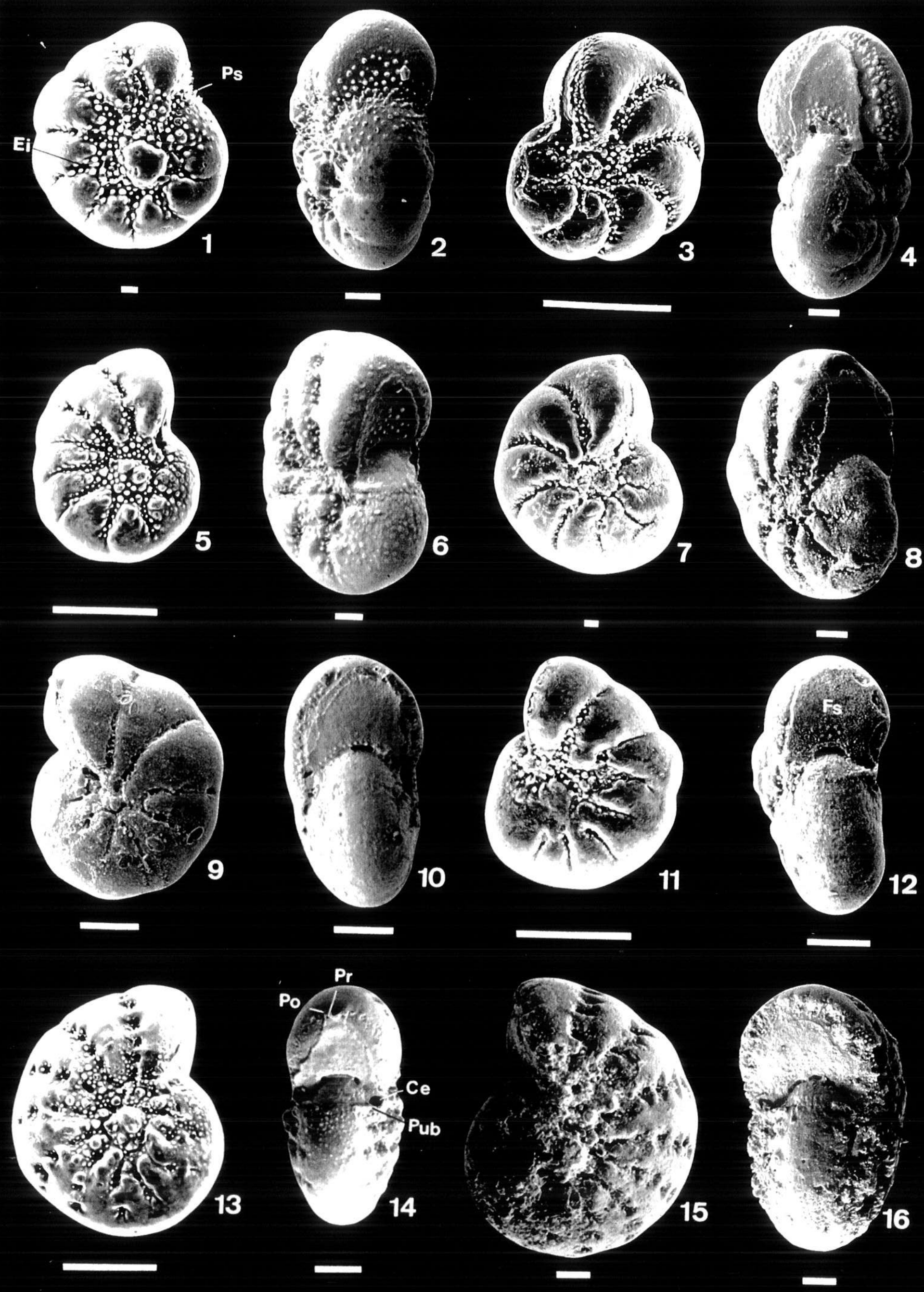


\section{Estampa 19}

1 - 5 - Cribroelphidium cf. vadescens. 1 - Vista lateral, x 300, $50 \mu \mathrm{m} ; 2$ - Vista da periferia e abertura, x 300, $50 \mu \mathrm{m} .3$ - Vista lateral, x 350, $50 \mu \mathrm{m} ; 4$ - Vista de perfil e detalhe da abertura, x 350, $50 \mu \mathrm{m} .5$ - Vista de perfil e detalhe da abertura cribrada e com fenda superior, $\mathrm{x} 400,20 \mu \mathrm{m}$.

6 - Elphidiella sp. Vista lateral oblíqua mostrando ponticuli e fossetas não homólogas às dos Elphidium, x 200, $50 \mu \mathrm{m}$.

7 - 8 - Cribroelphidium cf. atlanticum .7 - Vista periférica oblíqua, x 300, $50 \mu$ m; 8 Vista de perfil, $\mathrm{x} 300,50 \mu \mathrm{m}$

9 - Cribroelphidium cf. vadescens. Vista lateral de indivíduo com canais umbilicais, talvez devido a variação ecofenotípica, x 250, $50 \mu \mathrm{m}$.

10 - 11 - Elphidium articulatum. 10 - Vista lateral, x 165, $100 \mu \mathrm{m} ; 11$ - Vista de perfil de exemplar corroído e com face apertural quebrada com processos retrais aparentes, $\mathrm{x} 165,100 \mu \mathrm{m}$.

12 - 14 - Cribroelphidium poeyanum. 12 - Vista lateral, x 150, $100 \mu \mathrm{m} ; 13$ - Vista da periferia e abertura, x 200, $50 \mu \mathrm{m} .14$ - Vista da periferia e abertura, x 230, $50 \mu \mathrm{m}$.

15 - 16 - Cribroelphidium excavatum f. selseyensis. 15 - Vista lateral de exemplar com muitas câmaras quebradas, x 250, $50 \mu \mathrm{m}$. 16 - Vista lateral de outro exemplar com avançado grau de corrosão, x 150, $100 \mu \mathrm{m}$.

17 - 18 - Elphidium mexicanum. 17 - Vista lateral com "ponte", fossetas interseptais arredondadas e proloculum megalosférico, x 420, $20 \mu \mathrm{m} ; 18$ - Vista da periferia aguda, $\mathrm{x} 400,20 \mu \mathrm{m}$. 

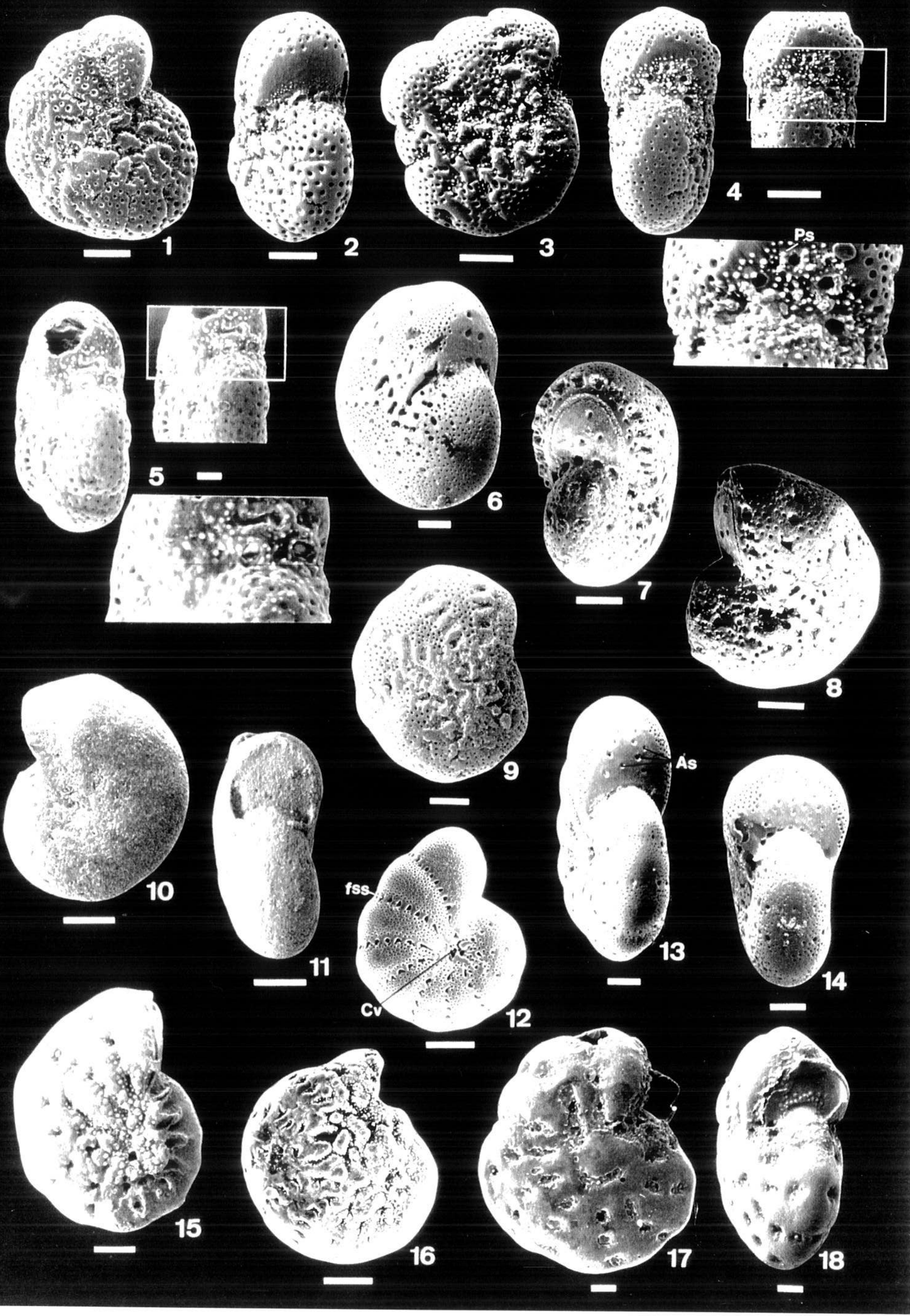


\section{Estampa 20}

Exemplares teratológicos:

1 - Quinqueloculina subpoeyana ? x 165, $100 \mu \mathrm{m}$ - S7 , lâm. 15

2 - Miliolina sidebottomi ? x 200, 50 بm - LV4 (122-126 cm), lâm. 72

3 - Quinqueloculina subpoeyana ? x 150, 100 بm - LBE 89/2, lâm. 109

4 - Massilina protea ? x 180, 100 m - LBE 89/2, lâm. 109

5 - Miliolina sidebottomi ? x 210, $50 \mu \mathrm{m}$ - S1i $\mathrm{i}_{10}$, lâm. 23

6 - Indivíduo dúvida, x 240, 50 بm - S1i 2 , lâm. 60

7 - Ammonia beccarii, x 250, 50 m - LBE 89/2, lâm. 106

8 - Ammonia beccarii, x 350, 50 Hm - LV4 (2-6 cm), lâm. 64

9 - Ammonia beccarii, x 310, 50 m - LV4 (94-96 cm), lâm. 70

10 - Uvigerina ? x 700, 20 بm - LBE 89/2, lâm. 110 

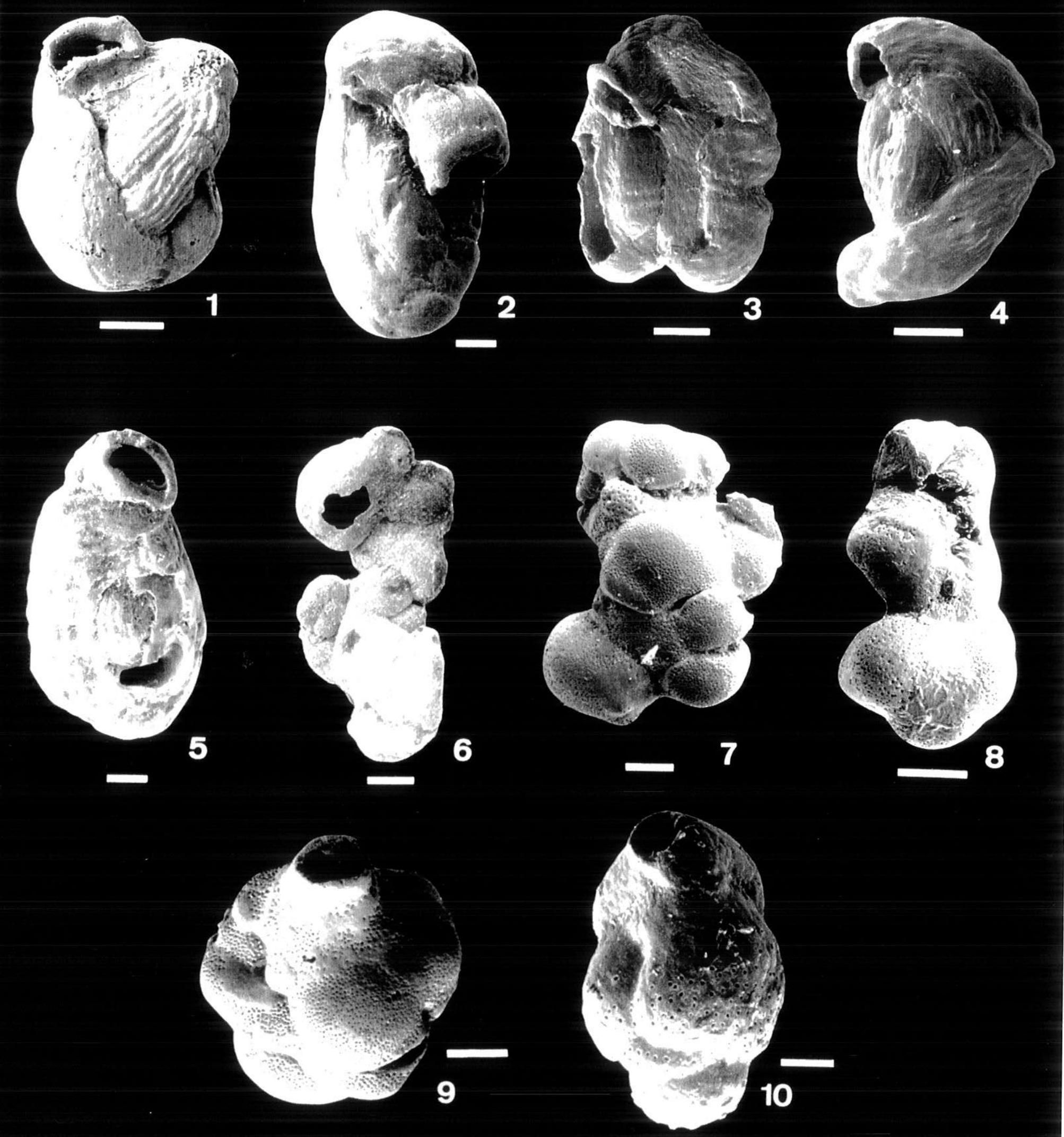


\section{Estampa 21}

1- 2 - Colônia de diatomáceas, 1- x 360, $50 \mu \mathrm{m}$ - S17, lâm 6; 2- Detalhe do topo de uma das colônias anteriores, x 1000, $10 \mu \mathrm{m}$.

\begin{tabular}{|c|c|c|c|}
\hline \multicolumn{4}{|c|}{ Fig. 1 } \\
\hline Elementos & Fórmula & \multicolumn{2}{c|}{ Peso \% } \\
\hline $\mathrm{Ca}$ & $\mathrm{CaO}$ & 64.56 & 66.00 \\
\hline $\mathrm{Si}$ & $\mathrm{SiO}_{2}$ & 0.49 & 0.71 \\
\hline $\mathrm{K}$ & $\mathrm{K}_{2} 0$ & 0.45 & 0.44 \\
\hline $\mathrm{Mg}$ & $\mathrm{MgO}$ & 4.87 & 3.39 \\
\hline
\end{tabular}

Tab. - Análise de EDS de dois pontos obtidos das duas colônias ilustradas. O valor restante para completar $100 \%$ corresponde ao Au utilizado para metalização do material. Esse tipo de material só ocorre em Araruama, não tendo sido observado em nenhuma das outras áreas lagunares ou mesmo nos testemunhos analisados. Da mesma forma, diatomáceas epizóicas em foraminíferos só ocorrem em Araruama.

3 - 4 - Colônia de diatomáceas. 3 - Vista geral, x $270,50 \mu \mathrm{m}$, procedência: $\mathrm{S}_{2}$; 4 Vista de detalhe do topo, x 270, $50 \mu \mathrm{m}$.

5 - 6 - Colônia de diatomáceas. 5 - Vista geral, x 290, $50 \mu \mathrm{m}$, procedência: $\mathrm{S} 1_{5} ; 6$ Vista de detalhe do topo, $\mathrm{x} 290,50 \mu \mathrm{m}$.

7 - 8 - Vista de detalhe, retirada do exemplar ilustrado em [8], de diatomáceas epizóicas em abertura suplementar de Miliolinella loeblichi, x 1400, $10 \mu \mathrm{m}$, procedência: S2 48 - Localização do detalhe ilustrado em [7], esse exemplar corresponde ao mesmo ilustrado na estampa 7 [13], x 220, $50 \mu \mathrm{m}$.

9 - Diatomáceas epizóicas entre as costelas de Caecum brasilicum (gastrópode), procedência: $1 \mathrm{~m}$ de profundidade da Lagoa de Itaipú x 2000, $5 \mu \mathrm{m}$. Foto gentilmente cedida pelo Prof. Ricardo Absalão (UFRJ).

10 - 12 - Tholosina ? . 10- Vista geral, x 350, $50 \mu \mathrm{m}, 11$ - Mesmo exemplar anterior, $270,100 \mu \mathrm{m} ; 12$ - x 230, $100 \mu \mathrm{m}$. Esse exemplares somente ocorrem em Jacarepiá e Saquarema. 


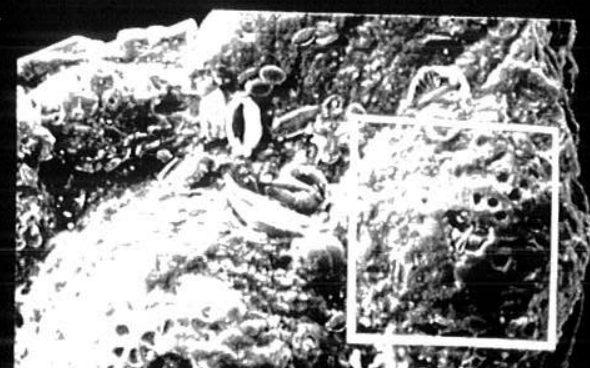

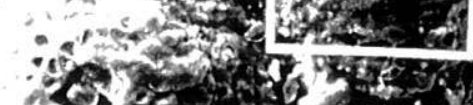

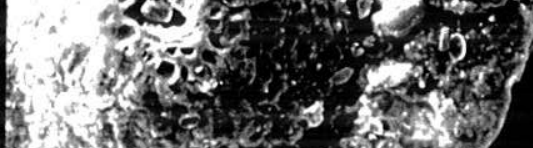

* $\rightarrow$ ofingos

$x \rightarrow-2+x$ nos
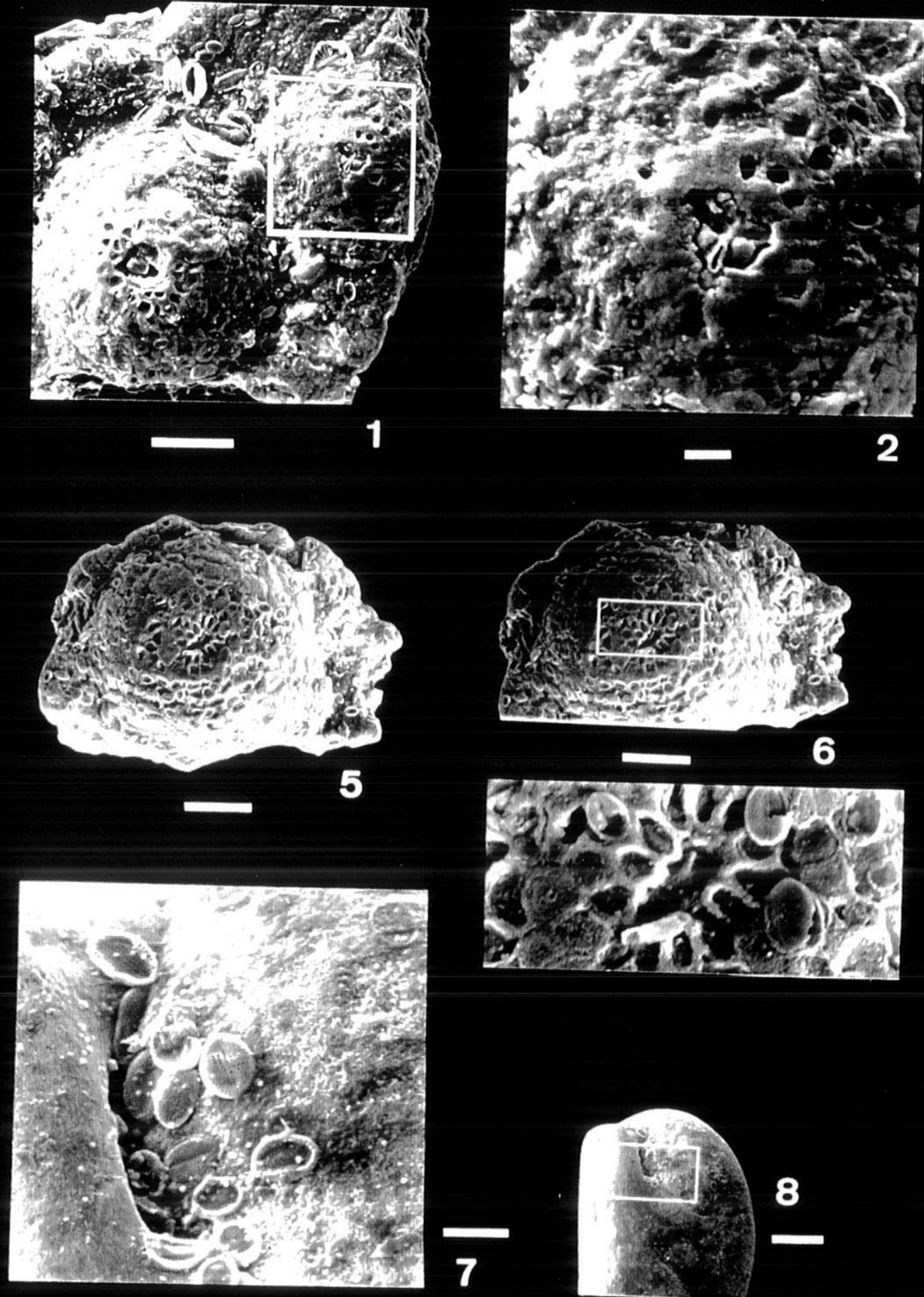

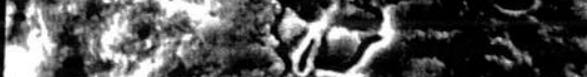

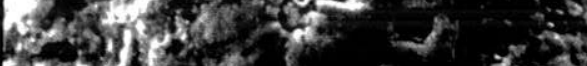

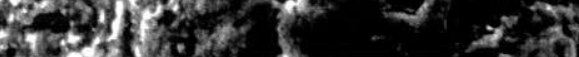

1.

1

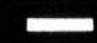

2
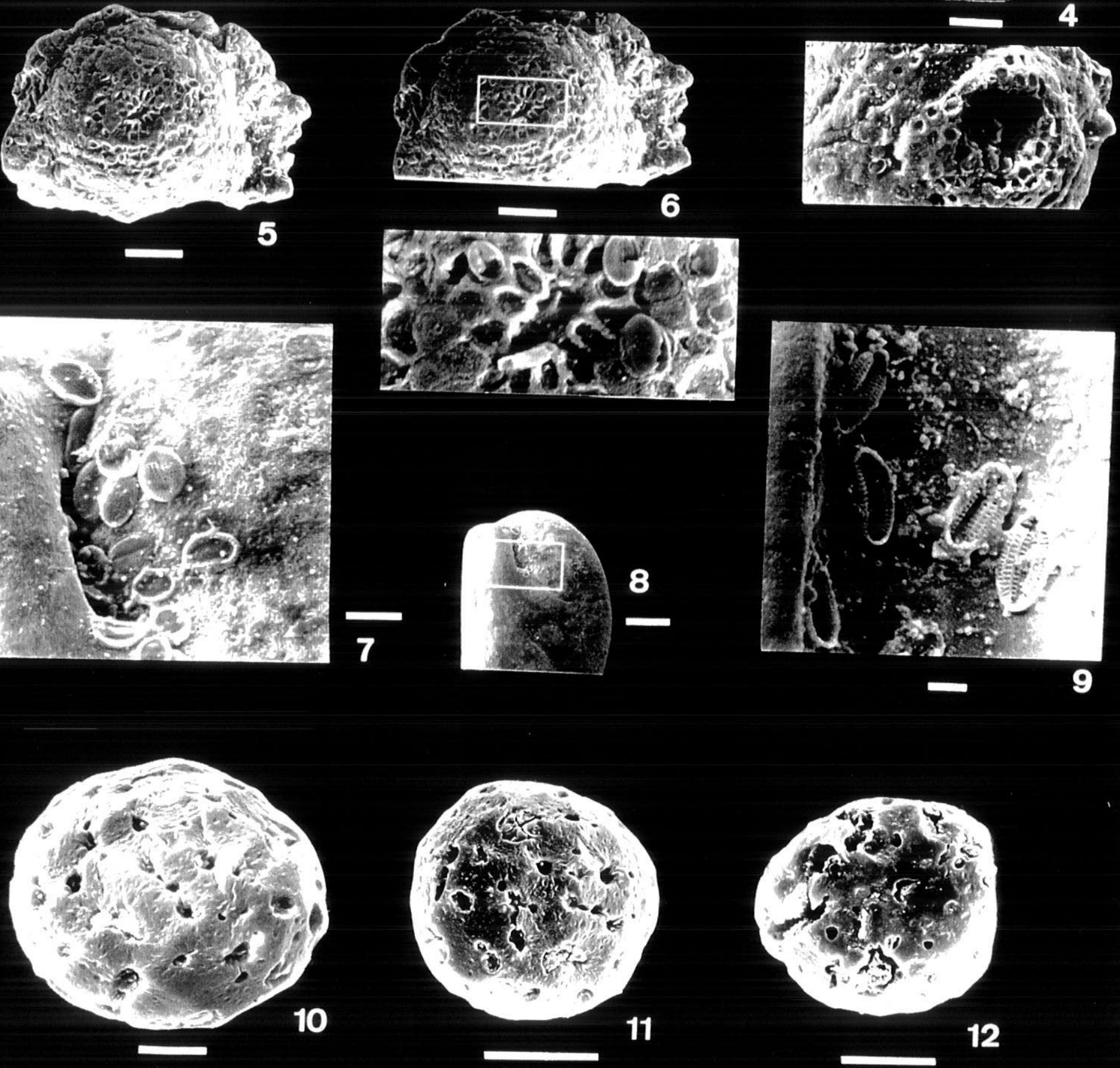


\section{Estampa 22}

1 - 4 - Heleobia sp. ?. 1 - x 160, 100 Mm, procedência: LBE 89/2, lâm. 112; 2 - x 140, $100 \mu \mathrm{m}$, procedência: LV4 (41-45 cm), lâm. 68; 3 - x 130, $100 \mu \mathrm{m}$, procedência: LBE 89/2, lâm. 112; 4 - x 130, 100 m, procedência: LV4 ( 244 - 246 cm), lâm. 82.

5 - Hydrobia sp. A. Observar espira alta, abertura arredondada, com ângulo apical estreito e ornamentação restrita a linhas de crescimento muito finas, x 50, $200 \mu \mathrm{m}$.

6 - Sayella aff. crosseana. x 30, $500 \mu \mathrm{m}$.

7,8,10 - Pleurotomaria? . 7 - x 150, $100 \mu \mathrm{m} ; 8$ - x 130, $100 \mu \mathrm{m} ; 10$ - x 100, $100 \mu \mathrm{m}$.

9 - Caecum brasilicum, x 60, $200 \mu \mathrm{m}$. 

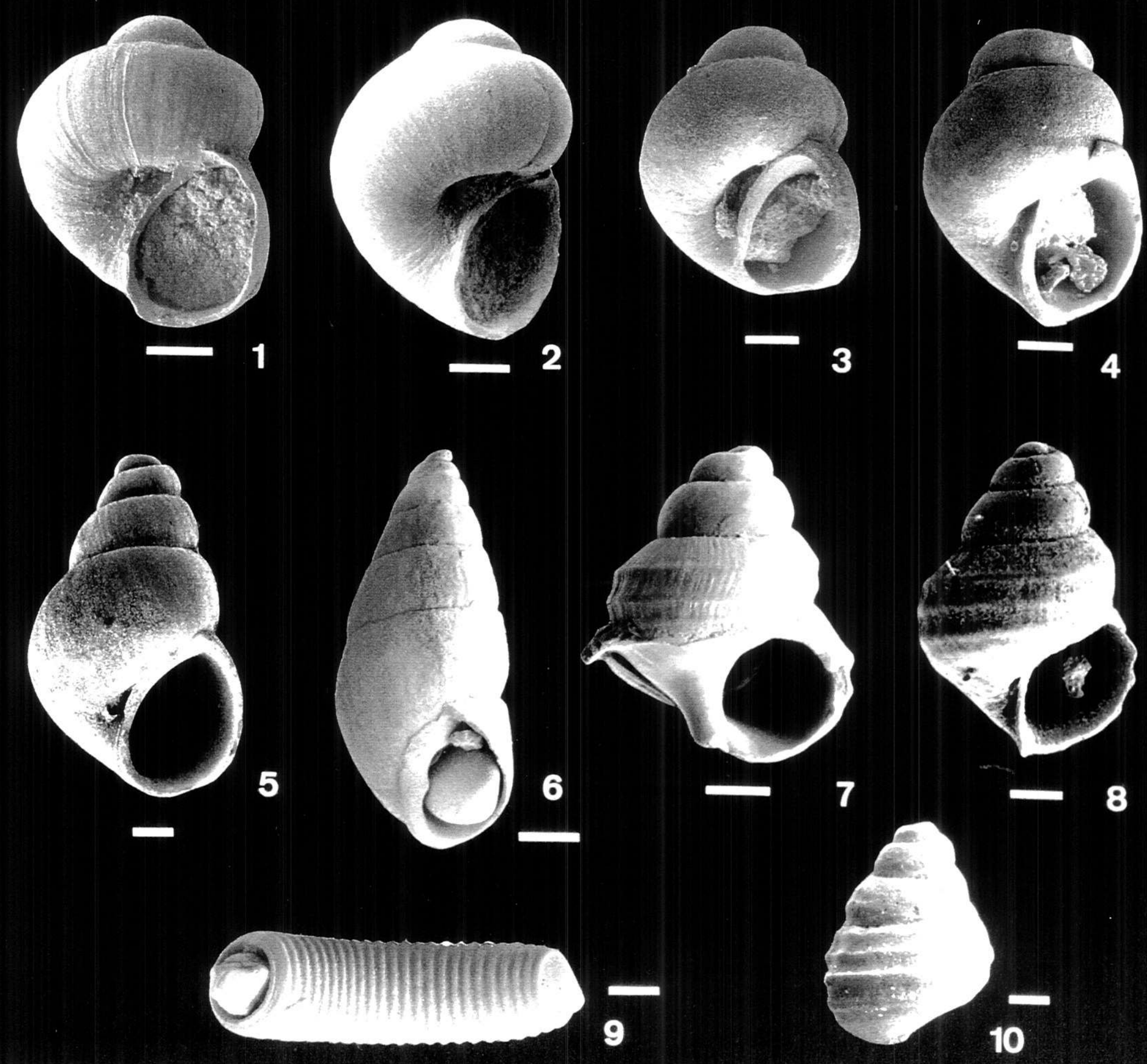
Estampa 23

1 - 2 - Chara ? 1 - Vista lateral, x 150, $100 \mu \mathrm{m} ; 2$ - Vista basal, x 120, $100 \mu \mathrm{m}$.

3 - 4 - Lamprothamnium ? 3 - Vista lateral, x 160, $100 \mu \mathrm{m}$; 4 - Vista basal, x 200, 50 $\mu \mathrm{m}$. 

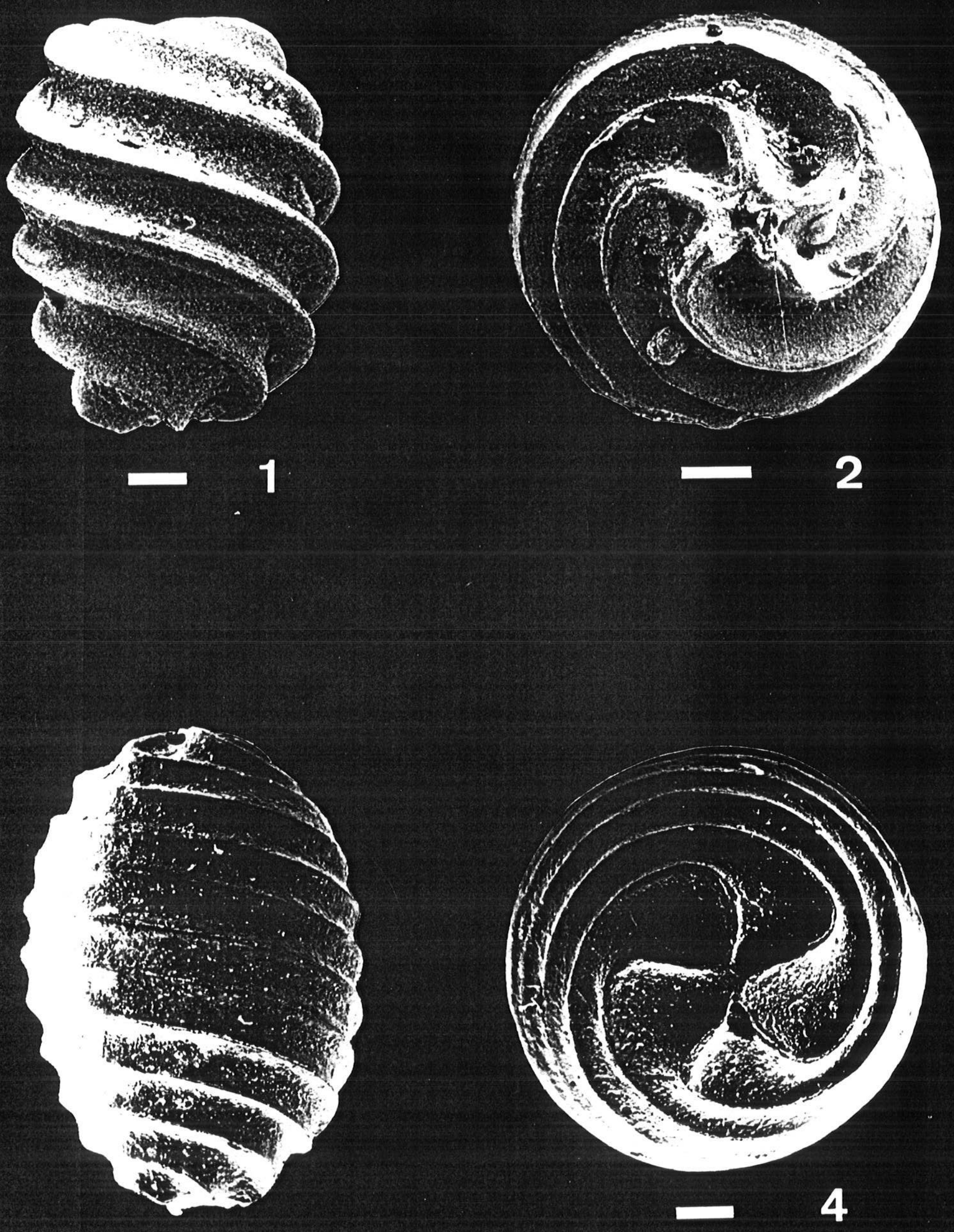


\section{Estampa 24}

1- 9 - Cyprideis salebrosa. 1- Vista externa da carapaça, x 95, $100 \mu \mathrm{m} ; 2$ - Carapaça interna, x 100, $100 \mu \mathrm{m} ; 3$ - Detalhe das cicatrizes musculares na carapaça interna, $\mathrm{x}$ 400, $10 \mu \mathrm{m} .4$ - Carapaça externa, x 100, $100 \mu \mathrm{m} ; 5$ - Carapaça interna, x 100, 100

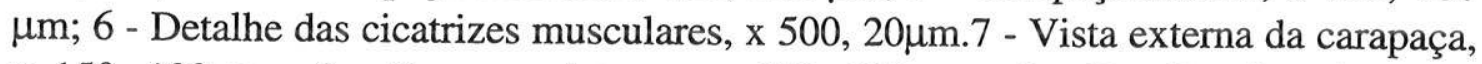
x 150, $100 \mu \mathrm{m} ; 8$ - Carapaça interna, x 150, $100 \mu \mathrm{m} ; 9$ - Detalhe das cicatrizes musculares na carapaça interna, $x 725,20 \mu \mathrm{m}$.

10-12 - Loxoconcha paranensis. 10- Vista externa da carapaça, x 140, $100 \mu \mathrm{m} ; 11$ Carapaça interna, x 165, $100 \mu \mathrm{m} ; 12$ - Detalhe das cicatrizes musculares, $x$ 115, 100 $\mu \mathrm{m}$.

13-14 - Paracypris sp. 13- Vista externa da carapaça, x 135, $100 \mu \mathrm{m}$; 14- Carapaça interna, x 135, $100 \mu \mathrm{m}$. 


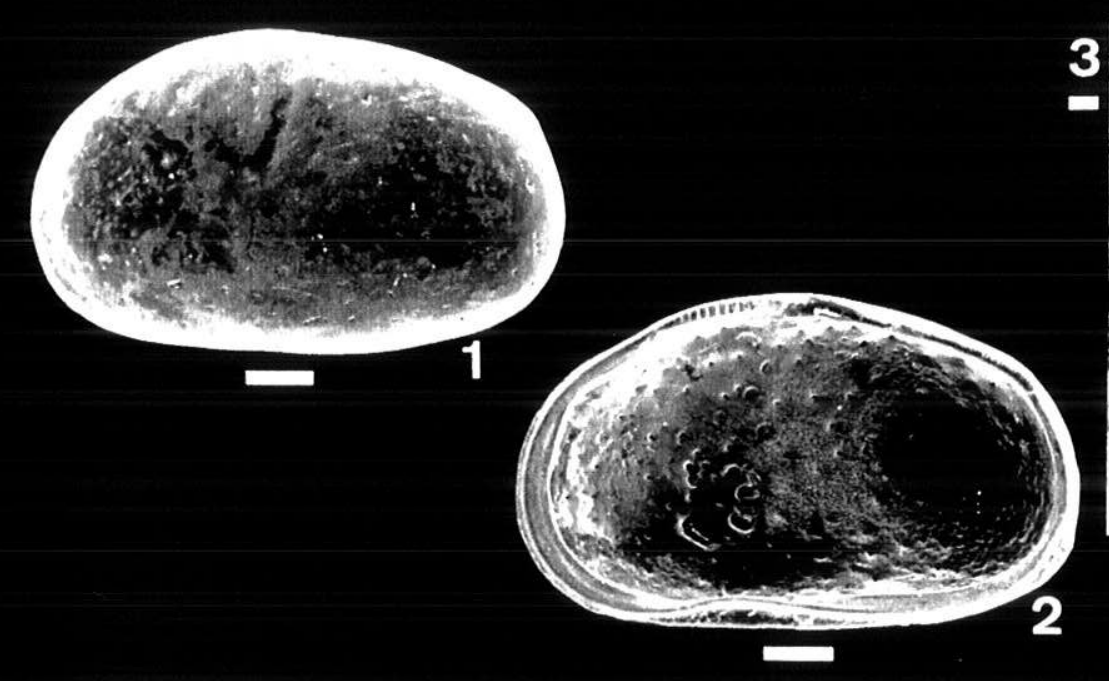

3. S.

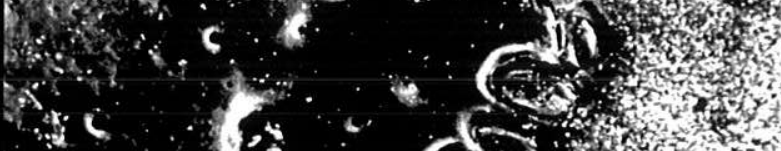
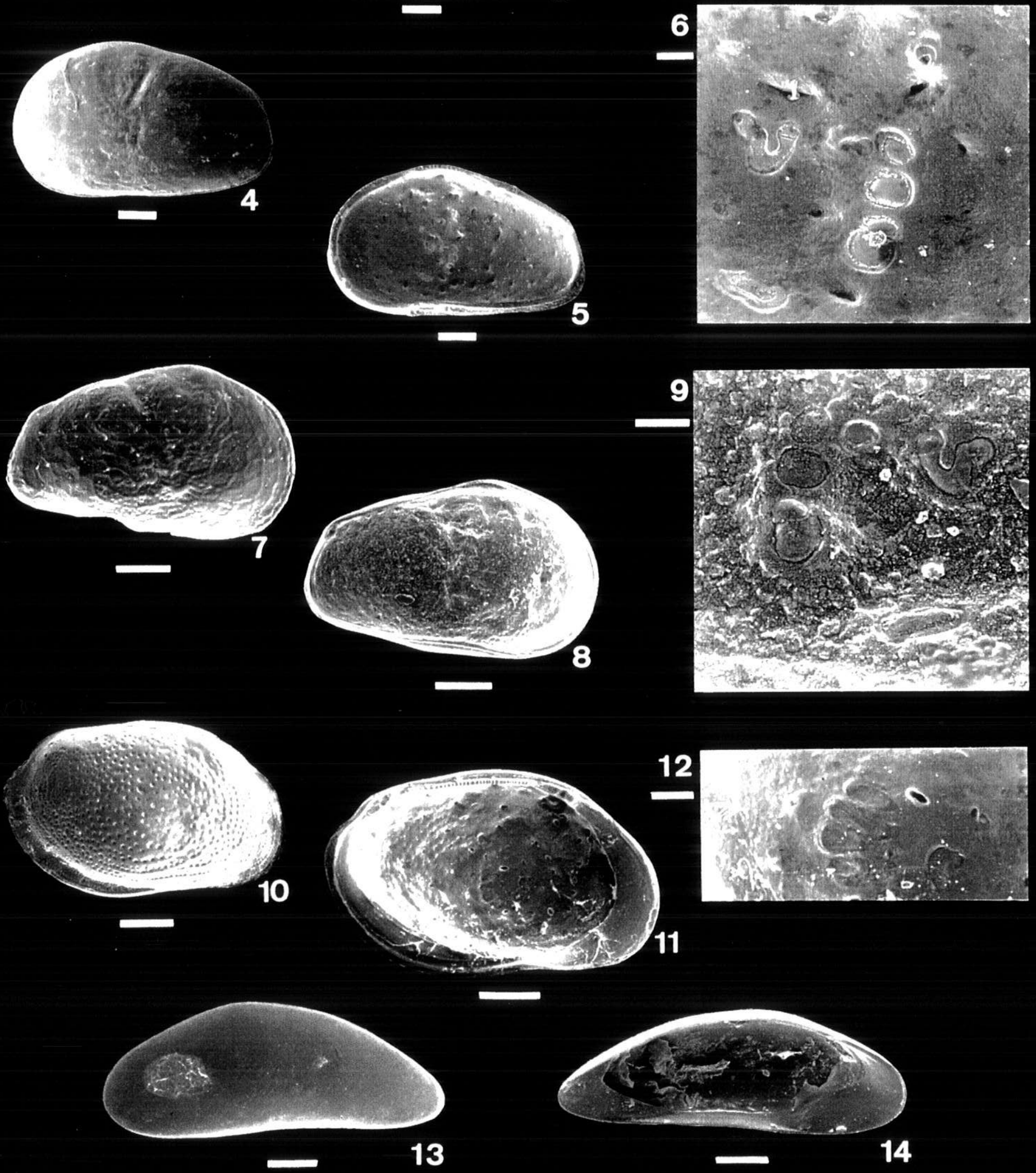


\section{Estampa 25}

1 - 7 - Perissocytheridea cf. kroemmelbein . 1 - Vista externa da carapaça, x 170, 100 $\mu \mathrm{m} ; 2$ - Detalhe dos porocanais crivados na carapaça externa, x 1000, $10 \mu \mathrm{m} ; 3$ Carapaça interna, x 170, $100 \mu \mathrm{m} ; 4$ - Detalhe das cicatrizes musculares na carapaça interna, x 700, $20 \mu \mathrm{m}$. 5 - Vista externa da carapaça, x 170, $100 \mu \mathrm{m}$; 6 - Carapaça interna, x 170, $100 \mu \mathrm{m} ; 7$ - Detalhes das cicatrizes musculares na internas, x 500, 20 $\mu \mathrm{m}$. 

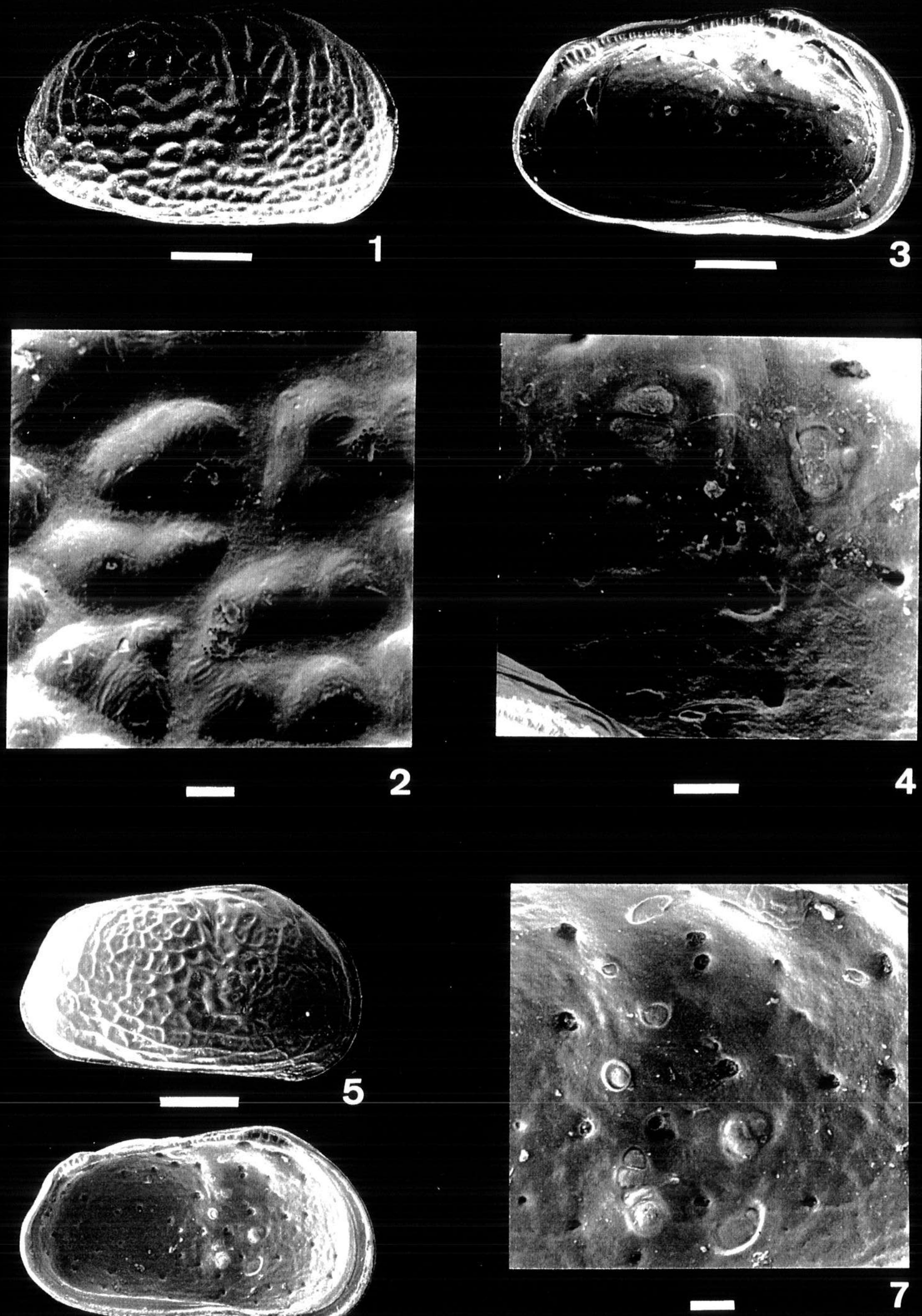

6 
Estampa 26

Esboço esquemático

1 - 2 - Cornuloculina ?. 1 - Vista lateral; 2 - Vista da abertura.

3-Agglutinella sp. A. Vista lateral

4-5. Siphonaperta sp. A. 4 - Vista lateral, 5- Vista lateral e da abertura

6-7 - Quinqueloculina dilatata? Vista lateral

8-Quinqueloculina laevigata. Vista lateral

9-11 - Quinqueloculina lamarckiana. 9- 10- Vista lateral, 11- Vista da abertura

12- Quinqueloculina milletti. Vista lateral

13-14 - Affinetrina concisa. Vista lateral

15-16 - Affinetrina concisa subsp. A. Vista lateral

17-18 - Triloculina asymmetrica. Vista lateral

19-22 - Triloculina fichteliana. Vista lateral

23-25 - Triloculina trigonula. 23-24 - Vista lateral, 25 - Vista da abertura

26-27 - Varidentella implexa. Vista lateral 


\section{QUINQUELOCULINA}

ELPHIDIUM
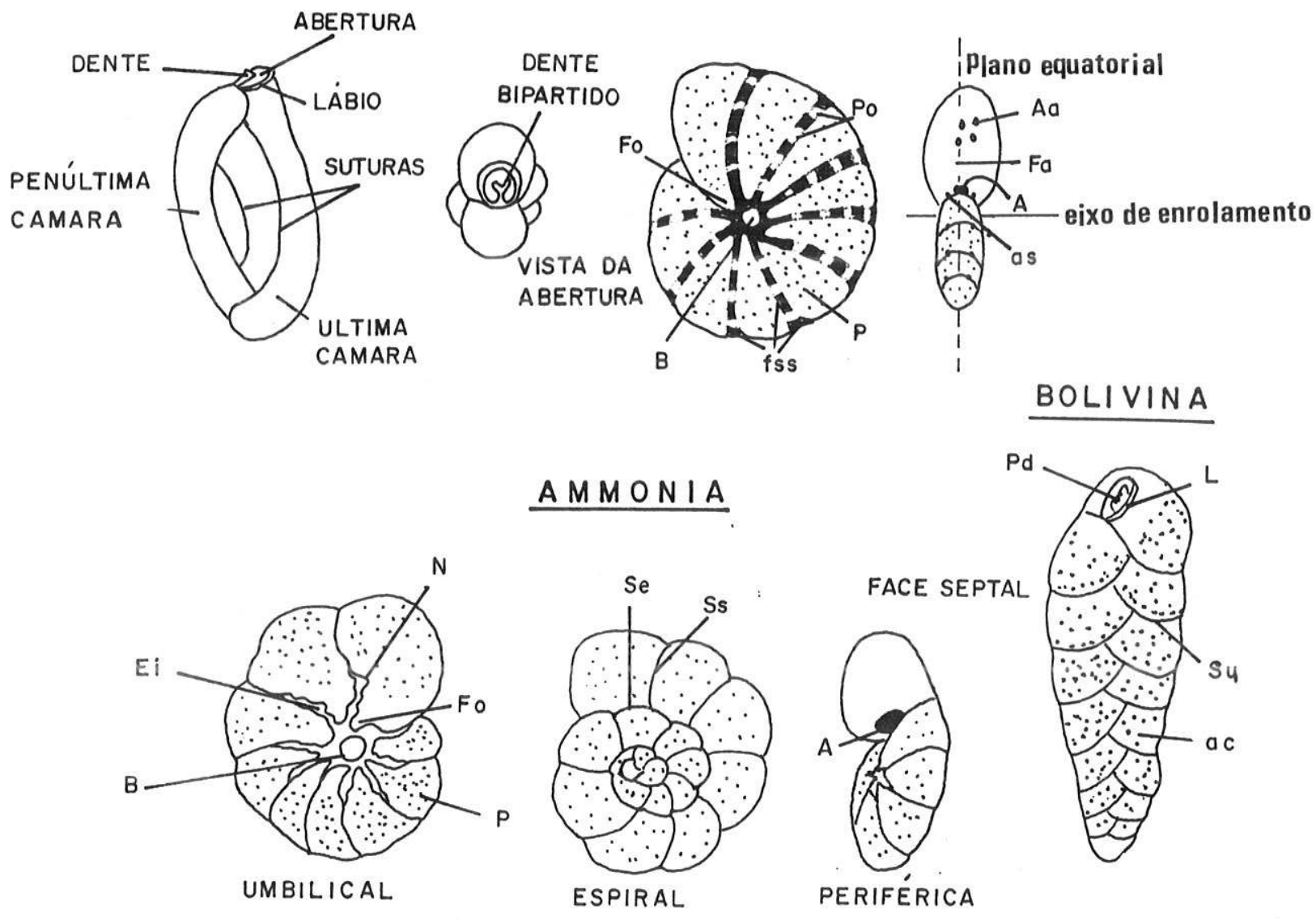

AMMONIA

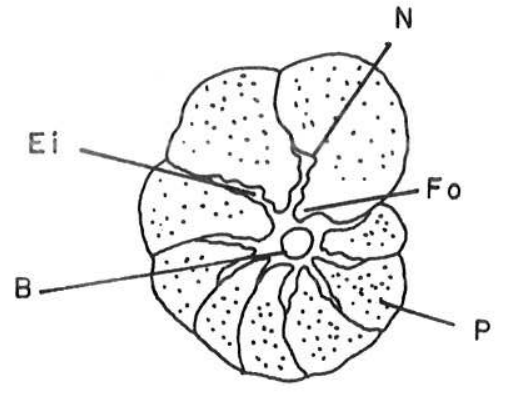

UMBILICAL

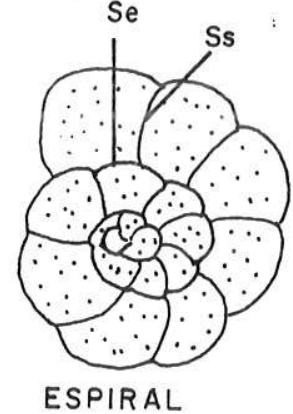

PERIFERICA

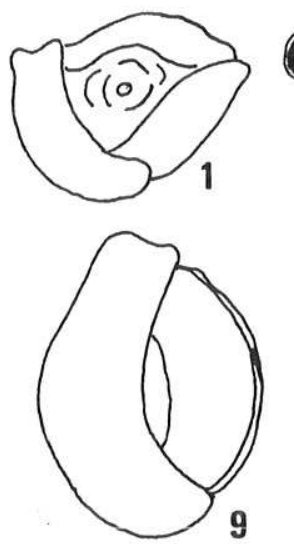

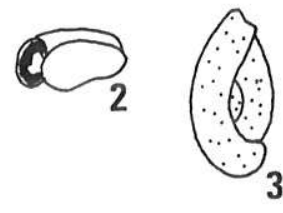
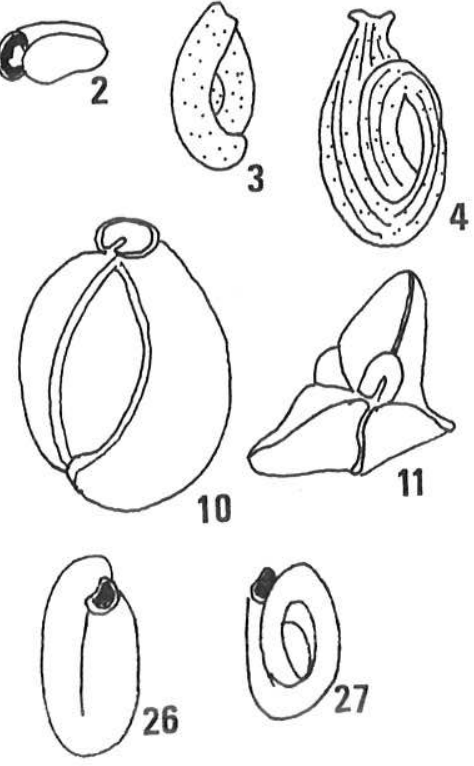

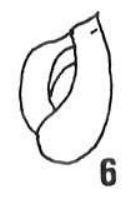

32
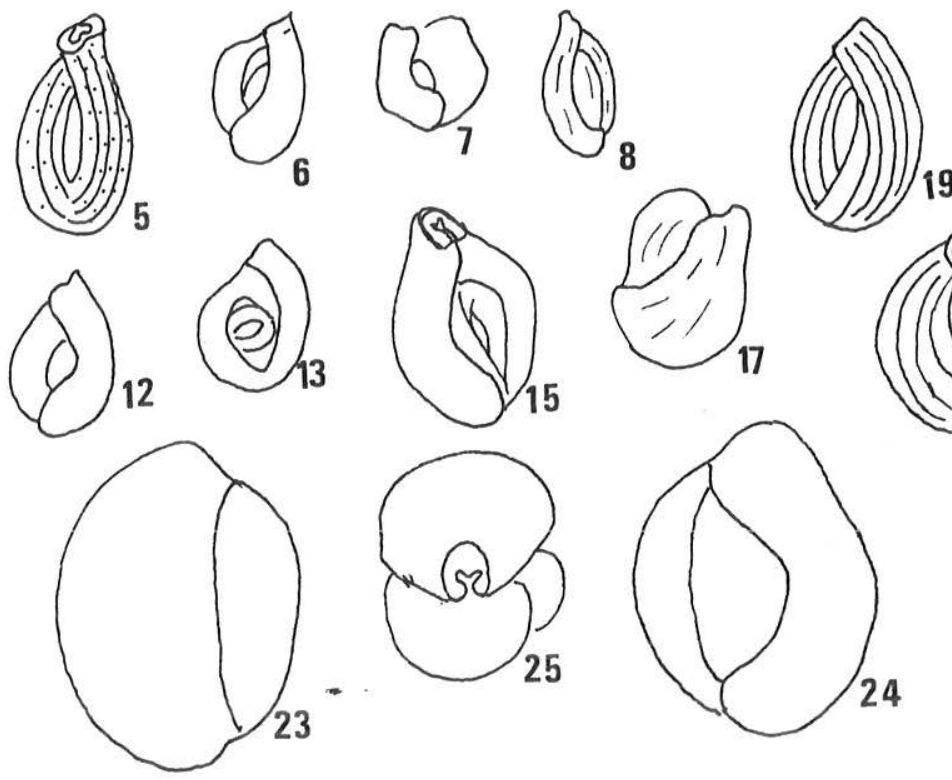

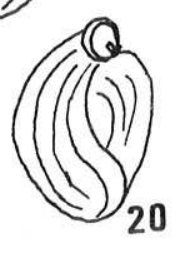




\section{REFERÊNCIAS BIBLIOGRÁFICAS DA TAXONOMIA}

Estão referenciadas abaixo somente os textos que não constem nas referências do Treatease de Loeblich \& Tappan 1988; de Medioli \& Scott 1983; Hottinger et al. 1993 e que não foram verificados no catálogo de Ellis e Messina (1940ss).

ANDERSEN,H. 1953. Two new spesies of Haplophragmoides from the Louisiana Coast. Contributions to the Cushman Foundation for Foraminiferal Research, 4, ṗ̄.1, p.21-22.

BARBOSA, C.F. 1991. Caracterização biossedimentológica quantitativa do sistema estuário manguezal da Baía de Guaratuba, P.R. Dissertação (Mestrado/IGc) USP, inédito.

BARBOSA, C.F. 1995. Foraminifera e Arcellacea ("Thecamoebia") Recentes do Estuário de Guaratuba, Paraná, Brasil. Anais da Academia Brasileira de Ciências, v. 67, n. 4, p. 465-492.

BARBOSA, C. F. No Prelo. Zoneamentos de Foraminifera e Arcellacea ("Thecamoebia") nos pântanos salinos de Guaratuba, Paraná, Brasil. Anais Academia Brasileira de Ciências.

BENGTSON, P. 1988 Open nomenclature. Paleontology, v. 31, n.1. p. 223-22.

BOLTOVSKOY, E., GIUSSANI, G., WATANABE, S. \& WRIGHT,R. 1980. Atlas of Benthic Shelf Foraminifera of the Southwest Atlantic. Dr. W. Junk Publs. The Hague-Boston.

BOLTOVSKOY, E. e HINCAPIÉ DE MARTINEZ, S. 1983. Foraminiferos del manglar de Tesca, Cartagena, Colombia. Revista Espanola de Micropaleontologia, 15, no. 2, p. 205-220.

BOLTOVSKOY, E. e VIDARTE, L.M. 1977. Foraminiferos de la zona de manglar de Guayaquil (Ecuador). Revista del Museo Argentino de Ciencias Naturales "Bernardino Rivadavia"E Instituto Nacional de Investigación de las Ciencias Naturales, 5, no. 3, p. 31-40.

CHAPMAN, F. 1909. Report on the Foraminifera from the subantarctic islands of New Zealand. In: The subantactic islands of New Zealand. Ed. by C. Chilton. Wellington, New Zealand, Philos. Inst. Canterbury, vol. 1, p. 322.

CLOSS, D., 1962. Foraminíferos e Tecamebas da Lagoa dos Patos (R.G.S.): Escola de Geologia, Porto Alegre, Bol. No.11, p. 1-130.

CLOSS,D. e MADEIRA, M.L. 1966. Foraminifera from the Paranaguá Bay, State of Paraná, Brasil. Bol. da Univ. Federal do Paraná. Sér. Zool. II. No. 10, p. 139-162.

CUSHMAN, J.A. 1929. The Foraminifera of the Atlantic Ocean. United States National Museum, Bull. 104. Smithsonian Institution. 2 vol. (Antiquariaat Junk, Netherlands, Reprint 1970).

HAMLIN, W.H. 1960. Two new species of foraminifera from the west coast of the United States. Cushman Found. Foram. Res., Contr., Ithaca, N.Y.,vol.11,pt. 3,p. 87.

HOTTINGER, L. HALICZ, E. e REISS, Z. 1993. Recent Foraminifera from the Gulf of Aqaba, Red Sea. Slovenska Akademija Znanosti in Umetnosti., Ljubljana, 179 p.+ 230 pl.

LOEBLICH,A.R.Jr. e TAPPAN,H.1988. Foraminiferal Genera and their Classification. Van Nostrand Reinhold Company. New York. 2 vol.

MEDIOLI, F.S. e SCOTT,D.B. 1983. Holocene Arcellacea (Thecamoebians) from Eastern Canada. Cushman Foundation for Foraminiferal Research. Special Publ., 21.p. 1-63. 
MEDIOLI, F.S. e SCOTT,D.B. 1988. Lacustrine Thecamoebians (Mainly Arcellaceans) as potential tools for paleolimnological interpretations. Palaeogeography, Palaeoclimatology,

Palaeoecology, 62, p. 361-386.

PARKER, F.L.; PHLEGER,F.B. e PEIRSON,J.F. 1953. Ecology of foraminifera from San Antonio Bay and environs, Southwest Texas. Cushman Foundation for Foraminiferal Research. Special Publication, no. 2, p. 1-75.

PATTERSON, R.T., MACKINNON, K.D., SCOTT,D.B. e MEDIOLI, F.S. 1985. Arcellaceans ("Thecamoebians") in small lakes of New Brunswick and Nova Scotia: Modern Distribution and Holocene Stratigraphic changes. Journal of Foraminiferal Research. v. 15, n.2, p. 114-137.

PAWLOWSKI, J. e LEE, J.J. 1991.Taxonomic notes on some tiny, shallow water foraminifera from the northern Gulf of Elat (Red Sea). Micropaleontology, v. 37, n. 2, p. 149-162:

POAG, W.C. 1978. Paired foraminiferal ecophenotypes in Gulf Coast estuaries: Ecological and paleoecological implications. Transactions - Gulf Coast Association and Geological Societies. vol. XXVIII, p. 395-421.

PUJOS, M. 1984. Jadammina polystoma, témoin dún environnement contraignant dans léstuaire de la Gironde (France)- Benthos'83; 2nd INT. SYMP. BENTHIC FORAMINIFERA (Pau, April) 1983), p. 511-517.

REVETS,S.A. 1990. The genus Floresina, Gen. Nov. Journal of Foraminiferal Research, v. 20, no. 2 , p. $157-161$

REVETS,S.A. 1990. The revision of Buliminella Cushman,1911. Journal of Foraminiferal Research, v. 20, no.4, p. 336-348.

SCOTT, D.B. e MEDIOLI, F.S. 1980a. Quantitative studies of marsh foraminiferal distributions in Nova Scotia: implications for sea level studies. Cushman Foundation for Foraminiferal Research, Special Publication, n. 17, 58pp.

SCOTT,D.B.; SCHNACK,E.J.; FERREIRO,L.; ESPINOSA, M.; BARBOSA, C. F. 1990. Recent marsh foraminifera from the east coast of South America: Comparison to the Northern Heemisphere. In HEMLEBEN C. et al. (eds) Paleoecology, Biostratigraphy, Paleoceanography and Taxonomy of Agglutinated Foraminifera, Kluwer Acad. Publ., 717-737.

ZANINETTI, L. BRÖNNIMANN, P., BEURLEN, G. e MOURA, J.A. 1977. La mangrove de Guaratiba et la Baie de Sepetiba, Etat de Rio de Janeiro, Bresil: Foraminiferes et ecologie. Archives des Sciences, 30, pt. 2,p. 161-178. 